(1) (1)

(1) (1)

(1) (1) ( ) a a d 



\section{PRICES OF TOBACCO}

A REPORT ON THE PRICES OF TOBACCO TRANSMITTED IN RESPONSE TO SENATE RESOLUTION NO, 44, BY SENATOR BEVERIDGE, OF MAY 14, 1909

PREPARED BY THE COMMISSIONER OF CORPORATIONS OF THE DEPARTMENT OF COMMERCE AND LABOR Les?<smiles>[AsH]</smiles>

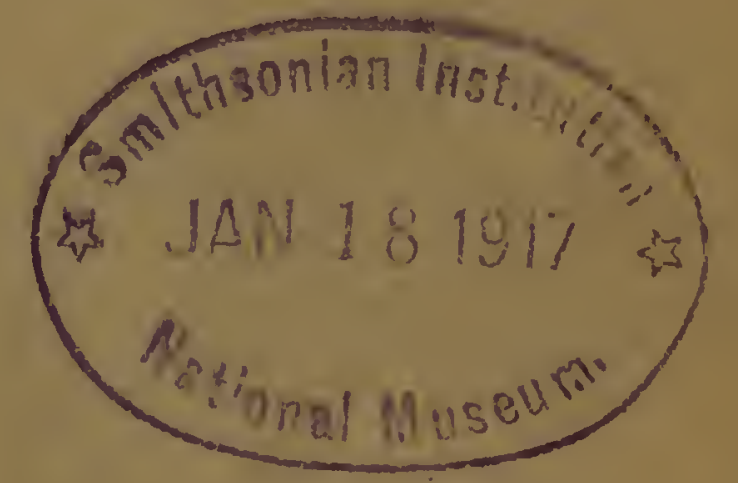

JUNE 5, 1909.-Read; referred to the Committee on Finance and ordered to be printed with illustrations

\section{WASHINGTON}

GOVERNMENT PRINTING OFFICE

1909 



\section{To the Senate:}

I transmit herewith a report on the prices of tobacco and the operations of corporations and others dealing in the same, prepared by the Commissioner of Corporations, of the Department of Commerce and Labor, in accordance with the following resolution of the Senate (No. 44) adopted May 14, 1909:

Resolved, That the President be requested to transmit to the Senate all information collected by the Department of Commerce and Labor affecting the prices of tobacco and the operations of corporations and others dealing in the same.

The White House, June 5, 1909.

WM. H. TAFT.

JUNE 4, 1909.

SIR: I have the honor to transmit herewith material and data affecting the prices of tobacco and the operations of corporations and others dealing in the same, prepared by the Commissioner of Corporations, and submitted to you herewith, in response to the resolution of the Senate adopted May 14, 1909.

Very respectfully,

The President, White House.

Ormsby McHarg, Acting Secretary.

JUNE 4, 1909.

SrR: I have the honor to transmit herewith material and data affecting the prices of tobacco and the operations of corporations and others dealing in the same, prepared in response to the resolution of the Senate adopted May 14, 1909, and under your direction, and in accordance with the law creating the Bureau of Corporations.

Very respectfully,

The Secretary of Commerce and Labor.

Herbert Knox SMith, Commissioner. 



\section{CONTENTS.}

Page.

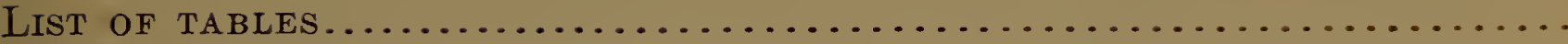

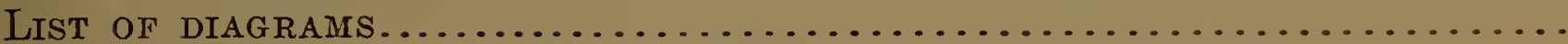

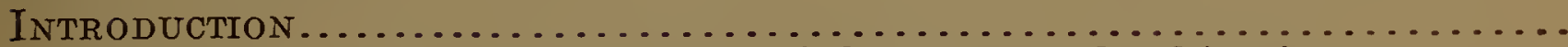

Summary of history and business of the Tobacco Combination..........

I. General survey of Prices and profits of the Tobacco Combination . .

Profits of the principal companies in the Tobacco Combination .......

Analysis of the business and profits of the American, Continental, and

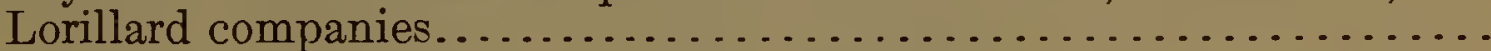

Sales and profits of the individual departments of the American,

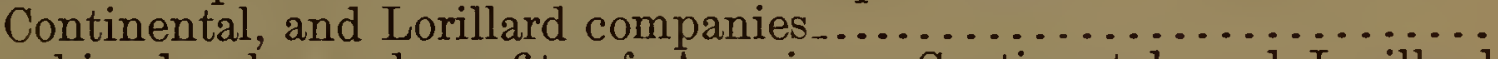

Combined sales and profits of American, Continental, and Lorillard companies and their leading subsidiary companies...............

Prices and profits of the individual departments of the principal

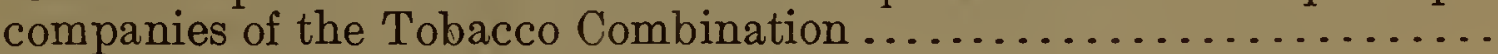

II. Prices and PRofits of Independent ManUfacturing concerns.....

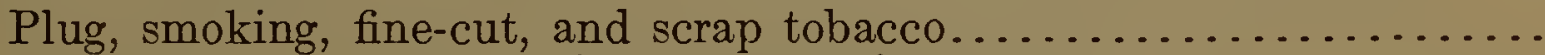

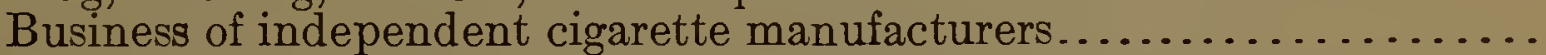

III. Plug and twist tobacco business of the Combination .............

General results of the plug and twist business of the American, Con-

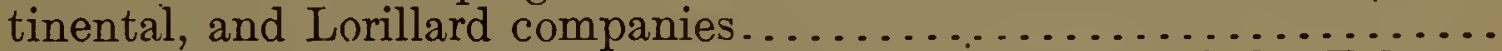

Results of the plug business of subsidiary companies of the Tobacco

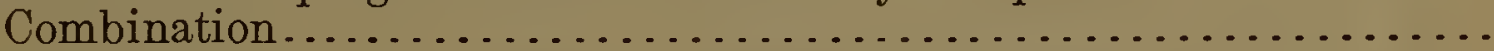

Results of the total plug-tobacco business of the Tobacco Combination...

Prices, costs, and profits of individual brands of plug tobacco made by the American, Continental, and Lorillard companies.............

Prices of plug tobacco before, during, and after the Spanish-war

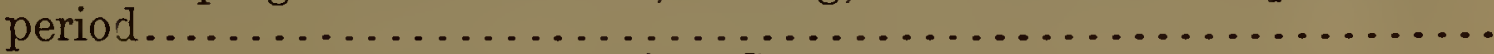

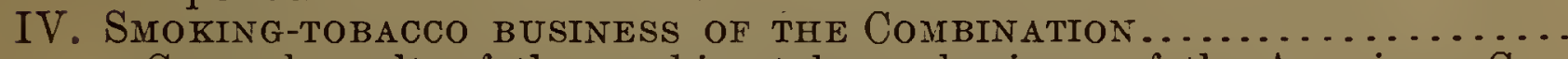

General results of the smoking-tobacco business of the American, Con-

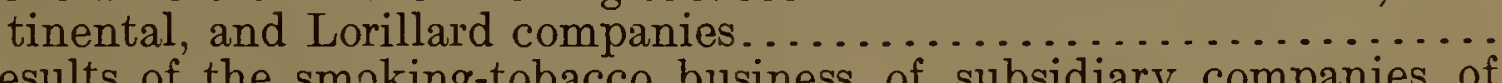

Results of the smoking-tobacco business of subsidiary companies of

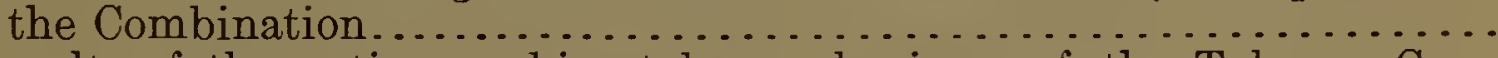

Results of the entire smoking-tobacco business of the Tobacco Com-

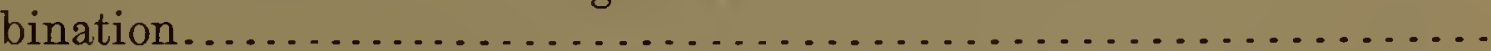

Prices, costs, and profits of individual brands of smoking tobacco made by the American, Continental, and Lorillard companies......

Prices of smoking tobacco before and after the Spanish-war period.....

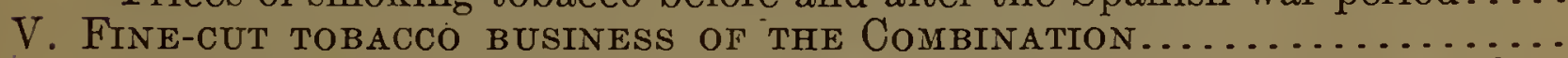

General results of the fine-cut tobacco business of the American, Con-

tinental, and Lorillard companies ................................
Results of the fine-cut tobacco business of the subsidiary concerns of

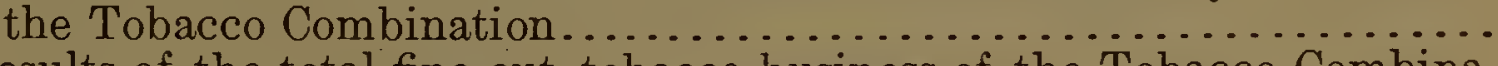

Results of the total fine-cut tobacco business of the Tobacco Combina-

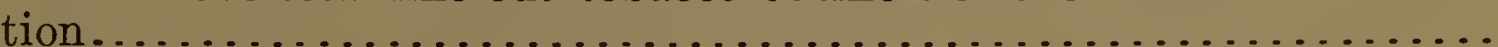

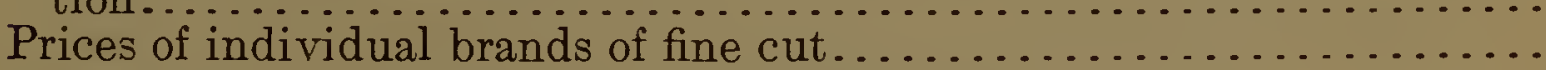

VI. Scrap-tobacco bUSiness of the Combination $\ldots \ldots \ldots \ldots \ldots \ldots \ldots \ldots$

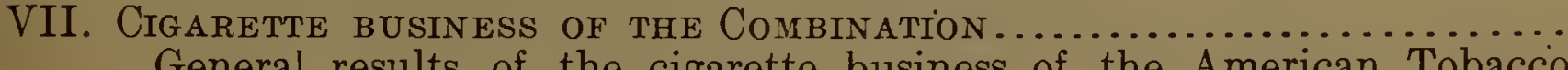

General results of the cigarette business of the American Tobacco Company in the domestic trade ..........................

Results of the cigarette business of subsidiary concerns of the American Tobacco Company ....................................

Combined cigarette business of the American Tobacco. Company and

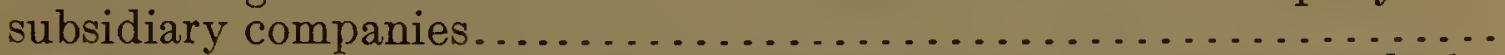

Prices, costs, and profits of individual brands of cigarettes made by the American Tobacco Company.........................

Prices of cigarettes before and after the Spanish-war period........... 
VIII. Little-cigar business of the Combination .......................

General results of the little-cigar business of the American Tobacco

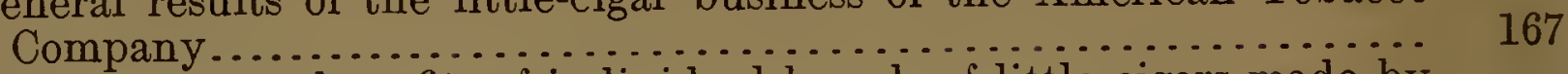

Prices, costs, and profits of individual brands of little cigars made by the American Tobacco Company......................... 170

IX. SNUFF BUSINESS of ThE Combination......................... 173

General results of the business of the American Snuff Company ...... 174

Prices, costs, and profits of individual brands of the American Snuff

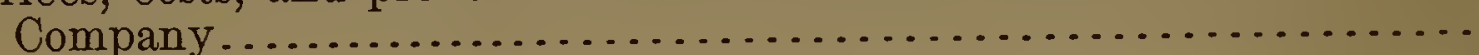




\section{LIST OF TABLE.}

Table 1. Proportion of output of the several classes of tobacco products made

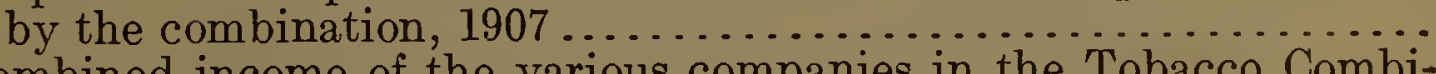

2. Combined income of the various companies in the Tobacco Combination (excluding duplications), $1890-1907 \ldots \ldots \ldots \ldots \ldots \ldots$.

3. American, Continental, and Lorillard companies-Separation of

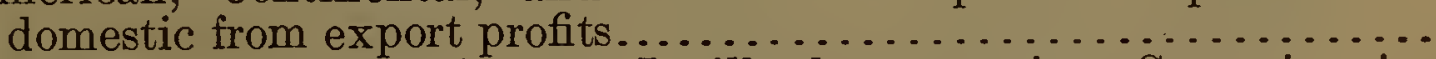

4. American, Continental, and Lorillard companies-Gross invoice value of sales, distinguishing domestic and export business.......

5. American, Continental, and Lorillard companies-Net value of sales and proportion represented by tax, cost, and profit, respectively (domestic business)

6. American, Continental, and Lorillard companies-Net value of sales less tax, and proportion represented by cost and profit respectively

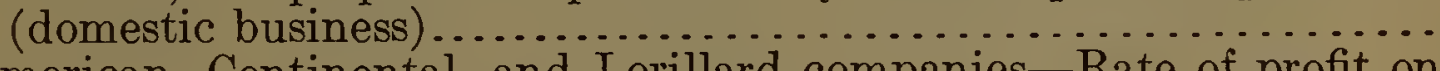

7. American, Continental, and Lorillard companies-Rate of profit on cost for the entire domestic business......................

8. American, Continental, and Lorillard companies - Quantity and net value, less tax, of sales by departments (domestic business)......

9. American, Continental, and Lorillard companies-Net profit by

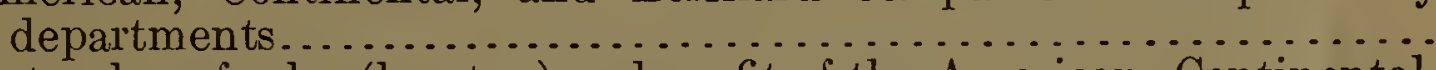

10. Net value of sales (less tax) and profit of the American, Continental,

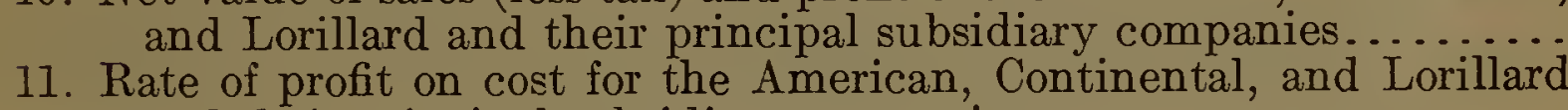

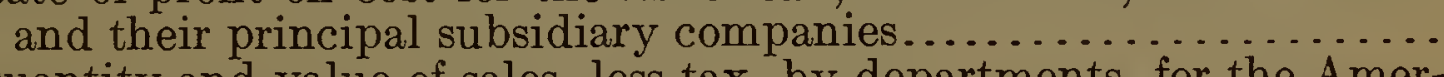

12. Quantity and value of sales, less tax, by departments, for the American, Continental, and Lorillard and their principal subsidiary

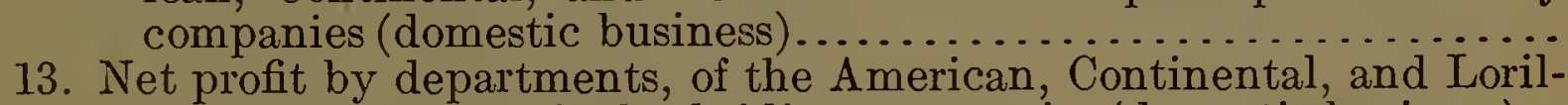
lard and their principal subsidiary companies (domestic business).

14. Average prices and profits, by departments, of the Tobacco Combi-

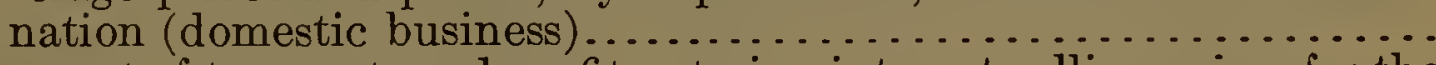

15. Amount of tax, cost, and profit entering into net selling price, for the several departments of the Tobacco Combination (domestic business) ...........................................................

16. Division of net selling price (less tax), between cost and profit, for the several departments of the Tobacco Combination..............

17. Rate of profit on cost (excluding tax) for the several departments

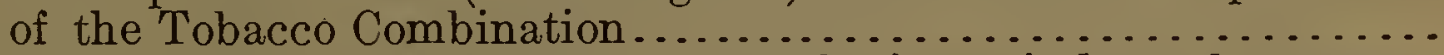

18. Combined value of sales, costs, and profits for 48 independent manufacturers of plug, smoking, fine-cut, and scrap tobacco, $1906 \ldots . .$.

19. Prices, costs, and profits for 45 independent tobacco manufacturing concerns in the domestic trade, by price groups, 1906 .........

20. Prices, costs, and profits for 48 independent manufacturers of plug, smoking, fine-cut, and scrap tobacco, classified according to their principal kind of product, $1906 \ldots \ldots \ldots \ldots \ldots \ldots \ldots \ldots \ldots \ldots$.

21. Smoking tobacco-Prices, costs, and profits for 17 independent manu-

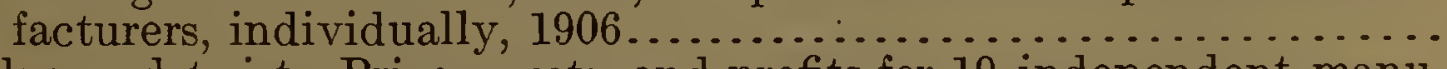

22. Plug and twist-Prices, costs, and profits for 19 independent manufacturers in the domestic trade, individually, $1906 \ldots \ldots \ldots \ldots . . . . .$.

23. Scrap tobacco-Prices, costs, and profits for 6 independent concerns,

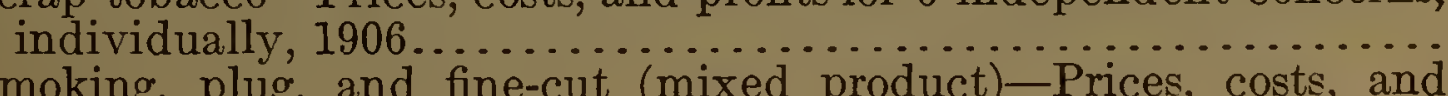

24. Smoking, plug, and fine-cut (mixed product) -Prices, costs, and
profits for 3 independent concerns, individually, $1906 \ldots \ldots \ldots \ldots$

Page. 
Table 25. Cigarettes-Prices, costs, and profits of 10 independent manufac-

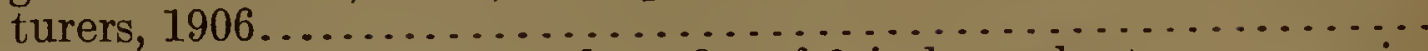

26. Cigarettes-Prices, costs, and profits of 9 independent concerns, in-

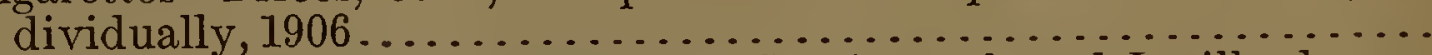

27. Plug and twist tobacco (American, Continental, and Lorillard companies)-Quantity of sales, net value of sales, and net profits (do-

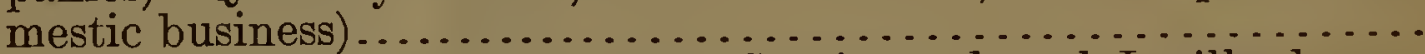

28. Plug and twist tobacco (American, Continental, and Lorillard companies)_-Prices, costs, and profits (domestic business)............

29. Plug and twist tobacco (American, Continental, and Lorillard companies)-Amount of tax, cost, and profit entering into net selling

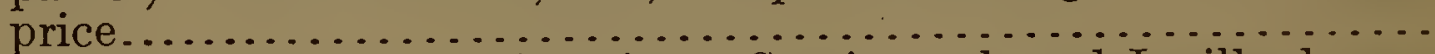

30. Plug and twist tobacco (American, Continental, and Lorillard companies) - Increase in price and increase in cost, 1900-1907 ........

31. Plug and twist tobacco (American, Continental, and Lorillard com-

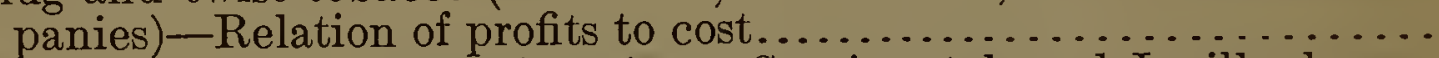

32. Plug and twist tobacco (American, Continental, and Lorillard companies)-Division of net selling price (less tax) between cost and

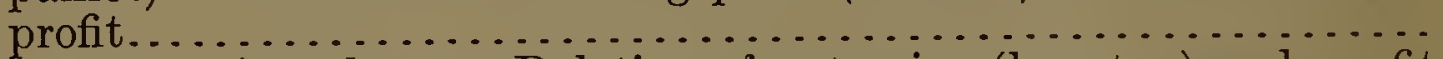

33. Plug and twist tobacco-Relation of net price (less tax) and profit of American, Continental, and Lorillard companies to the proportion of business controlled by Tobacco Combination..............

34. Plug and twist tobacco-Quantity of sales and average price for principal subsidiary companies of American Tobacco Company .......

35. Plug and twist tobacco-Prices, costs, and.profits of principal subsidiary companies of American Tobacco Company (R. J. Reynolds, Nall \& Williams, Spaulding \& Merrick)...............

36. Plug and twist tobacco-Comparison of prices and profits of parent

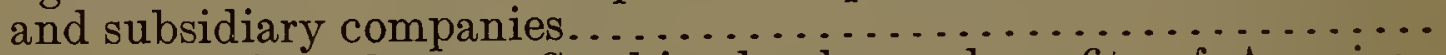

37. Plug and twist tobacco-Combined sales and profits of American Tobacco Company and principal subsidiary companies. .........

38. Plug and twist tobacco-Prices, costs, and profits of the Tobacco

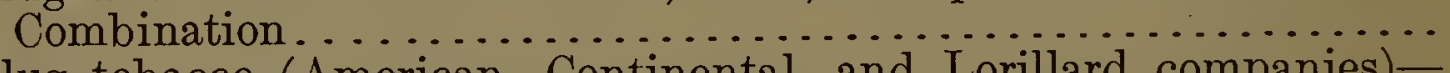

39. Plug tobacco (American, Continental, and Lorillard companies)Prices, costs, and profits for leading individual brands..........

40. Plug tobacco-Prices to consumers and to jobbers for brands now made by American and Lorillard companies (compiled from price

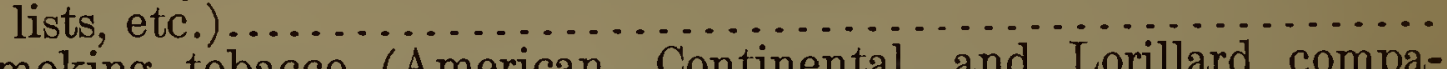

41. Smoking tobacco (American, Continental, and Lorillard companies)-Quantity of sales, net value of sales, and net profits (domes-

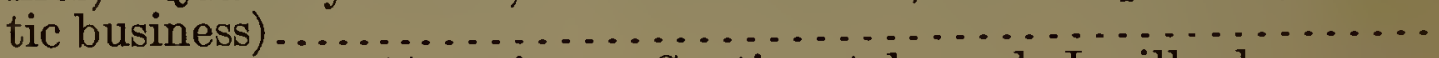

42. Smoking tobacco (American, Continental, and Lorillard companies)-Prices, costs, and profits (domestic business) .............

43. Smoking tobacco (American, Continental, and Lorillard companies)-Amount of tax, cost, and profit entering into net selling

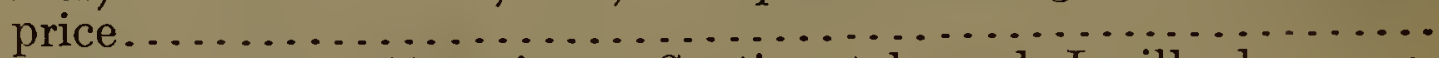

44. Smoking tobacco (American, Continental, and Lorillard companies)-Increase in price and increase in cost, 1899-1907 ..........

45. Smoking tobacco (American, Continental, and Lorillard compa-

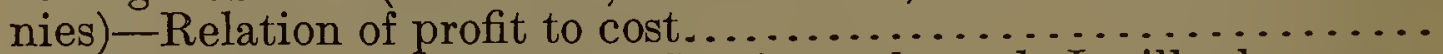

46. Smoking tobacco (American, Continental, and Lorillard companies)-Division of net selling price (less tax) between cost and profit.

47. Smoking tobacco-Relation of net price (less tax) and profit of American, Continental, and Lorillard companies to the proportion of the national output controlled by the Tobacco Combination...........

48. Smoking tobacco-Quantity of sales and average price of principal subsidiary companies making smoking tobacco.................

49. Smoking tobacco-Comparison of prices and profits of parent and

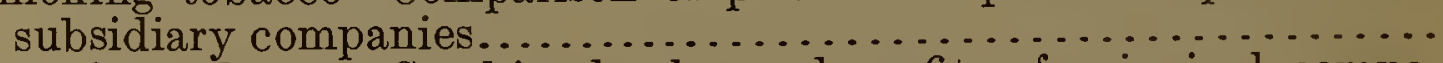

50. Smoking tobacco-Combined sales and profits of principal companies in Tobacco Combination.............................

51. Smoking tobacco-Prices, costs, and profits of the Tobacco Com-

52. Plug-cut smoking tobacco (American, Continental, and Lorillard companies)-Prices, costs, and profits for leading individual brands.

Page. 
Table 53. Long-cut smoking tobacco (American, Continental, and Lorillard companies)-Prices, costs, and profits for leading individual brands.

54. Granulated smoking tobacco (American, Continental, and Lorillard companies)-Prices, costs, and profits for leading individual brands..

55. Smoking tobacco-Consumers' price and average net price to jobbers, including and excluding tax, on brands made by the American Tobacco Company ..................................

56. Fine-cut tobacco (American, Continental, and Lorillard companies)-Quantity of sales, net value of sales, and net profit (domes-

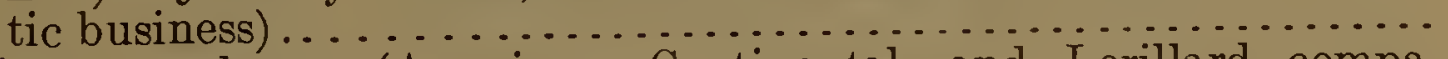

57. Fine-cut tobacco (American, Continental, and Lorillard companies-Prices, costs, and profits in domestic business . ............

58. Fine-cut tobacco (American, Continental, and Lorillard companies)-A mount of tax, cost, and profit entering into net selling price.

59. Fine-cut tobacco (American, Continental, and Lorillard companies)-Increase in price and increase in cost, 1899-1907 . . . . . . . .

60. Fine-cut tobacco (American, Continental, and Lorillard companies)-Relations of profits to costs in domestic business..........

61. Fine-cut tobacco (American, Continental, and Lorillard companies)-Division of net selling price (less tax) between cost and

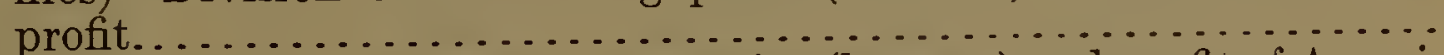

62. Fine-cut tobacco-Relation of net price (less tax) and profit of American, Continental, and Lorillard companies to the proportion of the national output controlled by the Tobacco Combination..........

63. Fine-cut tobacco-Spaulding \& Merrick-Prices, cost and profit....

64. Fine-cut tobacco-Comparison of prices and profits of American, Continental, and Lorillard companies with Spaulding \& Merrick..

65. Fine-cut tobacco-Total sales and profits of Tobacco Combination....

66. Fine-cut tobacco-Prices, costs, and profits of Tobacco Combination..

67. Fine-cut tobacco-Consumers' price and net average price to jobbers for various brands now controlled by Tobacco Combination.......

68. Scrap tobacco-Quantity of sales and average net price for American Tobacco Company and each subsidiary company making scrap....

69. Scrap tobacco-Combined sales and profits of the companies in Tobacco Combination...................................

70. Scrap tobacco-Prices, costs, and profits of Tobacco Combination ..

71. Cigarettes (American Tobacco Company)-Quantity of sales, net value of sales, and net profits (domestic business) .............

72. Cigarettes (American Tobacco Company)-Prices, costs, and profits

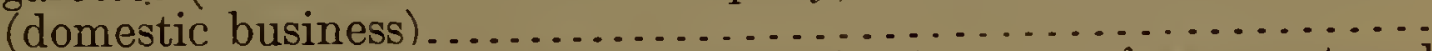

73. Cigarettes (American Tobacco Company)-Amount of tax, cost and profit entering into net selling price......................

74. Cigarettes (American Tobacco Company)-Relation of profit to cost.

75. Cigarettes (American Tobacco Company)-Division of net selling price (less tax) between cost and profit .........................

76. Cigarettes (American Tobacco Company)-Relation of net price (less tax) and profit to the proportion of national output for domestic consumption controlled by the American Tobacco Company......

77. Cigarettes-Quantity and sales and average prices of the several subsidiary companies of the American Tobacco Company ...........

78. Cigarettes-Prices, costs, and profits for the S. Anargyros, Monopol, and John Bollman companies, combined .......................

79. Cigarettes - Quantity of sales, net value of sales, and net profits of the S. Anargyros, Monopo!, and John Bollman companies, combined.

Page.

110

113

118

125

126

128

80. Cigarettes-Amount of tax, cost, and profit entering into net selling price for the S. Anargyros, Monopol, and John Bollman companies,

81. Cigarettes-Relation of profit to cost for the $\mathrm{S}$. Anargyros, Monopol,

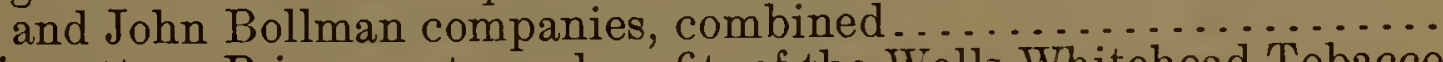

82. Cigarettes-Prices, costs, and profits of the Wells-Whitehead Tobacco

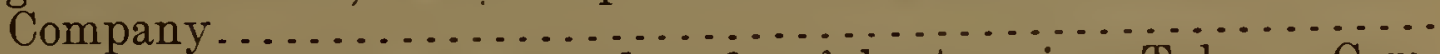

83. Cigarettes-Combined sales and profits of the American Tobacco Company and its principal subsidiary companies.................

84. Cigarettes (American Tobacco Company)-Prices, costs, and profits

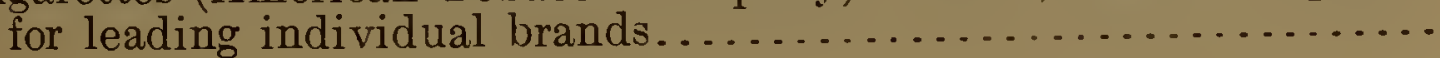


Table 85. Cigarettes-Average net prices to consumers and jobbers on brands of cigarettes made by the American Tobacco Company (compiled from price lists, etc.) .................................

86. Little cigars (American Tobacco Company)-Quantity of sales, net value of sales, and profits (domestic business) .................

87. Little cigars (American Tobacco Company)-Prices, costs, and profits

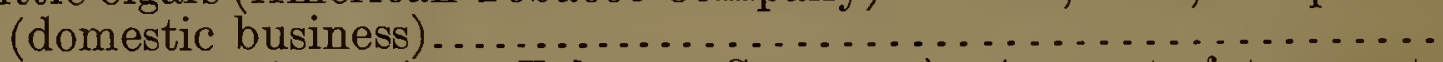

88. Little cigars (American Tobacco Company)-Amount of tax, cost, and profit entering into net selling price....................

89. Little cigars (American Tobacco Company)-Relation of profit to

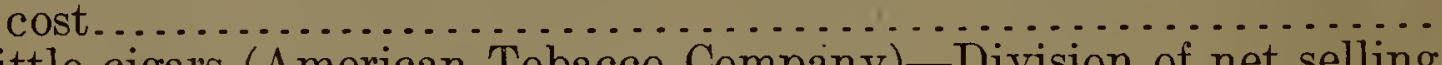

90. Little cigars (American Tobacco Company)-Division of net selling

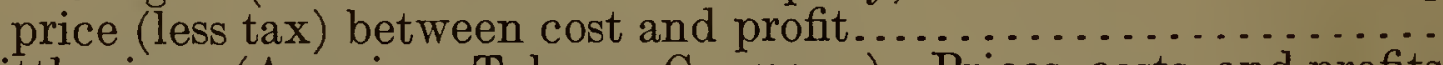

91. Little cigars (American Tobacco Company)-Prices, costs, and profits for leading individual brands...........................

92. Snuff-Profits of American Snuff Company, 1900 to $1907 . \ldots . \ldots$.

93. Snuff (American Snuff Company)-Quantity of sales, net value of

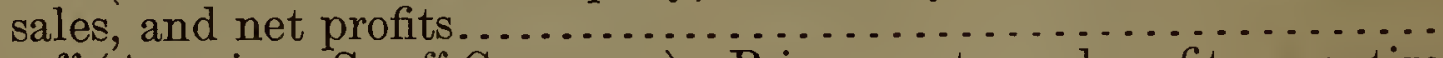

94. Snuff (American Snuff Company)-Prices, costs, and profits on entire

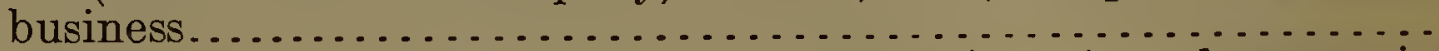

95. Snuff (American Snuff Company) - Increase in price, decrease in

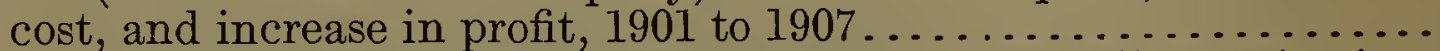

96. Snuff (American Snuff Company)-Division of net selling price into

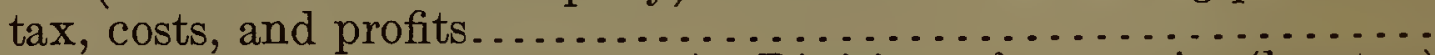

97. Snuff (American Snuff Company)-Division of net price (less tax) between costs and profit..................................

98. Snuff (American Snuff Company)-Relation of profits to cost.......

99. Snuff (American Snuff Company) - Relation of net price (less tax) and profit to proportion of national output controlled...............

100. Snuff (American Snuff Company)-Prices, costs, and profits of representative brands of strong Scotch snuff.......................

101. Snuff (American Snuff Company) - Prices, costs, and profits of representative brands of sweet Scotch and salt snuff...................

102. Snuff (American Snuff Company) - Prices, costs, and profits of repre-

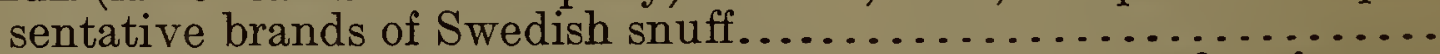

103. Snuff (American Snuff Company) - Prices, costs, and profits of representative brands of Maccaboy snuff.........................

Page. 


\section{LIST OF DIAGRAMS.}

1. Plug and twist tobacco-Prices, costs, and profits of theAmerican, Continental, and Lorillard companies and of the entire Tobacco Combination....

2. Plug tobacco (American, Continental, and Lorillard companies)-Prices,

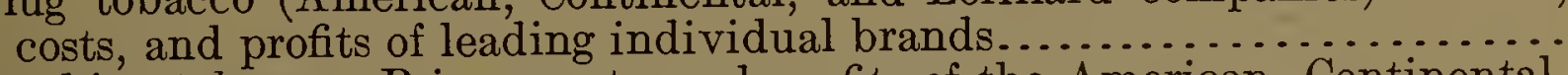

3. Smoking tobacco-Prices, costs, and profits of the American, Continental, and Lorillard companies and of the entire Tobacco Combination .........

4. Plug-cut smoking tobacco (American, Continental, and Lorillard companies) - Prices, costs, and profits of leading individual brands..........

5. Long-cut smoking tobacco (American, Continental, and Lorillard companies)-Prices, costs, and profits of leading individual brands ..........

6. Granulated smoking tobacco (American, Continental, and Lorillard companies)-Prices, costs, and profits of leading individual brands..........

7. Fine-cut tobacco-Prices, costs, and profits of the American, Continental, and Lorillard companies and of the entire Combination................

8. Scrap tobacco-Prices, costs, and profits of the Combination...............

9. Cigarettes (American Tobacco Company) - Prices, costs, and profits............

10. Cigarettes (American Tobacco Company) -Prices, costs, and profits of lead-

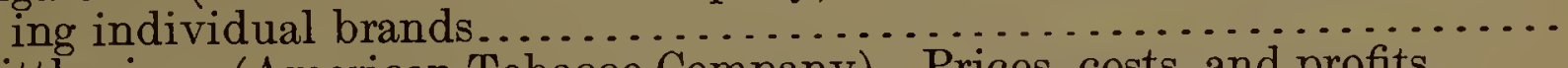

11. Little cigars (American Tobacco Company) - Prices, costs, and profits........

12. Little cigars (American Tobacco Company)-Prices, costs, and profits of

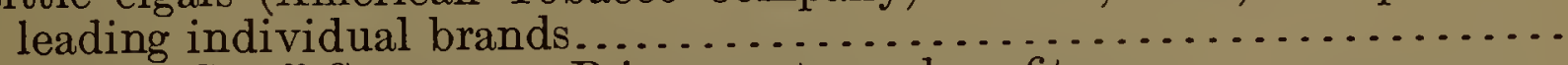

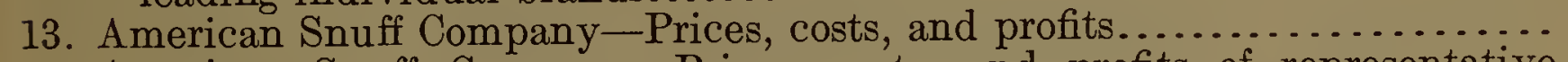

14. American Snuff Company-Prices, costs, and profits of representative

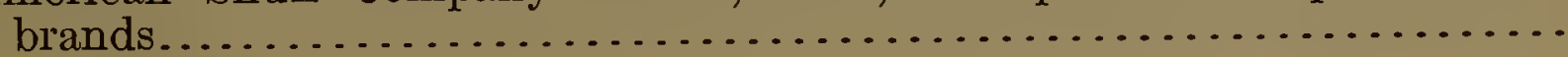





\section{PRICES OF TOBACCO AND OPERATIONS OF CORPORATIONS AND. OTHERS DEALING IN THE SAME.}

\section{INTRODUCTION.}

This report is presented in accordance with Senate Resolution 44, adopted May 14, 1909, which was as follows:

Resolved, That the President be requested to transmit to the Senate all information collected by the Department of Commerce and Labor affecting the prices of tobacco, and the operations of corporations and others dealing in the same.

The Bureau of Corporations has already submitted to the President and by his direction publishèd a report covering part of the subjectmatter called for in this resolution. This report is entitled, "Report of the Commissioner of Corporations on the Tobacco Industry: Part I, Position of the Tobacco Combination in the Industry." It contains a history of the organization of the American Tobacco Company and the various other companies which from time to time have been organized in affiliation with it and which together constitute what may be conveniently termed "The Tobacco Combination." It also contains a description of the present organization of the companies in the combination and of their business, and a description of the growth of their output, showing what proportion of the total output of the country the Combination has controlled from year to year. The Bureau has in preparation a complete report covering the subject of the prices of tobacco and the operations of corporations and others dealing in the same, the information for which has been secured in accordance with the law creating the Bureau. It is impossible to transmit to the Senate immediately the full results of this investigation and the entire body of material collected, but the more important material, showing in substance the results of the investigation, is included in the present preliminary report.

Any consideration of the subject of the tobacco industry during recent years is necessarily largely a consideration of the relation of the Tobacco Combination to the industry. This is evident from the fact that the Tobacco Combination controls substantially threefourths of the business of manufacturing tobacco, other than cigars, in the United States. Of course, the independent business, even excluding that in cigars, is large in absolute amount, the value of the output of independent concerns being probably in the neighborhood of $\$ 35,000,000$ per year at the present time. The independent business is, however, divided among a large number of concerns (some few of which are, however, of considerable size), which makes an analysis of the results much more difficult than in the case of the Tobacco Combination, the accounts of all the concerns of which are kept in substantially a uniform manner and for the most part at one 
central office. The American Tobacco Company and other companies in the combination have given the Bureau full and ready access to their books and records, so that very precise information regarding their business is available. Most of the other important concerns in the tobacco-manufacturing industry have also opened their books and records to the Bureau of Corporations, but in many cases these records are not available save for the most recent years, and in many cases they are not kept in such a manner as to show with accuracy the prices, costs, and profits in the separate branches of the industry. A large proportion of the independent concerns manufacture two or three different classes of tobacco, and the average results of the entire business, which are often all that can be secured, may furnish comparatively little information regarding the results of the individual departments.

The Tobacco Combination is, in ordinary speech, designated as the "American Tobacco Company." As a matter of fact, the American Tobacco Company is the central and dominant factor in the Combination at the present time; but the business of the American Tobacco Company, even taking into account the dividends which it receives from subsidiary corporations, does not represent the entire business which is controlled by the companies which act in unison under the general leadership of the American Tobacco Company. Consequently the term "Tobacco Combination" is a more accurate description than the term "American Tobacco Company," and it is used in this report where reference is made to the business of the affiliated companies as a whole.

SUMMARY OF HISTORY AND BUSINESS OF THE TOBACCO COMBINATION.

It will be advantageous, at this point, briefly to summarize the information already obtained, as published in the report of the Bureau of Corporations above mentioned, regarding the history and organization of the Tobacco Combination and its position in the industry.

The American Tobacco Company, the original corporation around which the combination has since centered, was organized in 1890 . It took in the principal cigarette manufacturers of the country, and from the outset had a large degree of monopoly in the cigarette business.

The American Tobacco Company during the nineties built up a very considerable business in plug tobacco and smoking tobacco. In December, 1898, the Continental Tobacco Company was organized. Thereupon the American Tobacco Company transferred its plug tobacco business to the Continental Tobacco Company, which, at or about the same time, took in a number of the other leading manufacturers of plug tobacco. The Continental and the American companies together also possessed a considerable proportion of the business of manufacturing smoking and fine-cut tobacco. The American held stock in the Continental and the same men controlled both companies.

In March, 1900, the American Snuff Company was organized. It took over the snuff business of the American and Continental companies, and also took in other leading snuff manufacturers, including the Atlantic Snuff Company, a combination which had been formed in 1898 independently of the American Tobacco Company interests. 
The American Tobacco Company (including the Continental and Lorillard companies) received nearly half of the stock issued by the American Snuff Company, and the latter became the snuff branch of the Tobacco Combination.

The American Cigar Company was organized in January, 1901. The American and Continental companies transferred to it their cigar business, which was comparatively small, and some other manufacturers were also taken in. The greater part of the stock was held by the American and Continental companies. This company has never secured any such proportion of the cigar business as the other companies in the combination control in the other branches of tobacco manufacture.

In June, 1901, the Consolidated Tobacco Company was organized by the leading men in the directorates of the American and Continental companies. This was a holding company and did not itself manufacture tobacco. It took over nearly all of the common stock of the American and Continental companies, issuing its bonds in exchange therefor at the rate of $\$ 200$ for $\$ 100$ for the common stock of the American, and of $\$ 100$ for $\$ 100$ for the common stock of the Continental. The preferred stocks of the American and Continental companies, for the most part, remained in the hands of the public. The Consolidated issued $\$ 30,000,000$ of stock, subsequently increased to $\$ 40,000,000$, which was paid in cash. This arrangement concentrated the control of these two great companies in the hands of the Consolidated Tobacco Company, whose stock was held, for the most part, by a very limited number of men.

In October, 1904, the American, Continental and Consolidated companies were merged under the name of American Tobacco Company. This company gave its common stock of $\$ 40,242,400$ almost wholly in exchange at par for the $\$ 40,000,000$ stock of the Consolidated, and as the preferred stock of the reorganized company has no voting power the control of the company rests in the same limited body of men who had held the stock of the Consolidated.

The reorganized American Tobacco Company, by stock ownership, directly or indirectly dominates all the companies comprising the Tobacco Combination.

It is itself a large manufacturing concern, its output being chiefly cigarettes, little cigars, plug, smoking, and fine-cut tobacco, Subsidiary to the American Tobacco Company are three other important combinations: (1) The American Cigar Company, much the greater part of whose stock is held by the American Tobacco Company. (2) The American Snuff Company, not quite half of whose stock is owned by the American Tobacco Company, but which operates.in entire unison with that company. (3) The British-American Tobacco Company, approximately two-thirds of the stock of which is held by the American Tobacco Company, most of the remainder being held by the Imperial Tobacco Company, a British combination. The BritishAmerican Company conducts the export and foreign business of the combination.

Each of these four combinations--the American Tobacco Company, American Cigar Company, American Snuff Company, and BritishAmerican Tobacco Company-holds stock in a large number of subsidiary corporations either engaged in the same lines of business as the parent company or in lines contributory to that business. In 
1906 the Tobacco Combination consisted of no less than 86 corporations doing business in the United States and its dependencies and in Cuba, in addition to various corporations controlled by the BritishAmerican Tobacco Company and doing business exclusively in foreign countries. Most of the subsidiary corporations are engaged in the manufacture of some class of tobacco, but a considerable number are engaged in selling at wholesale or retail; others manufacture articles contributory to tobacco manufacture, such as licorice, containers of various sorts, etc.; others manufacture or exploit patents for machinery; others handle by-products of the tobacco business; a. few are engaged in the production of leaf tobacco (in Porto Rico and Cuba only); and two or three handle advertising schemes, manufacture pipes and smokers' supplies, etc.

The Tobacco Combination manufactures much the greater part of all classes of tobacco in the United States, except cigars. The following statement shows, for 1907, the total output of the several classes of tobacco products, the output of the Combination, and the proportion manufactured by the Combination. The proportion of the plug, twist, and smoking tobacco business in 1907 was less than in 1906 .

TABLE 1.-Proportion of output of the several classes of tobacco products made by the Combination, $190 \%$.

\begin{tabular}{|c|c|c|c|}
\hline Class of products. & $\begin{array}{l}\text { Total output } \\
\text { of the United } \\
\text { States. }\end{array}$ & $\begin{array}{l}\text { Output of the } \\
\text { Combination. }\end{array}$ & $\begin{array}{c}\text { Per cent } \\
\text { made by the } \\
\text { Combination. }\end{array}$ \\
\hline Cigarettes................ & $5,270,556,938$ & $3,975,809,425$ & 75.4 \\
\hline Little cigars.................. & $1,074,083,976$ & $975,692,600$ & 90.8 \\
\hline Cigars............................. & $7,302,029,811$ & $1,057,822,004$ & 14.5 \\
\hline ...........pounds. & $172,002,513$ & $132,484,125$ & 77.0 \\
\hline Smoking.......... & $179,172,512$ & $123,412,393$ & 68.9 \\
\hline Fine cut......... & $12,457,917$ & $10,135,740$ & 81.4 \\
\hline Snuff........... & $23,305,340$ & $22,307,105$ & 95.7 \\
\hline Total manufactured tobacco and snuff........ do.. & $386,938,282$ & $288,339,363$ & 74.5 \\
\hline
\end{tabular}




\section{GENERAL SURVEY OF PRICES AND PROFITS OF THE TOBACCO COMBINATION.}

PROFITS OF THE PRINCIPAL COMPANIES IN THE TOBACCO COMBINATION.

A complete presentation of the profits of the Tobacco Combination, as a whole, is impossible at the present time, owing to the absence of information regarding the profits of a few of the subsidiary companies. Although, since the merger of 1904, the American Tobacco Company directly or indirectly controls all the companies in the Combination, the income account of the American Tobacco Company alone would not show the entire profits of the Combination. It would show only the income derived from its own manufacturing and selling business, plus the dividends or interest received by it on securities of subsidiary companies held by it or the interest on loans made to them. Although the American Tobacco Company in many cases holds the entire stock of subsidiary corporations there are other cases in which it holds only a controlling interest, and the dividends received by the American on such stock do not represent the entire dividends paid by the company. Moreover, the dividends paid by subsidiary companies are in many cases decidedly less than their net earnings, part of the earnings from year to year being retained and added to the investment in the business. Since in all cases the subsidiary compa-. nies, even when part of their stock is held by individuals, are completely dominated and controlled by the Combination, it is proper to consider the entire net earnings of all the companies, even though a part of them may not come to the treasury of the American Tobacco Company, as the joint earnings of the Combination, and the real significance of the Combination's business can only be determined by considering all of the companies together.

In order to show correctly the earnings of the Combination the earnings of the American and Continental companies from their own manufacturing business should be presented, and to these should be added the earnings of each of the subsidiary companies, no account whatever being taken of intercompany payments. On account of the absence of full information regairding the profits of some of the subsidiary companies this calculation can not be made completely. The figures for most of the leading subsidiary companies are, however, available, and an approximately complete total of the earnings of the companies in the corporation can therefore be arrived at. In those cases where no figures of the earnings of a subsidiary company are available the dividends which it has paid to the parent company may be substituted for the full figure of earnings in arriving at the approximate total.

In presenting the data for the earnings of the American and Continental companies from the business which they directly operate, it is desirable to include therewith the business of the P. Lorillard Company. This company occupies a somewhat different position from the other subsidiary companies, in that it is treated as a mere branch of the American (formerly of the Continental). The Lorillard Com- 
pany does not sell its own products, but turns them over to the American Tobacco Company, which acts as its selling agent, so that in order to obtain the total profit on the output sold by the American Tobacco Company it is necessary to include the profit of the Lorillard Company. Calculations of the profit in different branches of the business and the prices and profits per unit of output therefore require a combination of the figures of the Lorillard Company with those of the American and Continental.

For the purpose of analyses subsequently to be made regarding the business of individual subsidiary companies, it is necessary to take into account the fact that some of these companies employ in their business large sums of money borrowed from the parent companythe American or the Continental. In other words, the assets on which the business is conducted include not merely the assets directly owned by the subsidiary company (its capital plus its surplus), but also a large amount of money turned over to its use by the controlling company. Were the profit of such a subsidiary company compared simply with the assets which it directly owned, the rate of return would in some cases appear far higher than the true rate obtained on the assets actually employed in the business. Of course, if the money borrowed from the parent company in such cases is to be considered as part of the assets used in the business the earnings of the subsidiary company must be calculated without any deduction of the interest paid to the parent company. Conversely, of course, the income of the company which makes the loan must represent only its own business and must exclude interest received on such loans.

What holds true in regard to the loans made by the American and Continental companies to their subsidiary companies also holds true of the loans made by the Consolidated Tobacco Company to the American and Continental companies themselves. The money thus borrowed was added to the assets used in the business, and the rate of profit can properly be judged only by taking the total of the assets, including this borrowed money, and comparing it with the earnings without making any deduction of the interest paid on the borrowed money. In the statement of the profits of the American, Continental, and Lorillard companies and of the subsidiary companies presented in the table below, therefore, no deduction is made from the gross earnings of any company on account of the interest which it paid on borrowed money used in its own business. Obviously the total income of the Combination would appear the same (except so far as the interest on the small amount of money borrowed from outside sources is concerned) were the interest payments made by a given company deducted from its earnings and included with the earnings of the lending company; but such a procedure would not permit a satisfactory presentation of the real facts in regard to the business of individual companies.

It should be clearly understood in considering all the tables showing the profits of the Tobacco Combination that the profits include not only interest on the investment made by the companies out of their own capital and surplus, but also interest on borrowed money (other than ordinary current accounts payable) used in the business. The rates of profit as calculated in the various tables thus include both profit and interest. This is, however, the ordinary method of business concerns in calculating their profit, save only that interest on money borrowed from outside sources (as distinguished frominterest . 
on the capital directly invested by the concerns) is ordinarily deducted from income before the rate of profit is computed. As already explained, the peculiar relations of the companies in the Tobacco Combination to one another with respect to loans render necessary the practice here adopted in computing the rate of profit. While for some of the individual subsidiary companies the rate of profit would appear somewhat different if interest on borrowed money were deducted, for the parent companies, such as the American and Continental, and for the Combination as a whole, this item of interest on borrowed money is small as compared with the total profits.

It should be noted at this point that the data presented in this report regarding prices and profits not only of the American Tobacco Company and its constituent companies, but of independent concerns, end with the year 1907. For convenience conditions as they existed in 1907 are sometimes referred to herein as "present conditions." There have, however, been some changes in conditions since that time which particularly affect the situation in the present year, 1909. The price of certain kinds of leaf tobacco was very materially advanced during 1908, and this increase, while it had little effect upon the cost of production of tobacco manufactured during that year, has undoubtedly affected the cost of production of certain kinds of tobacco for the year 1909. In particular, the price of Burley leaf tobacco, which is largely used in manufacturing plug tobacco, was about twice as high in 1908 as it had been for some years before. The Bureau has obtained no information as to the effect which the increase in cost of tobacco products resulting from this advance in the price of leaf tobacco has had upon the prices of such tobacco products or upon the profits of the manufacturers.

Table 2 shows the combined earnings of the companies in the Combination, so far as ascertained, for the years 1890 to 1907 .

The first column shows the earnings of the American, Continental, and Lorillard companies from their own manufacturing and selling business. It includes no income derived from stock holdings or from interest on money loaned to subsidiary companies, and it has been increased by the amount of the interest paid by the American, Continental, and Lorillard companies on money borrowed by them. The losses of the American and Continental companies as agents for the American Cigar Company from 1902 to 1905 are here excluded. (See Table 2.)

The second column of the table shows the combined earnings of those companies subsidiary to the American, Continental, and Lorillard companies for which the information is available, not, however, including the American Snuff and American Cigar companies, the figures for which are given separately in the next two columns. For the year 1907 the figures of profit of subsidiary companies include 19 companies and cover all the principal companies other than those just mentioned, engaged in the domestic business. It does not include the British-American Tobacco Company. For the earlier years the number of subsidiary companies covered by this column is less, either because they were not then controlled by the combination or because specific data regarding their profits are not available.

The third column in the table covers the dividends received by the American, Continental, and Consolidated tobacco companies from those subsidiary companies for which separate income accounts have not been secured. In the absence of figures of earnings for any given 
subsidiary company, the amount of dividends which it has paid on the stock held by the American, Continental, and Consolidated companies has been included in this column. The most important factor contributing to this column of dividends in the years since 1904 is the British-American Tobacco Company, which is a British corporation for which the Bureau of Corporations has secured no financial reports. The dividends received from the British-American Tobacco Company by the American Tobacco Company amounted in 1907 to $\$ 2,392,053.87$, or more than 85 per cent of the total amount in this column for that year. As the American Tobacco Company owns only about two-thirds of the stock of the British-American Tobacco Company, and as the profits of the latter probably considerably exceed its dividends, it will be seen that, if the actual earnings of the British-American Tobacco Company were available, the total earnings of the combination would be considerably increased, perhaps by two or three million dollars for 1907. This column also includes dividends received by the American, Continental, and Consolidated companies from stock which they held in the Imperial Tobacco Company, a British corporation. The stocks held by the American companies in this British combination are a comparatively small minority interest, and the Imperial can not be considered a part of the American Tobacco Combination; so that it would be improper to add its entire earnings to the earnings of the companies covered by this table.

The fourth column shows the profits of the American Snuff Company. These figures represent the earnings of the American Snuff Company from the business which it directly operates, including the business of the Garrett and Weyman companies, which, although separate corporate existence was maintained until 1907, were operated practically as branches, and for which the actual profits are available. To these direct profits are added the dividends received from two or three minor snuff companies in which the American Snuff Company holds stock; the actual profits of these minor companies have not been ascertained.

The fifth column shows the profits of the American Cigar Company, organized in 1901. It should be particularly noted that for the years 1902 to 1905 , in order to show correctly the results of the cigar business of the Combination, the business of the American and Continental tobacco companies as agents for the American Cigar Company has been combined with the direct business of the American Cigar Company. During these years the American and Continental companies, which controlled the American Cigar Company and held the greater part of its stock, aided that company by handling practically all of its product through their established selling departments, and they, as such agents, incurred very large losses. Since they owned nearly all of the stock of the American Cigar Company, it was immaterial to the American and Continental companies whether these losses appeared in their own income accounts or in that of the American Cigar Company. A correct presentation of the different branches of the business, however, requires the elimination of these losses from the income accounts of the American and Continental companies and their inclusion with that of the American Cigar Company. On its cigar business as a whole the Combination lost large sums in 1902 and 1903, while, by reason of the losses of the American and Continental companies in handling the product of the American 
Cigar Company, the profits of the cigar business of the Combination in 1904 and 1905 were much less than the reported profits of the American Cigar Company.

It should be noted, however, that the profits of the American Cigar Company as given in the table do not include the entire profits or losses of the Combination on the cigar business. The American Cigar Company holds stock in a considerable number of subsidiary corporations, the most important of which is the Havana Tobacco Company, operating in Cuba. The income accounts of these subsidiary corporations have not been obtained, and the table includes only the dividends or interest on securities held by the American Cigar Company in these companies. These companies have not, however, been particularly profitable, and were their income accounts available they would add little to the combined income of the cigar business as given in the table and might in some years reduce it or increase the losses.

The last column shows the sum of the figures in the preceding columns and gives approximately the entire earnings of the Tobacco Combination, but the figures in each year would be somewhat greater if the actual earnings of each and every company were availableprobably in the more recent years two or three millions more.

TABLE 2.-Combined income of the various companies in the Tobacco Combination (excluding duplications), 1890-190\%.

\begin{tabular}{|c|c|c|c|c|c|c|}
\hline \multirow[b]{2}{*}{ Year. } & \multicolumn{3}{|c|}{$\begin{array}{l}\text { American, Continental, and Lorillard } \\
\text { companies. }\end{array}$} & \multirow[b]{2}{*}{$\begin{array}{l}\text { American } \\
\text { Snuff Com- } \\
\text { pany. }\end{array}$} & \multirow[b]{2}{*}{$\begin{array}{l}\text { American } \\
\text { Cigar Com- } \\
\text { pany.b }\end{array}$} & \multirow[b]{2}{*}{ Grand total. } \\
\hline & $\begin{array}{c}\text { Earnings of } \\
\text { own business. } a\end{array}$ & $\begin{array}{c}\text { Earnings of } \\
\text { principal } \\
\text { subsidiary } \\
\text { companies. }\end{array}$ & $\begin{array}{l}\text { Dividends } \\
\text { and interest } \\
\text { from com- } \\
\text { panies not } \\
\text { covered by } \\
\text { preceding. }\end{array}$ & & & \\
\hline 1890. & $\$ 2,511,180.12$ & & & & & $\$ 2,511,180.12$ \\
\hline $1891 .$. & $4,396,794.93$ & & & & & $4,396,794.93$ \\
\hline 1892. & $4,739,301.65$ & & & & & $4,739,301.65$ \\
\hline 1893. & $4,334,467.34$ & & & & & $4,334,467.34$ \\
\hline 1894. & $5,065,493.61$ & & $\$ 3,922.36$ & & & $5,069,415.97$ \\
\hline 1895. & $3,917,908.78$ & & $53,612.77$ & & & $3,971,521.55$ \\
\hline 1896. & $3,412,899.97$ & & $180,297.02$ & & & $3,593,196.99$ \\
\hline 1897. & $3,996,115.21$ & & $183,345.45$ & & & $4,179,460.66$ \\
\hline 1898. & $3,584,785.51$ & & $232,983.29$ & & & $3,817,768.80$ \\
\hline 1899. & $6,473,726.65$ & $\$ 235,215.79$ & $495,608.48$ & & & $7,204,550.92$ \\
\hline 1900. & $9,218,273.64$ & $683,237.64$ & $296,943.39$ & $\$ 531,667.92$ & - 10 & $10,730,122.59$ \\
\hline 1901. & $12,310,072.20$ & $1,524,860.89$ & $321,925.00$ & $1,066,605.31$ & $\$ 157,259.65$ & $15,380,723.05$ \\
\hline 1902. & $15,744,700.21$ & $2,470,699.59$ & $1,129,374.73$ & $1,739,616.84$ & $* 3,055,251.44$ & $18,029,139.93$ \\
\hline 1903. & $18,815,116.93$ & $3,278,500.73$ & $1,506,064.92$ & $2,177,827.75$ & $* 1,228,232.40$ & $24,549,277.93$ \\
\hline 1904 & $16,229,579.36$ & $4,905,610.18$ & $1,912,885.53$ & $2,458,419.37$ & $460,329.54$ & $25,966,823.98$ \\
\hline 1905. & $18,347,881.30$ & $5,715,046.58$ & $2,820,300.07$ & $3,232,809.70$ & $1,330,225.27$ & $31,446,262.92$ \\
\hline 1906. & $20,856,677.48$ & $6,638,629.75$ & $2,333,496.41$ & $3,808,333.62$ & $3,082,378.86$ & $36,719,516.12$ \\
\hline 1907. & $19,246,729.78$ & $8,151,145.06$ & $2,776,133.71$ & $3,539,048.92$ & $2,287,098.28$ & $36,000,155.75$ \\
\hline
\end{tabular}

$a$ Excluding business of American and Continental Tobacco companies as agents of the American Cigar Company for years 1902 to 1905 , inclusive.

$b$ Including business of American and Continental Tobacco companies as agents of the American Cigar Company for years 1902 to 1905, inclusive.

* Loss. 
The figures in this table for the period from 1890 to 1898 cover only the American Tobacco Company and the four or five relatively unimportant foreign companies in which the American at that time held stock. The profits were mainly from the cigarette business. The decline in the total profits after 1894 was due to large losses in the plug-tobacco branch of the company's business.

Beginning with 1899, the aggregate earnings shown in the table represent a much wider range and volume of business and were based on a much greater amount of assets than during the preceding years, and no comparison of the movement of the total earnings from one period to the other can be made without bearing these facts in mind. Even since 1899 there has been added, from time to time, to the aggregate income of the Combination an income from new concerns, which were either bought up or in which stock interests were secured, so that the increase in profits since that time does not represent merely the growth of the volume of output or the increase in the rate of profit of the Combination on business which it possessed in 1899. Nevertheless, a large part of the increase in the profit is due either to an increased rate of profit per unit of output or to an increase in the volume of output of plants which were already controlled at the beginning of this period of the Combination's history.

It will be seen that there was a very rapid increase in the aggregate profit of the Combination from 1899 to 1903 . The combined profit had been approximately $\$ 7,204,550.92$ in the former year and was approximately $\$ 24,549,277.93$ in the latter year, an increase of more than threefold. There was a moderate increase in the profit from 1903 to 1904, and a very marked increase from 1904 to 1906 . The profits in the latter year reached their maximum, approximately $\$ 36,719,516.12$, or nearly 5.0 per cent more than in 1903 , and this despite the fact that there had been very little addition to the number of companies controlled by the Combination and very little acquisition of additional business by purchase from outside concerns. The profits in 1907 were a trifle less than in 1906 .

It will be seen from this table that, although the profits of the manufacturing business of the American, Continental, and Lorillard companies have increased very greatly, the income of the subsidiary corporations in the Combination has increased much more rapidly; whereas in 1899 the profits of the manufacturing business of the American, Continental, and Lorillard companies constituted practically 90 per cent of the total profits of the Combination, in 1907 the direct profits of those three companies constituted less than 55 per cent of the total profits of the Combination.

The growth in the profits derived from subsidiary companies is largely due to the addition to the number of subsidiary companies controlled, although it is in considerable part due to an increase in their volume of business and rate of profit per unit of output after they entered the Combination. Beginning about the year 1900, as more fully explained in the already published Report on the history of the Tobacco Combination, the policy of the American Tobacco Company and the affiliated combinations has been more and more to add to their control of the tobacco business by acquiring stocks in subsidiary companies rather than by buying up directly the assets and business of formerly independent concerns. Some of the subsidiary companies which have been added to the Combination during 
this period were companies which were organized at the instance of the American and Continental companies, and which took over part of the business which the American and Continental had formerly possessed, at the same time taking in the business of some outside concerns-such, for example, as the Snuff and Cigar companies. In other cases, the new subsidiary companies were companies which had formerly been independent, control of which was acquired by stock purchase. In still other cases, formerly independent concerns, operated by individuals or firms, were acquired by the device of organizing a corporation for taking over their property, the stock of such corporation being acquired by the controlling company.

There would be no significance whatever in comparing the profits of the Tobacco Combination, as shown in the above table, with the reported capitalization of the Combination or with the reported assets. In the case of the principal companies in the Tobacco Combination, it has been the practice to distinguish the tangible assets from the "patents, trade-marks, and good will," or intangible assets, in the private accounts, although in the published financial reports the intangible assets are combined with the plant assets. The item of patents, trade-marks, and good will has been used in the accounts to balance any deficiency between the tangible assets and the amount of capital securities issued, and consequently has varied from time to time with the changes in the capitalization whether by the issue of additional securities without an increase of assets, or by a reduction of the securities without a change in the actual assets.

The importance of the item of good will, or intangible assets, as it appears on the books of the American Tobacco Company, including the Lorillard company, at the present time may be judged by the fact that of the total assets of that company, other than the $\$ 107,000,000$ of stock holdings and loans to subsidiary companies-in other words, of the total assets in the direct business of the company-in 1907, $\$ 52,478.354 .52$ consisted of tangible assets and $\$ 104,957,987.19$ of good will. As more fully set forth later, there is no doubt that a large legitimate value can be assigned to the good will of the American Tobacco Company; in many cases it has paid for it in cash. Nevertheless, the good-will item as it now appears represents, in a considerable part, the mere balancing of overcapitalization: in popular phraseology it in part represents "water.". The overcapitalization in 1907 , however, was much less than in some of the earlier years, owing to the fact that the American Tobacco Company has redeemed part of its bonds out of its surplus profits, and has, to that extent, reduced its capitalization and its valuation of good will.

It would be possible to show substantially the tangible assets of all of the companies, or of nearly all of the companies, covered by the above table of profits. For the American, Continental, and Lorillard companies, for example, the net tangible assets employed in the manufacturing business, not including the investments in stock holdings and the like, amounted, in 1907 , to $\$ 52,478,354.52$, and the net earnings of $\$ 19,246,729.78$ represented approximately 36 per cent on the value of the net tangible assets. Such a comparison between tangible assets and profits, however, would not be a fair one. The tobacco business is peculiar in that, even under competitive conditions, a value attaches to the reputation of established brands which enables the manufacturer to obtain a profit on the tangible assets used 
in producing those brands more or less in excess of the normal rate of business profit in industries where such brand values do not exist. To some extent, it may. be said that such brand values often represent a real investment of capital in that, in order to establish them, the manufacturer often has to incur losses, practically out of his capital, at the outset, such losses being principally due to extraordinary expenses of advertising and pushing the sale which are necessary in the case of new brands. However this may be, it is certain that the American Tobacco Company and the other companies in the combination have paid actual cash, in many cases, purely for the value of the brands which have been acquired. In other words, when a concern has been purchased the price paid for it has often much exceeded the tangible assets acquired, and a corresponding increase has been made to the good will or "brand value" account of the Combination.

Had all of the brands controlled by the Combination been acquired by cash purchases there would be no difficulty in arriving at the actual cost or investment of the combination in the asset known as patents, trade-marks, and good will. A large proportion of the brands, however, have been acquired in exchange for stocks of the American and Continental companies; but such stock payments were by no means equivalent to cash. The Bureau of Corporations is not prepared at the present time to report in detail on the subject of overcapitalization of the concerns in the Tobacco Combination, or on the cash value of the good will acquired from time to time. A report on this subject is in process of preparation. A few facts bearing on the overcapitalization of the principal concern in the Tobacco Combination, the American Tobacco Company, may, however, be presented.

At the time of the formation of the original American Tobacco Company in 1890 it issued $\$ 25,000,000$ of capital stock. The tangible assets acquired from the concerns joining the Combination amounted to only $\$ 3,545,108.02$. The difference between the capitalization and the tangible assets, $\$ 21,454,891.98$, was written down on the books as good will. The company also had, however, $\$ 1,825$,353.74 of notes given by individuals entering the Combination and subsequently paid up. The amount of these notes was treated as a surplus and not balanced by the capital stock. It is entirely evident that although, under competitive conditions, the concerns that entered the Combination may have had a considerable amount of actual brand value, or good will, it could not have exceeded a comparatively small fraction of the value assigned to it on the books of the Combination. The reason why the American Tobacco Company in its early years was able to earn liberal dividends on its entire capitalization lay in its monopoly power. At the outset the Combination controlled substantially 90 per cent of the cigarette business, and it for several years was able to guarantee its position of approximate monopoly by securing a control of all the principal patented cigarette machines.

When the Continental Tobacco Company was organized in 1898 and 1899 , it issued $\$ 48,844,600$ of preferred stock and $\$ 48,846,100$ of common stock. The organizers of the Combination itself do not deny that the entire amount of common stock, at any rate, represented merely a bonus or overcapitalization. Among other evidences on this point are the facts with regard to the acquisition of the 
Liggett \& Myer Tobacco Company, which was brought into the Continental in April, 1899. A syndicate had acquired the business of this company for $\$ 12,500,000$. This syndicate turned it over, together with $\$ 5,000,000$ in cash, or $\$ 17,500,000$, to the Continental Tobacco Company in exchange for $\$ 35,000,000$ of its stock, half common and half preferred. Again, the Continental Tobacco Company issued $\$ 6,000,000$ of its securities, half common and half preferred, in exchange for the $\$ 3,000,000$ of common stock of the P. Lorillard Company, which was clearly worth no more than par, since it had paid only on the average about 6 per cent dividends and since the company had accumulated only an insignificant surplus.

Further overcapitalization occurred in connection with the organization of the Consolidated Tobacco Company and was expressed in the good-will account of the reorganized American Tobacco Company when the Consolidated was merged with it in October, 1904. For the common stock of the American Tobacco Company the Consolidated 'Tobacco Company in 1901 issued its bonds at the rate of $\$ 200$ for $\$ 100$. For $\$ 54,550,000$ of the American stock $\$ 109,100,000$ of bonds were issued. As the Consolidated was merely a holding company, this transaction did not at the time make any change in the book accounts of the American Tobacco Company. At the time of the merger of 1904, however, the reorganized American Tobacco Company issued its securities to an amount sufficient to cover the $\$ 54,550,000$ of bonds which the Consolidated had issued in excess of the par value of the common stock of the old American company which had been acquired. To balance this additional capitalization it was necessary to increase the so-called good-will account, and accordingly more than $\$ 36,000,000$ was addled to the good-will account of the American Tobacco Company, the difference between this $\$ 36,000,000$ and the $\$ 54,550,000$ of additional securities being balanced by an arbitrary addition to the book value of the stocks of subsidiary companies. This transaction added nothing whatever to the actual assets in the manufacturing business of the American Tobacco Company; and the increase in the good-will item at that time meant nothing else than the watering of the assets account to correspond to the watering of the capital securities.

It is evident, therefore, from these facts that no comparison of any significance can be made between the net earnings of the Tobacco Combination and its capitalization or its reported assets.

ANALYSIS OF THE BUSINESS AND PROFITS OF THE AMERICAN, CONTINENTAL, AND LORILLARD COMPANIES.

The profits of the Tobacco Combination which have been presented in the preceding pages comprise the results of a wide variety of business. Any adequate understanding of the relation of the Combination to the tobacco business requires a separation of these different branches as far as possible. The snuff and cigar branches of the business may be readily separated, inasmuch as each of these branches is in the hands of a distinct group of corporations headed, respectively, by the American Cigar Company and the American Snuff Company. The principal other branches of the business of the Tobacco Combination are: Plug and twist tobacco, smoking tobacco, fine-cut tobacco, scrap tobacco, cigarettes, and little cigars. It would be desirable, if practicable, to present combined figures showing the entire quantity 
and value of sales, costs, and profits in each branch of the business for all of the companies in the Tobacco Combination together. Inasmuch, however, as some of the subsidiary companies do not in their reports distinguish one branch of the business from another, it is impossible to present such a complete separation of the several branches for all of the companies together. Nevertheless the data for the parent companies and for the leading subsidiary companies can be thus analyzed.

The data for the parent companies alone, namely, the American and Continental Tobacco companies, represent a large proportion of the total business. With the business of the American and Continental companies, however, must be combined that of the P. Lorillard Company, for the reason that that company does not sell its own products, but turns them over to the American (and formerly also to the Continental) for sale, so that the total profits on any given branch of the Lorillard business can be ascertained only by considering both the profits of the Lorillard Company and the company which sells its products.

In Table 2 above have been presented the total profits of the American, Continental, and Lorillard companies from their own business-that is, exclusive of the dividends which they receive from stocks held in other companies and of the interest on money loaned to other companies. By far the greater part of these direct profits is derived from the manufacture and sale of tobacco, but a small amount is derived from miscellaneous sources, particularly from interest on bank balances. There are also some expenses which are not charged directly against the departments and which can not strictly be assigned as departmental expenses. In the table below these miscellaneous profits or expenses are distinguished from the profits which may properly be considered as belonging to the manufacture and sale of tobacco designated as departmental profits.

The greater part of the departmental profits of the American, Continental, and Lorillard companies at all times has been derived from their domestic business, and during recent years all comes from that source. The table below distinguishes the profits of the domestic business from those of the export business. It will be noted from the table, also, that there is some difference between the total departmental profits and the sum of the profits calculated as arising from individual departments in the domestic business and from the export business, respectively. This difference, which ranges from a negative figure of $\$ 158,005.91$ to a positive figure of $\$ 336,268.65$, represents certain elements of profits or expenses which are properly assignable to the manufacture and sale of tobacco, but which can not be definitely assigned to any particular department. The column of domestic profits represents the sum of the profits for the several individual departments in the domestic business so far as it is possible to assign the profits or expenses to individual departments. The undistributed amounts are small, so that this column represents with substantial accuracy the true profits of the domestic business of the American, Continental, and Lorillard companies. ${ }^{a}$ For the

$a$ The comparatively large figure undistributed in 1899 represents profits of certain concerns acquired by the Continental Tobacco Company in 1899 for the period between such acquisitions and June 30 of that year, when the Combination first took full charge of the accounting of these concerns. 
years 1893 and 1894, which are the first in which the export profits are distinguished in the accounts from the domestic profits, the domestic profits represent simply the difference between the total departmental profits and the export profits, since it has been entirely impossible from the available records to assign profits to individual departments.

TABLE 3.-American, Continental, and Lorillard companies-Separation of domestic from export profits.

\begin{tabular}{|c|c|c|c|c|c|c|}
\hline \multirow[b]{2}{*}{ Year. } & \multicolumn{3}{|c|}{ Total profits. } & \multicolumn{3}{|c|}{ Distribution. } \\
\hline & $\begin{array}{l}\text { Total } \\
\text { income } \\
\text { from own } \\
\text { business. }\end{array}$ & $\begin{array}{l}\text { Miscella- } \\
\text { neous } \\
\text { profits } \\
\text { or losses. }\end{array}$ & $\begin{array}{l}\text { Depart- } \\
\text { mental } \\
\text { profits. }\end{array}$ & $\begin{array}{c}\text { Domestic } \\
\text { profits dis- } \\
\text { tributed to } \\
\text { individual de- } \\
\text { partments. }\end{array}$ & $\begin{array}{l}\text { Export } \\
\text { profits. }\end{array}$ & $\begin{array}{l}\text { Amounts } \\
\text { undis- } \\
\text { tributed. }\end{array}$ \\
\hline 1890. & $\$ 2,511,180.12$ & $\$ 1,110.57$ & $\$ 2,510,069.55$ & $\therefore$ & & \\
\hline 1891. & $4,396,794.93$ & $2,060.37$ & $4,394,734.56$ & & & \\
\hline 1892 & $4,739,301.65$ & $4,759.29$ & $4,734,542.36$ & & & \\
\hline $1893 .$. & $4,334,467.34$ & $16,550.82$ & $4,317,916.52$ & ….. & $\$ 514,160.41$ & \\
\hline $1894 .$. & $5,065,493.61$ & $17,261.56$ & $5,048,232.05$ & $\ldots \ldots \ldots \ldots$ & $487,255.07$ & n......... \\
\hline $1895 \ldots$ & $3,917,908.78$ & $15,208.18$ & $3,902,700.60$ & $\$ 3,412,061.45$ & $545,132.40$ & $* \$ 54,493.25$ \\
\hline 1896. & $3,412,899.97$ & $* 162,972.49$ & $3,575,872.46$ & $2,823,478.86$ & $824,101.95$ & $* 71,708.35$ \\
\hline 1897. & $3,996,115.21$ & & $3,996,115.21$ & $3,207,032.97$ & $811,344.95$ & $* 22,262.71$ \\
\hline 1898 & $3,584,785.51$ & & $3,584,785.51$ & $2,664,191.64$ & $1,010,233.15$ & $* 89,639.28$ \\
\hline 1899 & $6,473,726.65$ & $100,079.66$ & $6,373,646.99$ & 5,$122 ; 970.99$ & $914,407.35$ & $336,268.65$ \\
\hline 1900 & $9,218,273.64$ & $35,133.42$ & $9,183,140.22$ & $8,486,966.57$ & $685,090.56$ & $11,083.09$ \\
\hline 1901 & $12,310,072.20$ & $36,933,65$ & $12,273,138.55$ & $11,779,024.65$ & $652,119.81$ & $* 158,005.91$ \\
\hline 1902 & $15,744,700.21$ & $27,037.23$ & $15,717,662.98$ & $15,587,866.27$ & $37,727.50$ & $167,524.21$ \\
\hline 1903 & $18,815,116.93$ & $45,136.64$ & $18,769,980.29$ & $18,735,888.85$ & $2,706.59$ & $36,798.03$ \\
\hline $1904 .$. & $16,229,579.36$ & $148,496.08$ & $16,081,083.28$ & $16,007,402.49$ & . & $73,680.79$ \\
\hline 1905 & $18,347,881.30$ & $458,079.19$ & $17,889,802.11$ & $17,913,829.59$ & $1,305.11$ & $* 22,722.37$ \\
\hline 1906. & $20,856,677.48$ & $171,604.86$ & $20,685,072.62$ & $20,641,708.06$ & 341.03 & $43,023.53$ \\
\hline 1907 & $19,246,729.78$ & $233,424.90$ & $19,013,304.88$ & $19,025,726.27$ & 170.24 & $* 12,591.63$ \\
\hline
\end{tabular}

* Loss.

In considering this table it should be borne in mind that the period from 1890 to 1898 represents a much narrower scope and volume of business than the later period. The figures for the earlier period cover only the American Tobacco Company itself, while from 1899 to 1903 they include the American, Continental, and Lorillard companies, and for 1904 to 1907 the reorganized American, with which the Continental had been merged, and the Lorillard Company.

During the nineties the American Tobacco Company had a large export business in cigarettes, so that in some years the profits from the export business made up approximately one-fourth, or even more, of the total profits. The Continental and Lorillard companies added practically nothing to the export trade of the Combination, since the products which they manufactured, principally plug and smoking tobacco, are exported only in very small quantities from the country as a whole. Moreover, the volume of the export business of the American Tobacco Company itself was less after 1898 than before, partly because of the transfer of some of the foreign business to concerns established in the interest of the American Tobacco Company in the foreign countries themselves. During the years 1899 to 1901 , therefore, export profits were a smaller proportion of the total profits 
of the Combination than heretofore. In 1902, on account of a very active campaign on the part of the American Tobacco Company against foreign concerns, especially in Great Britain, the export business showed a loss. In 1903 the entire export business of the Tobacco Combination was turned over to a new corporation, the BritishAmerican Tobacco Company, and the small amounts of profits or losses appearing thereafter in the above table represent mere adjustments, or accounts left over from the previous period.

Table 4 shows the gross or invoice value of the sales of the American, Continental, and Lorillard companies for each year, distinguishing the domestic from the export sales.: The gross value or price is subject to discounts, but information is not available by which to show the proportion of the net value, less discounts, attributable to the domestic and export business, respectively. In all probability, however, the proportion of the net value is substantially the same as that of the gross value. In the table the sales of cigars, cheroots, and stogies by the American and Continental companies as agents for the American Cigar Company during the years 1902 to 1905 have been omitted as not being properly a part of the regular business of those companies. As already explained, the figures of profits for these companies given in Table 2 and in Table 3 are also exclusive of the losses incurred by the American and Continental in the cigar business during this period, these having been deducted from the profits of the American Cigar Company.

TABLE 4.-American, Continental and Lorillard companies-Gross invoice value of sales, distinguishing domestic and export business.

\begin{tabular}{|c|c|c|c|}
\hline Year. & Total. & Domestic sales. & Foreign sales. \\
\hline 1890. & $\$ 11,818,207.83$ & $\$ 11,060,900.51$ & $\$ 757,307.32$ \\
\hline $1891 \ldots$ & $18,363,167.07$ & $17,471,765.65$ & $891,401.42$ \\
\hline $1892 \ldots$ & $20,523,464.39$ & $19,603,928.50$ & $919,535.89$ \\
\hline $1893 .$. & $20,938,376.51$ & $19,835,218.91$ & $1,103,157.60$ \\
\hline $1894 \ldots$ & $21,155,985.09$ & $20,112,135.76$ & $1,043,849.33$ \\
\hline $1895 \ldots$ & $24,361,215.57$ & $23,036,512.83$ & $1,324,702.74$ \\
\hline $1896 \ldots$ & $26,767,914.42$ & $25,059,931.50$ & $1,707,982.92$ \\
\hline $1897 \ldots$ & $29,286,409.46$ & $27,294,057.96$ & $1,992,351.50$ \\
\hline $1898 \ldots .$. & $31,997,159.37$ & $29,474,810.96$ & $2,522,348.41$ \\
\hline $1899 \ldots$. & $69,614,694.29$ & $67,451,584.16$ & $2,163,110.13$ \\
\hline $1900 \ldots$ & $73,078,756.20$ & $70,762,573.69$ & $2,316,182.51$ \\
\hline $1901 \ldots$ & $74,283,790.68$ & $71,814,833.09$ & $2,468,957.59$ \\
\hline $1902 a$. & $79,117,482.27$ & $77,028,567.27$ & $2,088,915.00$ \\
\hline $1903 a \ldots$ & $77,189,571.26$ & $77,025,237.86$ & $164,333.40$ \\
\hline $1904 a \ldots$ & $75,115,737.79$ & $75,115,737.79$ & \\
\hline $1905 a \ldots$ & $80,178,720.84$ & $.80,178,720.84$ & \\
\hline $1906 \ldots \ldots \ldots \ldots . . . \ldots \ldots$ & $85,960,237.97$ & $85,960,237.97$ & \\
\hline $1907 \ldots \ldots \ldots \ldots \ldots \ldots \ldots \ldots$ & $85,923,085.08$ & $85,923,085.08$ & \\
\hline
\end{tabular}

$u$ Excluding sales of cigars, cheroots, and stogies, all domestic, which were as follows: $1902, \$ 3,584,353.44 ; 1903, \$ 6,758,201.54 ; 1904, \$ 8,940,882.11 ; 1905, \$ 5,638,120.33$.

It will be seen that during the years 1890 to 1898 , when the figures represent only the business of the American Tobacco Company, the export sales constituted from about 5 per cent to about 8 per cent of the total sales. After the new combination of 1899, the proportion of the total business represented by foreign sales was much 
less, ranging from $2 \frac{1}{2}$ to 3 per cent, while during the more recent years the sales of the American, Continental, and Lorillard companies have been confined to the domestic business. Having thus separated the value of the sales and the profits of the domestic business from those of the export business, attention may be confined to the domestic business.

The gross value of the sales of the American, Continental, and Lorillard companies is made up first of the discounts allowed to jobbers, deducting which leaves the net value of sales, and then of (1) the amount of taxes paid to the Federal Government, (2) the cost of the product, (3) and the profit. The discount allowed to jobbers on sales averages in the neighborhood of 10 per cent of the invoice price. The variations from year to year are not worthy of special consideration at this point, and the analysis of the results of the business may properly start with the net value of the domestic sales after deducting discounts.

Table 5 shows the total net value of domestic sales of the American, Continental, and Lorillard companies, the amount of tax paid, the cost of manufacture and sale, and the profit, and likewise shows the proportion of the net value represented by the three elements, respectively.

TABlE 5.-American, Continental, and Lorillard companies-Net value of sales and proportion represented by tax, cost, and profit, respectively (domestic business).

\begin{tabular}{|c|c|c|c|c|c|c|c|}
\hline \multirow{2}{*}{ Year. } & \multicolumn{4}{|c|}{ Amount represented by- } & \multicolumn{3}{|c|}{ Proportion represented by- } \\
\hline & $\begin{array}{l}\text { Net value of } \\
\text { sales. }\end{array}$ & Tax. & Cost. & Profit. & Tax. & Cost. & Profit. \\
\hline & & & & & Per cent. & Per cent. & Per cent. \\
\hline $1895 \ldots$ & $\$ 21,120,561.70$ & $\$ 4,071,055.14$ & $\$ 13,637,445.11$ & $\$ 3,412,061.45$ & 19.3 & 64.6 & 16.1 \\
\hline 1896. & $22,235,508.62$ & $4,786,115.76$ & $14,625,914.00$ & $2,823,478.86$ & 21.5 & 65.8 & 12.7 \\
\hline $1897 .$. & $23,485,333.81$ & $5,859,836.87$ & $14,418,463.97$ & $3,207,032.97$ & 24.9 & 61.4 & 13. 7 \\
\hline 1898 & $26,923,627.35$ & $8,674,345.07$ & $15,585,090.64$ & $2,664,191.64$ & 32.2 & 57.9 & 9.9 \\
\hline 1899. & $61,920,705.44$ & $21,582,820.74$ & $35,214,913.71$ & $5,122,970.99$ & 34.8 & 56.9 & 8.3 \\
\hline 1900 & $67,589,568.18$ & $23,856,691.80$ & $35,245,909.81$ & $8,486,966.57$ & 35.3 & 52.1 & 12.6 \\
\hline $1901 \ldots$ & $67,147,552.13$ & $20,737,075.29$ & $34,631,452.19$ & $11,779,024.65$ & 30.9 & 51.6 & 17.5 \\
\hline 1902. & $71,786,348.15$ & $16,222,318.27$ & $39,976,163.61$ & $15,587,866.27$ & 22.6 & 55.7 & 21.7 \\
\hline $1903 \ldots$ & $71,704,514.23$ & $12,962,499.45$ & $40,006,125.93$ & $18,735,888.85$ & 18.1 & 55.8 & 26.1 \\
\hline $1904 .$. & $69,981,891.92$ & $12,374,293.68$ & $41,600,195.75$ & $16,007,402.49$ & 17.7 & 59.4 & 22.9 \\
\hline $1905 \ldots$ & $73,261,513.01$ & $12,992,612.42$ & $42,355,071.00$ & $17,913,829.59$ & 17.7 & 57.8 & 24.5 \\
\hline $1906 .$. & $80,050,489.98$ & $14,285,733.43$ & $45,123,048.49$ & $20,641,708.06$ & 17.8 & 56.4 & 25.8 \\
\hline $1907 \ldots$ & $79,604,641.91$ & $14,557,284.72$ & $46,021,630.92$ & $19,025,726.27$ & 18.3 & 57.8 & 23.9 \\
\hline
\end{tabular}

This table shows that the net value of the sales of the American, Continental, and Lorillard companies in their domestic business increased from $\$ 21,120,561.70$ in 1895 (the first year for which the details of costs and profits for individual departments are available) to $\$ 79,604,641.91$ in 1907 . The great increase from 1898 to 1899 was, of course, chiefly due to the organization of the Continental Tobacco Company and the acquisition of the Lorillard Company. The sales increased rapidly from 1899 to 1902 , declined slightly during the next two years, and then again increased rapidly until 1906 , when the maximum was reached, $\$ 80,050,489.98$, the sales for 1907 being slightly less. 
The amount of tax paid by these companies to the Federal Government has varied greatly, partly because of changes in the volume of the business and partly because of changes in the rates of taxation. The maximum amount paid, as might be expected, was during the years 1899 to 1901 , when the war-revenue rates of tax were in force. It will be recalled that the rate of taxation on cigarettes and little cigars was increased in 1897 , that the rate on cigarettes was again increased in 1899 , and that at the same time the rate on the still more important products, plug and smoking tobacco, was doubled. The amount of tax collected from these companies fell off greatly in 1902 and 1903 on account of the reduction in the taxes. Part of the additional taxes imposed during the war were taken off on July 1, 1901, and the rest on July 1,1902 , save only that the rate on cigarettes remained considerably higher than it had been prior to the war. The increase in the tax collected from these companies since 1904 represents simply the increase in the volume of their output.

The cost of the output of the American, Continental, and Lorillard companies shows, broadly speaking, a steady increase since 1899 , corresponding to the increased volume of output. Very striking, however, are the changes in the profits, and particularly when the profits are compared with the taxes paid. As the amount of tax paid fell off, the amount of profit increased. From 1899 to 1903 the taxes fell off about $\$ 8,000,000$, while the profits increased about $\$ 13,600,000$, rising from $\$ 5,122,970.99$ in 1899 to $\$ 18,735,888.85$ in 1903 . The profits fell off somewhat in 1904, but again increased, reaching the maximum in $1906, \$ 20,641,708.06$. It should be noted that the profits stated in this table are the sum of the profits of the several departments as computed, and that there are small amounts of profits or expenses properly connected with the departments which were not included because they can not be distributed to individual departments.

The proportions of the net value of sales which are represented respectively by the tax, the cost, and the profit, as shown in the last three columns of the table, have varied very greatly. During the years 1895 and 1896, before the increase in the taxes, the proportion of the value of the product of the American Tobacco Company represented by taxes was 19.3 per cent and 21.5 per cent, respectively, while cost represented 64.6 and 65.8 per cent, and profits 16.1 and 12.7 per cent, respectively. During the years 1899 and 1900 , when the full war-revenue rates were in effect, the tax represented a little over one-third of the selling price of the products as a whole- 34.8 and 35.3 per cent, respectively-cost represented 56.9 per cent and 52.1 per cent, respectively, and profit 8.3 per cent and 12.6 per cent, respectively. With the reduction in the war-revenue rates the proportion of the value of the product represented by tax fell, so that during the years 1903 to 1907 it represented a little over one-sixth of the value. The proportion represented by cost during these five years has ranged from 55.8 per cent to 59.4 per cent, while the proportion represented by profit has been, roughly, one-fourth, or, more precisely, from 22.9 per cent to 26.1 per cent.

The real charge made by a tobacco manufacturer to the public is, of course, the price less the tax. The tax is supposed to be a payment which the consumer makes to the Government and which is merely collected by the manufacturer on behalf of the Government. 
So, also, the cost exclusive of tax represents, strictly speaking, the cost of manufacture, and the tax is not an element of the manufacturer's cost, but an element which the Government adds to the price to the consumer. To be sure, the manufacturer when the tax is increased may not be able so to raise his price as to collect the entire additional amount of the tax from the consumer, although it is ordinarily the expectation and intent of any government in making such an increase of the tax that the manufacturer shall accomplish that result. Even in that case, however, it is scarcely proper to speak of the additional tax as an additional cost of manufacture. It means simply that the manufacturer has not been able to shift the burden as it was expected that he should. It would obviously be unfair to judge the price policy of a manufacturer of tobacco by considering merely the changes in the price, including tax, or to judge the profits of his business by showing the relation which the profits bear to the cost, including tax. Under a perfect working of the internal-revenue taxesthat is, under a perfect shifting of the entire amount of the tax to the consumer-the only expense which the tax really adds to the cost of manufacture is the interest upon the money invested in paying the tax, between the time of such payment and the time when the goods are actually sold, plus the small amount of tax paid on goods which are consumed by fire, returned by the purchaser, and not again sold, etc. The manufacturer pays the tax only a very short time before he sells the goods, so that the interest on his investment in the tax is quite insignificant as compared with the total cost.

For these reasons, in the following and other tables in this report, analyses are presented of the net value or net price of tobacco products, exclusive of tax, and computations are made of the relation between profit and the cost of manufacture, exclusive of the amount of the tax.

Table 6 shows the net value, less tax, of the sales of the American, Continental, and Lorillard companies, and shows what proportion of that net value is represented by the cost (exclusive of taxation) and the profit, respectively.

TABLE 6.-American, Continental, and Lorillard companies-Net value of sales, less tax, and proportion represented by cost and profit, respectively (domestic business).

\begin{tabular}{|c|c|c|c|c|c|}
\hline \multirow[t]{2}{*}{ Year. } & \multirow{2}{*}{$\begin{array}{c}\text { Net value of } \\
\text { sales (less tax). }\end{array}$} & \multirow[t]{2}{*}{ Cost. } & \multirow[t]{2}{*}{ Profit. } & \multicolumn{2}{|c|}{$\begin{array}{l}\text { Proportion of net } \\
\text { price represented } \\
\text { by- }\end{array}$} \\
\hline & & & & Cost. & Profit. \\
\hline & & & & Per cent. & Per cent. \\
\hline 1895. & $\$ 17,049,506.56$ & $\$ 13,637,445.11$ & $\$ 3,412,061.45$ & 80.0 & 20.0 \\
\hline $1896 \ldots$ & $17,449,392.86$ & $14,625,914.00$ & $2,823,478.86$ & 83.8 & 16.2 \\
\hline 1897. & $17,625,496.94$ & $14,418,463.97$ & $3,207,032.97$ & 81.8 & 18.2 \\
\hline 1898. & $18,249,282.28$ & $15,585,090.64$ & $2,664,191.64$ & 85.4 & 14.6 \\
\hline 1899 & $40,337,884.70$ & $35,214,913.71$ & $5,122,970.99$ & 87.3 & 12.7 \\
\hline 1900. & $43,732,876.38$ & $35,245,909.81$ & $8,486,966.57$ & 80.6 & 19.4 \\
\hline $1901 \ldots$ & $46,410,476.84$ & $34,631,452.19$ & $11,779,024.65$ & 74.6 & 25.4 \\
\hline 1902. & $55,564,029.88$ & $39,976,163.61$ & $15,587,866.27$ & 71.9 & 28.1 \\
\hline 1903. & $58,742,014.78$ & $40,006,125.93$ & $18,735,888.85$ & 68.1 & 31.9 \\
\hline 1904. & $57,607,598.24$ & $41,600,195.75$ & $16,007,402.49$ & 72.2 & 27.8 \\
\hline $1905 \ldots$ & $60,268,900.59$ & $42,355,071.00$ & $17,913,829.59$ & 70.3 & 29.7 \\
\hline 1906. & $65,764,756.55$ & $45,123,048.49$ & $20,641,708.06$ & 68.6 & 31.4 \\
\hline $1907 \ldots$ & $65,047,357.19$ & $46,021,630.92$ & $19,025,726.27$ & 70.8 & 29.2 \\
\hline
\end{tabular}


Attention has already been called to the fact that the figures of profit as used throughout this report represent the total profit of the business, including not only interest on the capital directly invested by the specific companies for which the figures are given, but also interest on borrowed money - the latter, however, being comparatively unimportant in the case of the principal companies. In other words, interest is not treated as a cost, and the combination has had to provide for return on its investment as well as on its borrowed money out of the profits as shown in this and other tables. It is, of course, customary in the business world thus to treat interest on investment (save in some cases that on borrowed money) as part of the profit.

This table shows that the net value of the sales of the American Tobacco Company exclusive of tax during the period 1895 to 1898 increased gradually from $\$ 17,049,506.56$ to $\$ 18,249,282.28$. During the first year after the formation of the Continental Tobacco Company the sales less tax brought $\$ 40,337,884.70$. The net value less tax increased rapidly until 1903, fell off slightly in 1904, and again increased, reaching a maximum of $\$ 65,764,756.55$ in 1906 , or about 60 per cent more than in 1899.

During the first four years covered by the table the profits of the American Tobacco Company represented from about 14.6 to 20.0 per cent of the net prices charged, exclusive of taxation. In the first year after the formation of the Continental the profit of the American, Continental, and Lorillard companies represented 12.7 of the value of their sales exclusive of tax. The proportion represented by profit rose very rapidly, being 19.4 per cent in 1900 , and nearly one-third in 1903 , or, more precisely, 31.9 per cent. Since that time there has been no very marked change in the proportion represented by profit, it having ranged from 27.8 per cent to 31.4 per cent.

TABLE 7.-American, Continental, and Lorillard companies-Rate of profit on cost for the entire domestic business.

\begin{tabular}{|c|c|c|c|}
\hline Year. & $\begin{array}{l}\text { Rate of } \\
\text { profit. }\end{array}$ & Year. & $\begin{array}{l}\text { Rate of } \\
\text { profit. }\end{array}$ \\
\hline 1895. & $\begin{array}{r}\text { Per cent. } \\
25.0\end{array}$ & 1902. & $\begin{array}{r}\text { Per cent. } \\
39.0\end{array}$ \\
\hline $1896 .$. & 19. 3 & 1903. & 46.8 \\
\hline $1897 .$. & 22.2 & 1904. & 38.5 \\
\hline $1898 .$. & 17.1 & $1905 \ldots$ & 42.3 \\
\hline 1899. & 14.5 & $1906 \ldots$ & 45.7 \\
\hline 1900. & 24.1 & 1907. & 41.3 \\
\hline 1901.. & 34.0 & & \\
\hline
\end{tabular}

Table 7 shows the percentage which the profit has borne to the cost (exclusive of the federal tax) for the American, Continental, and Lorillard companies for each year. It will be seen that the rate of profit obtained by the American Tobacco Company on the cost of its output during the years 1895 to 1898 declined from 25 per cent to 17.1 per cent. The rate of profit of this company on its cigarette business, in which it controlled a large proportion of the entire output of the country, was much higher, but the total profits were reduced 
by the losses of the plug-tobacco business. In 1899, the first year after the formation of the Continental Tobacco Company, the rate of profit for the American, Continental, and Lorillard companies combined on their cost amounted to 14.5 per cent. The ratio increased rapidly until it reached 46.8 per cent in 1903 . This was the maximum, but the rate in $1906,45.7$ per cent, was only a little lower. The average rate for the six years 1902 to 1907 has considerably exceeded 40 per cent on the cost of manufacture, exclusive of taxation.

SALES AND PROFITS OF THE INDIVIDUAL DEPARTMENTS OF THE AMERICAN, CONTINENTAL, AND LORILLARD COMPANIES.

Table 8 shows the quantity of sales of the several classes of products of the American, Continental, and Lorillard companies and their value exclusive of taxation for each year from 1895 to 1907 . The quantities of cigarettes, little cigars, and cheroots can not, of course, be compared with the quantities of other products, which are expressed in pounds, but the values show the relative importance of the different departments from year to year.

TABLE 8.-Quantity and net value (less tax) of sales by departments-American, Continental, and Lorillard companies (domestic business).

\begin{tabular}{|c|c|c|c|c|}
\hline Year. & Smoking. & Plug. & Fine cut. & Cigarettes. \\
\hline Quantity: & Pounds. & Pounds. & Pounds. & Thousands. \\
\hline $1895 \ldots$ & $17,766,435$ & $20,330,834$ & 557,441 & $2,919,704$ \\
\hline 1896. & $16,925,504$ & $31,140,360$ & 550,968 & $3,094,531$ \\
\hline 1897 & $20,224,130$ & $37,841,644$ & 553,559 & $2,883,194$ \\
\hline 1898 & $23,371,951$ & $32,991,072$ & 687,394 & $2,564,488$ \\
\hline $1899 \ldots$ & $45,188,840$ & $85,967,529$ & $4,452,722$ & $2,49 \Sigma, 963$ \\
\hline $1900 \ldots$ & $\tilde{52}, 204,714$ & $99,495,661$ & $5,807,276$ & $2,229,446$ \\
\hline 1901. & $54,542,875$ & $101,088,522$ & $5,647,432$ & $1,936,350$ \\
\hline 1902. & $62,284,742$ & $113,745,181$ & $4,888,411$ & $1,831,593$ \\
\hline 1903. & $65,446,760$ & $108,990,415$ & $3,476,085$ & $2,032,864$ \\
\hline $1904 \ldots$ & $69,723,494$ & $93,856,635$ & $3,674,272$ & $2,044,804$ \\
\hline $1905 \ldots$ & $74,237,918$ & $99,281,275$ & $4,233,404$ & $2,032,417$ \\
\hline $1906 \ldots$ & $75,412,313$ & $111,426,951$ & $4,345,083$ & $2,300,532$ \\
\hline $1907 \ldots \ldots$ & $73,597,565$ & $103,680,598$ & $4,538,321$ & $2,836,734$ \\
\hline Value, less tax: & Dollars. & Dollars. & Dollars. & Dollars. \\
\hline $1895 \ldots \ldots$ & $4,434,502.18$ & $a 3,153,315.83$ & $150,676.30$ & $8,093,711.46$ \\
\hline $1896 \ldots$ & $4,173,829.29$ & $4,029,562.58$ & $149,973.49$ & $7,613,474.62$ \\
\hline 1897. & $4,799,186.05$ & $4,597,759.75$ & $147,025.27$ & $6,526,974.58$ \\
\hline $1898 \ldots$ & $\tilde{\jmath}, 520,454.82$ & $5,506,209.92$ & $178,035.05$ & $5,186,676.98$ \\
\hline 1899. & $9,106,678.33$ & $21,393,915.06$ & $1,085,472.13$ & $5,020,879.17$ \\
\hline 1900 & $10,816,908.59$ & $23,166,155.69$ & $1,332,495.44$ & $4,654,414.41$ \\
\hline 1901 & $12,193,006.33$ & $26,059,562.38$ & $1,485,310.06$ & $4,108,934.70$ \\
\hline 1902 & $15,521,564.47$ & $31,879,446.80$ & $1,634,691.74$ & $4,195,813.25$ \\
\hline 1903. & $17,645,798.00$ & $32,998,612.52$ & $1,358,590.14$ & $4,618,057.15$ \\
\hline $1904 \ldots$ & $19,606,211.88$ & $29,702,068.10$ & $1,399,297.69$ & $4,609,397.17$ \\
\hline 1905 & $20,108,533.67$ & $31,803,325.03$ & $1,554,590.84$ & $4,419,287.52$ \\
\hline 1906 & $21,075,033.06$ & $34,968,470.48$ & $1,576,096.57$ & $4,940,852.58$ \\
\hline $190 \bar{i}$ & $19,904,074.03$ & $33.708,150.81$ & $1,609,116.26$ & $6,240,247.46$ \\
\hline
\end{tabular}

a Computed hy deducting 10 per cent discount from invoice price.

Sit42_s. Doc. 7 S, 61-1_-3 
TABLE 8.-Quantity and net value (less tax) of sales by departments-American, Continental, and Lorillard companies (domestic business)-Continued.

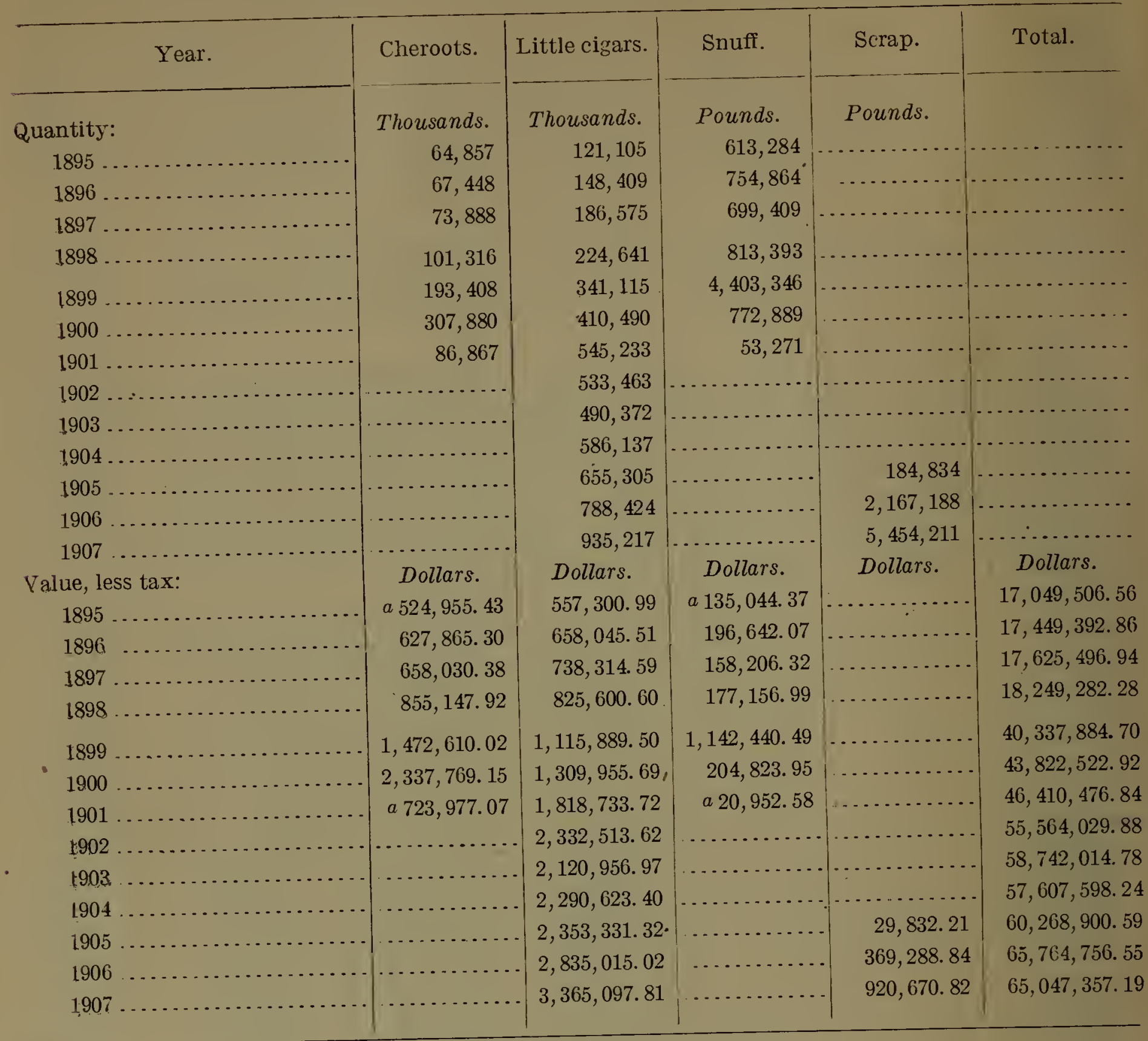

$a$ Gross invoice price, less tax.

It will be seen that during the period 1895 to 1898 , when the figures represent only the business of the American Tobacco Company, the cigarette sales were, on the whole, the most important, although by 1898 both the sales of plug tobacco and those of smoking tobacco exceeded those of cigarettes in value. Since the formation of the Continental Tobacco Company, which was chiefly a plug and smoking tobacco manufacturer, these two branches of the business have become much more important than the cigarette business. This table, which is confined to the American, Continental, and Lorillard companies, however, does not show the full importance of the cigarette business of the Tobacco Combination, since the value of the output of cigarettes made by subsidiary companies at the present time exceeds the value of those made by the American Tobacco Company itself, while in the case of the plug and smoking branches of the business she greater part of the output is made by the parent companies. The plug and smoking tobacco business of the American, Continental, and Lorillard companies also shows a much more marked increase since 1899 than the cigarette business. The most rapid rate of 
increase in any branch of the business is in little cigars, but they are still much less important than cigarettes in aggregate value.

In 1907 the proportion of the total value of sales represented by the different departments was as follows:

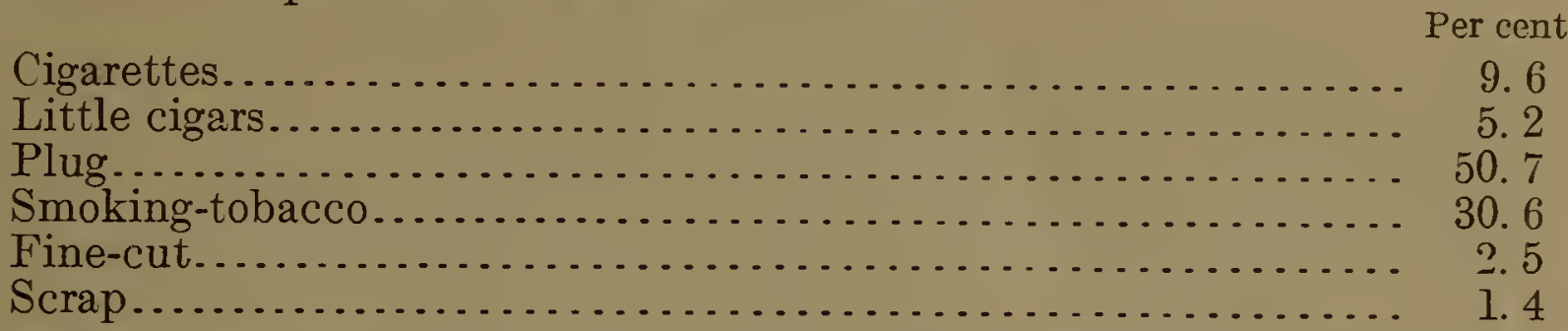

Table 9 shows the amount of profit obtained by the American Continental, and Lorillard companies from each branch of their domestic business for each year since 1895.

TABLE 9.-Net profit by departments-American, Continental, and Lorillard companies.

\begin{tabular}{|c|c|c|c|c|c|c|}
\hline \multicolumn{2}{|l|}{ Year. } & Smoking. & \multicolumn{2}{|r|}{ Plug. } & Fine cut. & Cigarettes. \\
\hline 1895. & & $\$ 559,009.82$ & \multicolumn{2}{|c|}{$* \$ 892,687.88$} & $\$ 24,118.21$ & $\$ 3,574,362.60$ \\
\hline $1896 .$. & & $740,586.07$ & \multicolumn{2}{|c|}{$* 1,378,345.78$} & $19,819.68$ & $3,289,736.33$ \\
\hline 1897. & & $937,068.95$ & \multicolumn{2}{|c|}{$* 889,730.25$} & $30,176.12$ & $2,886,093.29$ \\
\hline 1898 & & $736,518.96$ & \multicolumn{2}{|c|}{$* 926,302.86$} & $* 6,398.52$ & $2,705,306.70$ \\
\hline 1899 & & $1,085,522.47$ & \multicolumn{2}{|c|}{$1,606,965.15$} & $77,635.57$ & $2,630,373.73$ \\
\hline 1900. & & $1,976,404.34$ & \multicolumn{2}{|c|}{$4,121,017.42$} & $* 39,404.01$ & $2,341,869.51$ \\
\hline 1901 & & $2,562,272.25$ & \multicolumn{2}{|c|}{$7,016,591.22$} & $* 107,734.86$ & $1,871,365.15$ \\
\hline 1902 & & $3,706,059.93$ & \multicolumn{2}{|c|}{$10,140,562.13$} & $314,755.67$ & $1,320,848.95$ \\
\hline 1903. & & $4,051,635.90$ & \multicolumn{2}{|c|}{$11,986,675.43$} & $400,823.55$ & $2,106,697.39$ \\
\hline 1904 & & $4,610,698.40$ & \multicolumn{2}{|c|}{$8,660,296.31$} & $443,390.45$ & $1,868,813.06$ \\
\hline 1905 & & $5,698,148.99$ & \multicolumn{2}{|c|}{$9,362,073.73$} & $479,801.12$ & $1,802,124.52$ \\
\hline 1906 & & \multirow{2}{*}{$\begin{array}{l}6,384,233.58 \\
5,876,688.18\end{array}$} & \multirow{2}{*}{\multicolumn{2}{|c|}{$\begin{array}{l}11,588,114.65 \\
10,308,708.34\end{array}$}} & $493,338.67$ & $1,950,746.78$ \\
\hline 1907. & & & & & $451,709.79$ & $2,026,468.46$ \\
\hline Year. & Cheroots. & Little cig & ars. & Snuff. & Scrap. & Total. \\
\hline 1895 & $\$ 94,638.39$ & $\$ 52,62$ & 31 & & & $\$ 3,412,061.45$ \\
\hline $1896 \ldots$ & $108,999.88$ & 60,64 & .77 & $* \$ 17,964.09$ & & $2,823,478.86$ \\
\hline 1897. & $113,795.25$ & 125,140 & .44 & 4, 489.17 & & $3,207,032.97$ \\
\hline 1898. & $56,506.25$ & 96,50 & .90 & $2,057.21$ & & $2,664,191.64$ \\
\hline 1899. & $* 229,590.33$ & 22,508 & .74 & $* 70,444.34$ & & $5,122,970.99$ \\
\hline $1900 \ldots$ & $* 15,543.98$ & 132,37 & & $* 29,750.22$ & & $8,486,966.57$ \\
\hline $1901 \ldots$ & $93,540.71$ & $3 s 0,76 \subseteq$ & 20 & $2,220.98$ & & $11,779,024.65$ \\
\hline $1902 \ldots$ & & 105,639 & 59 & & & $15,587,866.27$ \\
\hline $1903 \ldots$ & & 190,056 & 58 & & & $18,735,888.85$ \\
\hline $1904 \ldots$. & & 424,20 & 27 & & & $16,007,402.49$ \\
\hline $1905 \ldots$ & & 600,044 & 86 & & $* \$ 28,363.63$ & $17,913,829.59$ \\
\hline $1906 \ldots .$. & & 541,198 & 44 & & $* 315,924.06$ & $20,641,708.06$ \\
\hline $1907 \ldots . .$. & & 527,869 & & & $* 165,718.03$ & $19,025,726.27$ \\
\hline
\end{tabular}

* Loss.

The proportion of the profits derived from the different branches of the business in some of the years bears little relation to the proportion of the sales made by each department. Some of the departments at times have been much more profitable than others; in fact, in some years certain departments have incurred heavy losses. Particularly 
noticeable are the very large losses of the American Tobacco Company in its plug-tobacco business from 1895 to 1898 . These were due to the effort of the company to get a very large proportion of the total output of the country, the ultimate result of which was to bring the leading competitors into combination with the American. The losses of the plug business had to be made up out of the large profits of the cigarette business. After the leading competitors had been brought into the Combination, however, the plug business became very profitable, and in every year since 1900 it has contributed more to the profits of the American, Continental, and Lorillard companies than any other one branch. In 1903, when the profits in the plug business reached their maximum, they represented more than 60 per cent of the total profits. The profits of the smoking-tobacco business during the more recent years rank next to those of plug tobacco, and the profits in the smoking department have continued to increase since 1903, while those in plug have been less than in that year.

In 1907 the proportion of the total profits derived from each branch of the business was as follows:

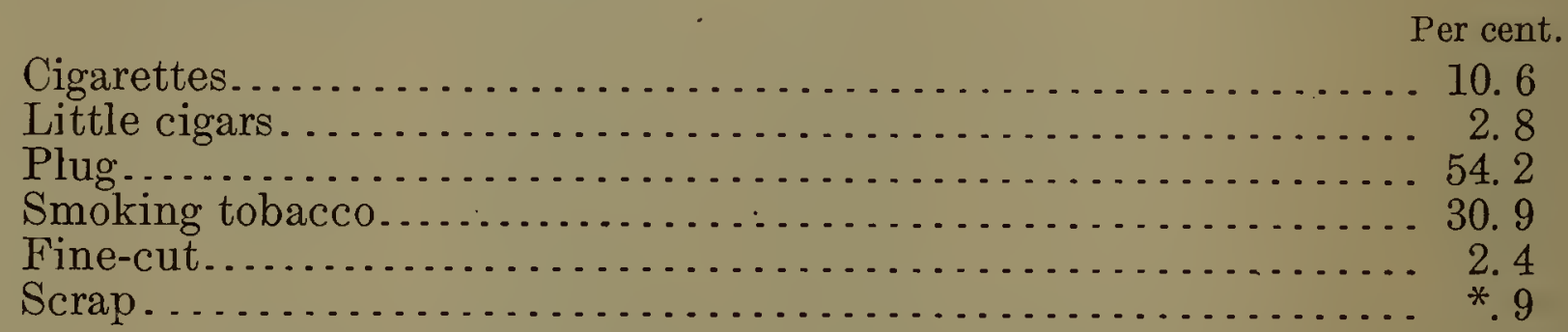

This table shows that in 1907 the proportion of the profit contributed by each department, with the exception of the little cigar and scrap departments, which in 1907 lost money, was roughly similar to the proportion of the sales which the department represented. In other words, there is no very great difference in the rate of profit on cost in the several departments at the present time; but, as already indicated, during some of the earlier years there were very great differences as among departments.

COMBINED SALES AND PROFITS OF AMERICAN, CONTINENTAL, AND LORILLARD COMPANIES AND THEIR LEADING SUBSIDIARY COMPANIES.

The figures of the American, Continental, and Lorillard companies, above presented, represent a very large fraction of the total business of the Tobacco Combination in plug, smoking, fine-cut, and scrap tobacco, and in cigarettes and little cigars. As already stated, data are not available by which to show the total sales and profits of all the companies of the Combination in these respective branches of the business. Data have, however, been secured for most of the important subsidiary companies manufacturing these products, and the combined results of the business of the American, Continental, and Lorillard companies and these subsidiary companies, from 1899 to 1907, may now be presented. There were no subsidiary companies engaged in the domestic business prior to 1899 .

Table 10 shows the total value less tax of the sales of smoking, plug, fine-cut, and scrap tobacco, cigarettes, little cigars, and cheroots (also snuff during the period before the formation of the American 
Snuff Company) for the American, Continental, and Lorillard companies and their leading subsidiary companies combined in the domestic trade. It also shows the cost (excluding tax) and the profits of this business, as well as the proportions of the value represented by cost and profit respectively. It should be clearly understood that the table does not include the American Cigar Company and its subsidiary companies or the American Snuff Company and its subsidiary companies.

TABLE 10.-Net value of sales (less tax) and profit of the American, Continental, and Lorillard and their principal subsidiary companies.

[American Cigar and American Snuff companies not included.]

\begin{tabular}{|c|c|c|c|c|c|}
\hline \multirow{2}{*}{ Year. } & \multirow{2}{*}{$\begin{array}{l}\text { Net value (less } \\
\text { tax). }\end{array}$} & \multirow{2}{*}{ Cost. } & \multirow{2}{*}{ Profit. } & \multicolumn{2}{|c|}{$\begin{array}{l}\text { Proportion of net } \\
\text { price represented } \\
\text { by- }\end{array}$} \\
\hline & & & & Cost. & Profit. \\
\hline 1899.. & $\$ 41,201,984.91$ & $\$ 35,843,798.13$ & $\$ 5,358.186 .78$ & Per cent. & Per cent. \\
\hline $1900 .$. & $48,298,515.23$ & $39,101,174.25$ & $9,197,340.98$ & $\begin{array}{l}81.0 \\
81.0\end{array}$ & $\begin{array}{l}13.0 \\
19.0\end{array}$ \\
\hline $1901 .$. & $53,731,962.89$ & $40,428,077.35$ & $13,303,885.54$ & 75.2 & 24.8 \\
\hline 1902. & $66,940,446.09$ & $49,188,056.00$ & $17,752,390.09$ & 73.5 & 26.5 \\
\hline $1903 .$. & $74,953,380.98$ & $53,676,326.64$ & $21,277,054.34$ & 71.6 & 28.4 \\
\hline $1904 .$. & $76,516,936.74$ & $57,201,374.81$ & $19,315,561.93$ & 74.8 & 25.2 \\
\hline 1905. & $81,257,925.87$ & $59,079,427.06$ & $22,178,498.81$ & 72.7 & 27.3 \\
\hline 1906 & $88,685,851.83$ & $63,739,863.62$ & $24,945,988.21$ & 71.9 & 28.1 \\
\hline 1907. & $92,731,297.03$ & $68,026,468.07$ & $24,704,828.96$ & 73.4 & 26.6 \\
\hline
\end{tabular}

The business of the subsidiary companies of the American and Continental companies has rapidly increased in importance, partly because of the acquisition from time to time of stock in additional companies and partly because of the rapid growth of the business of some of the companies after their acquisition. It will be seen by comparing the above table with Table 6 that in 1899 the value of the sales of the American, Continental, and Lorillard companies alone (less tax) was $\$ 40,337,884.70$, while, including the business of their principal subsidiary companies, the value was only a little greater, $\$ 41,201,984.91$. On the other hand, in 1907 the value of the direct business of the American and Lorillard companies was $\$ 65,047,357.19$, while the value of their output plus that of the leading subsidiary companies was $\$ 92,731,297.03$. In other words, the principal subsidiary companies had about 40 per cent as much business as the parent companies and contributed about 30 per cent of the total business. Were figures for all of the subsidiary companies available, the proportion of the total business in the hands of subsidiary companies would appear somewhat larger still.

A comparison of the figures of profits given in this table with those given in Table 6 for the American, Continental, and Lorillard companies alone shows that the subsidiary companies do not contribute as large a proportion of the profits as they do of the volume of business of the Combination. In 1899 nearly all of the profits were those of the parent companies, whereas in 1907 the profits of the American, 
Continental, and Lorillard companies on their own business were $\$ 19,025,726.27$, and the profits of the principal subsidiary companies engaged in the same branches of the business were $\$ 5,679,102.69$, making a total of $\$ 24,704,828.96$. The profits of the principal subsidiary companies were thus between one-fifth and one-fourth of the total profits in these branches of the business.

By comparing this table with Table 6 above, which presents similar figures for the American, Continental, and Lorillard companies alone, it will be seen that for the Combination as a whole (that is, for the American, Continental, and I corillard companies, and their principal subsidiary companies, not including the American Cigar and American Snuff companies) the proportion of the net value of the product represented by profit is in each year somewhat lower than for the American, Continental, and Lorillard companies alone, the business of the subsidiary companies being somewhat less profitable than that of the parent companies. The movement of the figures from year to year is, however, almost exactly the same. There was a very rapid increase in the proportion of the net value represented by profit from 1899 , when it was 13.0 per cent, to 1903 , when it reached 29.4 per cent. The proportion represented by profit has never been quite so large since, but there has been no great variation. In 1907 profit represented 26.6 per cent of the net value, less tax, of the product of all of these companies.

Table 11 shows the percentage which the profits of the Combination as a whole (that is, of the principal companies taken together) has borne from year to year to the cost of production, exclusive of the internal-revenue tax. This table is similar to Table 7 above, except that it includes the subsidiary companies.

TABLE 11.-Rate of profit on cost for the American, Continental, and Lorillard and their principal subsidiary companies.

[American Cigar and American Snuff companies not included.]

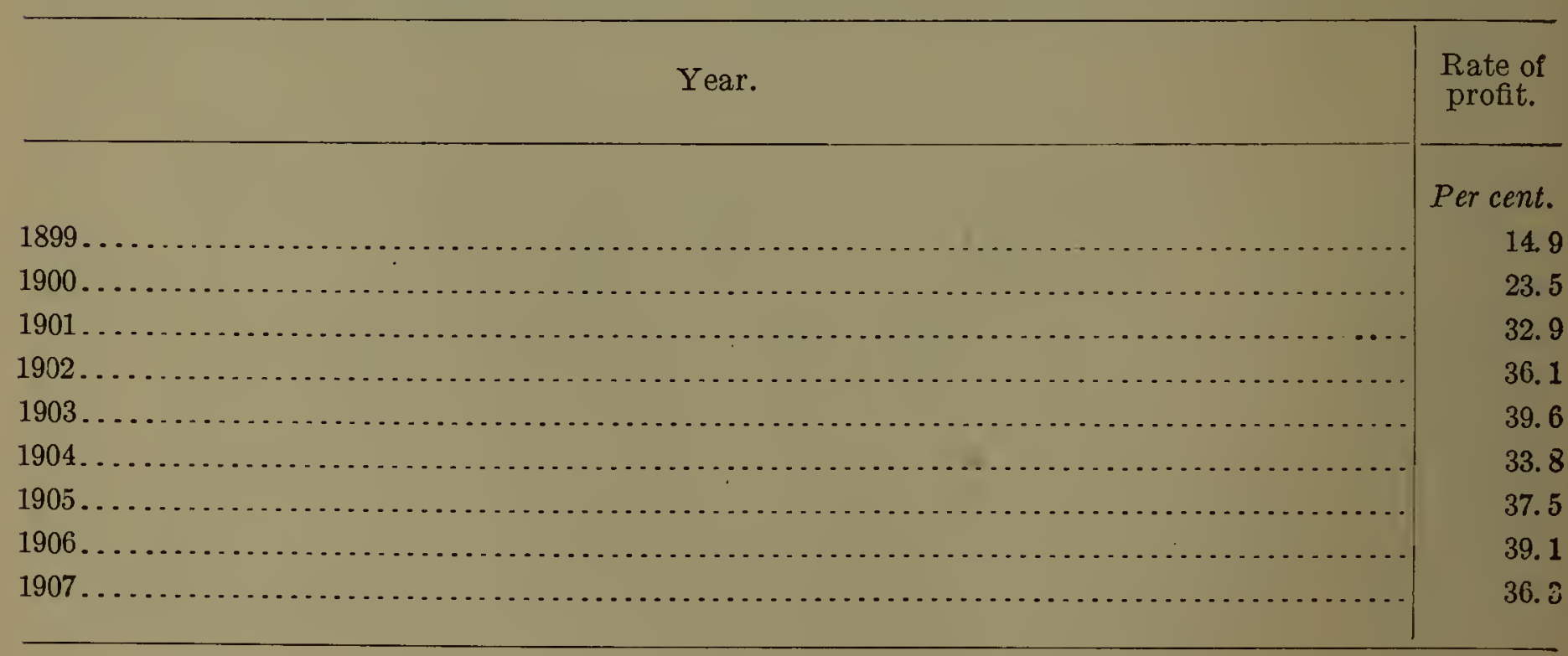

It will be seen that the rate of profit for the Combination as a whole has been a trifle lower in each year except 1899 than the rate for the American, Continental, and Lorillard companies alone; but otherwise the table shows little diference. The percentage of profit on cost for the entire Combination increased from 14.9 per cent in 1899 , to 39.6 per cent in 1903 , and in 1907 was 36.3 per cent. 
PRICES AND PROFITS OF THE INDIVIDCAL DEPARTMENTS OF THE PRINCIPAL COMPANIES OF THE TOBACCO COMBINATION.

The total profits of the American, Continental, and Lorillard companies, as well as the total for these companies and their principal subsidiary companies combined, represent a wide variety of business. The profits of the different departments of the business vary considerably, and at certain periods of time have differed much more greatly than in the more recent years.

Where the purpose is to present a comparison of conditions with respect to the prices and profits of the different departments of the business at one period of time with those at another, a somewhat greater degree of comparability is secured by confining attention to the business of the American, Continental, and Lorillard companies alone. It has already been made clear that from time to time during recent years the Combination has secured control of additional subsidiary companies. In some cases the business of these companies was, or afterwards became, more profitable than the business of the parent companies themselves; but in more numerous cases the business of the subsidiary companies thus acquired was less profitable than that of the parent companies. The addition of such new business from time to time tends to some slight degree to make the figures for the Combination as a whole for the later years less comparable with those for the earlier years. Nevertheless, it has been found that for the important departments of the business, except cigarettes, the movements of prices, costs, and profits for the Combination as a whole differ so slightly from the movements for the corresponding departments of the American, Continental, and Lorillard companies alone that it is practically immaterial for the purposes of reaching general conclusions whether the one set of figures be used or the other. Since, moreover, as to any given date greater interest attaches to the results of the business of the Combination as a whole than to the results of the business of the parent companies alone, it has been deemed preferable in this summary presentation to show the figures for the entire Combination by departments.

Because of the wholly distinct character of the organization of the Combination's snuff and cigar business, the data for these two branches are not presented at the present point. The data for the snuff business will be taken up more fully later; while the Bureau is not prepared at the present time to report on the cigar business. It should be understood, therefore, that the following tables, which show the general results by departments of the business of the Combination, represent the combined business of the American, Continental, and Lorillard companies, and of their leading subsidiary companies exclusive of the American Cigar and American Snuff companies. As already explained, data for some of the minor subsidiary companies have not been secured, but the figures here presented represent very nearly the entire business of the Combination in the departments which they cover.

Table 12 shows the quantity of sales of the several classes of products by the Tobacco Combination, and the net value thereof less tax. 
TABLE 12.-Quantity and value of sales (less tax), by departments, for the American, Continental, and Lorillard, and their principal subsidiary companies (domestic business).

[The business of the American Cigar and American Snuff companies is not included.]

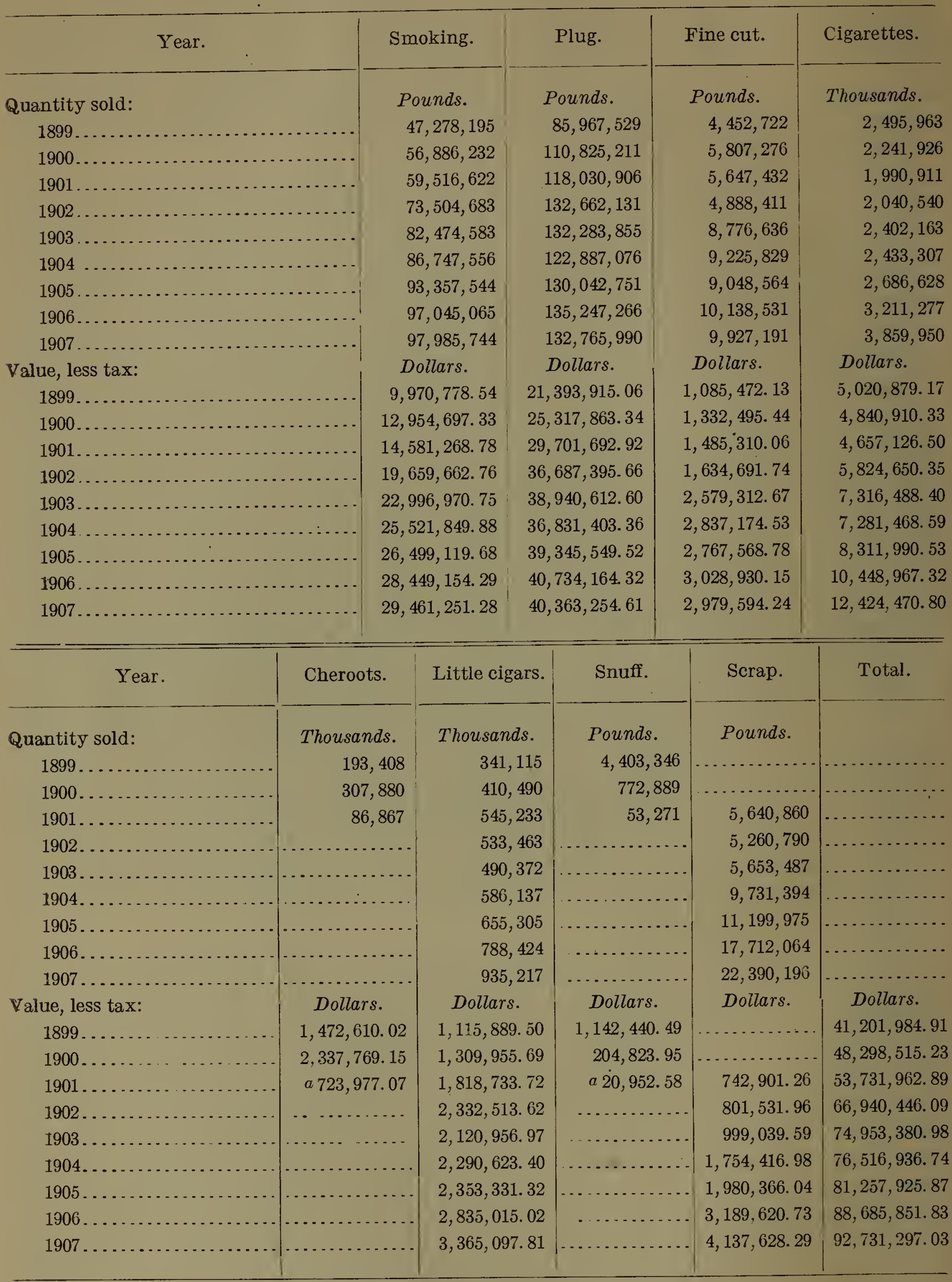

a Gross invoice price, less tax.

The little-cigar business of the Combination is wholly in the hands of the American Tobacco Company itself, but in each of the other branches of the business there are, during recent years, important subsidiary concerns having a very considerable fraction of the total output. The relative importance of the different branches of the 
business is, broadly, the same--as judged by the value of sales-for the Combination as a whole as for the American, Continental, and Lorillard companies alone. One of the noteworthy features of the table, however, is the very marked increase in the value of the cigarettes sold by the Combination as a whole, whereas the American Tobacco Company alone has shown comparatively little increase in the value of the output of cigarettes.

For 1907 the proportions of the total value of the output of the Combination represented by the business of the subsidiary concerns in the several branches, as based on the above table,'were as follows:

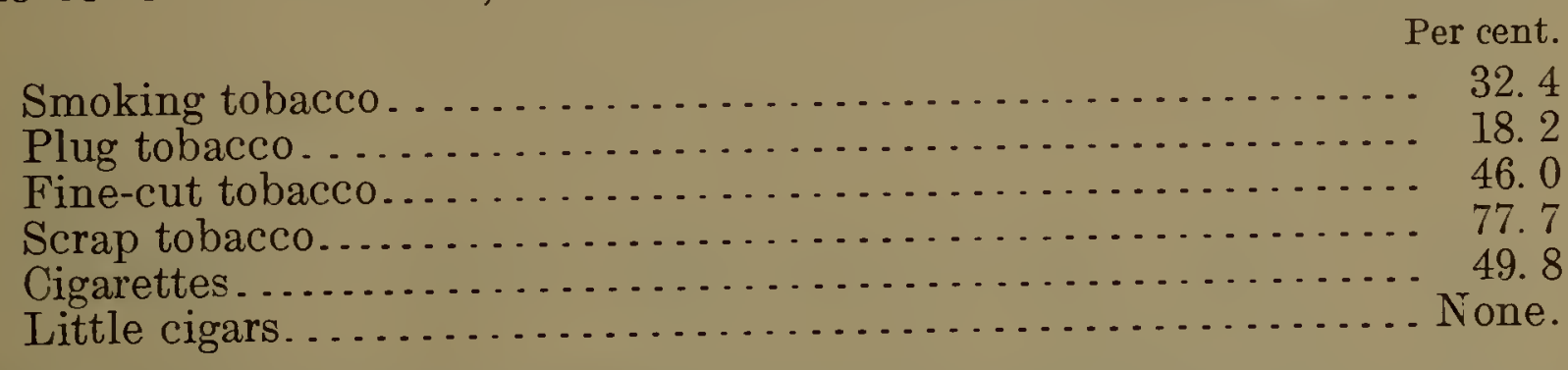

Were figures for all of the subsidiary companies included the proportion of the business which they handle would be somewhat greater in the case of smoking and plug tobacco, but for the other branches of the business the above figures include all of the subsidiary companies which handle these products respectively.

Table 13 shows the profits of the several branches of the business for the American, Continental, and Lorillard companies and their principal subsidiary companies combined.

TABLE 13.-Net profit, by departments, of the American, Continental, and Lorillard and their principal subsidiary companies (domesiic business).

[The business of the American Cigar and American Snuff companies is not included.]

\begin{tabular}{|c|c|c|c|c|c|c|}
\hline Year. & & Smoking. & \multicolumn{2}{|c|}{ Plug. } & Fine cut. & Cigarettes. \\
\hline 1899. & & $\$ 1,320,738.26$ & \multicolumn{2}{|c|}{$\$ 1,606,965.15$} & $\$ 77,635.57$ & $\$ 2,630,373.73$ \\
\hline 1900. & & $2,563,833.04$ & \multicolumn{2}{|c|}{$4,164,888.88$} & $* 39,404.01$ & $2,420,943.76$ \\
\hline 1901. & & $3,466,879.65$ & \multicolumn{2}{|c|}{$7,560,624.44$} & $* 107,734.86$ & $1,926,516.71$ \\
\hline 1902. & & $5,006,884.63$ & \multicolumn{2}{|c|}{$11,019,712.61$} & $314,755.67$ & $1,320,090.78$ \\
\hline 1903 & & $5,129,836.90$ & \multicolumn{2}{|c|}{$12,971,161.84$} & $506,204.70$ & $2,259,782.97$ \\
\hline 1904 & & $6,185,850.53$ & \multicolumn{2}{|c|}{$9,837,348.45$} & $573,686.40$ & $2,146,861.02$ \\
\hline 1905 & & $7,711,171.85$ & \multicolumn{2}{|c|}{$10,569,390.48$} & $604,299.23$ & $2,662,677.65$ \\
\hline 1906. & & $8,754,351.47$ & \multicolumn{2}{|c|}{$12,267,025.49$} & $666,733.59$ & $3,196,605.30$ \\
\hline $1907 \ldots$ & & $9,105,265.99$ & \multicolumn{2}{|c|}{$11,558,909.84$} & $529,312.33$ & $3,329,127.82$ \\
\hline Year. & Cheroots. & \multicolumn{2}{|c|}{ Little cigars. } & Snuff. & Scrap. & Total. \\
\hline 1899 & $* \$ 229,590.33$ & \multicolumn{2}{|c|}{$\$ 22,508.74$} & $* \$ 70,444.34$ & & $\$ 5,358,186.78$ \\
\hline $1900 \ldots$ & $* 15,543.98$ & \multicolumn{2}{|c|}{$132,373.51$} & $* 29,750.22$ & $\therefore \ldots \ldots \ldots$ & $9,197,340.98$ \\
\hline 1901. & \multirow[t]{2}{*}{$93,540.71$} & \multicolumn{2}{|c|}{$340,769.20$} & $2,220.98$ & $\$ 21,068.71$ & $13,303,885.54$ \\
\hline 1902. & & \multicolumn{2}{|c|}{$105,639.59$} & & $* 14,693.19$ & $17,752,390.09$ \\
\hline $1903 \ldots$ & \multicolumn{3}{|c|}{$190,056.58$} & & $220,011.35$ & $21,277,054.34$ \\
\hline $1904 \ldots$ & \multicolumn{3}{|c|}{$424,204.27$} & & $147,611.26$ & $19,315,561.93$ \\
\hline $1905 \ldots$ & \multicolumn{3}{|c|}{$600,044.86$} & & $30,914.74$ & $22,178,498.81$ \\
\hline $1906 \ldots$ & \multicolumn{3}{|c|}{$541,198.44$} & & $* 479,926.08$ & $24,945,988.21$ \\
\hline $1907 \ldots$ & \multicolumn{3}{|c|}{$527,869.53$} & & $* 345,656.55$ & $24,704,828.96$ \\
\hline
\end{tabular}

*Loss. 
This table shows that the subsidiary companies contribute a particularly large proportion of the profits in the smoking tobacco business. In the plug, fine cut, and scrap business the subsidiary companies contribute a smaller proportion of the profits than they do of the volume of sale (as measured by value); in other words, they are less profitable than the parent companies. The proportions of the total profit for all the companies covered by the table which are represented by the profits of the subsidiary companies are as follows:

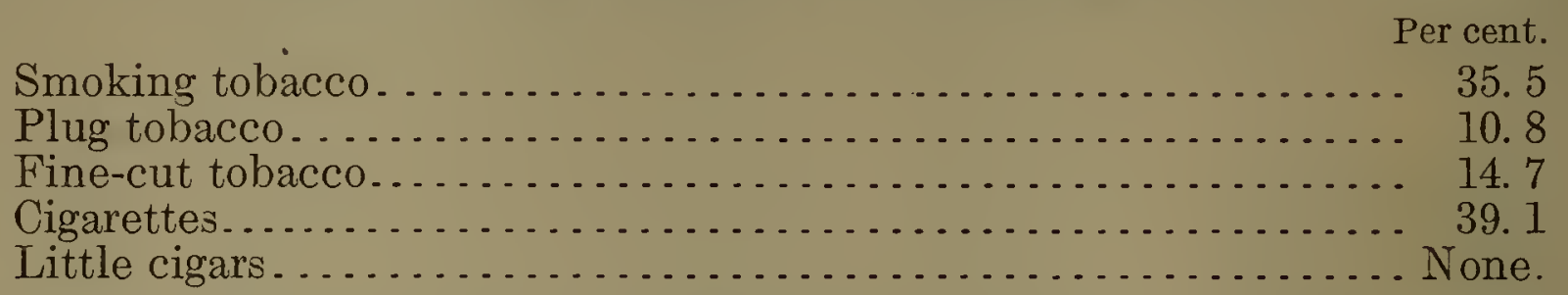

On scrap tobacco both the American Tobacco Company and its subsidiary companies lost money in 1907.

From the above tables, showing the quantity of sales of the several departments of the Combination, the net value exclusive of tax and the amount of profit, may be computed the average price less tax, the profit per pound or per thousand, the proportions of the price represented by cost and profit, and the rate of profit on cost. For the years before 1899 the same data may be computed for theAmerican Tobacco Company alone from Tables 8 and 9. More detailed tables presented subsequently show also for each department the average net price per unit, including tax, and the average tax per unit, and these tables may conveniently be brought together and summarized at the present point.

The most significant data with relation to the different departments are the average prices per unit, exclusive of the internal-revenue tax, and the profit per unit. Table 14 shows, for the principal companies of the Tobacco Combination (exclusive of the American Snuff and American Cigar companies), the average price, less tax, and the average profit for each year from 1895 to 1907 . In the case of cigarettes and little cigars the data for the earlier years are fairly comparable with those for the later; but there is little significance in comparing the results of the other branches of the business prior to 1899 , when the Combination included only the American Tobacco Company which had a small proportion of the output of these products, with those for the later years. In the more detailed analysis of the results of the different departments of the business, given later, comments showing to what extent the figures are or are not comparable are presented. It will be noted that in Table 14 the figures given for cigarettes represent only the business of the American Tobacco Company and do not include the subsidiary companies. The subsidiary companies for the most part make only Turkish cigarettes, while the American Tobacco Company makes cigarettes from domestic leaf. The subsidiary companies first became important only during the most recent years, and as the product which they make is very different in character and much higher priced than the cigarettes made from domestic leaf the inclusion of the business of the subsidiary companies would render the average price and profit for the Combination as a whole during these more recent years wholly incomparable with the average during the earlier years, when the business represented only cigarettes of domestic leaf. The figures for little cigars 
also represent only the product of the American Tobacco Company, but none of the subsidiary companies is engaged in the manufacture of little cigars.

TABLE 14.-Average prices and profits, by departments, of the Tobacco Combination (domestic business).

[American Cigar and American Snuff companies not included.]

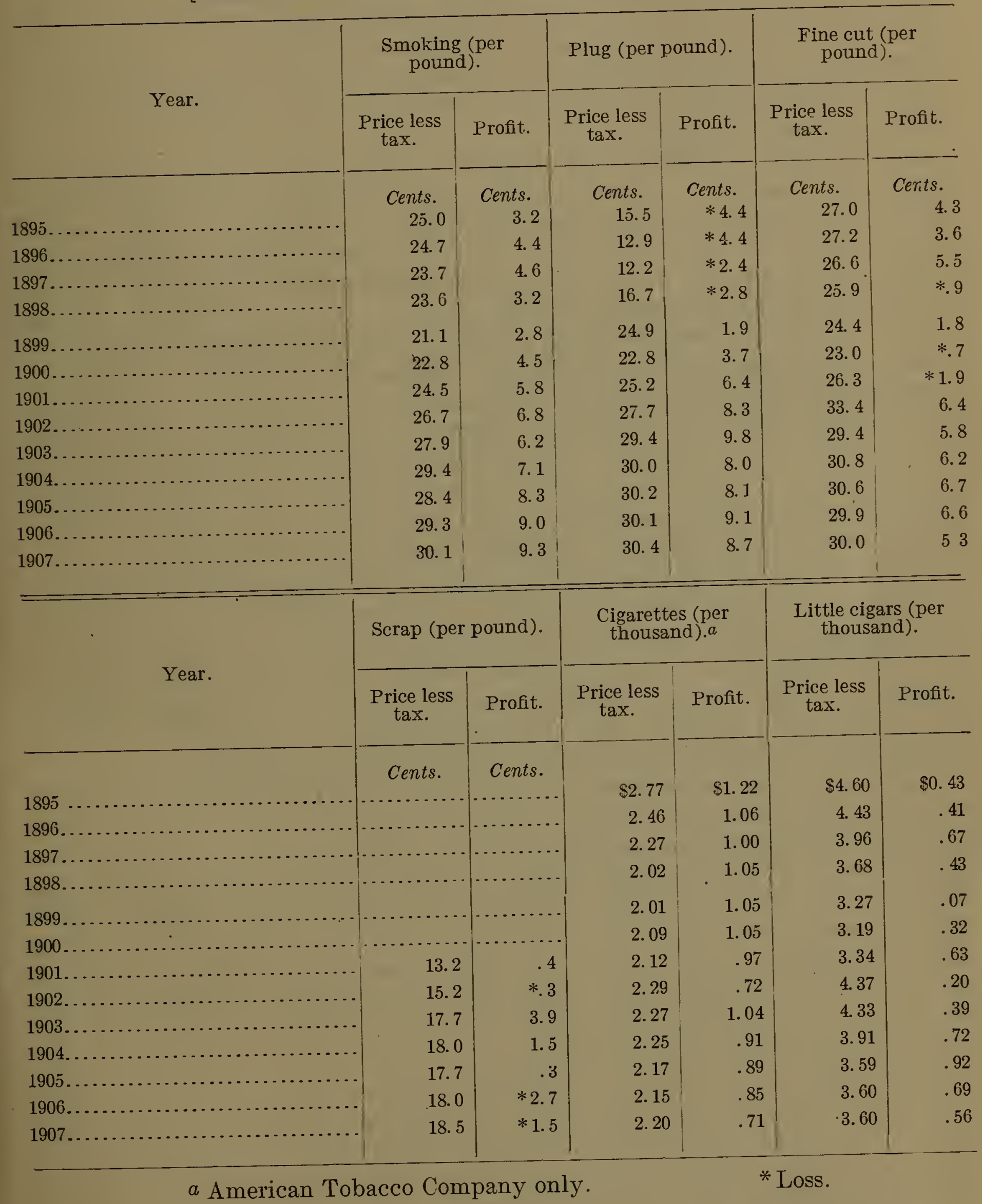

It is unnecessary at this point to comment in detail on the movements of prices and profits shown by this table, as the data for the departments severally are repeated at a later point and fully discussed there.

Owing to the fact that, as already stated, the prices and profits of the American Tobacco Company during the period from 1895 to 1898 
are in general scarcely comparable with the prices and profits of the Tobacco Combination in more recent years, attention may be confined to the movement of prices and profits since 1899 . It will be seen that between 1899 and 1907 the average price of smoking tobacco exclusive of tax increased 42.7 per cent; plug tobacco (between 1900 and 1907, precise data for 1899 not being available), 33.3 per cent; fine-cut tobacco, 23 per cent; cigarettes, 9 per cent; and little cigars 10.1 per cent. Plug and smoking tobacco are the two most important products of the Combination. In the case of cigarettes and little cigars this comparison has little significance, owing to the changes in the proportions of the different grades included in the average.

In considering these increases in the prices of smoking, plug, and fine-cut tobacco, it is only. proper to state that there have been general increases in the prices of most commodities during recent years, owing in part at least to the increased supply of gold. The average wholesale price of 258 commodities selected by the Bureau of Labor as typical was 27.3 per cent higher in 1907 than in 1899 and 17.2 per cent higher than in 1900 . There has also been an advance in wages during this period. How far the price of the raw materials entering into the manufacture of tobacco-other than leaf tobacco-and how far the wages of employees in the tobacco industry have increased during this period, the bureau has not determined. There has been an increase in the price of leaf tobacco, the most important element of cost, during the years from 1899 to 1907, which has tended to increase the cost of manufacture. It is evident from the columns of the above table showing the profits on smoking, plug, and fine-cut tobacco, however, that the costs have increased very much less than the price, so that the profit per pound increased nearly as much between 1899 and 1907 as the price increased. That the cost of manufacture of the Combination has not increased more rapidly may be due in part to economies resulting. from its large-scale business and efficient administration.

It may be noted also that some increase in the profit per pound on tobacco would be expected merely by reason of the increase in the prices of commodities generally. It is evident that with an increase of 27 per cent in the average prices of commodities between 1899 and 1907 , the manufacturer who made 1 cent per pound profit in 1899 would not be as well off if he made 1 cent per pound in 1907 as he was before, because he could buy fewer commodities with his profits. This consideration, however, is relatively unimportant in view of the increase of several fold in the profits of the more important branches of the business.

The table shows that on smoking tobacco the profit increased from 2.8 cents per pound in 1899 to 9.3 cents in 1907; on plug from about 1.9 cents to 8.7 cents; and on fine-cut from 1.8 cents to 5.3 cents. For plug tobacco the maximum profit was reached in. 1903 , for smoking in 1907, and for fine cut in 1905; but in none of these three departments has there been any great variation in profit since 1903. For cigarettes, on the other hand, the profit per thousand during the more recent years has been somewhat lower than during the earlier years. This may be in some small part due to the fact that the Tobacco Combination controlled a larger proportion of 
the cigarette business of the country in the earlier years than in the later, but it appears to a greater extent to be due to the higher rate of taxation on cigarettes at the present time as compared with the years before the Spanish war. The prices of cigarettes to the consumer being absolutely fixed by custom, the Combination has not been able to raise its price to jobbers as much as the tax has increased. Moreover, as more fully explained later, the figures for cigarettes from year to year are not altogether comparable on account of the variations in the proportions of the business represented by different types of cigarettes. The same statement holds true with regard to the figures for little cigars. It will be seen that the scraptobacco business is the only branch in which the Tobacco Combination was not during 1906 and 1907, making a profit. This branch of the business is comparatively small and also relatively new, and there is very active competition in it.

The effect of changes in the internal-revenue tax on prices and profits is very important and striking.

Table 15 shows, for each of the departments of the business of the Tobacco Combination (i. e., for the American, Continental, and Lorillard companies and their principal subsidiary companies, not including the American Cigar and American Snuff companies), the average net price per pound or per thousand and the amount thereof represented by tax, cost, and profit, respectively. The figures for each department will be discussed more in detail at a later point.

TABLE 15.-Amount of tax, cost, and profit entering into net selling price for the several departments of the Tobacco Combination (domestic business).

[American Cigar and American Snuff companies not included.]

\begin{tabular}{|c|c|c|c|c|c|c|c|c|}
\hline \multirow{3}{*}{ Year. } & \multicolumn{4}{|c|}{ Smoking (per pound). } & \multicolumn{4}{|c|}{ Plug (per pound). } \\
\hline & \multirow{2}{*}{$\begin{array}{c}\text { Net } \\
\text { price. }\end{array}$} & \multicolumn{3}{|c|}{ Elements of price. } & \multirow{2}{*}{$\begin{array}{c}\text { Net } \\
\text { price. }\end{array}$} & \multicolumn{3}{|c|}{ Elements of price. } \\
\hline & & Tax. & Cost. & Profit. & & Tax. & Cost. & Profit. \\
\hline $1895 \ldots$ & $\begin{array}{r}\text { Cents. } \\
31.0\end{array}$ & $\begin{array}{r}\text { Cents. } \\
6.0\end{array}$ & $\begin{array}{r}\text { Cents. } \\
21.8\end{array}$ & $\begin{array}{r}\text { Cents. } \\
3.2\end{array}$ & $\begin{array}{r}\text { Cents. } \\
21.5\end{array}$ & $\begin{array}{r}\text { Cents. } \\
6.0\end{array}$ & $\begin{array}{r}\text { Cents. } \\
19.9\end{array}$ & $\begin{array}{l}\text { Cents. } \\
\quad * 4.4\end{array}$ \\
\hline 1896. & 30.7 & 6.0 & 20.3 & 4. 4 & 18.9 & 6.0 & 17.3 & $* 4.4$ \\
\hline 1897. & 29.7 & 6.0 & 19.1 & 4.6 & 18.2 & 6.0 & 14.6 & $* 2.4$ \\
\hline $1898 \ldots$. & 32.1 & a 8.5 & 20.4 & 3.2 & 25.2 & a 8.5 & 19.5 & $* 2.8$ \\
\hline $1899 . .$. & 33.1 & 12.0 & 18.3 & 2.8 & 36.9 & 12.0 & 23.0 & 1.9 \\
\hline $1900 \ldots$ & 34.8 & 12.0 & 18.3 & 4.5 & 34.8 & 12.0 & 19.1 & 3.7 \\
\hline $1901 \ldots$ & 35.3 & $a 10.8$ & 18.7 & 5.8 & 36.1 & $a 10.9$ & 18.8 & 6.4 \\
\hline 1902. & 34.5 & 7.8 & 19.9 & 6.8 & 35.5 & $a 7.8$ & 19.4 & 8.3 \\
\hline 1903. & 33.9 & 6.0 & 21.7 & 6.2 & 35.4 & 6.0 & 19.6 & 9.8 \\
\hline $1904 \ldots$ & 35.4 & 6.0 & 22.3 & 7.1 & 36.0 & 6.0 & 22.0 & 8.0 \\
\hline 1905. & 34.4 & 6.0 & 20.1 & 8.3 & 36.2 & 6.0 & 22.1 & 8.1 \\
\hline $1906 \ldots$ & 35.3 & 6.0 & 20.3 & 9.0 & 36.1 & 6.0 & 21.0 & 9.1 \\
\hline $1907 \ldots \ldots$ & 36.1 & 6.0 & 20.8 & 9.3 & 36.4 & 6.0 & 21.7 & 8.7 \\
\hline
\end{tabular}

$a$ Rate of tax changed during year. This is an average. $\quad *$ Loss. 
TABLE 15.-Amount of tax, cost, and profit entering into net selling price for the several departments of the Tobacco Combination (domestic business)-Continued.

[American Cigar and American Snuff companies not included.]

\begin{tabular}{|c|c|c|c|c|c|c|c|c|}
\hline \multirow{3}{*}{ Year. } & \multicolumn{4}{|c|}{ Fine cut (per pound). } & \multicolumn{4}{|c|}{ Scrap (per pound). } \\
\hline & \multirow{2}{*}{$\begin{array}{c}\text { Net } \\
\text { price. }\end{array}$} & \multicolumn{3}{|c|}{ Elements of price. } & \multirow{2}{*}{$\begin{array}{c}\text { Net } \\
\text { price. }\end{array}$} & \multicolumn{3}{|c|}{ Elements of price. } \\
\hline & & Tax. & Cost. & Profit. & & Tax. & Cost. & Profit. \\
\hline 1895. & $\begin{array}{r}\text { Cents. } \\
33.0\end{array}$ & $\begin{array}{r}\text { Cents. } \\
6.0\end{array}$ & $\begin{array}{r}\text { Cents. } \\
22.7\end{array}$ & $\begin{array}{r}\text { Cents. } \\
4.3\end{array}$ & Cents. & Cents. & Cents. & $\begin{array}{c}\text { Cents. } \\
\ldots \ldots \ldots\end{array}$ \\
\hline $1896 .$. & 33.2 & 6.0 & 23.6 & 3.6 & & & & \\
\hline 1897. & 32.6 & 6.0 & 21.1 & 5.5 & & & & \\
\hline $1898 .$. & 34.4 & a 8.5 & 26.8 & $* 0.9$ & & & & \\
\hline $1899 .$. & 36.4 & 12.0 & 22.6 & 1.8 & & & & .... \\
\hline 1900 & 35.0 & 12.0 & 23.7 & $* 0.7$ & & & & $\cdots$ \\
\hline 1901. & 37.2 & $a_{10.9}$ & 28.2 & $* 1.9$ & 24.0 & a 10.8 & 12.8 & 0.4 \\
\hline 1902. & 41.2 & $a 7.8$ & 27.0 & 6.4 & 23.0 & a 7.8 & 15.5 & $* .3$ \\
\hline 1903 & 35.4 & 6.0 & 23.6 & 5.8 & 23.7 & 6.0 & 13.8 & 3.9 \\
\hline 1904 & 36.8 & 6.0 & 24.6 & 6.2 & 24.0 & 6.0 & 16.5 & 1.5 \\
\hline 1905 & 36.6 & 6.0 & $2 \dot{3} .9$ & 6.7 & 23.7 & 6.0 & 17.4 & .3 \\
\hline 1906 & 35.9 & 6.0 & 23.3 & 6.6 & 24.0 & 6.0 & 20.7 & *2.7 \\
\hline 1907. & 36.0 & 6.0 & 24.7 & 5.3 & 24.5 & 6.0 & 20.0 & $* 1.5$ \\
\hline \multirow{3}{*}{ Year. } & \multicolumn{4}{|c|}{ Cigarettes $c$ (per thousand). } & \multicolumn{4}{|c|}{ Little cigars (per thousand). } \\
\hline & \multirow{2}{*}{$\begin{array}{c}\text { Net } \\
\text { price. }\end{array}$} & \multicolumn{3}{|c|}{ Elements of price. } & \multirow{2}{*}{$\begin{array}{l}\text { Net } \\
\text { price. }\end{array}$} & \multicolumn{3}{|c|}{ Elements of price. } \\
\hline & & Tax. & Cost. & Profit. & & Tax. & Cost. & Profit. \\
\hline 1895. & $\$ 3.27$ & $\$ 0.50$ & $\$ 1.55$ & $\$ 1.22$ & $\$ 5.10$ & $\$ 0.50$ & $\$ 4.17$ & $\$ 0.43$ \\
\hline $1896 .$. & 2.96 & .50 & 1. 40 & 1.06 & 4. 93 & .50 & 4.02 & .41 \\
\hline $1897 .$. & 2.94 & $a .67$ & 1. 27 & 1.00 & 4. 68 & $a .72$ & 3. 29 & .67 \\
\hline 1898.. & 3.27 & $a 1.25$ & .97 & 1.05 & 4.68 & 1.00 & 3.25 & .43 \\
\hline 1899. & 3. 51 & 1. 50 & .96 & 1.05 & 4. 27 & 1.00 & 3.20 & .07 \\
\hline $1900 \ldots$ & 3. 59 & 1.50 & 1.04 & 1.05 & 4. 19 & 1.00 & 2.87 & .32 \\
\hline $1901 .$. & 3. 39 & ${ }^{a} 1.27$ & 1.15 & .97 & 4. 10 & $a .76$ & 2.71 & .63 \\
\hline 1902. & 3.29 & $b 1.00$ & 1. 57 & .72 & 4. 91 & .54 & 4. 17 & .20 \\
\hline 1903.. & 3.27 & b 1.00 & 1.23 & 1.04 & 4. 87 & .54 & 3.94 & .39 \\
\hline $1904 \ldots$ & 3.24 & b. .99 & 1.34 & .91 & 4.45 & .54 & 3.19 & .72 \\
\hline $1905 \ldots$ & 3.14 & b. .97 & 1.28 & .89 & 4. 13 & .54 & 2. 67 & .92 \\
\hline 1906. & 3. 13 & b. 98 & 1.30 & .85 & 4. 14 & .54 & 2. 91 & .69 \\
\hline 1907. & 3. 19 & b. 99 & 1. 49 & .71 & 4.14 & .54 & 3.04 & .56 \\
\hline
\end{tabular}

$a$ Rate of tax changed during year. This is an average.

$b$ This is the average rate on the two classes of cigarettes, one taxed at $\$ 1.08$ per thousand and the other at $\$ 0.54$ per thousand.

$c$ American Tobacco Company alone. The cigarette business of subsidiary companies is not comparable from year to year.

* Loss.

For reasons already stated, it is impossible to draw strictly correct conclusions from this table regarding the effect of the increase in the internal-revenue taxes in 1897 and 1898 upon prices and profits. Save in the case of cigarettes and little cigars, the volume and character of the business covered during the period 1895 to 1898 is so different from that covered during the later period that comparisons of prices and profits have little significance. Data from other sources, 
showing the movement of prices at the time the taxes were increased, will be presented in connection with the analysis of the individual branches of the business. It may be stated at this point that the evidence goes to show that the prices of smoking, plug, and fine-cut tobacco were very generally increased by the manufacturers by an amount sufficient at least to cover the increase in the tax, but that in the case of cigarettes and little cigars the increase in price was somewhat less than the increase in tax. For the period since 1899 the figures in the above table are comparable, particularly in the case of smoking, plug, and fine-cut tobacco.

The most striking fact shown by this table is that in the case of plug, smoking, and fine-cut tobacco (plug and smoking being the most important branches of the business) there was little if any reduction in the average net price charged to the public at the time when the internal-revenue tax was reduced from 12 cents to 6 cents per pound in 1901 and 1902 . In the case of cigarettes, where the tax was reduced from $\$ 1.50$ per thousand on all cigarettes to $\$ 1.08$ per thousand on cigarettes retailing at 10 for 5 cents and to $\$ 0.54$ per thousand on cigarettes retailing at 20 for 5 cents (the classification in the statute being based on the wholesale price of $\$ 2$ per thousand), there was some reduction in the average net price at that time, but this was chiefly due to increased sales of the cheap cigarettes which had been practically driven out by the high tax during the war perior. In the case of little cigars the apparent increase in the average net price at the time when the tax was reduced is misleading, since it is due to the inclusion of certain higher-class products which had not formerly been included in this group.

It will be seen that in the case of plug, smoking, and fine-cut tobacco the proportion of the net price represented by the internal-revenue tax is much smaller at the present time, not only than during Spanishwar period, when the taxes were higher, but also than during the period prior to the Spanish war, when the taxes were the same as at present. In the case of cigarettes, the proportion represented by tax during the more recent years, although lower than during the high-tax period of the Spanish war, is greater than it was in 1896 , when the tax was $\$ 0.50$ per thousand on all cigarettes, as compared with $\$ 1.08$ per thousand on the more valuable and $\$ 0.54$ per thousand on the less valuable cigarettes at the present time. In the case of little cigars there is comparatively little difference in the proportion represented by tax at the present time as compared with the years before the tax was increased. In all cases except cigarettes and scrap tobacco (the latter being a relatively unimportant and unprofitable branch of the business) the proportion of the net price represented by profit is not only much greater at the present time than during the period of the Spanish war, but also much greater than during the period before the Spanish war (though in the case of little cigars the difference is much less marked than in the case of plug, smoking, and fine-cut tobacco).

It will be noted from this table that the cost of most of the products has in general been higher during the more recent years than during the earlier. In a rough way it may be said that the costs reached their highest point from 1903 to 1905 (in the case of little cigars and cigarettes in 1902). The unusually high costs during this period were largely due to extraordinary advertising expenditures, the apparent purpose of which was to enable the Combination to maintain the price 
of its products notwithstanding the reduction of the internal-revenue tax. There has been a marked reduction in these advertising expenses during the most recent years, but at the same time there has been in the case of most of the products a decided increase in the cost of leaf tobacco, so that the total costs were not materially lower in 1907 than in 1903 and 1904 (in the case of cigarettes the cost in 1907 was higher than in any other year except 1902.)

It should be emphasized at this point that all of the tables of prices and profits in the present report end with thr year 1907. The Bureau has not collected data covering the years 1908 and 1909. The published reports of the American Tobacco Company show that its aggregate profits in 1908 were somewhat greater than in any other year, but as there was an increase in the volume of its business, it is presumable that there was little if any increase in the profit per unit. The price of leaf tobacco, which in a broad way had been increasing up to 1907, increased further in 1908; and the leaf which is entering into the product now being manufactured in general costs decidedly more than it did four or five years ago. In the case of Burley leaf tobacco, which is used to a great extent in making plug, the price in 1908 was practically double that in 1907 , so that, except to the extent to which other types of tobacco may have been substituted for. Burley (which can be done only to a limited degree), the cost of the plug tobacco being manufactured at the present time has undoubtedly very much increased. The exceptionally high price of Burley leaf in 1908 would not, however, affect the cost of production of the plug sold in that year, as the leaf is kept for some time before it is used.

Table 16 shows the net price less tax for each of the departments of the combination (not including the American Cigar and American Snuff companies) and the proportions thereof represented by cost and profit respectively.

TABLE 16.-Division of net selling price (less tax) between cost and profit, for the several departments of the Tobacco Combination.

[American Cigar and American Snuff companies not included.]

\begin{tabular}{|c|c|c|c|c|c|c|c|c|c|}
\hline \multirow{3}{*}{ Year. } & \multicolumn{3}{|c|}{ Smoking. } & \multicolumn{3}{|c|}{ Plug. } & \multicolumn{3}{|c|}{ Fine cut. } \\
\hline & \multirow{2}{*}{$\begin{array}{l}\text { Net price } \\
\text { less tax } \\
\text { (per } \\
\text { pound). }\end{array}$} & \multicolumn{2}{|c|}{$\begin{array}{l}\text { Proportion repre- } \\
\text { sented by- }\end{array}$} & \multirow{2}{*}{$\begin{array}{l}\text { Net price } \\
\text { less tax } \\
\text { (per } \\
\text { pound). }\end{array}$} & \multicolumn{2}{|c|}{$\begin{array}{l}\text { Proportion repre- } \\
\text { sented by- }\end{array}$} & \multirow{2}{*}{$\begin{array}{l}\text { Net price } \\
\text { less tax } \\
\text { (per } \\
\text { pound). }\end{array}$} & \multicolumn{2}{|c|}{$\begin{array}{l}\text { Proportion repre- } \\
\text { sented by- }\end{array}$} \\
\hline & & Cost. & Profit. & & Cost. & Profit. & & Cost. & Profit. \\
\hline 1895. & $\begin{array}{l}\text { Cents. } \\
25.0\end{array}$ & $\begin{array}{r}\text { Percent. } \\
87.4\end{array}$ & $\begin{array}{r}\text { Percent. } \\
12.6\end{array}$ & $\begin{array}{l}\text { Cents. } \\
15.5\end{array}$ & $\begin{array}{r}\text { Per cent. } \\
128.3\end{array}$ & $\begin{array}{l}\text { Per cent. } \\
\quad * 28.3\end{array}$ & $\begin{array}{l}\text { Cents. } \\
\quad 27.0\end{array}$ & $\begin{array}{r}\text { Percent. } \\
84.0\end{array}$ & $\begin{array}{r}\text { Percent. } \\
16.0\end{array}$ \\
\hline 1896. & 24.7 & 82.3 & $\quad 17.7$ & 12.9 & 134.2 & $* 34.2$ & 27.2 & 86.8 & 13.2 \\
\hline 1897. & 23.7 & 80.5 & 19.5 & 12.2 & 119.4 & $* 19.4$ & 26.6 & 79.5 & 20.5 \\
\hline 1898. & 23.6 & 86.7 & 13.3 & 16.7 & 116.8 & $* 16.8$ & 25.9 & 103.6 & $* 3.6$ \\
\hline $1899 \ldots$ & 21.1 & 86.8 & 13.2 & 24.9 & 92.5 & 7.5 & 24.4 & 92.8 & 7.2 \\
\hline 1900. & 22.8 & 80.2 & 19.8 & 22.8 & 83.5 & 16.5 & 23.0 & 103.0 & $* 3.0$ \\
\hline $1901 \ldots$ & 24.5 & 76.2 & 23.8 & 25.2 & 74.5 & 25.5 & 26.3 & 107.3 & $* 7.3$ \\
\hline $1902 \ldots$ & 26.7 & 74.5 & 25.5 & 27.7 & 70.0 & 30.0 & 33.4 & 80.7 & 19.3 \\
\hline $1903 \ldots$ & 27.9 & 77.7 & 22.3 & 29.4 & 66.7 & 33.3 & 29.4 & 80.4 & 19.6 \\
\hline $1904 \ldots$ & 29.4 & 75.8 & 24.2 & 30.0 & 73.3 & 26.7 & 30.8 & 79.8 & 20.2 \\
\hline $1905 \ldots$ & 28.4 & 70.9 & 29.1 & 30.2 & 73.1 & 26.9 & 30.6 & 78.2 & 21.8 \\
\hline $1906 \ldots$ & 29.3 & 69.2 & 30.8 & 30.1 & 69.9 & 30.1 & 29.9 & 78.0 & 22.0 \\
\hline $1907 \ldots$ & 30.1 & 69.1 & 30.9 & 30.4 & 71.4 & 28.6 & 30.0 & 82.2 & 17.8 \\
\hline
\end{tabular}

* Loss. 
TABLE 16.-Division of net selling price (less tax) between cost and profit, for the several departments of the Tobacco Combination-Continued.

[American Cigar and American Snuffi companies not included.]

\begin{tabular}{|c|c|c|c|c|c|c|c|c|c|}
\hline \multirow{3}{*}{ Year. } & \multicolumn{3}{|c|}{ Scrap. } & \multicolumn{3}{|c|}{ Cigarettes.a } & \multicolumn{3}{|c|}{ Little cigars. } \\
\hline & \multirow{2}{*}{$\begin{array}{l}\text { Net price } \\
\text { less tax } \\
\text { (per } \\
\text { pound). }\end{array}$} & \multicolumn{2}{|c|}{$\begin{array}{l}\text { Proportion repre- } \\
\text { sented by- }\end{array}$} & \multirow{2}{*}{$\begin{array}{l}\text { Net price } \\
\text { less tax } \\
\text { (per thou- } \\
\text { sand). }\end{array}$} & \multicolumn{2}{|c|}{$\begin{array}{l}\text { Proportion repre- } \\
\text { sented lyy- }\end{array}$} & \multirow{2}{*}{$\begin{array}{l}\text { Net price } \\
\text { less tax } \\
\text { (per thou- } \\
\text { sand). }\end{array}$} & \multicolumn{2}{|c|}{$\begin{array}{l}\text { Proportion repre- } \\
\text { sented by- }\end{array}$} \\
\hline & & Cost. & Profit. & & Cost. & Profit. & & Cost. & Profit. \\
\hline 995. & Cents. & $\begin{array}{c}\text { Percent. } \\
\ldots . . . . .\end{array}$ & Percent. & $\$ 2.77$ & $\begin{array}{r}\text { Percent. } \\
55.8\end{array}$ & $\begin{array}{r}\text { Percent. } \\
44.2\end{array}$ & $\$ 4.60$ & $\begin{array}{r}\text { Percent. } \\
90.6\end{array}$ & $\begin{array}{r}\text { Per cent. } \\
9.4\end{array}$ \\
\hline 1896. & & & & 2.46 & วti. 8 & 43. 2 & 4. 43 & 90.8 & 9.2 \\
\hline 1897. & & & & 2.27 & 5.5 .8 & 44.2 & 3.96 & 83.1 & 16.9 \\
\hline 1898. & & & & 2.02 & 47.8 & 52.2 & 3.68 & 88.3 & 11.7 \\
\hline 1899 & & & & 2.01 & 47.6 & 52.4 & 3.27 & 98.0 & 2.0 \\
\hline 1900. & & $\ldots \ldots$ & $\cdots$ & 2.09 & 49.7 & 50.3 & 3.19 & 89.9 & 10.1 \\
\hline 1901. & 13.2 & 97.2 & 2.8 & 2.12 & 54.5 & 45.5 & 3.34 & 81.3 & 18.7 \\
\hline 1902. & 15.2 & 101.8 & $* 1.8$ & 2.29 & 68.5 & 31.5 & 4.37 & 95.5 & 4.5 \\
\hline $1903 \ldots$ & 17.7 & 78.0 & 22.0 & $2.2 \bar{i}$ & 54.4 & 45.6 & 4. 33 & 91.0 & 9.0 \\
\hline $1904 \ldots$ & 18.0 & 91.6 & 8.4 & 2.25 & 59.5 & 40.5 & 3.91 & 81.5 & 18.5 \\
\hline $1905 \ldots$. & 17.7 & 98.4 & 1.6 & 2.17 & 59.2 & 40.8 & 3.59 & 74.5 & 25.5 \\
\hline $1906 \ldots$ & 18.0 & 115.0 & $* 15.0$ & 2.15 & 60.5 & 39.5 & 3. 60 & 80.9 & 19.1 \\
\hline $1907 \ldots$ & 18.5 & 108.4 & $* 8.4$ & 2.20 & $6 \bar{i} .5$ & 32.5 & 3.60 & 84.3 & 15.7 \\
\hline
\end{tabular}

a Excluding subsidiary companies.

*Loss.

It will be seen that in all the departments except cigarettes and scrap (the latter being a small and, up to and including 1907, an unprofitable business) the proportion of the net price less taxwhich is the real charge made by the manufacturer for his goodsrepresented by profit is much higher during the more recent years than during the years 1899 and 1900 , when the Combination first became dominant in the smoking, plug, and fine-cut business. In 1907 , of the net price, less tax, for smoking tobacco, 30.9 per cent was represented by profit, in the case of plug tobacco 28.6 per cent, finecut 17.8 per cent, cigarettes 32.5 per cent, and little cigars 15.7 per cent, while on scrap there was a loss. 
Table 17 shows the rate of profit on cost (the internal-revenue tax not being counter as a part of the cost, for reasons already explained) for the several departments of the Tobacco Combination.

TABLE 17.- Rate of profit on cost (excluding tax) for the several departments of the Tobacco Combination.

[American Cigar and American Snuff companies not included.]

\begin{tabular}{|c|c|c|c|c|c|c|}
\hline Year. & Smoking. & $\begin{array}{l}\text { Plug and } \\
\text { twist. }\end{array}$ & $\begin{array}{l}\text { Fine } \\
\text { cut. }\end{array}$ & Scrap. & $\begin{array}{l}\text { Ciga- } \\
\text { rettes. }\end{array}$ & $\begin{array}{l}\text { Little } \\
\text { cigars. }\end{array}$ \\
\hline & Per cent. & Per cent. & Per cent. & Per cent & Per cent. & Per cent. \\
\hline 189. & 14.4 & $* 22.1$ & 19.1 & & 79.1 & 10.4 \\
\hline 1896. & 21.6 & $* 25.5$ & 15.2 & & 76.1 & 10.2 \\
\hline 1897. & 24.3 & $* 16.2$ & 25.8 & & 79.3 & 20.4 \\
\hline 1898. & 15.4 & $* 14.4$ & $* 3.5$ & & 109.0 & 13.2 \\
\hline $1899 \ldots$ & 15.3 & 8.1 & 7.7 & & 110.9 & 2.1 \\
\hline $1900 \ldots \ldots$ & 24.7 & 19.7 & $* 2.9$ & & 101.3 & 11.2 \\
\hline 1901. & 31.2 & 34.1 & $* 6.8$ & 2.9 & 83.6 & 23.1 \\
\hline 1902. & 34.2 & 42.9 & 23.8 & $* 1.8$ & 45.9 & 4.7 \\
\hline 1903. & 28.7 & 49.9 & 24.4 & 28. 2 & 83.9 & 9.8 \\
\hline 1904. & 32.0 & 36.4 & 25.3 & 9.2 & 68.2 & 22.7 \\
\hline $1905 .$. & 41.0 & 36.7 & 27.9 & 1. 6 & 68.9 & 34.2 \\
\hline $1906 \ldots \ldots$ & 44.5 & 43.1 & 28.2 & $* 13.1$ & 65.2 & 23.6 \\
\hline $1907 \ldots \ldots \ldots$ & 44.7 & 40.1 & 21.6 & $* 7.7$ & 48.1 & 18.6 \\
\hline
\end{tabular}

a Subsidiary companies excluded for reasons already explained.

* Loss.

The variations in the rate of profit on cost for the several departments from time to time correspond substantially to the variations in the absolute amount of profit per pound or per thousand already set forth. It will be noted that in 1907 the Combination made a profit of 44.7 per cent on the cost of smoking tobacco, of 40.1 per cent on the cost of plug and twist tobacco, 21.6 per cent on fine cut. 48.1 per cent on cigarettes, and 18.6 per cent on little cigars.

As already stated, it should be borne in mind that the profit as shown in all these tables is based on the actual cost of manufacture, without any inclusion of interest charges; in other words, the figure of profit includes interest on investment as well as profit in the narrower sense. This is, however, the ordinary method of calculating profits in the business world.

It should also, of course, be plainly understood that these percentages of profit do not represent the rate on the investment, but the rate on the cost of products, which is an entirely different thing. 


\section{PRICES AND PROFITS OF INDEPENDENT MANU- FACTURING CONCERNS.}

The Bureau of Corporations, in addition to obtaining information relative to prices and profits from the American Tobacco Company and its numerous subsidiary concerns, has obtained from the books of practically all of the principal independent concerns data relative to these subjects. The information obtained from the books of the American Tobacco Company, as already seen, is complete in all its details relative to costs, profits, and prices of the different clepartments of the business, as well as for separate brands which are manufactured by the Combination. The independent tobacco manufacturing concerns, on the other hand, with few exceptions, have not developed such an elaborate system of cost accounting as has the American Tobacco Company for its own factories and for those of its subsidiary concerns. It is impossible, therefore, to make such minute study and comparisons relative to prices and profits for brands and departments of these concerns as have been made for the American Tobacco Company. The information available, although fairly complete in itself, pertains more to the prices and profits for the entire business of each separate concern than for separate branches of the business of the respective concerns. Moreover, while the investigation of the American Tobacco Company has covered practically the entire period since its organization, and data have been obtained reaching back to 1890 , in some of its phases, and practically complete information on costs and profits, carried back to 1895, it has been impossible to obtain similar information for any large proportion of the independent tobacco trade. In fact, fairly complete information for the larger part of the entire independent trade could not be secured prior to 1906, and the data presented in the following pages refer entirely to that year.

While, as has been pointed out in Part I of the Report of the Commissioner of Corporations on the Tobacco Investigation, there are several hundred different tobacco-manufacturing concerns in the United States operating at the present time, the data presented in the following pages cover only 48 different plants, making plug, smoking, scrap, and fine-cut tobacco (of which 3 manufacture chiefly for export), and 10 making cigarettes. These, however, include nearly all the most important independent manufacturers, and prices and profits prevailing among them are representative for the greater part of the entire independent output.

PLUG, SMOKING, FINE-CUT, AND SCRAP TOBACCO.

Table 18 shows the general results of the business of the 48 independent concerns making plug, smoking, fine-cut, and scrap tobacco (including also a small amount of snuff), for the year 1906. 
As chief interest attaches to the domestic business, the corresponding data are also given separately for those 45 concerns which manufacture exclusively or almost exclusively for the domestic trade. ${ }^{a}$

TABLE 18.-Combined value of sales, costs, and profits for 48 independent manufacturers of plug, smoking, fine-cut, and scrap tobacco, 1906.

\begin{tabular}{|c|c|c|c|c|}
\hline & \multicolumn{2}{|c|}{48 concerns. } & \multicolumn{2}{|c|}{$\begin{array}{c}45 \text { concerns in domestic } \\
\text { business. }\end{array}$} \\
\hline & Amount. & $\begin{array}{l}\text { A verage } \\
\text { (per } \\
\text { pound). }\end{array}$ & Amount. & $\begin{array}{l}\text { A verage } \\
\text { (per } \\
\text { pound). }\end{array}$ \\
\hline Quantity (pounds)........ & $47,612,799$ & & $46,315,204$ & Cents. \\
\hline Net value, including tax. & $\$ 14,032,593.66$ & 29.5 & $\$ 13,817,789.76$ & 29.8 \\
\hline Tax.................. & $2,782,089.27$ & 5.9 & $2,778,912.24$ & 6.0 \\
\hline Net value, less tax. & $11,250,504.39$ & 23.6 & $11,038,877.52$ & 23.8 \\
\hline Cost................... & $10,246,674.09$ & 21.5 & $10,050,026.27$ & 21.7 \\
\hline Profit.. & $1,003,830.30$ & 2.1 & $988,851.25$ & 2.1 \\
\hline
\end{tabular}

This table covers an output of 47,612,799 pounds of tobacco. The total output of these classes of tobacco and snuff by independent concerns in 1906 was $88,236,788$ pounds, so that the figures cover about 55 per cent of the independent business. Of the total output covered by the table, 19,134,565 pounds consisted of plug and twist tobacco (of which $1,297,595$ pounds was the output of the three concerns which manufacture chiefly for the export trade), 26,498,168 pounds of smoking tobacco and scrap, 1,866,272 pounds of fine-cut, and 113,794 pounds of snuff. The proportion of the total independent output of plug and twist represented by the data covered by the above table is about 60 per cent, for smoking tobacco a little over 50 per cent, for fine-cut about 75 per cent, and for snuff about 15 per cent.

The output of the 48 concerns represented a total value, including tax, of $\$ 14,032,593.66$, or an average of 29.5 cents per pound. For the 45 concerns in the domestic business the average value, including

a The independent concerns making plug, smoking, fine-cut, and scrap for which data are included in this report are the following: Scotten \& Dillon, Globe Tobacco Company, Scotten Tobacco Company, Campbell Tobacco Company, Shields \& Son, Mrs. G. B. Miller \& Co., Clark \& Snover, Penn Tobacco Company, R. Whalen \& Co., Michigan Tobacco Works, Bendixen Tobacco Company, J. F. Zahn Tobacco Company, The Eight Hour Tobacco Company, J. J. Bagley, United States Tobacco Company, J. N. Cullingworth, J. G. Dill, Larus \& Bro., Zimmer \& Co., Hancock Brothers, Clark \& Co., Sparrow \& Gravely, East Tennessee Tobacco Company, J. H. Maclin, Bailey Brothers, Taylor Brothers, Brown \& Williamson, Ogburn \& Hill, Turner, Powell \& Co., T. T. Mayo, J. H. McElwee, J. D. Rowlett, Smith \& Scott Tobacco Company, Schmitt Brothers Tobacco Works, Independent Snuff Company, Brunswick Tobacco Company, Eagle Tobacco Company, John Weisert Tobacco Company, Weisert Brothers Tobacco Company, Strater Brothers Tobacco Company, Fluhrer Tobacco Company, Lovell \& Buffington Tobacco Company, Axton-Fisher Tobacco Company, The Spence Brothers Company, J. L. Walker Tobacco Company, E. O. Eshelby Tobacco Company, Ryan-Hampton Tobacco Company, and Boone Tobacco Company.

The following independent cigarette manufacturing concerns have furnished information which enters into the report: Ware-Kramer \& Co., the Surbrug Company, Khedivial Company, Turco-American Tobacco Company, J. B. Krinsky, Philip Kassel \& Co., The Crescent Tobacco Company, Federal Cigarette Company, Prudential Tobacco Company, and M. Melachrino. 
tax, was 29.8 cents per pound, or, excluding tax, 23.8 cents. These figures may be compared with the average net value, less tax, for the entire output of plug, smoking, fine-cut, and scrap tobacco manufactured by the principal companies in the Tobacco Combination for the domestic trade, which amounted in 1906 to 29 cents per pound (excluding tax), or 5.2 cents per pound more than the average value of the output of the independent concerns covered by the table. The relatively higher average value of the product of the American Tobacco Company is principally due to the fact that that concern controls by far the greater proportion of the high-priced brands on the market at the present time.

The total profit obtained by these 48 independent concerns in 1906 amounted to $\$ 1,003,830.30$, or an average of 2.1 cents per pound. For the 45 concerns in the domestic business the average profit was the same (disregarding fractions), although the average profit of the three concerns engaged primarily in the export trade was only about 1.2 cents per pound. The profit of the independent concerns averaged much less than that of the Tobacco Combination. The average profit of the principal companies in the combination on their domestic plug, smoking, fine-cut, and scrap business in 1906 was 8.2 cents per pound, or nearly four times as much as for these independent concerns.

It will be seen further that the average rate of profit of the 48 inclependent concerns on their cost was 9.8 per cent, and for the 45 engager in the domestic trade, the same, while the Tobacco Combination on its domestic trade in these same products made a profit of 39.1 per cent on cost.

In view of the fact that the average price of the independent concerns is materially lower than the average for the Combination, it is interesting to classify the independent concerns according to the value of their output and to compare the profit of those which make the higher priced product with the profit of the Combination. In Table 10 the data of prices, costs, and profits for the 45 concerns engager in the domestic trade are classified in groups according to the value of the product. In placing a concern in any given group, the average price of its entire product is necessarily the basis, although it may manufacture some higher or some lower priced goods.

TABLE 19.-Prices, costs, and profits for 45 independent tobacco-manufacturing concerns in the domesiic trade, by price groups, 1906.

\begin{tabular}{|c|c|c|c|c|c|c|c|c|}
\hline \multirow[b]{2}{*}{$\begin{array}{l}\text { Groups: Concerns having } \\
\text { average price of - }\end{array}$} & \multicolumn{2}{|c|}{ Sales. } & \multicolumn{3}{|c|}{ Net price (per pound) } & \multirow[b]{2}{*}{$\begin{array}{c}\text { Cost } \\
\text { (per } \\
\text { pound). }\end{array}$} & \multirow[b]{2}{*}{$\begin{array}{l}\text { Profit } \\
\text { (per } \\
\text { pound). }\end{array}$} & \multirow[b]{2}{*}{$\begin{array}{l}\text { Rate of } \\
\text { profit on } \\
\text { cost. }\end{array}$} \\
\hline & Quantity. & $\begin{array}{l}\text { Propor- } \\
\text { tion of } \\
\text { total in } \\
\text { group. }\end{array}$ & $\begin{array}{l}\text { Includ- } \\
\text { ing } \\
\text { tax. }\end{array}$ & Tax. & $\begin{array}{l}\text { Ex- } \\
\text { clud- } \\
\text { ing } \\
\text { tax. }\end{array}$ & & & \\
\hline 20 to 25 cents per pound.. & $\begin{array}{l}\text { Pounds. } \\
4,988,282\end{array}$ & $\begin{array}{c}\text { Percent. } \\
10.8\end{array}$ & $\begin{array}{r}\text { Cents. } \\
23.4\end{array}$ & $\begin{array}{c}\text { Cents. } \\
6.0\end{array}$ & $\begin{array}{r}\text { Cents. } \\
17.4\end{array}$ & $\begin{array}{l}\text { Cents. } \\
\quad 16.4\end{array}$ & $\begin{aligned} \text { Cents. } \\
\quad 1.0\end{aligned}$ & $\begin{array}{r}\text { Per cent. } \\
6.1\end{array}$ \\
\hline 25 to 30 cents per pound... & $23,705,126$ & 51.2 & 27.9 & 6.0 & 21.9 & 20.2 & 1.7 & 8. 4 \\
\hline 30 to 35 cents per pound... & $15,257,043$ & 32.9 & 32.5 & 6.0 & 26.5 & 23.7 & 2.8 & 11.8 \\
\hline 35 to 40 cents per pound... & 945,848 & 2.0 & 37.0 & 6.0 & 31.0 & 27.7 & 3.3 & 11.9 \\
\hline 40 and above.............. & $1,418,905$ & 3.1 & 51.2 & 6.0 & 45.2 & 38.6 & 6.6 & 17.1 \\
\hline Total. & $46,315,204$ & 100.0 & 29.8 & 6.0 & 23.8 & 21.7 & 2.1 & 9.7 \\
\hline
\end{tabular}


It will be seen from this table that whereas the average price of the Tobacco Combination on substantially its entire output of plug, smoking, fine-cut, and scrap tobacco in the domestic trade was in 190635 cents per pound (including tax), much the greater proportion of the sales of the independent concerns consisted of tobacco worth less than 35 cents per pound (including tax). In fact, only a little over 5 per cent of the sales of the independent concerns consisted of the sales of those having an average price of 35 cents per pound or more. The greatest proportion of the independent sales is found in the group comprising those concerns whose average price, including tax, is from 25 to 30 cents per pound, which group represented a little over 50 per cent of the total independent sales covered by the table. For this important group the average profit per pound was 1.7 cents, representing 8.4 per cent on cost. For the comparatively important group of concerns selling at from 30 to 35 cents per pound on the average the profit was 2.8 cents per pound, or 11.8 per cent on cost; while for the group selling at from 35 to 40 cents per pound on the average the profit was 3.3 cents per pound, or also 11.9 per cent on cost. The profits for these two groups may be compared with those of the Tobacco Combination, which averaged 8.2 cents per pound on a product of an average value of 35 cents, the rate of profit of the Combination on cost being 39.1 per cent, or considerably more than three times as high as for the independent concerns of this class. Even for the limited number of independent concerns whose product is higher priced than the average for the Combination, namely, the group averaging 40 cents or more per pound, the profit was only 6.6 cents per pound, or 17.1 per cent on cost.

The above table shows that not only is the profit per pound higher on the higher-priced goods, but also the rate of profit on cost increases as the price increases.

It is impossible to separate completely the results of the different branches of the industry as carried on by the 48 independent concerns covered by the above tables. Many of these concerns manufacture two or more classes of tobacco, and their cost-accounting system does not ordinarily show separately the results of the business in these classes. Nevertheless, in the case of most of the independent concerns for which data are available the great bulk of their business consists of some one class of tobacco, and in such cases no serious error is caused by treating the concern as though it were engaged exclusively in that branch. Three of the 48 concerns, however, have their business so divided among different branches that they can not be classed in one group or another, but the results of their business must be presented separately as mixed business.

Table 20 shows the results of the business of these 48 concerns, classified according to the character of their principal products. 
TABLE 20.-Prices, costs, and profits for 48 independent manufacturers of plug, smoking, fine-cut, and scrap tobacco, classified according to their principal kind of product, 1906.

\begin{tabular}{|c|c|c|c|c|c|c|c|c|}
\hline \multirow{3}{*}{$\begin{array}{c}\text { Concerns making } \\
\text { chiefly- }\end{array}$} & \multirow{3}{*}{$\begin{array}{c}\text { Quantity } \\
\text { of } \\
\text { sales. }\end{array}$} & \multirow{3}{*}{$\begin{array}{l}\text { Tet value } \\
\text { including } \\
\text { tax. }\end{array}$} & \multirow{3}{*}{ Profit. } & \multicolumn{4}{|c|}{ Arerages. } & \multirow{3}{*}{$\begin{array}{l}\text { Rate of } \\
\text { profit } \\
\text { on } \\
\text { cost. }\end{array}$} \\
\hline & & & & \multicolumn{2}{|c|}{ Net price (per pound). } & \multirow{2}{*}{$\begin{array}{c}\text { Cost } \\
\text { (per } \\
\text { pound) }\end{array}$} & \multirow{2}{*}{$\begin{array}{l}\text { Profit } \\
\text { (per } \\
\text { pound). }\end{array}$} & \\
\hline & & & & $\begin{array}{l}\text { cluding Tax. } \\
\text { tax. }\end{array}$ & $\begin{array}{l}\text { cluding } p \\
\text { tax. }\end{array}$ & & & \\
\hline $\begin{array}{l}\text { Plug a } n \mathrm{~d} \text { twist } \\
\text { (22 concerns)... }\end{array}$ & $\begin{array}{l}\text { Pounds. } \\
16,480,014\end{array}$ & $\$ 5,061,429.05$ & $\$ 406,184.41$ & $\begin{array}{l}\text { Cents. Cents. } \\
30.7 \quad \text { a j.6 }\end{array}$ & $\begin{array}{l}\text { Cents. } \\
25.1\end{array}$ & $\begin{array}{r}\text { Cents. } \\
22.6\end{array}$ & $\begin{array}{r}\text { Cents. } \\
2.5\end{array}$ & $\begin{array}{r}\text { Per cent. } \\
11.1\end{array}$ \\
\hline $\begin{array}{c}\text { Smoking (17 con- } \\
\text { cerns).......... }\end{array}$ & $10,718,914$ & $3,402,344.36$ & $245,742.60$ & 31.7 & 25.7 & 23.4 & 2.3 & 9.8 \\
\hline Scrap (6 concerns) & $8,498,205$ & $2,359,086.26$ & 94, j65. 08 & 27.8 & 21.8 & 20.7 & 1.1 & 5. 3. \\
\hline $\begin{array}{c}\text { M i x e d }(3 \text { con- } \\
\text { cerns }) . . . . . . . .\end{array}$ & $11,915,666$ & $3,209,733.99$ & $257,338.21$ & 26.9 & 20.9 & 18. & 2.2 & 11.8 \\
\hline $\begin{array}{l}\text { Total ( } 48 \\
\text { concerns) }\end{array}$ & $47,612,799$ & $14,032,593.66$ & $1,003,830.30$ & 29.5 & 23.6 & 21.5 & 2.1 & 9.8 \\
\hline
\end{tabular}

a No tax on export product included in this group.

It will be seen that 22 of the 48 concerns were engaged primarily in the plug and twist tobacco business (this includes 3 engaged in the export trade). Their output amounted to $16,480,014$ pounds of an average value, exclusive of tax, of 25.1 cents per pound, from which an average profit of 2.5 cents per pound was derived. For the concerns engaged exclusively in the domestic trade, the average value per pound would be slightly greater, and the profit about 2.6 cents per pound. The Tobacco Combination in its domestic trade in 1906 obtained an average price for plug and twist tobacco of 30.1 cents per pound (excluding tax), with an average profit of 9.1 cents per pound.

Seventeen of the concerns made principally smoking tobacco, their output being 10,718,914 pounds, of an average value, excluding tax, of 25.7 cents per pound, with an arerage profit of 2.3 cents per pound. The sales of the Combination in 1906 commanded an average price, less tax, of 29.3 cents per pound and a profit of 9 cents per pound.

Six of the concerns were engaged primarily in the scrap-tobacco business, their output being 8,498,205 pounds, of an average value, less tax, of 21.8 cents and an average profit of 1.1 cents per pound. The average value of the scrap manufactured by the Combination in this year was lower, 18 cents pound, and it lost on the average 2.7 cents per pound. In the case of this comparatively small branch of the business, therefore, the independent concerns are more prosperous. than the Combination.

In the above table showing the cost per pound of the output of these 48 independent concerns no separation has been made between manufacturing costs and selling and advertising costs. Many of the concerns do not keep their accounts in such a way that these two. classes of costs can be separated. Data showing such separation of costs were, however, obtained for 23 of the concerns, and, since the: average costs and average net price and profit for these 23 concerns: correspond almost exactly with the averages for the entire 48 concerns, it is probable that the proportions of costs represented by manufacturing and freight on the one hand and by selling and advertising on the other hand for these 23 are substantially the same as for all of the concerns. The total costs per pound for these 23 concerns 
(corering an output of $29,911,960$ pounds) average 21.7 cents per pound, made up of 17.9 cents cost of manufacture (including freight) and 3.8 cents selling and advertising costs. The selling and advertising costs are a smaller proportion of the total costs in the case of these independent concerns than in the case of the Combination. Thus, the total cost of the plug and twist tobacco of the principal concerns in the Tobacco Combination in 1906 was 21 cents per pound, made up of 16.8 cents for manufacturing expenses (including freight) and 4.2 cents for selling and advertising. In the smoking-tobacco business of the Combination in 1906 the total cost per pound was 20.3 cents, made up of 16.6 cents for manufacture and freight and 3.7 cents for selling and advertising. As these are the two most important branches, it is evident that the selling and advertising cost on the entire plug, smoking, fine-cut, and scrap business of the Combination is a somewhat larger proportion of the total cost than in the case of the independent concerns.

The average profits of the independent concerns, as shown in the above tables, of course include some concerns which make much more than others. To show the variations among individual concerns with respect to their average prices and profits, the four tables below are presented, which show the average net selling price, including and excluding tax, the cost of production and sale, and the profit per pound for each of the 45 manufacturers engaged in the domestic business included in the preceding tables. The concerns are arranged under each class of product according to the average price which they receive, from the highest to the lowest. The rate of tax for all of these concerns in 1906 was 6 cents per pound.

Table 21 presents these data for the 17 concerns manufacturing smoking tobacco.

TABLE 21.-Smoking tobacco-Prices, costs, and profits for 17 independent manufacturers individually, 1906.

\begin{tabular}{|c|c|c|c|c|c|}
\hline \multirow{2}{*}{ Concern. } & \multicolumn{2}{|c|}{$\begin{array}{l}\text { Net selling price (per } \\
\text { pound). }\end{array}$} & \multirow{2}{*}{$\begin{array}{l}\text { Cost (per } \\
\text { pound.) }\end{array}$} & \multirow{2}{*}{$\begin{array}{l}\text { Profit (per } \\
\text { pound.) }\end{array}$} & \multirow{2}{*}{$\begin{array}{l}\text { Rate of } \\
\text { profit on } \\
\text { cost. }\end{array}$} \\
\hline & $\begin{array}{l}\text { Including } \\
\text { tax. }\end{array}$ & $\begin{array}{l}\text { Excluding } \\
\text { tax. }\end{array}$ & & & \\
\hline & Cents. & Cents. & Cents. & Cents. & Per cent. \\
\hline $1 .$. & $61 . \overline{5}$ & $5 \check{.} \tilde{5}$ & 49. 3 & 6.2 & 12.6 \\
\hline $2 .$. & 34.5 & 28.5 & 25.2 & 3.3 & 13.1 \\
\hline 3. & 34.4 & 28.4 & 24.8 & 3.6 & 14.5 \\
\hline $4 \ldots$ & 33.5 & 27.5 & $21 . \tilde{5}$ & 6.0 & 27.9 \\
\hline $5 \ldots \ldots$ & 31.7 & 25.7 & 22.9 & 2.8 & 12.2 \\
\hline $6 \ldots \ldots \ldots \ldots$ & 31.0 & 25.0 & 23.7 & 1.3 & 5.5 \\
\hline $7 \ldots \ldots$ & 30.7 & 24.7 & 20.8 & 3.9 & 18. 8 \\
\hline $8 \ldots \ldots$ & 30.3 & 24.3 & 16.3 & 8.0 & 49.1 \\
\hline $9 \ldots$ & 30.0 & - 24.0 & 22.7 & 1.3 & 5.7 \\
\hline $10 \ldots$ & 29.5 & 23.5 & 21.9 & 1.6 & 7.3 \\
\hline $11 \ldots$ & 28.9 & 22.9 & 19.4 & 3.5 & 18.0 \\
\hline $12 \ldots$ & 28.5 & 22.5 & 22.1 & .4 & 1.8 \\
\hline $13 \ldots \ldots \ldots \ldots$ & 28.4 & 22.4 & 22.6 & $* .2$ & $* 9$ \\
\hline $14 \ldots \ldots \ldots \ldots$ & 27.3 & 21.3 & 19.4 & 1.9 & 9.8 \\
\hline 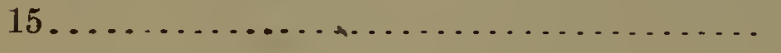 & 25.1 & 19.1 & 19.5 & $* .4$ & $* 2.1$ \\
\hline $16 \ldots \ldots \ldots \ldots$ & 24.8 & 18.8 & 18.1 & .7 & 3.9 \\
\hline $17 \ldots \ldots \ldots \ldots$ & 23.6 & 17.6 & 19.1 & $* 1.5$ & $* 7.9$ \\
\hline Total average .................... & $31 . \overline{7}$ & 25.7 & 23.4 & 2.3 & 9.8 \\
\hline
\end{tabular}


It will be seen that the four concerns whose product ranges in average value from 33.5 to 61.5 cents per pound had profits ranging from 3.3 to 6.2 cents per pound, the rate of profit on cost ranging from 12.6 per cent to 27.9 per cent. The five concerns whose product averaged from 30 to 31.7 cents per pound in value show profits ranging from 1.3 cents to 8 cents per pound, the rate of profit on cost ranging from 5.5 per cent to 49.1 per cent. Of the eight concerns whose product was worth less than 30 cents per pound, three sold at a loss in 1906 and the others made profits ranging from 0.4 cent to 3.5 cents per pound, all but one, however, making less than 2 cents per pound; the per cent on cost ranged from a loss of 7.9 per cent to a profit of 18 per cent for these eight concerns.

Table 22 presents similar data for the 19 independent manufacturers whose business is principally in plug and twist tobacco for the domestic trade.

TABLE 22.-Plug and twist-Prices. cosis, and profits for 19 independent manufacturers in the domestic trade, individually, 1906.

\begin{tabular}{|c|c|c|c|c|c|}
\hline \multirow{2}{*}{ Concern. } & \multicolumn{2}{|c|}{$\begin{array}{l}\text { Net selling price } \\
\text { (per pound). }\end{array}$} & \multirow{2}{*}{$\begin{array}{l}\text { Cost (per } \\
\text { pound). }\end{array}$} & \multirow{2}{*}{$\begin{array}{l}\text { Profit (per } \\
\text { pound). }\end{array}$} & \multirow{2}{*}{$\begin{array}{l}\text { Rate of } \\
\text { profit on } \\
\text { cost. }\end{array}$} \\
\hline & $\begin{array}{l}\text { Including } \\
\text { tax. }\end{array}$ & $\begin{array}{l}\text { Excluding } \\
\text { tax. }\end{array}$ & & & \\
\hline 1. & $\begin{array}{l}\text { Cents. } \\
\quad 40.6\end{array}$ & $\begin{array}{l}\text { Cents. } \\
\quad 34.6\end{array}$ & $\begin{array}{l}\text { Cents. } \\
27.7\end{array}$ & $\begin{array}{l}\text { Cents. } \\
\quad 6.9\end{array}$ & $\begin{array}{r}\text { Per cent. } \\
24.9\end{array}$ \\
\hline 2. & $3 \pi .4$ & 31.4 & 27.9 & 3.5 & 12.5 \\
\hline 3. & 35.3 & 29.3 & 26.7 & 2.6 & 9. 7 \\
\hline $4 .$. & $3 \pm 0$ & 28.0 & 24.7 & 3.3 & 13.4 \\
\hline $5 .$. & 33.9 & $2 \pi .9$ & 26.5 & 1.4 & 5.3 \\
\hline 6 . & 33.6 & $2 \overline{7} .6$ & 24.0 & 3.6 & 15.0 \\
\hline 7 . & 32.7 & 26.7 & 24.5 & 2.2 & 9.0 \\
\hline 8. & 32.6 & 20.6 & 24.7 & 1.9 & 7.7 \\
\hline $9 .$. & 32.4 & 26.4 & 22.8 & 3.6 & 15.8 \\
\hline $10 .$. & 31.8 & 25.8 & 23.1 & 2.7 & 11.7 \\
\hline $11 .$. & 30.8 & 24.8 & 24.5 & .3 & 1.2 \\
\hline 12. & 30.7 & $24 . \vec{\imath}$ & 20.2 & 4. 5 & 22.3 \\
\hline $13 .$. & 30.4 & 24.4 & 21.9 & 2.5 & 11.4 \\
\hline 14. & 30.3 & 24.3 & 23.5 & .8 & 3.4 \\
\hline 15. & 29.7 & 23.7 & 21.7 & 2.0 & 9.2 \\
\hline $16 .$. & 28.6 & 22.6 & 22.0 & .6 & 2.7 \\
\hline 17. & $2 \pi .5$ & 21.5 & 17.4 & 4.1 & 23.6 \\
\hline 18. & 24.7 & 18.7 & 16.9 & 1.8 & 10.7 \\
\hline 19.. & 20.2 & 14.2 & 12.9 & 1.3 & 10.1 \\
\hline Total a verage. & 31.9 & 25.9 & 23.3 & 2.6 & 11.2 \\
\hline
\end{tabular}

Of these 19 manufacturers there were three whose output was valued on the average at 3.5 cents per pound or more. Their profits were 2.6 cents, 3.5 cents, and 6.9 cents per pound, respectively, the rate of profit on cost ranging from 9.7 per cent to 24.9 per cent. There were 11 concerns the average price of whose product was between 30 and 35 cents per pound. Their profits ranged from 0.3 cent to 4.5 cents, seven making 2 cents or more per pound. The rate of profit on cost for the 11 ranged from 1.2 per cent to 22.3 per cent. 
Five of the concerns sold at average prices ranging from 20.2 cents to 29.7 cents per pound. One of these five made 4.1 cents per pound profit, but none of the others made more than 2 cents. The rate of profit on cost for these concerns ranged from 2.7 per cent to 23.6 per cent.

Table 23 shows similar information for the six independent concerns whose principal output consists of scrap tobacco. The prices of these concerns ranged from 23.4 cents to 31.8 cents (excluding tax, from 17.4 cents to 25.8 cents). Five of them made profits ranging from 0.9 cent to 2.2 cents, the rate on cost ranging from 4 per cent to 14.5 per cent. One concern incurred a loss of 3 cents per pound. It will be recalled that the Tobacco Combination in 1906 and 1907 lost money on its scrap business.

TABLE 23.-Scrap tobacco-Prices, costs, and profits for six independent concerns, individually, 1906.

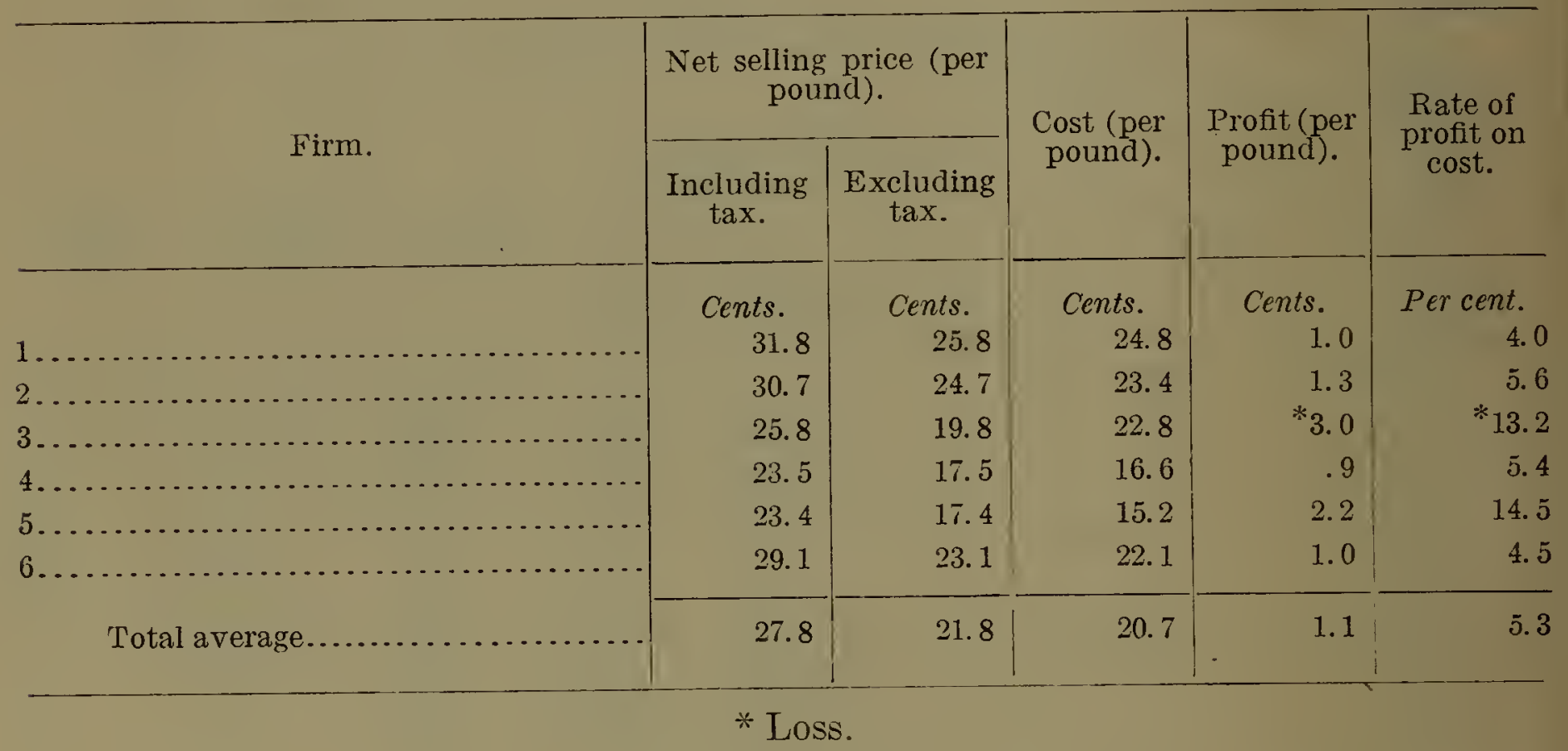

Table 24 shows the prices, costs, and profits of the three concerns whose product was of such a mixed character that they can not be classed with the other groups. The average price of their product ranged from 26 cents to 29.9 cents, and the profit from 0.6 to 2.6 cents per pound, the rate of profit on cost being from 3 per cent to 14.9 per cent.

TABLE 24.-Smoking, plug, and fine-cut (mixed product)-Prices, costs, and profits for three independent concerns individually, 1906.

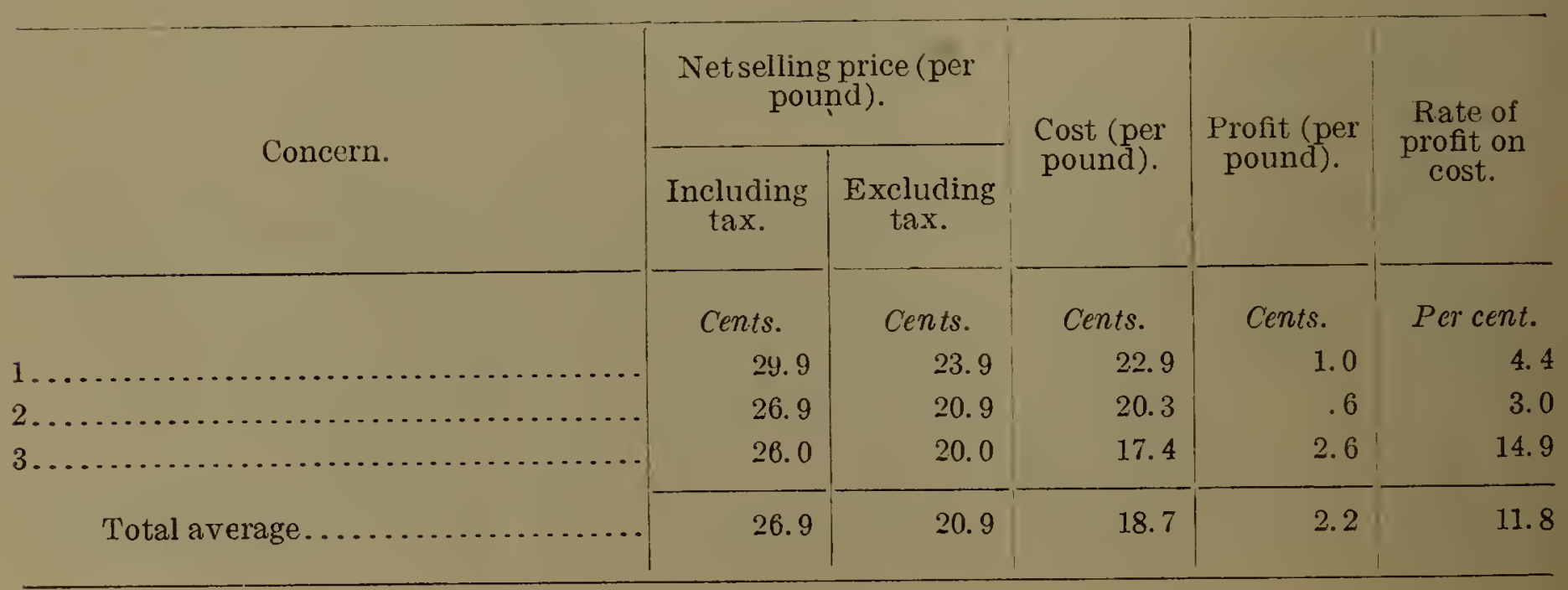


The question naturally arises why the profits of these independent concerns are not only much lower per pound but represent a much lower percentage on cost than for the Tobacco Combination. In the absence of detailed information regarding the changes in the conditions of the business of these independent manufacturers from year to year, no complete and adequate answer can be made to this question. The fact that the average value of the independent output is lower than that of the Combination's output would explain a lower amount of profit per pound, but not a lower per cent of profit on cost.

The available data regarding the prices of a number of the principal brands made by these independent manufacturers indicate that such brands as were in existence before the Spanish war were in general raised in price sufficiently to cover the increased tax, and on the other hand that when the taxes were reduced in 1901 and 1902 the prices of these brands were generally maintained with little change, and in some cases have been advanced. It has been seen that the Tobacco Combination, as a result of maintaining prices substantially unchanged when the tax was reduced, increased its profits greatly, so that in recent years it has made very much more than during the war period, and more than the constituent companies had made before the war period.

It might be expected on first thought that the independent manufacturers, by maintaining their prices when the taxes were reduced, would also have increased their profits so that at the present time they would be making comparatively high profits. It should be remembered, however, that the Tobacco Combination has from time to time bought up some of the most prosperous independent concerns. It appears, moreover, that, in the hope of increasing their output in the face of the popularity of the brands possessed by the Combination, the independent concerns have since the war taxes were reduced introduced and sold new brands at relatively lower prices and profits than they obtained on their old brands, and that they have done this to a greater proportionate extent than the Combination.

There can be little doubt also that the costs of the independent concerns have increased very materially, while the Combination, on account of its very large business and the progressive concentration of its production in large plants, has been able largely to resist the tendency of costs to increase. Both the Combination and the independent concerns have had to pay somewhat more for their leaf tobacco in recent years than before, but the Combination has partly offset this increase in leaf prices by economies in other directions. To what extent independent concerns have been able to bring about similar economies, the available data are not sufficient to show. There is no doubt that they have, in general, had to increase their advertising and selling expenses to a greater degree than the Combination has. It appears, moreover, from such information as is available, that the cost of the leaf tobacco used by independent concerns has in general increased more than the cost of the leaf used by the Combination. This results from the fact that the independent concerns, which in general make a cheaper grade of tobacco selling at a lower price, naturally use the lower grades of leaf to a relatively greater extent than the Combination does, and the prices of the lower grades of leaf have gone up more than the prices of the higher grades. In other words, 
the cost of the leaf tobacco used by the independent concerns has, so far as can be ascertained from the available information, increased distinctly more than the cost of the leaf used by the Combinationnot only by a greater percentage, but by an actually greater amount per pound.

Another element which has tended to increase the cost to independent manufacturers as compared with the Combination has been the advance in the price of licorice, which is an important raw material in plug tobacco, some kinds of smoking tobacco, and scrap. Very nearly all of the licorice manufactured in the United States was in 1906 either manufactured by a subsidiary company of the Combination (the MacAndrews \& Forbes Company) or by concerns working in close agreement with it. The price which these concerns charged to independent manufacturers was higher than the price which they charged to the Combination, whereas previous to the time when the Combination entered into the licorice business the prices to all manufacturers of tobacco were substantially the same. This difference in the cost of licorice is not a large element in comparison with the cost of a pound of tobacco, but it is sufficient to affect appreciably the profits of the independent concerns, perhaps by one-fourth or even one-half of a cent per pound.

\section{BUSINESS OF INDEPENDENT CIGARETTE MANUFACTURERS.}

During recent years a large business has developed in the United States in the manufacture of Turkish cigarettes; that is, cigarettes made wholly or partly from imported Turkish tobacco. These cigarettes are, in general, of decidedly higher grade than the cigarettes made from domestic tobacco. The American Tobacco Company manufactures very nearly all of the cigarettes made strictly from domestic tobacco. It does not itself manufacture Turkish cigarettes, but it has important subsidiary concerns which do so. The independent concerns, however, have a very large Turkish cigarette business, probably substantially equal to that of the Tobacco Combination itself.

Data for these independent concerns are available only for the year 1906. Little information, however, would be secured by comparing the average prices and profits of that year with the earlier years, because of the constant change in the character of the cigarettes included in the total. As in the case of the Tobacco Combination, independent manufacturers at first produced chiefly highgrade Turkish cigarettes, but from time to time have produced more brands selling to the consumer at 10 for 10 cents, or even 10 for 5 cents. The average price of all the independent output of Turkish cigarettes, therefore, like that of the Combination itself, has declined, not because of the reduction in the price of individual brands, but because of an increased proportion of the cheaper brands.

Table 25 shows the prices, costs, and profits of ten independent manufacturers of cigarettes, nine of which make either exclusively Turkish cigarettes or cigarettes containing a mixture of Turkish and domestic tobacco, while one makes exclusively domestic cigarettes. The average prices, costs, and profits of the nine concerns, which make few, if any, exclusively domestic cigarettes, are also shown. 
[ABLE 25.-Cigarettes-Prices, costs, and profits for 10 independent manufacturers, 1906.

[A verage computed per thousand.]

\begin{tabular}{|c|c|c|c|}
\hline & Amount. & $\begin{array}{c}\text { Average } \\
\text { price per } \\
\text { thousand for } \\
10 \text { companies. }\end{array}$ & $\begin{array}{l}\text { A verage for } \\
9 \text { companies } \\
\text { making Turk- } \\
\text { ish and mixed } \\
\text { cigarettes. }\end{array}$ \\
\hline Output (number). & $413,940,500$ & & \\
\hline Net ralue........ & $\$ 2,408,690.48$ & $\$ 5.82$ & $\$ 6.21$ \\
\hline Tax.............. & $447,055.74$ & 1.08 & 1.08 \\
\hline Value less tax.... & $1.961,634.74$ & 4. 74 & 5. 13 \\
\hline Cost............ & $1.823,478.96$ & 4. 41 & 4.78 \\
\hline $\begin{array}{l}\text { Profit............ } \\
\text { Per cent of profit } 0\end{array}$ & $138,155.78$ & .33 & .35 \\
\hline Per cent of profit 0 & & 1.0 & 7.4 \\
\hline
\end{tabular}

This table covers the output of $413,940,500$ cigarettes. The total output of cigarettes by independent concerns in 1906 was $1,128,564,000$, so that these figures cover over 35 per cent of the business. The net value of cigarettes, including tax, was $\$ 2,408$,690.48 , and the profits of the business $\$ 138,155.78$. The average net price, including tax, for all these concerns was $\$ 5.82$ per thousand or, excluding tax, $\$ 4.74$ per thousand. The profit was $\$ 0.33$ per thousand, or 7.5 per cent. . It will be recalled that the profit of the American Tobacco Company on its domestic cigarettes in 1906 represented 65.2 per cent on cost; while for the principal subsidiaries of the American Tobacco Company manufacturing high-grade cigarettes, namely, S. Anargyros, John Bollman \& Co., and the Monopol Tobacco Works, the rate of profit on cost was 31.8 per cent.

For those nine independent concerns whose output consists of Turkish cigarettes, or of cigarettes made from mixed Turkish and domestic leaf, the average net value per thousand was $\$ 6.21$, including tax, or $\$ 5.13$, less tax, and the profit $\$ 0.35$ per thousand, or 7.4 per cent on cost. These figures may be compared with those of S. Anargyros, John Bollman \& Co., and the Monopol Tobacco Works controlled by the Combination. The average price of these three companies, including tax, in 1906 was $\$ 7.59$ per thousand, or, excluding tax, $\$ 6.51$, and the average profit was $\$ 1.57$, or 31.8 per cent on cost.

The cigarette business of these independent concerns is therefore relatively much less profitable than that of the Tobacco Combination. It should be noted, however, that the figures obtained by the Bureau do not include the business of two or three of the most important and profitable independent manufacturers of Turkish cigarettes.

Table 26 shows the average prices, costs, and profits for the nine independent concerns making Turkish and mixed Turkish and domestic cigarettes, individually. It will be seen that the prices of these concerns differ greatly, ranging from $\$ 2.32$ per thousand (excluding tax) to $\$ 10.92$ per thousand. The profits range from $\$ 0.12$ to $\$ 2.90$ per thousand, and the rate of profit on cost from 4.1 per cent to 36.2 per cent. 
TABLE 26.-Cigarettes-Prices, costs, and profits for 9 independent concerns, individually, 1906.

\begin{tabular}{|c|c|c|c|c|c|}
\hline \multirow{2}{*}{ Nature of output of concern. } & \multicolumn{2}{|c|}{$\begin{array}{l}\text { Average price (per } \\
\text { thousand). }\end{array}$} & \multirow{2}{*}{$\begin{array}{l}\text { Cost (per } \\
\text { thousand). }\end{array}$} & \multirow{2}{*}{$\begin{array}{l}\text { Profit (per } \\
\text { thousand). }\end{array}$} & \multirow{2}{*}{$\begin{array}{l}\text { Rate of } \\
\text { profit on } \\
\text { cost. }\end{array}$} \\
\hline & $\begin{array}{l}\text { Including } \\
\text { tax. }\end{array}$ & $\begin{array}{l}\text { Excluding } \\
\text { tax. }\end{array}$ & & & \\
\hline & & & & & Per cent. \\
\hline 1. High-grade Turkish............ & $\$ 12.00$ & $\$ 10.92$ & $\$ 8.02$ & $\$ 2.90$ & 36.2 \\
\hline 2. High-grade Turkish.... & 16.88 & 15.80 & 15. 18 & .62 & 4.1 \\
\hline 3. Medium-grade Turkish... & 8.60 & 7.52 & 6.86 & .66 & 9.6 \\
\hline 4. Medium-grade Turkish... & 5.36 & 4.28 & 3.97 & .31 & 7.8 \\
\hline 5. Medium-grade Turkish......... & 4.54 & 3.46 & 3.31 & .15 & 4.5 \\
\hline 6. Low-grade Turkish and domestic & 3.88 & 2.80 & 2.48 & .32 & 12.9 \\
\hline 7. Low-grade Turkish and domestic & 3.88 & 2.80 & 2.68 & .12 & 4.5 \\
\hline 8. Low-grade Turkish and domestic & 3.80 & 2.72 & 2.32 & .40 & 17.2 \\
\hline ๑. Low-grade Turkish and domestic & 3.40 & 2.32 & 1.98 & .34 & 17.2 \\
\hline
\end{tabular}




\section{PLUG AND TWIST TOBACCO BUSINESS OF THE COMBINATION.}

Plug tobacco, with which the comparatively small amount of twist is included in the statistics, is the most important product of tobacco in the United States with the exception of cigars. It is the most important product of the Tobacco Combination, which, as already stated, has only a comparatively small part of the cigar business. The output of plug and twist tobacco in the United States in 1907 was $172,002,513$ pounds, of which the Tobacco Combination produced $132,484,125$ pounds.

The American Tobacco Company at its inception in 1890 had no plug-tobacco business. It acquired a plug-tobacco plant in 1891 and others in 1895 and 1898, and during the period 1895 to 1898 built up a very considerable plug-tobacco business. In doing so, howerer, it sold its output at low prices and incurred heary expenses in adrertising and selling, so that the plug business resulted in a large loss. It can not be said, therefore, that prior to 1899 the Tobacco Combination had any degree of control over the plugtobacco business.

With the formation of the Continental Tobacco Company in 1899 , howerer, the Combination secured a very considerable proportion of the total plug and twist output of the country; namely, about 56 per cent in that year. The American Tobacco Company turned over its entire plug business to the Continental, which at the same time took in a number of other concerns. The Continental was the representative of the Tobacco Combination in the plug business until 1904 , when it was merged with the reorganized American Tobacco Company. Since that time the American Tobacco Company has itself produced the greater part of the Combination's output of plug tobacco. Several of the subsidiary companies, however, also produce considerable quantities of plug tobacco. In 1906, of the total output of $149,119,539$ pounds made by the Tobacco Combination, 103,796,577 pounds, or 69.6 per cent, was made by the American Tobacco Company itself and 45,322,962 pounds by its subsidiary companies.

The Combination's control of the plug-tobacco business has materially increased since 1899, and in 1907 it had 77 per cent of the country's entire output.

In considering the results of the plug-tobacco business of the Combination, it is desirable first to present the data for the business directly owned and operated by the Continental Tobacco Company and its successor, the American Tobacco Company, and later to take up the business of the subsidiary companies. The business of the P. Lorillard Company, however, is best considered jointly with that of the Continental and American companies, for the reason that 
the Lorillard Company does not sell its own product, but turns it over to the American (formerly to the Continental) to be marketed. The plug-tobacco business of the American Tobacco Company and the Lorillard Company together constitutes nearly three-fourths of the entire plug business of the Tobacco Combination, and the results of the business of these two companies, therefore, correspond very closely with the results of the entire business, including that of subsidiary companies.

GENERAL RESULTS OF THE PLUG AND TWIST BUSINESS OF THE AMERICAN, CONTINENTAL, AND LORILLARD COMPANIES.

The following table shows the sales of plug tobacco, including twist, by the American, Continental, and Lorillard companies for each year from 1895 to 1907 , together with the net value thereof, exclusive of the internal-revenue tax, and the profits thereon. The table is confined to the domestic business, but in the case of plug tobacco the export business of these companies has always been insignificant, so that this table covers nearly the entire output of these companies.

TABLE 27.-Plug and twist tobacco-American, Continental and Lorillard companies: Quantity of sales, net value of sales, and net profits (domestic business).

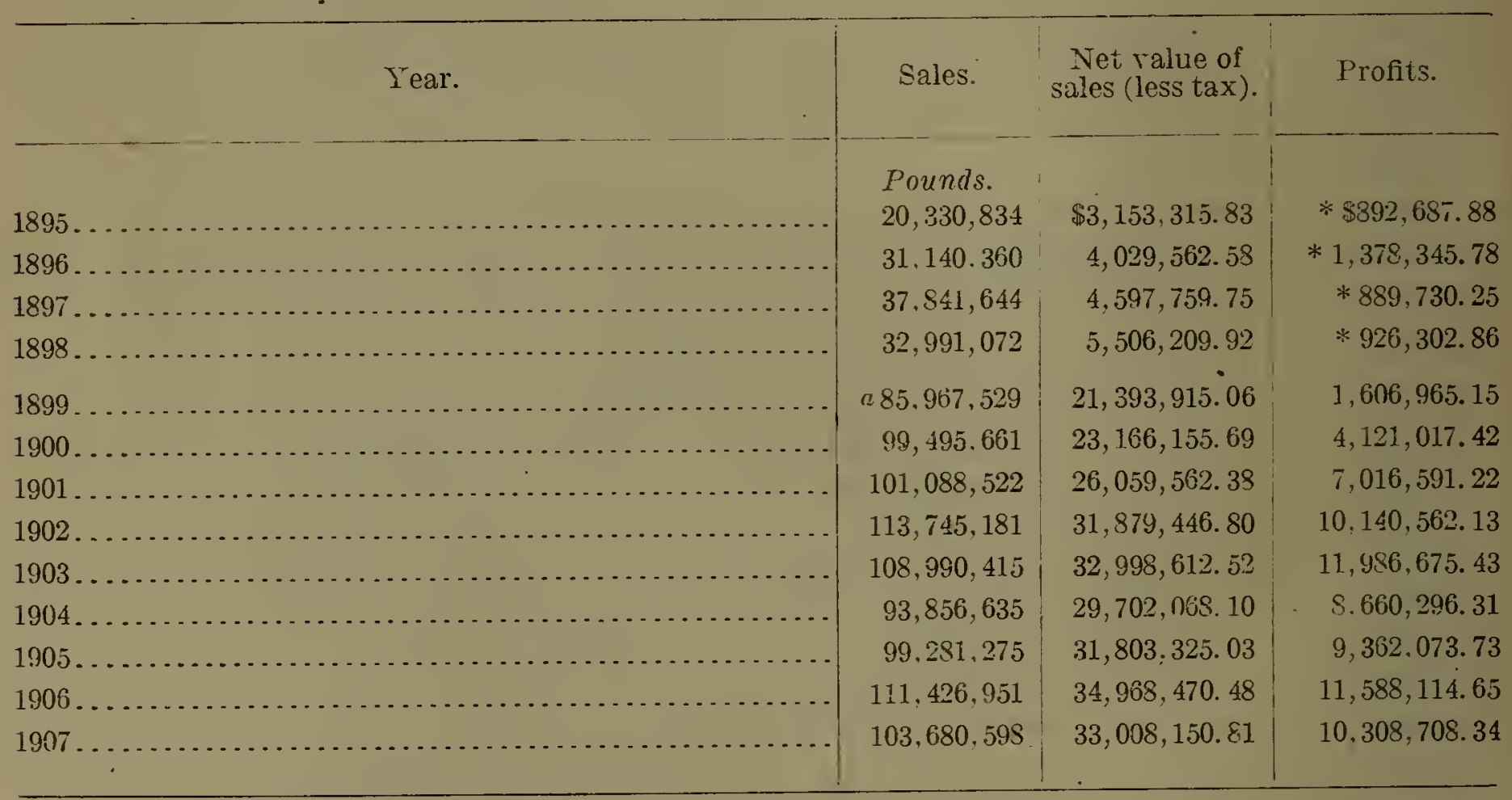

a Owing to the fact that the Continental Tobacco Company was just formed and that the business of some of the concerns acquired was not included during part of the year, the figures for output in this year are somewhat doubtful and the average prices, costs, and profits per pound based thereon are correspondingly not entirely certain.

* Loss.

It should be emphasized, in considering this table and those which follow, that there is no continuity between the figures for the years 1895 to 1898 and the figures for the years 1899 and following. The data for the first four years covered by the table represent exclusively the business of the American Tobacco Company, which, as stated above, then possessed a comparatively smaller proportion of the plug-tobacco business. The enormous increase in the output covered by the table for 1899 was due to the formation of the new combina- 
tion-the Continental Tobacco Company-and from this time on the Tobacco Combination possessed a very considerable proportion of the national output. The losses of the American Tobacco Company during the period 1895 to 1898 are, of course, not typical of the general position of the plug-tobacco business under conditions of competition, and the change from a loss during these years to a profit during the following years can not be considered as in itself an indication of the effect of the combination upon conditions in the industry generally. Most important plug-manufacturing concerns were making a profit during the period 1895-1898, and the fact that the American Tobacco Company lost money was due to its strenuous effort to obtain a large proportion of the business, the ultimate result of which was to bring the other leading concerns into combination with it.

Considering only the period since 1899 , it will be seen that the output of the American, Continental, and Lorillard companies increased from about $86,000,000$ pounds in 1899 (the figure for this year not being entirely certain) to nearly $114,000,000$ pounds in 1902 , after which it declined considerably and again rose to over 111,000,000 pounds in 1906 . There was, however, a considerable decrease in 1907 . The decline in the output of the American, Continental, and Lorillard companies from 1902 to 1904 was wholly offset by an increase in the output of the subsidiary companies controlled by the Combination, the actual output of the Combination as a whole increasing from $134,671,000$ pounds in 1902 to $138,388,000$ pounds in 1904 . Owing to the fact that the year 1899 is not strictly comparable with succeeding years as to profits and costs, the year 1900 has generally been taken as the first year for comparison with successive years. In 1899 the reorganization and shifting of operations incident to the combination of the concerns engaged in plug manufacture required much of the time a.d attention of the officials. The changes in accounting methods during the year, moreover, make the correctness of certain figures of costs somewhat doubtful.

For 1900 the Continental and Lorillard companies sold plug tobacco to a value, excluding the internal-revenue tax, of $\$ 23,166,155.69$, on which they made a profit of $\$ 4,121,017.42$. By 1903 the net value of the sales had risen to nearly $\$ 33,000,000$, but the profit per pound had increased nearly threefold and the total profits were approximately $\$ 12,000,000$. The maximum value of the output of plug by these three companies was in 1906 nearly $\$ 35,000,000$, but the profits were somewhat less than in 1903 . There was some decline both in the net value of sales and in the profits in 1907 .

The general results of the plug-tobacco business of these companies may be much better appreciated by the presentation of averages per pound of output. The following table and accompanying diagram show, for the American, Continental, and Lorillard companies combined, the average net price of plug tobacco in the domestic business, the amount of the internal-revenue tax, the net price exclusive of the tax, the various elements of cost, and the profit. The diagram also gives graphically corresponding information for the Combination as a whole.

$87442-\mathrm{S}$. Doc. $78,61-1-5$ 
TABLE 28.-Plug and twist tobacco-American, Continental, and Lorillard companies: Prices, costs, and profits in domestic business.

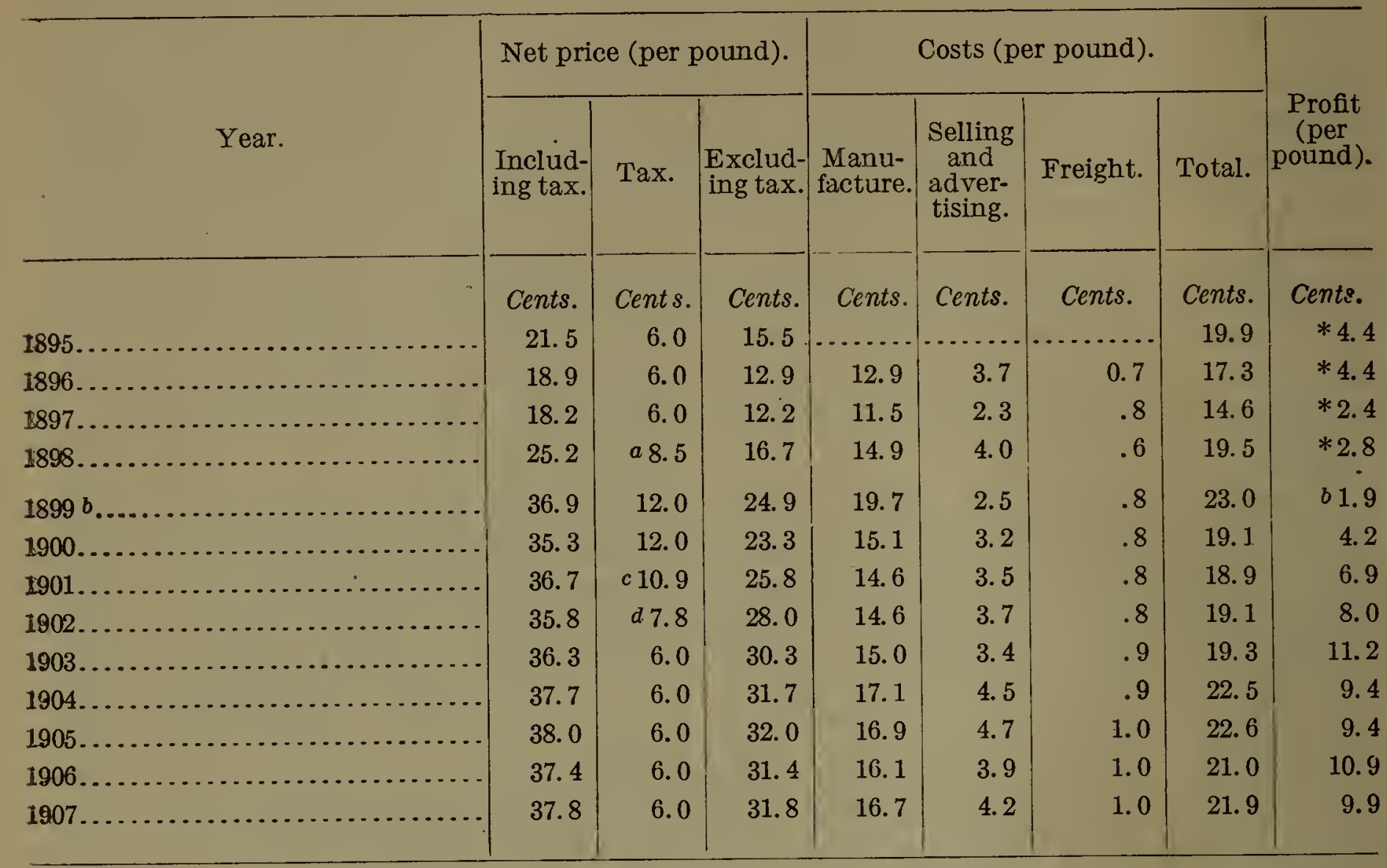

Tax to June 14, 6 cents; thereafter, 12 cents; average based on quantities produced. 3 Approximate; see note to Table 27.

c First half year, 12 cents; second half, 9.6 cents; average based on quantities produced.

$d$ First half year, 9.6 cents; second half, 6 cents; average based on quantities produced.

* Loss.

It will be seen that the American Tobacco Company during its active competitive campaign from 1895 to 1898 lost from 2.4 cents to 4.4 cents per pound on its plug-tobacco business. For the first year of the Continental Tobacco Company, 1899, the profits of the Continental, including the Lorillard, averaged about 2 cents per pound (the precise amount for this particular year being uncertain because of the uncertainty as to the correctness of the figures of output on which the average is based). They increased very markedly in the next four years, reaching 11 cents per pound in 1903, the highest for any year. Since then the changes have been comparatively slight, and in 1907 the average profit was 9.9 cents per pound.

A more condensed view of the results of the plug-tobacco business of the American, Continental, and Lorillard companies, and particularly of the relation between the changes in the tax and the profits, may be gained from Table 29. This table shows the three elements which together make up the price-namely, the amount of tax paid to the Government, the cost of manufacture, and the profit. 
TABLE 29.-Plug and twist tobacco-American, Continental, and Lorillard companies: Amount of tax, cost, and profit entering into net selling price.

\begin{tabular}{|c|c|c|c|c|}
\hline \multirow{2}{*}{ Year. } & \multicolumn{3}{|c|}{ Elements entering into price. } & \multirow{2}{*}{$\begin{array}{l}\text { Net price, } \\
\text { including } \\
\text { tax (per } \\
\text { pound). }\end{array}$} \\
\hline & $\begin{array}{l}\text { Tax (per } \\
\text { pound). }\end{array}$ & $\begin{array}{l}\text { Cost (per } \\
\text { pound). }\end{array}$ & $\begin{array}{l}\text { Profit (per } \\
\text { pound). }\end{array}$ & \\
\hline $1895 .$. & $\begin{array}{l}\text { Cents. } \\
\quad 6.0\end{array}$ & $\begin{array}{c}\text { Cents. } \\
19.9\end{array}$ & $\begin{array}{l}\text { Cents. } \\
\quad * 4.4\end{array}$ & $\begin{array}{c}\text { Cents. } \\
21.5\end{array}$ \\
\hline 1896 & 6.0 & 17.3 & $* 4.4$ & 18.9 \\
\hline 1897. & 6.0 & 14.6 & $* 2.4$ & 18.2 \\
\hline 1898. & 8.5 & 19.5 & $* 2.8$ & 25.2 \\
\hline $1899 a_{\ldots}$. & 12.0 & 23.0 & 1.9 & 36.9 \\
\hline $1900 \ldots$ & 12.0 & 19.1 & 4. 2 & 35.3 \\
\hline 1901. & 10.9 & 18.9 & 6.9 & 36.7 \\
\hline 1902. & 7.8 & 19.1 & 8.9 & 35.8 \\
\hline $1903 .$. & 6.0 & 19.3 & 11.0 & 36.3 \\
\hline 1904. & 6.0 & 22.5 & 9.2 & 37.7 \\
\hline $1905 \ldots$ & 6.0 & 22.6 & 9.4 & 38.0 \\
\hline $1906 \ldots$ & 6.0 & 21.0 & 10.4 & 37.4 \\
\hline $1907 \ldots \ldots \ldots \ldots$ & 6.0 & 21.9 & 9.9 & 37.8 \\
\hline
\end{tabular}

$a$ Data for this year not entirely certain.

* Loss.

The net price received by the American Tobacco Company for its output during the period 1895-1898 was exceedingly low, especially in the first two years, and though there was a considerable increase in 1898 it was practically offset by an increase in the cost and in the tax. No comparison can be made between the prices charged by the American Tobacco Company and the average price obtained by the Continental and Lorillard companies after the new combination of 1899 . Confining attention to the later period, it will be seen that the net price of the Continental Tobacco Company, including the Lorillard Company, for the first year for which certain data are available, 1900 , was 35.3 cents, without deduction of the tax. The average net price has never been lowered since that time. Notwithstanding the reduction of the internal-revenue tax from 12 cents in 1900 to 6 cents in the later years, the average net price, including tax, obtained by the American, Continental, and Lorillard companies for the four years 1904-1907 was from 2.1 cents to 2.7 cents higher than in 1900. Had there been no change in the cost of manufacture the profit would have been more than 8 cents higher in each of these years than it was in 1900 . There has, however, been an increase in the price of leaf and other raw materials, so that the net profit has increased a little less than the amount of reduction in the tax if comparison be made between 1900 and 1907. As between 1899 and 1907, however, the profit increased 8 cents a pound, while the reduction in the tax was 6 cents a pound.

Especially striking are the changes in the profit from 1900 to 1903. There was comparatively little change during this period in the cost of manufacture. The amount of tax paid fell 1.1 cents per pound on the average between 1900 and 1901, and the profit increased 2.7 cents per pound, the net price, even including the tax, having advanced. From 1900 to 1902 the tax decreased 4.2 cents per pound 
and the profit increased 4.7 cents per pound. From 1900 to 1903 the tax decreased 6 cents per pound and the profit increased 6.8 cents per pound, the price including tax having increased 1 cent but the cost having increased 0.2 cent. Out of the net price of 35.3 cents obtained by the American, Continental, and Lorillard companies in 1900 the Government received more than one-third, 12 cents. Out of the net price of 37.8 cents in 1907 the Government received only 6 cents, or less than one-sixth. The profit of the combination represented but little over one-ninth of the price in 1900, while in 1907 it represented more than one-fourth of the price, and in some of the years preceding 1907 a still larger proportion.

The true price obtained by any manufacturer of tobacco is, of course, the difference between what he collects from the public and the amount which he has to pay to the Government. The real charge which the manufacturer makes to the public is the price less the tax, the tax being a charge which the Government levies. Similarly, the real cost of tobacco is the cost exclusive of the tax. It will be seen from Table 28 that the average net price exclusive of tax received by the American, Continental, and Lorillard companies for their plug and twist tobacco in the domestic trade increased very rapidly from 1900 until 1903, being 23.3 cents in the former year and 30.3 cents in the latter. There was a further moderate increase until 1905, when the price excluding tax averaged 32 cents, while in 1906 and 1907 it was a fraction of a cent lower. The cost of manufacture and sale changed comparatively little from 1900 to 1903 , being only 0.2 cent higher in the latter year than in the former. Costs were considerably higher in 1904 and 1905 than in the preceding years, which accounts for the slight decline in the profit per pound. In 1906 and 1907 the costs were again a little lower, although still higher than from 1900 to 1903.

In the following table a comparison of prices, costs, and profits for each year from 1901 to 1907 is made with the data for the year 1900:

TABLE 30.-Plug and twist tobacco-American, Continental, and Lorillard companies: Increase in price and increase in cost, 1900-190\%.

Year.
$\ldots$

* Decrease.

The table shows for 1901, for example, how much the net price, less tax, exceeded the net price of 1900 , how much the cost exceeded (or fell below) the cost of 1900, and the difference between these two figures, which represents the increase in the profit over 1900 . A 
similar comparison is made between each year and the year 1900. The year 1900 is taken as a basis for comparison instead of 1899 , partly because the figures of prices and profits for 1899 are not absolutely certain (for reasons already explained), but chiefly because in the year 1899 the business of the Continental Tobacco Company was not fully organized and the costs of operation were presumably somewhat above normal. It should be borne in mind, however, that in 1900 the Combination already possessed a very considerable degree of control over the output of plug tobacco in the country, and that the profits were much higher than in 1899 .

It will be seen from this table that the sole cause of the increase in the profit of the American, Continental, and Lorillard companies on their plug business during the later years as compared with 1900 has been the increase in the net price, less tax. Costs have also increased, owing to increased advertising expenses and increases in the prices of leaf and other materials; but, since the increase was less than the increase in the selling price, there has been a marked increase in the profit. For 1903, when the profits were at a maxium, the price exceeded that of 1900 by 7 cents, while the cost was only 0.2 cent higher, making an increase of 6.8 cents in profits. For 1907 the net price was 8.5 cents higher than in 1900; costs had increased 2.8 cents, so that profits increased 5.7 cents.

The following table shows the percentage which the profits of the American, Continental, and Lorillard companies on their plug business bear in each year to the cost of manufacture, exclusive of tax:

TABLE 31.-Plug and twist tobacco-American, Continental, and Lorillard companies: Relation of profits to costs.

\begin{tabular}{|c|c|c|c|}
\hline Year. & $\begin{array}{c}\text { Cost, } \\
\text { excluding } \\
\text { tax (per } \\
\text { pound). }\end{array}$ & $\begin{array}{l}\text { Profit (per } \\
\text { pound). }\end{array}$ & $\begin{array}{l}\text { Rate of } \\
\text { profit on } \\
\text { cost. }\end{array}$ \\
\hline $1899 a \ldots .$. & $\begin{array}{l}\text { Cents. } \\
23.0\end{array}$ & $\begin{array}{l}\text { Cents. } \\
\quad 1.9\end{array}$ & $\begin{array}{r}\text { Per cent. } \\
8.1\end{array}$ \\
\hline $1900 \ldots \ldots \ldots$ & 19.1 & 4.2 & 21.6 \\
\hline 1901. & 18.9 & 6.9 & 36.8 \\
\hline 1902. & 19.1 & 8.9 & 46.6 \\
\hline 1903 & 19.3 & 11.0 & 57.0 \\
\hline $1904 \ldots$ & 22.5 & 9.2 & 41.2 \\
\hline 1905. & 22.6 & 9.4 & 41.7 \\
\hline $1906 \ldots$ & 21.0 & 10.4 & 49.6 \\
\hline $1907 .$. & 21.9 & 9.9 & 45.4 \\
\hline
\end{tabular}

$a$ Data not entirely certain; see note $a$, Table 27.

Confining attention to the period since 1900, it will be seen that in that year the profit represented 21.6 per cent on the cost. (The rate in 1899 had been much lower-about 8 per cent.) With the very rapid increase in the profit, due to the increase in price, the percentage of profit on cost rose to 57 per cent in 1903 . This was the maximum. Since that time the percentage of profit has ranged from 41.2 per cent to 49.6 per cent, and in 1907 it was 45.4 per cent.

Another method of presenting the relation between the profits, prices, and costs is by showing what proportion of the net selling 
price (exclusive of tax) is represented by cost and what proportion by profit. This is done in the following table for the plug-tobacco business of the American, Continental, and Lorillard companies:

TABLE 32.-Plug and twist tobacco-American, Continental, and Lorillard companies: Division of net selling price (less tax) between cost and profit.

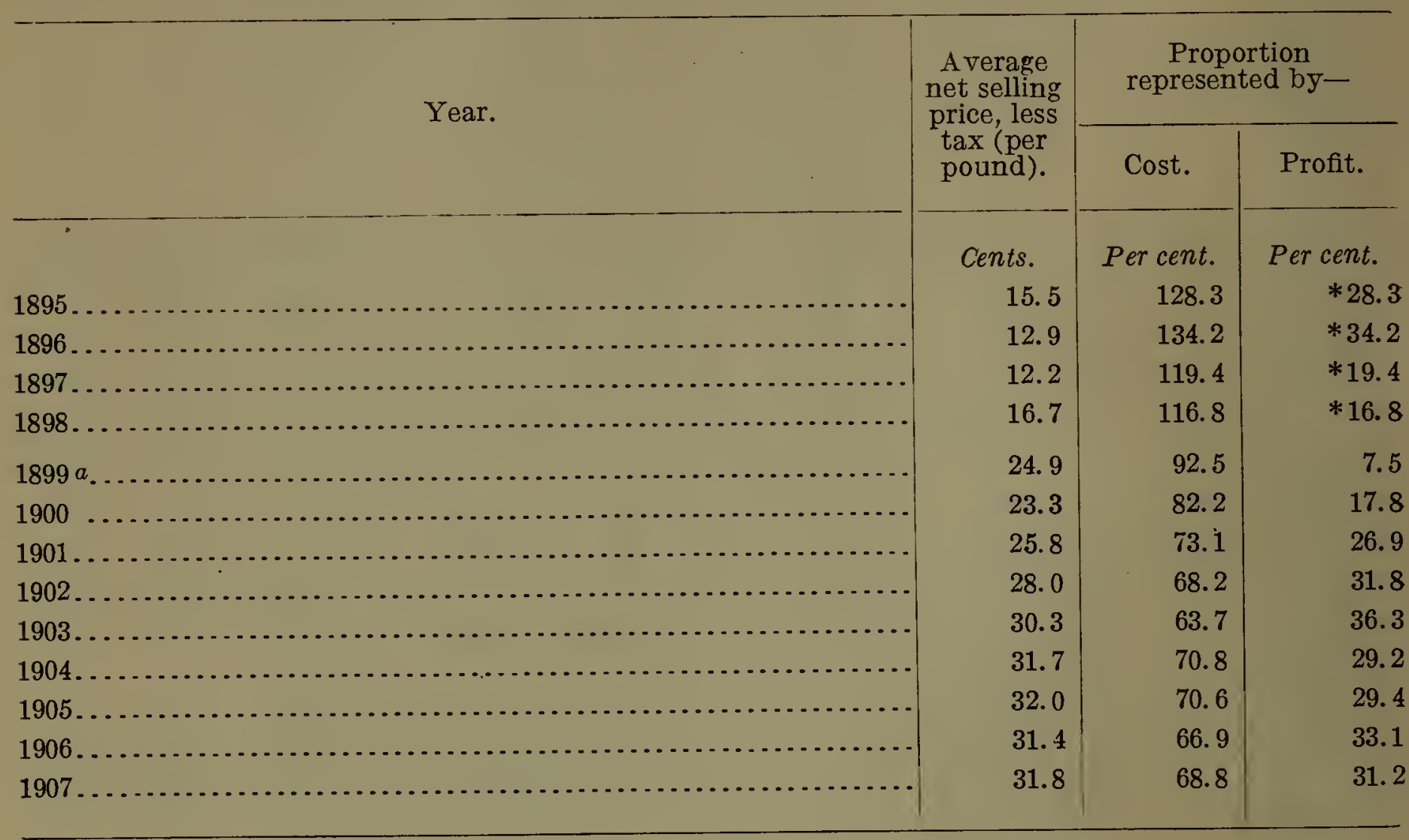

* Loss.

$a$ See note $a$, Table 27

From 1895 to 1898 the cost of the plug tobacco manufactured by the American Tobacco Company exceeded the net selling price. For 1900 , the first year after the new plug combination for which the data are entirely certain, the profit of the Continental and Lorillard companies represented 17.8 per cent of the net selling price, while 82.2 per cent was represented by cost. For 1899 the proportion represented by profit had been much lower, about 7.5 per cent. By 1903 the proportion of the selling price represented by profit had increased to 36.3 per cent, while cost represented only 63.7 per cent. In 1907 profit represented 31.2 per cent of the selling price and cost 68.8 per cent.

The average net price, less tax, obtained by the American, Continental and Lorillard Companies for plug and twist tobacco, and their average profit per pound from year to year, may be compared with the percentage of plug-tobacco business controlled by the combination in order to determine whether there is any relation between the movement of prices and the changes in the degree of control. The proper comparison, of course, is not that with the proportion of the national output directly produced by the American, Continental, and Lorillard companies, but with the proportion produced by all companies in the Combination. Whatever degree of monopolistic power is possessed by the combination results from the large proportion of the output controlled by the Combination as a whole. The proportion of the output controlled by the combination is shown in Part I of the Report of the Commissioner of Corporations on the Tobacco Industry, page 365 . This represents the output both for domestic consumption and for export, but as the exports are exceedingly small the proportions practically represent those in domestic business. 
TABLE 33.-Plug and twist tobacco-Relation of net price (less tax) and profit of American, Continental, and Lorillard companies to the proportion of business controlled by Tobacco Combination.

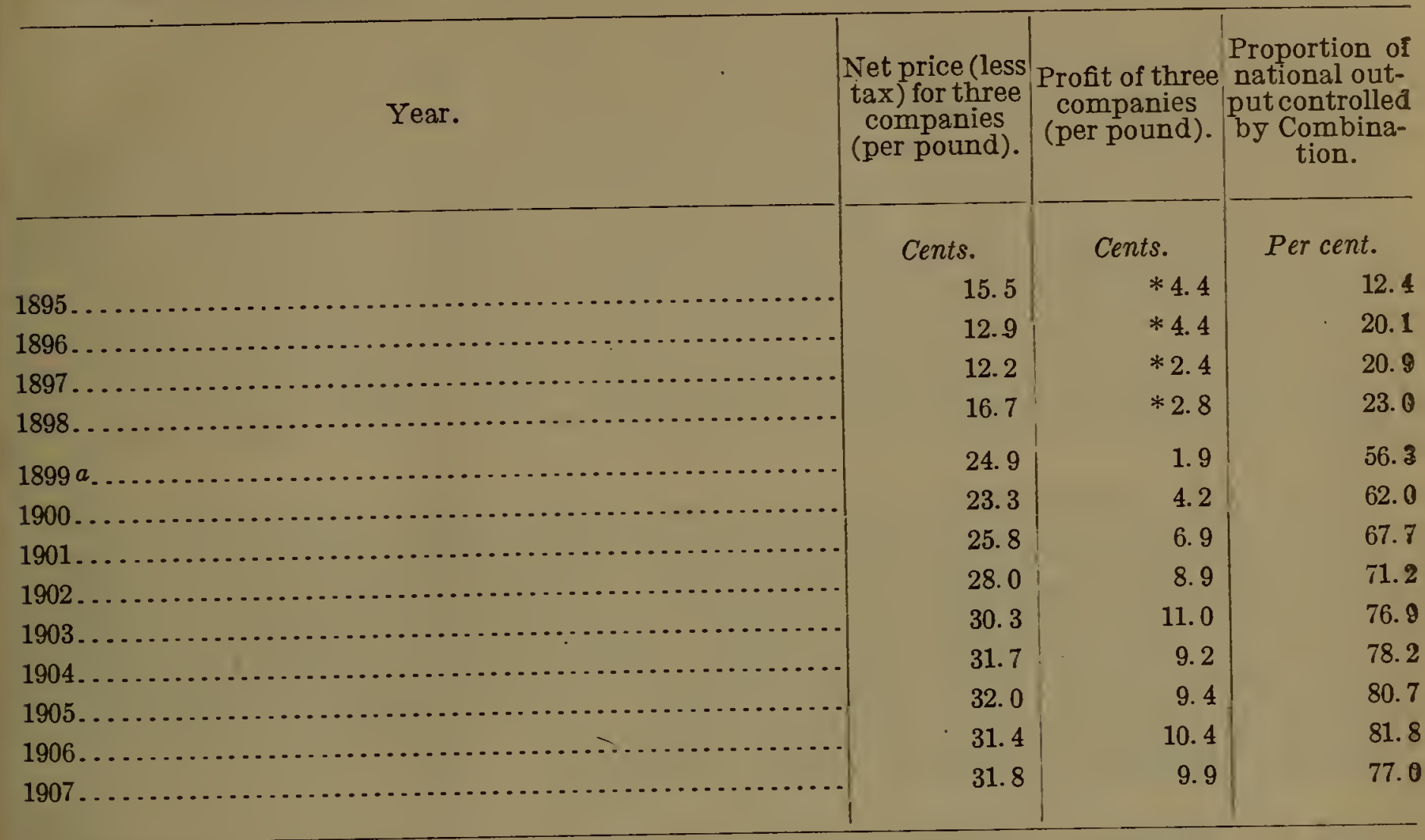

$a$ See note $a$, Table 27 .

* Loss.

This table shows that from the period from 1895 to 1898 the American Tobacco Company controlled between one-eighth and one-fourth of the national output of plug tobacco. It was the attempt to increase its proportion of the total which resulted in the heavy losses shown by the table.

In the first vear after the formation of the Continental Tobacco Company, the Tobacco Combination controlled 56.3 per cent of the output of plug and twist tobacco in the United States, and the profits of the American and Lorillard companies averaged about 2 cents per pound. The proportion of the output controlled increased from year to year until 1903, when it reached 76.9 per cent, and the profit per pound increased also in each year, reaching 11 cents in 1903. In the period from 1903 to 1906 the proportion of the output controlled also continued to increase, but at a less rapid rate than before. The profit per pound did not increase, but was in each year, from 1.904 to 1907 , a little less than in 1903 , though there was no great variation.

\section{RESULTS OF THE PLUG BUSINESS OF SUBSIDIARY COMPANIES OF THE} TOBACCO COMBINATION.

The principal subsidiary companies engaged in the manufacture of plug tobacco-other than the Lorillard company, which has already been considered in connection with the American and Continental companies - are, in the order of their importance: The R.J. Reynolds Tobacco Company, the Nall \& Williams Tobacco Company, the R. A. Patterson Tobacco Company, the Liipfert-Scales Company, and the F. R. Penn Tobacco Company. Other less important companies making plug tobacco are: D. H. Spencer \& Sons, Nashville Tobacco Works, and Spaulding \& Merrick. The latter company, however, practically ceased to manufacture plug in 1906. Data of 
costs, prices, and profits have been secured for the Reynolds, Patterson, Nall \& Williams, and Spaulding \& Merrick concerns. The Patterson Tobacco Company, however, makes even more smoking tobacco than plug, and data are not available by which to distinguish its costs, profits, and prices of plug tobacco from those of smoking tobacco. In order to show approximately, therefore, the general results of the plug business of the subsidiary companies, the data for the Reynolds, Nall \& Williams, and Spaulding \& Merrick concerns are presented. These three concerns in 1906 produced about $25,000,000$ pounds of plug tobacco out of a total output of about 32,500,000 pounds for all the subsidiary concerns (except Lorillard), combined. Spaulding \& Merrick in 1906 and 1907 produced very little plug tobacco, but in the years 1903 to 1905 its output was considerable.

The following table shows, for each year since acquisition by the combination, the quantity of sales, the net price including tax, and the net price excluding tax, for the R. J. Reynolds, Nall \& Williams, and Spaulding \& Merrick concerns. The first two of these concerns manufacture exclusively plug tobacco, but in the case of Spaulding \& Merrick plug has at all times been a less important branch of its business than smoking and fine-cut tobacco.

TABLE 34.-Plug and twist tobacco-Quantity of sales and average price for principal subsidiary companies of American Tobacco Company.

\begin{tabular}{|c|c|c|c|c|c|c|c|c|c|}
\hline \multirow[b]{2}{*}{ Year. } & \multicolumn{3}{|c|}{ R. J. Reynolds Tobacco Co. } & \multicolumn{3}{|c|}{ Nall \& Williams. . } & \multicolumn{3}{|c|}{ Spaulding \& Merrick. } \\
\hline & Sales. & $\begin{array}{l}\text { Net } \\
\text { price, } \\
\text { includ- } \\
\text { ing tax } \\
\text { (per } \\
\text { pound). }\end{array}$ & $\begin{array}{l}\text { Net } \\
\text { price, } \\
\text { exclud- } \\
\text { ing tax } \\
\text { (per } \\
\text { pound). }\end{array}$ & Sales. & $\begin{array}{c}\text { Net } \\
\text { price, } \\
\text { includ- } \\
\text { ing tax } \\
\text { (per } \\
\text { pound). }\end{array}$ & $\begin{array}{l}\text { Net } \\
\text { price, } \\
\text { exclud- } \\
\text { ing tax } \\
\text { (per } \\
\text { pound). }\end{array}$ & Sales. & $\begin{array}{l}\text { Net } \\
\text { price, } \\
\text { includ- } \\
\text { ing tax } \\
\text { (per } \\
\text { pound). }\end{array}$ & $\begin{array}{l}\text { Net } \\
\text { price, } \\
\text { exclud- } \\
\text { ing tax } \\
\text { (per } \\
\text { pound). }\end{array}$ \\
\hline 1900. & $\begin{array}{l}\text { Pounds. } \\
11,329,550\end{array}$ & $\begin{array}{l}\text { Cents. } \\
\quad 31.0\end{array}$ & $\begin{array}{l}\text { Cents. } \\
19.0\end{array}$ & Pounds. & Cents. & Cents. & Pounds. & Cents. & $\begin{array}{l}\text { Cents. } \\
\ldots \ldots . . .\end{array}$ \\
\hline 1901. & $16,942,384$ & 32.3 & 21.5 & & & & & & \\
\hline 1902. & $18,916,950$ & 33.2 & 25.4 & & & & & & $\cdots$ \\
\hline 1903. & $22,760,138$ & 31.5 & 25.5 & & $\ldots$ & . & 533,302 & 31.1 & 25.1 \\
\hline 1904 & $24,721,016$ & 30.8 & 24. 8 & $3,673,284$ & 28.5 & 22.5 & 636,141 & 33.8 & 27.8 \\
\hline 1905. & $26,772,152$ & 30.5 & 24.5 & $3,526,534$ & 30.3 & 24.3 & 462,790 & 36.3 & 30.3 \\
\hline 1906. & $19,687,894$ & 30.3 & 24.3 & $4,107,921$ & 29.6 & 23. 6 & 24,500 & 25.9 & 19.9 \\
\hline $1907 \ldots$ & $25,406,359$ & 31.5 & 25.5 & $3,669,153$ & 30.2 & 24.2 & 9,880 & 24.6 & 18. 6 \\
\hline
\end{tabular}

This table shows that the R. J. Reynolds Tobacco Company is much the most important of the subsidiary concerns of the American Tobacco Company in the plug business. Its sales constitute during the later years from three-fifths to three-fourths of the entire output of all the subsidiary concerns, exclusive of the P. Lorillard company. In 1907 the sales of the Reynolds company were equal to approximately one-fourth of the combined sales of the American and Lorillard companies. The Reynolds company, to a large extent, makes what is known as flat-plug tobacco, which differs somewhat in character from the sweet or navy plug, which is the principal product of the American and Lorillard companies. The flat plug is largely sold in the Southern States. It commands a somewhat lower price than the average price of sweet or navy plug, and has also been subject to somewhat greater competition during the more recent years. 
The sales of the Reynolds company increased from $11,329,550$ pounds in 1900 to a maximum of 26,772,152 pounds in 1905. They fell off very considerably in 1906, but in 1907 were not greatly below the sales of 1905 . It will be seen also that the Reynolds company did not reduce its average price at the time when the internal-revenue tax was reduced. It will be recalled that the tax was reduced by successive stages from 12 cents in 1901 to 6 cents, the year 1903 being the first full year in which the latter rate was in force. The average net price, including tax for the Reynolds company, had been 31 cents in 1900 and rose to 31.5 cents in 1903 , so that the net price less tax increased from 19 cents to 25.5 cents. There has been no very material change in the average price received by the Reynolds company since 1903, the average for 1907 being the same as in that year.

The stock of the Nall \& Williams Tobacco Company was acquired by the Tobacco Combination in 1903, and the first report available covers the year 1904 . In that year this company produced $3,673,284$ pounds, and, with comparatively slight variations in 1905 and 1906 , its sales in 1907 were substantially the same as in 1904 . The price including tax and the price tess tax (the tax not having changed) have been a trifle higher during the years 1905 to 1907 than during 1904.

The stock in Spaulding \& Merrick (Incorporated) was acquired by the combination in 1902, and the first report covers the year 1903 . In that year Spaulding \& Merrick sold 533,302 pounds of plug tobacco. Its sales increased in 1904, but fell off again in 1905, and since that time have been insignificant, this concern having practically given up the plug branch of the business. The average net price less tax for the Spaulding \& Merrick company's output of plug increased from 25.1 cents in 1903 to 30.3 cents in 1905 . The figures for the last two years cover such a small output that they have no significance.

Table 35 presents the combined results of the plug business of the Reynolds, Nall \& Williams, and Spaulding \& Merrick companies, showing the quantity of sales, the average price including and excluding tax, the costs, and the profit.

TABLE 35.-Plug and twist tobacco-Prices, costs, and profits of principal subsidiary companies of American Tobacco Company (R. J. Reynolds, Nall \& Williams, Spaulding \& Merrick).

\begin{tabular}{|c|c|c|c|c|c|c|c|c|}
\hline \multirow[b]{2}{*}{ Year. } & \multirow[b]{2}{*}{ Sales. } & \multicolumn{3}{|c|}{ Price (per pound). } & \multicolumn{3}{|c|}{ Cost (per pound). } & \multirow{2}{*}{$\begin{array}{c}\text { Profit } \\
\text { (per } \\
\text { pound) }\end{array}$} \\
\hline & & $\begin{array}{l}\text { Includ- } \\
\text { ing tax. }\end{array}$ & Tax. & $\begin{array}{l}\text { Exclud- } \\
\text { ing tax. }\end{array}$ & $\begin{array}{l}\text { Manu- } \\
\text { facture } \\
\text { and } \\
\text { freight. }\end{array}$ & $\begin{array}{l}\text { Selling } \\
\text { and } \\
\text { advertis- } \\
\text { ing. }\end{array}$ & Total. & \\
\hline 1900. & $\begin{array}{c}\text { Pounds. } \\
11,329,550\end{array}$ & $\begin{array}{r}\text { Cents. } \\
31.0\end{array}$ & $\begin{array}{l}\text { Cents. } \\
12.0\end{array}$ & $\begin{array}{r}\text { Cents. } \\
19.0\end{array}$ & $\begin{array}{r}\text { Cents. } \\
14.8\end{array}$ & $\begin{array}{r}\text { Cents. } \\
3.8\end{array}$ & $\begin{array}{r}\text { Cents. } \\
18.6\end{array}$ & $\begin{array}{r}\text { Cents. } \\
0.4\end{array}$ \\
\hline $1901 \ldots$ & $16,942,384$ & 32.3 & 10.8 & 21.5 & 14.7 & 3.6 & 18.3 & 3.2 \\
\hline 1902. & $18,916,950$ & 33.2 & 7.8 & 25.4 & 16.2 & 4.6 & 20.8 & 4.6 \\
\hline 1903. & $23,293,440$ & 31.5 & 6.0 & 25.5 & 17.0 & 4.3 & 21.3 & 4.2 \\
\hline $1904 \ldots$ & $29,030,441$ & 30.6 & 6.0 & 24.6 & 15.2 & 5.3 & 20.5 & 4.1 \\
\hline $1905 \ldots$ & $30,761,476$ & 30.5 & 6.0 & 24.5 & 15.1 & 5.5 & 20.6 & 3.9 \\
\hline $1906 .$. & $23,820,315$ & 30.2 & 6.0 & 24.2 & 15.4 & 5.9 & 21.3 & 2.9 \\
\hline $1907 \ldots$. & $29,085,392$ & 31.3 & 6.0 & 25.3 & 16.7 & 4.3 & 21.0 & 4.3 \\
\hline
\end{tabular}


Since, as will be seen from Table 34 , above, the average price per pound of the Nall \& Williams Company is substantially the same as that of the Reynolds Company, and since the Spaulding \& Merrick output is very much less than that of the other two concerns, the combination of the figures for the three concerns for the years 1903 to 1907 is substantially comparable with the figures for the Reynolds Tobacco Company alone for the period 1900 to 1902 . It will be seen that the average price including tax for these concerns during the years 1903 to 1907 , when the tax rate was 6 cents per pound, was substantially the same as in 1900 , when the tax rate was 12 cents per pound. The net price excluding tax rose from 19 cents in 1900 to a maximum of 25.5 cents in 1903 , an increase of 6.5 cents, or slightly more than the reduction in the internal-revenue tax. Since that time the prices have been a trifle lower, although the average for 1907 was substantially the same as in 1903, namely, 25.3 cents.

The costs, both of manufacture and of sale, however, increased from 1900 to 1903, the increase in manufacturing cost being 2.2 cents per pound, and in selling cost 0.5 cent per pound. Consequently, although the price increased 6.5 cents, the profit increased only 3.8 cents between 1900 and 1903 . From 1904 to 1906 the manufacturing cost was somewhat lower than in 1903, but the Combination increased its selling and advertising expenses in the endeavor to push this branch of the business, so that the profits fell off, reaching a minimum of 2.9 cents in 1906 . The increase in manufacturing cost in 1907 was more than offset by a reduction in selling and advertising costs, so that, owing to the increase in the net price, the profit increased to 4.3 cents per pound.

Table 36 compares the net price per pound and the net profit of the American, Continental, and Lorillard companies in their domestic plug business with the price and profit of the three principal subsidiary companies-Reynolds, Nall \& Williams, and Spaulding \& Merrick.

TABLE 36.-Plug and twist tobacco-Comparison of prices and profits of parent and subsidiary companies.

\begin{tabular}{|c|c|c|c|c|c|c|}
\hline \multirow[b]{2}{*}{ Year. } & \multicolumn{2}{|c|}{ Sales. } & \multicolumn{2}{|c|}{$\begin{array}{l}\text { Net prices, excluding } \\
\text { tax (per pound). }\end{array}$} & \multicolumn{2}{|c|}{ Net profit (per pound). } \\
\hline & $\begin{array}{l}\text { American, } \\
\text { Continental, } \\
\text { and Lorillard. }\end{array}$ & $\begin{array}{l}\text { Principal } \\
\text { subsidiary } \\
\text { companies. }\end{array}$ & $\begin{array}{l}\text { American, } \\
\text { Conti- } \\
\text { nental, and } \\
\text { Lorillard. }\end{array}$ & $\begin{array}{l}\text { Subsidiary } \\
\text { companies. }\end{array}$ & $\begin{array}{l}\text { American, } \\
\text { Continental, } \\
\text { and Lorillard. }\end{array}$ & $\begin{array}{l}\text { Subsidiary } \\
\text { companies. }\end{array}$ \\
\hline 1900. & $\begin{array}{l}\text { Pounds. } \\
99,495,661\end{array}$ & $\begin{array}{l}\text { Pounds. } \\
11,329,550\end{array}$ & $\begin{array}{l}\text { Cents. } \\
23.3\end{array}$ & $\begin{array}{r}\text { Cents. } \\
19.0\end{array}$ & ${ }_{4.2}$ & $\begin{array}{l}\text { Cents. } \\
0.4\end{array}$ \\
\hline 1901. & $101,088,522$ & $16,942,384$ & 25.8 & 21.5 & 6.9 & 3.2 \\
\hline $1902 .$. & $113,745,181$ & $18,916,950$ & 28.0 & 25.4 & 8.9 & 4.6 \\
\hline $1903 \ldots$ & $108,990,415$ & $23,293,440$ & 30.3 & 25.5 & 11.0 & 4.2 \\
\hline $1904 \ldots .$. & $93,856,635$ & $29,030,441$ & 31.7 & 24.6 & 9.2 & 4.1 \\
\hline $1905 \ldots .$. & $99,281,275$ & $30,761,476$ & 32.0 & 24.5 & 9.4 & 3.9 \\
\hline 1906. & $111,426,951$ & $23,820,315$ & 31.4 & 24.2 & 10.4 & 2.9 \\
\hline 1907. & $103,680,598$ & $29,085,392$ & 31.8 & 25.3 & 9.9 & 4.3 \\
\hline
\end{tabular}


It will be seen that in 1900 the sales of these subsidiary companies (then including only the Reynolds company) were about one-ninth of the sales of the American, Continental, and Lorillard companies, while by 1907 they were considerably over one-fourth. The table shows conspicuously that the subsidiary companies handle a lower grade of tobacco than the parent companies, the difference in net price (less tax) ranging from 2.6 cents to 7.5 cents per pound.. Roughly speaking, the average net price (less tax) for the subsidiary companies is about three-fourths of that for the parent companies in most years. The fact that the subsidiary companies handle a lower grade of plug tobacco largely explains the fact that their profits per pound are decidedly lower than those of the American, Continental, and Lorillard companies. In 1902, the year in which the difference is least conspicuous, the American, Continental, and Lorillard companies made a profit of 8.9 cents per pound on their plug business, while the subsidiary companies made 4.6 cents.

RESULTS OF THE TOTAL PLUG-TOBACCO BUSINESS OF THE TOBACCO COMBINATION.

Table 37 shows the combined sales, value (less tax), and profit of the plug-tobacco business of the American, Continental, and Lorillard companies and of the principal subsidiary companies, the business of the parent and of the subsidiary companies being distinguished. The total represents very nearly the entire plug-tobacco business of the Tobacco Combination in the domestic trade.

TABLE 37.-Plug and twist tobacco-Combined sales and profits of American Tobacco Company and principal subsidiary companies.

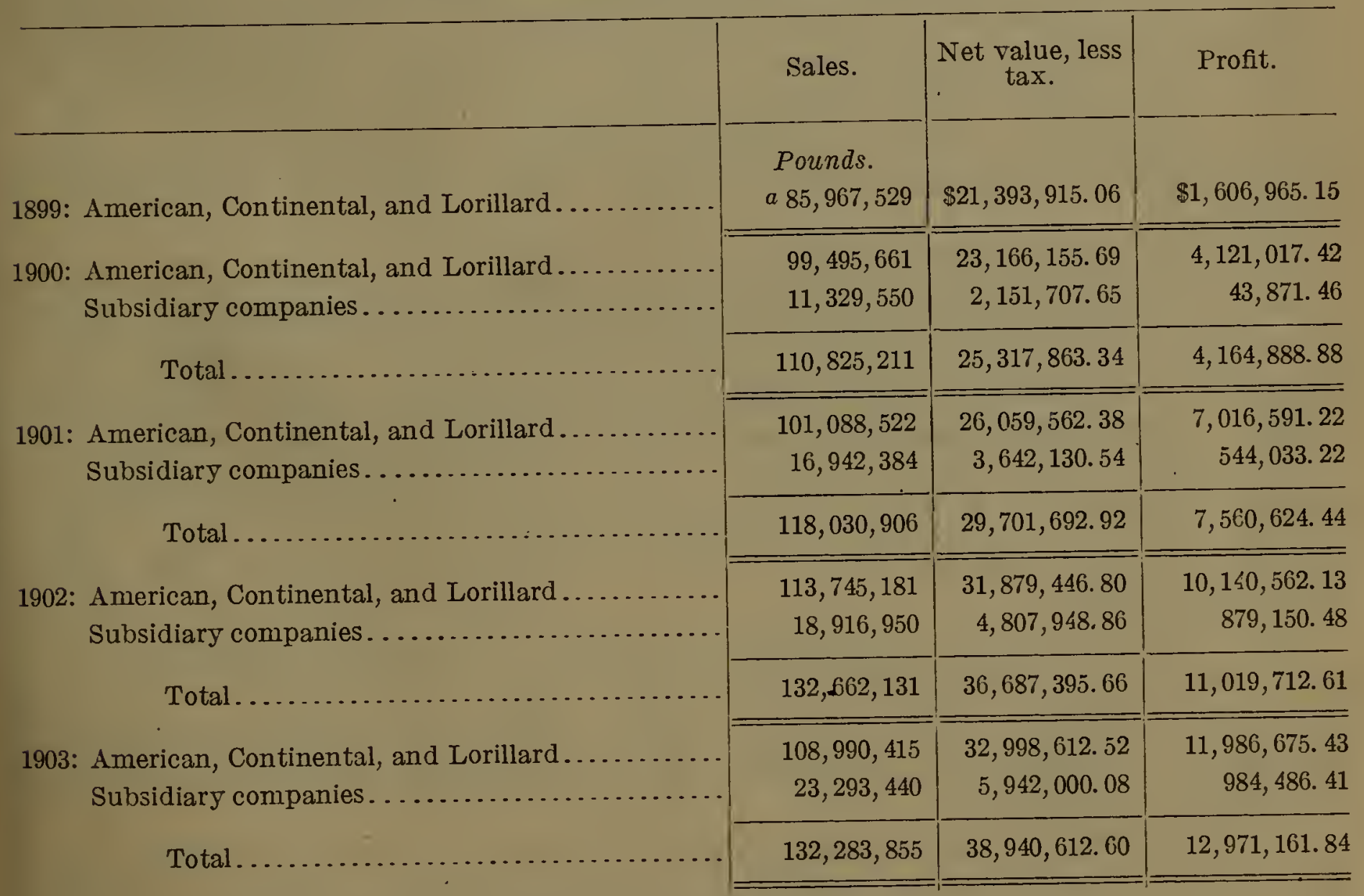

$a$ See note $a$, Table 27 
TABLE 37.-Plug and twist tobacco-Combined sales and profits of American Tobacco Company and principal subsidiary companies-Continued.

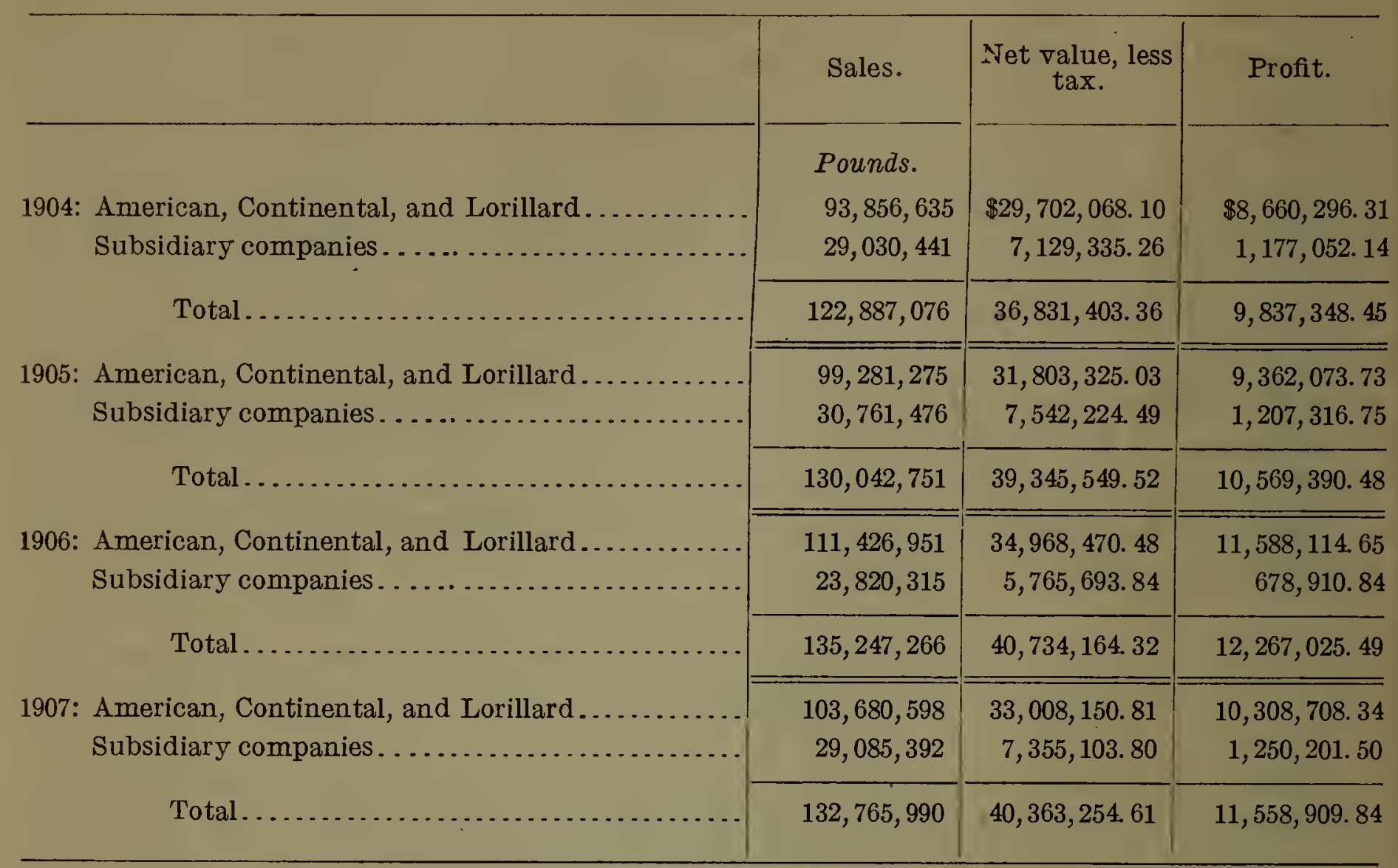

This table shows the great magnitude of the plug-tobacco business of the combination, which during recent years has amounted annually to more than $130,000,000$ pounds, of a net value, excluding tax, of about $\$ 40,000,000$. The sales of the combination increased very rapidly from 1899 , when they were $85,967,529$ pounds, to 1902 , when they amounted to $132,662,131$ pounds. This increase was largely due to the acquisition of additional plants from formerly independent concerns and the acquisition of stock in formerly independent concerns. Since that time there has been some.variation in the sales of the combination, but no general tendency toward increase. The plug-tobacco business of the country as a whole is substantially stationary.

The net value of the output of the Tobacco Combination has, however, jncreased relatively much more than the quantity of sales. From a value of $\$ 21,393,915.06$ in 1899 it has increased to $\$ 40,363,254.61$ in 1907 , the value in that year, however, being a trifle less than in 1906. Even more marked has been the increase in the profit of the combination on plug tobacco. From $\$ 1,606,965.15$ in 1899 , the profit increased to $\$ 12,971,161.84$ in 1903 . This was the largest profit for any year, but in 1907 the profits were no less than $\$ 11,558,909.84$.

The sales for the companies covered by the table, therefore, increased between 1899 and 190754 per cent, the value (less tax) 89 per cent, and the profit 619 per cent. Were the business of all the subsidiary companies included, the percentages of increase would be slightly greater.

Table 38 shows the average prices, costs, and profits per pound for the entire plug-tobacco business of the principal companies in the combination, covering very nearly the entire domestic business of the Tobacco Combination in plug tobacco. Diagram 1 gives this same information graphically in contrast with like data for the combination as a whole. 


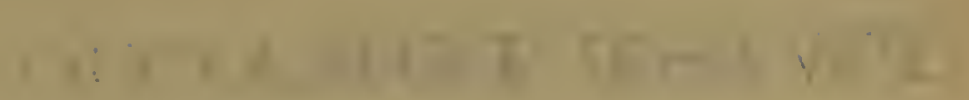

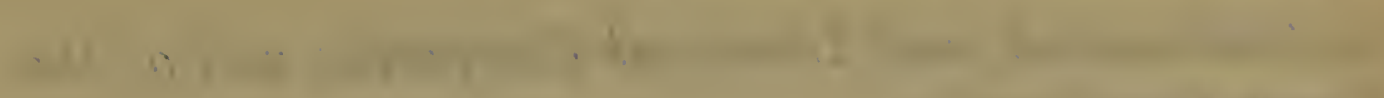
1.

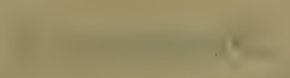

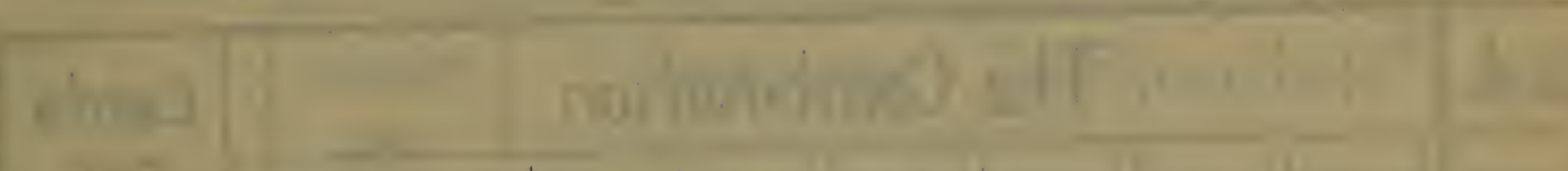

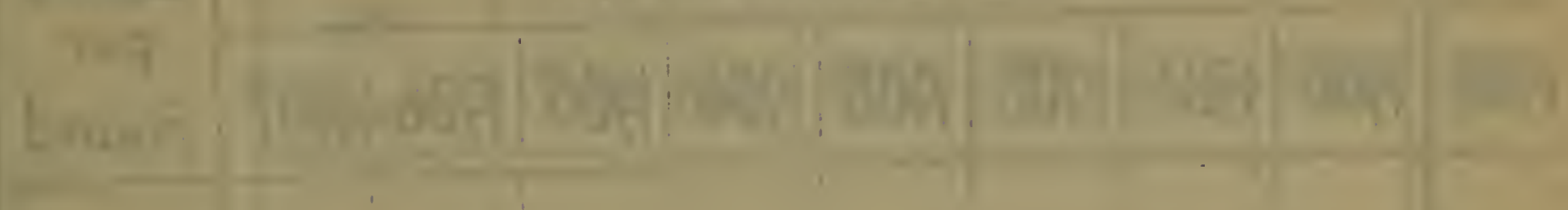

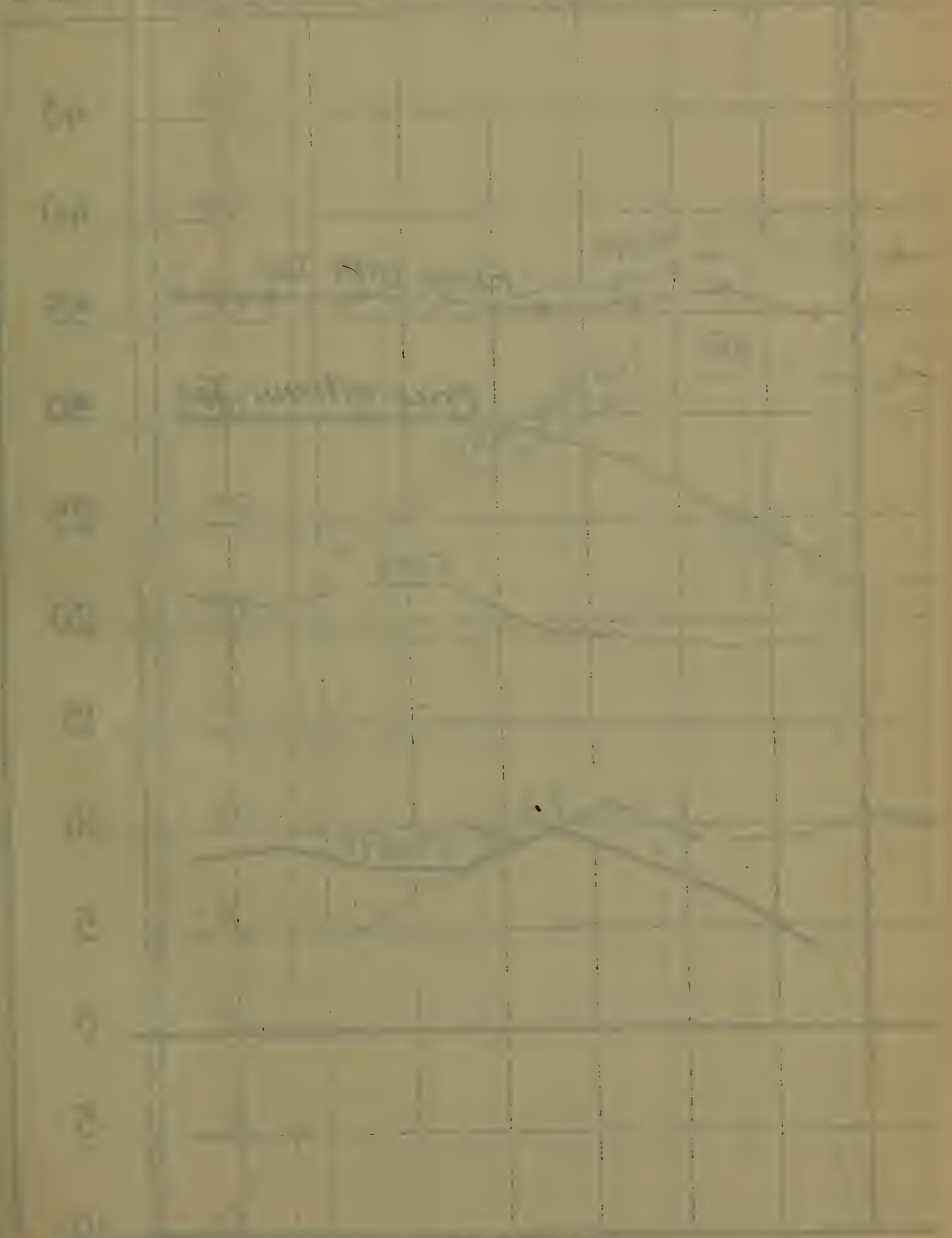




\section{his * - 5i:40u}

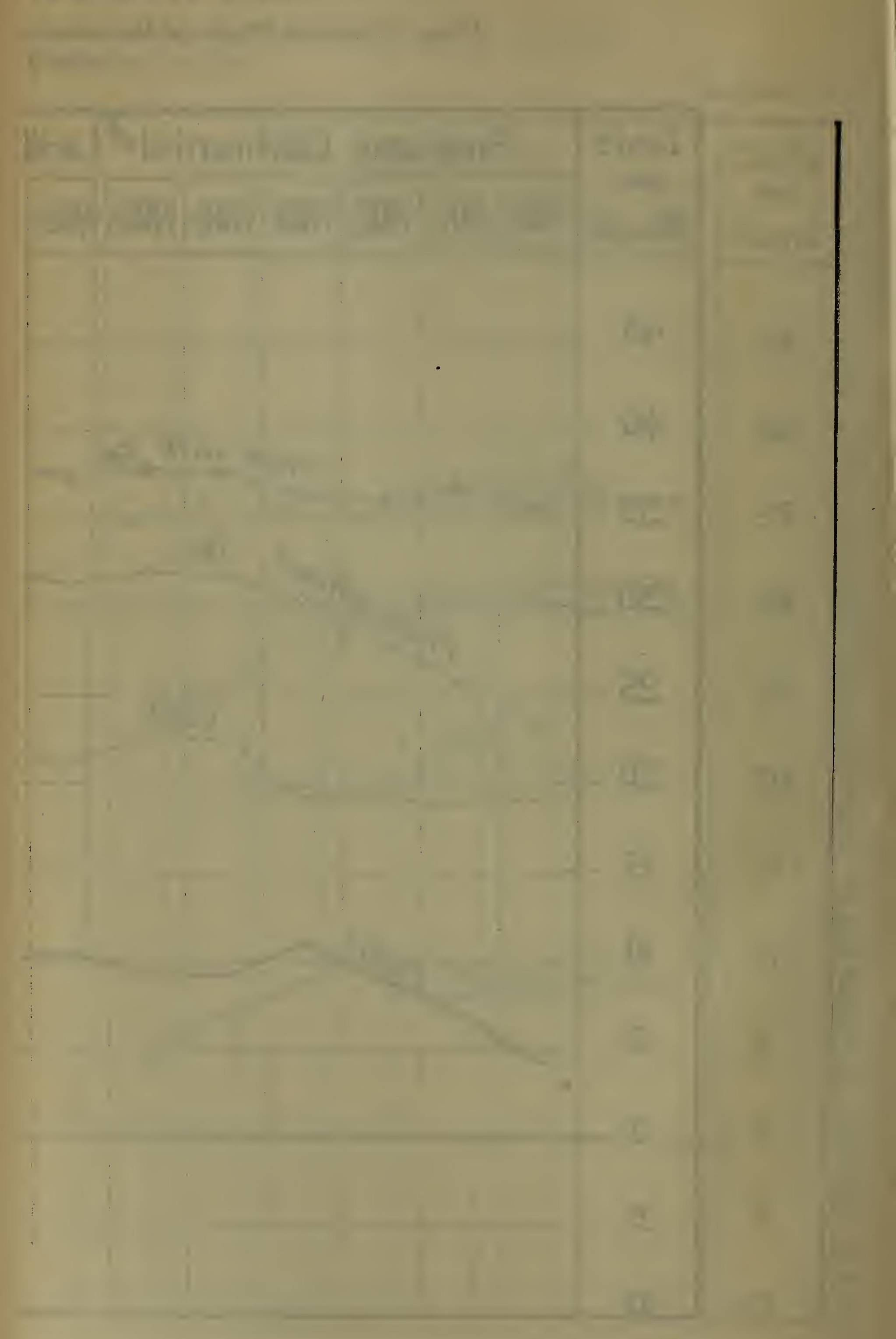


TABLE 38.-Plug and twist tobacco-Prices, costs, and profits of the Tobacco Combination.

\begin{tabular}{|c|c|c|c|c|c|c|c|c|}
\hline \multirow[b]{2}{*}{ Year. } & \multirow[b]{2}{*}{ Sales. } & \multicolumn{3}{|c|}{ Price (per pound). } & \multicolumn{3}{|c|}{ Costs (per pound). } & \multirow{2}{*}{$\begin{array}{c}\text { Profit } \\
\text { (per } \\
\text { pound). }\end{array}$} \\
\hline & & $\begin{array}{l}\text { Includ- } \\
\text { ing tax. }\end{array}$ & Tax. & $\begin{array}{l}\text { Exclud- } \\
\text { ing tax. }\end{array}$ & $\begin{array}{l}\text { Manu- } \\
\text { facture } \\
\text { and } \\
\text { freight. }\end{array}$ & Sale. & 'Total. & \\
\hline $1899 a$. & $\begin{array}{l}\text { Pounds. } \\
85,967,529\end{array}$ & $\begin{array}{r}\text { Cents. } \\
\quad 36.9\end{array}$ & $\begin{array}{r}\text { Cents. } \\
12.0\end{array}$ & $\begin{array}{r}\text { Cents. } \\
24.9\end{array}$ & $\begin{array}{r}\text { Cents. } \\
20.5\end{array}$ & $\begin{array}{r}\text { Cents. } \\
2.5\end{array}$ & $\begin{array}{r}\text { Cents. } \\
23.0\end{array}$ & $\begin{array}{r}\text { Cents. } \\
1.9\end{array}$ \\
\hline 1900. & $110,825,211$ & 34.8 & 12.0 & 22.8 & 15.8 & 3.3 & 19.1 & 3.7 \\
\hline 1901 & $118,030,906$ & 36.1 & 10.9 & 25.2 & 15.3 & 3.5 & 18.8 & 6.4 \\
\hline 1902. & $132,662,131$ & 35.5 & 7.8 & 27.7 & 15.5 & 3.9 & 19.4 & 8.3 \\
\hline $1903 \ldots$ & $132,283,855$ & 35.4 & 6.0 & 29.4 & 16.1 & 3.5 & 19.6 & 9.8 \\
\hline 1904 & $122,887,076$ & 36.0 & 6.0 & 30.0 & 17.3 & 4.7 & 22.0 & 8.0 \\
\hline 1905 & $130,042,751$ & 36.2 & 6.0 & 30.2 & 17.2 & 4.9 & 22.1 & 8.1 \\
\hline 1906 & $135,247,266$ & 36.1 & 6.0 & 30.1 & 16.8 & 4.2 & 21.0 & 9.1 \\
\hline $1907 \ldots$ & $132,765,990$ & 36.4 & 6.0 & 30.4 & 17.5 & 4.2 & 21.7 & 8.7 \\
\hline
\end{tabular}

$a$ See note ${ }^{a}$, Table 27 .

The year 1899 is not comparable with 1900 as to prices, because the lower-priced Reynolds product is not included. The profits in that year were much lower than in the later years.

The year 1900 was the last in which the full war-revenue tax rate of 12 cents per pound was collected on plug tobacco. The average price in that year, including tax, was 34.8 cents per pound; and in no year since that time, notwithstanding the reduction in the tax, has the average price, including tax, been so low. During the years 1903 to 1907 , with the tax rate of 6 cents per pound, the prices ranged from 35.4 cents to 36.4 cents. Consequently the net price, excluding tax, has been much higher during the recent years than in 1900 . It averaged 22.8 cents in 1900 , and from 29.4 cents to 30.4 cents during the years 1903 to 1907.

The cost of manufacture has increased, being 15.8 cents in 1900 , 16.1 cents in 1903 , and 17.5 cents in the year 1907 . This increase has been due to increased prices of leaf tobacco. During the years 1904 to 1907 , moreover, the costs of selling and advertising were considerably higher than in 1900 , principally on account of increased expenditure for advertising. The total costs, during the years 1904 to 1907 , were from 2 to 3 cents higher than in 1900, as compared with an increase of between 7 and 8 cents in the net price, excluding tax. The average profit per pound during the years 1904 to 1907 , therefore, has been somewhat more than double the profit of 1900 , ranging from 8.0 to 9.1 cents, as compared with 3.7 cents in 1900 ; and over four times as much as in 1899. The maximum profits were in 1903 , 9.8 cents per pound. The cost of manufacture and sale in that year was a little higher than in 1900, while the average price, less tax, was 6.8 cents higher.

It should be noted that the figures for the American, Continental, and Lorillard companies alone, previously presented, show more correctly the true movement of prices and profits for the entire period from 1900 to 1907 than the figures for all the companies combined. The marked increase in the business of the Reynolds. Tobacco Company in low-grade tobacco and the addition of the low-grade tobacco business of Nall \& Williams, beginning with 1904 , tend, of course, relatively to reduce the average price for the entire 


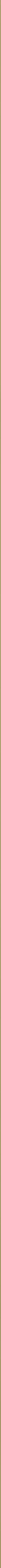


business during the later years. The data for the American, Continental, and Lorillard companies alone cover substantially the same proportions of the different grades of plug tobacco throughout the entire period.

PRICES, COSTS, AND PROFITS OF INDIVIDUAL BRANDS OF PLUG TOBACCO MADE BY THE AMERICAN, CONTINENTAL, AND LORMLLARD COMPANIES.

The tables hitherto presented make it clear that the average price and average profit of the Tobacco Combination on plug tobacco have been very much higher during the later years than during the first years after the formation of the Continental Tobacco Company. Such an increase in average prices and profits might, however, be due in large part to an increased proportion of sales of brands under high prices and high profits, and only to a less degree to the increase in the prices and profits on specific brands. It is therefore necessary to consider the movement of the prices, costs, and profits of individual brands.

No information is available by which to show the costs and profits on individual brands of plug tobacco prior to their acquisition by the combination. The movement of the prices of brands prior to their acquisition by the combination can, however, be ascertained with a fair degree of accuracy from published price lists. The information from the records of the American Tobacco Company itself regarding the prices, costs, and profits of brands since 1899, when the Continental Tobacco Company was organized, are, however, sufficient to show clearly the causes for the increase of the average price and average profit on the business as a whole during that period

Table 39 shows the average net price including tax, the average net price excluding tax, the average cost, and the average profit per pound on 14 leading brands of plug tobacco manufactured by the American, Continental, and Lorillard companies. The figures are compiled from the records of the combination itself. The general movement can be seen more clearly by the accompanying diagrams.

TABLE 39.-Plug tobacco-American, Continental, and Lorillard companies: Prices, costs, and profits for leading individual brands.

\begin{tabular}{|c|c|c|c|c|c|c|c|c|c|}
\hline \multirow{3}{*}{ Year. } & \multirow{3}{*}{ Tax. } & \multicolumn{4}{|c|}{ Brand No. 1 (per pound). } & \multicolumn{4}{|c|}{ Brand No. 2 (per pound). } \\
\hline & & \multicolumn{2}{|c|}{ Price. } & \multirow[b]{2}{*}{ Cost. } & \multirow[b]{2}{*}{ Profit. } & \multicolumn{2}{|c|}{ Price. } & \multirow[b]{2}{*}{ Cost. } & \multirow[b]{2}{*}{ Profit. } \\
\hline & & $\begin{array}{l}\text { Includ- } \\
\text { ing tax. }\end{array}$ & $\begin{array}{l}\text { Exclud- } \\
\text { ing tax. }\end{array}$ & & & $\begin{array}{l}\text { Includ- } \\
\text { ing tax. }\end{array}$ & $\begin{array}{l}\text { Exclud- } \\
\text { ing tax. }\end{array}$ & & \\
\hline 1899. & $\begin{array}{r}\text { Cents. } \\
12.0\end{array}$ & $\begin{array}{l}\text { Cents. } \\
\quad 36.1\end{array}$ & $\begin{array}{r}\text { Cents. } \\
24.1\end{array}$ & $\begin{array}{r}\text { Cents. } \\
22.7\end{array}$ & $\begin{array}{r}\text { Cents. } \\
1.4\end{array}$ & $\begin{array}{l}\text { Cents. } \\
\quad 36.5\end{array}$ & $\begin{array}{r}\text { Cents. } \\
24.5\end{array}$ & $\begin{array}{r}\text { Cents. } \\
19.9\end{array}$ & $\begin{array}{r}\text { Cents. } \\
4.6\end{array}$ \\
\hline $1900 \ldots \ldots \ldots \ldots$ & 12.0 & 37.7 & 25.7 & 19.8 & 5.9 & 38.1 & 26.1 & 21.9 & 4.2 \\
\hline 1901 (first half).. & 12.0 & 37.8 & 25.8 & 17.4 & 8.4 & 38.7 & 26.7 & 19.5 & 7.2 \\
\hline 1901 (second half).. & 9.6 & 36.9 & 27.3 & 18.0 & 9.3 & 37.9 & 28.3 & 19.8 & 8.5 \\
\hline 1902 (first half).... & 9.6 & 37.3 & 27.7 & 17.1 & 10.6 & 38.3 & 28.7 & 18.8 & 9.9 \\
\hline 1902 (second half)... & 6.0 & 36.6 & 30.6 & 18.4 & 12.2 & 37.4 & 31.4 & 20.8 & 10.6 \\
\hline $1903 \ldots \ldots \ldots \ldots$. & 6.0 & 37.3 & 31.3 & 18.0 & 13.3 & 38.0 & 32.0 & 19.9 & 12.1 \\
\hline $1904 \ldots$ & 6.0 & 38.9 & 32.9 & 20.9 & 12.0 & 40.1 & 34.1 & 23.6 & 10.5 \\
\hline $1905 \ldots$ & 6.0 & 38.9 & 32.9 & 21.2 & 11.7 & 39.2 & 33.2 & 24.0 & 9.2 \\
\hline $1906 \ldots$ & 6.0 & 38.9 & 32.9 & 19.0 & 13.9 & 39.3 & 33.3 & 21.6 & 11.7 \\
\hline $1907 .$. & 6.0 & 38.8 & 32.8 & 19.4 & 13.4 & 39.2 & 33.2 & 22.8 & 10.4 \\
\hline
\end{tabular}


TaBle 39.-Plug tobacco-American, Continental, and Lorillard companies: Prices, costs, and profits for leading individual brands-Continued.

\begin{tabular}{|c|c|c|c|c|c|c|c|c|c|}
\hline \multirow{3}{*}{ Year. } & \multirow{3}{*}{ Tax. } & \multicolumn{4}{|c|}{ Brand No. 3 (per pound). } & \multicolumn{4}{|c|}{ Brand No. 4 (per pound). } \\
\hline & & \multicolumn{2}{|c|}{ Price. } & \multirow[b]{2}{*}{ Cost. } & \multirow[b]{2}{*}{ Profit. } & \multicolumn{2}{|c|}{ Price. } & \multirow[b]{2}{*}{ Cost. } & \multirow[b]{2}{*}{ Profit } \\
\hline & & $\begin{array}{l}\text { Includ- } \\
\text { ing tax. }\end{array}$ & $\begin{array}{l}\text { Exclud- } \\
\text { ing tax. }\end{array}$ & & & $\begin{array}{l}\text { Includ- } \\
\text { ing tax. }\end{array}$ & $\begin{array}{l}\text { Exclud- } \\
\text { ing tax. }\end{array}$ & & \\
\hline 1899 & $\begin{array}{r}\text { Cents. } \\
12.0\end{array}$ & $\begin{array}{l}\text { Cents. } \\
29.0\end{array}$ & $\begin{array}{l}\text { Cents. } \\
17.0\end{array}$ & $\begin{array}{r}\text { Cents. } \\
15.9\end{array}$ & $\begin{array}{r}\text { Cents. } \\
1.1\end{array}$ & $\begin{array}{r}\text { Cents. } \\
33.9\end{array}$ & $\begin{array}{r}\text { Cents. } \\
21.9\end{array}$ & $\begin{array}{r}\text { Cents. } \\
20.0\end{array}$ & $\begin{array}{r}\text { Cents. } \\
1.9\end{array}$ \\
\hline $1900 \ldots \ldots \ldots \ldots$ & 12.0 & 32.5 & 20.5 & 16.9 & 3.6 & 38.0 & 26.0 & 20.3 & 5.7 \\
\hline 1901 (first half).... & 12.0 & 33.2 & 21.2 & 16.1 & 5.1 & 38.1 & 26.1 & 19.5 & 6.6 \\
\hline 1901 (second half).. & 9.6 & 32.3 & 22.7 & 16. 6 & 6.1 & 37.0 & 27.4 & 19.0 & 8.4 \\
\hline 1902 (first half).... & 9.6 & 32.7 & 23.1 & 15.3 & 7.8 & 37.6 & 28.0 & 17.8 & 10.2 \\
\hline 1902 (second half).. & 6.0 & 32.2 & 26.2 & 16.2 & 10.0 & 37.0 & 31.0 & 19.7 & 11.3 \\
\hline $1903 \ldots . . . \ldots . .$. & 6.0 & 32.5 & 26.5 & 16.0 & 10.5 & 37.6 & 31.6 & 19.4 & 12.2 \\
\hline 1904. & 6.0 & 33.3 & 27.3 & 19.3 & 8.0 & 39.7 & 33.7 & 23.3 & 10.4 \\
\hline 1905. & 6.0 & 33.4 & 27.4 & 18.7 & 8.7 & 39.6 & 33.6 & 23.0 & 10.6 \\
\hline 1906. & 6.0 & 33.5 & 27.5 & 16.2 & 11.3 & 40.0 & 34.0 & 20.5 & 13.5 \\
\hline $1907 \ldots$ & 6.0 & 33.5 & 27.5 & 17.1 & 10.4 & 40.1 & 34.1 & 22.1 & 12.0 \\
\hline \multirow{3}{*}{ Year. } & \multirow{3}{*}{ Tax. } & \multicolumn{4}{|c|}{ Brand No. 5 (per pound). } & \multicolumn{4}{|c|}{ Brand No. 6 (per pound). } \\
\hline & & \multicolumn{2}{|c|}{ Price. } & \multirow{2}{*}{ Cost. } & \multirow{2}{*}{ Profit. } & \multicolumn{2}{|c|}{ Price. } & \multirow[b]{2}{*}{ Cost. } & \multirow[b]{2}{*}{ Profit. } \\
\hline & & $\begin{array}{l}\text { Includ- } \\
\text { ing tax. }\end{array}$ & $\begin{array}{l}\text { Exclud- } \\
\text { ing tax. }\end{array}$ & & & $\begin{array}{l}\text { Includ- } \\
\text { ing tax. }\end{array}$ & $\begin{array}{l}\text { Exclud- } \\
\text { ing tax. }\end{array}$ & & \\
\hline 1899 & $\begin{array}{r}\text { Cents. } \\
12.0\end{array}$ & $\begin{array}{r}\text { Cents. } \\
\quad 57.3\end{array}$ & $\begin{array}{r}\text { Cents. } \\
\quad 45.3\end{array}$ & $\begin{array}{r}\text { Cents. } \\
29.3\end{array}$ & $\begin{array}{r}\text { Cents. } \\
16.0\end{array}$ & $\begin{array}{r}\text { Cents. } \\
73.8\end{array}$ & $\begin{array}{r}\text { Cents. } \\
61.8\end{array}$ & $\begin{array}{r}\text { Cents. } \\
43.7\end{array}$ & $\begin{array}{r}\text { Cents. } \\
18.1\end{array}$ \\
\hline $1900 \ldots \ldots \ldots \ldots$ & 12.0 & 58.1 & 46.1 & 26.8 & 19.3 & 74.0 & 62.0 & 35.3 & 26.7 \\
\hline 1901 (first half).... & 12.0 & 56.8 & 44.8 & 27.7 & 17.1 & 72.3 & 60.3 & 34.8 & 25.5 \\
\hline 1901 (second half).... & 9.6 & 55.6 & 46.0 & 27.8 & 18.2 & 70.9 & 61.3 & 34.7 & 26.6 \\
\hline 1902 (first half).... & 9.6 & 55.9 & 46.3 & 26.0 & 20.3 & 71.3 & 61.7 & 31.3 & 30.4 \\
\hline 1902 (second half)... & 6.0 & 55.6 & 49.6 & 28.8 & 20.8 & 70.8 & 64.8 & 38.1 & 26.7 \\
\hline $1903 \ldots \ldots \ldots \ldots$ & 6.0 & 56.1 & 50.1 & 27.9 & 22.2 & 70.9 & 64.9 & 36.7 & 28.2 \\
\hline 1904. & 6.0 & 59.7 & 53.7 & 33.5 & 20.2 & 72.5 & 66.5 & 42.6 & 23.9 \\
\hline 1905. & 6.0 & 59.9 & 53.9 & 35.0 & 18.9 & 75.4 & 69.4 & 50.9 & 18.5 \\
\hline $1906 \ldots$ & 6.0 & 60.1 & 54.1 & 30.1 & 24.0 & 76.0 & 70.0 & 41.5 & 28.5 \\
\hline $1907 \ldots \ldots \ldots \ldots$ & 6.0 & 60.1 & 54.1 & 32.7 & 21.4 & 77.1 & 71.1 & 41.2 & 29.9 \\
\hline \multirow{3}{*}{ Year. } & \multirow{3}{*}{ Tax. } & \multicolumn{4}{|c|}{ Brand No. 7 (per pound). } & Bral & ad No. 8 (p & er poun & d). \\
\hline & & Pri & ice. & & & $\operatorname{Pr}$ & ice. & & \\
\hline & & $\begin{array}{l}\text { Includ- } \\
\text { ing tax. }\end{array}$ & $\begin{array}{l}\text { Exclud- } \\
\text { ing tax. }\end{array}$ & Cost. & Profit. & $\begin{array}{l}\text { Includ- } \\
\text { ing tax. }\end{array}$ & $\begin{array}{l}\text { Exclud- } \\
\text { ing tax. }\end{array}$ & Cost. & Profit. \\
\hline $1899 \ldots$ & $\begin{array}{r}\text { Cents. } \\
12.0\end{array}$ & $\begin{array}{r}\text { Cents. } \\
46.5\end{array}$ & $\begin{array}{r}\text { Cents. } \\
34.5\end{array}$ & $\begin{array}{r}\text { Cents. } \\
32.5\end{array}$ & $\begin{array}{r}\text { Cents. } \\
2.0\end{array}$ & $\begin{array}{r}\text { Cents. } \\
28.7\end{array}$ & $\begin{array}{r}\text { Cents. } \\
16.7\end{array}$ & $\begin{array}{r}\text { Cents. } \\
15.5\end{array}$ & $\begin{array}{r}\text { Cents. } \\
1.2\end{array}$ \\
\hline $1900 \ldots \ldots \ldots \ldots$ & 12.0 & 47.9 & 35.9 & 33.0 & 2.9 & 35.1 & 23.1 & 16.4 & 6.7 \\
\hline 1901 (first half).... . & 12.0 & 47.9 & 35.9 & 29.6 & 6.3 & 32.5 & 20.5 & 15.3 & 5.2 \\
\hline 1901 (second half)... & 9.6 & 47.3 & 37.7 & 29.7 & 8.0 & 31.5 & 21.9 & 15.4 & 6.5 \\
\hline 1902 (first half)...... & 9.6 & 47.4 & 37.8 & 29.0 & 8.8 & 31.9 & 22.3 & 13.9 & 8.4 \\
\hline 1902 (second half).... & 6.0 & 46.9 & 40.9 & 31.9 & 9.0 & 30.2 & 24.2 & 18.2 & 6.0 \\
\hline $1903 \ldots \ldots \ldots \ldots$ & 6.0 & 47.6 & 41.6 & 31.5 & 10.1 & 30.0 & 24.0 & 16.6 & 7.4 \\
\hline $1904 \ldots$ & 6.0 & 52.1 & 46.1 & 35.3 & 10.8 & 32.2 & 26.2 & 19.0 & 7.2 \\
\hline 1905. & 6.0 & 54.1 & 48.1 & 36.5 & 11.6 & 33.5 & 27.5 & 17.8 & 9.7 \\
\hline $1906 \ldots$ & 6.0 & 54.3 & 48.3 & 33.1 & 15.2 & 33.5 & 27.5 & 15.8 & 11.7 \\
\hline $1907 \ldots$ & 6.0 & 53.8 & 47.8 & 33.2 & 14.6 & 33.5 & 27.5 & 17.1 & 10.4 \\
\hline
\end{tabular}


TABLE 39.-Plug tobacco-American, Continental, and Lorillard companies: Prices, costs, and profits for leading individual brands-Continued.

\begin{tabular}{|c|c|c|c|c|c|c|c|c|c|}
\hline \multirow{3}{*}{ Year. } & \multirow{3}{*}{ Tax. } & \multicolumn{4}{|c|}{ Brand No. 9 (per pound). } & \multicolumn{4}{|c|}{ Brand No. 10 (per pound). } \\
\hline & & \multicolumn{2}{|c|}{ Price. } & \multirow[b]{2}{*}{ Cost. } & \multirow[b]{2}{*}{ Profit. } & \multicolumn{2}{|c|}{ Price. } & \multirow[b]{2}{*}{ Cost. } & \multirow[b]{2}{*}{ Profit. } \\
\hline & & $\begin{array}{l}\text { Includ- } \\
\text { ing tax. }\end{array}$ & $\begin{array}{l}\text { Exclud- } \\
\text { ing tax. }\end{array}$ & & & $\begin{array}{l}\text { Includ- } \\
\text { ing tax. }\end{array}$ & $\begin{array}{l}\text { Exclud- } \\
\text { ing tax. }\end{array}$ & & \\
\hline $1899 \ldots$ & $\begin{array}{r}\text { Cents. } \\
12.0\end{array}$ & $\begin{array}{r}\text { Cents. } \\
29.3\end{array}$ & $\begin{array}{r}\text { Cents. } \\
17.3\end{array}$ & $\begin{array}{r}\text { Cents. } \\
18.1\end{array}$ & $\begin{array}{r}\text { Cents. } \\
* 0.8\end{array}$ & $\begin{array}{l}\text { Cents. } \\
45.8\end{array}$ & $\begin{array}{r}\text { Cents. } \\
\quad 33.8\end{array}$ & $\begin{array}{r}\text { Cents. } \\
27.1\end{array}$ & $\begin{array}{r}\text { Cents. } \\
6.7\end{array}$ \\
\hline $1900 \ldots \ldots \ldots$. & 12.0 & 33.1 & 21.1 & 17.2 & 3.9 & 47.7 & 35.7 & 27.4 & 8.3 \\
\hline 1901 (first half).... & 12.0 & 33.1 & 21.1 & 15.3 & 5.8 & 48.0 & 36.0 & 25.8 & 10.2 \\
\hline 1901 (second half)... & 9.6 & 32.3 & 22.7 & 15.6 & 7.1 & 46.4 & 36.8 & 24.9 & 11.9 \\
\hline 1902 (first half).... & 9.6 & 32.7 & 23.1 & 14.7 & 8.4 & 46.4 & 36.8 & 23.3 & 13.5 \\
\hline 1902 (second half).. & 6.0 & 32.0 & 26.0 & 16.2 & 9.8 & 46.0 & 40.0 & 25.6 & 14. 4 \\
\hline $1903 . . . \ldots \ldots . . .$. & 6.0 & 32.5 & 26.5 & 14.7 & 11.8 & 46.3 & 40.3 & 26.6 & 13. 7 \\
\hline $1904 \ldots$ & 6.0 & 33.6 & 27.6 & 16.9 & 10.7 & 46.7 & 40.7 & 28.8 & 11.9 \\
\hline $1905 .$. & 6.0 & 34.2 & 28.2 & 17.7 & 10.5 & 47.3 & 41.3 & 29.7 & 11.6 \\
\hline 1906. & 6.0 & 34.3 & 28.3 & 16.1 & 12.2 & 47.8 & 41.8 & 26.5 & 15.3 \\
\hline 1907. & 6.0 & 31.5 & 25.5 & 16.3 & 9.2 & 47.8 & 41.8 & 27.7 & 14.1 \\
\hline \multirow{3}{*}{ Year. } & \multirow{3}{*}{ Tax. } & \multicolumn{4}{|c|}{ Brand No. 11 (per pound). } & \multicolumn{4}{|c|}{ Brand No. 12 (per pound). } \\
\hline & & \multicolumn{2}{|c|}{ Price. } & \multirow[b]{2}{*}{ Cost. } & \multirow[b]{2}{*}{ Profit. } & \multicolumn{2}{|c|}{ Price. } & \multirow[b]{2}{*}{ Cost. } & \multirow[b]{2}{*}{ Profit. } \\
\hline & & $\begin{array}{l}\text { Includ- } \\
\text { ing tax. }\end{array}$ & $\begin{array}{l}\text { Exclud- } \\
\text { ing tax. }\end{array}$ & & & $\begin{array}{l}\text { Includ- } \\
\text { ing tax. }\end{array}$ & $\begin{array}{l}\text { Exclud- } \\
\text { ing tax. }\end{array}$ & & \\
\hline 1899. & $\begin{array}{r}\text { Cents. } \\
12.0\end{array}$ & $\begin{array}{r}\text { Cents. } \\
\quad 45.9\end{array}$ & $\begin{array}{r}\text { Cents. } \\
33.9\end{array}$ & $\begin{array}{r}\text { Cents. } \\
25.8\end{array}$ & $\begin{array}{r}\text { Cents. } \\
8.1\end{array}$ & $\begin{array}{r}\text { Cents. } \\
26.6\end{array}$ & $\begin{array}{l}\text { Cents. } \\
14.6\end{array}$ & $\begin{array}{r}\text { Cents. } \\
17.1\end{array}$ & $\begin{array}{l}\text { Cents. } \\
\quad * 2.5\end{array}$ \\
\hline $1900 \ldots \ldots \ldots$. & 12.0 & 47.8 & 35.8 & 26.9 & 8.9 & 29.7 & 17.7 & 13.4 & 4. 3 \\
\hline 1901 (first half)... & 12.0 & 48.0 & 36.0 & 25.6 & 10.4 & 30.4 & 18.4 & 13.8 & 4.6 \\
\hline 1901 (second half)... & 9.6 & 46.4 & 36.8 & 24.5 & 12.3 & 29.6 & 20.0 & 13.8 & 6.2 \\
\hline 1902 (first half).... . & 9.6 & 46.5 & 36.9 & 23.2 & 13.7 & 30.1 & 20.5 & 11.5 & 9.0 \\
\hline 1902 (second half).... & 6.0 & 46.0 & 40.0 & 25.5 & 14.5 & 29.1 & 23.1 & 12.2 & 10.9 \\
\hline $1903 \ldots \ldots \ldots \ldots$ & 6.0 & 46.3 & 40.3 & 25.5 & 14.8 & 29.0 & 23.0 & 13.4 & 9.6 \\
\hline $1904 \ldots$ & 6.0 & 46.7 & 40.7 & 28.0 & 12.7 & 29.6 & 23.6 & 14.7 & 8.9 \\
\hline $1905 \ldots$ & 6.0 & 47.3 & 41.3 & 28.8 & 12.5 & 29.7 & 23.7 & 14.7 & 9.0 \\
\hline $1906 \ldots$ & 6.0 & 47.8 & 41.8 & 25.3 & 16.5 & & & & \\
\hline $1907 \ldots$ & 6.0 & 47.8 & 41.8 & 26.9 & 14.9 & & & & \\
\hline \multirow{3}{*}{ Year. } & \multirow{3}{*}{ Tax. } & \multicolumn{4}{|c|}{ Brand No. 13 (per pound). } & Bran & d No. 14 (1 & er poun & d). \\
\hline & & $\operatorname{Pr}$ & ce. & & & Pri & ce. & & \\
\hline & & $\begin{array}{l}\text { Includ- } \\
\text { ing tax. }\end{array}$ & $\begin{array}{l}\text { Exclud- } \\
\text { ing tax. }\end{array}$ & Cost. & Profit. & $\begin{array}{l}\text { Includ- } \\
\text { ing tax. }\end{array}$ & $\begin{array}{l}\text { Exclud- } \\
\text { ing tax. }\end{array}$ & Cost. & Profit. \\
\hline $1899 .$. & $\begin{array}{r}\text { Cents. } \\
12.0\end{array}$ & Cents. & Cents. & Cents. & Cents. & Cents. & Cents. & Cents. & $\begin{array}{l}\text { Cents. } \\
\text {........ }\end{array}$ \\
\hline $1900 \ldots \ldots \ldots$ & 12.0 & 33.0 & 21.0 & 21.1 & $* 0.1$ & 25.1 & 13.1 & 15.4 & $* 2.3$ \\
\hline 1901 (first half)... & 12.0 & 30.8 & 18.8 & 19.0 & $* .2$ & 26.9 & 14.9 & 14.9 & $* .0$ \\
\hline 1901 (second half). & 9.6 & 31.5 & 21.9 & 27.2 & $* 5.3$ & 27.9 & 18.3 & 16.4 & 1.9 \\
\hline 1902 (first half) ..... . & 9.6 & 32.1 & 22.5 & 24.6 & $* 2.1$ & 28.3 & 18.7 & 15.9 & 2.8 \\
\hline 1902 (second half).... & 6.0 & 31.4 & 25.4 & 26.9 & $* 1.5$ & 27.1 & 21.1 & 15.5 & 5.6 \\
\hline $1903 \ldots \ldots \ldots$ & 6.0 & 31.2 & 25.2 & 25.3 & $* .1$ & 26.5 & 20.5 & 13.4 & 7.1 \\
\hline $1904 \ldots$ & 6.0 & 34.4 & 28.4 & 27.1 & 1.3 & 27.7 & 21.7 & 14.2 & 7.5 \\
\hline $1905 \ldots$ & 6.0 & 37.3 & 31.3 & 26.2 & 5.1 & 28.9 & 22.9 & 14.7 & 8.2 \\
\hline $1906 \ldots$ & 6.0 & 37.6 & 31.6 & 22.6 & 9.0 & 28.5 & 22.5 & 15.6 & 6.9 \\
\hline $1907 \ldots \ldots . .$. & 6.0 & 37.2 & 31.2 & 23.9 & 7.3 & 23.7 & 17.7 & 16.2 & 1.5 \\
\hline
\end{tabular}




PLUG TOBACCO.

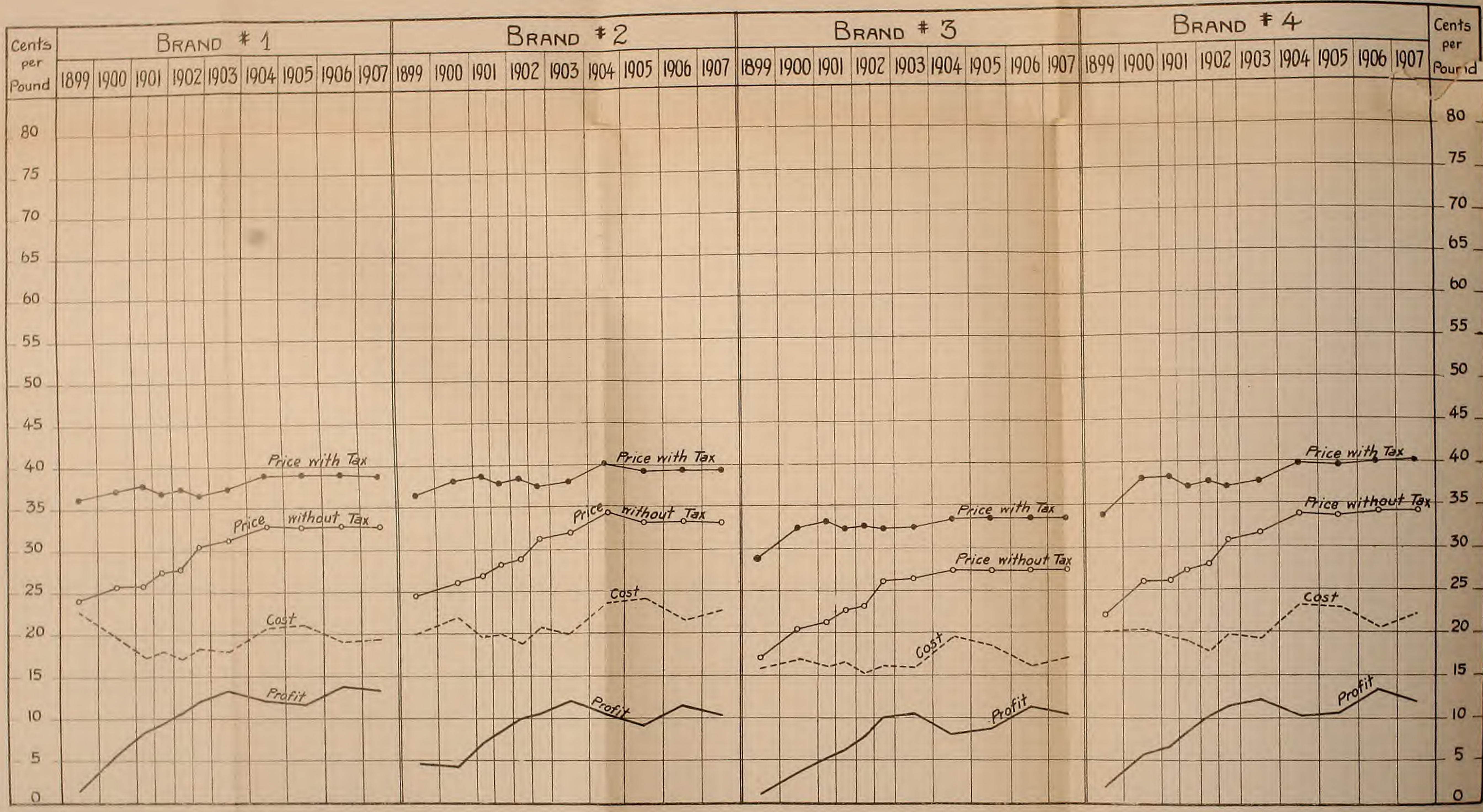






\section{If 2 onsition}

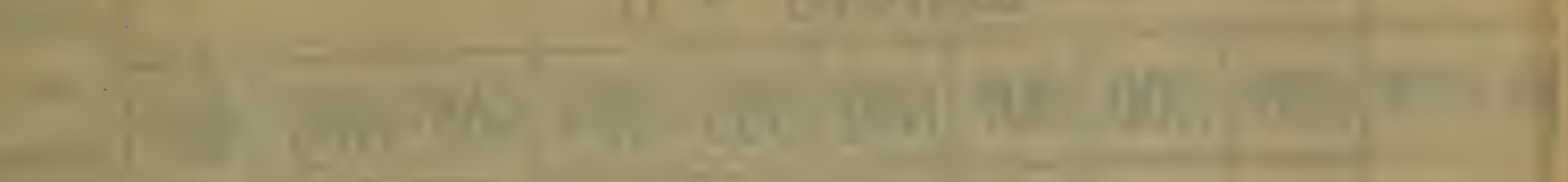

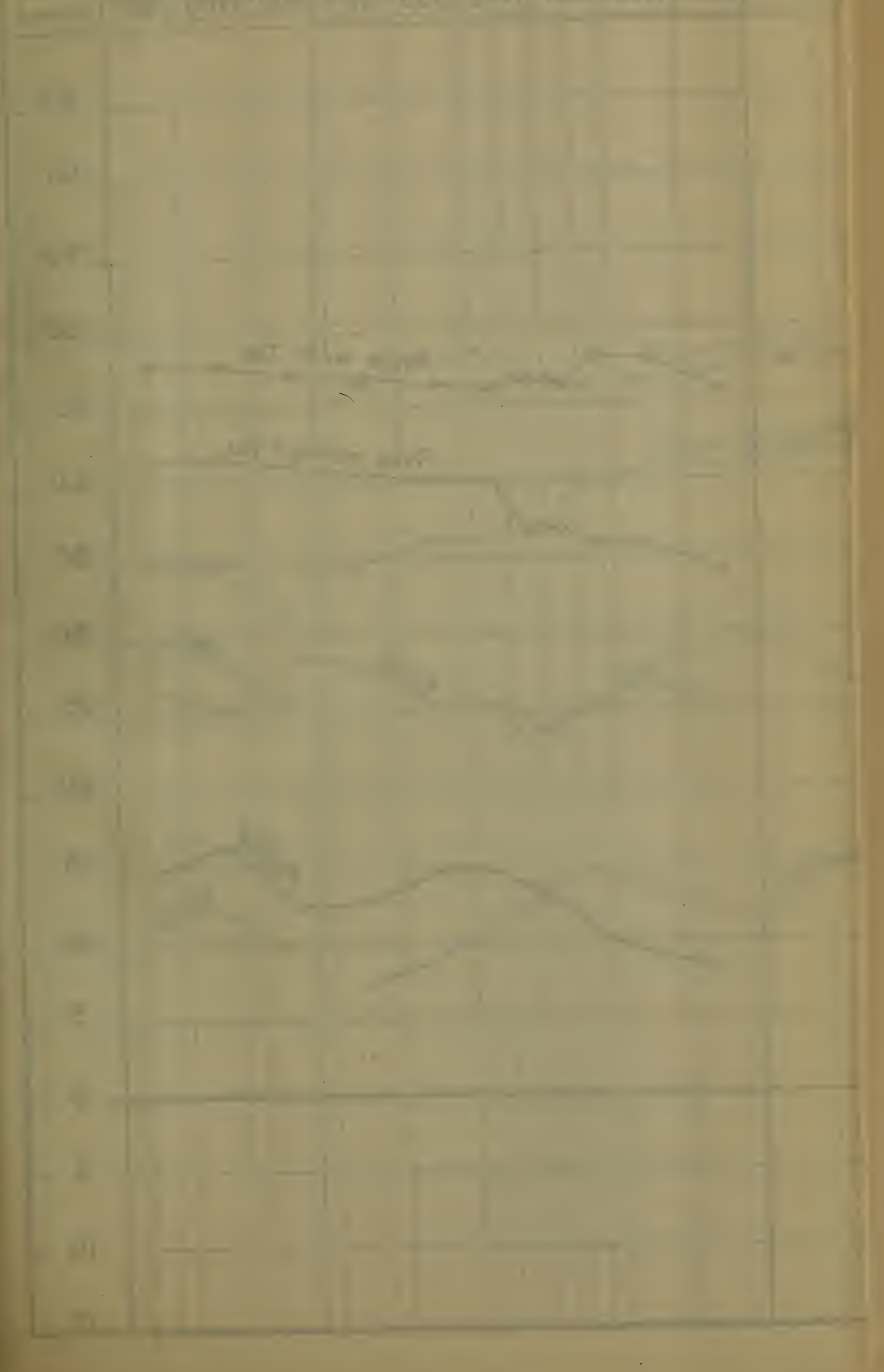




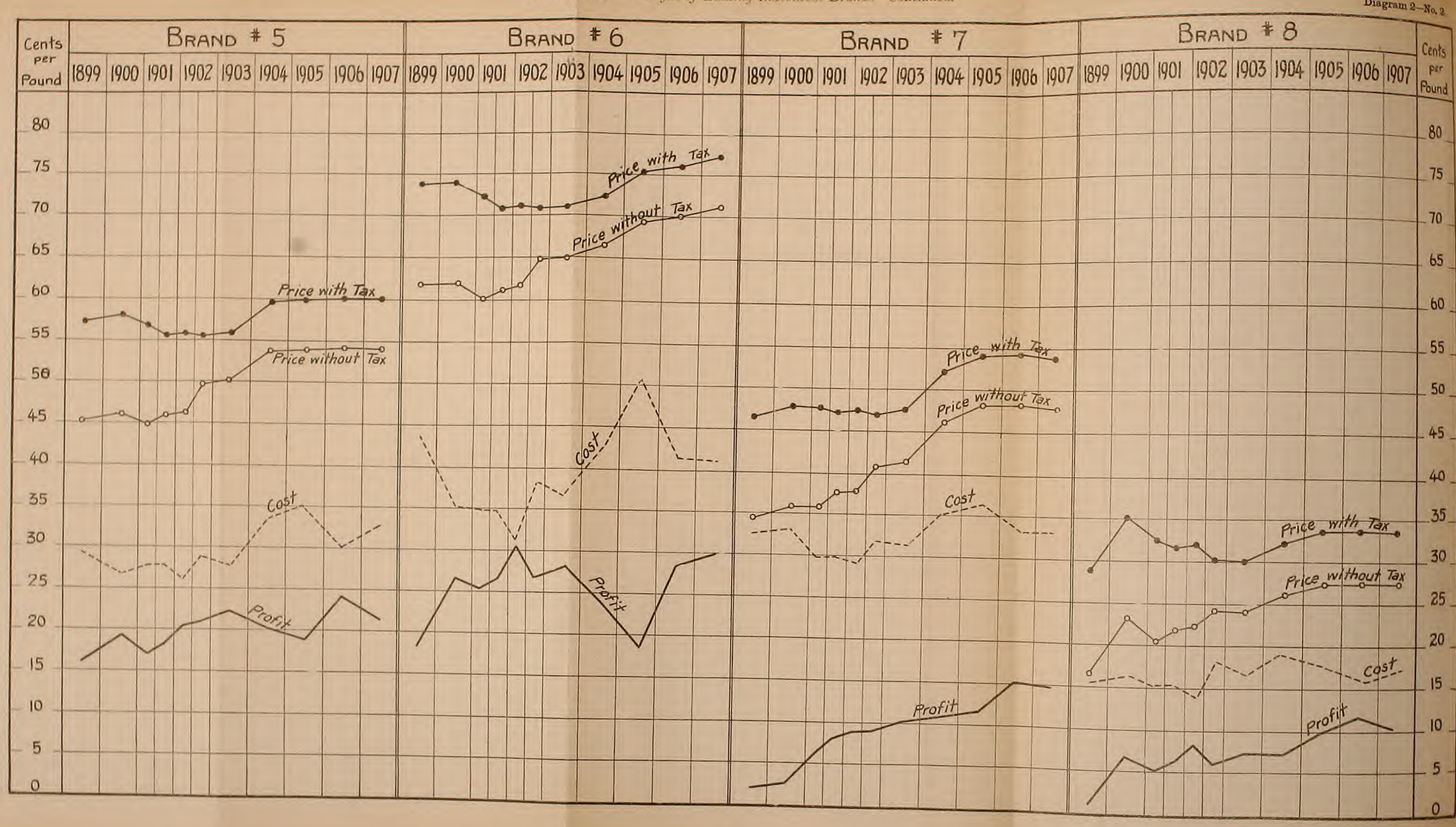



am 2-No. 3.

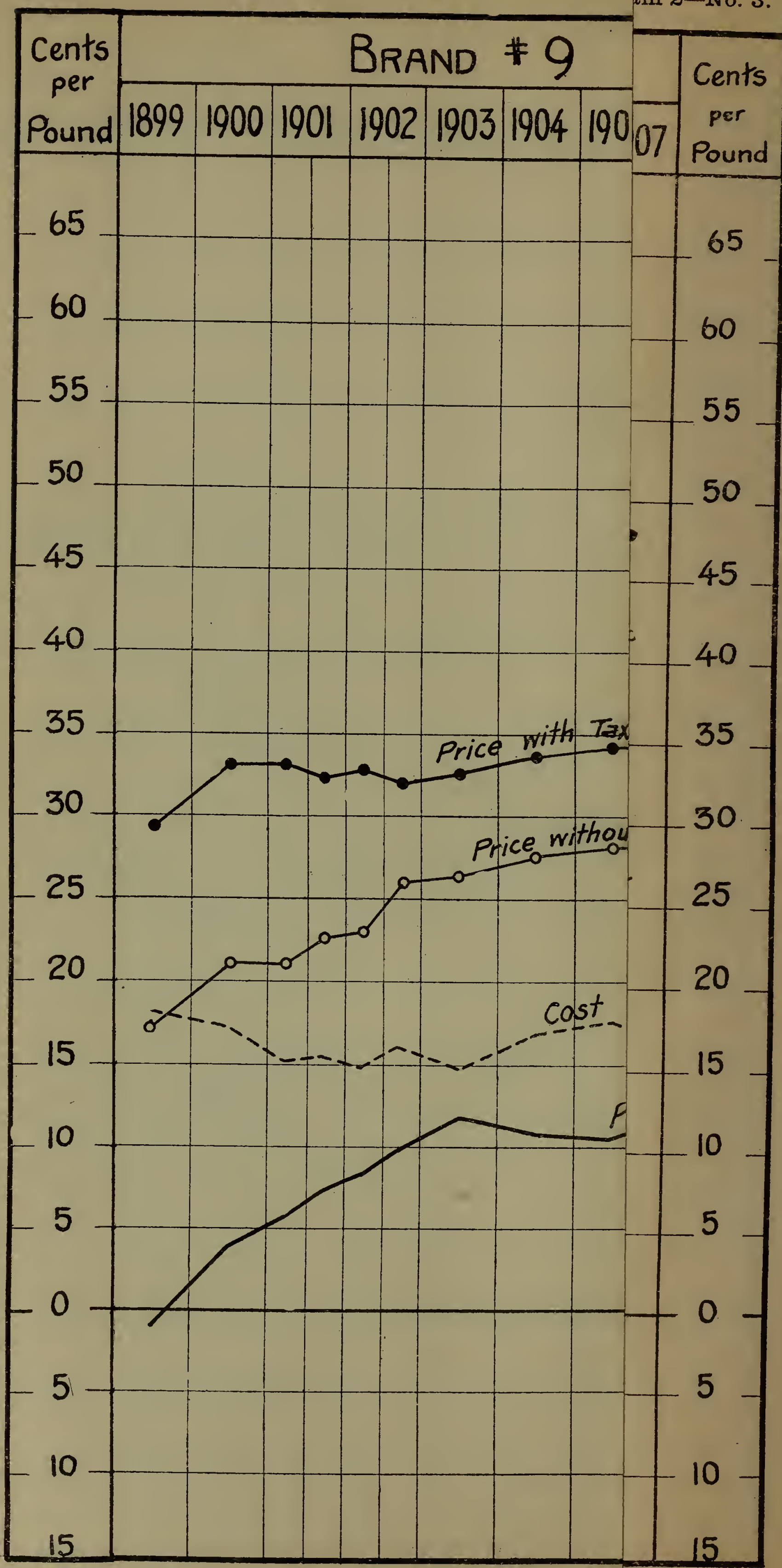




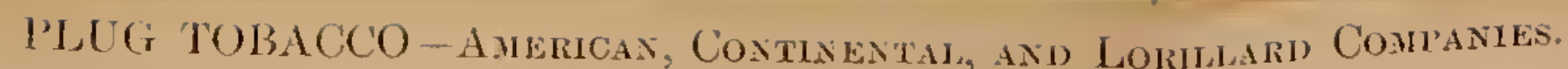

Prices, Costs, and Profits of Leading Individual Bronds-Continued.

Diagram $2-N_{0.3}$

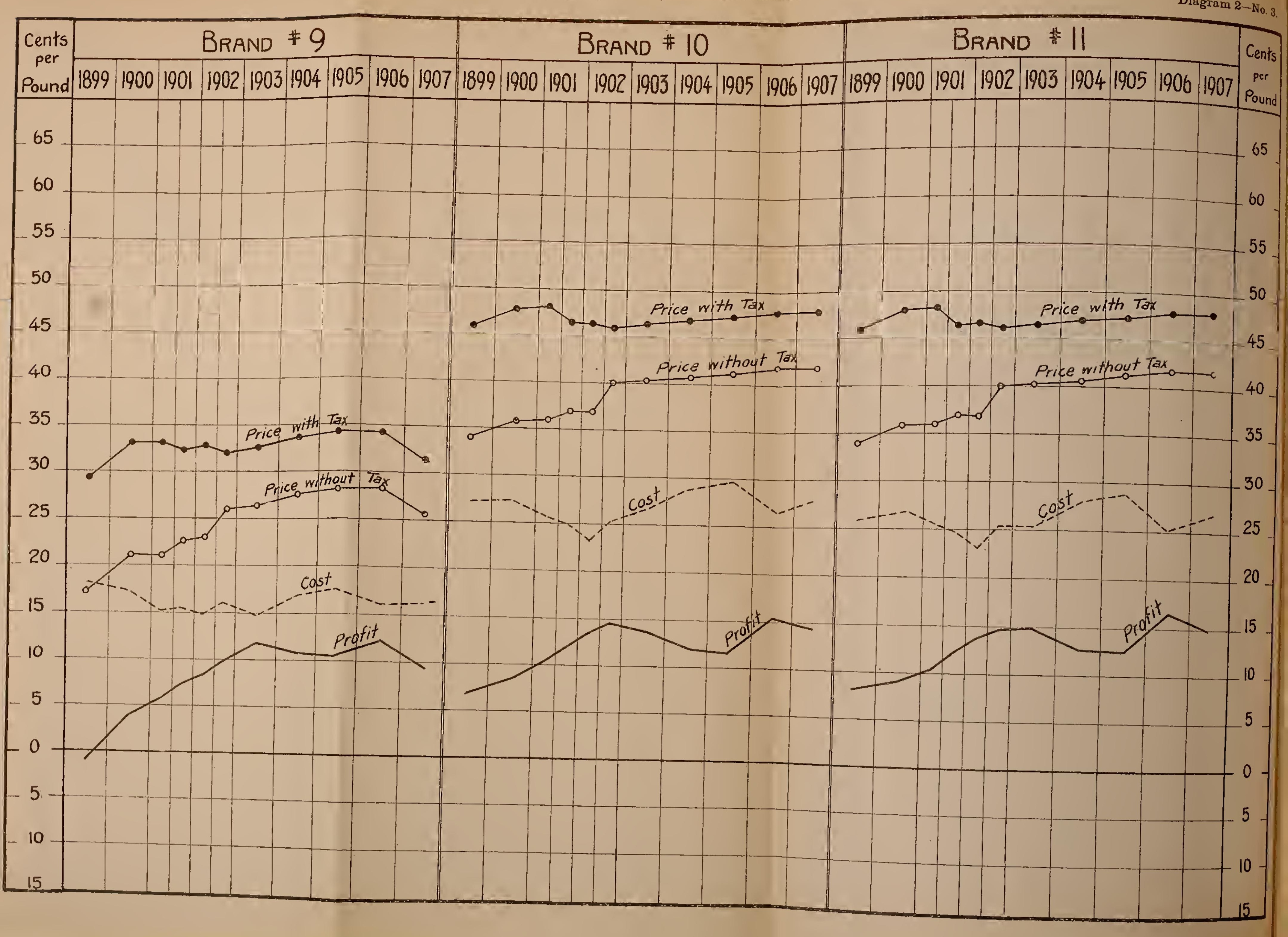




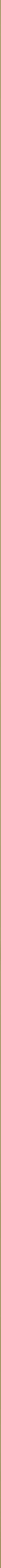


-No. 4.

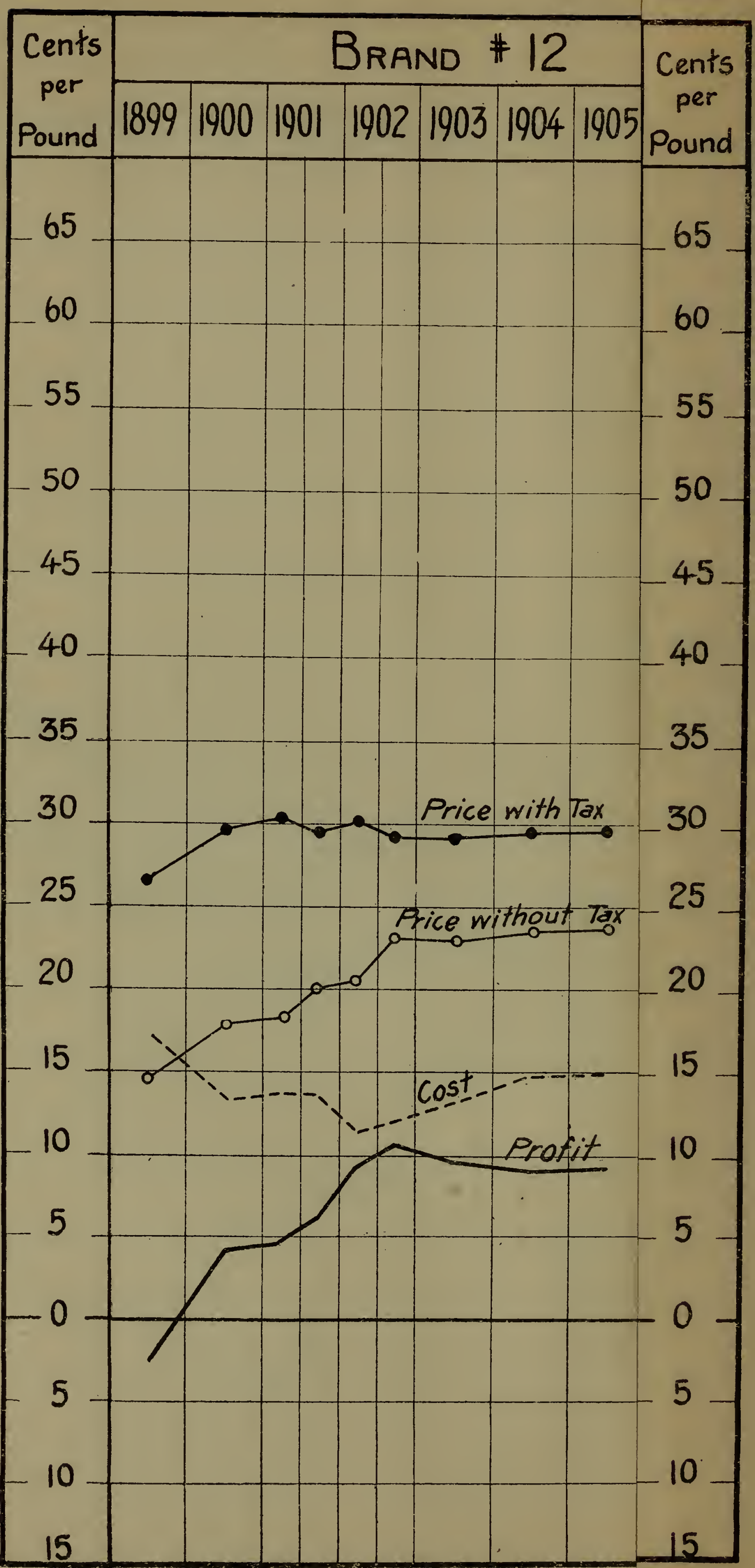


In considering the figures of prices and profits the changes in the rate of taxation should be at all times borne in mind. It will be recalled that in 1899 and 1900 and up to July 1, 1901, the tax on plug tobacco was 12 cents per pound; that during the second half of 1901 and the first half of 1902 it was 9.6 cents per pound; and that since July 1, 1902, it has been 6 cents per pound.

The table and diagrams show that on none of the brands of plug tobacco was there any but temporary reduction in the price charged to the public at the time of the reduction in the tax, and that, consequently, the net price less tax increased either immediately or soon after by the full amount of the reduction in the tax. There was no reduction of any appreciable amount in the price of seven of the brands at the time of the reduction in the tax (namely, Nos. $1,2,3,4,7,9$, and 12). There was a slight reduction in the price of the other seven brands at the time of the reduction in the tax, but the price was very soon again advanced to a point at least as high as prior to the reduction in the taxation. In the case of most of the brands, whether the price had remained constant at the time of the reduction in the tax or whether there had been some slight reduction in the price, the price was advanced from the second half of 1902 until about 1904 or 1905, since which time it has, in general, remained substantially stationary. In the case of 10 of the 14 brands (Nos. 1, 2, 3, 4, 5, 6, 7, 9, 13, and 14) the price including tax during the years 1904 to 1907 , when the tax rate was 6 cents, was higher than during the years 1899 and 1900, when the tax rate was 12 cents. (In the case of Brand No. 14 the price in 1907, however, was lower.) In the case of three others of the brands (Nos. 10, 11, and 12) the prices during the last four years covered by the table were substantially the same as during 1900 , while for the remaining brand (No. 8) the price during these four years has been considerably higher than during 1899, but somewhat lower than in 1900 .

The price, excluding tax, for every brand has increased very materially since 1899 and 1900 . In the case of every brand, in fact (with the exception of brand No. 14 for the year 1907), the net price, less tax, during the four years 1904 to 1907 exceeded the price during 1899 and 1900 by practically the full amount of the reduction in the internalrevenue tax, and in a number of cases by considerably more than that reduction. The diagrams show clearly that for the most of the brands there was a rapid increase in the net price, less tax, from 1900 to 1904 with comparatively stationary prices since that time, except that brands Nos. 9 and 14 show a considerable decrease in 1907. In the case of a few of the brands there was a considerable increase from 1904 to 1905 (brands $6,7,8$, and 13).

The cost of production and sale for some of the individual brands show very considerable fluctuations, these fluctuations being largely due to changes in the advertising expenses. The costs were, in general, higher in 1899 than in 1900, because of the newness of the organization in the former year. Broadly speaking, there has been some increase in the cost during the more recent years as compared with 1900 (due to increase in advertising expenses and in prices of leaf tobacco), but this increase in cost has been much less than the increase in the net price, less tax, for all of the brands. For nine brands (Nos. $2,4,5,6,7,8,10,11$, and 13) the costs during the more recent years 87442-S. Doc. $78,61-1-6$ 


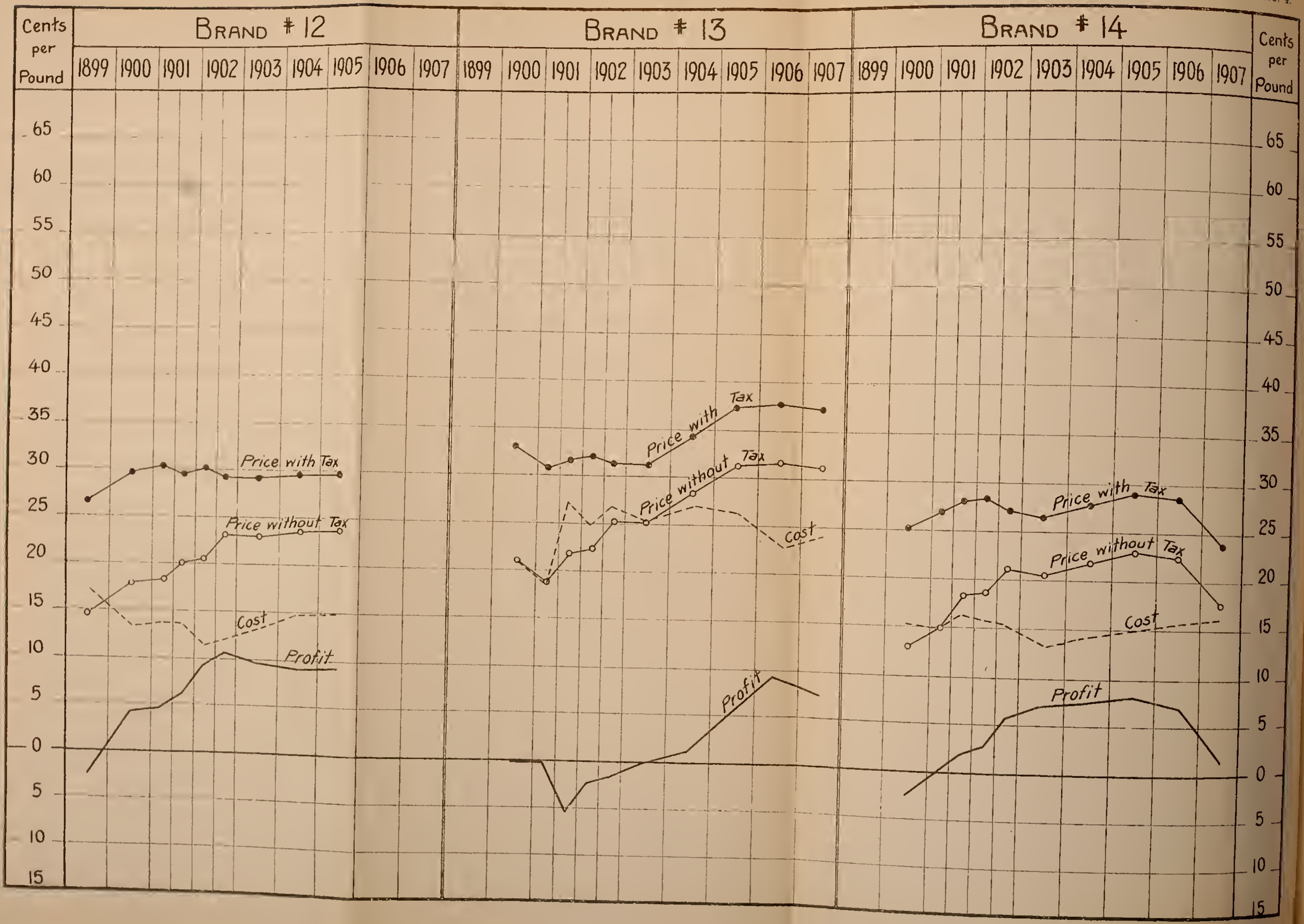




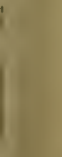


have been on the whole distinctly higher than during the earlier years, while for the other five (Nos. 1, 3, 9, 12, and 14) the costs during the more recent years have been either substantially the same or a trifle lower than during the earlier years.

Because, therefore, primarily of the marked increase in the net price, less tax, the profits on all of the brands have increased, and on most of them the increase has been marked. In the case of all the brands except two the profits during the years 1903 to 1907 have been, roughly speaking, from 5 to 10 cents per pound higher than even during 1900. For most of the brands the profits were considerably higher in 1900 than in 1899 , because of the exceptionally high costs in 1899. In the case of brands Nos. 5 and 6 the increase in profit has been less marked. Most of the brands show a rapid increase in profit from 1899 to 1903 or 1904 with comparatively little change since that time, although in several cases the profits have increased since 1904. Quite a number of the brands show a decline in profit in 1907 as compared with 1906, but the profit in 1907 for nearly all of the brands is higher than in any year prior to 1903.

The brands covered by the above table and diagrams are all brands which were in existence during the period of the war taxes and which have continued in existence to the present time. On such brands, as already stated, the Tobacco Combination in general made no reduction in price, or only a slight temporary reduction, at the time the war tax was removed. The question, however, arises to what extent the combination may have introduced new brands selling at lower prices and commanding lower profits at the time when the tax was reduced or shortly thereafter. Had large quantities of tobacco of such new brands at lower prices been sold, the average price and average profit on the combination's entire output of plug would, of course, have been reduced, notwithstanding the maintenance of the prices on the older brands. As a matter of fact, although some new brands were introduced, the combination did not push their sales actively; and, since consumers naturally prefer the well-known and established brands, comparatively small quantities of these new lowpriced brands were sold.

PRICES OF PLUG TOBACCO BEFORE, DURING, AND AFTER THE SPANISH WAR PERIOD.

The above tables have made it clear that the Tobacco Combination did not in general reduce the prices of the then existing brands of plug tobacco to the trade at the time when the war-revenue taxes were taken off in 1901 and 1902, or that if reductions were made the prices were very soon restored. Of course, if it had been true that the manufacturers of plug tobacco had paid out of their own pockets the increased taxes imposed during the Spanish war and the years immediately following instead of adding them to the price of tobacco and collecting them from the consumer, they would have been fully justified in maintaining the price unchanged when the tax was reduced (assuming, of course, that no other great decrease in costs had taken place). As a matter of fact, however, the Tobacco Combination, as well as most independent manufacturers of tobacco, had actually raised the prices of plug tobacco either to the consumer or to the jobber or to both when the taxes were increased in 1898 - as, in fact, was the expectation of Congress in imposing the additional taxes. 
It is impossible to present precise bookkeeping figures of the average prices of plug tobacco during the years before the war for comparison with the prices during and since the war. The Continental Tobacco Company, the plug-tobacco combination, was organized just a little after the taxes had been raised (December, 1898, and early in 1899), and it is impossible to obtain bookkeeping records of the business of the concerns which entered the combination, covering the period prior to that time, save only for the American Tobacco Company itself, which, as already stated, lost money during the years immediately preceding the war by reason of its active campaign to increase the volume of its plug business. It is, however, possible to obtain approximately accurate records of the movement of the prices of the leading brands of plug tobacco now made by the American and Lorillard companies, from the price lists and discount sheets issued by the various concerns during the earlier years and from invoices rendered by them to their customers. Prices for the earlier years compiled from such sources are of course less accurate than the bookkeeping figures available for the more recent years. For purposes of comparing the movement of prices from the earlier period down to the present time, it is more nearly accurate to compare the prices as shown by such price lists, discount sheets, and invoices throughout the entire period, rather than to compare the prices taken from price lists, etc., for the earlier period with the precise bookkeeping figures for the later period.

Table 40, therefore, shows the prevailing consumers' price and the price to jobbers, including and excluding tax, for 17 leading brands of plug tobacco now manufactured by the American and Lorillard companies. Most of these brands were acquired by the Combination at the time of the organization of the Continental Tobacco Company, but one of the brands included was prior to that time manufactured by the American Tobacco Company. The annual average prices to jobbers are computed by adding the monthly prices for each year and dividing by 12 . In the case of the consumers' price it has been judged preferable to show the prevailing price for the year (or half year where the tax changed); that is, the price which was in force during the greater part of each year, even in those years where there was a change, is used.

It should be understood that the consumers' price is based on the customary prices ordinarily charged by retailers for smaller plugs, single cuts of the larger plugs, such cuts usually being sold at either 5 or 10 cents. The method of changing the price to the consumer is by increasing or decreasing the weight of the cuts. The cuts or "spaces" are usually marked on the plug by the manufacturer. A change in price is accomplished either by marking more or fewer cuts upon a plug of the same total weight or by decreasing or increasing the weight of the plug itself. Of course some plug tobacco is sold to the consumer in larger quantities; he may purchase an entire plug instead of a cut from the plug. In such cases the retail dealer sometimes makes a reduction in the price. Most plug is, however, sold on the basis of the customary price per single cut. In some cases brands of plug tobacco are marked with one spacing on one side and another spacing on the other side. For example, it will be noted from the table below that brand No. 4 during a considerable period of time is indicated as having a price of 50 or 60 cents to the consumer. This 
means that a plug weighing 1 pound was marked on one side with 5 cuts and on the other with 6 cuts. The retail dealer in such cases has the choice of selling the smaller or the larger cut. Where the price to the retail dealer increases on a brand of this character he is, of course, likely to insist on selling the smaller cut to the consumer for the customary price. In some cases where, during the earlier years before the war, brands were thus marked with a double spacing, the information obtained by the bureau indicates that the retailer usually sold the larger cut rather than the smaller. In such cases only the price which would be based on the larger cut is entered in the table. For a large proportion of the brands, however, covered by the table there has never been but one spacing upon the plug at a single time.

For these reasons the consumers' prices shown in the table are somewhat less precise representations of the actual average price paid by the consumer than in the case of the jobbers' prices. The jobbers' prices represent prevailing jobbers' prices, some jobbers getting special discounts (ordinarily called "confidentials") which result in slightly lower prices. The so-called gratis goods which are sometimes given to jobbers (either consisting of free goods of the same brand or of free goods of a different brand, or even of a different kind of tobacco) have not ordinarily been deducted from the price, for the reason that they are considered by manufacturers as a form of advertising and calculated in their advertising expenses.

The brands in this table are arranged according to their price, the high-priced brands being shown first and the lower-priced later.

TABLE 40.-Plug tobacco-Prices to consumers and to jobbers for brands now made by American and Lorillard companies (compiled from price lists, etc.).

[Consumers' price per pound based on customary prices of single cuts.]

\begin{tabular}{|c|c|c|c|c|c|c|c|}
\hline \multirow{3}{*}{ Year. } & \multirow{3}{*}{$\begin{array}{l}\text { Tax (per } \\
\text { pound). }\end{array}$} & \multicolumn{3}{|c|}{ Brand No. 1 (per pound). } & \multicolumn{3}{|c|}{ Brand No. 2 (per pound). } \\
\hline & & \multirow{2}{*}{$\begin{array}{l}\text { Con- } \\
\text { sumers' } \\
\text { price. }\end{array}$} & \multicolumn{2}{|c|}{ Price to jobbers. } & \multirow{2}{*}{$\begin{array}{l}\text { Con- } \\
\text { sumers' } \\
\text { price. }\end{array}$} & \multicolumn{2}{|c|}{ Price to jobbers. } \\
\hline & & & $\begin{array}{l}\text { Includ- } \\
\text { ing tax. }\end{array}$ & $\begin{array}{l}\text { Exclud- } \\
\text { ing tax. }\end{array}$ & & $\begin{array}{l}\text { Includ- } \\
\text { ing tax. }\end{array}$ & $\begin{array}{l}\text { Exclud- } \\
\text { ing tax. }\end{array}$ \\
\hline 1889 . & $\begin{array}{r}\text { Cents. } \\
8.0\end{array}$ & $\begin{array}{r}\text { Cents. } \\
120\end{array}$ & $\begin{array}{r}\text { Cents. } \\
77.5\end{array}$ & $\begin{array}{r}\text { Cents. } \\
69.5\end{array}$ & $\begin{array}{r}\text { Cents. } \\
90\end{array}$ & $\begin{array}{r}\text { Cents. } \\
49.5\end{array}$ & $\begin{array}{r}\text { Cents. } \\
41.5\end{array}$ \\
\hline 1890. & 8.0 & 120 & 70.0 & 62.0 & 90 & 50.9 & 42.9 \\
\hline $1891 \ldots$ & 6.0 & 120 & 68.0 & 62.0 & 90 & 50.0 & 44.0 \\
\hline 1892. & 6.0 & 120 & 68.0 & 62.0 & 90 & 50.2 & 44.2 \\
\hline $1893 \ldots .$. & 6.0 & 120 & 68.0 & 62.0 & 90 & 52.0 & 46.0 \\
\hline $1894 \ldots \ldots$. & 6.0 & 120 & 68.0 & 62.0 & 90 & 52.0 & 46.0 \\
\hline $1895 \ldots \ldots$. & 6.0 & 120 & 68.0 & 62.0 & 90 & 52.0 & 46.0 \\
\hline $1896 \ldots \ldots \ldots$ & 6.0 & 120 & 68.0 & 62.0 & 90 & 52.0 & 46.0 \\
\hline $1897 \ldots \ldots \ldots \ldots$ & 6.0 & 120 & 68.0 & 62.0 & 90 & 52.1 & 46.1 \\
\hline 1898 (first half) . . . & 6.0 & 120 & 69.0 & 63.0 & 90 & 53.2 & 47.2 \\
\hline 1898 (second half).. & 12.0 & 120 & 74.0 & 62.0 & 90 & 58.5 & 46.5 \\
\hline $1899 \ldots \ldots \ldots \ldots \ldots$ & 12.0 & 120 & 75.5 & 63.5 & 90 & 50.4 & 47.4 \\
\hline $1900 \ldots \ldots \ldots$ & 12.0 & 120 & 76.5 & 64.5 & 90 & 59.4 & 47.4 \\
\hline 1901 (first half). . & 12.0 & 120 & 72.5 & 60.5 & 90 & 56.7 & 44.7 \\
\hline 1901 (second half).. & 9.6 & 120 & 72.2 & 62.6 & 90 & 56.4 & 46.8 \\
\hline 1902 (first half)... . . & 9.6 & 120 & 72.5 & 62.9 & 90 & 56.7 & 47.1 \\
\hline 1902 (second half). & 6.0 & 120 & 72.1 & 66.1 & 90 & 56.3 & 50.3 \\
\hline $1903 \ldots \ldots \ldots \ldots$ & 6.0 & 120 & 72.5 & 66.5 & 90 & 56.9 & 50.9 \\
\hline $1904 \ldots \ldots$. & 6.0 & 120 & 73.8 & 67.8 & 90 & 60.7 & 54.7 \\
\hline $1905 \ldots \ldots$. & 6.0 & 120 & 77.2 & 71.2 & 90 & 63.0 & 57.0 \\
\hline $1906 \ldots \ldots \ldots$ & 6.0 & 120 & 78.2 & 72.2 & 90 & 61.4 & 55.4 \\
\hline
\end{tabular}


TABLE 40.-Plug tobacco-Prices to consumers and to jobbers for brands now made by American and Lorillard companies (compiled from price lists, etc.)-Continued.

\begin{tabular}{|c|c|c|c|c|c|c|c|}
\hline \multirow{3}{*}{ Year. } & \multirow{3}{*}{$\begin{array}{l}\text { Tax (per } \\
\text { pound). }\end{array}$} & \multicolumn{3}{|c|}{ Brand No. 3 (per pound). } & \multicolumn{3}{|c|}{ Brand No. 4 (per pound). } \\
\hline & & \multirow{2}{*}{$\begin{array}{l}\text { Con- } \\
\text { sumers' } \\
\text { price. }\end{array}$} & \multicolumn{2}{|c|}{ Price to jobbers. } & \multirow{2}{*}{$\begin{array}{l}\text { Con- } \\
\text { sumers' } \\
\text { price. }\end{array}$} & \multicolumn{2}{|c|}{ Price to jobbers. } \\
\hline & & & $\begin{array}{l}\text { Includ- } \\
\text { ing tax. }\end{array}$ & $\begin{array}{l}\text { Exclud- } \\
\text { ing tax. }\end{array}$ & & $\begin{array}{l}\text { Includ- } \\
\text { ing tax. }\end{array}$ & $\begin{array}{l}\text { Exclud- } \\
\text { ing t7x. }\end{array}$ \\
\hline $1889 \ldots$ & $\begin{array}{r}\text { Cents. } \\
8.0\end{array}$ & $\begin{array}{r}\text { Cents. } \\
60\end{array}$ & $\begin{array}{r}\text { Cents. } \\
35.0\end{array}$ & $\begin{array}{r}\text { Cents. } \\
27.0\end{array}$ & $\begin{array}{r}\text { Cents. } \\
60\end{array}$ & $\begin{array}{r}\text { Cents. } \\
35.0\end{array}$ & $\begin{array}{r}\text { Cents. } \\
27.0\end{array}$ \\
\hline 1890. & 8.0 & 60 & 35.3 & 27.3 & $50-60$ & 35.0 & 27.0 \\
\hline $1891 \ldots$ & 6.0 & 60 & 36.5 & 30.5 & $50-60$ & 34.8 & 28.8 \\
\hline 1892. & 6.0 & 60 & 35.3 & 29.3 & $50-60$ & 35.0 & 29.0 \\
\hline $1893 \ldots$ & 6.0 & 60 & 38.1 & 32.1 & $50-60$ & 35.8 & 29.8 \\
\hline $1894 \ldots$ & 6.0 & 60 & ...... & . & $50-60$ & 36.0 & 30.0 \\
\hline $1895 \ldots$ & 6.0 & 60 & 37.0 & 31.0 & $50-60$ & 34.5 & 28.5 \\
\hline $1896 \ldots$ & 6.0 & 60 & 36.2 & 30.2 & $50-60$ & 34.0 & 28.0 \\
\hline $1897 \ldots \ldots \ldots$. & 6.0 & 60 & 35.3 & 29.3 & $50-60$ & 34.6 & 28.6 \\
\hline 1898 (first half)... . & 6.0 & 60 & 38.3 & 32.3 & $50-60$ & 37.1 & 31.1 \\
\hline 1898 (second half).. & 12.0 & 60 & 44.7 & 32.7 & 60 & 44.0 & 32.0 \\
\hline $1899 \ldots \ldots \ldots \ldots$ & 12.0 & 60 & 40.7 & 28.7 & 60 & 41.3 & 29.3 \\
\hline $1900 \ldots \ldots \ldots \ldots$ & 12.0 & 60 & 43.5 & 31.5 & 60 & 41.6 & 29.6 \\
\hline 1901 (first half)... & 12.0 & 70 & $\cdots \cdot$. & ...... & 60 & 40.0 & 28.0 \\
\hline 1901 (second half).. & 9.6 & 70 & 42.5 & 32.9 & 60 & 39.7 & 30.1 \\
\hline 1902 (first half)... & 9.6 & 70 & 44.0 & 34.4 & 60 & 40.0 & 30.4 \\
\hline 1902 (second half)... & 6.0 & 70 & 44.2 & 38.2 & 60 & 39.5 & 33.5 \\
\hline $1903 \ldots \ldots \ldots \ldots \ldots$ & 6.0 & 70 & 45.3 & 39.3 & 60 & 40.0 & 34.0 \\
\hline $1904 \ldots$. & 6.0 & 70 & 50.1 & 44.1 & 60 & 41.8 & 35.8 \\
\hline $1905 \ldots$. & 6.0 & 70 & 51.1 & 45.1 & 60 & 42.8 & 36.8 \\
\hline $1906 \ldots \ldots$. & 6.0 & 70 & 51.1 & 45.1 & 60 & 42.8 & 36.8 \\
\hline \multirow{3}{*}{ Year. } & \multirow{3}{*}{$\begin{array}{l}\text { Tax (per } \\
\text { pound). }\end{array}$} & \multicolumn{3}{|c|}{ Brand No. 5 (per pound). } & \multicolumn{3}{|c|}{ Brand No. 6 (per pound). } \\
\hline & & \multirow{2}{*}{$\begin{array}{l}\text { Con- } \\
\text { stumers' } \\
\text { price. }\end{array}$} & \multicolumn{2}{|c|}{ Price to jobbers. } & \multirow{2}{*}{$\begin{array}{l}\text { Con- } \\
\text { sumers' } \\
\text { price. }\end{array}$} & \multicolumn{2}{|c|}{ Price to jobbers. } \\
\hline & & & $\begin{array}{l}\text { Includ- } \\
\text { ing tax. }\end{array}$ & $\begin{array}{l}\text { Exclud- } \\
\text { ing tax. }\end{array}$ & & $\begin{array}{l}\text { Includ- } \\
\text { ing tax. }\end{array}$ & $\begin{array}{l}\text { Exclud- } \\
\text { ing tax. }\end{array}$ \\
\hline $1889 \ldots$ & $\begin{array}{r}\text { Cents. } \\
8.0\end{array}$ & $\begin{array}{l}\text { Cents. } \\
50-60\end{array}$ & $\begin{array}{c}\text { Cents. } \\
\quad 34.2\end{array}$ & $\begin{array}{l}\text { Cents. } \\
26.2\end{array}$ & $\begin{array}{l}\text { Cents. } \\
50.0\end{array}$ & $\begin{array}{c}\text { Cents. } \\
31.2\end{array}$ & $\begin{array}{c}\text { Cents. } \\
23.2\end{array}$ \\
\hline $1890 \ldots$ & 8.0 & $50-60$ & 34.8 & 26.8 & 50.0 & 31.7 & 23.7 \\
\hline $1891 \ldots$. & 6.0 & $50-60$ & 35.5 & 29.5 & 50.0 & 30.2 & 24.2 \\
\hline $1892 \ldots .$. & 6.0 & $50-60$ & 32.9 & 26.9 & 50.0 & 30.0 & 24.0 \\
\hline $1893 \ldots .$. & 6.0 & $50-60$ & 36.0 & 30.0 & 50.0 & 30.7 & 24.7 \\
\hline $1894 \ldots \ldots$ & 6.0 & $50-60$ & 34.0 & 28.0 & 50.0 & 31.0 & 25.0 \\
\hline $1895 \ldots .$. & 6.0 & $50-60$ & 34.0 & 28.0 & 50.0 & 31.0 & 25.0 \\
\hline $1896 \ldots . .$. & 6.0 & $50-60$ & 34.7 & 28.7 & 50.0 & 31.3 & 25.3 \\
\hline $1897 \ldots \ldots \ldots \ldots$ & 6.0 & $50-60$ & 35.5 & 29.5 & 50.0 & 32.6 & 26.6 \\
\hline 1898 (first half) .... & 6.0 & $50-60$ & 36.8 & 30.8 & 50.0 & 33.6 & 27.6 \\
\hline 1898 (second half).. & 12.0 & $50-60$ & 38.8 & 26.8 & 53.3 & 38.0 & 26.0 \\
\hline $1899 \ldots \ldots \ldots \ldots$ & 12.0 & $50-60$ & 38.2 & 26.2 & 53.3 & 37.4 & 25.4 \\
\hline $1900 \ldots \ldots \ldots \ldots$ & 12.0 & $50-60$ & 38.9 & 26.9 & 53.3 & 38.9 & 26.9 \\
\hline 1901 (first half)...... . . & 12.0 & $50-60$ & 39.9 & 27.9 & 53.3 & 39.8 & 27.8 \\
\hline $1901^{\circ}$ (second half).... & 9.6 & $50-60$ & 39.6 & 30.0 & 53.3 & 37.8 & 28.2 \\
\hline 1902 (first half) ....... & 9.6 & $50-60$ & 39.9 & 30.3 & 53.3 & 38.1 & 28.5 \\
\hline 1902 (second half)... & 6.0 & $50-60$ & 39.4 & 33.4 & 53.3 & 37.8 & 31.8 \\
\hline $1903 \ldots \ldots \ldots \ldots . . .$. & 6.0 & $50-60$ & 39.9 & 33.9 & 53.3 & 38.1 & 32.1 \\
\hline $1904 \ldots \ldots$ & 6.0 & 60 & 41.5 & 35.5 & 53.3 & 39.4 & 33.4 \\
\hline $1905 \ldots \ldots \ldots . .$. & 6.0 & $50-60$ & 40.0 & 34.0 & 53.3 & 40.0 & 34.0 \\
\hline $1906 \ldots \ldots \ldots . . .$. & 6.0 & $50-60$ & 40.0 & 34.0 & 53.3 & 40.0 & 34.0 \\
\hline
\end{tabular}


TABLE 40.-Plug tobacco-Prices to consumers and to jobbers for brands now made by American and Lorillard companies (compiled from price lists, etc.)-Continued.

\begin{tabular}{|c|c|c|c|c|c|c|c|}
\hline \multirow{3}{*}{ Year. } & \multirow{3}{*}{$\begin{array}{l}\text { Tax (per } \\
\text { pound). }\end{array}$} & \multicolumn{3}{|c|}{ Brand No. 7 (per pound). } & \multicolumn{3}{|c|}{ Brand No. 8 (per pound). } \\
\hline & & \multirow{2}{*}{$\begin{array}{l}\text { Con- } \\
\text { sumers' } \\
\text { price. }\end{array}$} & \multicolumn{2}{|c|}{ Price to jobbers. } & \multirow{2}{*}{$\begin{array}{l}\text { Con- } \\
\text { sumers' } \\
\text { price. }\end{array}$} & \multicolumn{2}{|c|}{ Price to jobbers. } \\
\hline & & & $\begin{array}{l}\text { Includ- } \\
\text { ing tax. }\end{array}$ & $\begin{array}{l}\text { Exclud- } \\
\text { ing tax. }\end{array}$ & & $\begin{array}{l}\text { Includ- } \\
\text { ing tax. }\end{array}$ & $\begin{array}{l}\text { Exclud- } \\
\text { ing tax. }\end{array}$ \\
\hline $1889 \ldots$ & $\begin{array}{r}\text { Cents. } \\
8.0\end{array}$ & $\begin{array}{r}\text { Cents. } \\
50.0\end{array}$ & $\begin{array}{r}\text { Cents. } \\
\quad 37.0\end{array}$ & $\begin{array}{r}\text { Cents. } \\
29.0\end{array}$ & $\begin{array}{r}\text { Cents. } \\
50.0\end{array}$ & $\begin{array}{l}\text { Cents. } \\
\quad 35.0\end{array}$ & $\begin{array}{r}\text { Cents. } \\
27.0\end{array}$ \\
\hline $1890 \ldots \ldots$ & 8.0 & 50.0 & 35.2 & 27.2 & 50.0 & 34.9 & 26.9 \\
\hline $1891 \ldots \ldots$. & 6.0 & 50.0 & 35.0 & 29.0 & 50.0 & 35.0 & 29.0 \\
\hline $1892 \ldots \ldots$ & 6.0 & 50.0 & 35.0 & 29.0 & 50.0 & 34.5 & 28.5 \\
\hline $1893 \ldots .$. & 6.0 & 50.0 & 36.0 & 30.0 & 50.0 & 37.4 & 31.4 \\
\hline $1894 \ldots \ldots$. & 6.0 & 50.0 & 36.0 & 30.0 & 50.0 & 38.0 & 32.0 \\
\hline $1895 \ldots \ldots$ & 6.0 & 50.0 & 36.0 & 30.0 & 50.0 & 36.7 & 30.7 \\
\hline $1896 \ldots \ldots$. & 6.0 & 50.0 & 35.7 & 29.7 & 50.0 & 35.2 & 29.2 \\
\hline $1897 \ldots \ldots . . . .$. & 6.0 & 50.0 & 35.5 & 29.5 & 50.0 & 37.3 & 31.3 \\
\hline 1898 (furst half)... & 6.0 & 50.0 & 37.0 & 31.0 & 50.0 & 37.3 & 31.3 \\
\hline 1898 (second half) & 12.0 & 60.0 & 43.0 & 31.0 & 60.0 & 43.4 & 31.4 \\
\hline $1899 \ldots \ldots . . . . . .$. & 12.0 & $50.0-63.0$ & 38.2 & 26.2 & 50.0 & 38.0 & 26.0 \\
\hline $1900 \ldots \ldots . . . . . .$. & 12.0 & 53.3 & 39.3 & 27.3 & 50.0 & 38.9 & 26.9 \\
\hline 1901 (first half) ... . & 12.0 & 53.3 & 40.7 & 28.7 & 50.0 & 38.4 & 26.4 \\
\hline 1901 (second half).. & 9.6 & 53.3 & 38.7 & 29.1 & 50.0 & 37.8 & 28.2 \\
\hline 1902 (first half) .... & 9.6 & 53.3 & 39.1 & 29.5 & 50.0 & 38.1 & 28.5 \\
\hline 1902 (second half).. & 6.0 & 53.3 & 38.6 & 32.6 & 50.0 & 37.5 & 31.5 \\
\hline $1903 \ldots \ldots \ldots \ldots$ & 6.0 & 53.3 & 39.1 & 33.1 & 50.0 & 38.4 & 32.4 \\
\hline $1904 \ldots \ldots \ldots$ & 6.0 & 53.3 & 39.7 & 33.7 & 54.5 & 40.4 & 34.4 \\
\hline $1905 \ldots . . .$. & 6.0 & 53.3 & 40.0 & 34.0 & 54.5 & 41.5 & 35.5 \\
\hline $1906 \ldots \ldots$ & 6.0 & 53.3 & 40.0 & 34.0 & 54.5 & 40.9 & 34.9 \\
\hline \multirow{3}{*}{ Year. } & \multirow{3}{*}{$\begin{array}{l}\text { Tax (per } \\
\text { pound). }\end{array}$} & \multicolumn{3}{|c|}{ Brand No. 9 (per pound). } & \multicolumn{3}{|c|}{ Brand No. 10 (per pound). } \\
\hline & & \multirow{2}{*}{$\begin{array}{l}\text { Con- } \\
\text { sumers' } \\
\text { price. }\end{array}$} & \multicolumn{2}{|c|}{ Price to jobbers. } & \multirow{2}{*}{$\begin{array}{l}\text { Con- } \\
\text { sumers' } \\
\text { price. }\end{array}$} & \multicolumn{2}{|c|}{ Price to jobbers. } \\
\hline & & & $\begin{array}{l}\text { Includ- } \\
\text { ing tax. }\end{array}$ & $\begin{array}{l}\text { Exclud- } \\
\text { ing tax. }\end{array}$ & & $\begin{array}{l}\text { Includ- } \\
\text { ing tax. }\end{array}$ & $\begin{array}{l}\text { Exclud- } \\
\text { ing tax. }\end{array}$ \\
\hline 1889. & $\begin{array}{r}\text { Cents. } \\
8.0\end{array}$ & $\begin{array}{l}\text { Cents. } \\
50.0\end{array}$ & $\begin{array}{r}\text { Cents. } \\
34.5\end{array}$ & $\begin{array}{r}\text { Cents. } \\
26.5\end{array}$ & $\begin{array}{r}\text { Cents. } \\
50\end{array}$ & $\begin{array}{l}\text { Cents. } \\
28.0\end{array}$ & $\begin{array}{r}\text { Cents. } \\
20.0\end{array}$ \\
\hline $1890 \ldots$ & 8.0 & 50.0 & (n....... & .......... & 50 & 28.0 & 20.0 \\
\hline $1891 \ldots . .$. & 6.0 & 50.0 & 34.7 & 28.7 & 50 & 26.0 & 20.0 \\
\hline $1892 \ldots \ldots$ & 6.0 & 50.0 & 35.0 & 29.0 & 45 & 26.3 & 20.3 \\
\hline $1893 \ldots .$. & 6.0 & 50.0 & 35.8 & 29.8 & 45 & 27.1 & 21.1 \\
\hline $1894 \ldots \ldots$ & 6.0 & 50.0 & 36.0 & 30.0 & 45 & 28.0 & 22.0 \\
\hline $1895 \ldots \ldots$. & 6.0 & 50.0 & 34.7 & 28.7 & 45 & 28.0 & 22.0 \\
\hline $1896 \ldots \ldots$. & 6.0 & 50.0 & 34.7 & 28.7 & 45 & 28.0 & 22.0 \\
\hline $1897 \ldots \ldots \ldots \ldots$ & 6.0 & 50.0 & 33.7 & 27.7 & 45 & 28.5 & 22.5 \\
\hline 1898 (first half) ..... & 6.0 & 50.0 & 37.5 & 31.5 & 45 & 31.8 & 25.8 \\
\hline 1898 (second half).. & 12.0 & 50.0 & 44.0 & 32.0 & 50 & 36.0 & 24.0 \\
\hline $1899 \ldots \ldots \ldots \ldots$ & 12.0 & 50.0 & 38.2 & 26.2 & 50 & 36.3 & 24.3 \\
\hline $1900 \ldots \ldots \ldots \ldots$ & 12.0 & 50.0 & 39.0 & 27.0 & 50 & 37.5 & 25.5 \\
\hline 1901 (first half) ..... & 12.0 & 50.0 & 39.1 & 27.1 & 50 & 37.4 & .25 .4 \\
\hline 1901 (second half) & 9.6 & 50.0 & 37.8 & 28.2 & 50 & 37.2 & 27.6 \\
\hline 1902 (first half)..... & 9.6 & 50.0 & 38.1 & 28.5 & 50 & 37.2 & 27.6 \\
\hline 1902 (second half).. & 6.0 & 50.0 & 37.7 & 31.7 & 50 & 36.7 & 30.7 \\
\hline $1903 \ldots \ldots \ldots . . . . .$. & 6.0 & 50.0 & 38.4 & 32.4 & 50 & 37.2 & 31.2 \\
\hline $1904 \ldots \ldots$ & 6.0 & 54.6 & 40.4 & 34.4 & 55 & 39.4 & 33.4 \\
\hline $1905 \ldots \ldots \ldots \ldots$ & 6.0 & 54.6 & 41.5 & 35.5 & 55 & 41.5 & 35.5 \\
\hline $1906 \ldots \ldots \ldots$ & 6.0 & 54.6 & 40.9 & 34.9 & 50 & 40.0 & 34.0 \\
\hline
\end{tabular}


TABLE 40.-Plug tobacco-Prices to consumers and to jobbers for brands now made by American and Lorillard companies (compiled from price lists, etc.)-Continued.

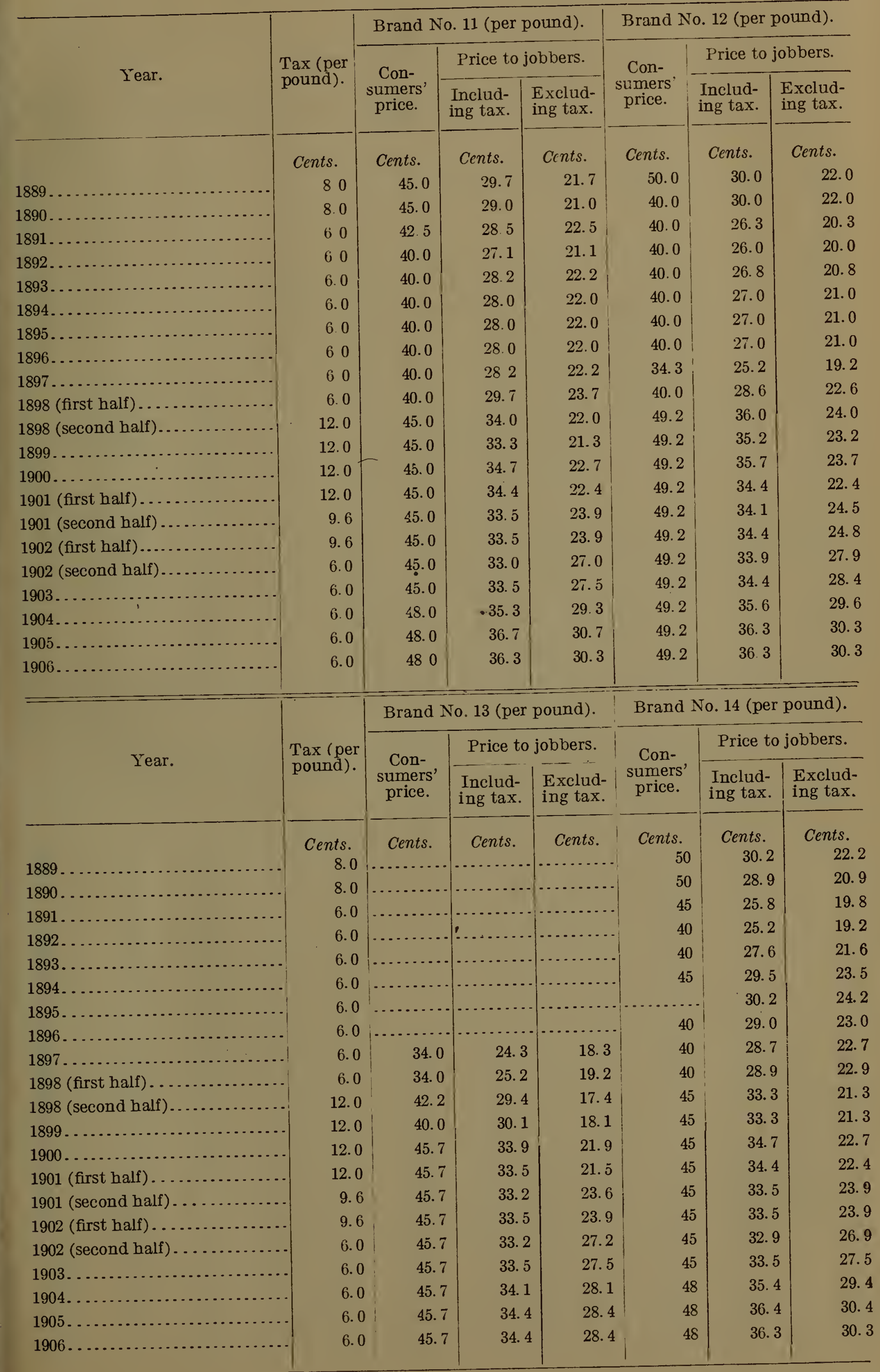


1

TABLE 40.-Plug tobacco-Prices to consumers and to jobbers for brands now made by American and Lorillard companies (compiled from price lists, etc.)-Continued.

\begin{tabular}{|c|c|c|c|c|c|c|c|}
\hline \multirow{3}{*}{ Year. } & \multirow{3}{*}{$\begin{array}{l}\text { Tax (per } \\
\text { pound). }\end{array}$} & \multicolumn{3}{|c|}{ Brand No. 15 (per pound). } & \multicolumn{3}{|c|}{ Brand No. 16 (per pound). } \\
\hline & & \multirow{2}{*}{$\begin{array}{l}\text { Consum- } \\
\text { ers' price. }\end{array}$} & \multicolumn{2}{|c|}{ Price to jobbers. } & \multirow{2}{*}{$\begin{array}{l}\text { Consum- } \\
\text { ers' price }\end{array}$} & \multicolumn{2}{|c|}{ Price to jobbers. } \\
\hline & & & $\begin{array}{l}\text { Includ- } \\
\text { ing tax. }\end{array}$ & $\begin{array}{l}\text { Exclud- } \\
\text { ing tax. }\end{array}$ & & $\begin{array}{l}\text { Includ- } \\
\text { ing tax. }\end{array}$ & $\begin{array}{l}\text { Exclud- } \\
\text { ing tax. }\end{array}$ \\
\hline 1889 & $\begin{array}{r}\text { Cents. } \\
8.0\end{array}$ & $\begin{array}{l}\text { Cents. } \\
\quad 40.0\end{array}$ & $\begin{array}{r}\text { Cents. } \\
32.2\end{array}$ & $\begin{array}{l}\text { Cents. } \\
\quad 24.2\end{array}$ & $\begin{array}{l}\text { Cents. } \\
50.0\end{array}$ & $\begin{array}{l}\text { Cents. } \\
\quad 30.3\end{array}$ & $\begin{array}{r}\text { Cents. } \\
22.3\end{array}$ \\
\hline 1890. & 8. 0 & 40.0 & 28.5 & 20.5 & 50.0 & 28.2 & 20.2 \\
\hline $1891 \ldots$. & 6.0 & 40.0 & 26.8 & 20.8 & .450 & 25.4 & 19.4 \\
\hline $1892 \ldots$ & 6.0 & 40.0 & 24.2 & 18.2 & 40.0 & 25.0 & 19.0 \\
\hline $1893 \ldots \ldots \ldots \ldots$ & 6.0 & 40.0 & 27.3 & 21.3 & 40.0 & 25.0 & 19.0 \\
\hline $1894 \ldots . . . \ldots$. & 6.0 & 40.0 & 28.0 & 22.0 & 40.0 & 25.0 & 19.0 \\
\hline 1895. & 6.0 & 40.0 & 26.0 & 20.0 & 30.0 & 13.6 & 7.6 \\
\hline 1896. & 6.0 & 40.0 & 26.0 & 20.0 & 30.0 & 18. 4 & 12.4 \\
\hline $1897 \ldots \ldots \ldots \ldots$ & 6.0 & 40.0 & 27.6 & 21.6 & 300 & 19.2 & 13.2 \\
\hline 1898 (first half)... & 6.0 & 40.0 & 29.8 & 238 & 300 & 21.0 & 15.0 \\
\hline 1898 (second half). & 12.0 & $40.0-50.0$ & 33.0 & 21.0 & 40.0 & 30.3 & 18.3 \\
\hline $1899 \ldots \ldots \ldots \ldots$ & 12.0 & $40.0-50.0$ & 34.5 & 22.5 & 400 & 29.9 & 17.9 \\
\hline $1900 \ldots \ldots \ldots \ldots$ & 12.0 & $500-45.7$ & 34.0 & 22.0 & 45.7 & 32.8 & 20.8 \\
\hline 1901 (first half). & 12.0 & 45.7 & 33.9 & 21.9 & 45.7 & $32 . \overline{5}$ & 20.5 \\
\hline 1901 (second half). & 9.6 & 457 & 32.2 & 226 & 40.0 & 32.2 & 22.6 \\
\hline 1902 (first half)... & 9.6 & 45.7 & 32.5 & 22.9 & 40.0 & 32.5 & 22.9 \\
\hline 1902 (second half). & 6.0 & 45.7 & 31.9 & 25.9 & 40.0 & 28.0 & 22.0 \\
\hline $1903 \ldots \ldots \ldots \ldots$. & 6.0 & 45.7 & 32.5 & 265 & 40.0 & 30.0 & 24.0 \\
\hline $1904 \ldots \ldots \ldots$ & 6.0 & 45.7 & 33.6 & 27.6 & 45.7 & 330 & 27.0 \\
\hline $1905 \ldots$. & 6.0 & 45.7 & 34.4 & 28.4 & 45.7 & 34.4 & 28.4 \\
\hline $1906 \ldots . . . . . . . .$. & 6.0 & 45.7 & 34.4 & 28.4 & 45.7 & 34.4 & 28.4 \\
\hline \multirow{3}{*}{\multicolumn{4}{|c|}{ Year. }} & \multirow{3}{*}{$\begin{array}{l}\text { Tax (per } \\
\text { pound). }\end{array}$} & \multicolumn{3}{|c|}{ Brand No. 17 (per pound). } \\
\hline & & & & & \multirow{2}{*}{$\begin{array}{l}\text { Con- } \\
\text { sumers' } \\
\text { price. }\end{array}$} & \multicolumn{2}{|c|}{ Price to jobbers. } \\
\hline & & & & & & $\begin{array}{l}\text { Includ- } \\
\text { ing tax. }\end{array}$ & $\begin{array}{l}\text { Exclud- } \\
\text { ing tax. }\end{array}$ \\
\hline $1889 \ldots$ & & & & $\begin{array}{l}\text { Cents. } \\
\quad 8.0\end{array}$ & $\begin{array}{r}\text { Cents. } \\
35.0\end{array}$ & $\begin{array}{l}\text { Cents. } \\
21.0\end{array}$ & $\begin{array}{r}\text { Cents. } \\
13.0\end{array}$ \\
\hline $1890 \ldots \ldots$. & & & & 8.0 & 31.0 & 21.3 & 13.3 \\
\hline $1891 \ldots . . .$. & & & & 6.0 & 34.8 & 23.5 & 17.5 \\
\hline $1892 \ldots \ldots \ldots$ & & & & 6.0 & 40.0 & 23.0 & 17.0 \\
\hline $1893 \ldots \ldots . .$. & & & & 6.0 & 40.0 & 27.7 & 21.7 \\
\hline $1894 \ldots \ldots \ldots \ldots$. & & & & 6.0 & 40.0 & 28.0 & 22.0 \\
\hline $1895 \ldots \ldots \ldots$ & & & & 6.0 & 40.0 & 28.0 & 22.0 \\
\hline $1896 \ldots \ldots \ldots \ldots$ & & & & 6.0 & 32.0 & 27.3 & 21.3 \\
\hline $1897 \ldots \ldots . . . . . .$. & & & & 6.0 & 36.9 & 25.6 & 19.6 \\
\hline 1898 (first half)... & & & & 6.0 & 36.9 & 28.8 & 22.8 \\
\hline 1898 (second half). & & & & -12.0 & 36.9 & 34.1 & 22.1 \\
\hline $1899 \ldots \ldots \ldots \ldots$ & & & & 12.0 & 36.9 & 34.4 & 22.4 \\
\hline $1900 \ldots \ldots \ldots \ldots$ & & & & 12.0 & 49.3 & 34.8 & 22.8 \\
\hline 1901 (first half)... & & & & 12.0 & 49.3 & 34.9 & 22.9 \\
\hline 1901 (second half). & & & & 9.6 & 49.3 & 33.2 & 23.6 \\
\hline 1902 (first half) ... . & & & & 9.6 & 49.3 & 33.5 & 23.9 \\
\hline 1902 (second half).. & & & & 6.0 & 49.3 & 33.0 & 27.0 \\
\hline $1903 \ldots \ldots \ldots \ldots \ldots$ & & & & 6.0 & 49.3 & 33.5 & 27.5 \\
\hline $1904 \ldots \ldots \ldots \ldots$ & & & & 6.0 & 49.3 & 33.5 & 27.5 \\
\hline $1905 \ldots \ldots \ldots \ldots \ldots$ & & & & 6.0 & 40.0 & 26.0 & 20.0 \\
\hline $1906 \ldots \ldots \ldots$ & & & & 6.0 & 40.0 & 26.2 & 20.2 \\
\hline
\end{tabular}


The price to the jobbers, which represents what the manufacturer gets for his product (but out of which he must pay the tax) will be considered first. It is scarcely necessary at the present time to take any account of the comparatively slight movements of prices during the very earliest years or to comment on the effect of the reduction in internal-revenue tax from 8 cents in 1890 to 6 cents in 1891. Chief interest attaches to the changes in the price which occurred when the internal-revenue taxes were increased in 1898 and when they were again decreased in 1901 and 1902 . It will be recalled that the increase in the tax from 6 to 12 cents took place on June 14, 1898 , and that the tax was reduced from 12 to 9.6 cents on July 1 , 1901, and to 6 cents on July 1, 1902.

The table shows that on practically all the brands listed, which are typical brands, the manufacturers were able to increase the price which they charged to jobbers by practically the full amount of the increase in the internal-revenue tax in 1898. Brand No. 8 is the only exception. This was increased materially for a short time but was again reduced, so that in 1899 it was little higher than it had been in 1897. Brands 5 and 7 were increased in price somewhat less than the increase in the tax, while all the other 14 brands increased by as much as the tax increased, or by more (by more in the case of brands $10,12,13,16$, and 17 , particularly).

Although the fact that there was little decrease in the price of the leading brands of plug to bacco sold by the Combination when the war taxes were reduced has already been seen from the bookkeeping records of brand prices, attention may also be called to the movements shown to have taken place at this period by the figures taken from price lists, invoices, and the like. This is the more desirable because Table 40 covers a larger number of brands than the table (Table 39) which shows the bookkeeping figures. This table shows clearly that the price to the jobbers on most of the brands was not decreased when the tax was reduced; or if there was some slight decrease in the price, it was soon restored to at least the former level and in many cases advanced. On brands $3,4,5,7,8$ (No. 8 being the brand which had not been increased during the war), 10 , and 13 , there was no appreciable reduction in price when the additional war tax was removed. On brands $6,9,11,12,14,15,16$, and 17 there was a slight reduction, but the price was again restored within a year or two. On brands 1 and 2 there was a reduction of about 3 cents per pound, or about half as much as the reduction in the tax, but the price was restored by 1904 or 1905 . The table also shows that there have been several instances in which, particularly during the past three or four years, there has been a decided increase in the jobbers' price.

It follows from what has been said with regard to the change in the price charged to the jobber that the net price less tax, which is what the manufacturer finally realizes, did not in general decline at the time when the internal-revenue taxes were increased in 1898, and that the net price less tax for these brands materially increased, when the taxes were reduced in 1901 and 1902 , so that the net prices, less tax, for the more recent years are decidedly higher than those for the same brands during the years before the war.

Turning to the consumers' prices, as shown in the above table, it will be seen that there has been less uniformity in the movements. In the two highest-priced brands (Nos. 1 and 2), and also on some of 
the less expensive brands (Nos. 5, 8, and 9), there was no increase in the price to the consumer when the tax was increased, and no decrease when the tax was reduced (save only that on brand No. 8 there was a temporary increase in the price during the latter half of 1898). On seven of the brands-Nos. 3 (where the increase, however, first occurred in 1901), 4, 12,13, 15, 16, and 17 (this brand increasing only in 1900)-the consumers' price was increased by as much'as or more than the increase in the tax. On five other brands (Nos. 6, 7, 10,11 , and 14) the price to the consumer was increased by either 3.3 or 5 cents per pound, the increase in the tax being 6 cents per pound. (The price of brand No. 7 was temporarily increased by 10 cents a pound, but fell back.)

In most of the cases where the consumers' price was unchanged or was increased by less than the amount of addition to the tax, the jobbers' price was increased by at least the full amount of the addition to the tax, so that either the jobber or the retailer, or both, had to reduce their margin of profit.

In no case was the price to the consumer reduced at the time the internal-revenue taxes were reduced in 1901 and 1902, and brand 17, the price of which was reduced markedly in 1905, is the only brand covered by the table on which the price to the consumer at the present time is lower than it was during the Spanish-war period, notwithstanding the fact that there has been a reduction of 6 cents in the internalrevenue tax.

It will be seen that on a considerable number of brands the increase in the price to the jobber for the more recent years as compared with the years before the war has been greater than the increase in the price to the Consumer. In other words, the jobber or the retailer, or both, are getting a narrower margin of profit than before the Combination was formed. This fact may be partly explained, perhaps, by the policy of the Combination in performing a greater part of the function of pushing the sale of goods than was performed by the independent concerns before the Combination was formed. Not only does the Combination do more advertising than the independent concerns, but, at least at times, it has made it a practice to give premiums or extra compensation of some sort to the salesmen employed by jobbers. These practices are, of course, methods of competition designed to increase the sales of the Combination's product, but they do to some extent tend to reduce the expenses of jobbers and make it possible for them to do business on a narrower margin of profit. To some extent, also, during the years since the war, the reduced margin of the jobber on the price of tobacco proper has been made up to him by premiums, gratis goods, and similar schemes, which are treated by the American Tobacco Company as advertising expenses and not as deductions from prices. However, the expenditures of this sort have been considerably reduced during the most recent years.

The brands of plug tobacco shown in the above table are typical of the brands now manufactured by the Tobacco Combination. They are, however, all brands which have been in existence for many years. Had any considerable number of new brands been introduced at relatively lower prices either when the taxes were increased in 1898 or when they were reduced in 1901 and 1902, and had these new brands 
acquired a large sale, they would, of course, have tended to reduce the average price obtained by the Combination for the entire output and rendered the movement of the average for the entire business different from the movement of the long-established brands. As already stated, however, while some new brands have been introduced from time to time at relatively lower prices and lower profits, the great bulk of the business has always been in these well-established brands; and the Combination has naturally especially pushed the sale of such brands and has not sought to develop the lower-priced and less profitable new brands. 


\section{SMOKING TOBACCO BUSINESS OF THE COMBINATION.}

At its inception in 1890 the American Tobacco Company, although primarily a manufacturer of cigarettes, had some smoking-tobacco business. Its principal brand was "Duke's Mixture," acquired in connection with the cigarette business of W. Duke, Sons \& Co. By the purchase of the Marburg and Gail \& Ax plants at Baltimore in 1891 the Combination added somewhat to its smoking-tobacco business, its output in 1891 being two and one-half times as great as in 1890. The company did not make any great effort to expand its smoking-tobacco business, as it did with regard to its plug business. Prices were not cut nor extraordinary expenses of advertising incurred. Nevertheless the output controlled by the American Tobacco Company increased year by year until in 1898 it was about 1.7 times as great as in 1891. The American Tobacco Company had control of 7.9 per cent of the national output of smoking tobacco in 1890 and 18 per cent in 1891, while by 1898 this proportion had risen to 26.9 per cent. The Combination evidently had no such control of the industry during this period as would enable it in any way to fix prices generally.

Although the Continental Tobacco Company was principally a combination of plug-tobacco manufacturers, several of the concerns taken in had a considerable smoking-tobacco business. The acquisition of the Blackwell's Durham Tobacco Company, through the purchase of the Union Tobacco Company by the American Tobacco Company, also added to the output of smoking tobacco controlled by the Combination in 1899. The total output of the Combination in that year was $55,633,859$ pounds, or considerably more than double the output controlled by the American Tobacco Company in 1898 . The Combination's control of the national output in 1899 was 54.3 per cent. Largely as the result of the acquisition of other formerly independent concerns from time to time the Combination's output rose to $123,412,393$ pounds in 1907 , and its proportion of the national output increased to 68.9 per cent.

During the years from 1899 to 1903, inclusive, both the American and Continental companies were manufacturers of smoking tobacco. At the end of 1903 the Continental transferred its entire smokingtobacco business to the American. The P. Lorillard Company, which had entered the Combination at the time of the formation of the Continental, had a considerable smoking tobacco business, and it retains this business until the present time, although the American acts as its selling agent. The American Tobacco Company itself is still much the largest manufacturer of smoking tobacco in the country. Nevertheless an increasing proportion of the total output of smoking tobacco controlled by the Combination is represented 
by the output of subsidiary companies. 'In 1899 , of the total output of the Combination, 77.7 per cent was produced by the American and Continental companies, and 22.3 per cent by subsidiary companies, including the Lorillard Company. In 1906, the American (the Continental having gone out of existence) produced 49.5 per cent of the total output of smoking tobacco manufactured by the Combination, while 50.5 per cent was manufactured by subsidiary companies. If the Lorillard Company be included with the American Tobacco Company, the proportion produced by the American and Lorillard companies represented, in 1906, about 60 per cent of the total output of smoking tobacco by the Combination, about 40 per cent being produced by subsidiary companies other than the Lorillard.

The results of the smoking-tobacco business of the American, Continental, and Lorillard companies, combined, consequently represent the results of a large proportion of the entire smoking-tobacco business of the Combination. The business of these three companies will, therefore, be considered first, and subsequently data will be given regarding the smoking-tobacco business of the principal subsidiary companies, and of the Combination as a whole.

GENERAL RESULTS OF THE SMOKING-TOBACCO BUSINESS OF THE AMERICAN, CONTINENTAL, AND LORILLARD COMPANIES.

Table 41 shows the quantity of smoking tobacco sold by the American, Continental, and Lorillard companies in the domestic trade from 1895 to 1907 , the net value thereof, exclusive of tax, and the net profit derived. The export business in smoking tobacco is insignificant, so that the domestic business represents practically the entire business of these companies in smoking tobacco.

TABLE 41.-Smoking tobacco-American, Continental, and Lorillard companies: Quantity of sales, net value of sales, and net profits (domestic business).

\begin{tabular}{|c|c|c|c|}
\hline & Sales. & $\begin{array}{l}\text { Net value (less } \\
\text { tax). }\end{array}$ & Profits. \\
\hline & $\begin{array}{l}\text { Pounds. } \\
17.766,435\end{array}$ & & \\
\hline $\begin{array}{l}1895 . . \\
1896 .\end{array}$ & $\begin{array}{l}17,766,435 \\
16,925,504\end{array}$ & $\begin{array}{r}\$ 4,434,502.18 \\
4,739\end{array}$ & $\$ 559,009.82$ \\
\hline 1897. & $\begin{array}{l}10,925,304 \\
20,224,130\end{array}$ & $\begin{array}{l}4,173,829.29 \\
4,799,186.05\end{array}$ & $\begin{array}{l}740,586.07 \\
937.068 .95\end{array}$ \\
\hline 1898 & $23,371,951$ & $\begin{array}{l}4,, 99,180.05 \\
5,520,454.82\end{array}$ & $\begin{array}{l}937,068.95 \\
736,518.96\end{array}$ \\
\hline 1899. & $45,188,840$ & $9,106,678.33$ & $1,085,522.47$ \\
\hline 1900 & $52,204,714$ & $10,816,908.59$ & $1,976,404.34$ \\
\hline 1901 & $54,542,875$ & $12,193,006.33$ & $2,562,272.25$ \\
\hline 1902. & $62,284,742$ & $15,521,564.47$ & $3,706,059.93$ \\
\hline 1903. & $65,446,760$ & $17,645,798.00$ & $4,051,635.90$ \\
\hline 1904 & $69,723,494$ & $19,606,211.88$ & $4,610,698.40$ \\
\hline 1905. & $74,237,918$ & $20,108,533.67$ & $5,698,148.99$ \\
\hline 1906. & $75,412,313$ & $21,075,033.06$ & $6,384,233.58$ \\
\hline 1907. & $73,597,565$ & $19,904,074.03$ & $5,876,688.18$ \\
\hline
\end{tabular}

The sales of smoking tobacco by the American Tobacco Company amounted to $17,766,435$ pounds in 1895 , the value thereof, exclusive of tax, being $\$ 4,434,502.18$ and the profit $\$ 559,009.82$. By 1898 the 
sales had increased about 30 per cent in quantity and in spite of an increase of only 25 per cent in their value the profits had increased over 30 per cent. In the first year after the formation of the Continental the combined sales of smoking tobacco by the American, Continental, and Lorillard companies were $45,188,840$ pounds, or nearly double the sales of the American Tobacco Company alone in the preceding year. The profit was $\$ 1,085,522.47$, or only about 50 per cent greater than the profit of the American in 1898.

The quantity of and value of sales increased in each year up to 1906. In that year the sales were $75,412,313$ pounds, of a value of $\$ 21,075,033.06$. The sales had thus increased about 70 per cent over 1899, and the value, less tax, had increased about 130 per cent. The profit, however, had multiplied nearly sixfold, being $\$ 6,384,233.58$ in 1906 . In 1907 there was a slight decline both in the quantity and value of sales and in the profit.

"Table 42 shows the general results of the smoking-tobacco business of the American, Continental, and Lorillard companies reduced to the basis of cents per pound. Diagram 3 shows the same data graphically and contrasts it with corresponding information for the Combination as a whole.

TABLE 42.-Smoking tobacco-American, Continental, and Lorillard companies: Prices, costs, and profits (domestic business).

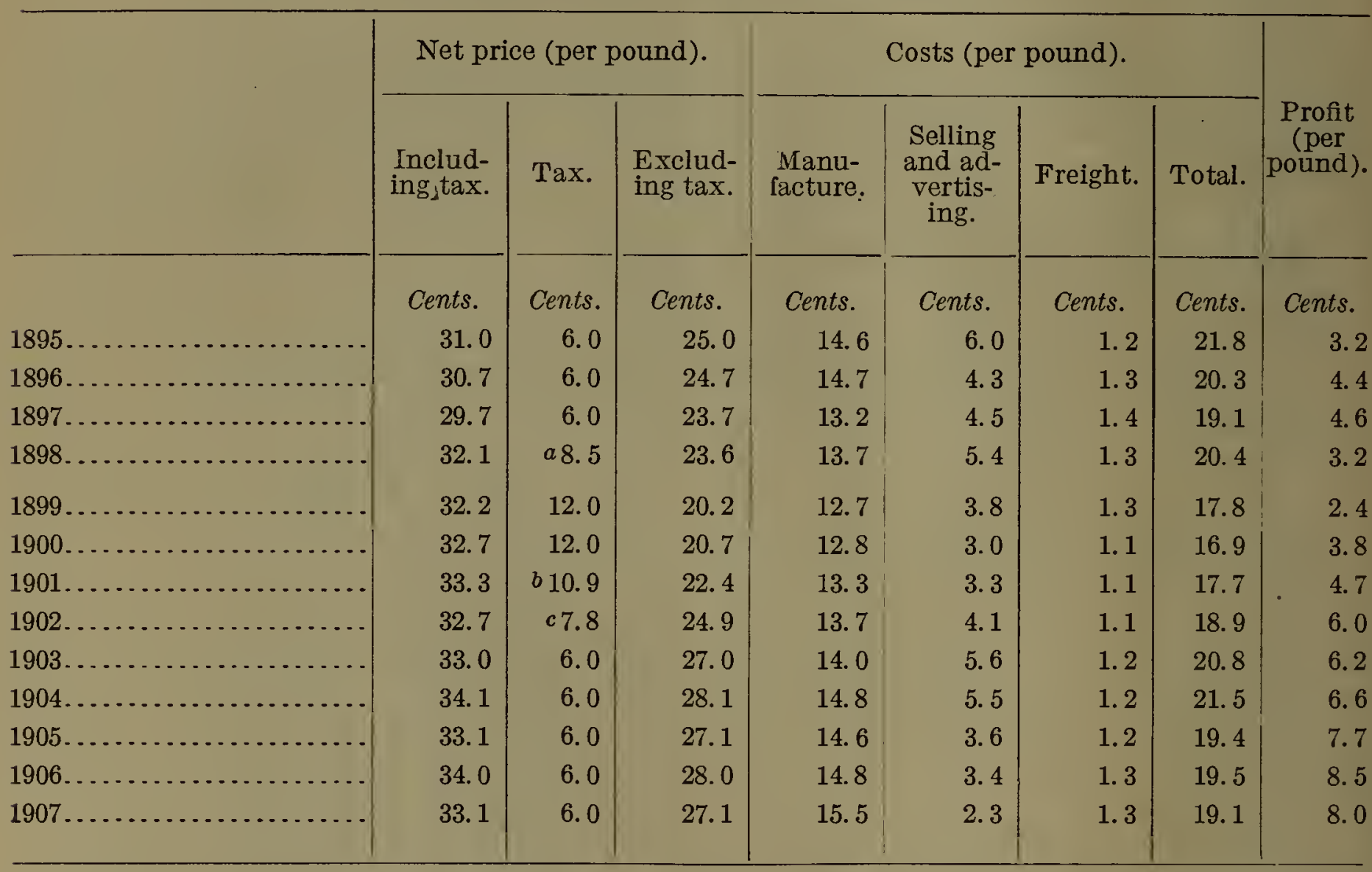

$a$ Tax to June 14, 6 cents; thereafter, 12 cents; average based on quantities produced at each rate.

$b$ First half year, 12 cents; second half, 9.6 cents; average based on quantities produced at each rate.

$c$ First half year, 9.6 cents; second half, 6 cents; average based on quantities produced at each rate.

The smoking-tobacco business differs from the plug-tobacco business in that some reasonable comparison may be made between the companies, from 1895 to 1898 , when the table covers only the business 


\section{Prices, Cithe}

Diagram 3.

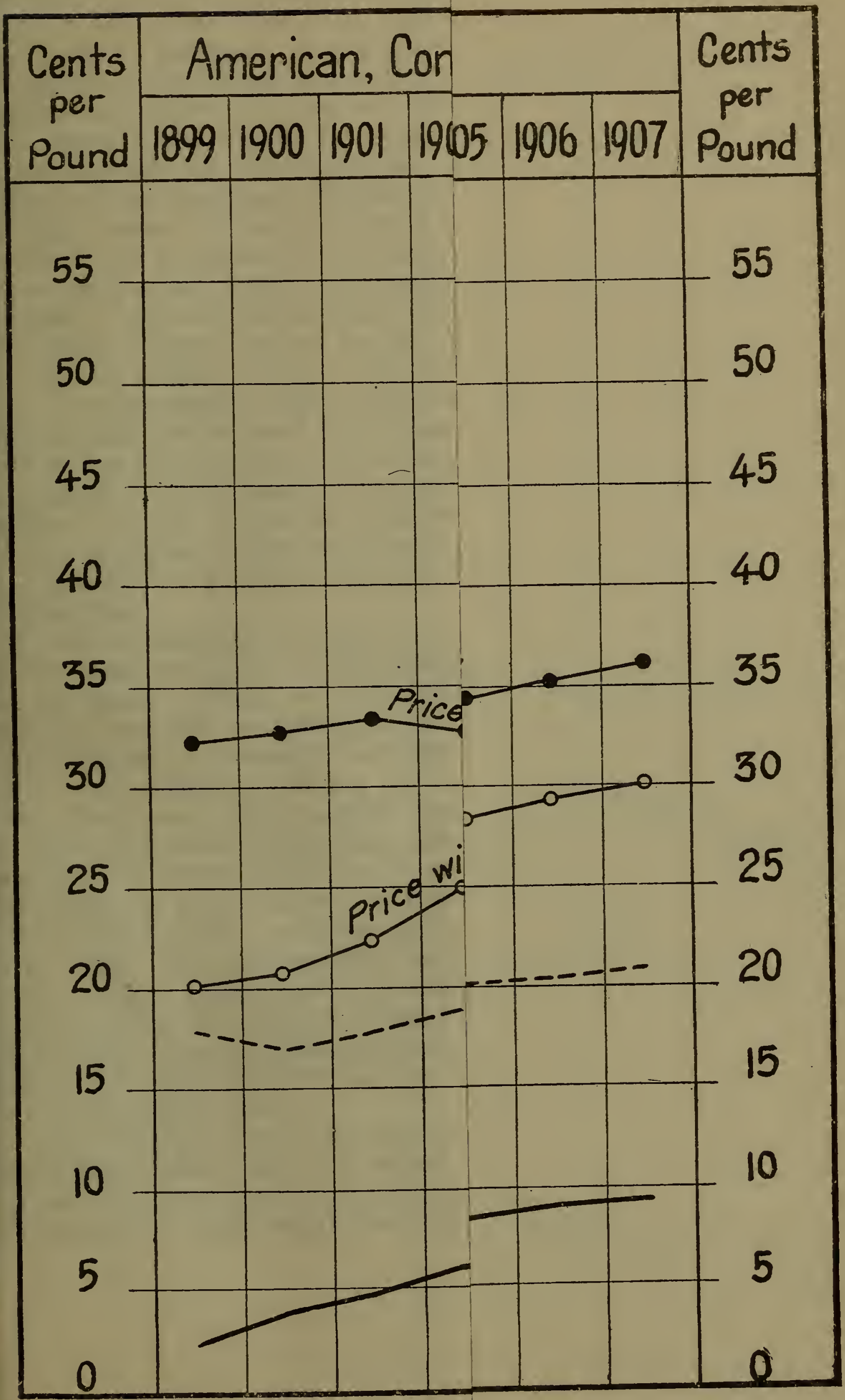





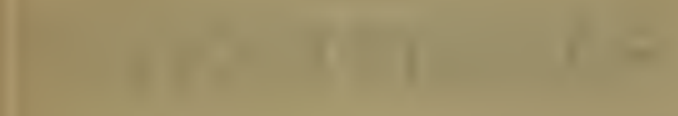

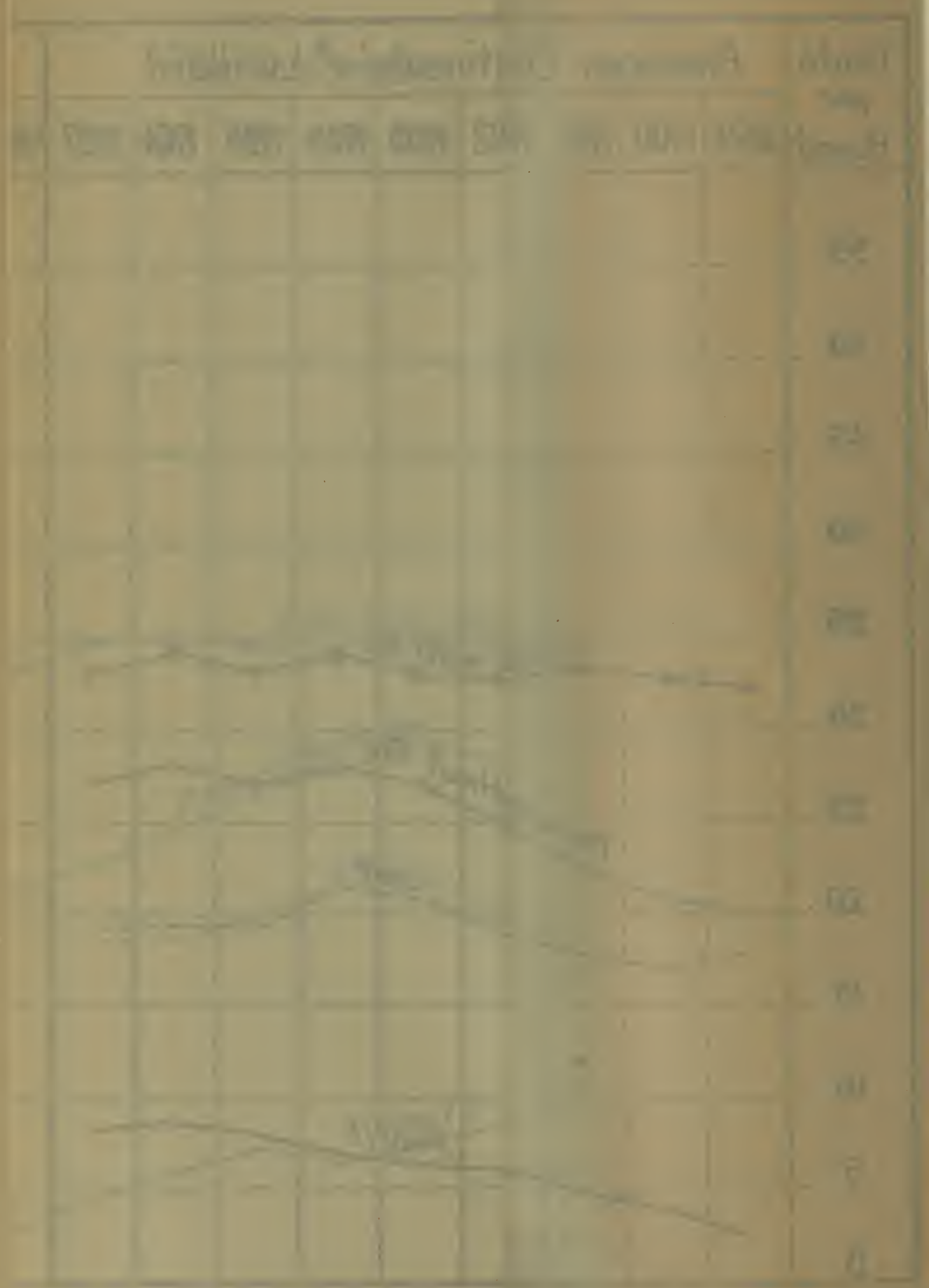


of the American Tobacco Company and the conditions after 1899. In the plug-tobacco business, as already stated, the conditions during the earlier period were wholly abnormal, owing to the fact that the American Tobacco Company was cutting prices severely in order to increase rapidly its volume of output. In the smoking-tobacco business, on the other hand, the American did not cut prices, and the results of its business during the four years, 1895 to 1898 , may be said to represent simply the results of the largest single manufacturer under competitive, but normal competitive, conditions. To be sure it is scarcely practicable to compare the net prices obtained on the entire business of the American with the net profits of the entire output of the American, Continental, and Lorillard companies during the later years. The addition of a large number of brands, as the result of the combination of 1898 , some of which brands were of a lower price than those principally sold by the American Tobacco Company, reduced the average price, less tax, in 1899, as compared with the average obtained by the American Tobacco Company alone during the earlier years. This reduction in the average price, less tax, on the entire output did not necessarily correspond to any reduction in the price of individual brands. It will be seen that the cost of the entire output of the American, Continental, and Lorillard companies in 1899 was also considerably lower than the cost of the product of the American Tobacco Company in the earlier years. While, therefore, prices and costs from the one period to the other can scarcely be properly compared, the profit per pound is roughly comparable.

It will be seen that during the four years, 1895 to 1898 , the profit of the American Tobacco Company per pound ranged from 3.2 cents to 4.6 cents. When a large amount of additional business was brought into the combination through the formation of the Continental Tobacco Company and the acquisition of the Jurillard company, the average profit per pound fell to 2.4 cents in 1899 . After 1899 there was a very marked rise in the profit per pound. It will be seen that notwithstanding the reduction in the internal-revenue tax from 12 cents in 1899 to 6 cents in 1903 the average net price, including the tax, received by the American, Continental, and Lorillard companies for smoking tobacco actually increased. The net price, less tax, consequently increased very greatly, and despite some increase in the cost of production, largely due to an increase in the price of leaf tobacco, there was a marked increase in the profit. Since 1903 there has been comparatively little variation in the profit per pound, although it was appreciably higher in 1906 and 1907 than in the preceding years.

A still clearer view of the relation between prices, costs, and profits is obtained from Table 43, which shows the three elements making up the net price received by the American, Continental, and Lorillard companies for their entire domestic sales of smoking tobacco. 
TABLE 43.-Smoking tobacco-American, Continental, and Lorillard companies: Amount of tax, cost, and profit entering into net selling price.

\begin{tabular}{|c|c|c|c|c|}
\hline \multirow{2}{*}{ Year. } & \multicolumn{3}{|c|}{$\begin{array}{l}\text { Elements entering into price } \\
\text { (per pound). }\end{array}$} & \multirow{2}{*}{$\begin{array}{l}\text { Net price, } \\
\text { includ- } \\
\text { ing tax } \\
\text { (per } \\
\text { pound). }\end{array}$} \\
\hline & Tax. & Cost. & Profit. & \\
\hline $1895 \ldots$ & $\begin{array}{r}\text { Cents. } \\
6.0\end{array}$ & $\begin{array}{l}\text { Cents. } \\
\quad 21.8\end{array}$ & $\begin{array}{l}\text { Cents. } \\
\quad 3.2\end{array}$ & $\begin{array}{l}\text { Cents. } \\
\quad 31.0\end{array}$ \\
\hline $1896 \ldots \ldots \ldots$. & 6.0 & 20.3 & 4.4 & 30.7 \\
\hline $1897 \ldots \ldots . . . \ldots \ldots$. & 6.0 & 19.1 & 4.6 & 29.7 \\
\hline $1898 \ldots \ldots \ldots \ldots \ldots \ldots$ & 8.5 & 20.4 & 3.2 & 32.1 \\
\hline $1899 \ldots$ & 12.0 & 17.8 & 2.4 & 32.2 \\
\hline $1900 \ldots \ldots \ldots \ldots \ldots . . . . . . .$. & 12.0 & 16.9 & 3.8 & 32.7 \\
\hline $1901 \ldots \ldots \ldots \ldots \ldots \ldots \ldots \ldots$ & 10.9 & 17.7 & 4.7 & 33.3 \\
\hline $1902 \ldots \ldots \ldots \ldots \ldots \ldots$ & 7.8 & 18.9 & 6.0 & 32.7 \\
\hline $1903 \ldots \ldots \ldots \ldots \ldots \ldots \ldots \ldots$ & 6.0 & 20.8 & 6.2 & 33.0 \\
\hline $1904 \ldots \ldots \ldots \ldots \ldots \ldots \ldots \ldots$ & 6.0 & 21.5 & 6.6 & 34.1 \\
\hline $1905 . \ldots \ldots \ldots \ldots \ldots \ldots \ldots$ & 6.0 & 19.4 & 7.7 & 33.1 \\
\hline $1906 \ldots \ldots \ldots \ldots \ldots \ldots \ldots \ldots$ & 6.0 & 19.5 & 8.5 & 34.0 \\
\hline $1907 \ldots \ldots \ldots \ldots \ldots \ldots \ldots \ldots$ & 6.0 & 19.1 & 8.0 & 33.1 \\
\hline
\end{tabular}

It will be seen that in 1895 the net price of 31 cents received by the American Tobacco Company was composed of 6 cents, the tax paid to the Government, of 21.8 cents, manufacturing and selling cost, and of a profit of 3.2 cents. The tax represented a little less than one-fifth of the net price to the public. In 1899, out of a net price of 32.2 cents received by the American, Continental, and Lorillard companies together, the tax represented 12 cents, or considerably over one-third, the cost 17.8 cents, and the profit 2.4 cents. The tax was reduced by two successive stages on July 1, 1901, and July 1, 1902. The year 1903 was the first after the war in which the present rate of 6 cents per pound was in effect during the entire year. In 1903 the net price, including tax, was 33 cents, as compared with 32.2 cents in 1899 . This net price was made up of 6 cents tax, 20.8 cents cost, and 6.2 cents profit. The tax was less than one-fifth of the price, whereas in 1899 it had been more than one-third. The profit in 1903 composed nearly one-fifth of the price, whereas in 1899 it was less than one-thirteenth of the price. The price, therefore, was in 19030.8 cent higher than in 1899, notwithstanding a decline of 6 cents in the tax. The cost, however, had increased 3 cents, so that the increase in profit was 3.8 cents per pound. For the years 1905 to 1907 the cost of manufacture and sale were appreciably lower than in 1903, while the selling price was the same or higher than in 1903, so that the profit ranged from 7.7 cents to 8.5 cents per pound as compared with 6.2 cents in 1903 .

In 1907, the last year covered by the table, the tax represented 18 per cent of the selling price, the cost of manufacture 58 per cent, and the profit 24 per cent; while in 1899 the tax had represented 37 per cent, the cost of manufacture 55 per cent, and the profit 8 per cent. The true price policy of the Tobacco Combination is to be judged by the net price, less tax, and the profit. It will be seen from Table 42 that the net price, less tax, for the entire domestic smoking tobacco business of the American, Continental, and Lorillard 
companies increased steadily from 20.2 cents in 1899 to 28.1 cents in 1904 , an increase of nearly 40 per cent. On account of the increase in cost, however, the profit increased by a less amount, namely, from 2.4 cents in 1899 to 6.6 cents in 1904 . Since 1904 there has been comparatively little change in the net price, although in 1905 and 1907 it was 1 cent lower than in 1904. There has, however, been a greater reduction in the cost than in the selling price. In particular the cost of advertising and selling, as will be seen from Table 42, has very materially decreased, namely, from 5.5 cents in 1904 to 2.3 cents in 1907. The combination increased its expenditures for advertising during the years immediately following the reduction of the internal-revenue tax, apparently with the intention of thereby keeping up its sales notwithstanding its failure to reduce prices. Having by these unusual advertising expenses more firmly established its brands it was able to reduce its outlay for advertising very materially. As the result of the reduction in costs the profit of the American, Continental, and Lorillard companies on smoking tobacco increased considerably, reaching its maximum in $1906-8.5$ cents as compared with 6.6 cents in 1904 .

The following table presents in another form the facts in regard to the changes in prices, costs, and profits since 1899. It shows the increase in the net price of smoking tobacco, exclusive of tax, during each year from 1899, the increase (or decrease) in cost, and the difference between these two figures, which represents the increase in profit, as compared with 1899 :

TABLE 44.-Smoking tobacco-American, Continental, and Lorillard companies: Increase in price (excluding tax) and increase in cost (excluding tax), 1899-190\%.

\begin{tabular}{|c|c|c|c|}
\hline Year. & $\begin{array}{l}\text { Increase in } \\
\text { price (ex- } \\
\text { cluding tax) } \\
\text { over 1899 } \\
\text { (per pound). }\end{array}$ & $\begin{array}{l}\text { Increase in } \\
\text { cost (exclud- } \\
\text { ing tax) over } \\
1899 \text { (per } \\
\text { pound). }\end{array}$ & $\begin{array}{c}\text { Difference= } \\
\text { increase in } \\
\text { profit over } \\
1899 \text { (per } \\
\text { pound). }\end{array}$ \\
\hline & Cents. & Cents. & Cents. \\
\hline $1900 \ldots$ & 0.5 & $* 0.9$ & 1.4 \\
\hline 1901. & 2.2 & $\begin{array}{r}* 0.1 \\
1.1\end{array}$ & $\begin{array}{l}2.3 \\
3.6\end{array}$ \\
\hline 1902 & $\begin{array}{l}4.8 \\
6.8\end{array}$ & $\begin{array}{l}1.1 \\
3.0\end{array}$ & $\begin{array}{l}3.0 \\
3.8\end{array}$ \\
\hline $1903 .$. & $\begin{array}{l}0.0 \\
7.9\end{array}$ & 3.7 & 4.2 \\
\hline $1905 \ldots$ & 6.9 & 1.6 & 5.3 \\
\hline $1906 \ldots$ & 7.8 & 1.7 & 6.1 \\
\hline 1907. & 6.9 & 1.3 & 5.6 \\
\hline
\end{tabular}

* Decrease.

This table shows, for example, that in 1904 the net price, exclusive of tax, was 7.9 cents higher than in 1899 , and that owing to an.increase of 3.7 cents in the cost the profit increased 4.2 cents. For 1907 the price, less tax, was 6.9 cents higher than in 1899 , the cost only 1.3 cents higher, and the profit consequently 5.6 cents higher. It follows from the figures already presented that the percentage of profit on cost in the smoking-tobacco business of the American, Continental, and Lorillard companies has greatly increased since 1899.

87442-S. Doc. $78,61-1 — 7$ 
Table 45 shows the cost, exclusive of tax, for each year, the profit, and the rate of profit on cost.

TABLE 45.-Smoking tobacco-American, Continental, and Lorillard companies: Relation of profit to cost.

\begin{tabular}{|c|c|c|c|}
\hline Year. & $\begin{array}{l}\text { Cost, ex- } \\
\text { cluding } \\
\text { tax (per } \\
\text { pound). }\end{array}$ & $\begin{array}{c}\text { Profit } \\
\text { (per } \\
\text { pound). }\end{array}$ & $\begin{array}{l}\text { Rate of } \\
\text { profit on } \\
\text { cost. }\end{array}$ \\
\hline & Cents. & Cents. & Per cent. \\
\hline 1895. & 21.8 & 3.2 & 14.4 \\
\hline $1896 \ldots$ & 20.3 & 4.4 & 21.6 \\
\hline $1897 \ldots \ldots \ldots$ & 19.1 & 4.6 & 24.3 \\
\hline $1898 \ldots \ldots \ldots$ & 20.4 & 3.2 & 15.4 \\
\hline $1899 \ldots \ldots . .$. & 17.8 & 2.4 & 13.5 \\
\hline $1900 \ldots \ldots \ldots$ & 16.9 & 3.8 & 22.4 \\
\hline $1901 \ldots \ldots \ldots \ldots . . . .$. & 17.7 & 4.7 & 26.6 \\
\hline $1902 \ldots \ldots .$. & 18.9 & 6.0 & 31.4 \\
\hline $1903 \ldots \ldots \ldots \ldots$. & 20.8 & 6.2 & 29.8 \\
\hline $1904 \ldots . . . . . .$. & 21.5 & 6.6 & 30.7 \\
\hline $1905 \ldots \ldots \ldots \ldots \ldots \ldots \ldots$ & 19.4 & 7.7 & 39.5 \\
\hline $1906 \ldots \ldots \ldots \ldots \ldots \ldots$ & 19.5 & 8.5 & 43.5 \\
\hline 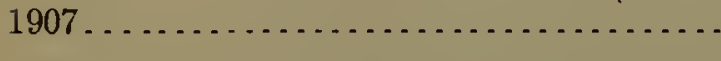 & 19.1 & 8.0 & 41.9 \\
\hline
\end{tabular}

It will be seen that during the period from 1895 to 1898, when the figures represent only the business of the American Tobacco Company, and represent normal competitive conditions, the rate of profit on cost ranged from 14.4 per cent to 24.3 per cent. In 1899 , the first year after the increase in the scope of the business resulting from the formation of the Continental and the acquisition of the Lorillard Company, the rate of profit was 13.5 per cent on cost. The rate of profit increased from year to year until 1902, when it was 31.4 per cent on cost. After a small decline in 1903 the rate again increased, reaching 43.5 per cent in 1906 and only a very little less in 1907 .

Another view of the relation between profits and costs is obtained by showing what proportion of the net price, exclusive of tax, consists of cost, and what proportion of profit. The following table shows the average net selling price, less tax, for the entire smokingtobacco output (domestic business) for the American, Continental, and Lorillard companies, and the percentage represented by cost and profit, respectively: 
TABLE 46.-Smoking tobacco-American, Continental, and Lorillard companies: Division of net selling price (less tax) between cost and profit.

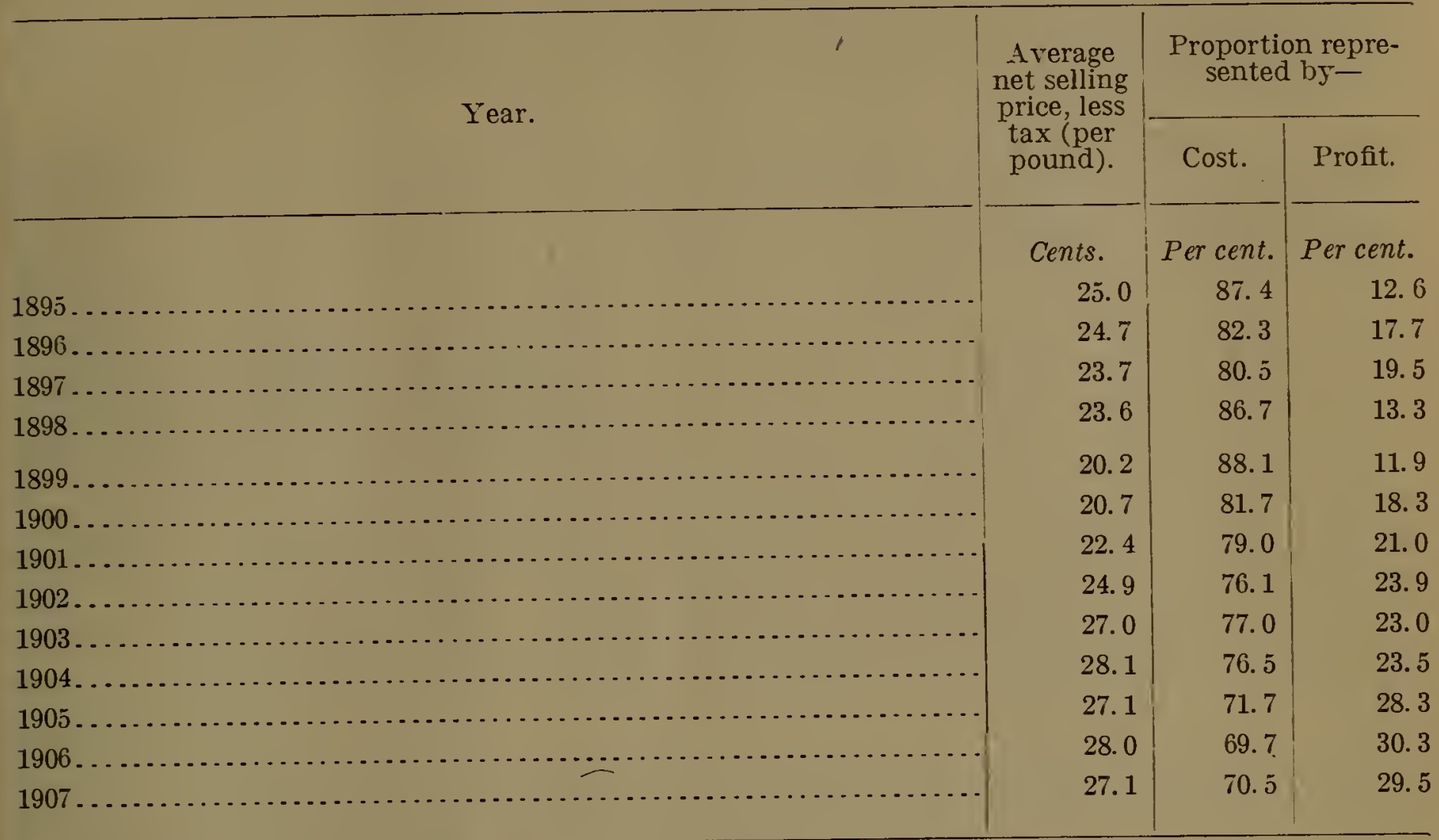

During the period from 1895 to 1898 , cost represented from 80.5 to 87.4 per cent of the net selling price, less tax, obtained by the American Tobacco Company; profit represented from 12.6 to 19.5 per cent. During the first year after the formation of the Continental, on a much larger volume of output, the cost represented 88.1 per cent of the selling price, and the profit 11.9 per cent. By 1903 the proportion represented by cost had fallen to 77 per cent, while profit represented 23 per cent. In 1906, the most profitable year, the proportion of the net selling price, less tax, represented by cost fell to 69.7 per cent, while 30.3 per cent was represented by profit. There was little change in 1907.

Table 47 shows the relation between the net selling price, less tax, and the net profit per pound, on the one hand, and the proportion of the business controlled by the Tobacco Combination on the other hand. The proportion controlled represents the entire business of all companies in the Tobacco Combination, while the prices and profits represent the business of the American, Continental, and Lorillard companies only. ${ }^{a}$ It should be noted, however, that the figures for the proportion of the business controlled include smoking tobacco proper and also scrap tobacco, while the figures of prices and profits represent only smoking tobacco proper, scraptobacco prices, and profits being presented elsewhere. The scraptobacco business has been one of rapidly increasing importance, and in 1907 it represented approximately one-fifth of the total output classed by the internal-revenue bureau as smoking tobacco. The Tobacco Combination has a much smaller proportion of the scrap business than of the smoking-tobacco business proper; in fact, its proportion of the scrap business is probably not much over 50 per cent

$a$ Although the proportion here given is the proportion of the entire output both for domestic consumption and export, the exports are so insignificant that it represents also practically the proportion of the domestic business only. 
(the exact figures are not obtainable). Consequently, the Combination's proportion of the smoking-tobacco business proper in the more recent years is larger than is shown in this table, and the increase in the proportion of the smoking-tobacco business proper controlled by the Combination is also greater than shown in the table.

TABLE 47.-Smoking tobacco-Relation of net price (less tax) and profit of American,

Continental, and Lorillard companies to the proportion of the national output controlled by the Tobacco Combination.

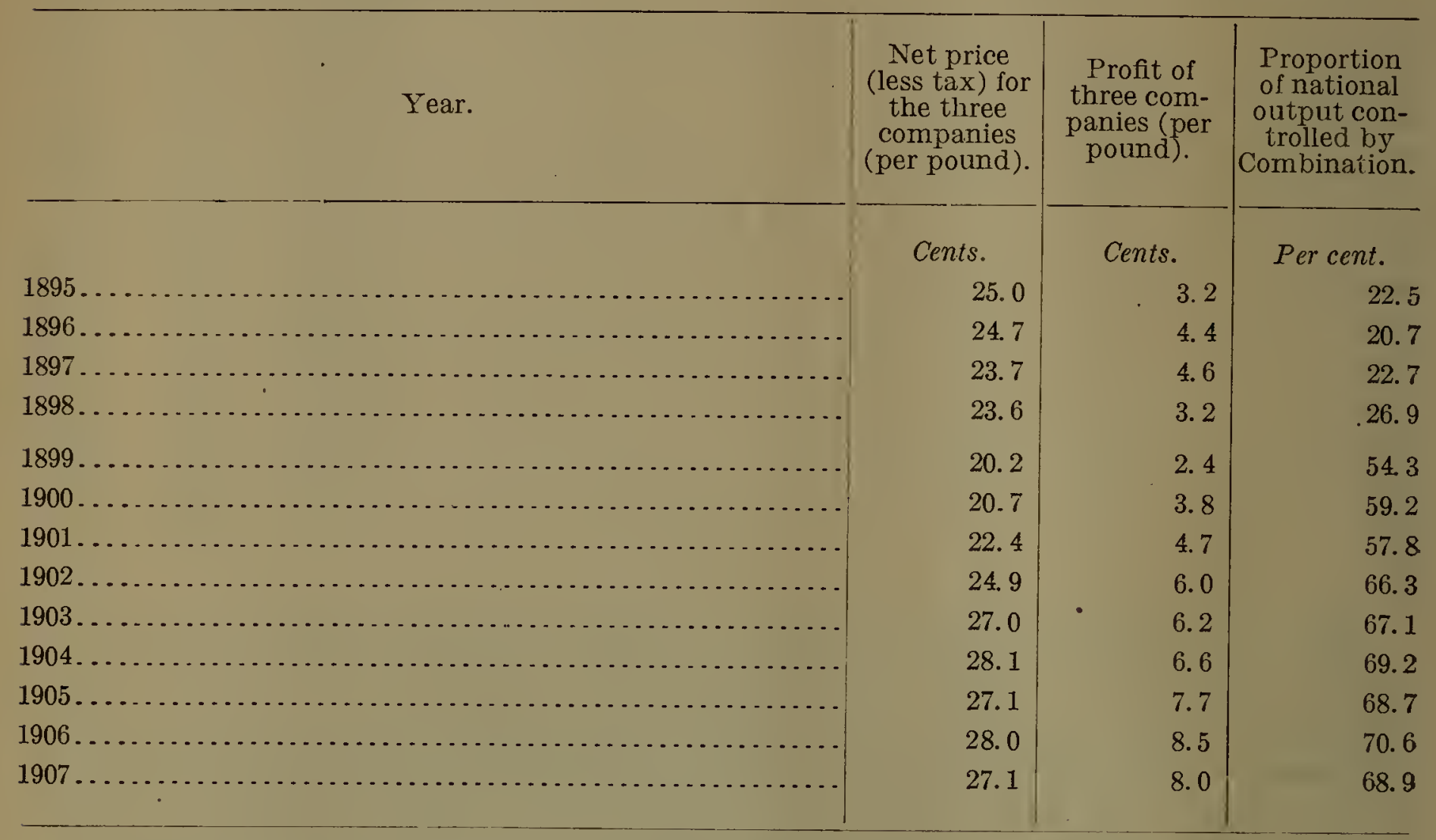

During the years 1895 to 1898 the American Tobacco Company controlled from about one-fifth to a little over one-fourth of the output of smoking tobacco in the country. The conditions were therefore essentially competitive, although the popularity of the principal brands of the American Tobacco Company doubtless enabled it to obtain a somewhat higher rate of profit per pound than the average for the entire output of the country.

In 1899 the Combination, which had now taken in a large smoking tobacco business through the organization of the Continental and the acquisition of Blackwell's Durham Tobacco Company, had 54.3 per cent of the national output. The percentage of control increased materially between 1899 and 1904, when it reached 69.2 per cent, and the net price per pound also increased in each year, while the profit increased in every year. After a slight decline in 1905 the proportion of the business controlled again increased, reaching 70.6 per cent in 1906 , but falling to 68.9 per cent in 1907 . There has been comparatively little change in the price, which in fact was 1 cent per pound lower in 1907 than in 1904, but owing to a reduction in cost, as already stated, the profit per pound had increased over 1904 .

\section{RESULTS OF SMOKING-TOBACCO BUSINESS OF SUBSIDIARY COMPANIES OF THE COMBINATION.}

The great bulk of the smoking-tobacco business of the subsidiary companies of the Tobacco Combination-other than the P. Lorillard company, the data for which have been combined with those for the 
American and Continental companies-is in the hands of five concerns, which are, in the order of their importance, Blackwell's Durham Tobacco Company, Spaulding \& Merrick, F. F. Adams Tobacco Company, R. A. Patterson Tobacco Company, and Monopol Tobacco Works. The latter does not manufacture the product which it sells, but it is made by other concerns in the Combination for the most part, or is imported. Data of prices, costs, and profits for all of the above concerns are available, but in the case of the $R$. A. Patterson Tobacco Company about two-fifths of the total output consists of plug tobacco, and it is impossible to separate the results of the plug-tobacco business from those of the smoking-tobacco business; consequently the figures for this company are not combined with those of the other smoking-tobacco concerns. The business of the other four concerns represents the great bulk of the total business of all the subsidiary concerns making smoking tobacco (other than the Lorillard company). Some minor concerns make small quantities of smoking tobacco, but the inclusion of their figures with those for the other subsidiary companies would not appreciably affect the results.

Table 48 shows the sales and the average prices of the Blackwell's, Monopol, Adams, and Spaulding \& Merrick concerns from the date of their acquisition by the Combination to $1907 .{ }^{a}$

TABLE 48.-Smoking tobacco-Quantity of sales and average price of principal subsidiary companies making smoking tobacco.

\begin{tabular}{|c|c|c|c|c|c|c|c|c|c|c|c|c|}
\hline \multirow[b]{2}{*}{ Year. } & \multicolumn{3}{|c|}{$\begin{array}{c}\text { Blackwell's Durham } \\
\text { Tobacco Co. }\end{array}$} & \multicolumn{3}{|c|}{$\begin{array}{l}\text { Monopol Tobacco } \\
\text { Works. }\end{array}$} & \multicolumn{3}{|c|}{ F. F. Adams Tobacco } & \multicolumn{3}{|c|}{ Spanlding \& Merrick. $c$} \\
\hline & Sales. & 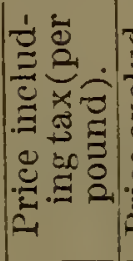 & 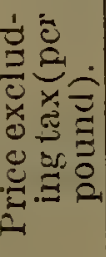 & Sales. & 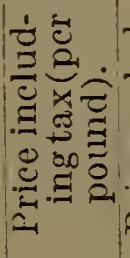 & 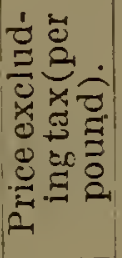 & Sales. & 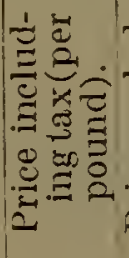 & 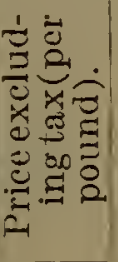 & Sales. & 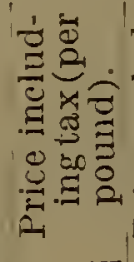 & 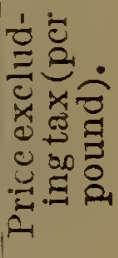 \\
\hline 1899 . & Pounds. & Cents. & Cents. & Pounds. & Cents. & Cents. & Pounds. & Cents. & Cents. & Pounds. & Cents. & Cents. \\
\hline 1900 & $\begin{array}{r}2,089,355 \\
4,681,518\end{array}$ & $\begin{array}{l}53.4 \\
57.7\end{array}$ & $\begin{array}{l}41.4 \\
45.7\end{array}$ & & & & & & & & & \\
\hline 1901. & $e 4,973,747$ & 58.1 & 48.0 & & & & & & & & & \\
\hline $1902 \ldots$ & $6,395,075$ & 57.8 & 50.0 & 531,690 & 70.5 & 62.7 & $f 4,293,176$ & 21.5 & 14.1 & & & \\
\hline $1903 \ldots$ & $6,538,699$ & 57.3 & 51.3 & 87,838 & 105.9 & 99.9 & $4,038,511$ & 25.6 & 19.6 & $6,362,775$ & 23.5 & 17.5 \\
\hline 1904. & $7,752,417$ & 57.5 & 51.5 & 136,258 & 93.6 & 87.6 & $3,742,516$ & 26.6 & 20.6 & $5,392,871$ & 25.2 & 19.2 \\
\hline 1905. & $7,839,708$ & 57.7 & 51.7 & 269,730 & 99.0 & 93.0 & $4,170,634$ & 27.5 & 21.5 & $6,839,554$ & 23.5 & 17.5 \\
\hline 1906. & $10,135,169$ & 55.2 & 49.2 & 263,912 & 104.7 & 98.7 & $4,187,672$ & 27.3 & 21.3 & $7,045,999$ & 23.5 & 17.5 \\
\hline $1907 .$. & $12,059,64 \overline{5}$ & 57.7 & 51.7 & $2,117,440$ & 69.1 & 63.1 & $3,703,396$ & 28.2 & 22.2 & $6,507,698$ & 23.8 & 17.8 \\
\hline
\end{tabular}

$a$ In the case of the F. F. Adams Tobacco Company a small quantity of fine-cut tobacco is included with the smoking tobacco. In 1906 this company made 5,194,000 pounds of smoking tobacco and 312,000 pounds of fine clit. As the price of fine cut is substantially similar to that of the smoking tobacco made by this concern, the inclusion of the figures of fine cut does not appreciably affect the average for the concern as a whole. The figures given for Spaulding \& Merrick represent its smokingtobacco business only.

$b$ Includes a small quantity of fine cut.

$c$ Smoking tobacco business only.

$d$ Six months.

$e$ Nine months.

$f$ Ten months. 
It is obvious from this table that the smoking tobacco sold by the Blackwell's Durham and Monopol companies is much higher priced than that sold by the Adams and Spaulding \& Merrick companies. Consequently, an average of the business for these four concerns taken together has comparatively little significance, although when the business of all four is combined with the much larger business of the American, Continental, and Lorillard companies the figures in the total are fairly comparable from year to year. The business of the Blackwell's company has increased much more rapidly than that of the F. F. Adams and Spaulding \& Merrick companies and in 1907 the Blackwell's output represents nearly half of the total for the four subsidiary companies covered by the table.

The stock of the Blackwell's Durham Tobacco Company was acquired by the American Tobacco Company early in 1899, but figures are available only for the last six months of that year. In 1900 , the first full year, the sales of this concern were 4,681,518 pounds. They increased rapidly, especially after 1905 , and stood at $12,059,645$ pounds in 1907 . It is noteworthy that, notwithstanding the reduction of the internal-revenue tax from 12 to 6 cents per pound between 1900 and 1903, there was no appreciable reduction in the price charged by this company for its product. (The year 1906 , in which the price is about 2 cents lower than in any other year between 1900 and 1907, is exceptional, the lower price apparantly being due to larger sales of those sizes of packages which bring a lower average price per pound.) Since the price in 1900 was more than 4 cents higher than in 1899 , although there was no change in the tax, it follows that the net price, less tax, during more recent years has been very much higher than during the year 1899, ranging from 49.2 to 51.7 cents in the later years, as compared with 41.4 cents in the earlier.

The business of the Monopol Tobacco Company, as shown by the table, has been exceedingly variable, both in quantity and in average price of product. This is due, not to changes in the demand for the various brands, but to changes in the number and character of the brands handled by the company. The sales in 1902, 531,690 pounds, include a very considerable quantity of high-grade smoking tobacco manufactured for export. This export business was turned over to the British-American Tobacco Company in 1903, which accounts for the great decline in the sales of the Monopol. From 1903 to 1905 the sales of the Monopol rapidly increased, partly owing to the transfer to that company of various high-grade brands formerly handled by other companies. In 1907 there was a great increase in the business of the Monopol, partly due to the fact that it became the selling agent for the tobaccos of the John W. Carroll Tobacco Company, control of which had recently been acquired by the Tobacco Combination. It is obvious from these changes in the character of the business of the Monopol that the changes in the average price received by it for its entire output have no significance. The number, character, and price of the brands handled at different periods of time have differed greatly.

The F. F. Adams Tobacco Company, acquired early in 1902, manufactures smoking tobacco of low price. Its sales show no tendency to increase, but there have been considerable fluctuations from year 
to year. The average price, including tax, for the product of this company was 21.5 cents during the last ten months of 1902 ; and, notwithstanding the fact that the internal-revenue tax had been reduced from 9.6 cents to 6 cents on July 1, 1902, the average price, including tax, rose to 25.6 cents in 1903 . It has increased still further since that time, amounting to 28.2 cents in 1907 . The price, less tax, for this company increased from 14.1 cents in 1902 to 22.2 cents in 1907 , or more than 50 per cent.

The Spaulding \& Merrick Company also manufactures low-grade smoking tobacco. This company was acquired early in 1902. Its sales have fluctuated considerably from year to year, the maximum being in 1906. No change has occurred in the tax during the period covered by the Spaulding \& Merrick figures, and there has been very little change in its prices, the only noteworthy one being the relatively high price of 1904 as compared with both the preceding and the following years.

Table 49 compares the quantity of sales, the net prices, and the net profits of the American, Continental, and Lorillard companies with those of the four principal subsidiary companies above named, for the years 1902 to 1907 .

TABLE 49.-Smoking tobacco-Comparison of prices and profits of părent und subsidiary companies.

\begin{tabular}{|c|c|c|c|c|c|c|}
\hline \multirow[b]{2}{*}{ Year. } & \multicolumn{2}{|c|}{ Sales. } & \multicolumn{2}{|c|}{$\begin{array}{l}\text { Net price excluding tax } \\
\text { (per pound). }\end{array}$} & \multicolumn{2}{|c|}{ Net profit (per pound). } \\
\hline & $\begin{array}{l}\text { American, } \\
\text { Continental, } \\
\text { and Loril- } \\
\text { lard. }\end{array}$ & $\begin{array}{l}\text { Principal } \\
\text { subsidiary } \\
\text { companies. }\end{array}$ & $\begin{array}{l}\text { American, } \\
\text { Continental, } \\
\text { and Loril- } \\
\text { lard. }\end{array}$ & $\begin{array}{l}\text { Subsidiary } \\
\text { companies. }\end{array}$ & $\begin{array}{l}\text { American, } \\
\text { Continental, } \\
\text { and Loril- } \\
\text { lard. }\end{array}$ & $\begin{array}{l}\text { Subsidiary } \\
\text { companies. }\end{array}$ \\
\hline 1902. & $\begin{array}{l}\text { Pounds. } \\
62,284,742\end{array}$ & $\begin{array}{l}\text { Pounds. } \\
11,219,941\end{array}$ & $\begin{array}{l}\text { Cents. } \\
24.9\end{array}$ & $\begin{array}{l}\text { Cents. } \\
\quad 36.9\end{array}$ & $\begin{array}{l}\text { Cents. } \\
6.0\end{array}$ & $\begin{array}{l}\text { Cents. } \\
11.6\end{array}$ \\
\hline 1903. & $65,446,760$ & $17,027,823$ & 27.0 & 31.4 & 6.2 & 6. 3 \\
\hline $1904 .$. & $69,723,494$ & $17,024,062$ & 28.1 & 34.8 & 6.6 & 9.3 \\
\hline 1905. & $74,237,918$ & $19,119,626$ & 27.1 & 33.4 & 7.7 & 10.5 \\
\hline $1906 \ldots . . .$. & $75,412,313$ & $21,632,752$ & 28.0 & 34.1 & 8.5 & 11.0 \\
\hline $1907 \ldots \ldots \ldots$ & $73,597,565$ & $24,388,179$ & 27.1 & 39.2 & 8.0 & 13.2 \\
\hline
\end{tabular}

The most significant feature of this table is the fact that the sales of the subsidiary companies have increased much more markedly than those of the parent companies, although the latter also have increased very greatly. This relatively greater increase in the output of the subsidiary companies has been due partly to the increase in the number of subsidiary companies included and partly to the fact that the sales of the Blackwell's Durham Tobacco Company have increased with exceptional rapidity. The table shows also that, whereas in the plug-tobacco business the grade manufactured by the American, Continental, and Lorillard companies is higher priced than that made by the subsidiary companies, the opposite is true with respect to smoking tobacco. The average price of the Blackwell's Durham Tobacco Company is about twice as great as that of the American, Continental, and Lorillard concerns; and even after the inclusion of the lower-priced tobaccos of the Adams and Spaulding 
\& Merrick concerns the average price of the subsidiary companies is still from one-sixth to one-half higher than that of the American Tobacco Company. The average profit per pound of the subsidiary companies is also greater than that of the American, Continental, and Lorillard companies, as might be expected from the fact that their product is of higher price.

\section{RESULTS OW THE ENTIRE SMOKING-TOBACCO BUSINESS OF THE TOBACCO COMBINATION.}

Table 50 shows the total sales, the total net value (less tax), and the profits of the smoking-tobacco business of the principal concerns in the Tobacco Combination. It distinguishes the data for the American, Continental, and Lorillard companies from those for the subsidiary companies and gives the total for both. This total includes very nearly the entire smoking-tobacco business of the Tobacco Combination, the output of subsidiary companies not here included being insignificant as compared with the total.

TABLE 50:-Smoking tobacco-Combined sales and profits of principal companies in Tobacco Combination.

\begin{tabular}{|c|c|c|c|}
\hline & Sales. & $\begin{array}{l}\text { Net value (less } \\
\text { tax). }\end{array}$ & Profit. \\
\hline $1899 \ldots$ & $\begin{array}{l}\text { Pounds. } \\
47,278,195\end{array}$ & $\$ 9,970,778.54$ & $\$ 1,320,738.26$ \\
\hline 1900. & $56,886,232$ & $12,954,697.33$ & $2,563,833.04$ \\
\hline 1901. & $59,516,622$ & $14,581,268.78$ & $3,466,879.65$ \\
\hline 1902 & $73,504,683$ & $19,659,662.76$ & $5,006,884.63$ \\
\hline 1903. & $82,474,583$ & $22,996,970.75$ & $5,129,836.90$ \\
\hline 1904. & $86,747,556$ & $25,521,849.88$ & $6,185,850.53$ \\
\hline 1905. & $93,357,544$ & $26,499,119.68$ & $7,711,171.85$ \\
\hline 1906 & $97,045,065$ & $28,449,154.29$ & $8,754,351.47$ \\
\hline 1907. & $97,985,744$ & $29,461,251.28$ & $9,105,265.99$ \\
\hline
\end{tabular}

This table shows the great and rapidly increasing importance of the smoking-tobacco business of the Combination. From sales of $47,278,195$ pounds in 1899 , worth $\$ 9,970,778.54$, there has been an increase in every year until in 1907 the sales were $97,985,744$ pounds, of a net value, excluding tax, of $\$ 29,461,251.28$. The sales thus substantially doubled, while the net value substantially trebled. The profit has increased even more markedly. From $\$ 1,320,738.26$ it rose to $\$ 9,105,265.99$, each year showing an increase over the preceding. The profits in 1907 were thus about seven times as much as in 1899 .

The increase in the quantity of sales has been in part due to the acquisition of additional concerns by the Combination, but to a large extent to the increased demand for smoking tobacco and the building up of the business already possessed by the Combination.

Table 51 shows the average prices, costs, and profits for the entire smoking-tobacco business of the American, Continental, and Lorillard companies and the principal subsidiary companies combined. This information is shown graphically in diagram 2, accompanying Table 42. 
TABLE 51.-Smoking tobacco-Prices, costs, and profits of the Tobacco Combination.

\begin{tabular}{|c|c|c|c|c|c|c|c|c|}
\hline \multirow[b]{2}{*}{ Year. } & \multirow[b]{2}{*}{ Sales. } & \multicolumn{3}{|c|}{ Price (per pound). } & \multicolumn{3}{|c|}{ Cost (per pound). } & \multirow{2}{*}{$\begin{array}{c}\text { Profit } \\
\text { (per } \\
\text { pound) }\end{array}$} \\
\hline & & $\mid \begin{array}{c}\text { Including } \\
\operatorname{tax} .\end{array}$ & Tax. & $\begin{array}{l}\text { Exclud- } \\
\text { ing tax. }\end{array}$ & $\begin{array}{l}\text { Mianufac- } \\
\text { ture and } \\
\text { freight. }\end{array}$ & Sale. & Total. & \\
\hline & Pounds. & Cents. & Cents. & $\begin{array}{l}\text { Cents. } \\
21.1\end{array}$ & $\begin{array}{c}\text { Cents. } \\
14.2\end{array}$ & $\begin{array}{l}\text { Cents. } \\
\quad 4.1\end{array}$ & $\begin{array}{r}\text { Cents. } \\
18.3\end{array}$ & $\begin{array}{r}\text { Cents. } \\
2.8\end{array}$ \\
\hline $\begin{array}{l}1899 . . \\
1900 \ldots\end{array}$ & $56,886,232$ & $\begin{array}{l}33.1 \\
34.8\end{array}$ & 12.0 & 22.8 & 14.5 & 3.8 & 18.3 & 4. 5 \\
\hline $1901 .$. & $59,516,622$ & 35.3 & 10.8 & 24.5 & 14.8 & 3.9 & 18.7 & 5.8 \\
\hline $1902 .$. & $73,504, C 83$ & 34.5 & 7.8 & 26.7 & 15.2 & 4.7 & 19.9 & 6.8 \\
\hline $1903 .$. & $82,474,583$ & 33.9 & 6.0 & 27.9 & 15.5 & 6.2 & 21.7 & 6.2 \\
\hline 1904 & $86,747,556$ & 35.4 & 6.0 & 29.4 & 16.5 & 5.8 & 22.3 & 7.1 \\
\hline 1905. & $93,357,544$ & 34.4 & 6.0 & 28.4 & 16.2 & 3.9 & 20.1 & 8.3 \\
\hline $1906 .$. & $97,045,065$ & 35.3 & 6.0 & 29.3 & 16.6 & 3.7 & 20.3 & 9.0 \\
\hline $1907 \ldots$ & $9 \bar{\imath}, 98 \overline{5}, 744$ & 36.1 & 6.0 & 30.1 & 18.0 & 2.8 & 20.8 & $9.3^{3}+x-1$ \\
\hline
\end{tabular}

The table shows in a striking manner that the marked reduction in the internal-revenue tax has brought no corresponding change in the average price of smoking tobacco received by the Combination. During the first year, 1899, the average price, including tax, was 33.1 cents, the tax 12 cents, and the net price, less tax, 21.1 cents. In 1907 the average price was 36.1 cents, an increase of 3 cents; and the tax had fallen 6 cents, so that the net price, less tax, was 30.1 cents, or 9 cents higher than in 1899 .

Considering more in detail the changes, it will be seen that there was a considerable increase in the price from 1899 to 1900, and a still further increase in 1901, notwithstanding the reduction in the tax which took place on July 1 of that year. In 1902, with a still lower rate of tax, there was some decline in the net price, including tax, but this decline was less than that in the tax, so that the net price, excluding tax, rose from 24.5 cents in 1901 to 26.7 cents in 1902 . The price fell slightly in 1903 , but not to the extent of the reduction in the tax, so that there was a further increase of 1.2 cents in the net price, excluding tax. In each year since 1903 the price has been somewhat higher than in that year.

There has also been some increase in the cost of doing business, but this increase has been much less than that in the net price, excluding tax. The cost of manufacture, including freight, has on the whole tended steadily upward, largely because of an increase in the price of leaf tobacco and other materials. For the three years 1904 to 1906 it was about 2 cents higher than in 1899 and 1900 . The cost of 1907 advanced still more, and was 3.8 cents higher than in 1899. The changes in the expenses of selling and advertising are very striking. It will be noted that about the time of the reduction in the internal-revenue taxes in 1901 and 1902 there was a decided increase in selling expenses. The Combination appears to have judged it wise policy to keep up its selling prices, but to maintain its output by extensive advertising and vigorous methods of pushing sales. The cost of selling consequently increased from 3.8 cents per pound in 1900 to 6.2 cents in 1903, the latter being the first full year of the present rate of tax. After that, however, the Combination was able to 
reduce its selling and advertising expenses, presumably, in part, at least, because of the increased popularity of brands resulting from such advertising, but apparently in part also because of the increased degree of control which it possessed over the output of the country. Year by year the selling expenses fell off, until in 1907 they avelaged 2.8 cents, or less than one-half as much as in 1903 . Because of this reduction in expense of selling, the total cost of doing business has been lower in the last three years covered by the table than it was in 1903 and 1904, notwithstanding the increase in the cost of manufacture and freight. Nevertheless, the total cost during the more recent years is somewhat higher than during the years 1899 to 1901 , so that the profits have not increased as much as the net selling price, less tax.

The table shows, however, that, with the single exception of 1903 , the profits have increased in each year, and that in 1907 they averaged about three and one-half times as much as in 1899, 9.3 cents, as compared with 2.8 cents per pound.

The Combination, therefore, has been able very greatly to expand its sales of smoking tobacco, while at the same time maintaining and even increasing its prices in the face of a reduction of the internalrevenue tax; and, despite some increase in the cost of doing business, its profits have very greatly increased. The profit of 1907 was 6.5 cents per pound higher than in 1899 , this difference in profit exceeding slightly the difference in the internal-revenue tax as between the two years.

PRICES, COSTS, AND PROFITS OF INDIVIDUAL BRANDS OF SMOKING TOBACCO MADE BY THE AMERICAN, CONTINENTAL, AND LORILLARD COMPANIES.

The increase in the average price, less tax, and in the average profit for the entire smoking-tobacco business of the American, Continental, and Lorillard companies, as well as for the entire smoking-tobacco business of the Tobacco Combination, as a whole, is chiefly due to an increase in the price and profit on most of the individual brands, although to some extent it is due to a relative increase in the sales of the higher priced and more profitable brands. As an illustration of the influence of changes in the relative proportion of more profitable and less profitable brands may be mentioned the fact that the sales of the Blackwell's Durham Tobacco Company have increased more rapidly than the total sales of other concerns in the Combination, about 150 per cent as compared with 80 per cent between 1900 and 1907 . This company sells practically only one brand, Bull Durham, which is a very high-priced brand commanding a high profit. Consequently, while the increase in the profit of Blackwell's Durham itself is one of the elements entering into the increase in the average profit on the entire output of the Tobacco Combination, the relatively greater increase in sales of this high-profit brand has tended still further to increase the arerage. An examination of the figures for a large number of individual brands made by the American, Continental, and Lorillard companies goes to show, however, that the increase in the profit on the smoking tobacco business is very largely due to an increase in the net price, less tax. In a great majority of the brands there was no reduction in the price at the time the internal-revenue tax was reduced in 1901 and 1902 , 
and for a large proportion of the brands the price, including tax, was higher in 1907 than it had been during the war-revenue period, lthough the tax was only 6 cents in the later years as compared with 12 cents in the earlier.

The smoking-tobacco business of the American Tobacco Company alls in to three classes, namely, plug cut, long cut, and granulated. These three classes are, roughly, of equal importance. Each includes orands differing considerably from one another in price, but the average price for the entire output of each class is approximately similar.

Plug-cut brands.--Table 52 shows the net price, including and excluding tax, the cost, and the profit for nine individual brands of smoking tobacco manufactured by the American, Continental, and Lorillard companies. Brands made by subsidiary concerns are not herein included. For convenience, the rate of tax is also indicated year by year, and the years and half years grouped according to the rate in force. The movement of the prices, costs, and profits may be clearly seen from the accompanying diagrams.

TABLE 52.-Plug-cut smoking tobacco-American, Continental, and Lorillard companies: Prices, costs, and profits for leading individual brands.

\begin{tabular}{|c|c|c|c|c|c|c|c|c|c|}
\hline \multirow{3}{*}{ Period. } & \multirow{3}{*}{$\begin{array}{c}\text { Tax } \\
\text { (per } \\
\text { pound). }\end{array}$} & \multicolumn{4}{|c|}{ Brand No. 1 (per pound). } & \multicolumn{4}{|c|}{ Brand No. 2 (per pound). } \\
\hline & & \multicolumn{2}{|c|}{ Price. } & \multirow[b]{2}{*}{ Cost. } & \multirow[b]{2}{*}{ Profit. } & \multicolumn{2}{|c|}{ Price. } & \multirow[b]{2}{*}{ Cost. } & \multirow[b]{2}{*}{ Profit. } \\
\hline & & $\begin{array}{c}\text { Including } \\
\text { tax. }\end{array}$ & $\begin{array}{l}\text { Exclud- } \\
\text { ing tax. }\end{array}$ & & & $\begin{array}{c}\text { Including } \\
\text { tax. }\end{array}$ & $\begin{array}{l}\text { Exclud- } \\
\text { ing tax. }\end{array}$ & & \\
\hline 1901 (firsthalf) .... & $\begin{array}{r}\text { Cents. } \\
12.0\end{array}$ & $\begin{array}{l}\text { Cents. } \\
\quad 35.2\end{array}$ & $\begin{array}{l}\text { Cents. } \\
23.2\end{array}$ & $\begin{array}{r}\text { Cents. } \\
18.9\end{array}$ & $\begin{array}{r}\text { Cents. } \\
4.3\end{array}$ & $\begin{array}{r}\text { Cents. } \\
35.1\end{array}$ & $\begin{array}{l}\text { Cents. } \\
23.1\end{array}$ & $\begin{array}{r}\text { Cents. } \\
20.2\end{array}$ & $\begin{array}{r}\text { Cents. } \\
2.9\end{array}$ \\
\hline 1901 (second half) & 9.6 & 35.7 & 26.1 & 21.5 & 4. 6 & 34.0 & 24.4 & 17.7 & 6.7 \\
\hline 1902 (first half) ..... & 9.6 & 36.0 & 26.4 & 20.1 & 6.3 & 35.0 & 25.4 & 18.6 & 6.8 \\
\hline 1902 (second half)... & 6.0 & 35.0 & 29.0 & 23.8 & 5.2 & 33.5 & 27.5 & 19.9 & 7.6 \\
\hline $1903 \ldots \ldots$. & 6.0 & 35.3 & 29.3 & 24.9 & 4.4 & 35.2 & 29.2 & 19.5 & 9.7 \\
\hline 1904. & 6.0 & 35.6 & 29.6 & 21.5 & 8.1 & $3 \bar{\imath} .2$ & 31.2 & 24.6 & 6.6 \\
\hline $1905 \ldots$ & 6.0 & 35.8 & 29.8 & 19.1 & 10.7 & 36.3 & 30.3 & 190 & 11.3 \\
\hline $1906 .$. & 6.0 & 36.0 & 30.0 & 18.9 & 11.1 & 36.5 & 30.5 & 19. 0 & 11.5 \\
\hline $1907 \ldots$ & 6.0 & 35.9 & 29.9 & 19.1 & 10.8 & 36.5 & 30.5 & 19.2 & 11.3 \\
\hline \multirow{3}{*}{ Period. } & \multirow{3}{*}{$\begin{array}{c}\text { Tax } \\
\text { (per } \\
\text { pound) }\end{array}$} & \multicolumn{4}{|c|}{ Brand No. 3 (per pound). } & \multicolumn{4}{|c|}{ Brand No. 4 (per pound). } \\
\hline & & \multicolumn{2}{|c|}{ Price. } & \multirow{2}{*}{ Cost. } & \multirow[b]{2}{*}{ Profit. } & \multicolumn{2}{|c|}{ Price. } & \multirow[b]{2}{*}{ Cost. } & \multirow[b]{2}{*}{ Profit. } \\
\hline & & $\begin{array}{c}\text { Including } \\
\text { tax. }\end{array}$ & $\begin{array}{l}\text { Exclud- } \\
\text { ing tax. }\end{array}$ & & & $\begin{array}{c}\text { Including } \\
\text { tax. }\end{array}$ & $\begin{array}{l}\text { Exclud- } \\
\text { ing tax. }\end{array}$ & & \\
\hline 1901 (first half)... & $\begin{array}{r}\text { Cents. } \\
12.0\end{array}$ & $\begin{array}{l}\text { Cents. } \\
\quad 34.2\end{array}$ & $\begin{array}{l}\text { Cents. } \\
\quad 22.2\end{array}$ & $\begin{array}{r}\text { Cents. } \\
18.3\end{array}$ & $\begin{array}{r}\text { Cents. } \\
3.9\end{array}$ & $\begin{array}{l}\text { Cents. } \\
\ldots \ldots . . .\end{array}$ & Cents. & $\begin{array}{l}\text { Cents. } \\
\ldots \ldots . .\end{array}$ & $\begin{array}{l}\text { Cents. } \\
\ldots . . . .\end{array}$ \\
\hline 1901 (second half). & 9.6 & 34.2 & 24.6 & 18.3 & 6.3 & 25.2 & 15.6 & 15.0 & 0.6 \\
\hline 1902 (first half).... & 9.6 & 34.8 & 25.2 & 18. 8 & 6.4 & 24.8 & 15.2 & 13.8 & 1.4 \\
\hline 1902 (second half).. & 6.0 & 34.3 & 28.3 & 22.6 & 5.7 & 23.3 & 17.3 & 16.2 & 1. 1 \\
\hline $1903 \ldots . . .$. & 6.0 & 35.0 & 29.0 & 19.7 & 9.3 & 24.7 & 18.7 & 13. 9 & 4.8 \\
\hline $1904 \ldots$. & 6.0 & 34.0 & 28.0 & 24.8 & 3.2 & 25.0 & 19.0 & 14.3 & 4.7 \\
\hline $1905 \ldots$ & 6.0 & 33.5 & 27.5 & 20.4 & 7.1 & 24.4 & 18.4 & 13.4 & 5.0 \\
\hline $1906 \ldots$ & 6.0 & 34.0 & 28.0 & 19.0 & 9.0 & 24.9 & 18.9 & 13.5 & 5.4 \\
\hline $1907 .$. & 6.0 & 34.0 & 28.0 & 19.5 & 8.5 & 25.7 & 19.7 & 14. 2 & 5.5 \\
\hline
\end{tabular}


TABLE 52.-Plug-cut smoking tobacco-American, Continental, and Lorillard com. panies: Prices, costs, and profits for leading individual brands-Continued.

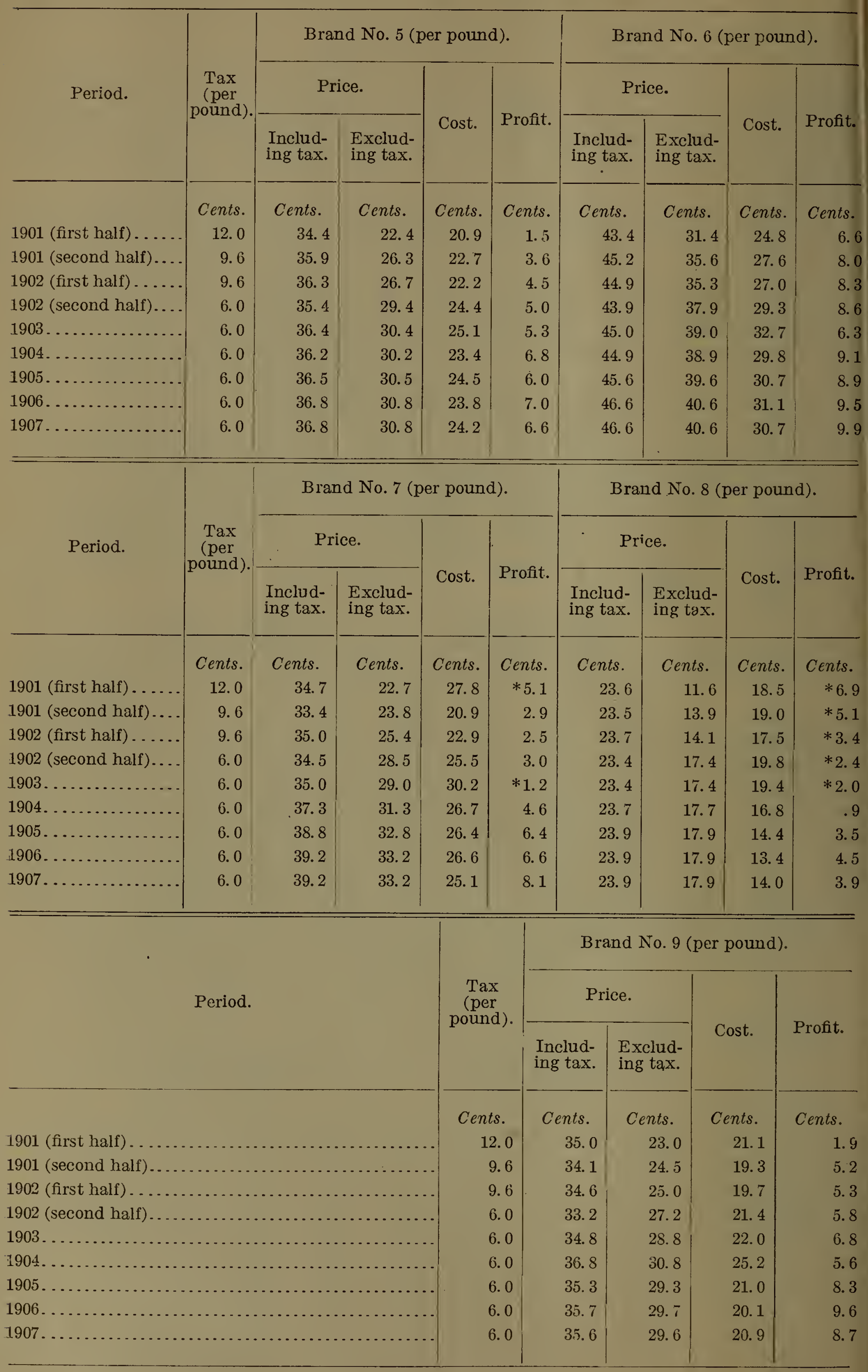

*Loss. 

Diagram 4-No. 1.

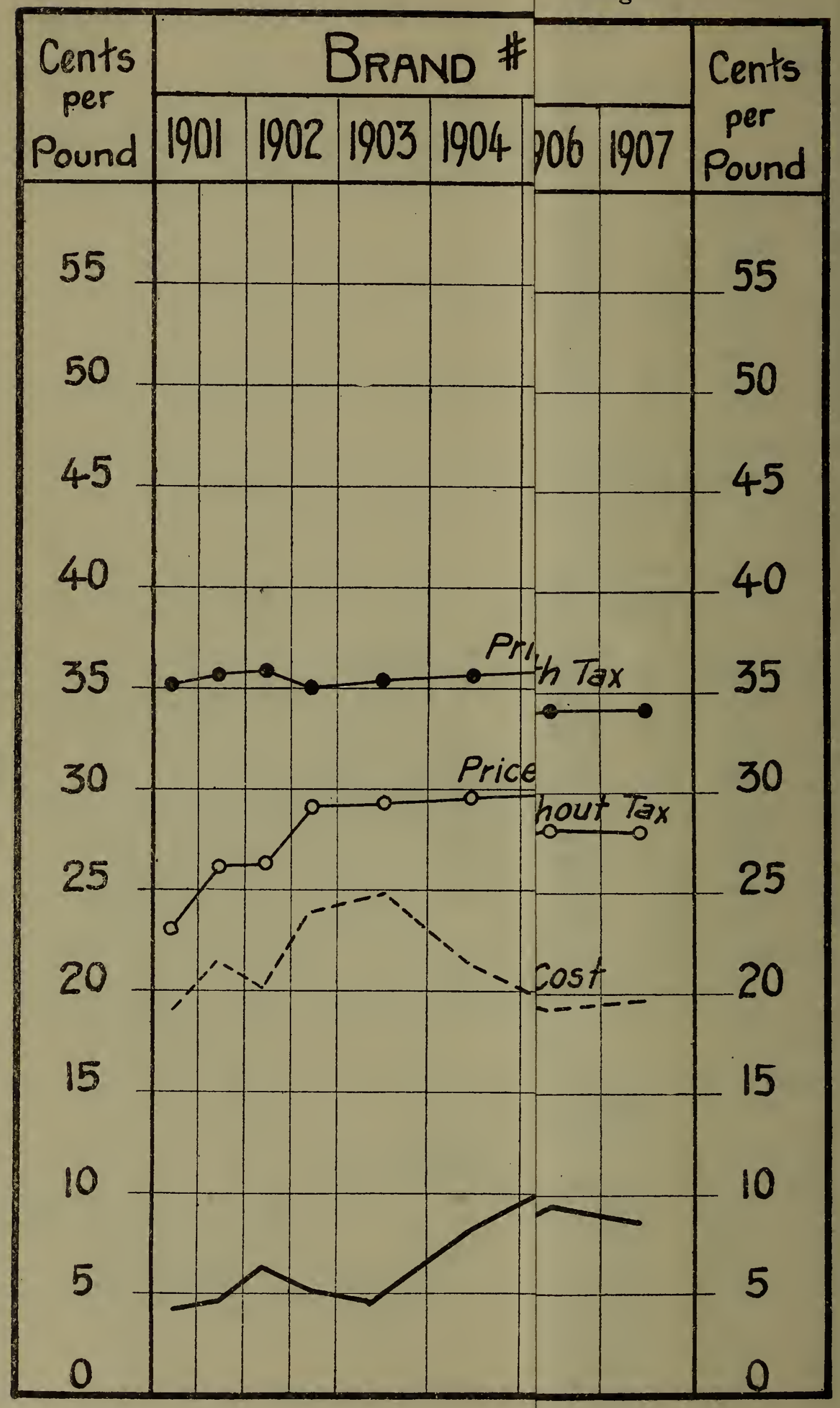


| 
PLUG CUT SMIOKING TOBACCO.

ANERICAN, CONTINENTAL, AND LORILLARD COMPANIES.

Prices, Costs, and Profits of Leading Individual Brands.

Diagram 4-No. 1

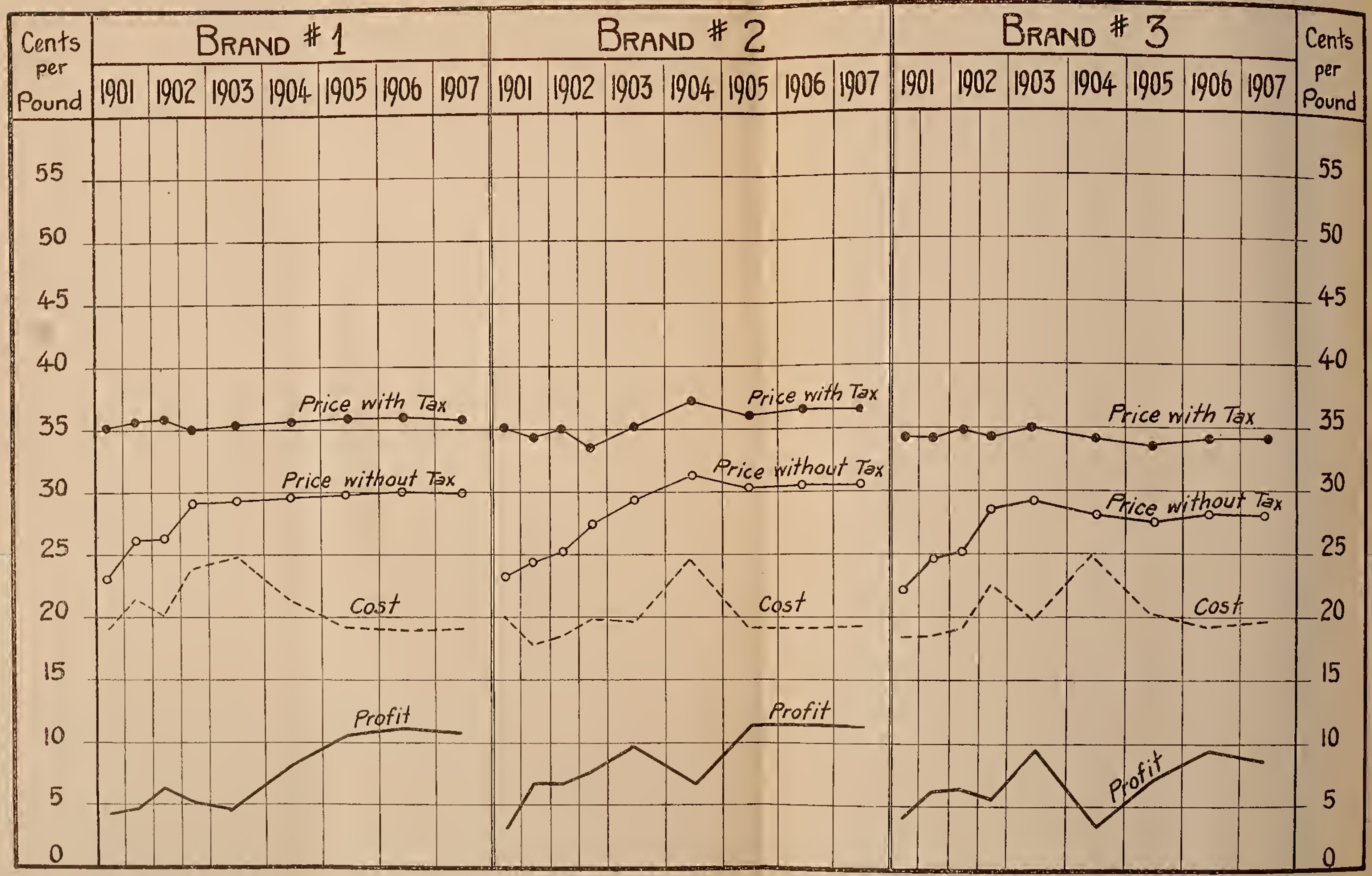




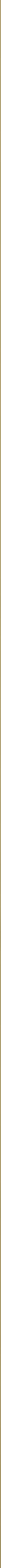


PLC

Diagram 4-No. 2.

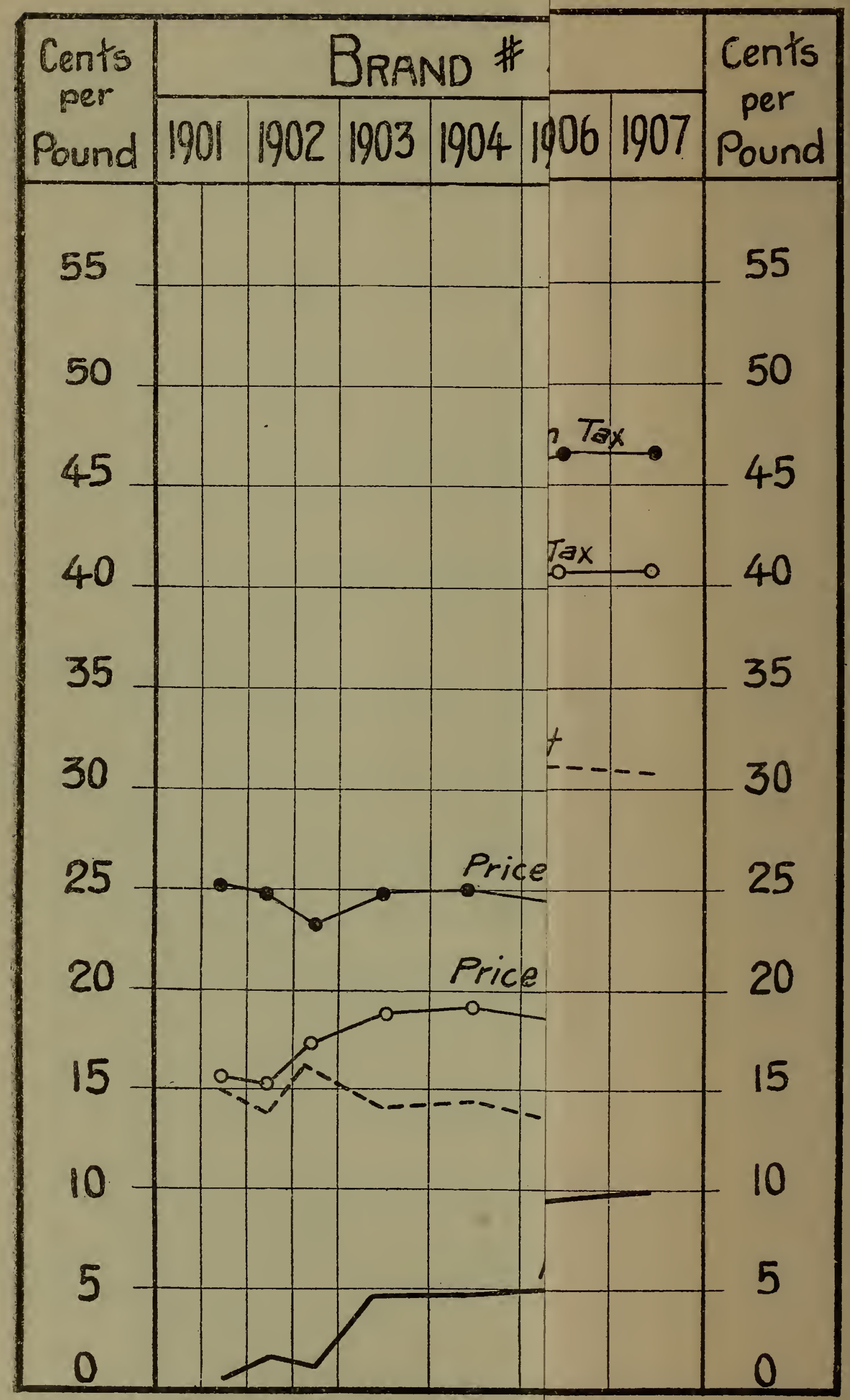




\section{Po dhend}


Dingram 4-No. 2

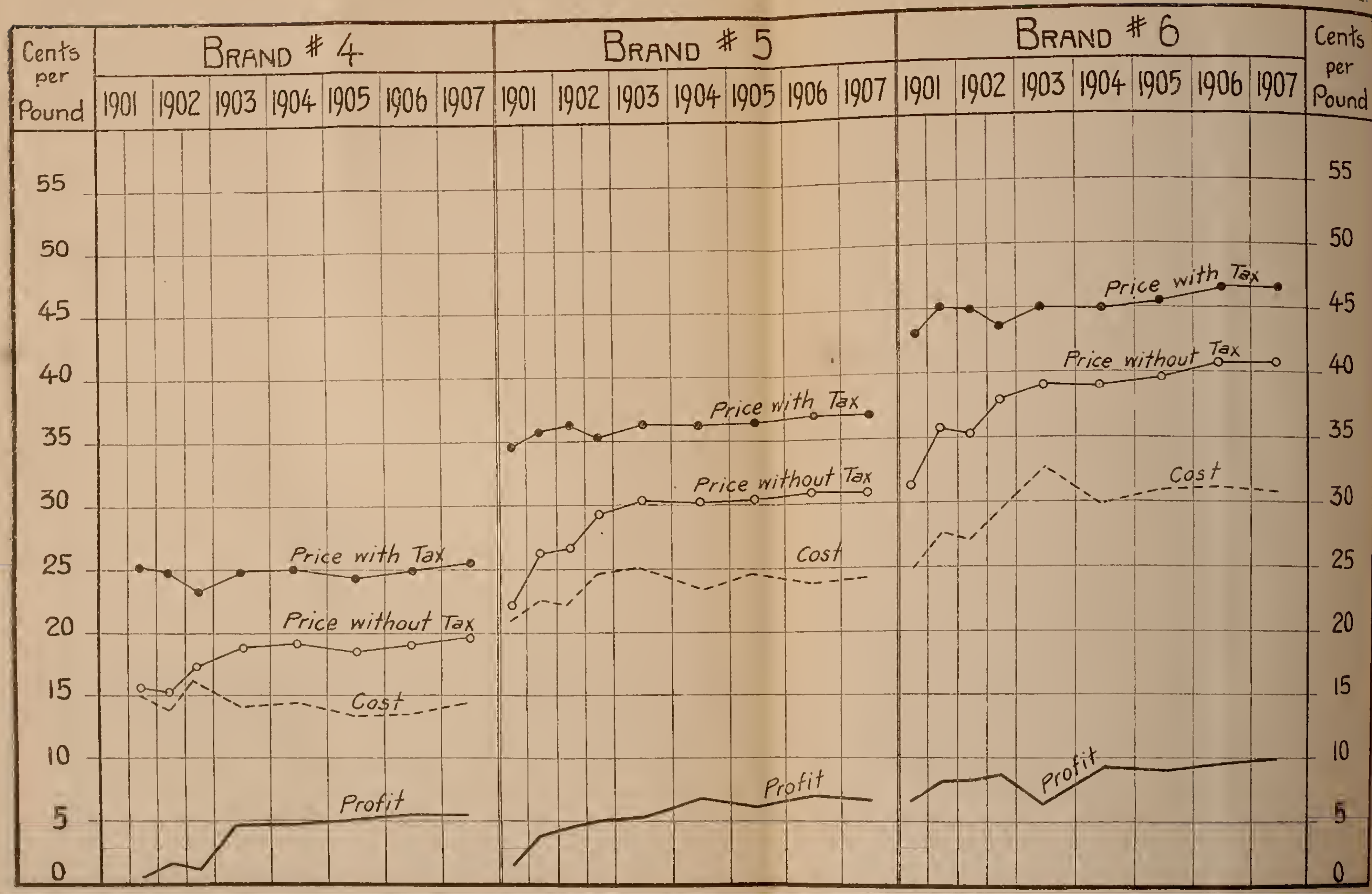




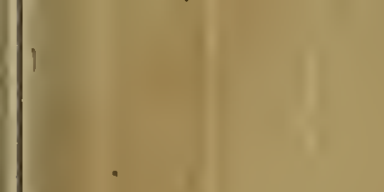

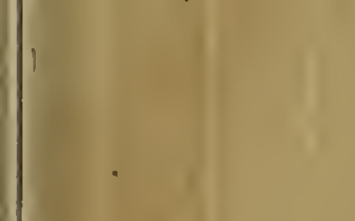
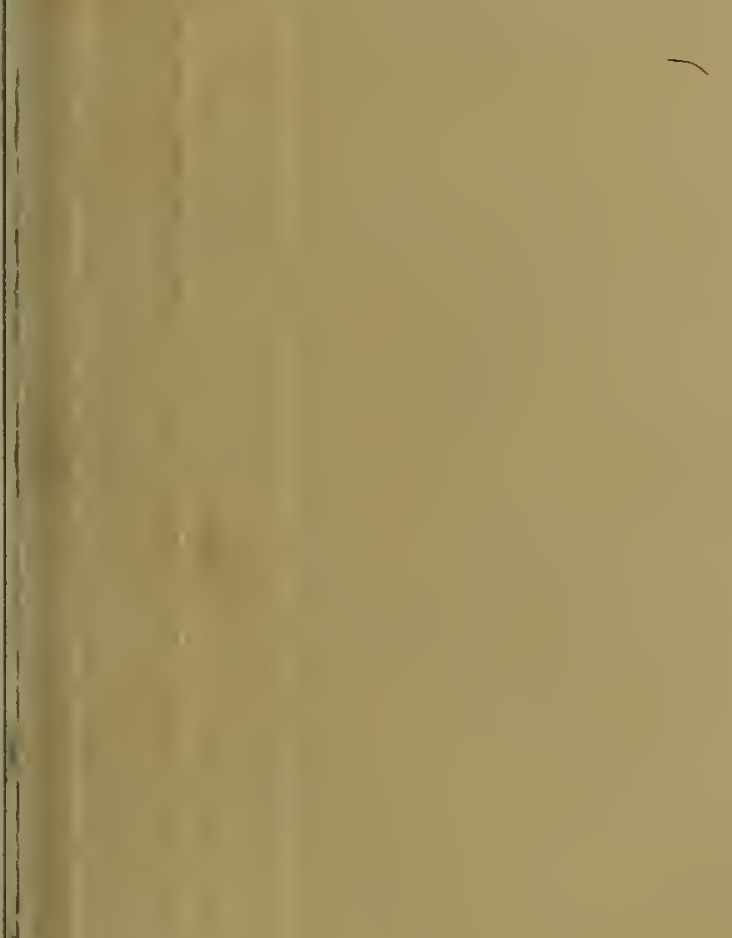
PLU

Diagram 4-No. 3.

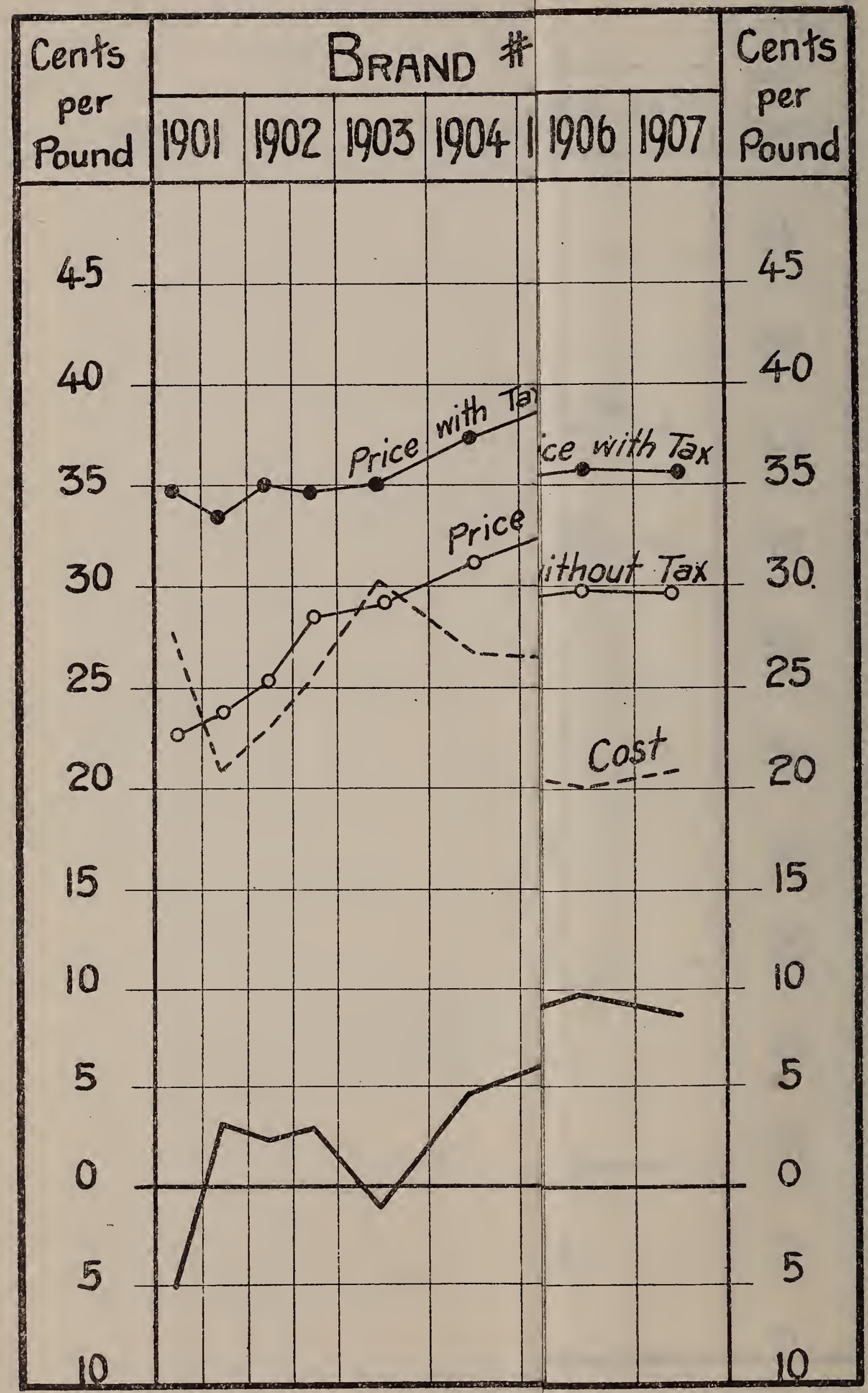


It will be seen from this table and diagram that there was practically no change in the price of the leading brands of plug-cut tobacco made by these companies when the internal-revenue tax was reduced from 12 cents in 1901 to 6 cents on July 1, 1902. In a few cases there was a temporary reduction of one or two cents in the price, but in all cases (excepting brands $S$ and 9) the average price for 1903 was at least as high as during the first half of 1901, notwithstanding the reduction of 6 cents in the tax. In the case of brands 5 and 6 the price in 1903 was in fact considerably higher than in the first half of 1901. Of course, the net price, less tax, therefore, increased for each brand (excepting brands 8 and 9) 6 cents or more per pound from the first half of 1901 up until 1903.

Several of the brands show a further increase in price in 1904. In no case has there been any appreciable reduction since 1903. In every case but one the price, including tax, in 1907 was at least as high as in 1901, notwithstanding the reduction of 6 cents in the internal-revenue tax; and in two or three cases (brands 5, 6, and 7) the price was distinctly higher in 1907 than in 1901. The net price, less tax, therefore, for all the brands but one was 6 cents or more higher in 1907 than in 1901.

It might seem, however, from an examination of the figures of cost shown in the table and diagrams that the policy of the American, Continental, and Lorillard companies in maintaining their prices from 1901 to 1903 or 1904, despite the reduction in tax (that is, in increasing their net price, less tax), was justified by the increase in costs. At least six of the nine brands of plug-cut tobacco show an increase in cost between 1901 and 1903 or 1904 ranging from 4 cents to 7 cents per pound. To some extent this increase in cost was unavoidable and due to an increase in the price of leáf tobacco. To quite as great an extent, however, and in some cases almost wholly, the increase in the aggregate cost during this period was due to a great expansion of advertising expenses, particularly in the form of premium schemes, gratis goods, and the like, the combination apparently judging it wise policy, instead of reducing its prices when the tax was reduced, to use every effort by large expenditures for advertising and pushing the sale of goods to maintain its output without reducing prices and so to strengthen the popularity of its brands as to promote a continuance of the high prices for the future.

The result of this policy of expansion of advertising expenses at the very time when the war taxes were taken off was in fact to maintain the volume of output of the leading brands, and ultimately the combination was able again to reduce its selling and advertising expenses without material loss of output. The table and diagrams show that for six of the nine brands of plug tobacco (all except 4, 5, and 6) there was a decided decrease in the total cost of manufacture and sale from 1903 or 1904 to 1907, while the cost for brands 4, 5, and 6 remained substantially constant. There was, in general, an increase in the cost of leaf tobacco during this period so that the reduction in the total cost, or the absence of an advance in the total cost, was, in most cases, wholly due to reduction in selling and advertising expenses. It will be seen by comparing the costs of 1907 with those of 1901 that in most of the cases there was little difference, although for two of the brands (5 and 6) the costs were distinctly higher in the later year 
Diagram 4-No.3.

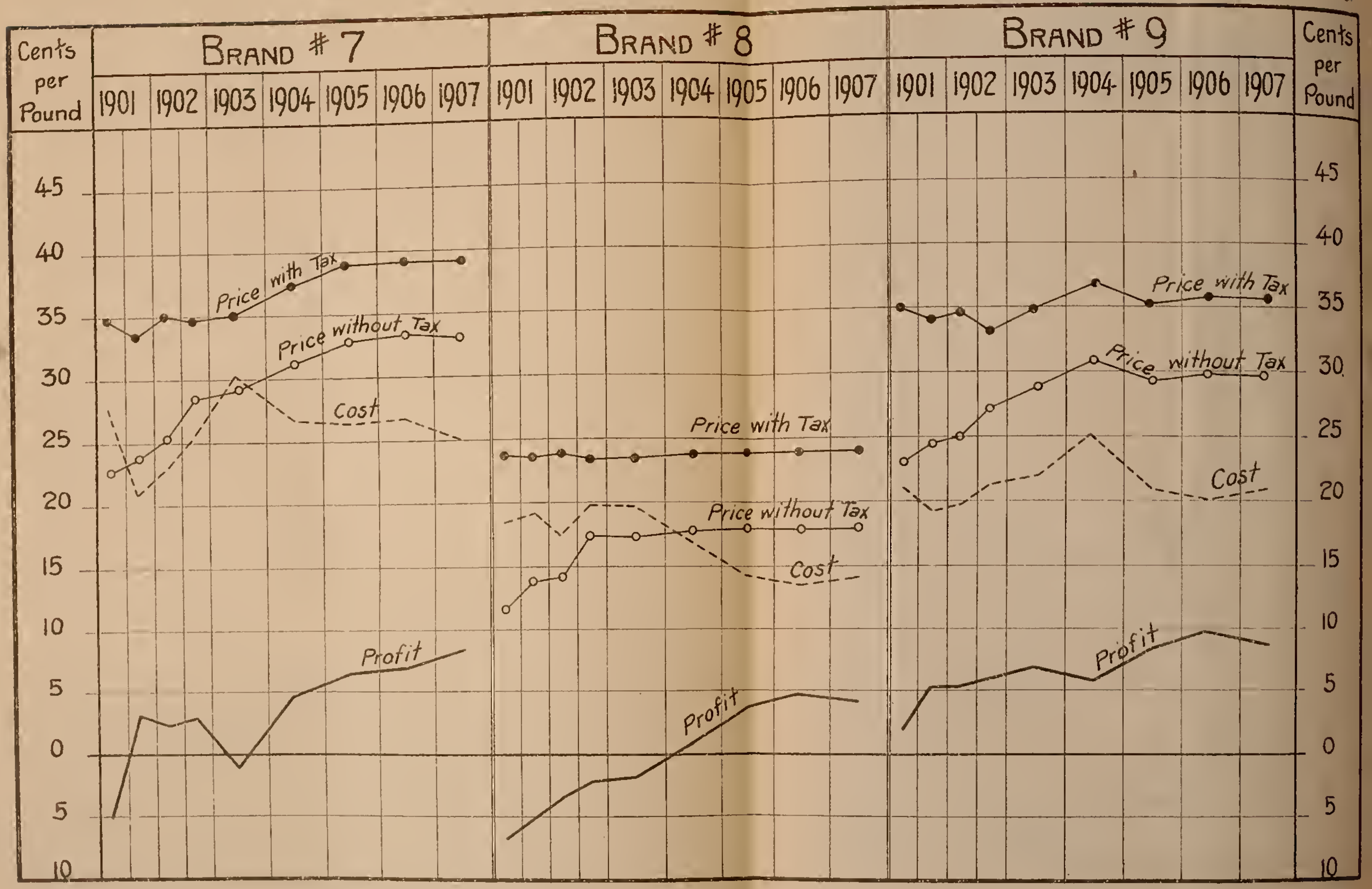




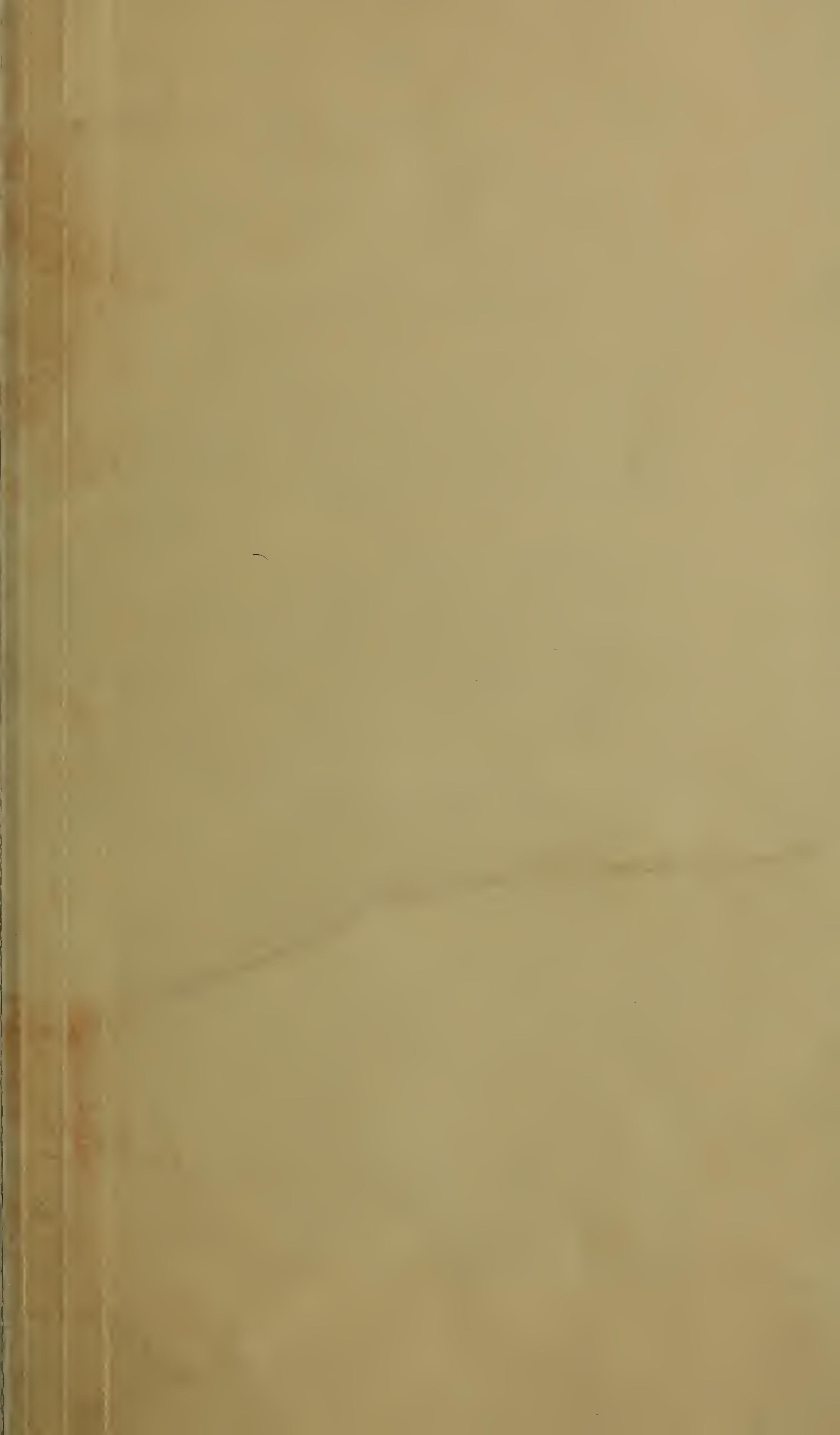


than in the earlier, while for brand 8 they were lower. Leaf, however, constituted a larger proportion of the total costs in 1907 than in 1901.

As the result of the increase in the net price, less tax, from 1901 to 1903, which exceeded the increase in cost for most of the brands, there was a very considerable increase in the profit on nearly all of the brands at this time. For several of the brands there was a decrease in profit in 1904, owing chiefly to an increase in advertising expenses, but the reduction in those expenses in 1905 restored the profit. Nearly all of the brands show an increase of 5 cents per pound or more in profit in 1906 as compared with 1901, and two of the brands (7 and 8 , the latter being a brand of considerable and increasing importance) show an increase of over 10 cents per pound in profit. Brand No. 8, however, had been sold at a loss during the earlier years and is still less profitable than some of the other brands. It will be seen that at the present time all the brands, except No. 8, are sold at a profit of 5 cents per pound or more, and that brands 1 and 2, the latter being an important brand, are sold at a profit of 10 cents or more, while brands 6 and 9 , which are important brands, command a profit of nearly 10 cents.

Long-cut tobacco.- Table 53 shows similar information regarding nine brands of long-cut tobacco made by the American, Continental, and Lorillard companies, the figures being likewise graphically presented in diagrams. It should be noted that brand No. 2 has a very small output as compared with the others.

TABLE 53.-Long-cut smoking tobacco-American, Coníinental, and Lorillard companies: Prices, costs, and profits for leading individual brands.

\begin{tabular}{|c|c|c|c|c|c|c|c|c|c|}
\hline \multirow{3}{*}{ Period. } & \multirow{3}{*}{$\begin{array}{c}\operatorname{Tax} \\
\text { (per } \\
\text { pound) }\end{array}$} & \multicolumn{4}{|c|}{ Brand No. 1 (per pound). } & \multicolumn{4}{|c|}{ Brand No. 2 (per pound). } \\
\hline & & \multicolumn{2}{|c|}{ Price. } & \multirow{2}{*}{ Cost. } & \multirow[b]{2}{*}{$\begin{array}{c}\text { Profit. } \\
\cdot\end{array}$} & \multicolumn{2}{|c|}{ Price. } & \multirow[b]{2}{*}{ Cost. } & \multirow[b]{2}{*}{ Profit. } \\
\hline & & $\begin{array}{l}\text { Includ- } \\
\text { ing tax. }\end{array}$ & $\begin{array}{l}\text { Exclud- } \\
\text { ing tax. }\end{array}$ & & & $\begin{array}{l}\text { Includ- } \\
\text { ing tax. }\end{array}$ & $\begin{array}{l}\text { Exclud- } \\
\text { ing tax. }\end{array}$ & & \\
\hline 1901 (first half).. & $\begin{array}{r}\text { Cents. } \\
12.0\end{array}$ & $\begin{array}{c}\text { Cents. } \\
\quad 34.2\end{array}$ & $\begin{array}{l}\text { Cents. } \\
\quad 22.2\end{array}$ & $\begin{array}{r}\text { Cents. } \\
14.0\end{array}$ & $\begin{array}{r}\text { Cents. } \\
8.2\end{array}$ & $\begin{array}{c}\text { Cents. } \\
52.9\end{array}$ & $\begin{array}{r}\text { Cents. } \\
40.9\end{array}$ & $\begin{array}{r}\text { Cents. } \\
24.8\end{array}$ & $\begin{array}{r}\text { Cents. } \\
\quad 16.1\end{array}$ \\
\hline 1901 (second half). & 9.6 & 33.9 & 24. 3 & 15.3 & 9.0 & 52.9 & 43.3 & 28.4 & 14.9 \\
\hline 1902 (first half).... & 9.6 & 34.1 & 24.5 & 17.7 & 6.8 & 53.0 & 43.4 & 27.0 & 16.4 \\
\hline 1902 (second half). & 6.0 & 33.6 & 27.6 & 16.5 & 11.1 & 51.0 & 45.0 & 28.9 & 16.1 \\
\hline $1903 \ldots \ldots \ldots \ldots$ & 6.0 & 34.8 & 28.8 & 16.6 & 12.2 & 49.1 & 43.1 & 30.8 & 12.3 \\
\hline $1904 \ldots$ & 6.0 & 35.5 & 29.5 & 18.4 & 11.1 & 51.1 & 45.1 & 32.3 & 12.8 \\
\hline $1905 \ldots$ & 6.0 & 35.2 & 29.2 & 16.9 & 12.3 & 51.3 & 45.3 & 32.8 & 12.5 \\
\hline $1906 \ldots$ & 6.0 & 35.3 & 29.3 & 15.2 & 14.1 & 51.7 & 45.7 & 32.3 & 13.4 \\
\hline $1907 .$. & 6.0 & 35.3 & 29.3 & 15.2 & 14.1 & 51.7 & 45.7 & 32.1 & 13.6 \\
\hline
\end{tabular}


Diagram 5-No. 1.

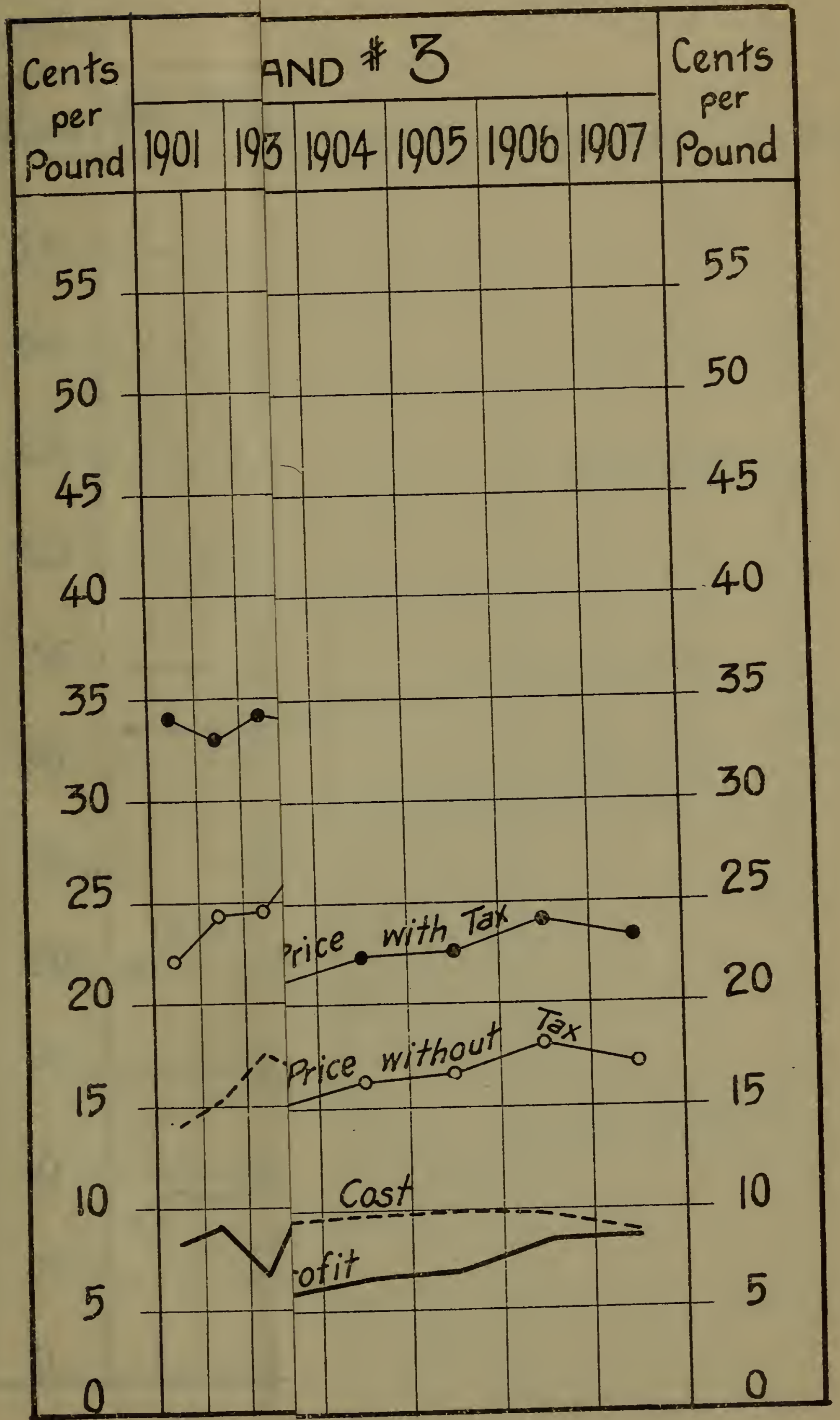



LONG CUT SMOKING TOBACCO.

AMERICAN, CONTINENTAL, AND LORILLARD COMPANIES.

Prices, Costs, and Profits of Leading Individual, Brands.

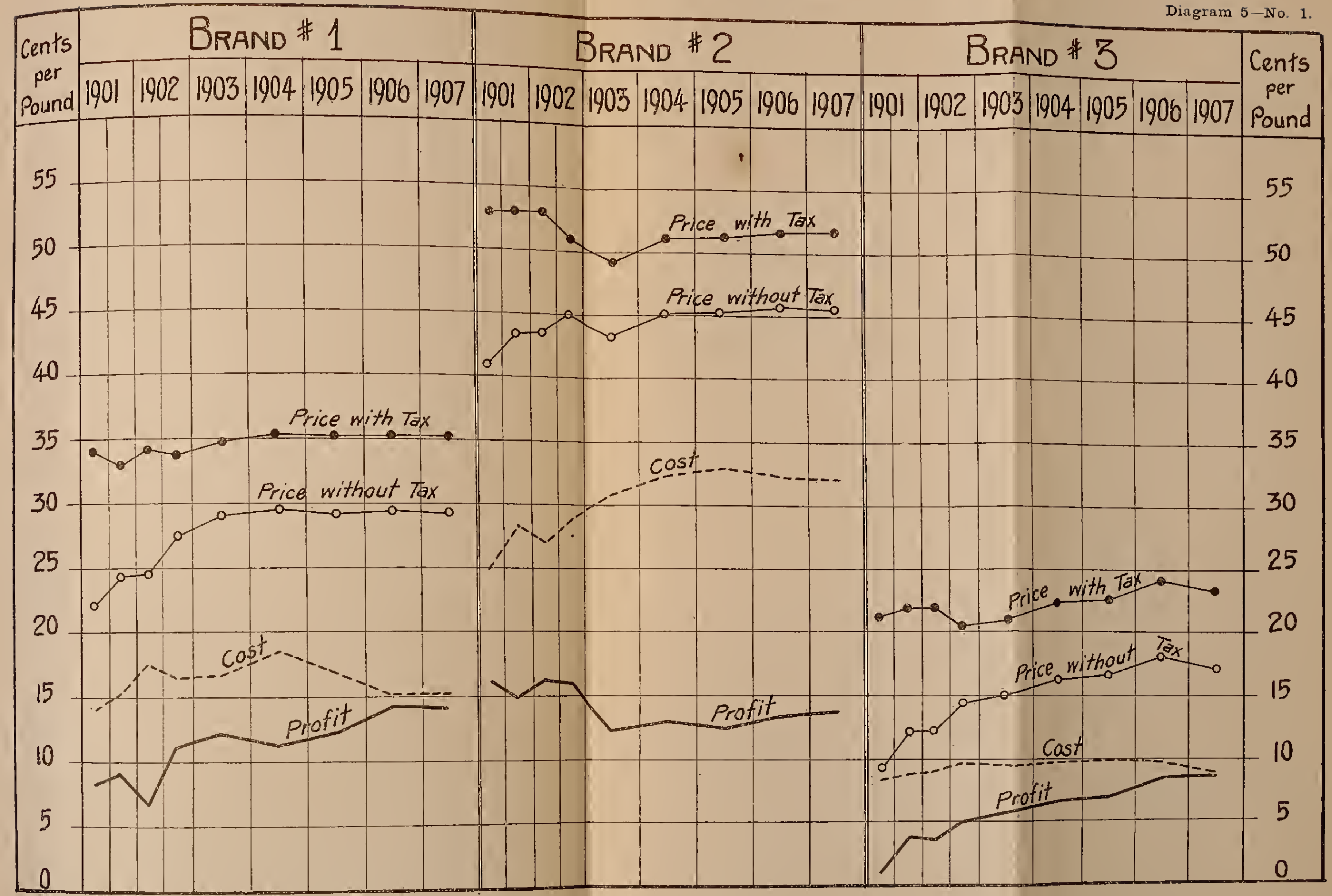




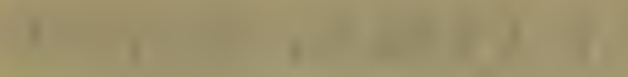

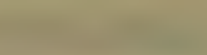

4

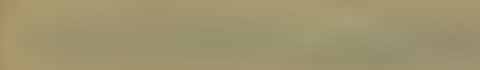

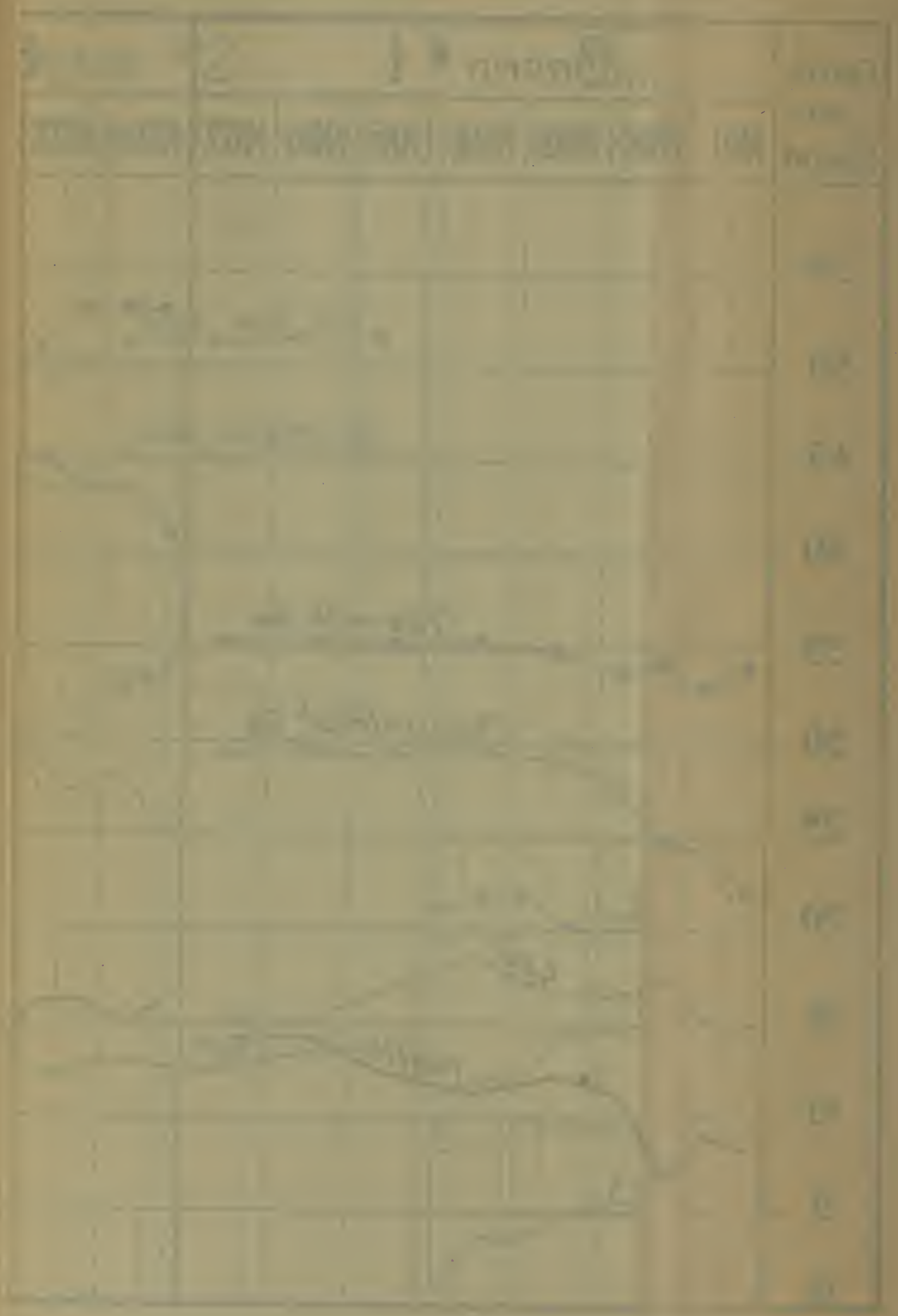


Diagram 5-No. 2.

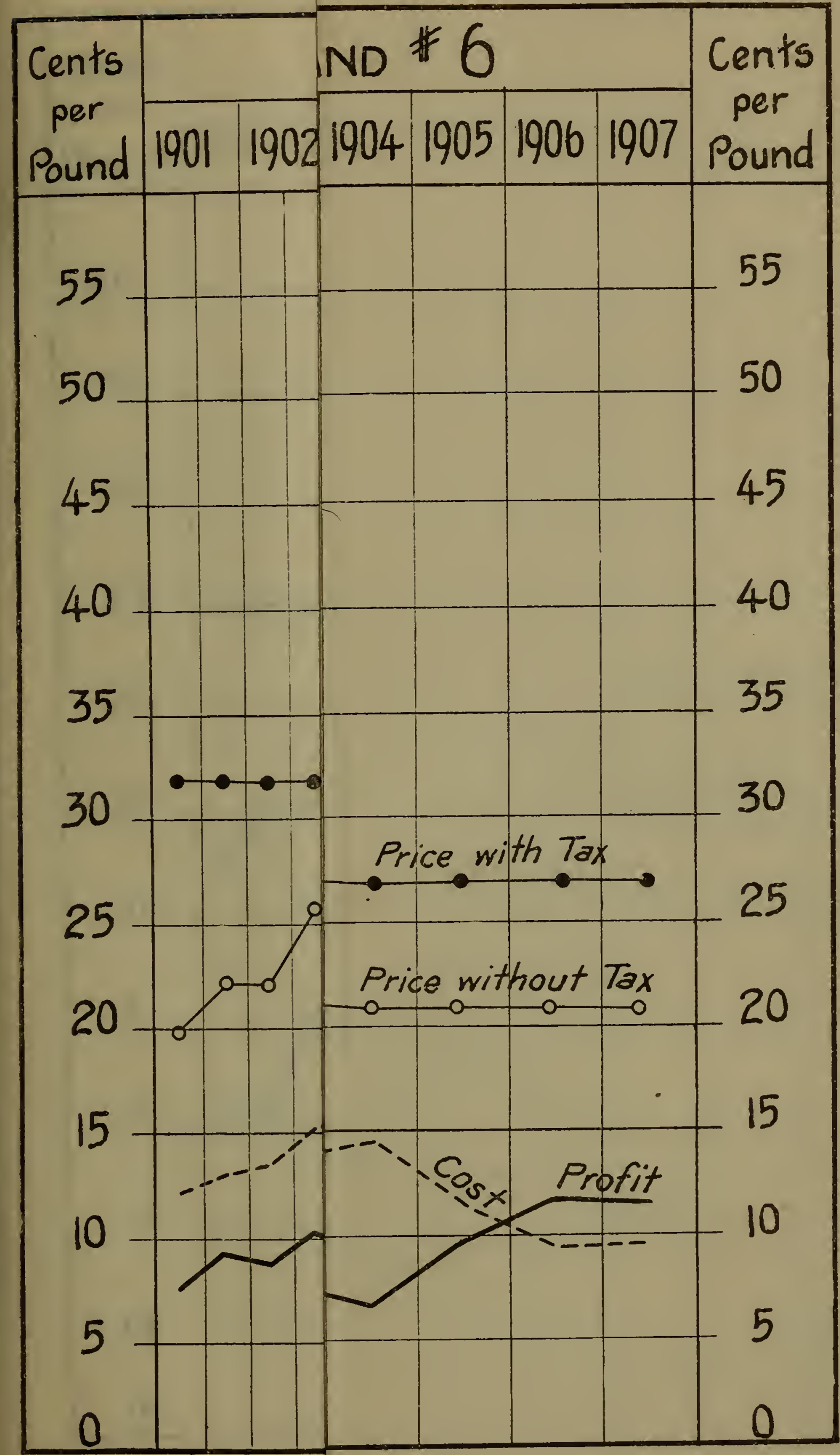





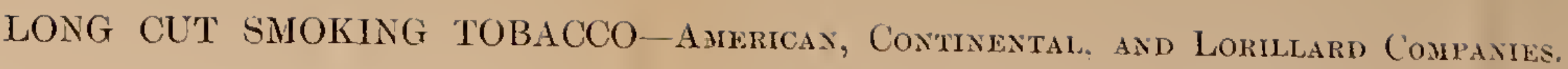

Prices, Costs, and Profits of Leading Individual, Brands-Continued.

Dingram 5-No. 2 .

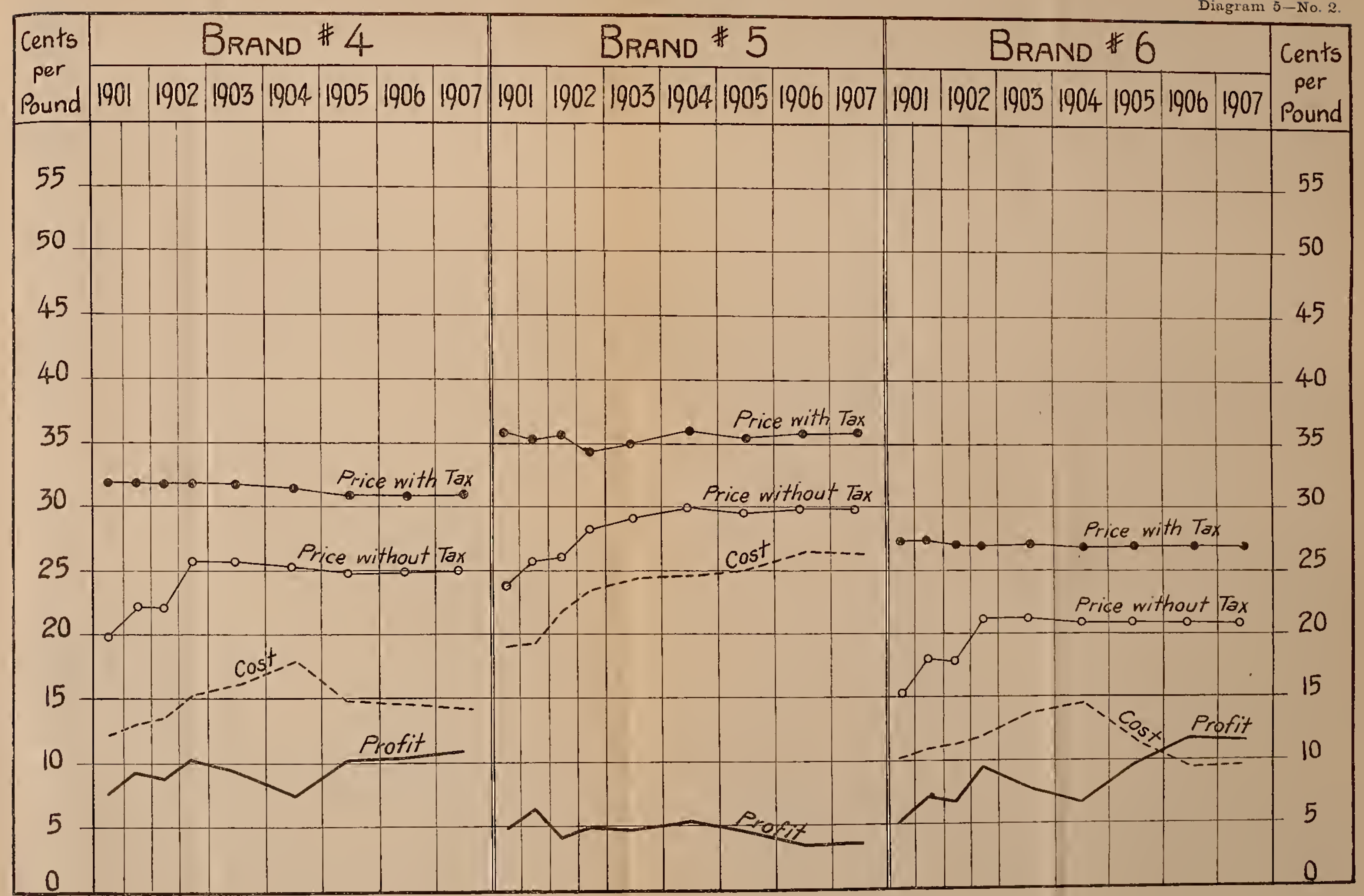




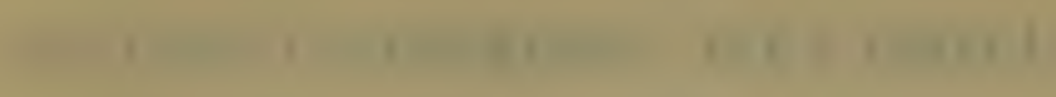

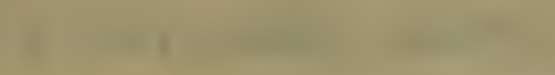

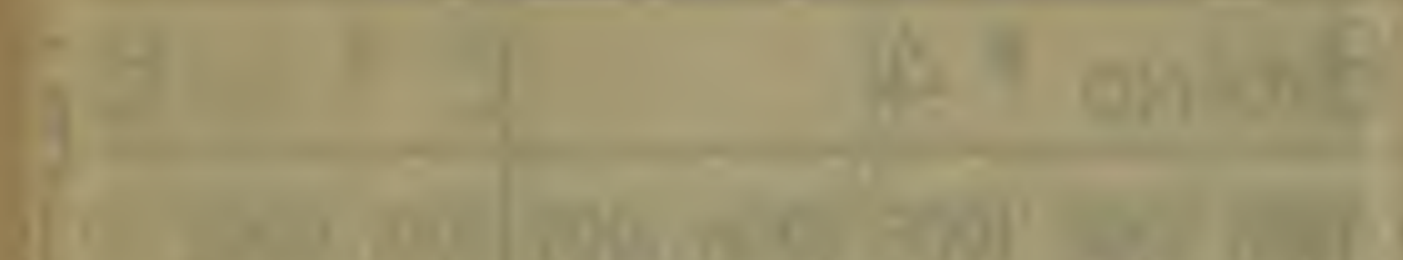

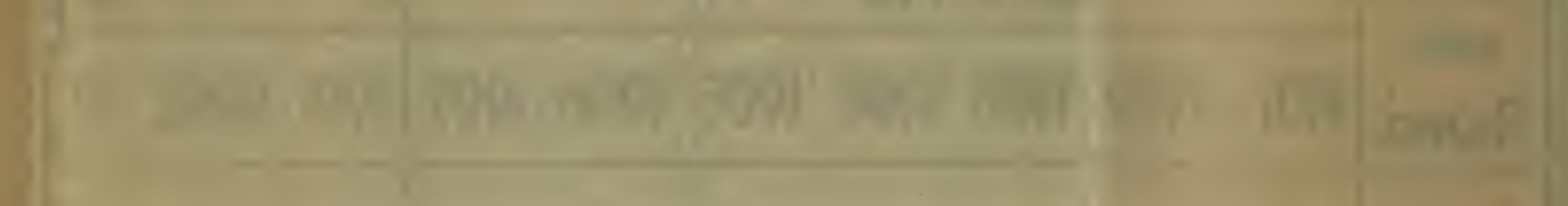

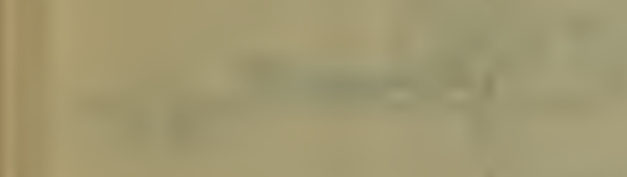

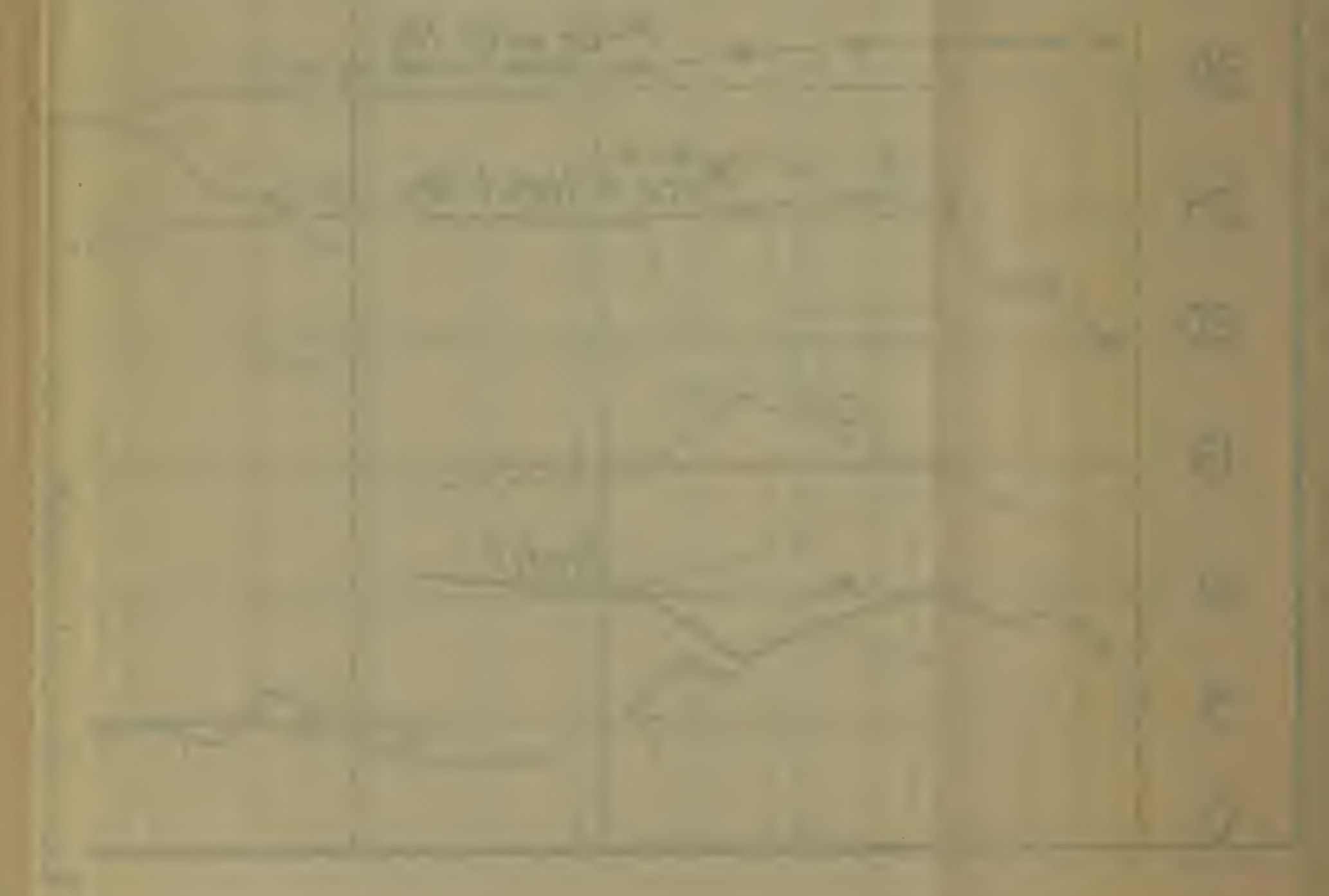


Diagram 5-No. 3.

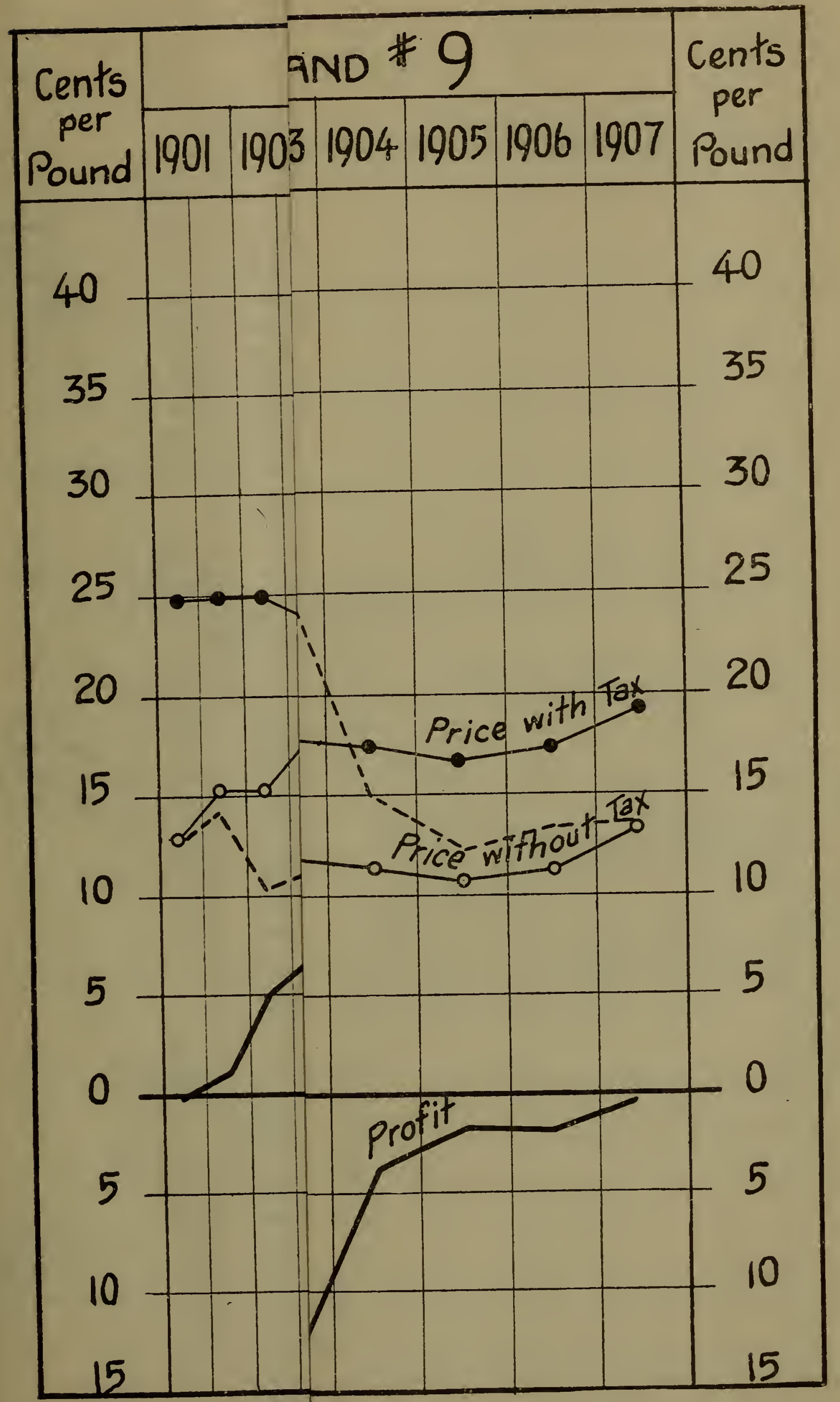



LONG CUT SMOKINit TOBACCO-American, Contmental, and Lorillard Conpanies.

Prices, Costs, and Profits of Leading Individual Brands-Continued.

Diagram 5-No. 3.

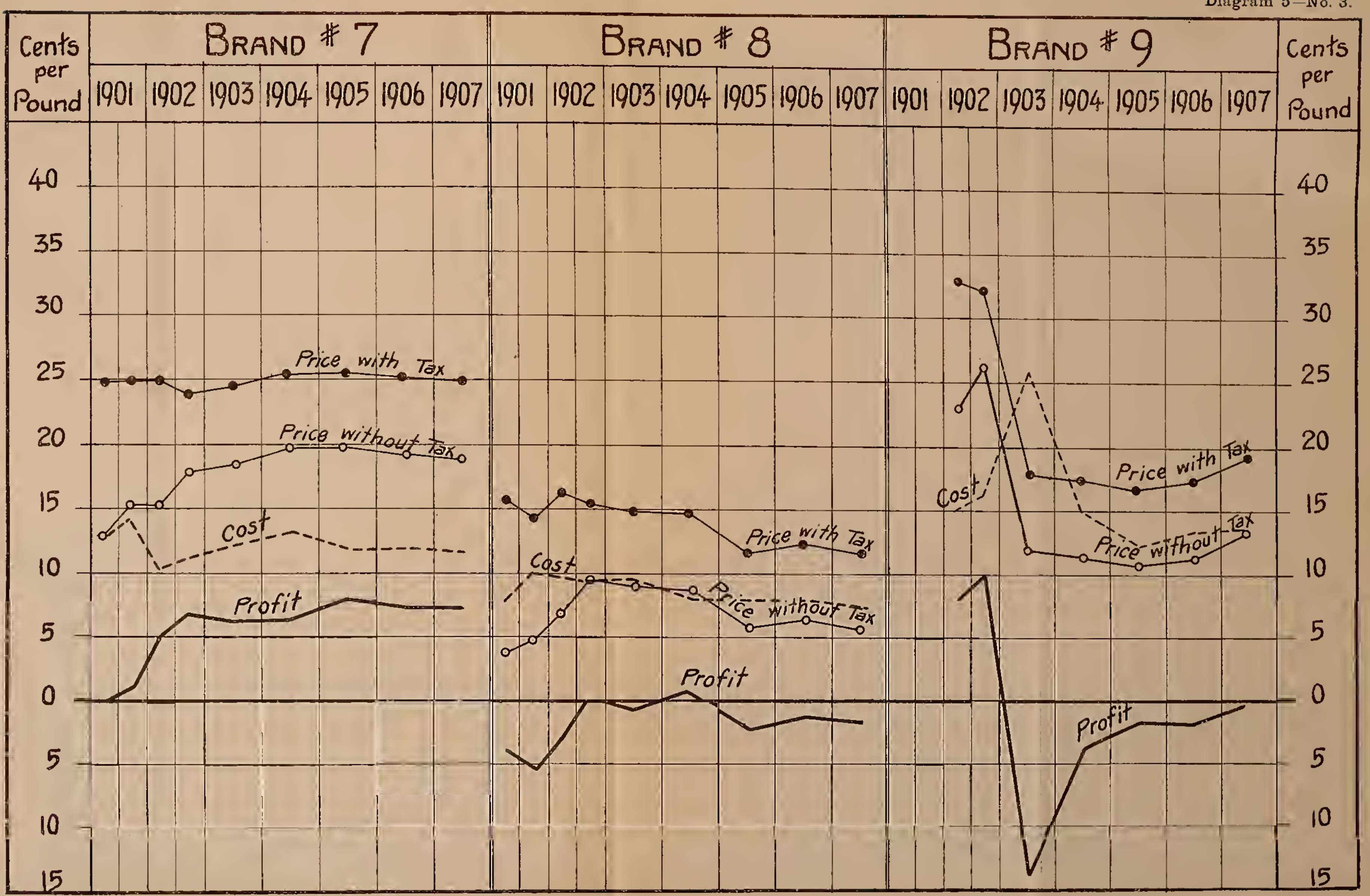



TABLE 53.-Long-cut smoking tobacco-American, Continental, and Lorillard companies: Prices, costs, and profits for leading individual brands-Continued.

\begin{tabular}{|c|c|c|c|c|c|c|c|c|c|}
\hline \multirow{3}{*}{ Period. } & \multirow{3}{*}{$\begin{array}{c}\text { Tax } \\
\text { (per } \\
\text { pound) }\end{array}$} & \multicolumn{4}{|c|}{ Brand No. 3 (per pound). } & \multicolumn{4}{|c|}{ Brand No. 4 (Fer pound). } \\
\hline & & \multicolumn{2}{|c|}{ Price. } & \multirow{2}{*}{ Cost. } & \multirow{2}{*}{ Profit. } & \multicolumn{2}{|c|}{ P'rice. } & \multirow{2}{*}{ Cost. } & \multirow{2}{*}{ Profit. } \\
\hline & & $\begin{array}{l}\text { Inclucl- } \\
\text { ing ta } \% \text {. }\end{array}$ & $\begin{array}{l}\text { Exclud- } \\
\text { ing tax. }\end{array}$ & & & $\begin{array}{l}\text { Includ- } \\
\text { ing tax. }\end{array}$ & $\begin{array}{l}\text { Exclud- } \\
\text { ing tax. }\end{array}$ & & \\
\hline 1901 (first half)... & $\begin{array}{r}\text { Cents. } \\
12.0\end{array}$ & $\begin{array}{l}\text { Cents. } \\
.21 .1\end{array}$ & $\begin{array}{r}\text { Cents. } \\
9.1\end{array}$ & $\begin{array}{r}\text { Cents. } \\
8.1\end{array}$ & $\begin{array}{r}\text { Cents. } \\
1.0\end{array}$ & $\begin{array}{r}\text { Cents. } \\
31.8\end{array}$ & $\begin{array}{l}\text { Cents. } \\
19.8\end{array}$ & $\begin{array}{r}\text { Cents. } \\
12.2\end{array}$ & $\begin{array}{r}\text { Cents. } \\
7.6\end{array}$ \\
\hline 1901 (second half)... & 9.6 & 21.9 & 12.3 & S. 7 & 3. 6 & 31.9 & 22.3 & 13.0 & 9.3 \\
\hline 1902 (first half)..... & 9.6 & 21.9 & 12.3 & 8.8 & 3.5 & 31.8 & 22.2 & 13.5 & 8.7 \\
\hline 1902 (second half)... & 6.0 & 20.5 & 14.5 & 9.6 & 4.9 & 31.7 & 25.7 & 15.2 & 10.5 \\
\hline $1903 \ldots \ldots \ldots \ldots \ldots$ & 6.0 & 21.0 & 15.0 & 9.3 & 5.7 & 31.6 & 25.6 & 16.2 & 9.4 \\
\hline $1904 \ldots \ldots \ldots \ldots \ldots$ & 6.0 & 22.3 & 16.3 & 9.6 & 6.7 & 31.3 & 25.3 & 17.9 & 7.4 \\
\hline $1905 \ldots \ldots \ldots \ldots$ & 6.0 & 22.6 & 16.6 & 9.8 & 6.8 & 30.8 & 24.8 & 14.7 & 10.1 \\
\hline $1906 \ldots \ldots \ldots \ldots \ldots$ & 6.0 & 24.0 & 18.0 & 9.7 & 8.3 & 30.9 & 24.9 & 14.6 & 10.3 \\
\hline $1907 \ldots \ldots \ldots \ldots \ldots$ & 6.0 & 23.2 & 17.2 & 8.7 & 8.5 & 31.0 & 25.0 & 14.2 & 10.8 \\
\hline \multirow{3}{*}{ Period. } & \multirow{3}{*}{$\begin{array}{c}\text { Tax } \\
\text { (per } \\
\text { pound). }\end{array}$} & \multicolumn{4}{|c|}{ Brand No. 5 (per pound). } & \multicolumn{4}{|c|}{ Braud No. 6 (per pound). } \\
\hline & & \multicolumn{2}{|c|}{ Price. } & \multirow[b]{2}{*}{ Cost. } & \multirow[b]{2}{*}{ Profit. } & \multicolumn{2}{|c|}{ Price. } & \multirow[b]{2}{*}{ Cost. } & \multirow[b]{2}{*}{ Profit. } \\
\hline & & $\begin{array}{l}\text { Includ- } \\
\text { ing tax. }\end{array}$ & $\begin{array}{l}\text { Exclud- } \\
\text { ing tax. }\end{array}$ & & & $\begin{array}{l}\text { Includ- } \\
\text { ing tax. }\end{array}$ & $\begin{array}{l}\text { Exclud- } \\
\text { ing tax. }\end{array}$ & & \\
\hline 1901 (first half).. & $\begin{array}{r}\text { Cents. } \\
12.0\end{array}$ & $\begin{array}{r}\text { Cents. } \\
35.7\end{array}$ & $\begin{array}{r}\text { Cents. } \\
23.7\end{array}$ & $\begin{array}{r}\text { Cents. } \\
18.9\end{array}$ & $\begin{array}{r}\text { Cents. } \\
4.8\end{array}$ & $\begin{array}{r}\text { Cents. } \\
27.4\end{array}$ & $\begin{array}{l}\text { Cents. } \\
15.4\end{array}$ & $\begin{array}{r}\text { Cents. } \\
10.2\end{array}$ & $\begin{array}{r}\text { Cents. } \\
5.2\end{array}$ \\
\hline 1901 (second half).... & 9.6 & $3 \overline{5} .4$ & 25.8 & 19.4 & 6.4 & $27 . \bar{j}$ & 17.9 & 10.8 & 7.1 \\
\hline 1902 (first half) ..... & 9.6 & 35.6 & 26.0 & 22.0 & 4.0 & 27.4 & 17.8 & 11.1 & 6.7 \\
\hline 1902 (second half).... & 6.0 & 34.3 & 28.3 & 23.4 & 4.9 & 27.1 & 21.1 & 11.8 & 9.3 \\
\hline $1903 \ldots \ldots \ldots \ldots \ldots$ & 6.0 & 35.0 & 29.0 & 24.4 & 4. 6 & $2 \pi .2$ & 21.2 & 13.6 & 7.6 \\
\hline $1904 \ldots$ & 6.0 & 35.9 & 29.9 & 24.7 & 5.2 & 26.9 & 20.9 & $14 . \overline{5}$ & 6.4 \\
\hline $1905 .$. & 6.0 & 35.5 & 29.5 & 25.0 & 4.5 & 26.9 & 20.9 & 11.4 & 9.5 \\
\hline 1906. & 6.0 & 35.8 & 29.8 & 26.5 & 3.3 & 26.9 & 20.9 & 9.3 & 11.6 \\
\hline 1907. & 6.0 & 35.8 & 29.8 & 26.4 & 3.4 & 26.9 & 20.9 & 9.5 & 11. 4 \\
\hline \multirow{3}{*}{ Period. } & \multirow{3}{*}{$\begin{array}{c}\text { Tax } \\
\text { (per } \\
\text { pound). }\end{array}$} & \multicolumn{4}{|c|}{ Brand No. 7 (per pound). } & \multicolumn{4}{|c|}{ Brand No. 8 (per pound). } \\
\hline & & \multicolumn{2}{|c|}{ Price. } & \multirow{2}{*}{ Cost. } & & Pri & ce. & & \\
\hline & & $\begin{array}{l}\text { Includ- } \\
\text { ing tax. }\end{array}$ & $\begin{array}{l}\text { Exclud- } \\
\text { ing tax. }\end{array}$ & & trorto. & $\begin{array}{l}\text { Includ- } \\
\text { ing tax. }\end{array}$ & $\begin{array}{l}\text { Exclud- } \\
\text { ing tax. }\end{array}$ & cust. & tron. \\
\hline 1901 (first half)... & $\begin{array}{r}\text { Cents } \\
12.0\end{array}$ & $\begin{array}{r}\text { Cents. } \\
24.8\end{array}$ & $\begin{array}{r}\text { Cents. } \\
12.8\end{array}$ & $\begin{array}{r}\text { Cents. } \\
12.9\end{array}$ & $\begin{array}{r}\text { Cents. } \\
\quad * 0.1\end{array}$ & $\begin{array}{r}\text { Cents. } \\
15.6\end{array}$ & $\begin{array}{r}\text { Cents. } \\
3.6\end{array}$ & $\begin{array}{r}\text { Cents. } \\
7.6\end{array}$ & $\begin{array}{l}\text { Cents. } \\
\quad * 4.0\end{array}$ \\
\hline 1901 (second half).. & 9.6 & 24.9 & $15.3 \cdot$ & 14.2 & 1.1 & 14.2 & 4.6 & 10.0 & $* 5.4$ \\
\hline 1902 (first half) ...... & 9.6 & 24.9 & 15.3 & 10.3 & 5.0 & 16.3 & 6.7 & 9.6 & $* 2.9$ \\
\hline 1902 (second half)... . & 6.0 & 23.8 & 17.8 & 11.2 & 6. 6 & 15.5 & 9.5 & 9.3 & .2 \\
\hline $1903 \ldots \ldots \ldots \ldots \ldots$ & 6.0 & 24.5 & 18.5 & 12.2 & 6.3 & 14.8 & 8.8 & 9.5 & $* .7$ \\
\hline $1904 \ldots$ & 6.0 & 25.6 & 19.6 & 13.2 & 6.4 & 14.6 & 8.6 & 7.9 & .7 \\
\hline $1905 \ldots$ & 6.0 & 25.7 & 19.7 & 11.8 & 7.9 & 11.6 & 5.6 & 7.9 & $* 2.3$ \\
\hline $1906 \ldots . .$. & 6.0 & 25.2 & 19. 2 & 12.0 & 7.2 & 12.4 & 6.4 & 7.7 & $* 1.2$ \\
\hline $1907 \ldots \ldots$ & 6.0 & 24.9 & 18.9 & 11.7 & 7.2 & 11.6 & 5.6 & 7.2 & $* 1.6$ \\
\hline
\end{tabular}

* Loss. 
TABLE 53.-Long-cut smoking tobacco-American, Continental, and Lorillard compa nies: Prices, costs, and profits for leading individual brands-Continued.

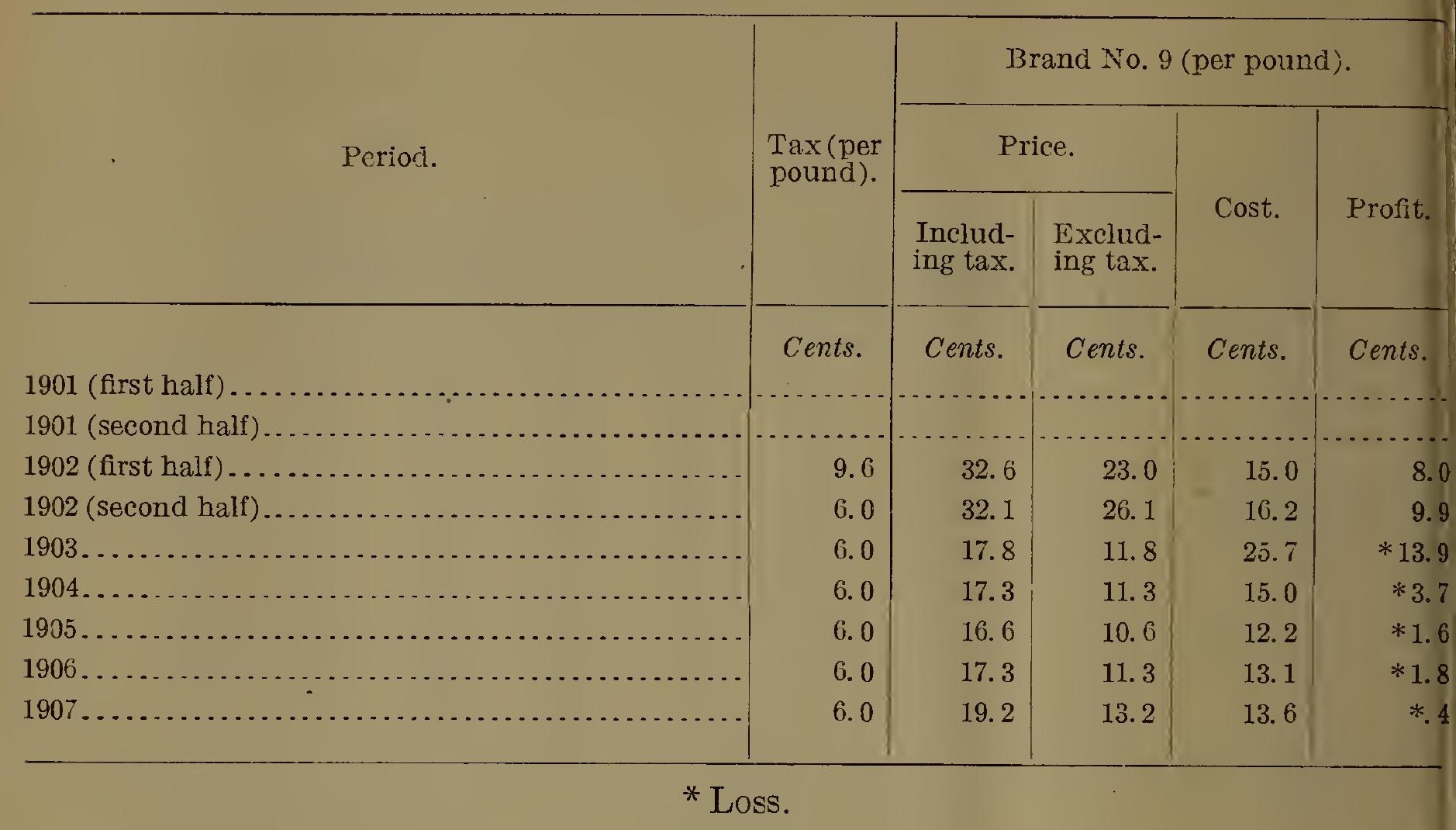

It will be seen that of the nine brands covered by the table, six $(1,3,4,5,6$, and 7$)$ either showed no decrease in price at the time the internal-revenue tax was reduced, or if there was some little decrease the price had recovered by 1903 so as to be as high in that year, under the 6-cent tax rate, as in 1901, under the 12-cent rate. Brand No. 2, as already stated, is unimportant in its output. It was, moreover, an absolutely new brand in 1901, and its price was apparently reduced with the hope of building it up into a large brand. Although the price of brand No. 8 was maintained with little change at the time the tax was reduced, the price was lowered from 1904 to 1905, and has never since recovered; but the company has evidently ceased to push the sale of this brand, for its output is steadily declining. Brand 9 was first put on the market in 1902, so that the marked reduction in price between that year and 1903 has no especial significance. This brand is still of comparatively small output and the Combination is evidently not pushing its sale actively.

The movements in the cost of the long-cut brands present no such degree of uniformity as in the case of the plug-cut brands, but the irregular movements in some of the brands for short periods are largely due to changes in advertising costs. This is especially true of brand No. 9, for which high advertising expenses were incurred in 1903, in the efforts to build up this new brand, but which were cut down greatly afterwards. For nearly all of the brands the total cost of manufacture and sale was approximately the same in 1907 as in 1901, although the net price, less tax, was generally decidedly higher than in 1901. In 1907, however, the proportion of the cost represented by leaf tobacco was generally larger than in 1901, there having been a considerable increase in the cost of leaf. Brand No. 2, which shows a marked increase in cost in 1907 over 1901, is, as already stated, a brand of very small output. Brand No. 5, which also shows a very marked increase in cost, had a very large 

Diagram 6-No. 1.

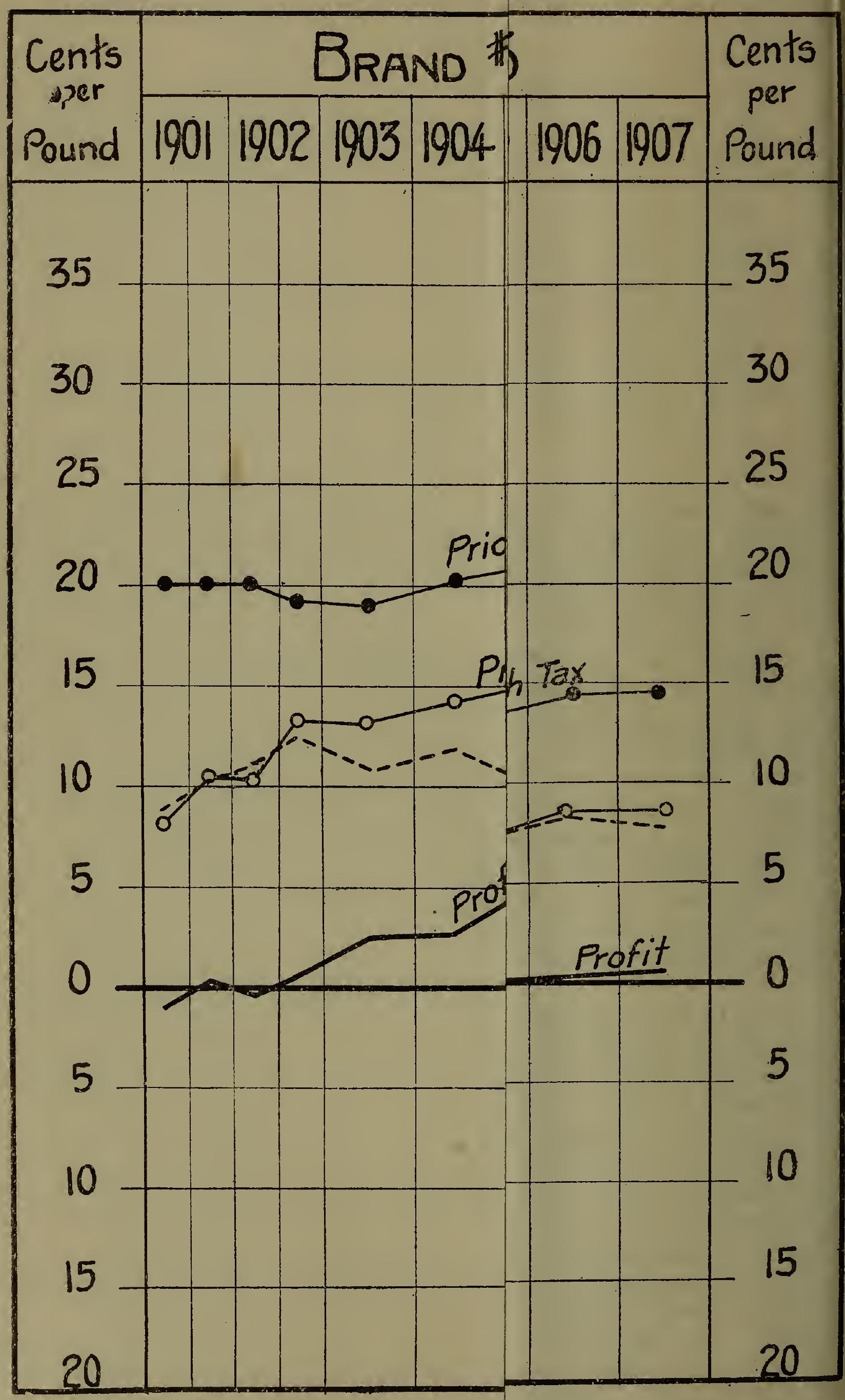


$x^{2}+x+2=1$

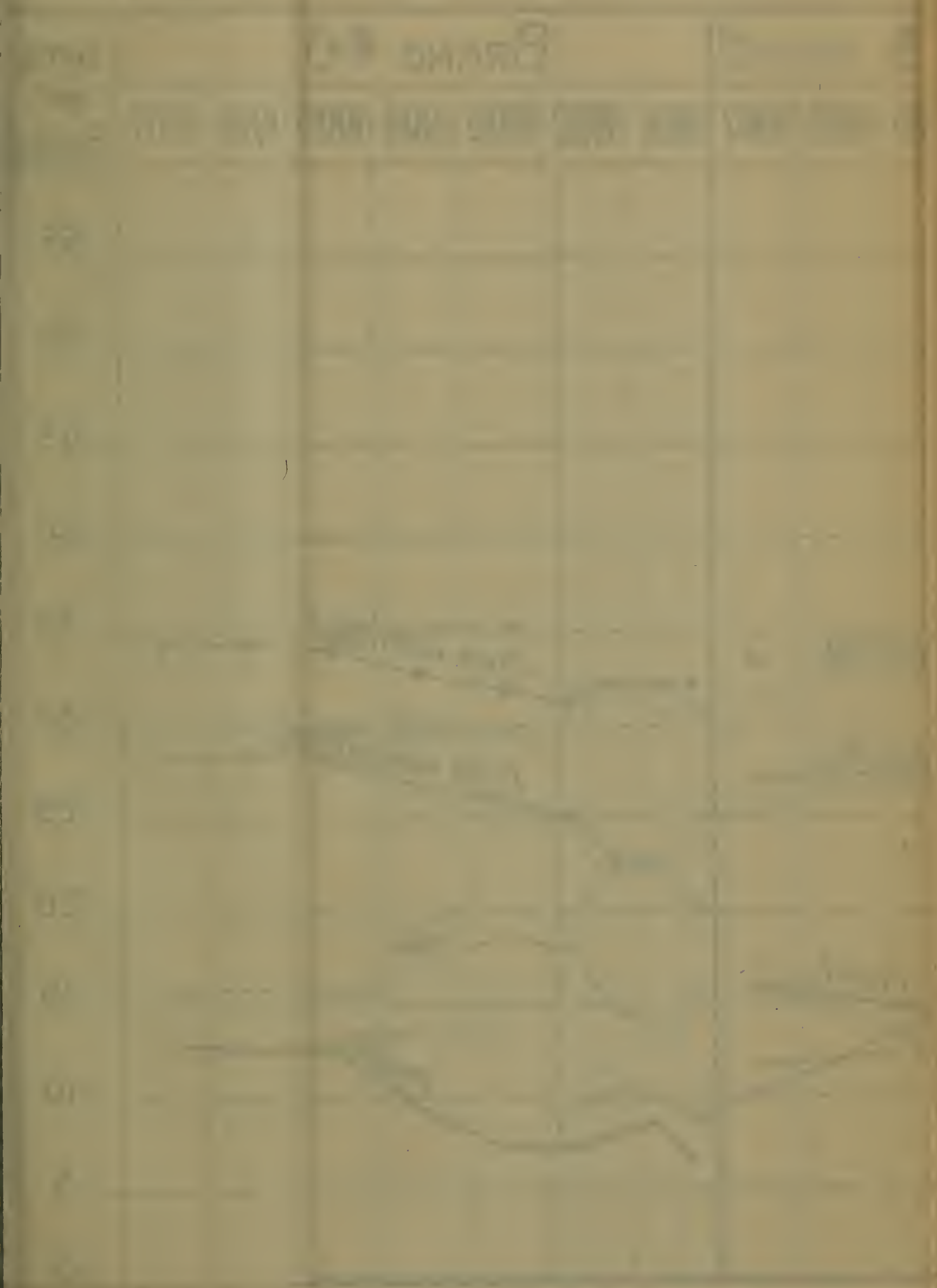


GRANULATED SMIOKING TOBACCO.

AMERICAN, CONTINENTAL, AND LORILLARD COMPANIES.

Prices, Costs, and Profits of Leading Individual Brands.

Diagram 6-No. 1

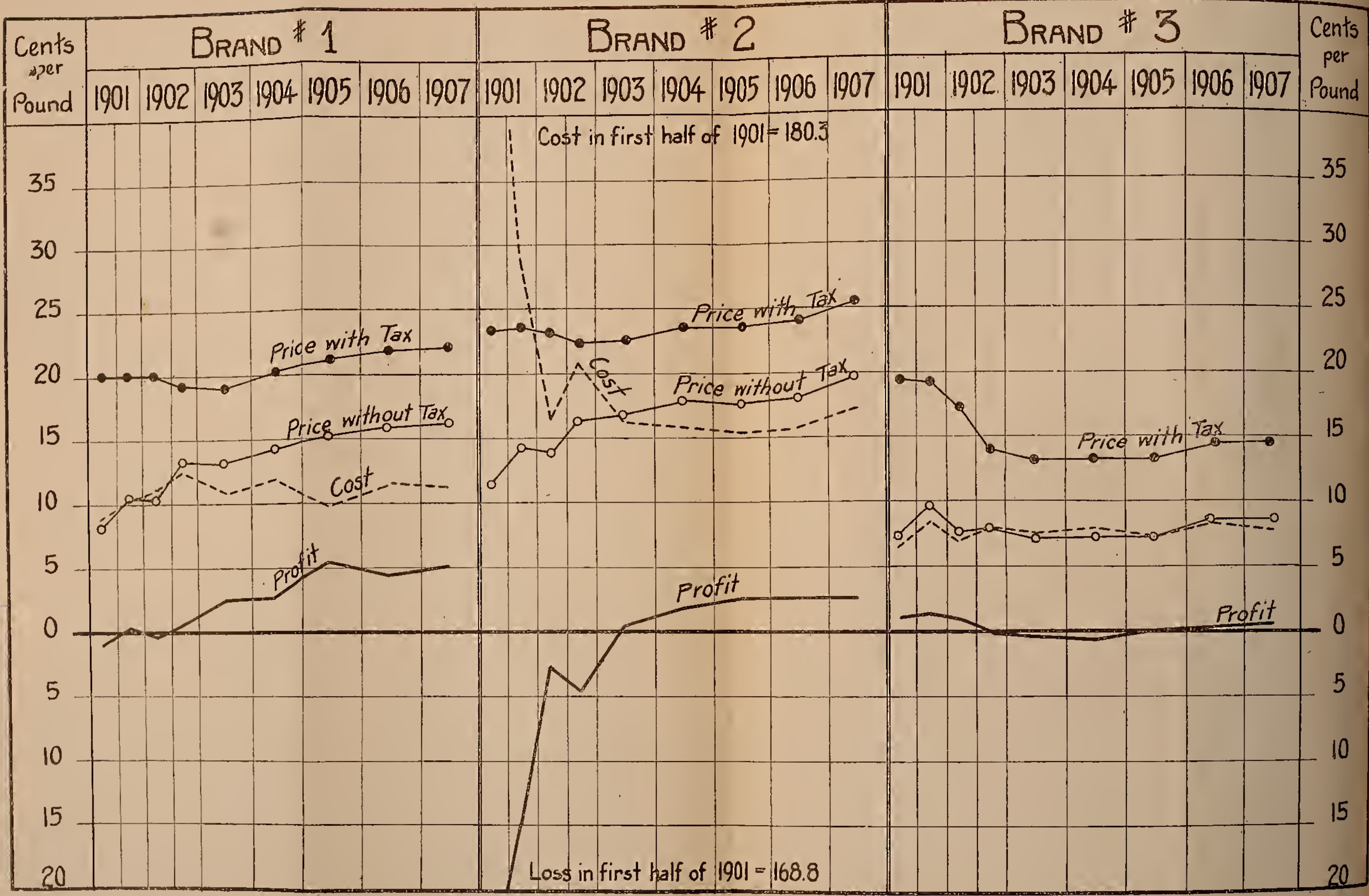


GRA

Diagram 6-No. 2.

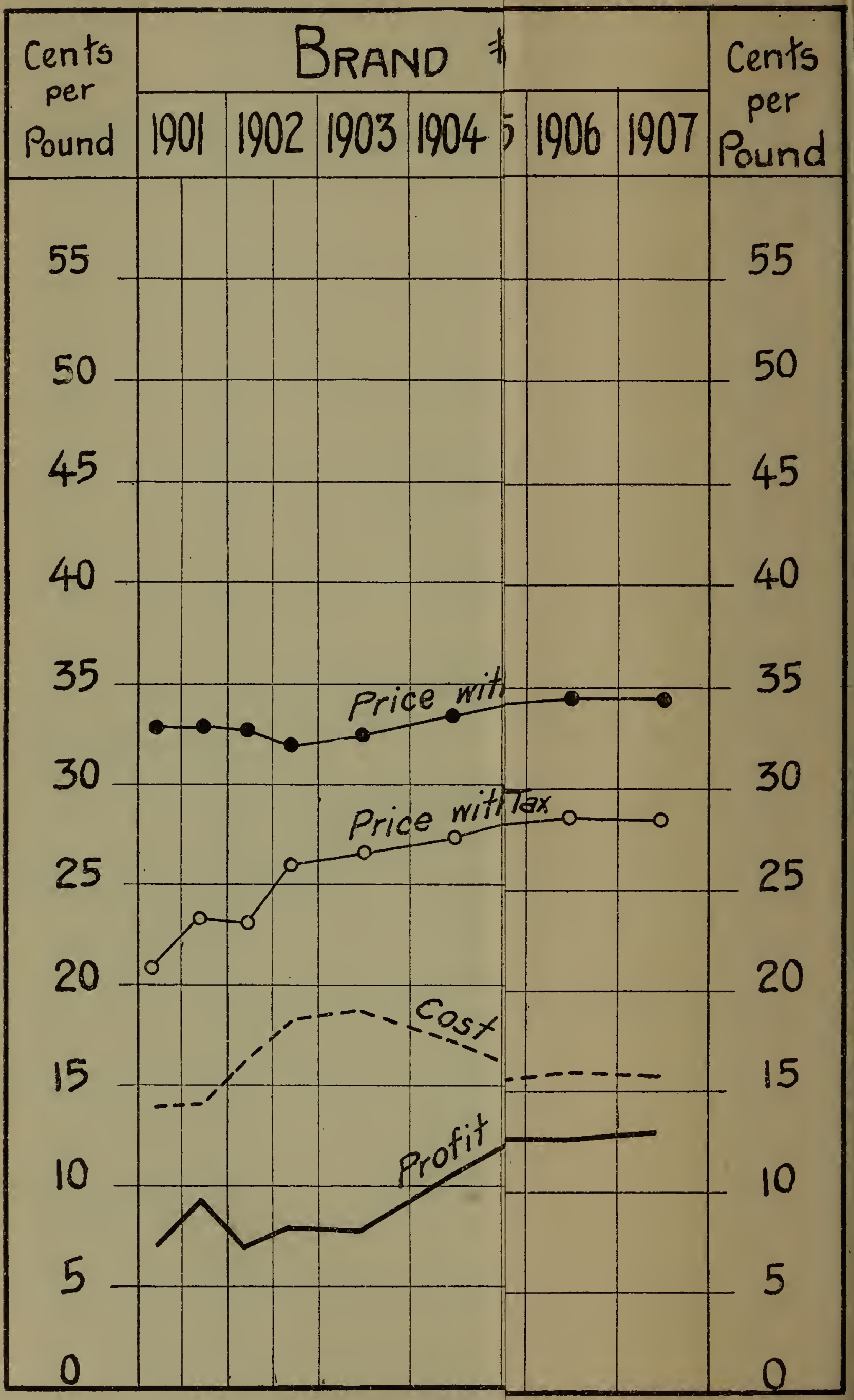




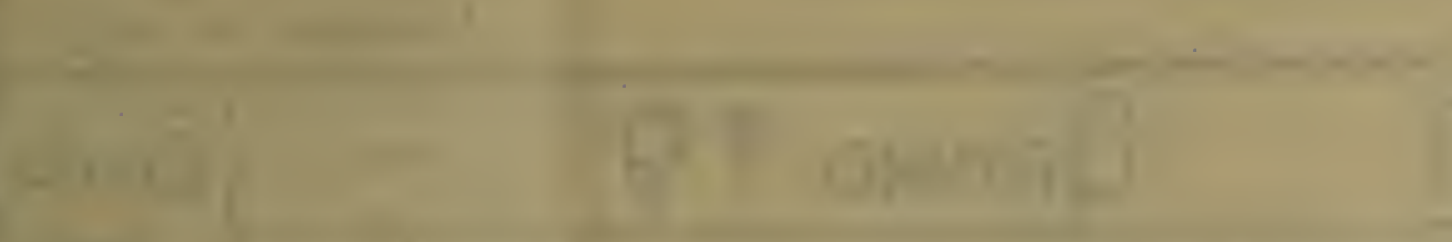

The

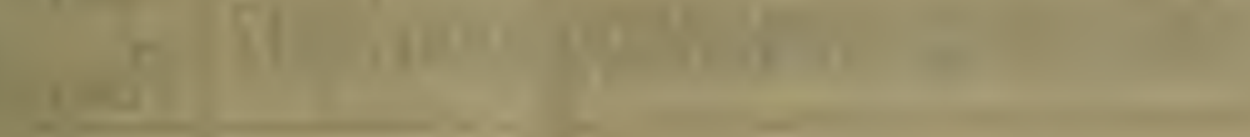

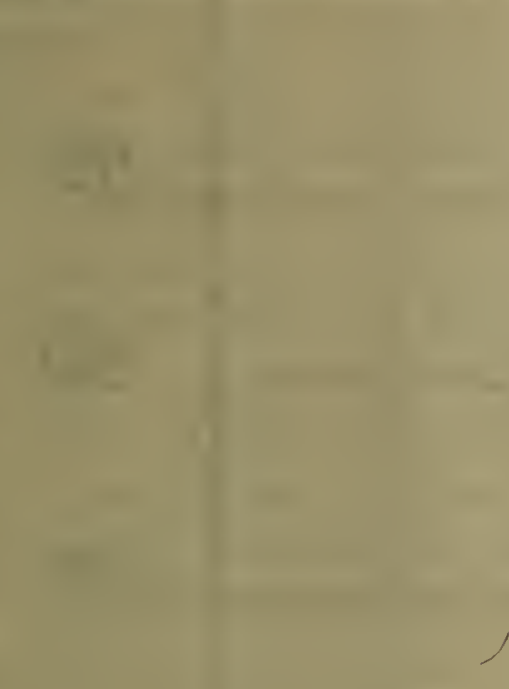

nin<smiles>[10BH]</smiles>

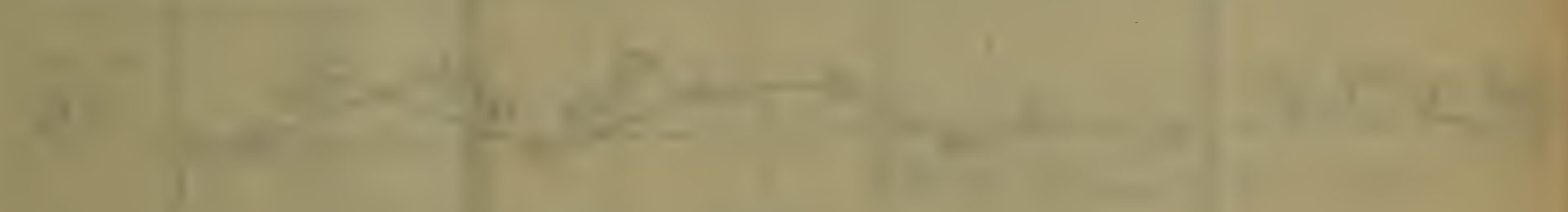
|

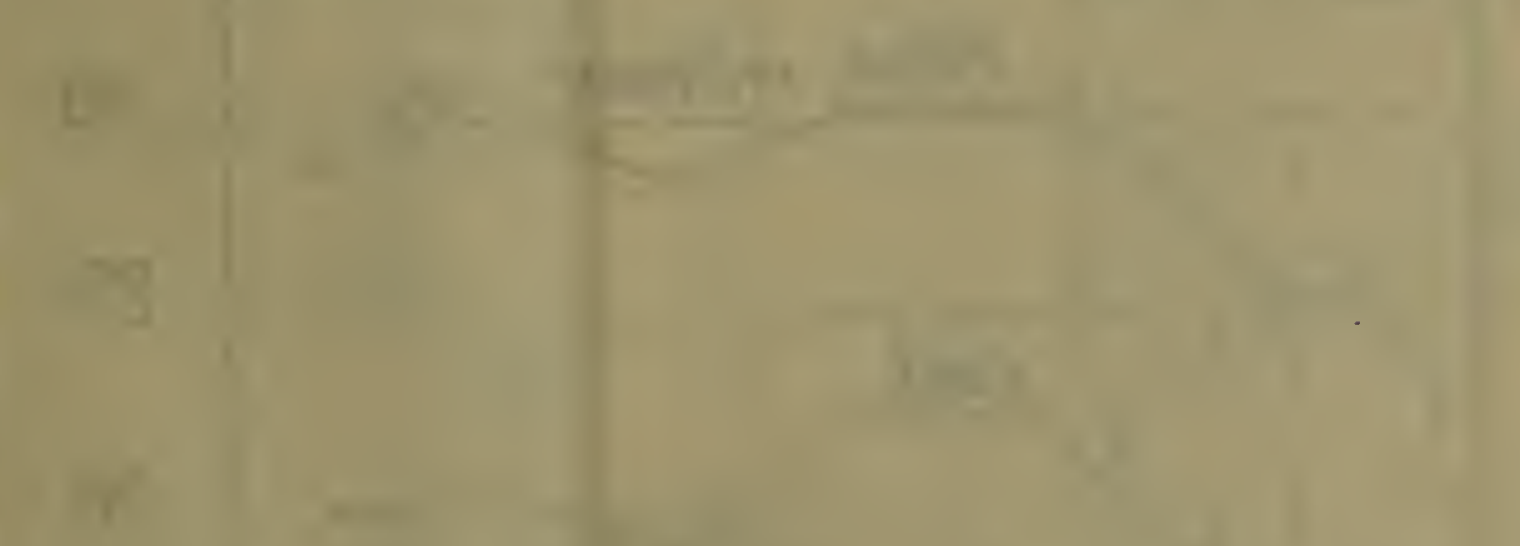

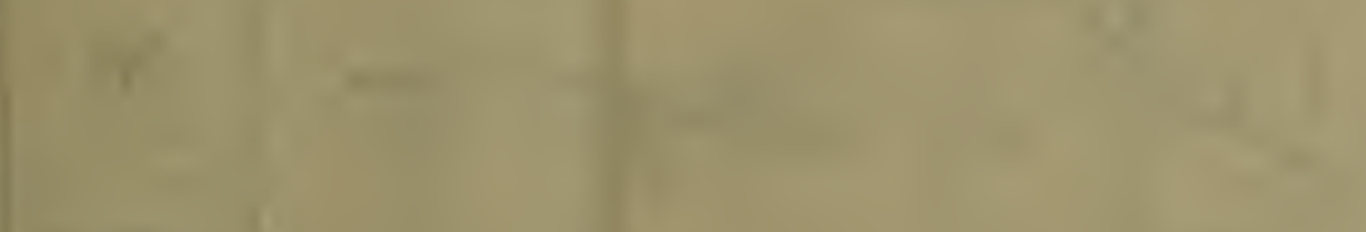

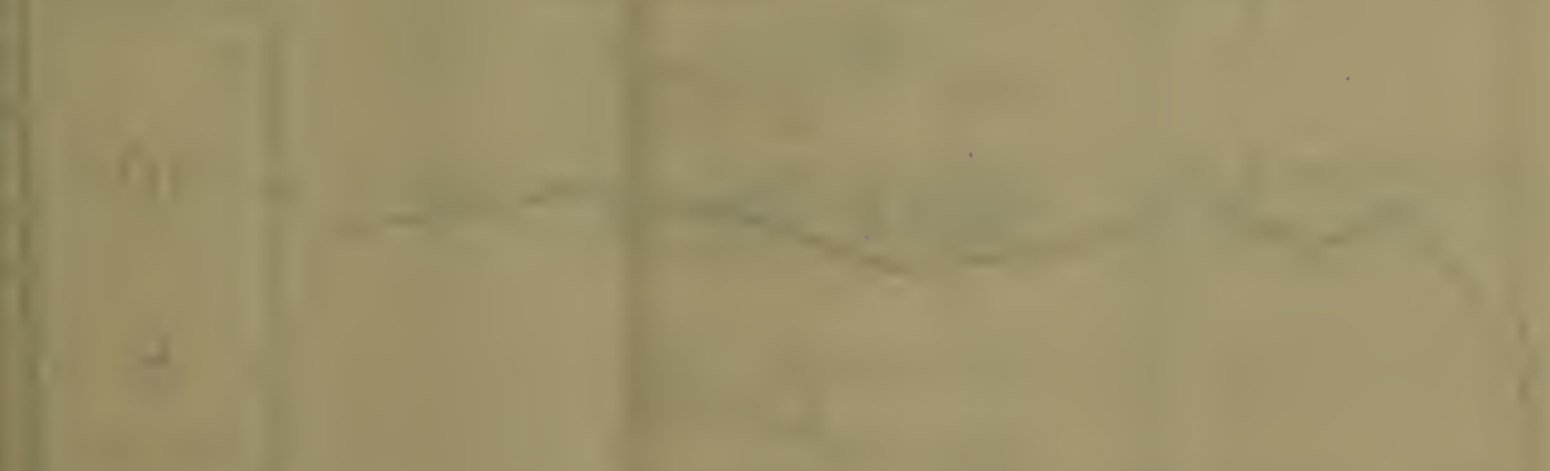


Diagram 6-No. 2

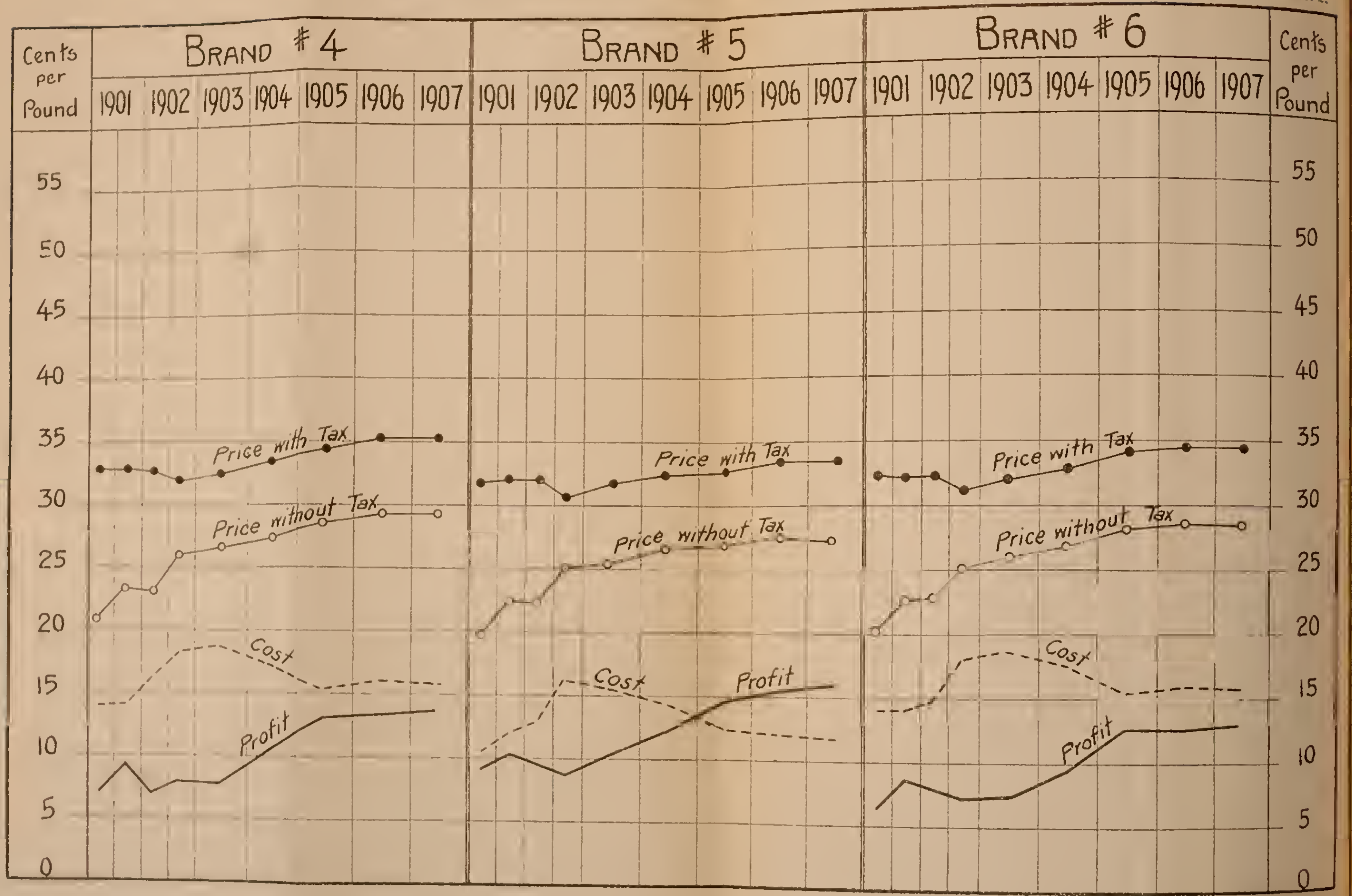




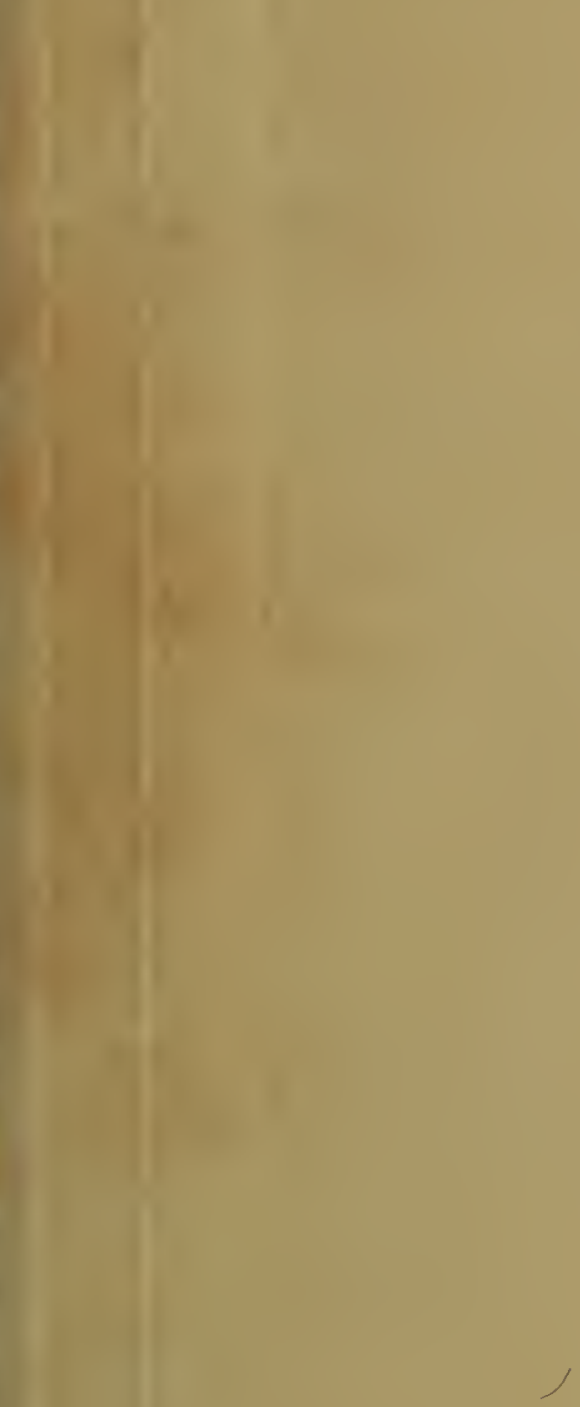


Diagram 6-No. 3.

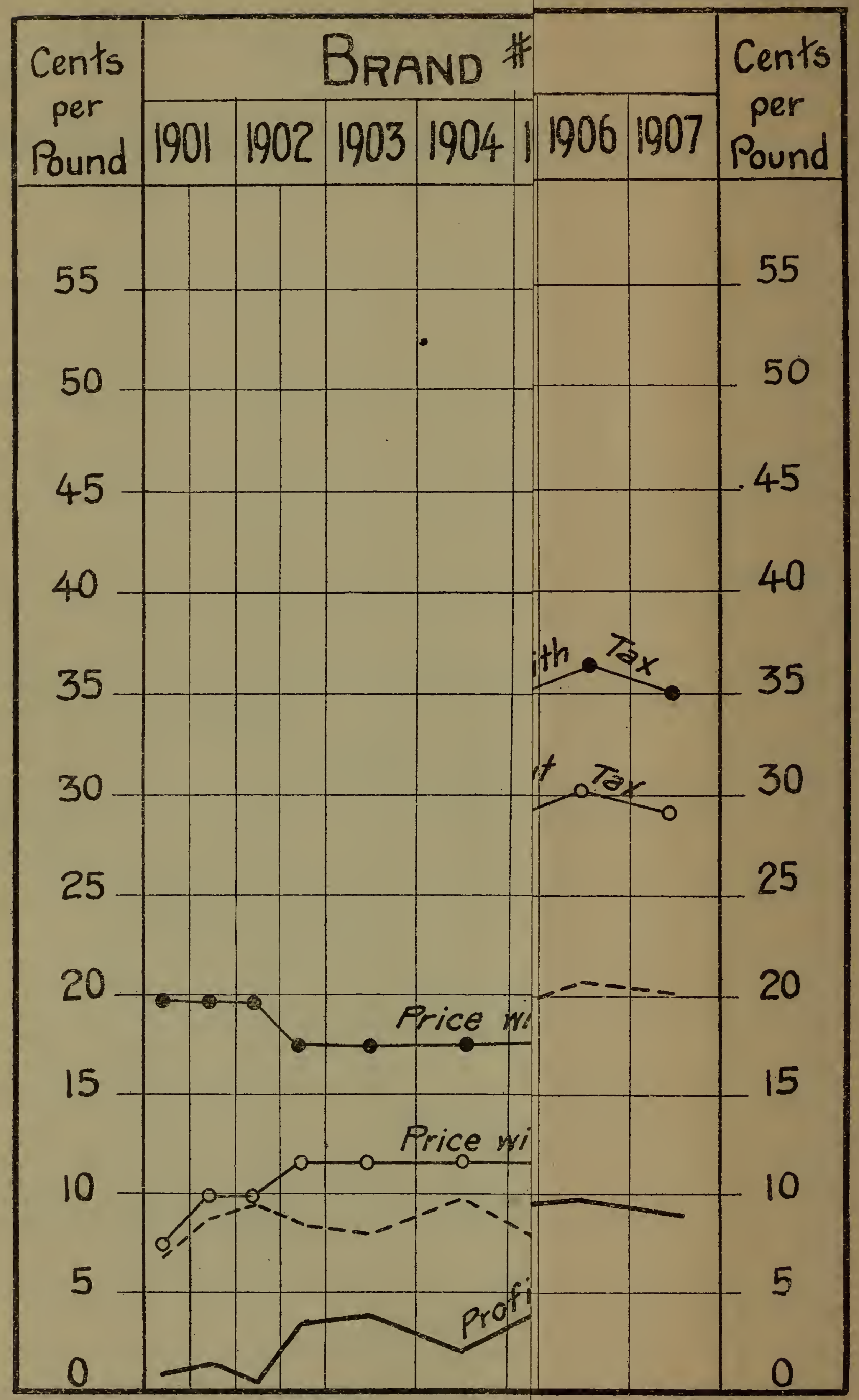


output at the beginning of the period, but the sales had fallen by 1907 to not more than 3 per cent of the amount sold in 1901 . The increase in the cost of this brand is wholly in the cost of leaf. The Combination has ceased its advertising expenses for the brand and is evidently withdrawing it from the market on account of its relatively unprofitable character as compared with other brands, although it has, at all times, shown a profit.

The increase in the profit on long-cut brands is somewhat less marked than on the plug-cut brands. For four of the nine brands, namely, 1, 3, 6, and 7-brands 1 and 7 being brands of large output-there was an increase of 5 cents or more per pound in the profit in 1907 as compared with 1901 . Brand 2, which shows a deline in profit, is unimportant; and brand 5 , which also shows some little decline, has, as already stated, been reduced from a very important brand to a very unimportant one. Brand 8 , which shows some decline in profit, is likewise decidedly decreasing in output, although it is still of considerable importance. Brand 9, which was a new brand in 1902 and still has only a small output, has shown a loss throughout the period, but by 1907 the loss had been reduced to practically nothing as compared with the very heavy loss of 1903, when the company was endeavoring to push sales of this brand by extensive advertising methods.

Granulated brands.-Table 54 and the accompanying diagrams show the costs, prices, and profits for nine of the leading brands of granulated tobacco made by the American, Continental, and Lorillard companies.

TABLE 54.-Granulated smoking tobacco-American, Continental, and Lorillard companies: Prices, costs, and profits for leading individual brands.

\begin{tabular}{|c|c|c|c|c|c|c|c|c|c|}
\hline \multirow{3}{*}{ Period. } & \multirow{3}{*}{$\begin{array}{c}T a x \\
\text { (per } \\
\text { pound). }\end{array}$} & \multicolumn{4}{|c|}{ Brand No. 1 (per pound). } & \multicolumn{4}{|c|}{ Brand No. 2 (per pound). } \\
\hline & & \multicolumn{2}{|c|}{ Price. } & \multirow{2}{*}{ Cost. } & \multirow{2}{*}{ Profit. } & \multicolumn{2}{|c|}{ Price. } & \multirow{2}{*}{ Cost. } & \multirow{2}{*}{ Profit. } \\
\hline & & $\begin{array}{l}\text { Includ- } \\
\text { ing tax. }\end{array}$ & $\begin{array}{l}\text { Exclud- } \\
\text { ing tax. }\end{array}$ & & & $\begin{array}{l}\text { Includ- } \\
\text { ing tax. }\end{array}$ & $\begin{array}{l}\text { Exclud- } \\
\text { ing tax. }\end{array}$ & & \\
\hline 1901 (first half).... & $\begin{array}{r}\text { Cents. } \\
12.0\end{array}$ & $\begin{array}{c}\text { Cents. } \\
20.1\end{array}$ & $\begin{array}{c}\text { Cents. } \\
8.1\end{array}$ & $\begin{array}{r}\text { Cents. } \\
8.8\end{array}$ & $\begin{array}{r}\text { Cents. } \\
* 0.7\end{array}$ & $\begin{array}{l}\text { Cents. } \\
23.5\end{array}$ & $\begin{array}{l}\text { Cents. } \\
\quad 11.5\end{array}$ & $\begin{array}{c}\text { Cents. } \\
180.3\end{array}$ & $\begin{array}{l}\text { Cents. } \\
* 168.8\end{array}$ \\
\hline 1901 (second half).. & 9.6 & 20.1 & 10.5 & 10.4 & .1 & 23.7 & 14.1 & 29.0 & $* 14.9$ \\
\hline 1902 (first half).... & 9.6 & 20.1 & 10.5 & 11.0 & *. 5 & 23.5 & 13.9 & 16.4 & $* 2.5$ \\
\hline 1902 (second half).. & 6.0 & 19.4 & 13.4 & 12.5 & .9 & 22.3 & 16.3 & 20.9 & $* 4.6$ \\
\hline $1903 \ldots \ldots \ldots \ldots$ & 6.0 & 19.2 & 13.2 & 10.8 & 2.4 & 22.7 & 16.7 & 16.2 & .5 \\
\hline 1904 & 6.0 & 20.4 & 14.4 & 11.9 & 2.5 & 23.7 & 17.7 & 15.8 & 1.9 \\
\hline 1905. & 6.0 & 21.2 & 15.2 & 9.8 & 5.4 & 23.7 & 17.7 & 15.4 & 2.3 \\
\hline $1906 .$. & 6.0 & 21.9 & 15.9 & 11.5 & 4.4 & 24.0 & 18.0 & 15.6 & 2.4 \\
\hline $1907 .$. & 6.0 & 22.2 & 16.2 & 11.1 & 5.1 & 25.6 & 19.6 & 17.3 & 2.3 \\
\hline
\end{tabular}

* Loss.

$87442-$ S. Doc. $78,61-1-8$ 
Diagram 6-No. 3.

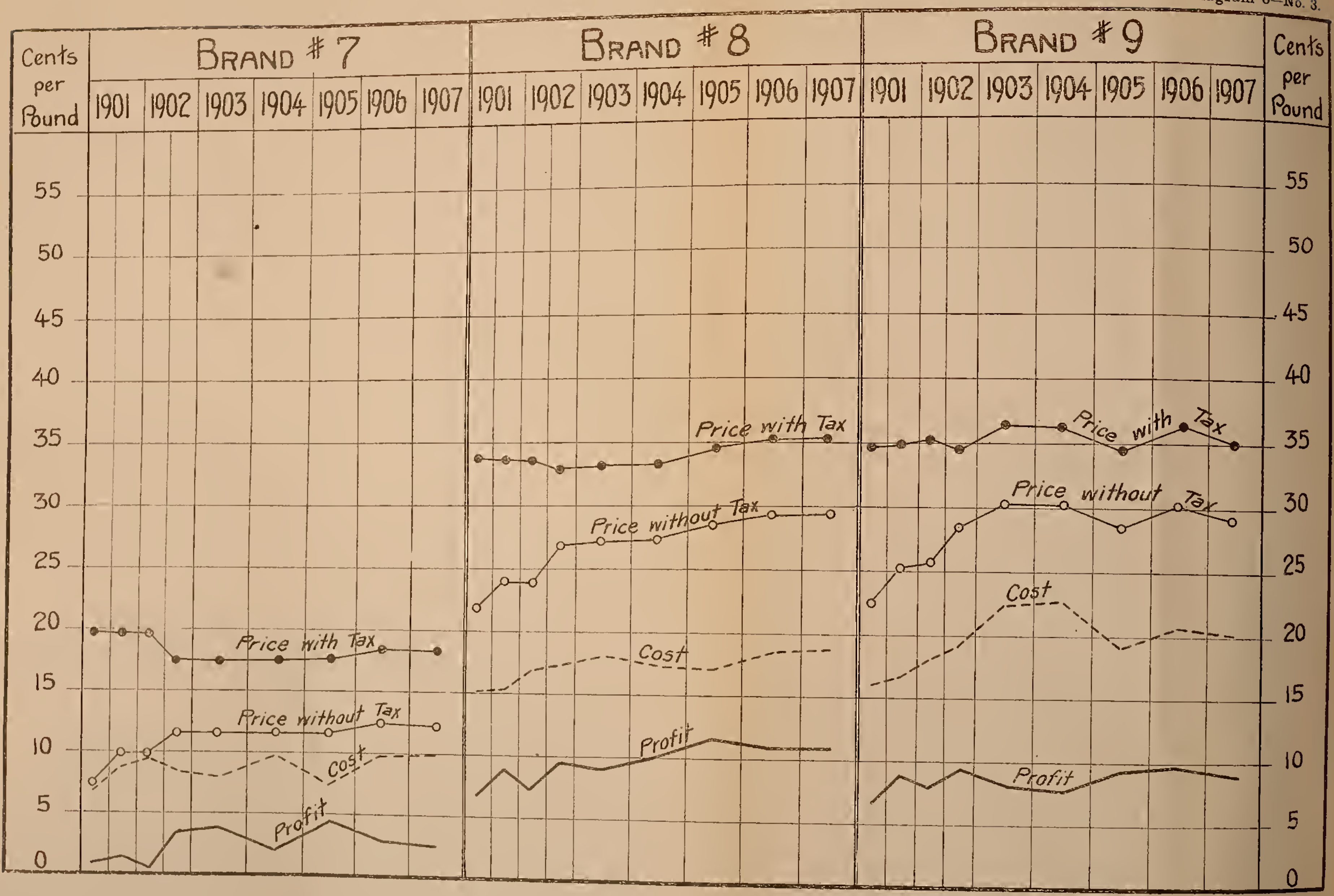




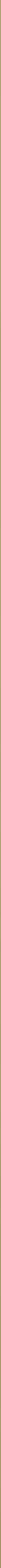


TABLE 54.-Granulated smoking tobacco-American, Continental, and Lorillard companies: Prices, costs, and profits for leading individual brands-Continued.

\begin{tabular}{|c|c|c|c|c|c|c|c|c|c|}
\hline \multirow{3}{*}{ Period. } & \multirow{3}{*}{$\begin{array}{c}\text { Tax } \\
\text { (per } \\
\text { pound). }\end{array}$} & \multicolumn{4}{|c|}{ Brand No. 3 (per pound). } & \multicolumn{4}{|c|}{ Brand No. 4 (per pound). } \\
\hline & & \multicolumn{2}{|c|}{ Price. } & \multirow{2}{*}{ Cost. } & \multirow{2}{*}{ Profit. } & \multicolumn{2}{|c|}{ Price. } & \multirow[b]{2}{*}{ Cost. } & \multirow[b]{2}{*}{ Profit. } \\
\hline & & $\begin{array}{l}\text { Includ- } \\
\text { ing tax. }\end{array}$ & $\begin{array}{l}\text { Exclud- } \\
\text { ing tax. }\end{array}$ & & & $\begin{array}{l}\text { Includ- } \\
\text { ing tax. }\end{array}$ & $\begin{array}{l}\text { Exclud- } \\
\text { ing tax. }\end{array}$ & & \\
\hline 1901 (first half)... & $\begin{array}{r}\text { Cents. } \\
12.0\end{array}$ & $\begin{array}{r}\text { Cents. } \\
19.5\end{array}$ & $\begin{array}{r}\text { Cents. } \\
7.5\end{array}$ & $\begin{array}{r}\text { Cents. } \\
6.5\end{array}$ & $\begin{array}{r}\text { Cents. } \\
1.0\end{array}$ & $\begin{array}{r}\text { Cents. } \\
32.9\end{array}$ & $\begin{array}{r}\text { Cents. } \\
20.9\end{array}$ & $\begin{array}{r}\text { Cents. } \\
13.9\end{array}$ & $\begin{array}{r}\text { Cents. } \\
7.0\end{array}$ \\
\hline 1901 (second half). & 9.6 & 19.3 & 9.7 & 8.6 & 1.1 & 33.0 & 23.4 & 14.1 & 9.3 \\
\hline 1902 (first half) ..... & 9.6 & 17.3 & 7.7 & 6.9 & 0.8 & 32.7 & 23.1 & 16.1 & 7.0 \\
\hline 1902 (second half)... . & 6.0 & 14.0 & 8.0 & 8.0 & $* 0.0$ & 32.0 & 26.0 & 18.1 & 7.9 \\
\hline $1903 \ldots \ldots \ldots \ldots$ & 6.0 & 13.2 & 7.2 & 7.5 & $* 0.3$ & 32.5 & 26.5 & 18.8 & 7.7 \\
\hline $1904 \ldots \ldots$. & 6.0 & 13.3 & 7.3 & 7.9 & $* 0.6$ & 33.4 & 27.4 & 17.0 & 10.4 \\
\hline $1905 \ldots \ldots$ & 6.0 & 13.3 & 7.3 & 7.3 & 0.0 & 34.5 & 28.5 & 15.5 & 13.0 \\
\hline $1906 \ldots \ldots \ldots \ldots$ & 6.0 & 14.5 & 8.5 & 8.3 & 0.2 & 35.3 & 29.3 & 16.0 & 13.3 \\
\hline $1907 \ldots \ldots \ldots \ldots$ & 6.0 & 14.6 & 8.6 & 7.9 & 0.7 & 35.3 & 29.3 & 15.7 & 13.6 \\
\hline \multirow{3}{*}{ Period. } & \multirow{3}{*}{$\begin{array}{c}\text { Tax } \\
\text { (per } \\
\text { pound) }\end{array}$} & \multicolumn{4}{|c|}{ Brand No. 5 (per pound). } & \multicolumn{4}{|c|}{ Brand No. 6 (per pound). } \\
\hline & & \multicolumn{2}{|c|}{ Price. } & \multirow[b]{2}{*}{ Cost. } & \multirow[b]{2}{*}{ Profit. } & \multicolumn{2}{|c|}{ Price. } & \multirow[b]{2}{*}{ Cost. } & \multirow[b]{2}{*}{ Profit. } \\
\hline & & $\begin{array}{l}\text { Includ- } \\
\text { ing tax. }\end{array}$ & $\begin{array}{l}\text { Exclud- } \\
\text { ing tax. }\end{array}$ & & & $\begin{array}{l}\text { Includ- } \\
\text { ing tax. }\end{array}$ & $\begin{array}{l}\text { Exclud- } \\
\text { ing tax. }\end{array}$ & & \\
\hline 1901 (first half). & $\begin{array}{r}\text { Cents. } \\
12.0\end{array}$ & $\begin{array}{l}\text { Cents. } \\
\quad 31.7\end{array}$ & $\begin{array}{l}\text { Cents. } \\
\quad 19.7\end{array}$ & $\begin{array}{r}\text { Cents. } \\
10.5\end{array}$ & $\begin{array}{r}\text { Cents. } \\
9.2\end{array}$ & $\begin{array}{r}\text { Cents. } \\
32.3\end{array}$ & $\begin{array}{l}\text { Cents. } \\
\quad 20.3\end{array}$ & $\begin{array}{r}\text { Cents. } \\
14.0\end{array}$ & $\begin{array}{r}\text { Cents. } \\
6.3\end{array}$ \\
\hline 1901 (second half). & 9.6 & 32.1 & 22.5 & 12.0 & 10.5 & 32.2 & 22.6 & 14.0 & 8.6 \\
\hline 1902 (first half)... & 9.6 & 32.1 & 22.5 & 12.9 & 9.6 & 32.3 & 22.7 & 14.6 & 8.1 \\
\hline 1902 (second half). & 6.0 & 31.0 & 25.0 & 16. 3 & 8.7 & 31.2 & 25.2 & 18.0 & 7.2 \\
\hline $1903 \ldots \ldots \ldots \ldots$ & 6.0 & 31.6 & 25.6 & 15.5 & 10.1 & 32.0 & 26.0 & 18.7 & 7.3 \\
\hline $1904 \ldots$ & 6.0 & 32.5 & 26.5 & 14. 4 & 12.1 & 32.8 & 26.8 & 17.5 & 9.3 \\
\hline $1905 \ldots$ & 6.0 & 32.8 & 26.8 & 12.3 & 14.5 & 34.1 & 28.1 & 15.4 & 12.7 \\
\hline $1906 \ldots$ & 6.0 & 33.5 & 27.5 & 12.1 & 15.4 & 34.5 & 28.5 & 15.9 & 12.6 \\
\hline $1907 \ldots \ldots \ldots \ldots$ & 6.0 & 33.5 & 27.5 & 11.7 & 15.8 & 34.5 & 28.5 & 15.6 & 12.9 \\
\hline \multirow{3}{*}{ Period. } & \multirow{3}{*}{$\begin{array}{c}\text { Táx } \\
\text { (per } \\
\text { pound). }\end{array}$} & \multicolumn{4}{|c|}{ Brand No. 7 (per pound). } & \multicolumn{4}{|c|}{ Brand No. 8 (per pound). } \\
\hline & & \multicolumn{2}{|c|}{ Price. } & \multirow{2}{*}{ Cost } & & $\operatorname{Pri}$ & & & \\
\hline & & $\begin{array}{l}\text { Includ- } \\
\text { ing tax. }\end{array}$ & $\begin{array}{l}\text { Exclud- } \\
\text { ing tax. }\end{array}$ & & Profit. & $\begin{array}{l}\text { Includ- } \\
\text { ing tax. }\end{array}$ & $\begin{array}{l}\text { Exclud- } \\
\text { ing tax. }\end{array}$ & Cost. & Profit. \\
\hline 1901 (first half). & $\begin{array}{r}\text { Cents. } \\
12.0\end{array}$ & $\begin{array}{r}\text { Cents. } \\
19.5\end{array}$ & $\begin{array}{r}\text { Cents. } \\
7.5\end{array}$ & $\begin{array}{r}\text { Cents. } \\
\cdot 6.8\end{array}$ & $\begin{array}{r}\text { Cents. } \\
0.7\end{array}$ & $\begin{array}{r}\text { Cents. } \\
33.8\end{array}$ & $\begin{array}{r}\text { Cents. } \\
21.8\end{array}$ & $\begin{array}{r}\text { Cents. } \\
15.1\end{array}$ & $\begin{array}{r}\text { Cents. } \\
\quad 6.7\end{array}$ \\
\hline 1901 (second half) & 9.6 & 19.5 & 9.9 & 8.7 & 1.2 & 33.6 & 24.0 & 15.4 & 8.6 \\
\hline 1902 (first half)... & 9.6 & 19.5 & 9.9 & 9.6 & 0.3 & 33.6 & 24.0 & 16.8 & 7.2 \\
\hline 1902 (second half)... & 6.0 & 17.5 & $11 . \dot{5}$ & 8.4 & 3.1 & 32.9 & 26.9 & 17.4 & 9.5 \\
\hline $1903 \ldots . . . \ldots \ldots$ & 6.0 & 17.5 & 11.5 & 7.9 & 3.6 & 33.2 & 27.2 & 18.0 & 9.2 \\
\hline $1904 \ldots$ & 6.0 & 17.5 & 11.5 & 9.7 & 1.8 & 33.4 & 27.4 & 17.4 & 10.0 \\
\hline $1905 . . .$. & 6.0 & 17.5 & 11.5 & 7.3 & 4.2 & 34.5 & 28.5 & 17.0 & 11.5 \\
\hline $1906 \ldots . .$. & 6.0 & 18.3 & 12.3 & 9.7 & 2.6 & 35.4 & 29.4 & 18. 5 & 10.9 \\
\hline $1907 \ldots \ldots \ldots \ldots$ & 6.0 & 18.2 & 12.2 & 9.9 & 2.3 & 35.5 & 29.5 & 18. 6 & 10.9 \\
\hline
\end{tabular}

* Loss. 
TABLE 54.-Granulated smoking tobacco-American, Continental, and Lorillard companies: Prices, costs, and profits for leading individual brands-Continued.

\begin{tabular}{|c|c|c|c|c|c|}
\hline \multirow{3}{*}{ Period. } & \multirow{3}{*}{$\begin{array}{l}\text { Tax (per } \\
\text { pound). }\end{array}$} & \multicolumn{4}{|c|}{ Brand No. 9 (per pound). } \\
\hline & & \multicolumn{2}{|c|}{ Price. } & \multirow{2}{*}{ Cost. } & \multirow{2}{*}{ Profit. } \\
\hline & & $\begin{array}{l}\text { Includ- } \\
\text { ing tax. }\end{array}$ & $\begin{array}{l}\text { Exclud- } \\
\text { ing tax. }\end{array}$ & & \\
\hline & $\begin{array}{r}\text { Cents. } \\
12.0\end{array}$ & $\begin{array}{r}\text { Cents. } \\
34.6\end{array}$ & $\begin{array}{r}\text { Cents. } \\
22.6\end{array}$ & $\begin{array}{r}\text { Cents. } \\
16.0\end{array}$ & $\begin{array}{r}\text { Cents. } \\
6.6\end{array}$ \\
\hline 1901 (second half)... & 9.6 & 34.9 & 25.3 & 16.5 & 8.8 \\
\hline 1902 (first half) .... . . & 9.6 & 35.4 & 25.8 & 17.9 & 7.9 \\
\hline 1902 (second half)... & 6.0 & 34.4 & 28.4 & 19.1 & 9.3 \\
\hline $1903 \ldots . . . \ldots \ldots . . .$. & 6.0 & 36.5 & 30.5 & 22.5 & 8.0 \\
\hline $1904 \ldots \ldots \ldots$. & 6.0 & 36.4 & 30.4 & 22.7 & 7.7 \\
\hline $1905 \ldots \ldots \ldots$ & 6.0 & 34.5 & 28.5 & 19.4 & 9.1 \\
\hline $1906 \ldots \ldots \ldots \ldots$ & 6.0 & 36.4 & 30.4 & 20.7 & 9.7 \\
\hline $1907 . . . \ldots \ldots \ldots \ldots \ldots$ & 6.0 & 35.0 & 29.0 & 20.1 & 8.9 \\
\hline
\end{tabular}

It will be seen that in the case of six of these brands $(1,2,4,6,8$, and 9) there was little if any decrease in the price at the time when the tax was reduced from 12 cents to 6 cents per pound, while, although the price of brand 5 was reduced appreciably, it was restored by 1903 . Brand No. 3 shows a marked decrease in price at the time the tax was reduced, which has never been recovered, but this is a brand of comparatively small output. Brand No. 7 showed a decline of about 2 cents in price when the tax was reduced 6 cents, and the price has not since been restored; this brand, however, is one of decreasing output. For seven of the nine brands, therefore, the price, less tax, in 1903 was substantially 6 cents per pound higher than in 1901. There has been comparatively little change in the price since 1903 for most of the brands. It will be seen that for seven of the nine brands $(1,2,4,5,6,8$, and 9$)$ the price, including tax, was as high in 1907 as it had been in 1901, notwithstanding the reduction of 6 cents in the tax, and for all but two of these brands the price was in fact 2 cents or more higher in 1907 than in 1901.

The increase in the net price, less tax, during the years from 1901 to 1902 or 1903 was partly offset by an increase in cost, but this additional cost in turn was in part due to added expenditures for advertising, the apparent purpose of which was to maintain the output of the brands in the face of the increase in the net price, less tax. For seven of the nine brands there was a considerable increase in cost from 1901 to 1902 or 1903 . In most of these cases there has been some increase in the leaf cost and also an increase in advertising expenses. The marked increase in the cost of brand 9 , which is a very important brand, is chiefly due to additional advertising. Brand 2 shows a very great decrease in cost from 1901 to 1902, but this was due to the fact that extraordinary expense of advertising had been incurred in 1901 on the basis of a relatively small output, the result of which was very greatly to increase the sales in the succeeding years. Brand 3 shows practically no change in costs at this time or later. 
It will be seen that for five of the nine brands $(1,2,3,7$, and 8 ) there has been very little change in cost since 1902 and 1903, although for most of these brands the leaf costs have increased, this increased cost being offset by a reduction in advertising expenses. Brands 4 , 5,6 , and 9 show lower costs during the later years than during 1902 and 1903 , the reduction being chiefly, if not wholly, in advertising expenses; in fact, the reduction in advertising expenses is in some cases greater than the total reduction in cost, leaf costs having actually increased.

All of the brands of granulated smoking tobacco except No. 3, which has a very small output, show a considerable increase in profit in 1907, as compared with 1901 . This is due to the fact that the price was, for most of the brands, decidedly higher in the latter year than in the earlier, while the costs had increased comparatively little. Brands 1, 2, 4, 5, and 6 show an increase of 5 cents or more per pound in profit for 1907 as compared with 1901 ; brands 7,8 , and 9 show a somewhat smaller increase, while for brand 3 the profit was nearly stationary, being at all times low and part of the time turning to a small loss.

It will be seen that for the last year covered by the table-1907the profit on four of the brands-namely, 4, 5, 6, and 8 -exceeded 10 cents per pound, while the profit for brand 9 , which is an important one, was nearly 10 cents per pound. Brand 1 shows a profit of about 5 cents per pound, while for the other three brands the profits were somewhat less.

The brands of smoking tobacco covered by the above tables are nearly all brands which were in existence during the Spanish war period, and in fact for years before that time. The prices of these established brands, as has been seen, were very little, if at all, reduced at the time when the taxes were reduced in 1901 and 1902 and are now generally higher than during the Spanish war period, notwithstanding the lower rate of taxation. The combination, to be sure, did introduce some new brands of smoking tobacco at the time when the taxes were reduced, the prices, costs, and profits of which are not shown in the tables. Some of these new brands were sold at lower prices and commanded lower profits than the majority of the brands covered by the table and diagrams. The introduction of these new brands, however, tended very little to reduce the average prices and profits of the Tobacco Combination on smoking tobacco. The combination naturally did not push their sales any more than was necessary, but on the contrary devoted special effort immediately after the taxes were reduced to advertising and pushing the sales of the higher-priced and more profitable brands in order to avoid the necessity of reducing their prices. The lower-priced brands thus introduced, therefore, in general never became of much importance. In a few cases the sales of such brands have been pushed to a considerable extent in order to meet the competition of some particular independent brand, but this is not the general case.

\section{PRICES OF SMOKING-TOBACCO BRANDS BEFORE AND AFTER THE SPANISH WAR PERIOD.}

The tables above presented make it clear that the American Tobacco Company in general did not reduce its average price for all smoking tobacco at the time the internal-revenue taxes were reduced 
in 1901 and 1902. This company and other manufacturers of smoking tobacco generally had, however, increased their prices at the time when the additional war taxes had been imposed in 1898 . Consequently, the present prices charged by the American Tobacco Company for those brands which were in existence before the war are in general higher than the prices of the same brands prior to the war, the rates of tax being the same. Owing to the lack of bookkeeping records of those companies which from time to time have entered the combination covering the period prior to such entry, it is impossible to show with absolute accuracy the movement of prices of smoking tobacco from the period before the Spanish war to the present time, but approximately correct records of the price movements of the leading brands have been obtained. from price lists, invoices, and similar sources of information. Table 55, below, shows the customary price to the consumer and the prevailing prices to jobbers, including and excluding taxation, for 12 brands of smoking tabacco now manufactured by the American and Lorillard companies. Some of these brands were already controlled by the American Tobacco Company in 1895, the first year covered by the table, but most of them were acquired by the combination either at the time when the Continental Tobacco Company was organized, in December, 1898, or shortly thereafter. The prices have been compiled and averaged in the same manner as the similar prices of plug tobacco already presented. (See p. 83, above.)

The consumers' prices shown in the table are those based on the more commonly used packages of the several brands. In some cases a brand is sold in only a single-size package of small weight, or in two small sizes, one double the other; but in other cases, in addition to the small packages, large packages are offered to the consumer at a lower price per pound. The great bulk of the trade, however, has been at all times in the smaller packages. The changes in the prices to the consumer on these small packages, as shown in the table, have been altogether due to changes in the size of the packages sold at a customary price. The most common prices are 5 cents and 10 cents. The sizes of packages in which smoking tobacco may be packed are prescribed by law. Prior to the Spanish war the packages most commonly used were 2 ounces, 3 ounces, and 4 ounces, no other small packages being authorized. When the tax was increased, on June 14, 1898, from 6 cents to 12 cents per pound, manufacturers were authorized to substitute for these packages, packages containing $1 \frac{2}{3}$ ounces, $2 \frac{1}{2}$ ounces, and $3 \frac{1}{3}$ ounces, respectively; and a 1 -ounce package, which had not previously been authorized, was provided for. Manufacturers very generally increased their prices to the consumers by wholly substituting these smaller packages for the larger packages previously sold at the same price. The character of the change may be indicated by reference to brand No. 3 in the table below. Prior to June 14, 1898, the consumer got 2 ounces of this brand for 5 cents (or 4 ounces for 10 cents), making a price of 40 cents per pound. After the tax was raised he got $1 \frac{2}{3}$ ounces for 5 cents (or $3 \frac{1}{3}$ ounces for 10 cents), making the price 48 cents per pound.

When the war-revenue tax was reduced in 1901 and again in 1902, so that it finally stood again at 6 cents, the same as before the war, the law continued to authorize the $1,1 \frac{2}{3}, 2 \frac{1}{2}$, and $3 \frac{1}{3}$ ounce packages, 
in addition to the 2,3 , and 4 ounce packages which had existed before the war. The manufacturer, therefore, had the option of continuing to sell the smaller package to the consumer at the same price as before, thereby continuing the same price per pound, or of giving the larger package and reducing the price per pound to the same basis as had existed before the war. How far this was done by the American Tobacco Company and the Lorillard Company on the leading brands already being sold is plainly shown by the table below.

TABLE 55.-Smoking tobacco-Consumers' price and average net price to jobbers, including and excluding tax on brands made by the American Tobacco Company.

[Compiled from price lists, invoices, discount circulars, etc.]

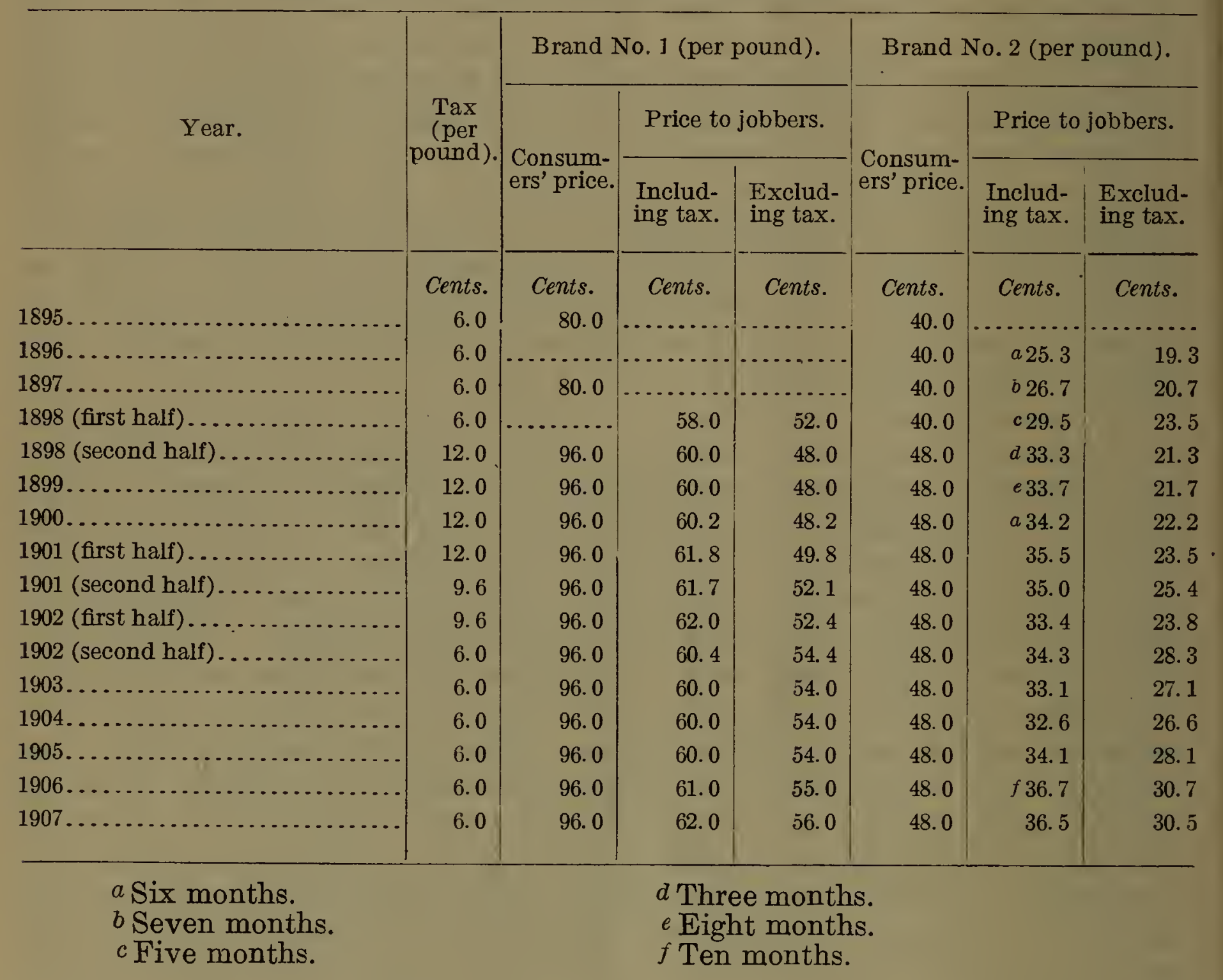


CABLE 55.-Smoking tobacco-Consumer's price and average net price to jobbers, including and excluding tax on brands made by the American Tobacco Company-Continued.

[Compiled from price lists, invoices, discount circulars, etc.]

\begin{tabular}{|c|c|c|c|c|c|c|c|}
\hline \multirow{3}{*}{ Year. } & \multirow{3}{*}{$\begin{array}{c}\text { Tax } \\
\text { (per } \\
\text { pound). }\end{array}$} & \multicolumn{3}{|c|}{ Brand No. 3 (per pound). } & \multicolumn{3}{|c|}{ Brand No. 4 (per pound). } \\
\hline & & \multirow{2}{*}{$\begin{array}{l}\text { Consum- } \\
\text { ers'price. }\end{array}$} & \multicolumn{2}{|c|}{ Price to jobbers. } & \multirow{2}{*}{$\begin{array}{l}\text { Consum- } \\
\text { ers' price. }\end{array}$} & \multicolumn{2}{|c|}{ Price to jobbers. } \\
\hline & & & $\begin{array}{l}\text { Includ- } \\
\text { ing tax. }\end{array}$ & $\begin{array}{l}\text { Exclud- } \\
\text { ing tax. }\end{array}$ & & $\begin{array}{l}\text { Includ- } \\
\text { ing tax. }\end{array}$ & $\begin{array}{l}\text { Exclud- } \\
\text { ing tax. }\end{array}$ \\
\hline $1895 \ldots$ & $\begin{array}{r}\text { Cents. } \\
6.0\end{array}$ & $\begin{array}{l}\text { Cents. } \\
40.0\end{array}$ & $\begin{array}{r}\text { Cents. } \\
25.0\end{array}$ & $\begin{array}{r}\text { Cents. } \\
19.0\end{array}$ & $\begin{array}{c}\text { Cents. } \\
. . . . . . . .\end{array}$ & $\begin{array}{l}\text { Cents. } \\
. . . . . .\end{array}$ & $\begin{array}{c}\text { Cents. } \\
\ldots . . . . . .\end{array}$ \\
\hline $1896 \ldots \ldots \ldots$ & 6.0 & 40.0 & a 25.0 & 19.0 & $\cdots$ & $\ldots .$. & $\cdots \ldots \ldots$ \\
\hline $1897 \ldots \ldots \ldots$. & 6.0 & 40.0 & 25.0 & 19.0 & …. & .... & $\ldots$. \\
\hline 1898 (first half) ... & 6.0 & 40.0 & 25.7 & 19.7 & 40.0 & $\ldots$. & $\ldots$. \\
\hline 1898 (second half).. & 12.0 & 48.0 & 32.0 & 20.0 & 48.0 & 34.0 & 22.0 \\
\hline $1899 \ldots \ldots \ldots$ & 12.0 & 48.0 & 30.7 & 18.7 & 48.0 & 35.0 & 23.0 \\
\hline $1900 \ldots \ldots \ldots$ & 12.0 & 48.0 & 31.7 & 19.7 & 48.0 & 36.6 & 24.6 \\
\hline 1901 (first half)..... & 12.0 & 48.0 & 30.4 & 18.4 & 48.0 & 37.0 & 25.0 \\
\hline 1901 (second half).. & 9.6 & 48.0 & b 29.4 & 19.8 & 48.0 & 37.0 & 27.4 \\
\hline 1902 (first half) ... & 9.6 & 48.0 & $c 28.3$ & 18.7 & 48.0 & 35.7 & 26.1 \\
\hline 1902 (second half).. & 6.0 & 48.0 & 30.0 & 24.0 & 48.0 & 35.8 & 29.8 \\
\hline $1903 \ldots . . . .$. & 6.0 & 48.0 & 28.8 & 22.8 & 48.0 & 36.5 & 30.5 \\
\hline $1904 \ldots .$. & 6.0 & 48.0 & 29.8 & 23.8 & 48.0 & 37.0 & 31.0 \\
\hline $1905 \ldots$ & 6.0 & 48.0 & $d 31.2$ & 25.2 & 48.0 & 37.0 & 31.0 \\
\hline $1906 \ldots$ & 6.0 & 48.0 & 31.5 & 25.5 & 48.0 & 37.0 & 31.0 \\
\hline $1907 \ldots \ldots \ldots$ & 6.0 & 53.3 & 32.0 & 26.0 & 48.0 & 37.0 & 31.0 \\
\hline \multirow{3}{*}{ Year. } & \multirow{3}{*}{$\begin{array}{c}\text { Tax } \\
\text { (per } \\
\text { pound). }\end{array}$} & \multicolumn{3}{|c|}{ Brand No. 5 (per pound). } & \multicolumn{3}{|c|}{ Brand No. 6 (per pound). } \\
\hline & & \multirow{2}{*}{$\begin{array}{l}\text { Consum- } \\
\text { ers' price. }\end{array}$} & \multicolumn{2}{|c|}{ Price to jobbers. } & \multirow[b]{2}{*}{$\begin{array}{l}\text { m- } \\
\text { ice. }\end{array}$} & \multicolumn{2}{|c|}{ Price to jobbers. } \\
\hline & & & $\begin{array}{l}\text { Includ- } \\
\text { ing tax. }\end{array}$ & $\begin{array}{l}\text { Exclud- } \\
\text { ing tax. }\end{array}$ & & $\begin{array}{l}\text { Includ- } \\
\text { ing tax. }\end{array}$ & $\begin{array}{l}\text { Exclud- } \\
\text { ing tax. }\end{array}$ \\
\hline $1897 \ldots \ldots \ldots \ldots$ & $\begin{array}{r}\text { Cents. } \\
6.0\end{array}$ & $\begin{array}{l}\text { Cents. } \\
\text { e } 40.0\end{array}$ & $\begin{array}{r}\text { Cents. } \\
32.0\end{array}$ & $\begin{array}{r}\text { Cents. } \\
26.0\end{array}$ & Cents. & Cents. & $\begin{array}{l}\text { Cents. } \\
. . . . . .\end{array}$ \\
\hline 1898 (first half).... & 6.0 & 40.0 & 32.0 & 26.0 & $\cdots$ & $\ldots$ & $\cdots$ \\
\hline 1898 (second half).... . . . . & 12.0 & 48.0 & 36.0 & 24.0 & - & $\cdots \cdot$ & $\cdots$ \\
\hline $1899 \ldots \ldots \ldots$ & 12.0 & 48.0 & 36.0 & 24.0 & $\ldots . .$. & $\ldots . .$. & $\cdots$ \\
\hline $1900 \ldots . . . . .$. & 12.0 & 48.0 & 36.0 & 24.0 & $f 24.0$ & $f 16.0$ & 4.0 \\
\hline 1901 (first half) ... & 12.0 & 48.0 & 36.0 & 24.0 & 24.0 & $g 15.0$ & 3.0 \\
\hline 1901 (second half).. & 9.6 & 48.0 & 36.0 & 26.4 & 24.0 & $\ldots$ & $\ldots$ \\
\hline 1902 (first half .... . & 9.6 & 48.0 & 36.0 & 26.4 & 24.0 & h 16.1 & 6.5 \\
\hline 1902 (second half).. & 6.0 & 48.0 & 35.0 & 29.0 & 24.0 & 14.4 & 8.4 \\
\hline $1903 \ldots$ & 6.0 & 48.0 & $\ldots \ldots \ldots$ & $\ldots \ldots \ldots$ & 24.0 & 15.6 & 9.6 \\
\hline 1904. & 6.0 & 48.0 & 37.0 & 31.0 & 24.0 & 16.8 & 10.8 \\
\hline 1905 & 6.0 & 48.0 & 37.0 & 31.0 & 24.0 & 13.5 & 7.5 \\
\hline $1906 \ldots$ & 6.0 & 48.0 & 37.0 & 31.0 & 24.0 & 12.8 & 6.8 \\
\hline$\ldots \ldots \ldots \ldots$ & 6.0 & 48.0 & 37.0 & 31.0 & 24.0 & 12.0 & 6.0 \\
\hline
\end{tabular}

$a$ Seven months. $b$ Three months. c Five months. d Eleven months. $e$ Eight months.

$f$ Two months.

$g$ April 27, 1901, to September 1.

$h$ Four months. 
TABLE 55.-Smoking tobacco-Consumers' price and average net price to jobbers, including and excluding tax on brands made by the American Tobacco Company-Continued.

[Compiled from price lists, invoices, discount circulars, etc.]

\begin{tabular}{|c|c|c|c|c|c|c|c|}
\hline \multirow{3}{*}{ Year. } & \multirow{3}{*}{$\begin{array}{c}\text { Tax } \\
\text { (per } \\
\text { pound). }\end{array}$} & \multicolumn{3}{|c|}{ Brand No. 7 (per pound). } & \multicolumn{3}{|c|}{ Brand No. 8 (per pound). } \\
\hline & & \multirow{2}{*}{$\begin{array}{l}\text { Consum- } \\
\text { ers' price. }\end{array}$} & \multicolumn{2}{|c|}{ Price to jobbers. } & \multirow{2}{*}{$\begin{array}{l}\text { Consum- } \\
\text { ers' price. }\end{array}$} & \multicolumn{2}{|c|}{ Price to jobbers. } \\
\hline & & & $\begin{array}{l}\text { Includ- } \\
\text { ing tax. }\end{array}$ & $\begin{array}{l}\text { Exclud- } \\
\text { ing tax. }\end{array}$ & & $\begin{array}{l}\text { Includ- } \\
\text { ing tax. }\end{array}$ & $\begin{array}{l}\text { Exclud- } \\
\text { ing tax. }\end{array}$ \\
\hline 1895. & $\begin{array}{r}\text { Cents. } \\
6.0\end{array}$ & $\begin{array}{l}\text { Cents. } \\
80.0\end{array}$ & $\begin{array}{r}\text { Cents. } \\
51.2\end{array}$ & $\begin{array}{r}\text { Cents. } \\
45.2\end{array}$ & $\begin{array}{l}\text { Cents. } \\
40.0\end{array}$ & $\begin{array}{l}\text { Cents. } \\
27.0\end{array}$ & $\begin{array}{r}\text { Cents. } \\
21.0\end{array}$ \\
\hline 1896 & 6.0 & 80.0 & 51.2 & 45.2 & 40.0 & 27.0 & 21.0 \\
\hline $1897 \ldots . . . \ldots$. & 6.0 & & & & 40.0 & 27.0 & 21.0 \\
\hline 1898 (first half) & 6.0 & 80.0 & 51.3 & 45.3 & 40.0 & 27.2 & 21.2 \\
\hline 1898 (second half) & 12.0 & 96.0 & 61.0 & 49.0 & 48.0 & 32.4 & 20.4 \\
\hline $1899 \ldots \ldots \ldots$ & 12.0 & 96.0 & 61.0 & 49.0 & 48.0 & 35.7 & 23.7 \\
\hline $1900 \ldots$ & 12.0 & 96.0 & 62.3 & 50.3 & 48.0 & 36.2 & 24.2 \\
\hline 1901 (first half)... & 12.0 & 96.0 & 63.0 & 51.0 & 48.0 & 36.1 & 24.1 \\
\hline 1901 (second half). & 9.6 & 96.0 & 61.0 & 51.4 & 48.0 & 36.1 & 26.5 \\
\hline 1902 (first half)... & 9.6 & 96.0 & 63.0 & $53: 4$ & 48.0 & 36.1 & 26.5 \\
\hline 1902 (second half) & 6.0 & 96.0 & 62.0 & 56.0 & 48.0 & 35.2 & 29.2 \\
\hline $1903 \ldots . . . \ldots . .$. & 6.0 & 96.0 & 63.0 & 57.0 & 48.0 & 36.0 & 30.0 \\
\hline 1904. & 6.0 & 96.0 & 61.3 & 55.3 & 48.0 & 35.4 & 29.4 \\
\hline 1905. & 6.0 & 96.0 & 63.0 & 57.0 & 48.0 & 36.7 & 30.7 \\
\hline 1906. & 6.0 & 96.0 & 63.0 & 57.0 & 48.0 & 36.8 & 30.8 \\
\hline $1907 \ldots$ & 6.0 & 96.0 & 63.0 & 57.0 & 48.0 & 37.0 & 31.0 \\
\hline \multirow{3}{*}{ Year. } & \multirow{3}{*}{$\begin{array}{c}\text { Tax } \\
\text { (per } \\
\text { pound). }\end{array}$} & \multicolumn{3}{|c|}{ Brand No. 9 (per pound). } & \multicolumn{3}{|c|}{ Brand No. 10 (per pound). } \\
\hline & & \multirow{2}{*}{$\begin{array}{l}\text { Consum- } \\
\text { ers' price. }\end{array}$} & \multicolumn{2}{|c|}{ Price to jobbers. } & \multirow{2}{*}{$\begin{array}{l}\text { Consum- } \\
\text { ers' price }\end{array}$} & \multicolumn{2}{|c|}{ Price to jobbers. } \\
\hline & & & $\begin{array}{l}\text { Includ- } \\
\text { ing tax. }\end{array}$ & $\begin{array}{l}\text { Exclud- } \\
\text { ing tax. }\end{array}$ & & $\begin{array}{l}\text { Includ- } \\
\text { ing tax. }\end{array}$ & $\begin{array}{l}\text { Exclud- } \\
\text { ing tax. }\end{array}$ \\
\hline & Cents. & Cents. & Cents. & Cents. & Cents. & Cents. & Cents. \\
\hline & 6.0 & 40.0 & & $22=$ & & & \\
\hline 1897 & 6.0 & 40.0 & 28.0 & 22.0 & & & 1 \\
\hline 1898 (first half). . & 6.0 & 40.0 & 24.8 & 18.8 & 40.0 & & . \\
\hline 1898 (second half). & 12.0 & 48.0 & 36.0 & 24.0 & 40.0 & $\ldots$ & .. \\
\hline $1899 \ldots \ldots \ldots \ldots$ & 12.0 & 48.0 & 35.4 & 23.4 & $b 48.0$ & $b 35.2$ & 23.2 \\
\hline $1900 \ldots$. & 12.0 & 48.0 & 35.9 & 23.9 & 48.0 & 35.4 & 23.4 \\
\hline 1901 (first half).. & 12.0 & 48.0 & 36.3 & 24.3 & 48.0 & 36.0 & 24.0 \\
\hline 1901 (second half). & 9.6 & 48.0 & 36.3 & 26.7 & 48.0 & 35.0 & 25.4 \\
\hline 1902 (first half) ... & 9.6 & 48.0 & 35.7 & 26.1 & 48.0 & 34.7 & 25.1 \\
\hline 1902 (second half). & 6.0 & 48.0 & 35.8 & 29.8 & 48.0 & 34.5 & 28.5 \\
\hline $1903 \ldots$ & 6.0 & 48.0 & 36.0 & 30.0 & 48.0 & 35.7 & 29.7 \\
\hline $1904 \ldots$ & 6.0 & 48.0 & 34.6 & 28.6 & 51.6 & 37.0 & 31.0 \\
\hline $1905 \ldots$ & 6.0 & 48.0 & 37.0 & 31.0 & 53.3 & 39.8 & 33.8 \\
\hline $1906 \ldots \ldots \ldots$ & 6.0 & 48.0 & 37.0 & 31.0 & 53.3 & $c 40.0$ & 34.0 \\
\hline $1907 \ldots$ & 6.0 & 48.0 & 37.0 & 31.0 & 53.3 & 40.0 & 34.0 \\
\hline
\end{tabular}

$a$ Seven months. $\quad b$ From June 15 (seven months). $\quad c$ Ten months. 
TABLE 5̃.-Smoking tobacco-Consumers' price and average net price to jobbers, including and excluding tax on brands made by the American Tobacco Company-Continued.

[Compiled from price lists, invoices, discount circulars, etc.]

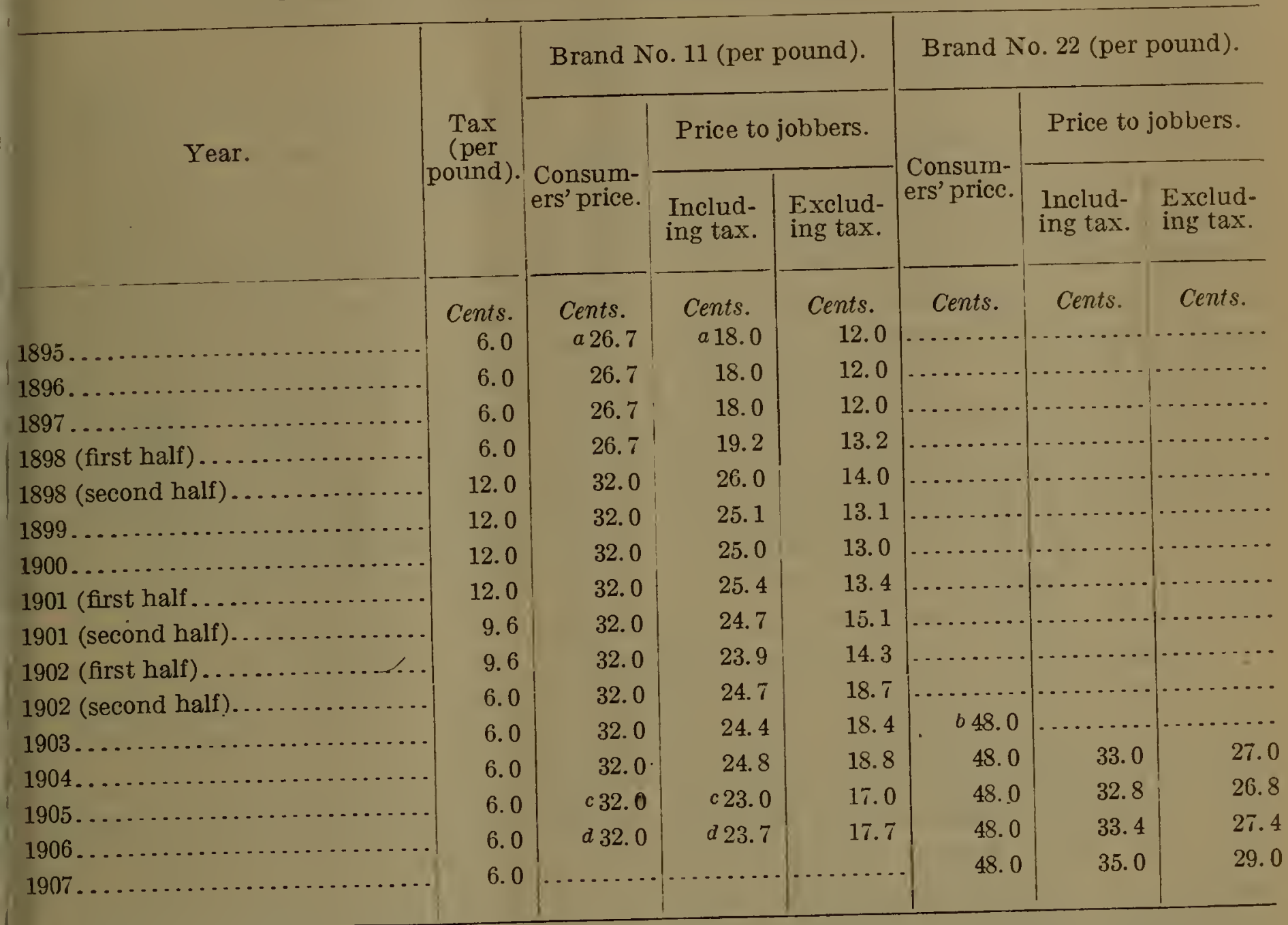

$a$ Eight months. $\quad b$ One month. $\quad c$ Eleven months. $\quad a$ Nine months.

Attention is first directed to the figures showing the price to jobbers; that is, the manufacturer's price for his goods, and to the changes which took place at the time of the increase in the $\operatorname{tax}$ in 1898 . Brands Nos. 6 and 12 were not in existence at that time, and there is no information regarding the changes in brand No. 10, leaving 9 brands for which the changes in the jobbers' prices at this time are shown (or in the case of brand No. 4 can be inferred with substantial certainty from the retail price). It will be seen that of these 9 brands, 6 (Nos. 2, 3, 7, 8, 9, and 11) were increased in price by the full amount of the addition to the tax, or more; and it is practically certain that the same was true of brand No. 4 , the price of which to the consumer was raised 8 cents a pound. On the high-priced brand No. 1 the charge to jobbers increased only 2 cents a pound, while on brand No. 5 the increase was 4 cents, or two-thirds as much as the increase in the tax. Since some of the brands increased in price considerably more than the reduction in the tax, it may be said broadly that the prices of these brands taken together increased at least as much as the increase in the tax.

The brands of the companies which have, since the organization of the Continental Tobacco Company, become subsidiary concerns of the combination, show the same general movement as the brands above tabulated. Bull Durham tobacco was an exception, its price remaining unchanged when taxes were advanced. 
On the other hand, it will be seen from the table that there was in general comparatively little decrease in the prices charged to jobbers for these brands of smoking tobacco when the tax was reduced from 12 cents per pound in the first half of 1901 to 6 cents per pound after July 1, 1902. In the case of brands $3,4,5,6,7,8$, and 9, the prices immediately after the reduction in the tax were quite as high as they had been during the war period (save that in the case of brand No. 4, although the prioes were as high as during 1898 and 1899, they were not quite so high as during 1901). In the case of the other four brands then in existence (No. 12 being introduced in 1903), there was a comparatively slight decrease in the prices at this time, but much less than the decrease in the tax. On three of these four brands the price was subsequently restored to the full level which had prevailed during the war. On brand No. 11, however, the price to jobbers, after the war-tax period never quite reached the level, which had been maintained from the middle of 1898 to the middle of 1901 , and there was a further reduction in the price of this brand in 1905 and 1906. In the case of brand No. 6, a very low-priced brand, there has been a marked reduction in the price since 1904 , but the net price less tax is still higher than it was during the war period.

Turning now to the prices charged to the consumer for the more commonly used packages of smoking tobacco of the several brands covered by the table, it will be seen that in the case of all of the brands for which data are available the price to the consumer increased by at least as much as the increase in the tax at the time of the Spanish war. The most common increase was from 40 to 48 cents per pound, or, in the case of the high-priced brands, from 80 to 96 cents per pound. Where the price was advanced from 80 to 96 cents there was, of course, a marked increase in the profit to the manufacturer, as the tax had increased only 6 cents per pound, but it does not follow that by increasing the price from 40 to 48 cents per pound when the tax rose 6 cents the manufacturer increased his profit. The cost of the smaller containers - tins, bags, etc.- used after the change in tax must have been practically the same as the cost of the larger packages used before, and, as the container is a considerable element in the total cost, it may be that the cost per pound of the tobacco, including the container, went up by as much as 2 cents, thus balancing the difference between the increase of 6 cents in tax and the increase of 8 cents in price.

On the other hand, there was absolutely no reduction in the price to the consumer on any of the brands covered by this table when the tax was reduced. In other words, on none of these brands were the larger packages substituted for the smaller. In fact, in two cases (brands Nos. 3 and 10) a still smaller package has since been substituted, so that the price to the consumer has been raised above the level which prevailed during the period of high taxes.

It appears therefore, that, so far as the brands covered by the table are concerned, the prices to jobbers were in nearly all cases increased at the time of the advance in the taxes in 1898, and in most cases the price to the consumer was also increased, the increase being sufficient at least to cover the addition to the tax. On these particular brands also it has been seen that there was practically no reduction in price when the tax was reduced in 1901 and 1902. 
These brands are among the most important made by the Combinaion and are typical of much the greater part of its business.

It is true that when the war taxes were reduced the Combination did introduce some new brands at relatively lower prices. For example, in addition to a brand which had been selling at retail at $1 \frac{2}{3}$ ounces for 5 cents, a somewhat similar brand might be put on the market selling at retail at 2 ounces for 5 cents, with a corresponding difference in the price to the jobber. The Combination, however, did not in general push the sales of these lower-priced brands. On the contrary, as already stated, the Combination actively advertised and pushed the sales of those established brands theprices of which were not reduced at the time the war taxes were taken off. By this policy the Combination was able largely to keep up the sales of these higher-priced brands and ultimately again to reduce the selling and advertising expenses, so that at present a very large proportion of its smoking-tobacco business consists of the high-priced and highprofit brands on which the price to the consumer and to the jobber is at least as high under the 6 -cent tax rate as it was during the war period under the 12-cent rate. 


\section{FINE-CUT TOBACCO BUSINESS OF THE COMBINATION.}

The fine-cut tobacco business is much less important than the plug and smoking tobacco business. The total output of fine cut for the country as a whole is equal to only about one-fifteenth of the output of plug and twist and is about the same proportion of the output of smoking tobacco. Moreover, the output of fine cut in recent years has been less than it was during the early nineties, although there has been only slight variation from year to year since 1896 . As shown by Table 12 , the fine-cut tobacco business, as measured by the value of the output, is the least important branch of the business of the Combination. It is advantageous, however, to consider the fine-cut tobacco at the present point, for the reason that the changes in the tax on this class of tobacco have been the same as the changes on plug and smoking tobacco.

The American Tobacco Company acquired its first considerable finecut tobacco business as early as 1891 in connection with its purchase of the Gail \& Ax plant. In that year it had about 3.3 per cent of the entire output of the country. It did not very materially increase its output of fine cut during the period up to 1898 . On account of the decline in the national output, its proportion of the business increased to about 6 per cent in 1898 . The concerns which entered the Continental Tobacco Company at the end of 1898 and the beginning of 1899 had a very considerable output of fine-cut tobacco, and the Tobacco Combination as a whole in 1899 had 48.5 per cent of the business of the country. Near the close of 1901 and early in 1902 the Combination secured control of two of the most important independent concerns in the fine-cut business, so that its proportion of the output rose to 73.7 per cent. It has further increased since that time, and in 1907 amounted to 81.4 per cent. A consideration of the prices and profits in the fine-cut tobacco business, therefore, naturally divides itself into three periods: (1) From 1891 to 1898, when the Combination possessed only a small fraction of the total business; (2) from 1899 to 1901 , when it possessed about one-half of the total business; and (3) from 1902 to 1907, when it controlled from threefourths to more than four-fifths of the business.

The greater part of the business of fine-cut tobacco controlled by the Tobacco Combination is in the hands of subsidiary companies. In 1906 the American Tobacco Company produced only 13.9 per cent of the fine cut made by the Combination as a whole, the remainder being manufactured by the three subsidiary companies. The Lorillard Company is, however, an important manufacturer of fine cut. Since the American Tobacco Company acts as the selling agent for the Lorillard Company, the business of these two concerns must be combined in order properly to ascertain costs and profits. The American and Lorillard companies together at the present time manufacture somewhat less than one-half of the total output of fine cut produced by the Tobacco Combination. The results of the fine-cut business of these two companies will be considered first, and later the business 
if the principal subsidiary concern in the fine-cut manufacture, jpaulding \& Merrick, will be taken up.

YENERAL RESULTS OF THE FINE-CUT BUSINESS OF THE AMERICAN, CONTINENTAL; AND LORILLARD COMPANIES.

The following table shows the quantity of sales of fine-cut tobacco y the American, Continental, and Lorillard companies in the domesic trade, the net value of those sales exclusive of internal-revenue ax, and the profits for each year from 1895 to 1907 . The exports of ine cut are insignificant, so that this table covers very nearly the ntire business.

A ALE 56.-Fine-cut tobacco-American, Continental, and Lorillard companies: Quantity of sales, net value of sales, and net profit (domestic business).

\begin{tabular}{|c|c|c|c|}
\hline & Sales. & $\begin{array}{l}\text { Net value of } \\
\text { sales (less tax). }\end{array}$ & Profits. \\
\hline 1895 & $\begin{array}{l}\text { Pounds. } \\
55 \overline{1}, 441\end{array}$ & $\$ 150.676 .30$ & $\$ 24,118.21$ \\
\hline 1896. & 550,968 & $149,973.49$ & 19.819 .68 \\
\hline 1897. & 553.559 & $14 \overline{7} .025 .2 \bar{\imath}$ & $30,176.12$ \\
\hline 1898 & 687,394 & $178,035.05$ & $* 6,398.52$ \\
\hline 1899 & $4,452,722$ & $1,085,472.13$ & $77,635.57$ \\
\hline 1900 & $5,807,276$ & $1,332,49 \tilde{.} .44$ & $* 39,404.01$ \\
\hline 1901. & $\tilde{j}, 647,432$ & $1,485,310.06$ & $* 107,734.86$ \\
\hline 1902 . & $4,888,411$ & $1,634,691.74$ & $314,755.67$ \\
\hline 1903. & $3,476,085$ & $1,358,590.14$ & $400,823.55$ \\
\hline 1904 & $3,674,272$ & $1,399,297.69$ & $443,390.45$ \\
\hline 1905 & $4,233,404$ & $1,554,590.84$ & $479,801.12$ \\
\hline 1906. & $4,345,083$ & $1,576,096.57$ & - $493,338.67$ \\
\hline 1907 & $4,538,321$ & $1,609,116.26$ & $451,709.79$ \\
\hline
\end{tabular}

* Loss.

For the years 1895 to 1898 , this table covers only the business of the American Tobacco Company itself, which at that time controlled only a small proportion of the national output. The American made no special attempts to build up its fine-cut business by price cutting, as it did in the plug business, and these four years taken together may be considered as representing normal competitive conditions. Owing to the small proportion of the output of the country controlled by the American, however, it can not be said that these figures represent in any sense the average results obtained by manufacturers in general under competitive conditions. The sales of fine cut by the American Tobacco Company in 1895 were 557,441 pounds, of a net value, exclusive of tax, of $\$ 150,676.30$, and the profits were $\$ 24,118.21$. Presumably in part on account of the increase in the tax in 1898 the fine-cut business of the American in that year resulted in a small loss.

In 1899, after the organization of the Continental, the combined fine-cut business of the American, Continental, and Lorillard companies amounted to 4,452,722 pounds, or about six and a half times as much as the American alone had sold in 1898. The value of the output was $\$ 1,085,472.13$. The profit was small, only $\$ 77,635.57$. During the next two years the Combination pursued a policy of active competition against the independent concerns in the fine-cut business, which 
concerns at that time had substantially one-half of the total output of the country. The Combination succeeded in increasing its output materially, but only at the cost of considerable losses.

Following this active competition, the leading competing concerns, Spaulding \& Merrick and D. H. McAlpin \& Co. were acquired. The output directly manufactured by the American, Continental, and Lorillard companies then fell off because they transferred some of their brands to Spaulding \& Merrick. The fine cut manufactured by the Combination as a whole increased from $5,642,808$ pounds in 1901 to $8,893,164$ pounds in $1902 .^{a}$ The losses which had been incurred by the American, Continental, and Lorillard companies in 1900 and 1901 immediately gave way to considerable profits, the profit in 1902 being $\$ 314,755.67$. Although in no year since 1902 has the quantity sold by these companies equaled that of 1902 , and although the net value, less tax, has been in each year less than in 1902 , the profits have in each year considerably exceeded those of 1902. The maximum profit was in 1906, when on sales of $4,345,083$ pounds, of a net value of $\$ 1,576,096.57$, the companies made a profit of $\$ 493,338.67$.

Table 57 and the accompanying diagram show the details of the prices, costs, and profits of the American, Continental, and Lorillard companies in the domestic fine-cut tobacco business, reduced to the basis of cents per pound. The diagram also shows corresponding information for the entire fine-cut business of the Combination.

TABLE 57.-Fine-cut tobacco-American, Continental, and Lorillard companies: Prices, costs, and profits in domestic business.

\begin{tabular}{|c|c|c|c|c|c|c|c|}
\hline & \multicolumn{3}{|c|}{ New price. } & \multicolumn{3}{|c|}{ Costs. } & \multirow[b]{2}{*}{$\begin{array}{c}\text { Profit } \\
\text { (per } \\
\text { pound). }\end{array}$} \\
\hline & $\begin{array}{l}\text { Includ- } \\
\text { ing tax } \\
\text { (per } \\
\text { pound). }\end{array}$ & $\begin{array}{l}\text { Tax (per } \\
\text { pound). }\end{array}$ & $\begin{array}{l}\text { Exclud- } \\
\text { ing tax } \\
\text { (per } \\
\text { pound). }\end{array}$ & $\begin{array}{l}\text { Manu- } \\
\text { facture } \\
\text { and } \\
\text { freight } \\
\text { (per } \\
\text { pound). }\end{array}$ & $\begin{array}{c}\text { Selling } \\
\text { and } \\
\text { adver- } \\
\text { tising } \\
\text { (per } \\
\text { pound). }\end{array}$ & $\begin{array}{c}\text { Total } \\
\text { (per } \\
\text { pound). }\end{array}$ & \\
\hline $1895 .$. & $\begin{array}{l}\text { Cents. } \\
\quad 33.0\end{array}$ & $\begin{array}{l}\text { Cents. } \\
6.0\end{array}$ & $\begin{array}{l}\text { Cents. } \\
27.0\end{array}$ & $\begin{array}{l}\text { Cents. } \\
\quad 20.1\end{array}$ & $\begin{array}{c}\text { Cents. } \\
2.6\end{array}$ & $\begin{array}{l}\text { Cents. } \\
\quad 22.7\end{array}$ & $\begin{array}{l}\text { Cents. } \\
\quad 4.3\end{array}$ \\
\hline $1896 \ldots$ & 33.2 & 6.0 & 27.2 & 20.7 & 2.9 & 23.6 & 3.6 \\
\hline $1897 .$. & 32.6 & $6: 0$ & 26.6 & 18.8 & 2.3 & 21.1 & 5.5 \\
\hline 1898. & 34.4 & b8. 5 & 25.9 & 18.6 & 8.2 & 26.8 & $* .9$ \\
\hline $1899 \ldots$ & 36.4 & 12.0 & 24.4 & 18.5 & 4. 1 & 22.6 & 1.8 \\
\hline $1900 \ldots$ & 35.0 & 12.0 & 23.0 & 19.3 & 4. 4 & 23.7 & $* .7$ \\
\hline $1901 \ldots$ & 37.2 & c 10.9 & 26.3 & 21.8 & 6.4 & 28.2 & $* 1.9$ \\
\hline $1902 .$. & 41.2 & d 7.8 & 33.4 & 22.3 & 4.7 & 27.0 & 6.4 \\
\hline $1903 .$. & 45.1 & 6.0 & 39.1 & 22.7 & 4.9 & 27.6 & 11.5 \\
\hline $1904 \ldots$ & 44. 1 & 6.0 & 38.1 & 22.5 & 3.5 & 26.0 & 12.1 \\
\hline $1905 \ldots$ & 42.7 & 6.0 & 36.7 & 22.3 & 3.1 & 25.4 & 11.3 \\
\hline $1906 \ldots$ & 42.3 & 6.0 & 36.3 & 21.6 & 3.3 & 24.9 & 11.4 \\
\hline $1907 .$. & 41.5 & 6.0 & 35.5 & 23.4 & 2.1 & 25.5 & 10.0 \\
\hline
\end{tabular}

$a$ The amount manufactured differs somewhat from the amount sold.

$b$ Tax to June 14,6 cents; thereafter, 12 cents; average based on quantities produced.

$c$ First half year, 12 cents; second half, 9.6 cents; average based on quantities produced.

$d$ First half year, 9.6 cents; second half, 6 cents; average based on quantities produced.

* Loss. 


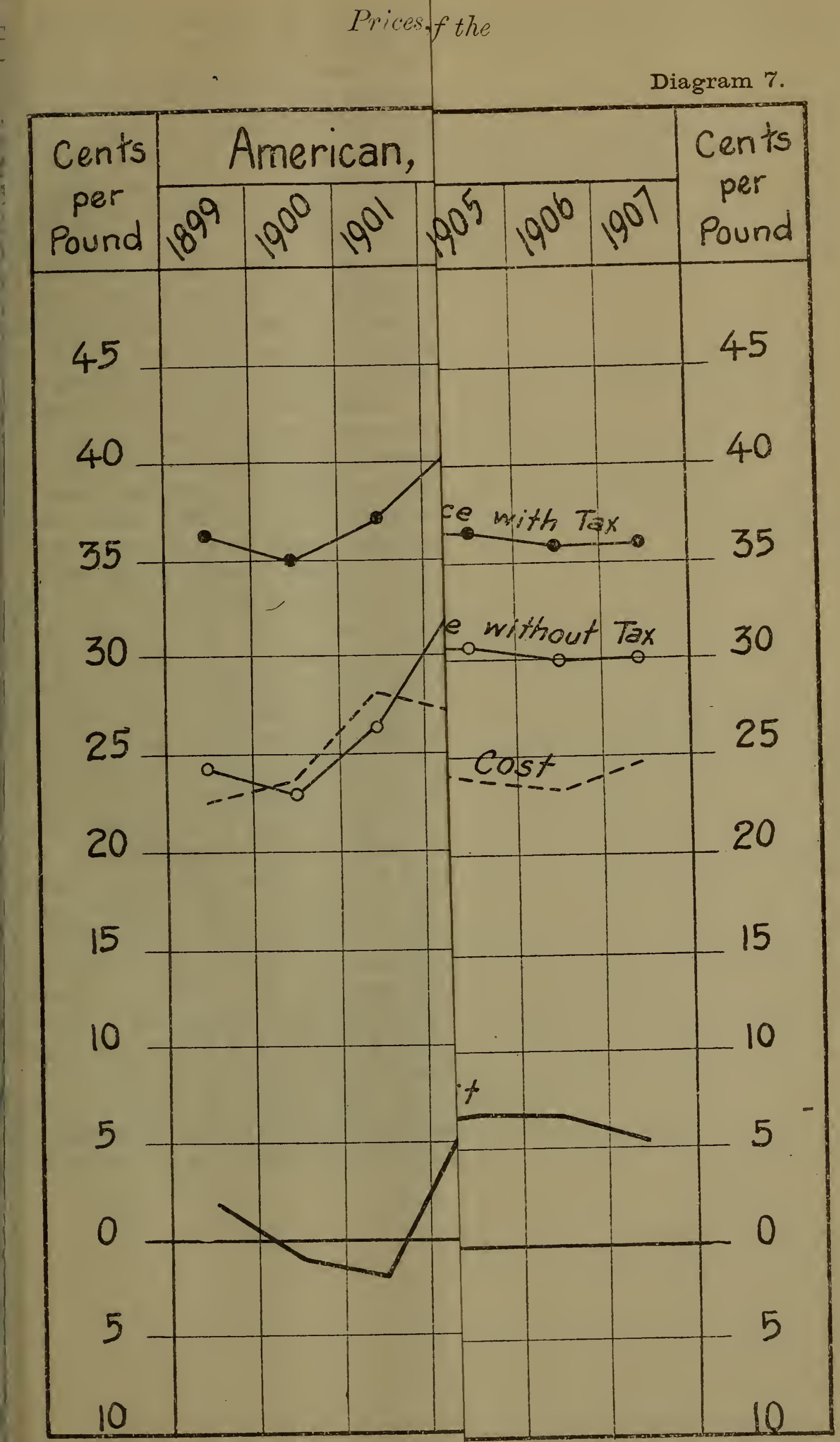



FINE CUT TOBACCO.

Prices. Costs, and Profits of the American. Continental, and Lorillard Companies am of the? entire Combination.

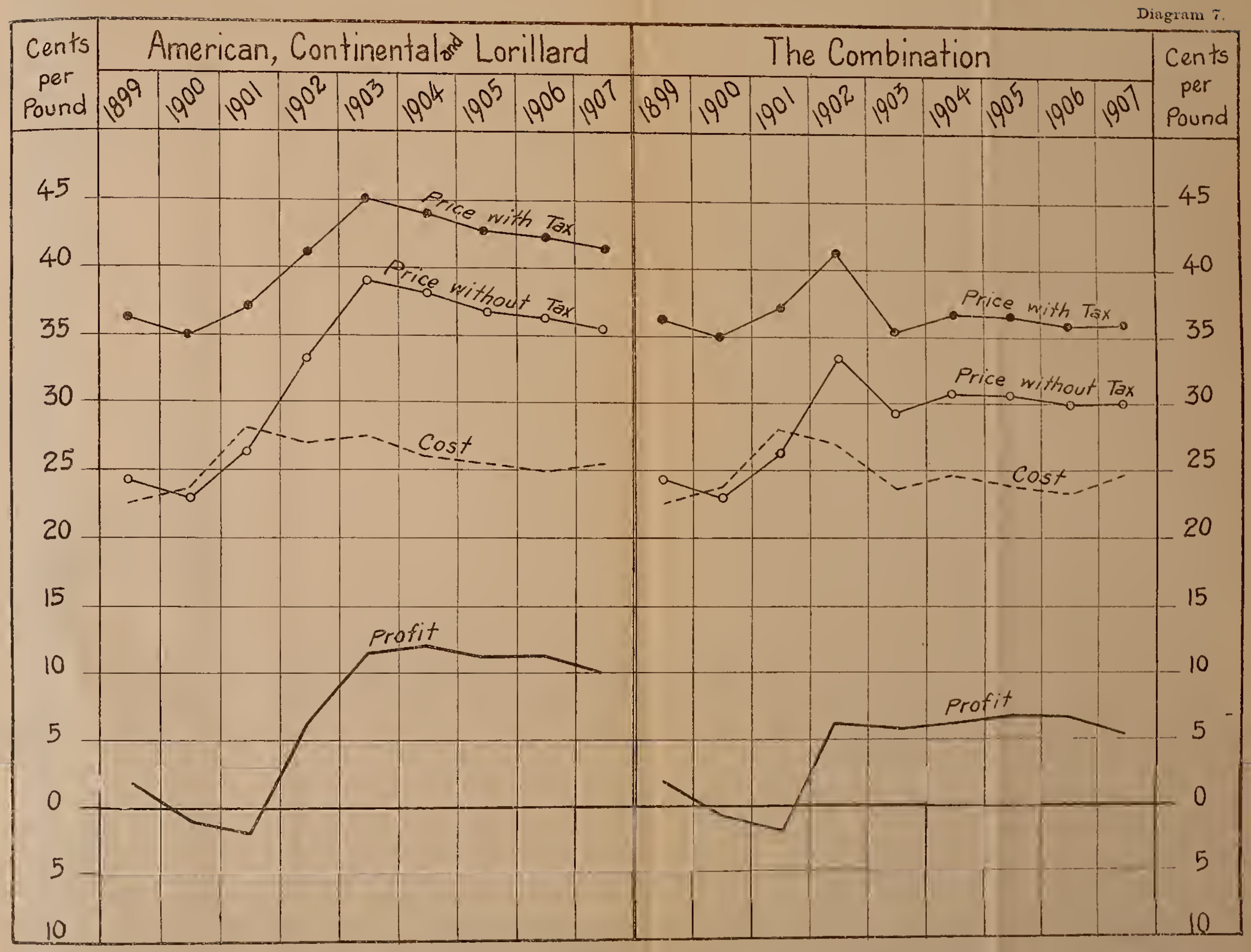



Although, on account of the great difference in the volume of output and number of brands covered as between the years $189 \tilde{5}$ to 1898 and the years from 1899 on, little significance attaches to a comparison of prices and costs as between the one period and the other, there is perhaps some significance in a comparison of the profit during the first period with the profit during the later years. In 1895 to 1897 the American Tobacco Company; as one of the large manufacturer's of fine cut under competitive conditions, made a profit of 3.6 to 5.5 cents, as compared with profits ranging from 10 to 12.1 cents during the period from 1903 to 1907 .

As already stated, the period from 1899 to 1901 was one of very active competition in the fine-cut tobacco business. The net price, including tax obtained by the American, Continental, and Lorillard companies for their output of fine-cut tobacco in the domestic trade ranged from 35 to 37.2 cents. Although there was an increase in 1901 over the two preceding years, and although the tax was lower in that year than in the two preceding years, the very marked increase in costs resulted in a greater loss in 1901 than in 1900. Taking the three years 1899 to 1901 together, there was a net loss in the fine-cut tobacco business of these companies.

The extraordinary change in conditions resulting from the acquisition of competing concerns in 1902 is strikingly shown in the table. Notwithstanding the reduction in the tax from an average of 10.9 cents in 1901 to 7.8 cents in 1902 and 6 cents in 1903, the price charged to the public for fine-cut tobacco markedly increased, so that the net price exclusive of tax increased nearly 50 per cent. This increase was, to be sure, in part due to a transfer of the manufacture of certain low-priced brands to Spaulding \& Merrick, but it was also in part due to advances in the prices of the brands retained. However, the point of importance is that owing to a reduction in selling and advertising expenses, which was also a result of the reduction in competition, the total cost of manufacture and sale fell at the same time that the price increased, so that instead of loss of 1.9 cents as in 1901 , there was a profit of 12.1 cents in 1904 . Since 1904 there has been some decline in the net price, but the costs have also decreased, so that the average profit has been nearly 11 cents per pound. Especially striking is the reduction in selling and advertising expenses, which fell from 6.4 cents in 1901 to 2.1 cents in 1907.

The following table shows the three elements entering into the net price charged to the public for fine-cut tobacco by the American, Continental, and Lorillard companies, namely, the tax, the cost of manufacture and sale, and the profit: 
TABLE 58.-Fine-cut tobacco-American, Continental, and Lorillard companies: Amount of tax, cost, and profit entering into net selling price.

\begin{tabular}{|c|c|c|c|c|}
\hline \multirow{2}{*}{ Year. } & \multicolumn{3}{|c|}{$\begin{array}{l}\text { Elements entering into net } \\
\text { price (per pound). }\end{array}$} & \multirow{2}{*}{$\begin{array}{l}\text { Net price } \\
\text { (per } \\
\text { pound). }\end{array}$} \\
\hline & Tax. & Cost. & Profit. & \\
\hline & Cents. & Cents. & Cents. & Cents. \\
\hline $1895 \ldots$. & 6.0 & 22.7 & 4.3 & $\begin{array}{l}33.0 \\
22\end{array}$ \\
\hline $1896 \ldots \ldots \ldots$ & 6.0 & 23.6 & $\begin{array}{r}3.6 \\
5.5\end{array}$ & 33.2 \\
\hline $1897 \ldots$ & 6.0 & 21.1 & 5.5 & 32.6 \\
\hline $1898 \ldots \ldots \ldots$. & 8.5 & 26.8 & $* .9$ & 34.4 \\
\hline 1899. & 12.0 & 22.6 & 1.8 & 36.4 \\
\hline $1900 \ldots \ldots \ldots \ldots \ldots$ & 12.0 & 23.7 & $* .7$ & 35.0 \\
\hline $1901 \ldots \ldots \ldots \ldots \ldots$ & 10.9 & 28.2 & $* 1.9$ & 37.2 \\
\hline $1902 \ldots \ldots \ldots \ldots \ldots$ & 7.8 & 27.0 & 6.4 & 41.2 \\
\hline $1903 \ldots \ldots \ldots \ldots \ldots$ & 6.0 & 27.6 & 11.5 & 45.1 \\
\hline $1904 \ldots \ldots \ldots \ldots \ldots$ & 6.0 & 26.0 & 12.1 & 44.1 \\
\hline $1905 \ldots \ldots \ldots$ & 6.0 & 25.4 & 11.3 & 42.7 \\
\hline $1906 \ldots \ldots \ldots \ldots \ldots$ & 6.0 & 24.9 & 11.4 & 42.3 \\
\hline $1907 \ldots \ldots \ldots \ldots \ldots \ldots \ldots$ & 6.0 & 25.5 & 10.0 & 41.5 \\
\hline
\end{tabular}

* Loss.

It will be seen that in 1895 to 1897 the tax represented less than one-fifth of the net selling price obtained by the American Tobacco Company, the cost of manufacture about two-thirds, and the profit from about one-ninth to one-sixth. In 1899, under conditions of active competition and increased tax, the tax represented nearly onethird of the net price and the cost nearly two-thirds, the profit being small. Because of a higher relative cost in the year before and in the two following the business showed losses varying from 0.7 to 1.9 cents per pound. In 1902, the first year after the acquisition of the principal competing concerns, the net price was nearly 5 cents higher than in 1899, notwithstanding a reduction of 4.2 cents in the average amount of tax paid, but this increase in price was partly due to the transfer of low-priced brands above mentioned. In 1902 the tax represented 19 per cent on the net selling price, cost 65 per cent, and profit 16 per cent. By 1904 the net price had risen nearly 3 cents more and stood at 7.7 cents higher than in 1899 , notwithstanding a reduction of 6 cents in the internal-revenue tax. In 1904 the tax represented only 14 per cent of the selling price, while the profit represented 27 per cent. The conditions have not greatly changed since that time, although there has been some decline in the price and in the profit. In 1907 the tax represented 14 per cent of the selling price and the profit 24 per cent.

The most significant figures are those of the net price less tax, and the profit. It will be seen from Table 57, above, that during the period of active competition from 1899 to 1901 the net price exclusive of tax obtained by the American, Continental, and Lorillard companies for their entire domestic output of fine-cut tobacco ranged from 23 to 26.3 cents. With the reduction in the amount of competition, and the coincident reduction in the internal-revenue tax, and the transfer of the low-priced brands to Spaulding \& Merrick, 
the net price exclusive of tax leaped to 33.4 cents in 1902 and to a maximum of 39.1 cents in 1903. Since that time the net price less tax has gradually declined and was 35.5 cents in 1907 , but owing to a reduction in the cost of manufacture and sale. there has not been so large a decrease in the profit.

The following table compares the price less tax, the cost, and the profit, for each year from 1900 to $190 \%$, with the corresponding figures for 1899. It shows for each year the increase in the net price less tax over 1899, the increase in cost, and the difference, which represents the increase (or decrease) in profit.

Table 59.-Fine-cut tobacco-Amcrican. Continental and Lorillard companies: Increase in price and increase in cost, 1899-1907.

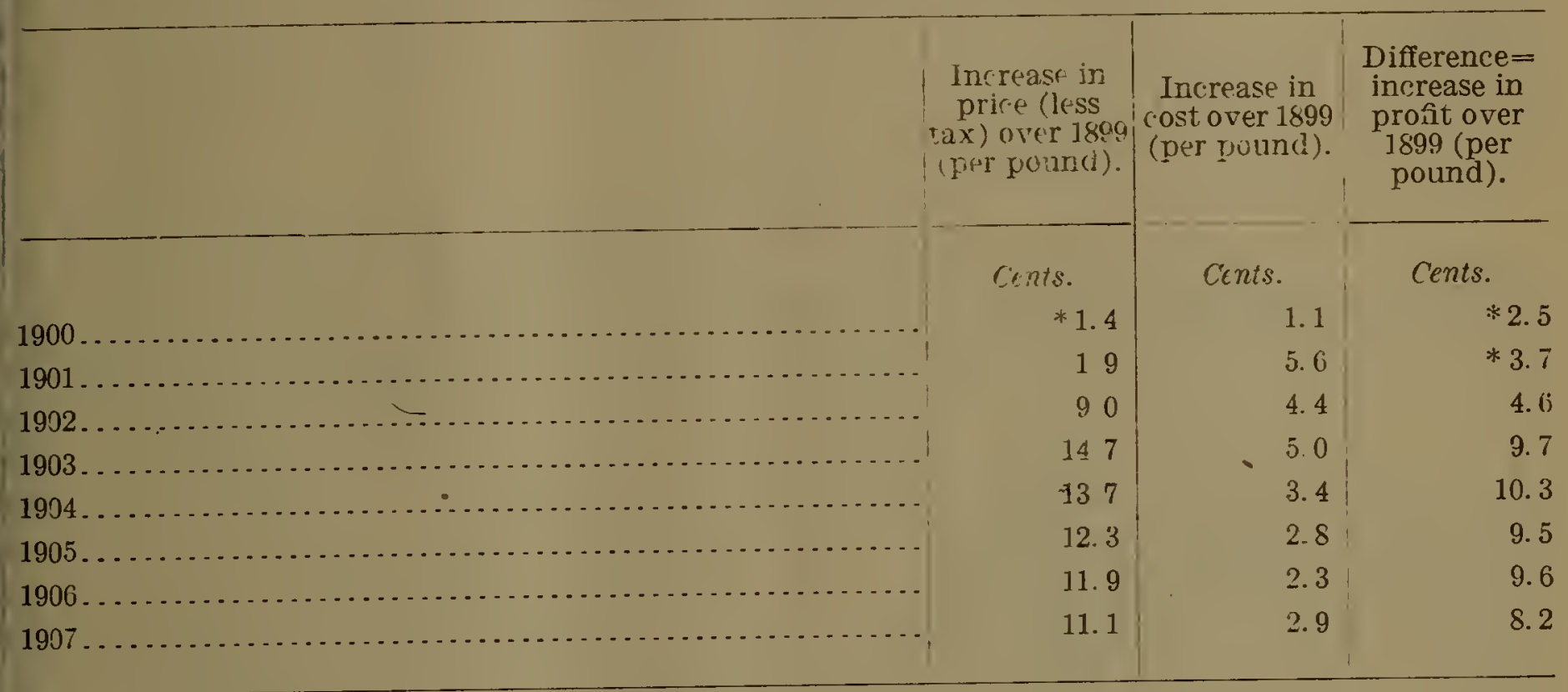

* Decrease.

This table shows that in 1903 the net price less tax exceeded that of 1899 by 14.7 cents. There had, however, been an increase of 5 cents in cost, so that the profit increased 9.7 cents per pound. In 1907 the net price less tax was 11.1 cents higher than in 1899 , but the cost was only 2.9 cents higher, so that the profit per pound was 8.2 cents higher than in the earlier year. Part of the increase in price and profit was due to the transfer of the lower grade brands, but the greater part was due to an increase in price and profit on the brands retained.

Table 60 shows the net cost per pound of fine-cut tobacco made by the American, Continental, and Lorillard companies for the domestic trade, the amount of profit per pound, and the per cent of profit on cost.

TabLe 60.-Fine-cut tobacco-American, Continental, and Lorillard companies: Relation of profits to costs in domestic business.

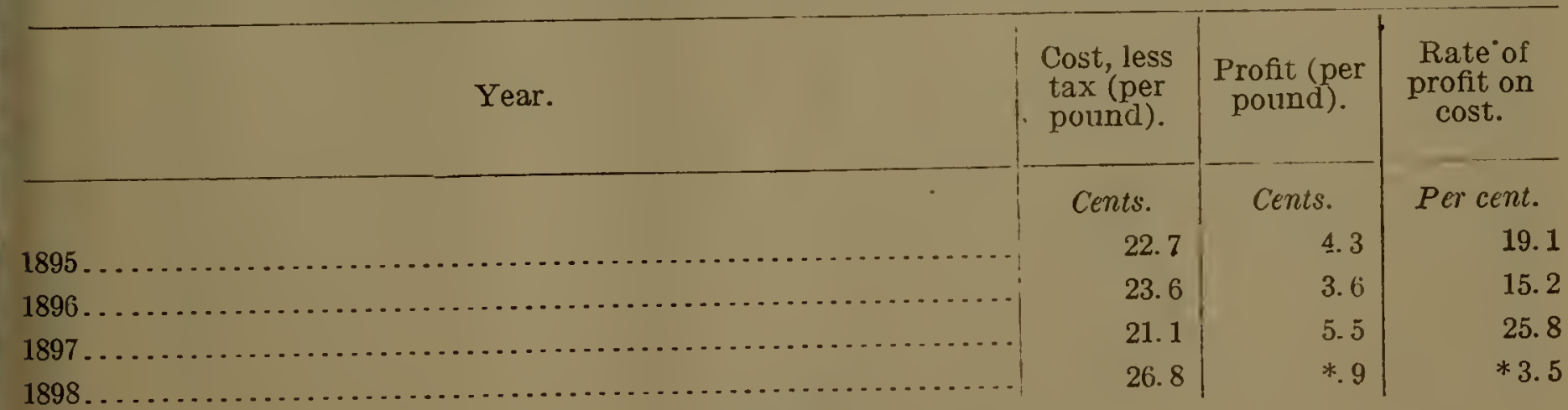

* Loss.

87442 -S. Doc. $78,61-1-\longrightarrow 9$ 
Table 60.-Fine-cut tobacco-American, Continental, and Lorillard companies. Relation of profits to costs in domestic business -Continued.

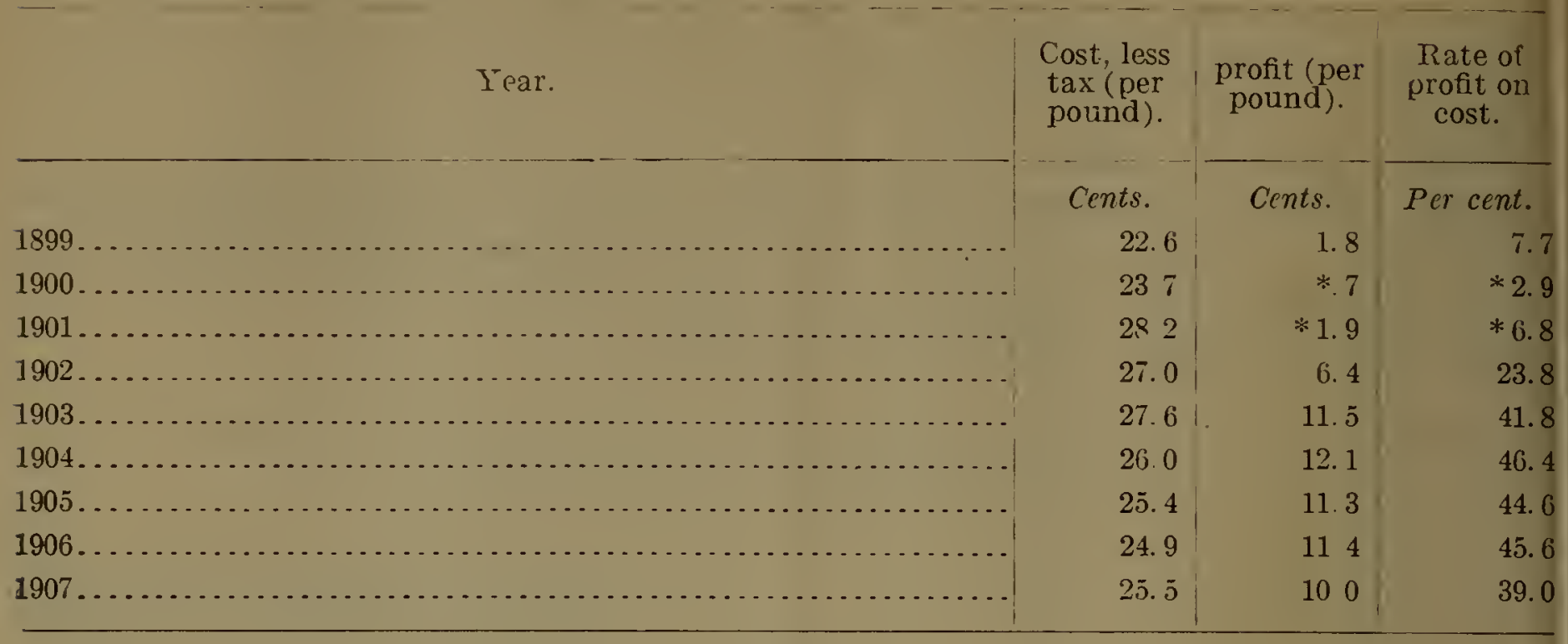

* Loss.

It will be seen that during the years 1895 to 1897 the American Tobacco Company, under competitive conditions, made from 15.2 per cent to 25.8 per cent profit on its cost in the fine-cut tobacco business. There was a loss in 1898 and again in 1900 and 1901, the latter, as already stated, being due to very active competition by the Combination against independent concerns. In the first year after the acquisition of the leading independent concerns-1902the American, Continental, and Lorillard companies obtained a profit equal to 23.8 per cent on cost, or practically the same as the profit of the American Tobacco Company in the prosperous year 1897. The rate of profit on cost increased to 46.4 per cent in 1904, but was a trifle lower in 1905 and 1906, and fell to 39 per cent in 1907.

Table 61 shows the net price, less tax, of fine-cut tobacco manufactured by these three companies for the domestic trade, and the percentages thereof represented by cost and by profit, respectively:

TAB LE 61.-Fine-cut tobacco-American, Continental, and Lorillard companies: Division of net selling price (less tax) between cost and profit.

\begin{tabular}{|c|c|c|c|}
\hline \multirow{2}{*}{ Year. } & \multirow{2}{*}{$\begin{array}{l}\text { A verage } \\
\text { net sell- } \\
\text { ing price } \\
\text { (per } \\
\text { poind). }\end{array}$} & \multicolumn{2}{|c|}{$\begin{array}{l}\text { Proportion repre- } \\
\text { sented by- }\end{array}$} \\
\hline & & Cost. & Profit. \\
\hline $1895 .$. & $\begin{array}{r}\text { Cents. } \\
27.0\end{array}$ & $\begin{array}{r}\text { Per cent. } \\
84.0\end{array}$ & $\begin{array}{r}\text { Per cent. } \\
16.0\end{array}$ \\
\hline $1896 \ldots$ & 27.2 & 86.8 & 13.2 \\
\hline $1897 \ldots \ldots$. & 26.6 & 79.5 & 20.5 \\
\hline $1898 \ldots \ldots \ldots \ldots \ldots \ldots \ldots \ldots \ldots$ & 25.9 & 103.6 & $* 3.6$ \\
\hline $1899 \ldots$ & 24.4 & 92.8 & 7.2 \\
\hline $1900 \ldots \ldots \ldots \ldots \ldots \ldots \ldots \ldots$ & 23.0 & 103.0 & $* 3.0$ \\
\hline $1901 \ldots \ldots \ldots \ldots \ldots \ldots \ldots \ldots$ & 26.3 & 107.3 & $* 7.3$ \\
\hline $1902 \ldots \ldots \ldots \ldots \ldots \ldots \ldots \ldots \ldots \ldots$ & 33.4 & 80.7 & 19.3 \\
\hline $1903 \ldots \ldots \ldots \ldots \ldots \ldots \ldots \ldots$ & 39.1 & 70.5 & 29.5 \\
\hline 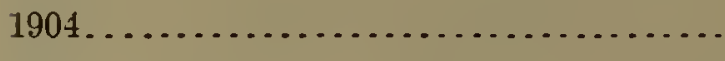 & 38.1 & 68.3 & 31.7 \\
\hline $1905 \ldots \ldots \ldots \ldots \ldots \ldots \ldots \ldots$ & 36.7 & 69.1 & 30.9 \\
\hline 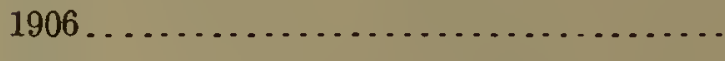 & 36.3 & 68.7 & 31.3 \\
\hline $1907 \ldots \ldots \ldots \ldots \ldots \ldots \ldots \ldots \ldots \ldots \ldots \ldots$ & 35.5 & 71.9 & 28.1 \\
\hline
\end{tabular}

* Loss 
nearly 50 per cent, to 39.1 cents, and there was a profit of 11.5 cents per pound, but this increase was in part due to higher prices and profits on brands acquired by the American from the D. H. McAlpin concern toward the close of 1901 .

\section{RESULTS OF THE FINE-CUT TOBACCO BUSINESS OF THE SUBSIDIARY CONCERNS OF THE TOBACCO COMBINATION.}

The only subsidiary concerns of the American Tobacco Company which make fine-cut tobacco-aside from the P. Lorillard Company, the data for which have already been combined with the data for the American and Continental companies-are Spaulding \& Merrick and the F. F. Adams Tobacco Company. The former makes more fine-cut tobacco than the American and Lorillard companies together, and fine cut constitutes a large proportion of its entire business. The F. F. Adams Tobacco Company, on the other hand, makes relatively little fine cut; in 1906 its output of fine cut was only 312,000 pounds as compared with $5,194,000$ pounds of smoking tobacco. On account of the lack of data by which to distinguish the prices, costs, and profits in the fine-cut business of the Adams company from the data for the smoking-tobacco business, the entire results of this company's business have been considered in connection with the discussion of smoking tobacco. Data are, however, available by which to separate the results of the fine-cut business of Spaulding \& Merrick from those of the other branches of its business:

The stock of Spaulding \& Merrick was acquired by the Combination in 1902, and the first report available is for 1903. The following table shows the average net price per pound, the elements of cost, and the profit per pound:

TABLE 63.-Fine-cut tobacco-Spaulding \& Merrick: Prices, costs, and profits.

\begin{tabular}{|c|c|c|c|c|c|c|c|}
\hline \multirow[b]{2}{*}{ Year. } & \multicolumn{3}{|c|}{ Net price (per pound). } & \multicolumn{3}{|c|}{ Cost (per pound). } & \multirow[b]{2}{*}{$\begin{array}{l}\text { Profit } \\
\text { (per } \\
\text { pound). }\end{array}$} \\
\hline & $\begin{array}{l}\text { Includ- } \\
\text { ing tax. }\end{array}$ & Tax. & $\begin{array}{l}\text { Exclud- } \\
\text { ing tax. }\end{array}$ & $\begin{array}{l}\text { Manufac- } \\
\text { ture and } \\
\text { freight. }\end{array}$ & $\begin{array}{l}\text { Selling } \\
\text { and ad- } \\
\text { vertising. }\end{array}$ & Total. & \\
\hline 1903. & $\begin{array}{l}\text { Cents. } \\
29.0\end{array}$ & $\begin{array}{r}\text { Cents. } \\
6.0\end{array}$ & $\begin{array}{l}\text { Cents. } \\
23.0\end{array}$ & $\begin{array}{r}\text { Cents. } \\
17.1\end{array}$ & $\begin{array}{r}\text { Cents. } \\
3.9\end{array}$ & $\begin{array}{r}\text { Cents. } \\
21.0\end{array}$ & $\begin{array}{r}\text { Cents. } \\
2.0\end{array}$ \\
\hline 1904. & 31.9 & 6.0 & 25.9 & 19.8 & 3.7 & 23.5 & 2.4 \\
\hline 1905. & 31.2 & 6.0 & 25.2 & 19.0 & 3.6 & 22.6 & 2.6 \\
\hline $1906 \ldots$ & 31.1 & 6.0 & 25.1 & 18.8 & 3.3 & 22.1 & 3.0 \\
\hline $1907 \ldots$ & 31.4 & $6.0^{\prime} 0$ & 25.4 & 20.6 & 3.4 & 24.0 & 1.4 \\
\hline
\end{tabular}

Table 64 shows, on the whole, that there has been no particular change in the volume of the fine-cut tobacco business of Spaulding \& Merrick, the sales in 1907 being only a triffe greater than in 1903. There has also been no great change in the average price of the product, although for the years 1904 to 1907 it ranged from 2.1 cents to 2.9 cents higher than in 1903 . The price of leaf and other raw materials entering into the cost of manufacture has increased, but, on the other hand, the cost of selling and advertising has somewhat decreased. The total costs were lower in 1903 than in any of the later years. The increase in price in the years 1903 to 1906 was 
largely offset by the increase in cost, so that the profit per pound increased only from 2 cents in 1903 to 3 cents in 1906. In 1907 the cost increased decidedly more than the price, so that the profits averaged but 1.4 cents per pound, or less than for any other year covered by the table.

Table 64 compares the output, the net price, and the profits of the American, Continental, and Lorillard companies in their fine-cut tobacco business with those of Spaulding \& Merrick.

TABLE 64.-Fine-cut tobacco-Comparison of prices and profits of American, Continental, and Lorillard companies with Spaulding \& Merrick.

\begin{tabular}{|c|c|c|c|c|c|c|}
\hline \multirow[b]{2}{*}{ Year. } & \multicolumn{2}{|c|}{ Sales. } & \multicolumn{2}{|c|}{$\begin{array}{l}\text { Net price, less tax (per } \\
\text { pound). }\end{array}$} & \multicolumn{2}{|c|}{ Profit (per pouud). } \\
\hline & $\begin{array}{l}\text { American, } \\
\text { Continental, } \\
\text { and Lorillard } \\
\text { companies. }\end{array}$ & $\begin{array}{l}\text { Spaulding } \\
\text { \& Merrick. }\end{array}$ & $\begin{array}{l}\text { American, } \\
\text { Continental, } \\
\text { and Lorillard } \\
\text { companies. }\end{array}$ & $\begin{array}{l}\text { Spaulding } \\
\text { \& Merrick. }\end{array}$ & $\begin{array}{l}\text { American, } \\
\text { Continental, } \\
\text { and Lorillard } \\
\text { companies. }\end{array}$ & $\begin{array}{l}\text { Spaulding } \\
\text { \& Merrick. }\end{array}$ \\
\hline 1903. & $\begin{array}{l}\text { Pounds. } \\
3,476,085\end{array}$ & $\begin{array}{l}\text { Pounds. } \\
5,300,551\end{array}$ & $\begin{array}{l}\text { Cents. } \\
\quad 39.1\end{array}$ & $\begin{array}{l}\text { Cents. } \\
23.0\end{array}$ & $\begin{array}{l}\text { Cents. } \\
11.5\end{array}$ & $\begin{array}{r}\text { Cents. } \\
2.0\end{array}$ \\
\hline 1904. & $3,674,272$ & $5,551,557$ & 38.1 & 25.9 & 12.1 & 2.4 \\
\hline 1905. & $4,233,404$ & $4,815,160$ & 36.7 & 25.2 & 11.3 & 2.6 \\
\hline $1906 \ldots .$. & $4,345,083$ & $5,793,448$ & 36.3 & 25.1 & 11.4 & 3.0 \\
\hline $1907 \ldots \ldots$ & $4,538,321$ & $5,388,870$ & 35.5 & 25.4 & 10.0 & 1.4 \\
\hline
\end{tabular}

It will be seen that in each year since 1903 the sales of Spaulding \& Merrick have considerably exceeded the sales of the American, Continental, and Lorillard companies, although the latter have increased considerably, while the sales of Spaulding \& Merrick have, on the whole, not increased. The net price, less tax, for the American, Continental, and Lorillard companies has decreased from year to year, while that of Spaulding \& Merrick has increased.

It is notable that the average price of the Spaulding \& Merrick product is, roughly, only about two-thirds as high as that of the Amelican, Continental, and Lorillard companies. It is partly because of the difference in the grade of fine cut sold that the profits of Spaulding \& Merrick are much lower than those of the American, Continental, and Lorillard companies. As already stated, the American, Continental, and Lorillard companies, when they acquired Spaulding \& Merrick in 1902, transferred to that company the manufacture of several of the lower-grade brands which they had previously manufactured.

\section{RESULTS OF THE TOTAL FINE-CUT TOBACCO BUSINESS OF THE TOBACCO} COMBINATION.

In Table 65 the results of the fine-cut tobacco business of the American, Continental, and Lorillard companies are combined with those for Spaulding \& Merrick for the years 1903 to 1907 . For comparison, data of the American, Continental, and Lorillard companies from 1899 to 1902 are given. 
TABLE 65.-Fine-cut tobacco-Total sales and profits of Tobacco Combination.

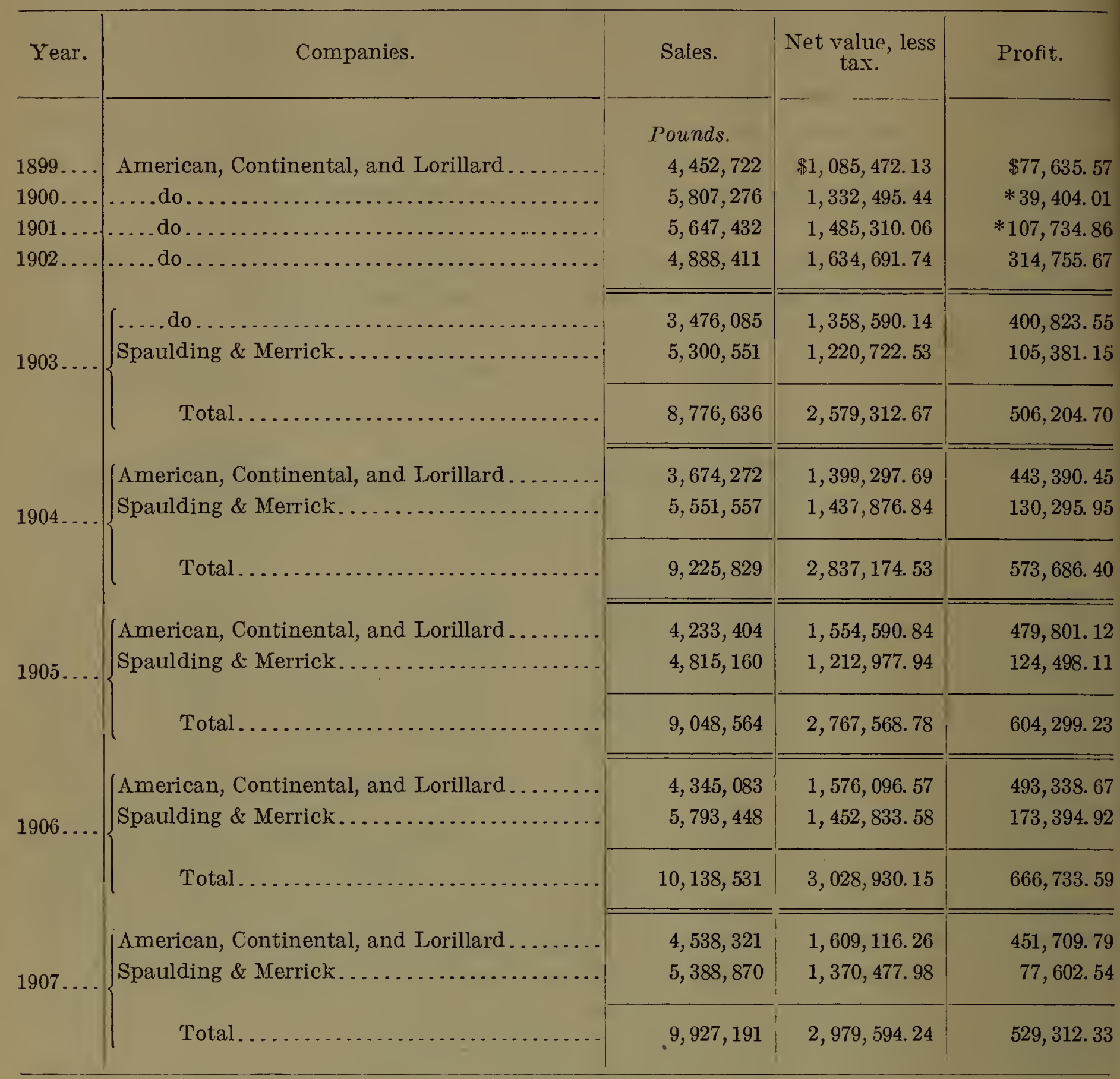

* Loss.

It will be seen from the above table that the total sales of fine cut in 1903, the first full year of operation of the Spaulding \& Merrick Company as a subsidiary of the Combination, almost doubled over the previous year. The sales further increased in succeeding years, and reached a maximum in 1906, when the total was $10,138,531$ pounds. There was a slight decrease in 1907.

The total net value, less tax, increased from $\$ 1,634,691.74$ in 1902 to $\$ 2,579,312.67$ in 1903 , following the acquisition of the Spaulding \& Merrick Company. After that the increase, as shown in the table, has approximately kept pace with the increase of business.

The profits of the Combination from its fine-cut business increased from $\$ 506,204.70$ in 1903 to $\$ 666,733.59$ in 1906 , the year of largest absolute returns. In 1907 the profit was considerably less, being only $\$ 529,312.33$.

In the following table the net average price of fine cut and the elements of cost are shown for the entire fine-cut business of the Combination from 1899 to 1907 , inclusive. Diagram 7 above shows this information graphically in connection with corresponding data for the American, Continental, and Lorillard companies. 
TABLE 66.-Fine-cut tobacco-Prices, costs, and profits of Tobacco Combination.

\begin{tabular}{|c|c|c|c|c|c|c|c|}
\hline \multirow[b]{2}{*}{ Year. } & \multicolumn{3}{|c|}{ Price (per pound). } & \multicolumn{3}{|c|}{ Costs (per pound). } & \multirow{2}{*}{$\begin{array}{c}\text { Profit } \\
\text { (per } \\
\text { pound). }\end{array}$} \\
\hline & $\begin{array}{l}\text { Includ- } \\
\text { ing tax. }\end{array}$ & Tax. & $\begin{array}{l}\text { Exclud- } \\
\text { ing tax. }\end{array}$ & $\begin{array}{l}\text { Manufac- } \\
\text { ture and } \\
\text { freight. }\end{array}$ & $\begin{array}{l}\text { Selling } \\
\text { and ad- } \\
\text { vertising. }\end{array}$ & Total. & \\
\hline & Cents. & Cents. & Conts. & Cents. & Cents. & $\begin{array}{r}\text { Cents. } \\
22.6\end{array}$ & $\begin{array}{r}\text { Cents. } \\
1.8\end{array}$ \\
\hline $\begin{array}{l}1899 \ldots \\
1900 \ldots\end{array}$ & $\begin{array}{l}50.4 \\
35.0\end{array}$ & 12.0 & 23.0 & 19.3 & 4.4 & 23.7 & $* .7$ \\
\hline $1901 \ldots$. & 37.2 & 10.9 & 26.3 & 21.8 & 6.4 & 28.2 & $* 1.9$ \\
\hline $1902 \ldots$ & 41.2 & 7.8 & 33.4 & 22.3 & 4.7 & 27.0 & 6.4 \\
\hline $1903 \ldots$ & 35.4 & 6.0 & 29.4 & 19.3 & 4.3 & 23.6 & 5.8 \\
\hline $1904 \ldots . . .$. & 36.8 & 6.0 & 30.8 & 20.9 & 3.7 & 24.6 & 6.2 \\
\hline $1905 \ldots \ldots \ldots$ & 36.6 & 6.0 & 30.6 & 20.6 & 3.3 & 23.9 & 6.7 \\
\hline $1906 \ldots \ldots \ldots$ & 35.9 & 6.0 & 29.9 & 20.0 & 3.3 & 23.3 & 6.6 \\
\hline $1907 \ldots \ldots \ldots$ & 36.0 & 6.0 & 30.0 & 21.9 & 2.8 & 24.7 & 5.3 \\
\hline
\end{tabular}

Loss.

Since the business of Spaulding \& Merrick, which was brought into the table first in 1903, represents, on the arerage, a lower-priced grade of fine-cut tobacco than that formerly manufactured by the American, Continental, and Lorillard companies, the full effect of the change in arerage prices from the earlier vears covered by the table to the later is not shown. Nevertheless, since, as abore stated, the American, Continental, and Lorillard companies transferred the manufacture of some of their lower-priced brands to Spaulding \& Merrick after the acquisition, and since the high-priced product of D. H. McAlpin \& Co. was first sold to any extent by the American in 1901, this table probably represents somewhat more nearly the true effect of the changes in prices and costs than the table which shows only the business of the American, Continental, and Lorillard companies. This table shows arerage net prices, exclusive of tax, much higher during the years 1903 to 1907 than during the years 1899 to 1901 , and since there was comparatively little change in the costs the profits are much higher in later years than in the earlier, during two of which, in fact, there was a loss.

Confining attention to the period from 1903 to 1907, it will be seen that there has been comparatively little change in the net price, in the cost of manufacture, or in the profit. The price, less tax, has ranged from 29.4 cents to 30.8 cents, the cost of manufacture and sale from 23.3 cents to 24.7 cents, and the profit from 5.3 cents to 6.7 cents per pound. There has been a considerable increase in the cost of manufacture, but this has been largely offset by a decrease in selling and advertising costs. This latter decrease is doubtless largely due to the increasing degree of control of the fine-cut tobacco business possessed by the Combination, rendering advertising and other methods of pushing the sale of goods less necessary than formerly. In 1907 the cost of selling and adrertising was only 2.8 cents per pound, as compared with 6.4 cents during the active competition of 1901 . 


\section{PRICES OF INDIVIDUAL BRANDS OF FINE CUT.}

The Bureau of Corporations has not secured any figures showing the exact average price, cost of manufacture, and the profit on individual brands of fine-cut tobacco manufactured by the Tobacco Combination. The general movement of prices of individual brands can, however, be ascertained from published price lists. As in other cases, the annual average prices from such price lists are computed by adding the monthly prices and dividing by 12 .

Table 67 , below, shows the consumer's price and the jobber's net average price of the leading brands of fine-cut tobacco now manufactured by the Tobacco Combination as taken from price lists, discount sheets, invoices, etc. The price lists and invoices, of course, show jobber's price, including tax, but for more convenient comparison the tax and the price, less tax, are also shown. The years are grouped according to the rates of tax in force. The table covers two brands now manufactured by the American Tobacco Company, three brands manufactured by the P. Lorillard Company, and three brands now manufactured by Spaulding \& Merrick. Two of these were owned by that concern prior to its acquisition by the combination early in 1902 , and the table shows the prices before as well as after the acquisition. The other brand was acquired by the Continental Tabacco Company from Daniel Scotten \& Co. at the close of 1898, but its manufacture was turned over to Spaulding \& Merrick after the acquisition of that concern.

TABLE 67.-Fine-cut tobacco-Consumers' price and net average price to jobbers for various brands nou controlled by Tobacco Combination.

[Compiled from price lists, invoices, etc.]

\begin{tabular}{|c|c|c|c|c|c|c|c|c|c|c|}
\hline \multirow{3}{*}{ Year. } & \multirow{3}{*}{$\begin{array}{c}\text { Tax } \\
\text { (per } \\
\text { pound). }\end{array}$} & \multicolumn{3}{|c|}{$\begin{array}{l}\text { Brand No. } 1 \text { (per } \\
\text { pound): }\end{array}$} & \multicolumn{3}{|c|}{$\begin{array}{l}\text { Brand No. } 2 \text { (per } \\
\text { pound). }\end{array}$} & \multicolumn{3}{|c|}{$\begin{array}{l}\text { Brand No. } 3 \text { (per } \\
\text { pound). }\end{array}$} \\
\hline & & \multirow[b]{2}{*}{$\begin{array}{l}\text { Con- } \\
\text { sum- } \\
\text { ers' } \\
\text { price. }\end{array}$} & \multicolumn{2}{|c|}{ Price to jobbers. } & \multirow[b]{2}{*}{$\begin{array}{l}\text { Con- } \\
\text { sum- } \\
\text { ers' } \\
\text { price. }\end{array}$} & \multicolumn{2}{|c|}{ Price to jobbers. } & \multirow[b]{2}{*}{$\begin{array}{l}\text { Con- } \\
\text { sum- } \\
\text { ers' } \\
\text { price. }\end{array}$} & \multicolumn{2}{|c|}{ Price to jobbers } \\
\hline & & & $\begin{array}{l}\text { In- } \\
\text { clud- } \\
\text { ing } \\
\text { tax. }\end{array}$ & $\begin{array}{l}\text { Ex- } \\
\text { clud- } \\
\text { ing } \\
\text { tax. }\end{array}$ & & $\begin{array}{l}\text { In- } \\
\text { clud- } \\
\text { ing } \\
\text { tax. }\end{array}$ & $\begin{array}{l}\text { Ex- } \\
\text { clud- } \\
\text { ing } \\
\text { tax. }\end{array}$ & & $\begin{array}{l}\text { In- } \\
\text { clud- } \\
\text { ing } \\
\text { tax. }\end{array}$ & $\begin{array}{l}\text { Ex- } \\
\text { clud- } \\
\text { ing } \\
\text { tax. }\end{array}$ \\
\hline $1896 \ldots$ & $\begin{array}{r}\text { Cents. } \\
6.0\end{array}$ & Cents. & Cents. & Cents. & $\begin{array}{r}\text { Cents. } \\
45\end{array}$ & $\begin{array}{r}\text { Cents. } \\
27.0\end{array}$ & $\begin{array}{r}\text { Cents. } \\
21.0\end{array}$ & Cents. & Cents. & Cents. \\
\hline $1897 \ldots \ldots . . . .$. & 6.0 & & & & 45 & 27.0 & 21.0 & & & \\
\hline 1898 (first half)... . & 6.0 & & & & 45 & 27.0 & 21.0 & 48 & & \\
\hline 1898 (second half) & 12.0 & & & & 50 & 36.0 & 24.0 & 48 & 33.6 & 21.6 \\
\hline $1899 \ldots$ & 12.0 & $\cdots$ & & ….. & 50 & 36.0 & 24.0 & 48 & 35.5 & 23.5 \\
\hline $1900 \ldots \ldots . . .$. & 12.0 & 80 & 63.3 & 51.3 & 50 & 34.2 & 22.2 & 48 & 36.4 & 24.4 \\
\hline 1901 (first half).... & 12.0 & 30 & 63.3 & 51.3 & 50 & 34.2 & 22.2 & 48 & 36.4 & 24.4 \\
\hline 1901 (second half) & 9.6 & 80 & 63.3 & 53.7 & 50 & 34.2 & 24.6 & 48 & 36.4 & 26.8 \\
\hline 1902 (first half).... & 9.6 & 80 & 63.3 & 53.7 & 50 & 34.2 & 24.6 & 48 & 36.4 & 26.8 \\
\hline 1902 (second half). & 6.0 & 80 & 61.8 & 55.8 & 50 & 33.3 & 27.3 & 48 & 35.5 & 29.5 \\
\hline $1903 \ldots \ldots \ldots \ldots$ & 6.0 & 80 & 62.7 & 56.7 & 50 & 34.6 & 28.6 & 48 & 35.5 & 29.5 \\
\hline 1904. & 6.0 & 80 & 62.7 & 56.7 & 50 & 34.2 & 28.2 & 48 & 35.5 & 29.5 \\
\hline $1905 \ldots$ & 6.0 & 80 & 62.7 & 56.7 & 50 & 36.0 & 30.0 & 48 & 35.5 & 29.5 \\
\hline $1906 \ldots$ & 6.0 & 80 & 62.7 & 56.7 & 50 & 36.0 & 30.0 & 48 & 35.5 & 29.5 \\
\hline $1907 \ldots$ & 6.0 & 80 & 62.7 & 56.7 & & & & 48 & 35.9 & 29.9 \\
\hline $1908 \ldots .$. & 6.0 & 80 & 62.7 & 56.7 & & & & 48 & 36.4 & 30.4 \\
\hline
\end{tabular}


TABLE 67.-Fine-cut tobacco-Consuniers price and net acerage price to jobbers for various brands now controlled by Tobacco Combination-Continued.

[Compiled from price lists, invoices, etc.]

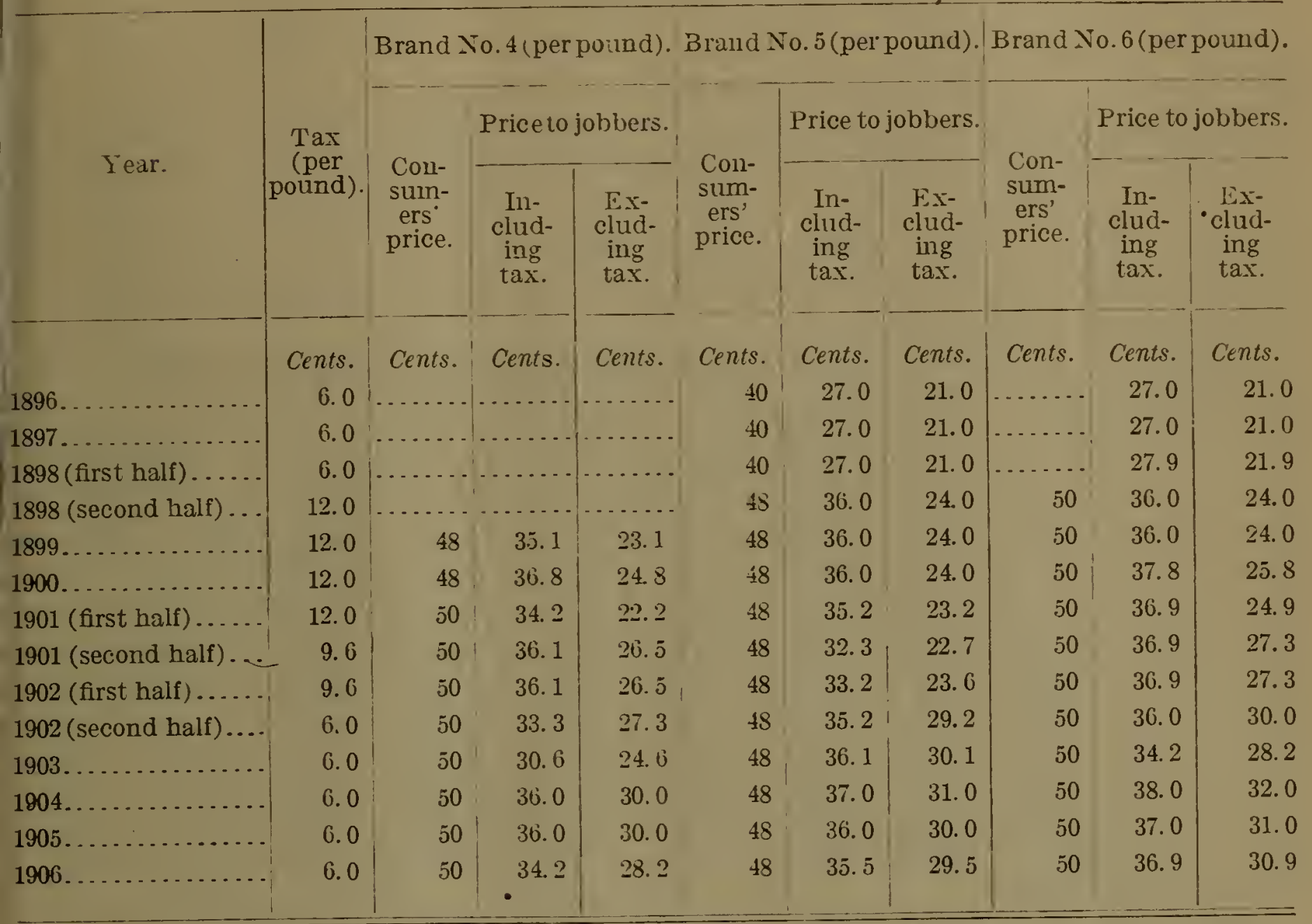

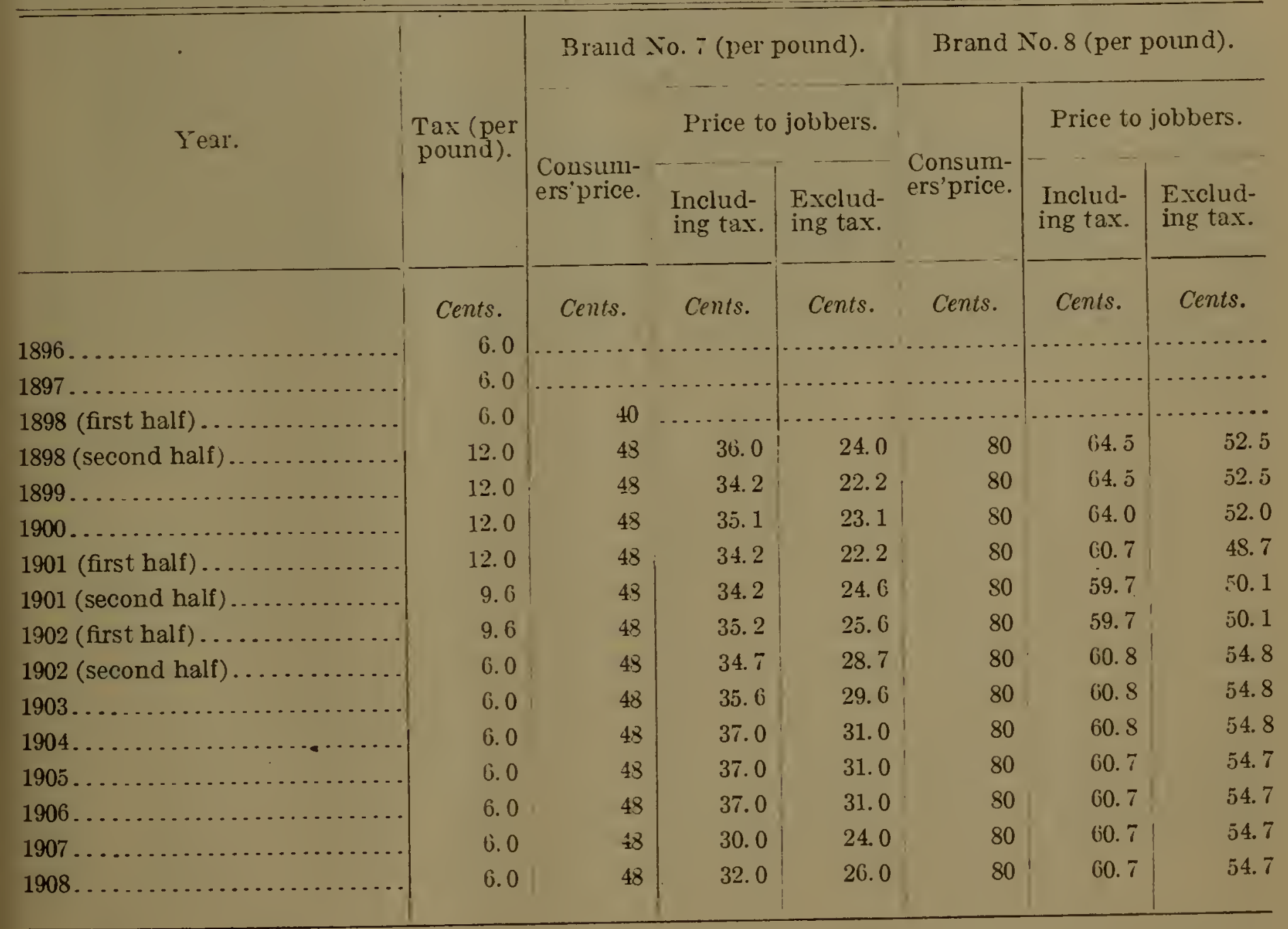

There are only three brands, Nos. 2, 5, and 6, covered by this table for which prices are available for several years prior to the time of the increase in internal-revenue taxes in 1898. They indicate that the 
price paid by the consumer and jobbers was increased by the manufacturer by more than the full advance in the tax. There has been no reduction since then in the consumer's price on any brand.

During the years.1900 and 1901 there was apparently active competition in the fine-cut tobacco business. The effect of this is reflected in a reduction of the price of several of the brands, notwithstanding the fact that there was no change in the rate of $\operatorname{tax}$ until the middle of 1901 . The prices of brands Nos. 2, 4, 5, 7, and 8 were all somewhat reduced. Moreover, when the tax was reduced from 12 cents to 9.6 cents, taking effect July 1, 1901, the prices of brands Nos. 5 and 8 were reduced, but the greater number remained unchanged.

On July 1, 1902, the tax was further reduced from 9.6 cents to 6 cents per pound. The table shows that brands Nos. 1, 2, 3, 4, 6, and 7 were reduced, but none of them to the full amount of the reduction in tax. Later all the brands were advanced so that the net price, less tax, by 1905, was higher than under the 12-cent tax. Brands Nos. 1 and 7 have been reduced slightly in price, including tax. Brand No. 4 was at first reduced in price, but has since been advanced to practically the same level as before the reduction in the tax. In the case of all the other brands the price, including tax, during the more recent years has been as high as or higher than before the tax was reduced. Broadly speaking, therefore, the net prices of these brands, if the tax is excluded, and, as shown in a separate column for each brand, have materially increased during the period since 1900 .

Although the data taken from price lists are less conclusive with regard to the movement of prices than data taken from bookkeeping figures, it would appear to be the fact that the very decided increase in the average net price, less tax, of the entire product of fine-cut tobacco controlled by the Combination during the more recent years as compared with the period from 1899 to 1901, while to a considerable extent due to an increase of the sales of higher-price brands and a decrease of the sales of the lower-price brands, has also in no small part been due to an increase in the prices, less tax, of individual brands. 


\section{SCRAP-TOBACCO BUSINESS OF THE COMBINATION.}

Scrap tobacco is classed by the Bureau of Internal-Revenue as smoking tobacco, but this classification arises primarily from the fact that it is put up in small packages of a size fixed by law, as smoking tobacco is, rather than from its use. Scrap tobacco is mainly used for chewing. It is made of the clippings resulting from the manufacture of cigars and from low grades of leaf tobacco.

The manufacture of scrap tobacco in any considerable quantity is practically a new industry in the United States, and the output for the country as a whole has increased very rapidly during recent years. The exact amount of the output, however, can not be ascertained, as it is not distinguished from other so-called "smoking" tobaccos. The American Tobacco Company and its subsidiary companies in 1907 , however, sold $22,390,196$ pounds, and the best available information from independent concerns indicates the probability that the total output of scrap for the country as a whole in that year was between $30,000,000$ and $40,000,000$ pounds, or more than one-sixth as much as the output of plug tobacco.

On the other hand it is probable that in 1900 the output of scrap tobacco was considerably under $10,000,000$ pounds. This rapid increase in the output of scrap tobacco, which is used for chewing chiefly, explains the fact that the output of plug tobacco, which is also used for chewing, has increased comparatively little since 1900. The relative importance from the standpoint of quantity or output of the scrap-tobacco business of the Tobacco Combination may be judged from the fact that its sales in $1907,22,390,196$ pounds, were equal to about one-sixth of its sales of plug tobacco, and to nearly one-fourth of its sales of smoking tobacco. Scrap tobacco is, however, of much lower price than plug tobacco, so that the value of the output of scrap by the Tobacco Combination in 1907 (exclusive of $\operatorname{tax}$ ) was only about one-tenth of the value of its output of plug.

The American Tobacco Company has less degree of control over the scrap-tobacco business than over any other branch except cigars. The exact proportion of the business controlled by the Combination can not be ascertained on account of the absence of exact figures of total scrap in the country, but the investigations of the Bureau indicate that the Combination's business is somewhere between 50 and 60 per cent of the total. The competition in the scrap-tobacco business has been very active, and, as will be seen later, the Combination has lost money on it.

The greater part of the scrap-tobacco business of the Tobacco Combination is in the hands of subsidiary companies. Most, if not all. of the scrap which is now sold by the American Tobacco Company proper is made for it by these subsidiary concerns, especially by 
Luhrman \& Wilbern; in fact, the American Tobacco Company first began to handle scrap as a separate department in 1905, and prior to that time all the scrap business controlled by the Combination was in the hands of subsidiary companies. The principal subsidiary company making scrap is Luhrman \& Wilbern, control of which was acquired in 1899. Its sales considerably exceed those of the American Tobacco Company itself, and moreover, it makes for the American most of the scrap which that company sells. The Pinkerton Tobacco Company, control of which was acquired in 1903, and Spaulding \& Merrick, which was acquired in 1902, but which first began the manufacture of scrap in 1905, are the other manufacturers of scrap in the Combination. Data showing the results of the business of these companies for each year since the acquisition are available, as well as data for the American Tobacco Company itself.

The following table shows for each year the quantity of sales of scrap tobacco, the average price including tax, and the average price less tax, for the American Tobacco Company itself, and for each of the four subsidiary concerns handling scrap.

TABLE 68.-Scrap tobacco-Quantity of sales and average net price for American Tobacco Company and each subsidiary company making scrap.

\begin{tabular}{|c|c|c|c|c|c|c|c|c|c|}
\hline & \multicolumn{3}{|c|}{ American Tobacco Co. } & \multicolumn{3}{|c|}{ Luhrman \& Wilbern. } & \multicolumn{3}{|c|}{ Pinkerton Tobacco Co. } \\
\hline & Sales. & $\begin{array}{l}\text { Price per } \\
\text { pound, } \\
\text { includ- } \\
\text { ing tax. }\end{array}$ & $\begin{array}{l}\text { Price per } \\
\text { pound, } \\
\text { exclud- } \\
\text { ing tax. }\end{array}$ & Sales. & $\begin{array}{l}\text { Price per } \\
\text { pound, } \\
\text { includ- } \\
\text { ing tax. }\end{array}$ & $\begin{array}{l}\text { Price per } \\
\text { pound, } \\
\text { exclud- } \\
\text { ing tax. }\end{array}$ & Sales. & $\begin{array}{l}\text { Price per } \\
\text { pound, } \\
\text { includ- } \\
\text { ing tax. }\end{array}$ & $\begin{array}{l}\text { Price per } \\
\text { pound. } \\
\text { exclud- } \\
\text { ing tax. }\end{array}$ \\
\hline 1900 & $\begin{array}{c}\text { Pounds. } \\
\ldots . . . . .\end{array}$ & Cents. & Cents. & $\begin{array}{l}\text { Pounds. } \\
4,776,650\end{array}$ & Cents. & Cents. & Pounds. & Cents. & Cents. \\
\hline 1901. & $\ldots \ldots \ldots$ & & & $5,640,860$ & 24.0 & 13.2 & & & . \\
\hline 1902. & & $\ldots$ & & $5,260,790$ & 23.0 & 15.2 & & & \\
\hline 1903. & & & & $5,653,487$ & 23.7 & 17.7 & & & $\ldots$ \\
\hline 1904 & $\cdots \ldots \ldots \ldots$ & $\ldots \ldots$ & & $7,636,919$ & 24.4 & 18.4 & $2,094,475$ & 22.6 & 16.6 \\
\hline 1905. & 184,834 & 22.1 & 16.1 & $8,570,125$ & 23.2 & 17.2 & $2,077,210$ & 25.3 & 19.3 \\
\hline $1906 \ldots$ & $2,167,188$ & 23.0 & 17.0 & $10,032,784$ & 23.1 & 17.1 & $2,421,064$ & 26.6 & 20.6 \\
\hline \multirow[t]{3}{*}{$1907 \ldots$} & $5,454,211$ & 22.9 & 16.9 & $7,439,380$ & 25.6 & 19.6 & $4,324,116$ & 22.5 & 16.5 \\
\hline & & & & \multicolumn{3}{|c|}{ Day \& Night Tobacco Co.a } & \multicolumn{3}{|c|}{ Spaulding \& Merrick. } \\
\hline & & & & Sales. & $\begin{array}{l}\text { Price per } \\
\text { pound, } \\
\text { includ- } \\
\text { ing tax. }\end{array}$ & $\begin{array}{l}\text { Price per } \\
\text { pound, } \\
\text { exclud- } \\
\text { ing tax. }\end{array}$ & Sales. & $\begin{array}{l}\text { Price per } \\
\text { pound, } \\
\text { includ- } \\
\text { ing tax. }\end{array}$ & $\begin{array}{l}\text { Price per } \\
\text { pound, } \\
\text { exclud- } \\
\text { ing tax. }\end{array}$ \\
\hline 1905 & & & & Pounds. & Cents. & Cents. & $\begin{array}{l}\text { Pounds. } \\
367,806\end{array}$ & $\begin{array}{l}\text { Cents. } \\
26.0\end{array}$ & $\begin{array}{l}\text { Cents. } \\
20.0\end{array}$ \\
\hline 1906. & & & & & & & $3,091,028$ & 25.7 & 19.7 \\
\hline $1907 \ldots$ & & & & $2,714,536$ & 24.0 & 18.0 & $2,457,953$ & 28.8 & 22.8 \\
\hline
\end{tabular}

$a$ Later absorbed by the Pinkerton Tobacco Company. 
It will be seen that the scrap is a low-priced product, and, moreover, that the prices received by each of the companies are approximately the same, ranging (including tax) from about 22 cents to about 29 cents per pound. The Luhrman \& Wilbern Company is the only one for which the figures extend back to the time when the war-revenue taxes were in force. In 1901, during the first half of which the full war-revenue rate of 12 cents per pound was in force, and during the second, half when it was 9.6 cents, the average price, including tax, for this company was 24 cents per pound, and excluding tax only 13.2 cents. There was practically no reduction in the price when the tax was reduced, and consequently the net price, less tax, for this company shows a very considerable increase. Its costs, however, have increased more than the price, so that the company is now losing money.

Table 69 shows the combined business of the American Tobacco Company and the four subsidiary concerns. It gives the quantity of sales, the net value thereof exclusive of tax, and the profit or loss.

TABLE 69.-Scrap tobacco-Combined sales and profits of the companies in Tobacco Combination.

\begin{tabular}{|c|c|c|c|c|}
\hline & Year. & Sales. & $\begin{array}{l}\text { Net ralue } \\
\text { (less } \operatorname{tax}) \text {. }\end{array}$ & Profit. \\
\hline 1900 & & $\begin{array}{l}\text { Pounds. } \\
4,776,650\end{array}$ & & \\
\hline 1901. & & $5,640,860$ & $\$ 742,901.26$ & $\$ 21,068.71$ \\
\hline 1902. & & $5,260,790$ & $801,531.96$ & $* 14,693.19$ \\
\hline 1903. & & $5,653,487$ & $999,039.59$ & $220,011.35$ \\
\hline 1904. & & $9,731,394$ & $1,754,416.98$ & $147,611.26$ \\
\hline 1905. & & $11,199,975$ & $1,980,366.04$ & $30,914.74$ \\
\hline 1906. & & $17,712,064$ & $3,189,620.73$ & $* 479,926.08$ \\
\hline 1907 & & $22,390,196$ & $4,137,628.29$ & $* 345,656.55$ \\
\hline
\end{tabular}

*Loss.

It will be seen that the sales of scrap tobacco controlled by the Combination increased from $4,776,650$ pounds in 1900 to $22,390,196$ pounds in 1907. The value increased even more. In 1901, the first year for which the value has been ascertained, it amounted to $\$ 742,901.26$, whereas it amounted in 1907 to $\$ 4,137,628.29$, or nearly six times as much as in 1901 . The scrap-tobacco business, however, has at no time been very profitable, and during three of the seven years has resulted in a loss. In fact, in 1906 the Combination lost on its scrap business no less than $\$ 479,926.08$.

The explanation of the losses in the scrap business during 1906 and 1907 may be seen from Table 70, and the accompanying diagram, which show the average price, including and excluding tax, the costs, and the profit or loss per pound for the entire scrap-tobacco business of the Combination. Diagram 8 shows the data. 
TABLE 70.-Scrap tobacco-Prices, costs, and profits of Tobacco Combination.

\begin{tabular}{|c|c|c|c|c|c|c|c|}
\hline \multirow[b]{2}{*}{ Year. } & \multicolumn{3}{|c|}{ Net price (per pound). } & \multicolumn{3}{|c|}{ Costs (per pound). } & \multirow{2}{*}{$\begin{array}{c}\text { Profit } \\
\text { (per } \\
\text { pound). }\end{array}$} \\
\hline & $\begin{array}{l}\text { Includ- } \\
\text { ing tax. }\end{array}$ & Tax. & $\begin{array}{l}\text { Exclud- } \\
\text { ing tax. }\end{array}$ & $\begin{array}{l}\text { Manufac- } \\
\text { ture and } \\
\text { freight. }\end{array}$ & Sale. & Total. & \\
\hline 1991. & $\begin{array}{l}\text { Cents. } \\
24.0\end{array}$ & $\begin{array}{r}\text { Cents. } \\
10.8\end{array}$ & $\begin{array}{l}\text { Cents. } \\
\quad 13.2\end{array}$ & $\begin{array}{r}\text { Cents. } \\
11.7\end{array}$ & $\begin{array}{r}\text { Cents. } \\
1.1\end{array}$ & $\begin{array}{l}\text { Cents. } \\
12.8\end{array}$ & $\begin{array}{r}\text { Cents. } \\
0.4\end{array}$ \\
\hline $1902 \ldots$ & 23.0 & 7.8 & 15.2 & 10.7 & 4. 8 & 15.5 & $* 0.3$ \\
\hline $1903 \ldots$ & 23.7 & 6.0 & 17.7 & 10.9 & 2.9 & 13.8 & 3.9 \\
\hline $1904 \ldots$ & 24.0 & 6.0 & 18.0 & 12.1 & 4.4 & 16.5 & 1.5 \\
\hline $1905 \ldots$ & 23.7 & 6.0 & 17.7 & 12.7 & 4. 7 & 17.4 & 0.3 \\
\hline $1906 \ldots \ldots \ldots$ & 24.0 & 6.0 & 18.0 & 16.4 & 4.3 & 20.7 & $* 2.7$ \\
\hline $1907 \ldots \ldots \ldots$ & 24.5 & 6.0 & 18.5 & 17.1 & 2.9 & 20.0 & $* 1.5$ \\
\hline
\end{tabular}

* Loss.

It will be seen that while the net price per pound of scrap has increased very materially since 1901 the cost of manufacture has increased still more, particularly during 1906 and 1907. The increasing demand for scrap increased likewise the demand for the raw material and has forced up its price. The selling and advertising expenses of scrap are also high relative to the value of the product. In 1902 the expenses of advertising and selling were 4.8 cents per pound, or not much less than half of the cost of manufacture itself. In 1905 the cost of selling and advertising was equal to more than 35 per cent of the cost of manufacture. Although there has been some decrease in the advertising and selling cost in 1906 and 1907, the great increase in the cost of manufacture has resulted in heavy losses. The loss per pound in 1906 was 2.7 cents, and in 1907, 1.5 cents. The only year in which there has been a considerable profit in the scrap business was 1903 , when the average profit was 3.9 cents per pound, the selling expenses in that year being much lower than in most of the other years. 


\section{SCRAP TOBACCO.}

Prices, Costs, and Profits of the Combination.

Diagram 8.

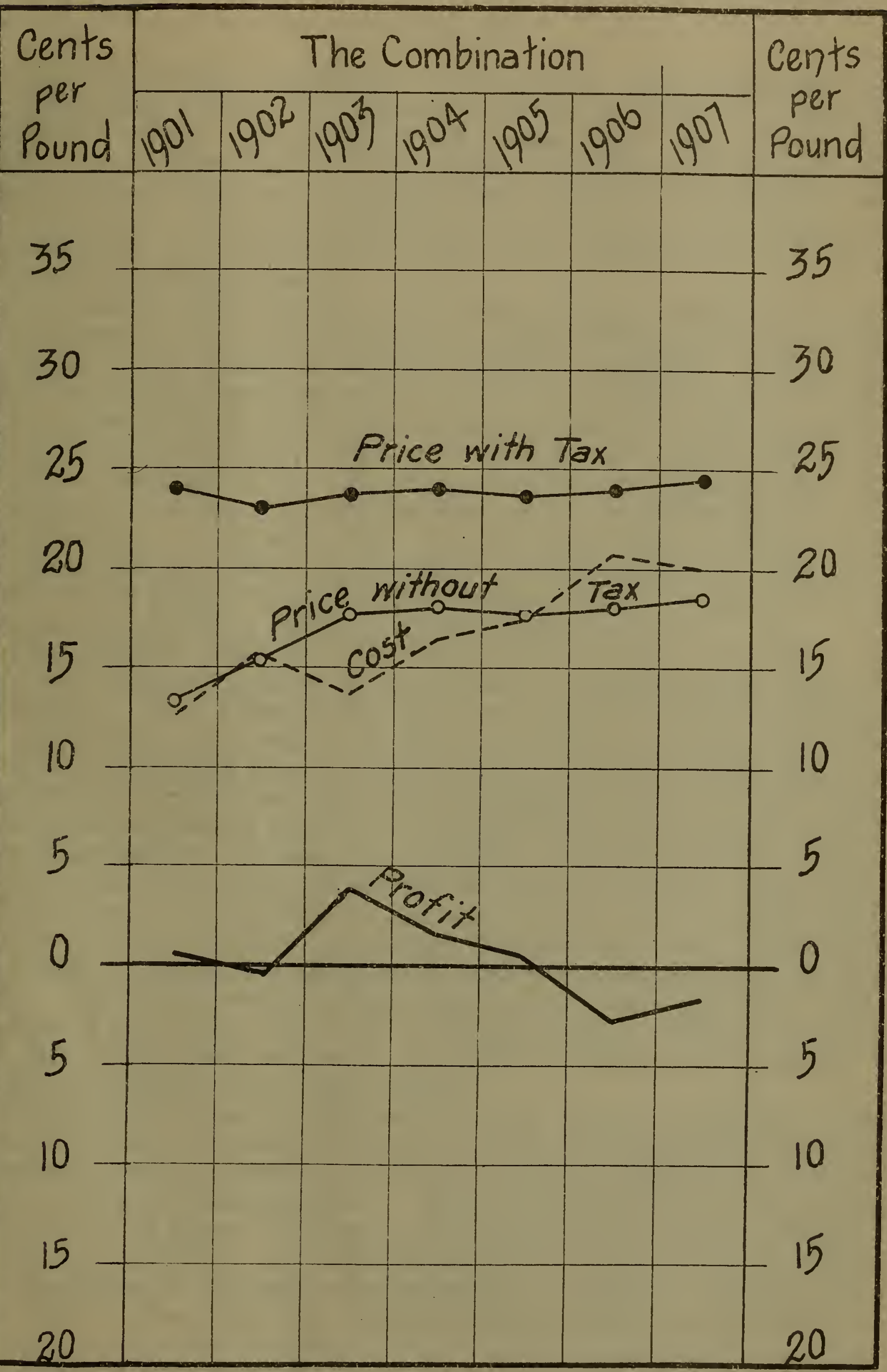





\section{CIGARETTE BLSSINESS OF THE COMBINATION.}

The manufacture of cigarettes ranks next to that of plug tobacco and smoking tobaceo in importance among the different classes of tobacco products. According to the census of 1905 the value of cigarettes manufactured in the United States in 1904 was $\$ 16,354,803$, and the ralue of plug and smoking tobacco and fine cut together was $\$ 110.090 .940$. From the standpoint of the Tobacco Combination the manufacture of cigarettes also ranks as less important than that of plug and smoking tobacco.

The history of the relation of the Tobacco Combination to the cigarette business of the Uniter States is quite different from that of its relation to the classes of tobacco hitherto considered. Whereas in the case of plug, smoking, and fine-cut tobacco the Tobacco Combination first became the dominant factor in 1899 after the organization of the Continental Tobacco Company, the domination of the Tobacco Combination orer the cigarette business began in 1890, and was greater in the early nineties than it has been during the most recent rears. As already stated, the American Tobaceo Company at its inception in 1890 was primarily a manufacturer of cigarettes, while at the present time cigarettes constitute but a small fraction of the business which it directly or indirectly controls.

The cigarette business also differ's from the plug, smoking, and fine-cut tobacco business in that there is a large export trade in cigarettes. The Tobacco Combination controls at the present time a much larger proportion of the manufacture of those cigarettes which are exported than of those which are made for domestic consumption. In 1906 the total output of cigarettes in the United States was 6,438,000,000, of which the Combination produced $5,309,000,000$ and independent concerns 1,129,000,000. The Combination, therefore, in that controlled 82.5 per cent of the total output. The output for domestic consumption, on the other hand, was 4,424,000,000, of which the Combination produced 3,297,000,000 and independent concerns $1,128,000,000$, the Combination's proportion being 74.5 per cent. It will be seen from these figures that practically none of the output of the independent concerns was exported. The Combination, on the other hand, exported in 1906, 2,012,000,000 cigarettes, or nearly two-fifths of its total output.

The present report is concerned with the prices of cigarettes in the domestic trade. Consequently, the figures presented with respect to control by the Combination are those relating exclusively to the output for domestic consumption. Although precise data are not available, it would appear that, at the inception of the American Tobacco Company in 1890 , it controlled substantially nine-tenths of the output of cigarettes for domestic consumption. In 1891 it controlled 88.1 per cent. ${ }^{a}$ The proportion controlled fell off slightly from that time

$a$ This figure includes so-called little cigars, as well as paper cigarettes, the national output of paper cigarettes not being reported by the internal-revenue bureau separately until 1898. 
until 1897, when it was 83.5 per cent. Sereral independent manufacturers of plug tobacco had gone into the cigarette business in retaliation for the attack which the American Tobacco Company made upon them in the plug business. Owing to the acquisition of such concerns by the Continental Tobacco Company the proportion of the output of cigarettes for domestic consumption controlled by the Combination increased after the formation of the Continental to 93 per cent in 1899 . Since that time the proportion controlled has fallen off, and in 1907 was 75.4 per cent. This decrease in the proportion of the business controlled by the Combination has been chiefly due to the development of the Turkish cigarette business.

Prior to about 1900 much the greater part of the cigarettes sold in the United States were those commonly called domestic cigarettesthat is, cigarettes made from domestic tobacco-but since 1900 there has been a rapid increase in the production of cigarettes from Turkish and other importer tobasco. Indenendent concerns initiated this branch of the business, and, althoigh the Combination has bought up some of them and has greatly expanded its own output of Turkish cigarettes, the independent concerns hare likewise greatly increased their output. They now have, presumably, between 40 and 50 per cent of the Turkish cigarette business. The American Tobacco Company and its subsidiary companies still produce very much the greater part of the output of cigarettes from domestic tobacco; but the rapidly increasing business of independent concerns in Turkish cigarettes has reduced the proportion of the total output of cigarettes for domestic consumption controlled by the Combination.

The American Tobacco Company has continued throughout the various changes in the form of the Tobacco Combination to be itself the principal manufacturer of cigarettes. In recent years, however, an increasing proportion of the total number of cigarettes produced by the Combination has been manufactured by subsidiary companies, and the proportion of the value of the output contributed by the subsidiary companies has increased more greatly still. Practically all of the business of manufacturing cigarettes for export, which was formerly directly conducted by the American Tobacco Company, has been turned over to the British-American Tobacco Company, a subsidiary concern. The S. Anargyros Company is the principal subsidiary concern of the Combination manufacturing cigarettes for domestic consumption, but there are also several others. Of the total number of cigarettes made by the Combination for domestic consumption at the present time, approximately one-fourth is manufactured by subsidiary companies and three-fourth by the American Tobacco Company itself, but the value of the output of the subsidiaries is only slightly less than that of the parent company. The Continental Tobacco Company and the P. Lorillard Company were never engaged in the manufacture of cigarettes.

In considering the relation of the Combination to the prices of cigarettes, therefore, the business of the American Tobacco Company will first be considered and, later, the business of the subsidiary companies. There would be no advantage whatever in combining the data for the American Tobacco Company with those for the subsidiary companies, in obtaining a rerage price and profits, for the reason that the type of cigarettes made by the American, namely, domestic cigarettes, is entirely different from those made by most of the sub- 
sidiary companies, which consist almost wholly of Turkish cigarettes commanding a decidedly higher price.

It is evident that any satisfactory presentation of the effect of the Tobacco Combination on the prices of cigarettes would require a comparison of the prices before 1890 with the prices since. It is, howerer, impossible at the present date to obtain any information of value regarding the prices prior to 1890 . Practically all that can be done is to determine in a rough way the effect of the increased production of Turkish cigarettes by independent concerns upon the prices and profits of the American Tobacco Company's cigarette business, and show in some measure the effect of the changes in the tax rate upon the prices and profits.

GENERAL RESULTS OF THE CIGARETTE BUSINESS OF THE AMERICAN TOBACCO COMPANY IN THE DOMESTIC TRADE.

It should be noted, in the first place, that average prices, average costs, and average profits per thousand cigarettes for the entire business of the American Tobacco Company furnish a very unsatisfactory basis for comparison from year to year. The difficulty arises from the fact that there are two wholly distinct grades of cigarettes manufactured by the company, namely, the cheap cigarettes, selling at 20 for 5 cents, and the ordinary cigarettes made from domestic tobacco selling in general at 10 for 5 cents. The present rate of tax on the cheaper cigarettes, which are specified in the law as those selling wholesale for not more than $\$ 2$ per thousand, is 54 cents per thousand, and the tax on the better grade is $\$ 1.08$ per thousand. During the Spanish war and the years immediately following there was no such distinction in the tax, but all cigarettes (except those weighing more than 3 pounds per thousand) were taxed at $\$ 1.50$ per thousand. The result, of course, was almost entirely to stop the manufacture of the cheaper grade of cigarettes. A cigarette selling at the retail price of 20 for 5 cents, equal to $\$ 2.50$ per thousand, must be manufactured and distributed by jobbers and retailers for $\$ 1$ if the tax is $\$ 1.50$. Its manufacture under such conditions is manifestly impossible. To be sure, prior to the Spanish war there had been no distinction in the rate of tax on different grades of cigarettes, but the tax on all cigarettes had been only 50 cents per thousand.

Prior to the war, therefore, the average price of all cigarettes manufactured by the American Tobacco Company was made up in part of cigarettes retailing at 5 cents for 10 (with a few at higher prices) and in part of cigarettes retailing at 5 cents for 20 . From 1898 to 1901 the average price represents practically only cigarettes selling at 5 cents or more for 10 , while at the present time there are again a considerable number of lower-priced cigarettes which enter into the average. For these reasons the following tables relating to the average prices, costs, and profits of all cigarettes manufactured by the American Tobacco Company, while they furnish significant information for each year by itself and for one year with another falling in the same period, can not be used as a basis for comparing the movement of prices and profits from one period to another. For that purpose it is necessary to consider the figures of prices for individual brands hereafter presented.

S7442-S. Doc. $78,61-1--10$ 
Table 71 shows the number of cigarettes sold by the Americun Tobacco Company in its domestic trade from year to year, the net value thereof, exclusive of tax, and the profit thereon from 1893 to 1907 , inclusive.

TABLE 71.-Cigarettes--American Tobacco Company: Quantity of sales; net value of sales, and net profits (domestic business).

\begin{tabular}{|c|c|c|c|}
\hline Year. & Sales. & $\begin{array}{l}\text { Net value of } \\
\text { sales (less tax). }\end{array}$ & Profits. \\
\hline $1893 \ldots$ & $\begin{array}{r}\text { Thousands. } \\
2,588,307\end{array}$ & $a \$ 7,820,000.00$ & $\$ 3,318,623.09$ \\
\hline $1894 \ldots$ & $2,601,033$ & $a 7,770,000.00$ & $3,529,014.98$ \\
\hline $1895 \ldots$ & $2,919,704$ & $8,093,711.46$ & $3,574,362.60$ \\
\hline 1896 . & $3,094,531$ & $7,613,474.62$ & $3,289,736.33$ \\
\hline $8897 \ldots$ & $2,883,194$ & $6,526,974.58$ & $2,886,093.29$ \\
\hline $1898 \ldots$ & $2,564,488$ & $5,186,676.98$ & $2,705,306.70$ \\
\hline $1899 \ldots$ & $2,495,963$ & $5,020,879.17$ & $2,630,373.73$ \\
\hline $1900 \ldots$ & $2,229,446$ & $4,654,414.41$ & $2,341,869.51$ \\
\hline $1901 \ldots$ & $1,936,350$ & $4,108,934.70$ & $1,871,365.15$ \\
\hline $1902 \ldots$ & $1,831,593$ & $4,195,813.25$ & $1,320,848.95$ \\
\hline $1903 \ldots$ & $2,032,864$ & $4,618,057.15$ & $2,106,697.39$ \\
\hline $1904 \ldots$ & $2,044,804$ & $4,609,397.17$ & $1,868,813.06$ \\
\hline $1905 \ldots$ & $2,032,417$ & $4,419,287.52$ & $1,802,124.52$ \\
\hline $1906 \ldots$ & $2,300,532$ & $4,940,852.58$ & $1,950,746.78$ \\
\hline $9907 \ldots \ldots$ & $2,836,734$ & $6,240,247.46$ & $2,026,468.46$ \\
\hline
\end{tabular}

a Approximate figure. The available data show the list price only. The net price has been calculated by assuming the rate of discount to have been the same as the average for 1895 and 1896 , viz, 11.3 per cent.

This table shows very considerable variations in the number of cigarettes sold by the American Tobacco Company in the domestic trade, and since the American Tobacco Company manufactures practically all the cigarettes which the Combination manufactures out of domestic leaf this table shows substantially the variations in the Combination's output of cigarettes made from domestic leaf and used for domestic consumption. Moreover, since the Combination has at all times controlled much the greater part of the total national output of cigarettes made from domestic leaf for domestic consumption, the variations in the output shown in this table conform in a general way to the variations in the national output of this class of cigarettes.

It will be seen that the output increased rapidly from 1893, the first year for which data of sales and profits are available, to 1896, when the number of cigarettes manufactured by the American Tobacco Company for domestic consumption was greater than in any other year. There was then a steady decline in the output until 1902 , when it was only $1,831,593,000$, as compared with $3,094,531,000$ in 1896. This decline was apparently partly due to legislation against the sale and purchase of cigarettes in the various States, partly to the increasing custom of the consumer's rolling his own cigarettes, and partly to an increase in the internal-revenue tax in 1897 and ggain in 1898. Since 1902, with the reduction in the internal-revenue tax, there has again been a considerable increase in the output of cigarettes for domestic consumption by the American Tobacco Company, the production in 1907 being 2,836,734,000. This increase has been chiefly in the cigarettes selling at 20 for 5 cents. 

Diagram 9 .

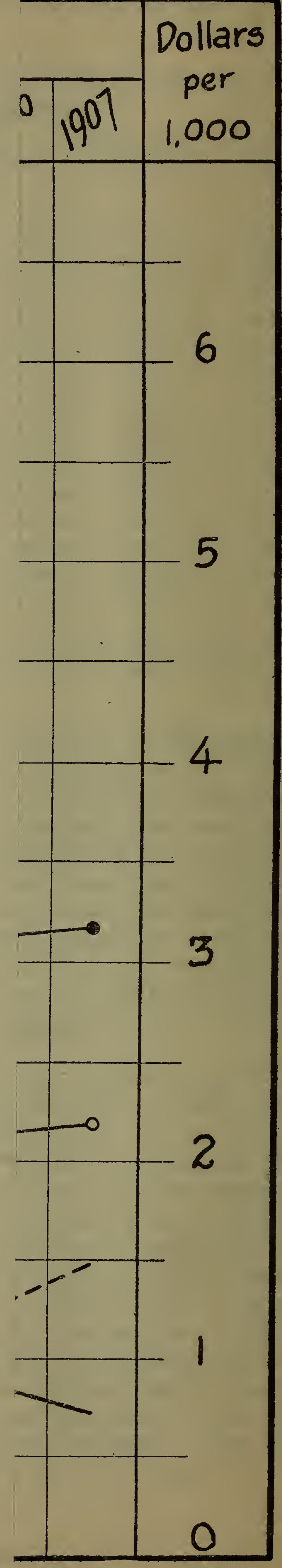


The variations in the value of the sales of cigarettes by the American Tobacco Company (exclusive of tax) correspond roughly, but only roughly, to the variations in the quantity sold. As already stated, the changes in the character of the cigarettes sold from time to time have had an important influence. Notwithstanding the increase in the quantity sold from 1893 to 1896 there was a decrease in the net value less tax, owing not to a reduction in the price of individual brands but to an increased sale of the cheap cigarettes retailing at 20 for 5 cents. The value of sales reached the maximum, $\$ 8,093,711.46$, in 1895 , and then fell off year by year until in 1901 it amounted to only $\$ 4,108,934.70$. By 1907 the value of the output had risen to $\$ 6,240,247.46$, which still was less than in the earlier years covered by the table.

The profits of the cigarette business of the American Tobacco Company have been materially less in recent years than during the nineties. The largest profits, so far as the period covered by the table goes, were in 1893 to 1896 , there being no great variation from year to year. They then steadily fell off, reaching a minimum of $\$ 1,320,848.95$ in 1902 , or only a little over one-third of the amount in 1893 and 1894 . There was a very marked increase in the profits in 1903 , but the amount in that year has not since been equaled, though there has been no very great variation in the annual profit of the cigarette business.

The following table and the accompanying diagram show the general results of the cigarette business of the American Tobacco Company in the domestic trade reduced to averages per thousand cigarettes:

TABLE 72.-Cigarettes-American Tobacco Company: Prices, costs, and profits (domestic business).

\begin{tabular}{|c|c|c|c|c|c|c|c|c|}
\hline \multirow[b]{2}{*}{ Year. } & \multicolumn{3}{|c|}{ Net price. } & \multicolumn{4}{|c|}{ Costs. } & \multirow[b]{2}{*}{ Profit. } \\
\hline & $\begin{array}{l}\text { Includ- } \\
\text { ing tax. }\end{array}$ & Tax. & $\begin{array}{l}\text { Exclud- } \\
\text { ing tax. }\end{array}$ & $\begin{array}{c}\text { Manufac- } \\
\text { ture. }\end{array}$ & \begin{tabular}{|c|} 
Selling \\
and ad- \\
vertising.
\end{tabular} & Freight. & Total. & \\
\hline & $\begin{array}{c}\text { Per } \\
\text { thousand. }\end{array}$ & $\begin{array}{c}\text { Per } \\
\text { thousand. }\end{array}$ & $\begin{array}{c}\text { Per } \\
\text { thousand. }\end{array}$ & $\begin{array}{c}\text { Per } \\
\text { thousand. }\end{array}$ & $\begin{array}{c}\text { Per } \\
\text { thousand. }\end{array}$ & $\begin{array}{c}\text { Per } \\
\text { thousand. }\end{array}$ & $\begin{array}{c}\text { Per } \\
\text { thousand. }\end{array}$ & $\begin{array}{c}\text { Per } \\
\text { thousand. }\end{array}$ \\
\hline $1895 \ldots$ & $\$ 3.27$ & $\$ 0.50$ & $\$ 2.77$ & $\$ 1.02$ & $\$ 0.49$ & $\$ 0.04$ & $\$ 1.55$ & $\$ 1.22$ \\
\hline 1896. & 2.96 & .50 & 2.46 & .90 & .46 & .04 & 1.40 & 1.06 \\
\hline 1897. & 2.94 & .67 & 2.27 & .89 & .34 & .04 & 1.27 & 1.00 \\
\hline $1898 \ldots$ & 3.27 & 1.25 & 2.02 & .78 & .16 & .03 & .97 & 1.05 \\
\hline $1899 \ldots$ & 3.51 & 1. 50 & 2.01 & .81 & .12 & .03 & .96 & 1.05 \\
\hline $1900 \ldots$ & 3.59 & 1.50 & 2.09 & .83 & .18 & .03 & 1.04 & 1.05 \\
\hline $1901 \ldots$ & 3.39 & 1.27 & 2.12 & .84 & .29 & .02 & 1.15 & .97 \\
\hline 1902. & 3.29 & 1.00 & 2.29 & 1.00 & .55 & .02 & 1. 57 & .72 \\
\hline 1903. & 3.27 & 1.00 & 2.27 & .96 & .25 & .02 & 1.23 & 1.04 \\
\hline $1904 \ldots$ & 3.24 & .99 & 2.25 & .90 & .42 & .02 & 1.34 & .91 \\
\hline $1905 \ldots$ & 3.14 & .97 & 2.17 & .97 & .29 & .02 & 1.28 & .89 \\
\hline $1906 \ldots \ldots \ldots$ & 3.13 & .98 & 2.15 & 1.03 & .25 & .02 & 1.30 & .85 \\
\hline $1907 \ldots \ldots \ldots$ & 3.19 & .99 & 2.20 & 1.17 & .29 & .03 & 1.49 & .71 \\
\hline
\end{tabular}

Because of the changes in the character of the cigarettes included in these averages from time to time, as already explained, little significance attaches to a comparison from one period to another. The decline in the net price, including tax, as well as in the net price, excluding tax (the tax being uniform), from 1895 to 1896 was chiefly due 
CIGARETTES.

AMERICAN TOBACCO COMPANY

Prives. Costs, and Inotits.

Diagram 9.

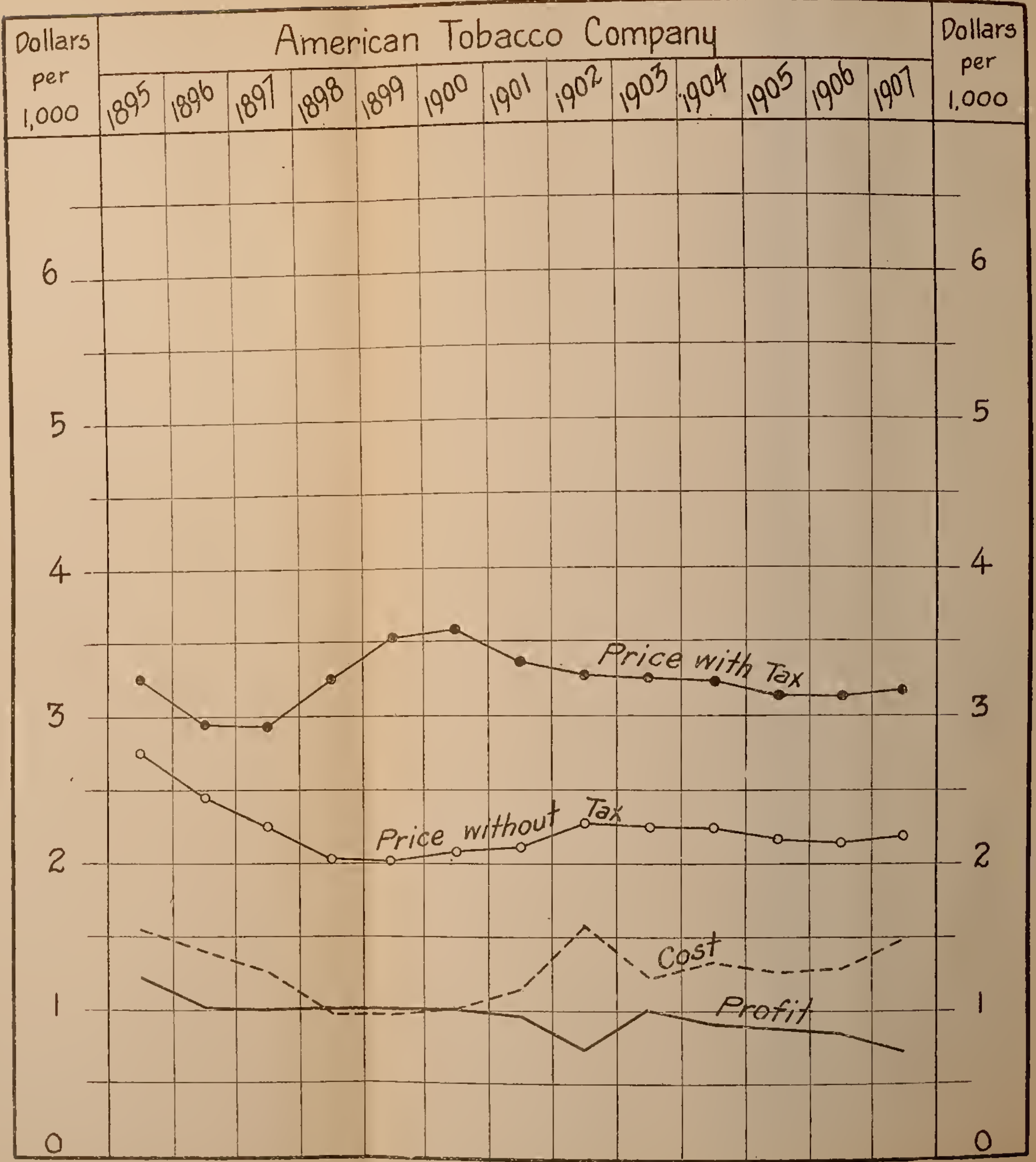




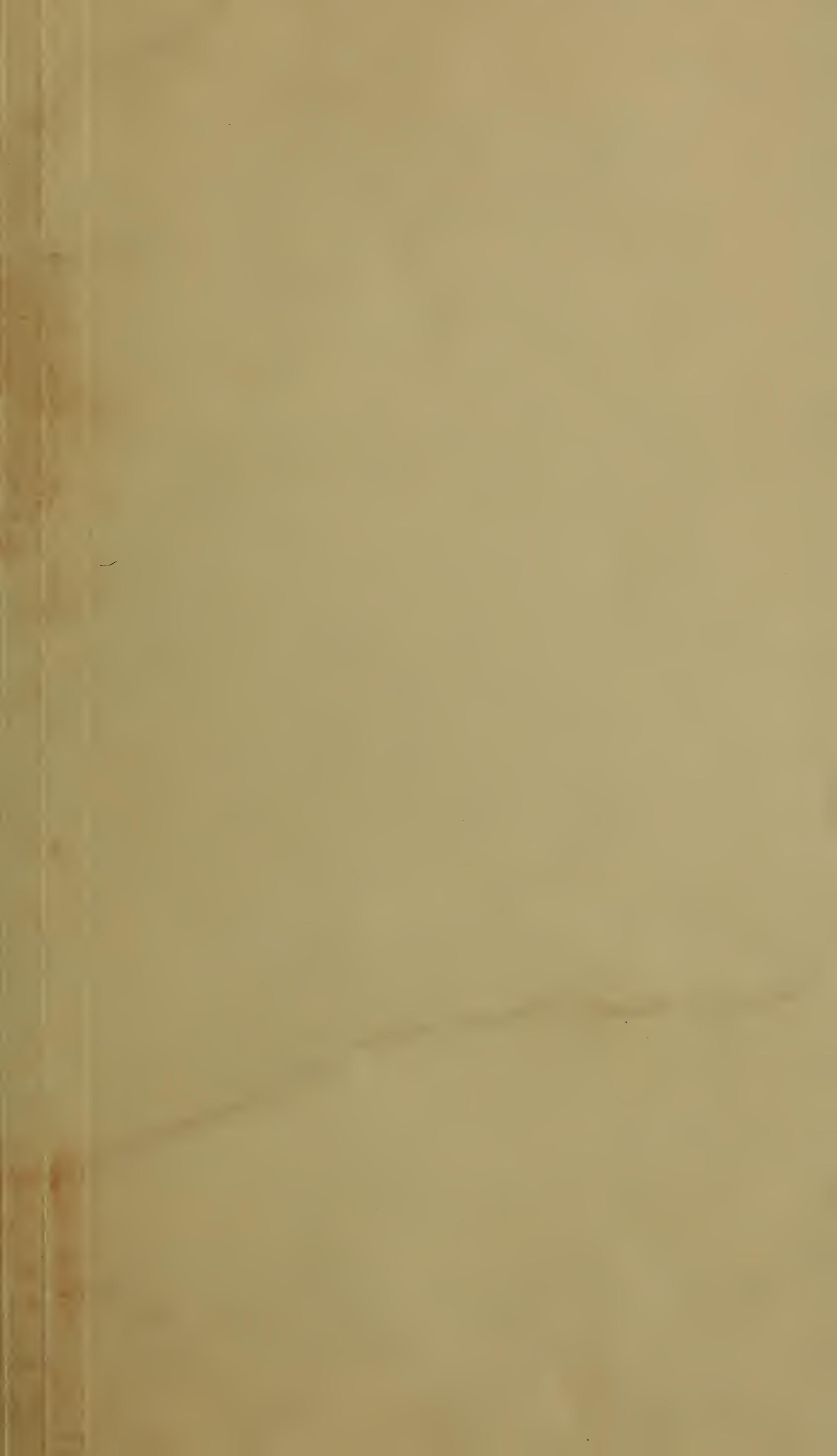


to an increased production of the cheap cigarettes, selling at 20 for 5 cents. At the same time there was, largely for the same reason, a decline in the average cost of cigarettes per thousand, and likewise a decline in the average profit. When the tax was advanced from $\$ 0.50$ to $\$ 1.25$ in 1897 , and again to $\$ 1.50$ in 1898 , the Combination largely ceased the manufacture of the cheap cigarettes, but it did not advance its price on other cigarettes by as much as the increase in the tax, so that the net price, exclusive of tax, fell from $\$ 2.77$ per thousand in 1895 to $\$ 2.01$ in 1899 and $\$ 2.09$ in 1900 , these being the two years in which the full war tax was in force on all cigarettes. The Combination was able to reduce its selling expenses very materially during this period, especially by reason of the increase in the percentage of control following 1896. The cost of manufacture also fell materially, notwithstanding the cutting out of the cheapest grade of cigarettes. The Combination was, therefore, able to maintain substantially the same profit during the war period as it had secured in 1896, notwithstanding the reduction in the net price, less tax.

In 1901 the taxes on cigarettes were changed, those on cigarettes selling at wholesale for more than $\$ 2$ per thousand (retailing at 10 for 5 cents) being taxed at $\$ 1.08$ per thousand, and those selling at wholesale for not more than $\$ 2$ per thousand (retailing at 20 for 5 cents) being taxed $\$ 0.54$ per thousand. The Combination reduced somewhat its average selling price at the time of the reduction of the tax, but not as much as the reduction in the tax, so that the net price, exclusive of tax, rose from $\$ 2.09$ in 1900 to $\$ 2.29$ in 1902 , the first full year of operation under the reduced taxes. The average cost of manufacture, however, increased, by reason of the increased cost of leaf and other raw materials. The Combination also increased the cost of selling and advertising, perhaps in part by reason of the growing competition of Turkish cigarettes, so that the total cost averaged $\$ 1.57$ in 1902 , as compared with only $\$ 0.96$ in 1899 . Consequently, the profit fell off, notwithstanding the increase in the net price, less tax, from $\$ 1.05$ per thousand in 1899 to $\$ 0.72$ in 1902. There have been no very great variations in the average price of the cigarettes manufactured by the American Tobacco Company for domestic consumption since 1902, although in no year has the average price been quite as high as in 1902 . The increased proportion of the cheap class of cigarettes selling at less than $\$ 2$ per thousand, which is evidenced by the decline in the average tax paid per thousand on the entire output, at least in part accounts for the fact that the average price has been lower during recent years than in 1902 . The variations in the cost of manufacture and sale have been greater than those in the price, the variations in manufacturing cost being largely due to changes in the price of leaf tobacco. These variations in costs are largely responsible for the variations in profits from year to year since 1902. The increase in the average cost of manufacture from $\$ 0.90$ in 1904 to $\$ 1.17$ in 1907 was, however, partly due to the fact that the American Tobacco Company put in a new brand of cigarettes with a Turkish name, selling at retail at 10 for 5 cents and especially designed to compete with the Turkish cigarettes. This brand costs somewhat more than most others of its class, and the profits are lower than the average for other brands. Its sales are now very large. 
TABLE 73.-Cigarettes-American Tobacco Company: Amount of tax, cost, and profit entering into net selling price.

\begin{tabular}{|c|c|c|c|c|}
\hline \multirow{2}{*}{ Year. } & \multicolumn{3}{|c|}{ Elements entering into price. } & \multirow{2}{*}{ Net price. } \\
\hline & Tax. & Cost. & Profit. & \\
\hline $1895 \ldots$ & $\begin{array}{r}\text { Per } \\
\text { thousand. } \\
\text { \$0 } 50\end{array}$ & $\begin{array}{r}\text { Per } \\
\text { thousand. } \\
\$ 1.55\end{array}$ & $\begin{array}{r}\text { Per } \\
\text { thousand. } \\
\$ 1.22\end{array}$ & $\begin{array}{c}P e r \\
\text { thousand. } \\
\quad \$ 3.27\end{array}$ \\
\hline $1896 \ldots$ & .50 & 1.40 & 1.06 & 2.96 \\
\hline $1897 \ldots$ & .67 & 1.27 & 1.00 & 2.94 \\
\hline $1898 .$. & 1.25 & .97 & 1.05 & 3. 27 \\
\hline $1899 .$. & 1.50 & .96 & 1.05 & 3. 51 \\
\hline $1900 \ldots$ & 1. 50 & 1.04 & 1.05 & 359 \\
\hline $1901 .$. & 1. 27 & 1.15 & .97 & 3.39 \\
\hline $1902 .$. & 1.00 & 1. 57 & .72 & 3. 29 \\
\hline $1903 .$. & 1.00 & 1.23 & 1.04 & 3. 27 \\
\hline $1904 .$. & .99 & 1.34 & .91 & 3.24 \\
\hline $1905 .$. & .97 & 1.28 & .89 & 3.14 \\
\hline $1906 \ldots$. & .98 & 1.30 & .85 & 3. 13 \\
\hline $1907 \ldots \ldots \ldots$ & .99 & 1. 49 & .71 & 3.19 \\
\hline
\end{tabular}

Table 73 shows the average net selling price of the American Tobacco Company for all cigarettes sold in the domestic trade, and the three elements entering into it, namely, tax, cost, and profit. The explanations already given regarding the changes in the conditions from year to year render comment on this table scarcely necessary. It may be noted, however, that the proportion of the selling price represented by the federal tax has varied greatly as the rates of tax have been changed. In 1895 and 1896 the tax of $\$ 0.50$ per thousand represented only from one-sixth to one-seventh of the net price charged by the manufacturer. During 1899 and 1900, when the full war taxes were charged, the tax represented more than two-fifths of the selling price. During the years from 1902 to 1907 , while the rates of $\$ 1.08$ and $\$ 0.54$, respectively, were in force, the amount of tax represented somewhat less than one-third of the selling price, the exact proportion in 1907 being 31 per cent.

Table 74 shows the net cost of manufacture and sale excluding the tax of the cigarettes produced by the American Tobacco Company for domestic consumption, the amount of profit, and the rate of profit figured on cost. It will be seen that the rate of profit on cost showed comparatively little variation from 1895 to 1897 , ranging from 76.1 per cent to 79.3 per cent. It increased markedly in 1898 and 1899 , being 110 per cent in the latter year. During the years 1902 to 1907 the rate of profit on cost showed very considerable fluctuations, and was not only decidedly lower than during the period from 1898 to 1900 , but on the whole was decidedly lower than during the years 1895 to 1897. 
Table 74.-Cigarettes-American Tobacco Company: Relation of profit to cost.

\begin{tabular}{|c|c|c|c|}
\hline Year. & $\begin{array}{l}\text { Cost (exclud- } \\
\text { ing } \operatorname{tax} \text { ). }\end{array}$ & Profit. & $\begin{array}{l}\text { Rate of profit } \\
\text { on cost. }\end{array}$ \\
\hline 1895. & $\begin{array}{r}\text { Perthousand. } \\
\$ 1.55\end{array}$ & $\begin{array}{r}\text { Per thousand. } \\
\$ 1.22\end{array}$ & $\begin{array}{r}\text { Per cent. } \\
79.1\end{array}$ \\
\hline $1896 \ldots \ldots \ldots$ & 1.40 & 1.06 & 76.1 \\
\hline $1897 \ldots \ldots \ldots \ldots \ldots$ & 1.27 & 1.00 & 79.3 \\
\hline $1898 \ldots \ldots \ldots \ldots \ldots \ldots$ & .97 & 1.05 & 109.0 \\
\hline $1899 \ldots \ldots \ldots \ldots \ldots$ & .96 & 1.05 & 110.0 \\
\hline $1900 \ldots \ldots \ldots \ldots \ldots \ldots$ & 1.04 & 1.05 & 101.3 \\
\hline $1901 \ldots \ldots \ldots \ldots \ldots$ & 1.15 & .97 & 83.6 \\
\hline $1902 \ldots \ldots \ldots \ldots \ldots \ldots$ & 1.57 & .72 & 45.9 \\
\hline $1903 \ldots \ldots \ldots \ldots \ldots \ldots$ & 1.23 & 1.04 & 83.9 \\
\hline $1904 \ldots \ldots \ldots \ldots \ldots$ & 1.34 & .91 & 68.2 \\
\hline $1905 \ldots \ldots \ldots \ldots \ldots$ & 1.28 & .89 & 68.9 \\
\hline $1906 \ldots \ldots \ldots \ldots \ldots \ldots$ & 1.30 & .85 & 65.2 \\
\hline $1907 \ldots \ldots \ldots \ldots \ldots$ & 1.49 & .71 & 48.1 \\
\hline
\end{tabular}

Table 75 shows the average net price, exclusive of tax, received by the American Tobacco Company for all cigarettes in the domestic trade, and the proportions thereof represented by cost and profit respectively. It will be seen that at all times the profit has represented a very considerable proportion of the net selling price less tax, but that there have been marked variations. During the period from 1895 to 1897 the profit represented from 43.2 per cent to 44.2 per cent of the selling price. During the years 1898 to 1900 more than one-half of the selling price was represented by profit; while during the years from 1901 to 1907 the proportion represented by profit ranged from 31.5 per cent to 45.6 per cent.

Table 75.-Cigarettes-American Tobacco Company: Division of net selling price (less tax) between cost and profit.

\begin{tabular}{c} 
Year. \\
\hline \\
1
\end{tabular}


Table 76 shows the relation between the net price and the profit of the American Tobacco Company on cigarettes in the domestic trade, and the proportion of the national output of cigarettes for domestic consumption controlled by the Combination:

TABLE 76.-Cigarettes-Relation of net price (less tax) and profit of American Tobacco Company to the proportion of the national output for domestic consumption controlled by the Tobacco Combination.

Year.
$\ldots$
1

The changes occurring from time to time in the proportions of the different classes of cigarettes whose prices make up the arerage net price for the company as a whole render it difficult to draw conclusions as to the relations between arerage net prices or profits on the entire output and the proportion of the national output controlled by the Combination. 'It may be noted, however', that the profit of the American Tobacco Company from 1895 to 1900 was higher than from 1904 to 1907 . The decreasing profits per thousand during the later years is in part due to an increasing proportion of cheap cigarettes selling at less than $\$ 2$ per thousand made by the American Tobacco Company since the rate of tax on cigarettes of that grade was reduced. The decline in profit, however, for the later years as compared with the years from 1898 to 1900 is, as shown by Table 72 , above, largely owing to increased advertising and selling expenses, and these in turn are in part due to the increased production of Turkish cigarettes and consequent increase of competition.

In considering the relation between the proportion of the national output controlled by the Combination, as shown in the above table, and the prices and profits of the American Tobacco Company in the cigarette business, it should be noted that the proportion of control is based on the output of all classes of cigarettes used for consumption in this country, including Turkish cigare ttes as well as those 
made from domestic leaf. The proportion of the cigarettes made from domestic leaf controlled by the Combination has not declined like the proportion of the total cigarette business, but on the contrary has been fully as high during the later years as during the earlier years covered by the above table. It is impossible to determine with precision how far the increased production of Turkish cigarettes by independent concerns has affected the price policy of the American Tobacco Company with reference to cigarettes made from domestic leaf, but the indications from the above figures of prices, costs, and profits are that, to some extent at least, the reduction in the profits of the American Tobacco Company on cigarettes made from domestic leaf has been due to the competion of Turkish cigarettes.

RESULTS OF THE CIGARETTE BUSINESS OF SUBSIDIARY CONCERNS OF THE AMERICAN TOBACCO COMPANY.

Three subsidiary concerns of the American Tobacco Company were in 1907 engaged in the manufacture and sale of cigarettes, namely, in the order of their importance: S. Anargyros (Incorporated), the John Bollman Company, and the Wells-Whitehead Tobacco Company. The total output of the subsidiary companies in 1907 was equal to more than one-third of the output of the plants directly owned by the American Tobacco Company.

The Wells-Whitehead Tobacco Company, now no longer in active operation, was the only one of these subsidiary concerns which made cigarettes of the same general type as the American Tobacco Company itself makes; namely, ordinary cigarettes made from domestic leaf. The S. Anargyros Company makes Turkish cigarettes. In this branch of the cigarette business the Tobacco Combination controls a much smaller proportion of the output than in cigarettes made from domestic leaf, its proportion being about 50 per cent. The John Bollman Company makes for the most part what are known as "Russian mouthpiece" cigarettes, having a special form of mouthpiece and commanding a higher price than the ordinary domestic cigarette. The Monopol Tobacco Works sells also high-grade cigarettes, chiefly Turkish cigarettes.

Consequently there would be no significance in combining the figures of prices. costs, and output for the American Tobacco Company with those of the subsidiary companies in arriving at averages. Moreover, on account of the differences in character of business of the Wells-Whitehead Company, as compared with the other subsidiary companies, there is no significance in averages for the combined business of these four subsidiary concerns. The data of costs and profits for the Anargyros, Monopol, and Bollman companies may, however, properly be combined.

The following table shows the annual sales and the average net price, less tax, for the Anargyros, Monopol, Bollman, and WellsWhitehead companies for each year for which data are available. In the case of all the companies except the John Bollman Company the data cover each year since acquisition by the Combination. The Bollman Company, although acquired in 1900, is not included back of 1905 . 
TABLE 77.-Cigarettes-Quantity of sales and average prices of the several subsidiary companies of the American Tobacco Company.

\begin{tabular}{|c|c|c|c|c|c|c|c|c|}
\hline \multirow{2}{*}{ Year. } & \multicolumn{2}{|c|}{ S. Anargyros. } & \multicolumn{2}{|c|}{$\begin{array}{c}\text { Monopol Tobacco } \\
\text { Works. }\end{array}$} & \multicolumn{2}{|c|}{ John Bollman Co. } & \multicolumn{2}{|c|}{$\begin{array}{l}\text { Wells-Whitehead } \\
\text { Tobacco Co. }\end{array}$} \\
\hline & Sales. & $\begin{array}{l}\text { Price, ex- } \\
\text { cluding } \\
\text { tax: }\end{array}$ & Sales. & $\begin{array}{l}\text { Price, ex- } \\
\text { cluding } \\
\text { tax. }\end{array}$ & Sales. & $\begin{array}{l}\text { Price, ex- } \\
\text { cluding } \\
\text { tax. }\end{array}$ & Sales. & $\begin{array}{l}\text { Price, ex- } \\
\text { cluding } \\
\text { tax. }\end{array}$ \\
\hline 1900 & $\begin{array}{c}\text { Thousands. } \\
\text { a } 12,480\end{array}$ & $\begin{array}{r}\text { Per } 1,000 \\
a \$ 14.94\end{array}$ & Thousands. & $\operatorname{Per} 1,000$ & Thousands. & Per 1,000 & Thousands. & $\begin{array}{l}\text { Per } 1,000 \text {. } \\
\ldots \ldots\end{array}$ \\
\hline 1901. & 54,561 & 10.05 & 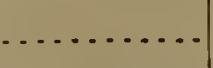 & $\ldots .$. & & & & \\
\hline 1902. & 133,625 & 8.40 & 75,322 & $\$ 6.73$ & & & & \\
\hline 1903. & 275,673 & 7.71 & 93,626 & 6.11 & & & & \\
\hline 1904 & 322,744 & 7.19 & 65,759 & 5.34 & & & & \\
\hline 1905. & 435,916 & 6.88 & b 55,328 & 5.06 & 74,300 & $\$ 5.75$ & $88,66 \tau$ & $\$ 2.10$ \\
\hline $1906 \ldots$ & 672,322 & 6.75 & 68,715 & 5.00 & 79,109 & 5.76 & 90,599 & 1.86 \\
\hline $1907 \ldots$ & 850,280 & 6.44 & & & 97,731 & 5.66 & 75,205 & 2.02 \\
\hline
\end{tabular}

$a$ Nine months.

$b$ Includes a few cigars and cheroots.

This table shows that at the present time the S. Anargyros Company has a far greater volume of output than all the other three concerns combined. When this company was first acquired by the Combination its sales were small, only 12,480,000 cigarettes in 1900. There has been a rapid increase in each year, until in 1907 the sales were $850,280,000$ cigarettes. This development has been largely due to the general increase in the popularity and consumption of Turkish cigarettes. The great reduction in the average price of the output of S. Anargyros from year to year, namely, from $\$ 14.94$ per thousand in 1900 to $\$ 6.44$ per thousand in 1907 , should not be understood as in any sense due to a reduction in the prices of cigarettes. It is due simply to an increased sale of cheaper Turkish cigarettes during the more recent years. When the business first started it was confined to very high-grade cigarettes, but the increasing popularity of Turkish cigarettes among ordinary consumers has led the Combination - and the same practice has been followed by independent concerns - to put out new brands at lower prices.

The sales of the Monopol Tobacco Works have fluctuated very considerably from year to year, but on the whole have decreased, partly on account of the transfer of the export business to the British-American Tobacco Company. The sales have ranged from $55,328,000$ to $93,626,000$ cigarettes. The changes in the average price of cigarettes sold by this company are also largely due to the changes in the character of the output rather than to changes in the prices of individual brands.

The output of the John Bollman Company has increased very considerably during the short period covered by the statistics, namely, from $74,300,000$ in 1905 to $97,731,000$ in 1907 . The character of the output of this company has not changed appreciably, so that the average prices are comparable. The price in 1907 was about 10 cents lower per thousand than in the two preceding years. 
The Wells-Whitehead Tobacco Company during the period of its existence manufactured ordinary cigarettes from domestic tobacco. Its sales fell off considerably in 1907 . The net price has shown considerable fluctutation during the three years covered by the table, ranging from $\$ 1.86$ to $\$ 2.10$ per thousand.

Table 78 shows the average prices, costs, and profits on cigarettes for the S. Anargyros, Bollman, and Monopol companies combined.

TABle 78.-Cigarettes-Prices, costs, and profits for the S. Anargyros, Monopol, and John Bollman companies, combined.

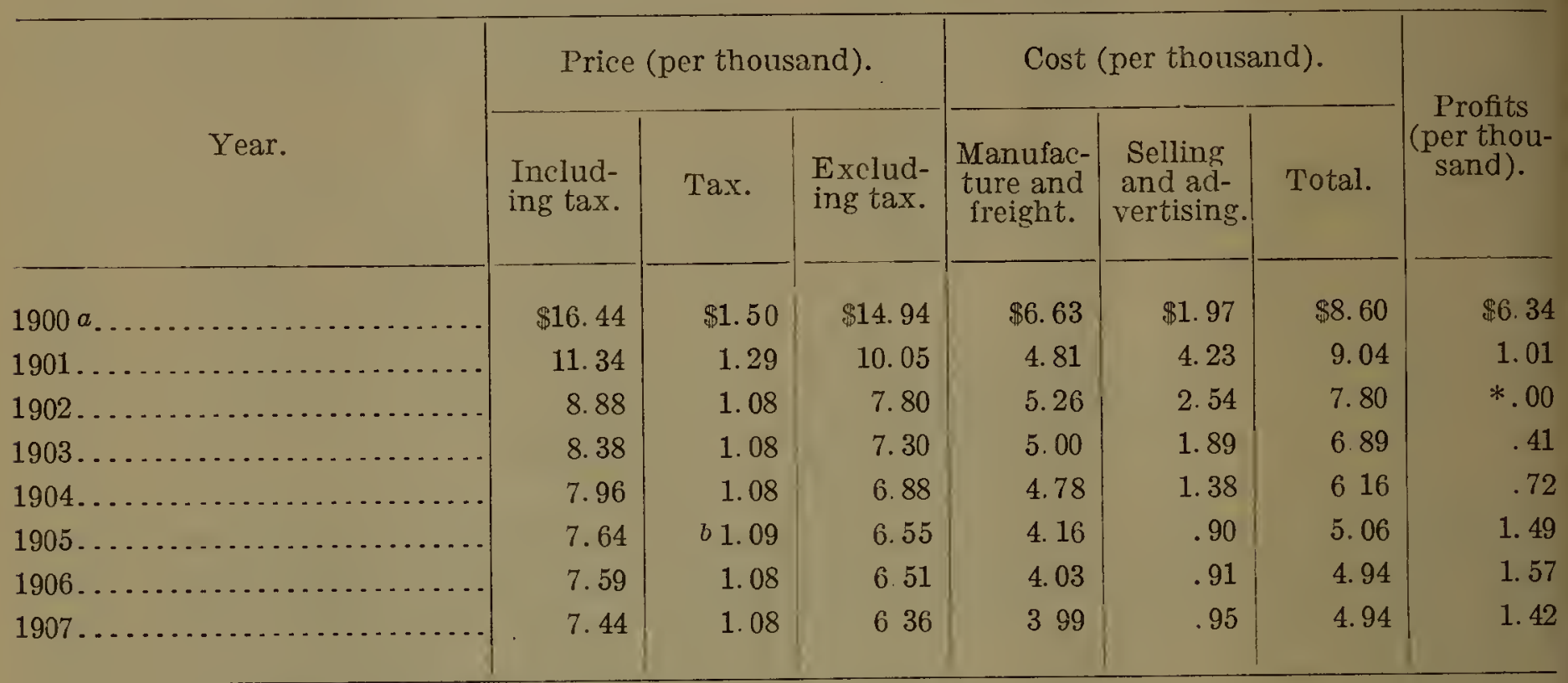

* A small loss, averaging less than 1 cent per 1,000 .

a Nine months ending December 31, 1900.

$b$ The sales include a few cigars, which affects the tax for this year.

For the reason already stated, the changes in the prices, costs, and profits of the S. Anargyros Company from year to year do not with any approach to correctness show the changes in the results for individual brands, but are in part due to changes in the character of the output covered by the statistics from year to year, and as this is the principal company in the group here presented the same statement applies to the entire group. It will be seen that side by side with the marked decline in the price there has also been a marked decline in the cost, due largely to the increased output of cheaper grades. Leaving out of consideration the year 1900, when the business was very small and covered only exceedingly high-grade cigarettes with a high price and a high profit, it will be seen that, notwithstanding the reduction in the average price, there has been a greater profit per thousand cigarettes during the years 1905 to 1907 than during the years 1901 to 1904 . In 1902, in fact, there was a small loss for the Anargyros Company, the only one included for that year in the above table. It is noteworthy that during both 1901 and 1902 the selling and advertising expenses were exceptionally high, due to the efforts of the Combination to build up its Turkish-cigarette business. In 1901 the selling expenses per thousand cigarettes were not much less than the cost of manufacturing them, and in 1902 they were equal to nearly half of the cost of manufacture. From that time until 1906 the selling expenses per thousand cigarettes were very materially reduced, this being the natural effect of the rapid growth in the output and the reduced necessity of heavy advertising expenses following the establishment of the leading brands in popular favor. 
During the years from 1905 to 1907 , in which there were no very narked changes in the general conditions of the business, the tax of ;1.08 has represented about 14 per cent of the net selling price for hese three companies together, the cost of manufacture and sale ibout 66 per cent, and the profit about 20 per cent.

Further information in regard to the combined business of the Anargyros, Monopol, and John Bollman companies is presented in he three succeeding tables. Comment on these tables is scarcely recessary. Table 79 shows the combined sales, net value of sales, and net profits of the S. Anargyros, Monopol, and John Bollman ompanies.

TABLE 79.-Cigarettes-Quantity of sales, net value of sales and net profits of the $S$. Anargyros, Monopol, and John Bollman companies, combined.

\begin{tabular}{|c|c|c|c|}
\hline Year. & Sales. & $\begin{array}{l}\text { Net value } \\
\text { of sales } \\
\text { (less tax). }\end{array}$ & Profit. \\
\hline & $\begin{array}{r}\text { Thousands. } \\
12.480\end{array}$ & $\$ 1864059 ?$ & 879.074 .25 \\
\hline $1901 \ldots$ & 54,561 & $548,191.80$ & $55,151.56$ \\
\hline 1902 & 208,947 & $1,628,837.10$ & *758. 17 \\
\hline $1903 \ldots .$. & 369,299 & $2,698,431.25$ & $153,085.58$ \\
\hline $1904 \ldots \ldots \ldots \ldots$. & 388,503 & $2,672,071.42$ & 278.047 .96 \\
\hline $1905 \ldots \ldots \ldots \ldots$ & 565,544 & $3,706,69590$ & $840,255.59$ \\
\hline-7 & 820,146 & $5,339,224.71$ & $1,287,550.40$ \\
\hline $07 \ldots \ldots \ldots \ldots . . .6$. & 948,011 & $6,032,19154$ & $1,343,461.61$ \\
\hline
\end{tabular}

a Nine months ending December 31, $1900 . \quad$ *Loss.

Table 80 shows the amount of tax, cost, and profit entering into the average net selling price of the S. Anargyros, Monopol, and John Bollman companies.

TABLE 80.-Cigarettes-Amount of tax, cost, and profit entering into net selling price for the S. Anargyros, Monopol, and John Bollman companies, combined.

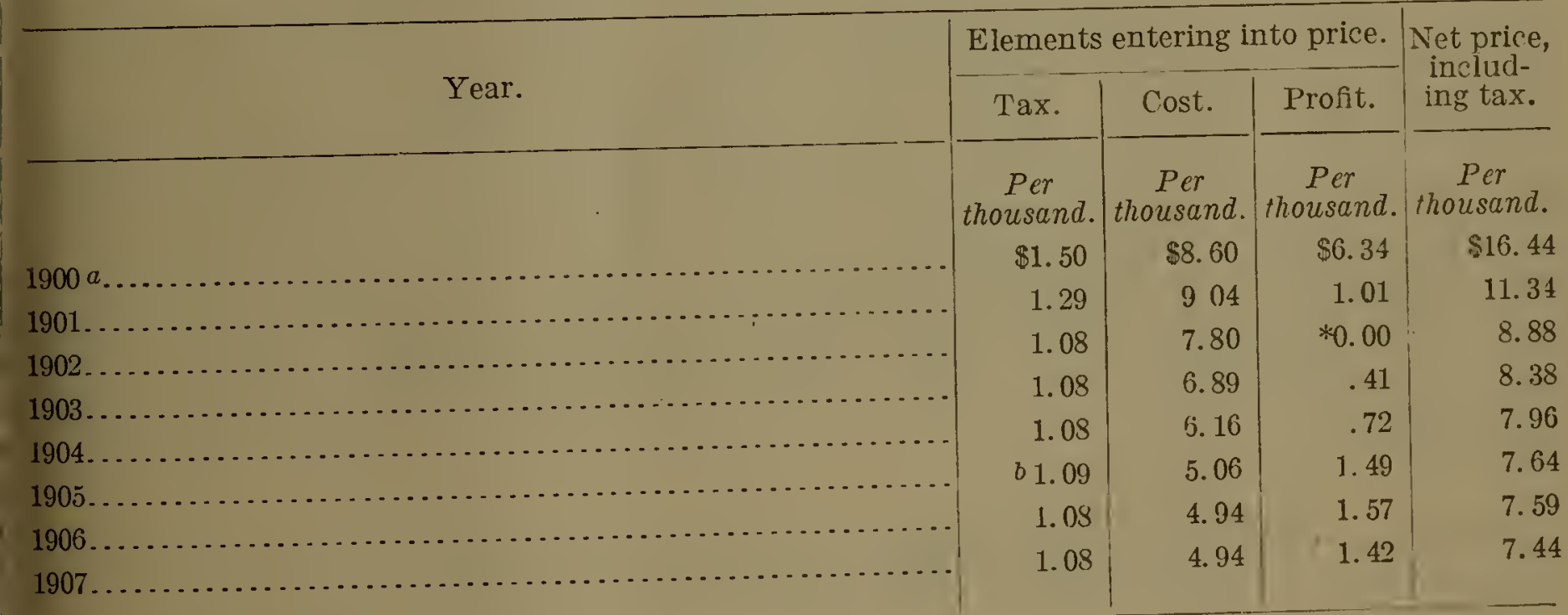

a Nine months ending December 31, 1900.

$b$ The sales include a few cigars which affect the average tax for this year.

* Loss, less than 1 cent. 
Table 81 shows the relation of profit to cost in the combined business of the S. Anargyros, Monopol, and John Bollman companies.

TABLE 81.-Cigarettes-Relation of profit to cost for the S. Anargyros, Monopol, and John Bollman companies, combined.

\begin{tabular}{|c|c|c|c|}
\hline Year. & $\begin{array}{l}\text { Cost ex- } \\
\text { cluding } \\
\text { tax. }\end{array}$ & Profit. & $\begin{array}{l}\text { Rate } \\
\text { of profit } \\
\text { on cost. }\end{array}$ \\
\hline $1900 a \ldots$ & $\begin{array}{c}\text { Per } \\
\text { thousand. } \\
\$ 8.60\end{array}$ & $\begin{array}{c}\text { Per } \\
\text { thousand. } \\
\text { \$6. } 34\end{array}$ & $\begin{array}{r}\text { Per cent. } \\
73.6\end{array}$ \\
\hline $1901 \ldots \ldots \ldots \ldots$ & 9.04 & 1.01 & 11.2 \\
\hline $1902 \ldots \ldots \ldots \ldots$ & 7.80 & $* 0.00$ & $* 0.0$ \\
\hline $1903 . . . \ldots \ldots \ldots \ldots . . . . . .$. & 6.89 & .41 & 6.0 \\
\hline $1904 \ldots \ldots \ldots \ldots \ldots \ldots$ & 6.16 & .72 & 11.6 \\
\hline $1905 . . . \ldots \ldots \ldots \ldots$ & 5.06 & 1.49 & 29.3 \\
\hline $1906 \ldots \ldots \ldots \ldots \ldots \ldots \ldots . . . \ldots \ldots \ldots$ & 4.94 & 1.57 & 31.8 \\
\hline $1907 \ldots \ldots \ldots \ldots \ldots \ldots \ldots \ldots \ldots \ldots \ldots$ & 4.94 & 1.42 & 28.7 \\
\hline
\end{tabular}

Table 82 shows the results of the business of the Wells-Whitehead Tobacco Company from 1905 to 1907.

TABLE 82.-Cigarettes-Prices, costs, and profits of the Wells-Whitehead Tobacco Company.

\begin{tabular}{|c|c|c|c|c|c|c|c|c|}
\hline \multirow[b]{2}{*}{ Year. } & \multirow[b]{2}{*}{ Sales. } & \multicolumn{3}{|c|}{ Prices (per thousand). } & \multicolumn{3}{|c|}{ Cost (per thousand). } & \multirow{2}{*}{$\begin{array}{l}\text { Profit } \\
\text { (per thou- } \\
\text { sand). }\end{array}$} \\
\hline & & $\begin{array}{l}\text { Price, in- } \\
\text { cluding } \\
\text { tax. }\end{array}$ & Tax. & $\begin{array}{l}\text { Price, less } \\
\quad \text { tax. }\end{array}$ & $\begin{array}{l}\text { Manufac- } \\
\text { ture and } \\
\text { freight. }\end{array}$ & $\begin{array}{l}\text { Selling } \\
\text { and ad- } \\
\text { vertising. }\end{array}$ & Total. & \\
\hline $1905 .$. & $\begin{array}{l}\text { Thou- } \\
\text { sands. } \\
88,667\end{array}$ & $\$ 3.18$ & $\$ 1.08$ & $\$ 2.10$ & $\$ 1.32$ & $\$ 0.55$ & $\$ 1.87$ & $\$ 0.23$ \\
\hline $1906 \ldots .$. & 90.599 & 2.94 & 1.08 & 1.86 & 1.60 & .72 & 2.32 & *. 46 \\
\hline $1907 \ldots$. & 75,205 & 3.10 & 1.08 & 2.02 & 1.29 & 1.27 & 2.56 & $* .54$ \\
\hline
\end{tabular}

${ }^{*}$ Loss.

The business of the Wells-Whitehead Tobacco Company during 1906 and 1907 resulted in a very considerable loss, and even in 1905 the profit was small. The prices during the latter two years were lower than in 1905 , while the costs were higher, especially the selling and advertising costs. It is noteworthy that in 1907 the selling and advertising: costs were practically equal to the cost of manufacture. The explanation of the unprofitableness of this company is apparently largely to be found in the high selling and advertising cost, due to active competition and to some large losses of the leaf-purchasing department.

COMBINED CIGARETTE BUSINESS OF THE AMERICAN TOBACCO COMPANY AND SUBSIDIARY COMPANIES.

Although, on account of the diversity in the character of the product of the several concerns, there is no significance in computing average prices, costs, and profits for the entire cigarette business of the Tobacco Combination, it is worth while to present a table showing the total quantity and value of sales and the total profits of the Combination from itscigarette business. Such a table follows. The 
table is substantially complete, although it does not include the figures for the John Bollman Company from 1900, when it was first acquired, until 1904, and also does not include the very small business of the Craft Tobacco Company. The table is confined to the trade in the United States, and does not include the export business, except a very small quantity exported by the Monopol Tobacco Works.

TABLE 83.-Cigarettes-Combined sales and profits of the American Tobacco Company and its principal subsidiary companies.

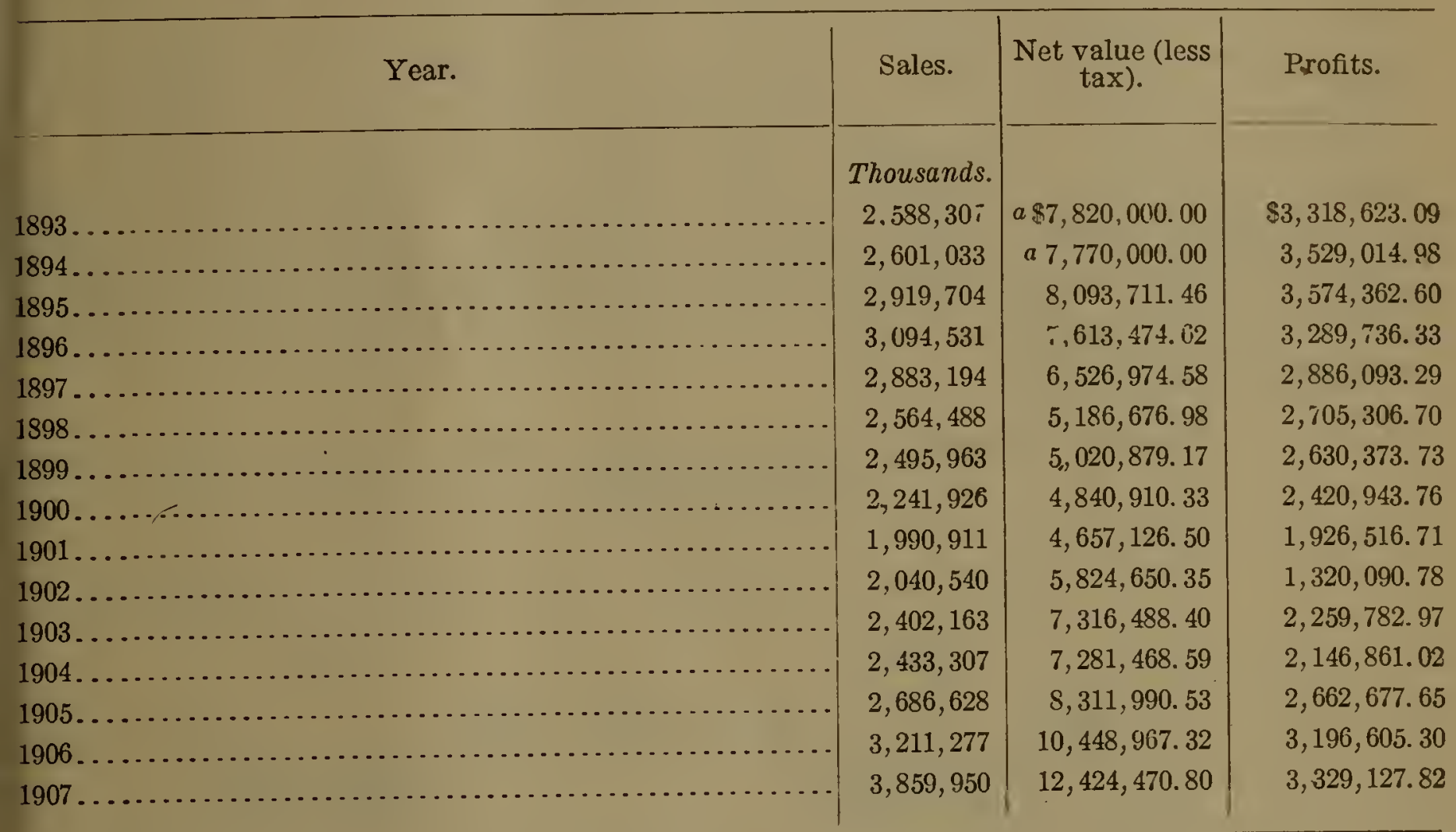

a Approximate figure. The available data shows the list price only. The net price has been calculated by assuming the rate of discount to have been the same as the average for 1895 and 1896 , viz, 11.3 per cent.

This table shows the cigarette industry of the Tobacco Combination as a whole during recent years in quite a different light from that which is gained by considering only the business of the American Tobacco Company proper. The number of cigarettes made by the subsidiary companies has increased relatively far more than the number made by the American Tobacco Company, and, as the cigarettes made by the subsidiary companies are of higher price than those made by the parent company, the proportion of the value of the output produced by the subsidiary companies has increased still more, until in 1906 the output of the subsidiary companies exceeded and in 1907 nearly equaled in value that of the American Tobacco Company itself. During those two years, moreover, the subsidiary concerns contributed about one-third of the total profit of the Combination in the cigarette business in the United States.

Confining attention to the period since 1900, when the subsidiary companies first appear, it will be seen that the number of cigarettes sold by the Combination as a whole declined considerably in 1901 , but has since increased rapidly, particularly during the years 1904 to 1907 , and in the latter year was about 72 per cent greater than in 1900. The value of the sales, however, has increased much more on account of the increased proportion of high-grade cigarettes sold. From $\$ 4,840,910.33$ in 1900 , the value rose to $\$ 12,424,470.80$ in 1907 , 
an increase of 157 per cent. The profits of the cigarette business of the Combination fell off from 1900 to 1902 , but increased rapidly in 1903, and again increased very considerably from 1904 in each year until 1907. The total profits of the business in 1907 were $\$ 3,329,127.82$, as compared with $\$ 2,420,943.76$ in 1900 , an increase of over one-third.

\section{PRICES, COSTS, AND PROFITS ON INDIVIDUAL BRANDS OF CIGARETTES MADE BY THE AMERICAN TOBACCO COMPANY.}

For reasons already stated, the average price, cost, and profit for the entire output of cigarettes made by the American Tobacco Company from year to year furnishes comparatively little information, owing to variations in the proportions of the output of cigarettes of different classes. A much truer view of the price policy of the American Tobacco Company with respect to cigarettes is obtained by considering the prices, costs, and profits on individual brands. Table 84 shows such data for five of the principal brands made by the company, and the figures are represented graphically in the accompanying diagram:

TABLE 84.-Cigarettes-American Tobacco Company: Prices, costs, and profits.for leading individual brands.

\begin{tabular}{|c|c|c|c|c|c|c|c|c|c|c|}
\hline \multirow{3}{*}{ Period. } & \multicolumn{5}{|c|}{ Brand No. 1 (per thousand). } & \multicolumn{5}{|c|}{ Brand No. 2 (per thousand). } \\
\hline & \multirow[b]{2}{*}{$\begin{array}{c}\text { Rate } \\
\text { of tax. }\end{array}$} & \multicolumn{2}{|c|}{ Price. } & \multirow[b]{2}{*}{ Cost. } & \multirow[b]{2}{*}{ Profit. } & \multirow[b]{2}{*}{$\begin{array}{l}\text { Rate } \\
\text { of tax. }\end{array}$} & \multicolumn{2}{|c|}{ Price. } & \multirow[b]{2}{*}{ Cost. } & \multirow[b]{2}{*}{ Profit. } \\
\hline & & $\begin{array}{l}\text { In- } \\
\text { cluding } \\
\text { tax. }\end{array}$ & $\begin{array}{c}\text { Ex- } \\
\text { cluding } \\
\text { tax. }\end{array}$ & & & & $\underset{\text { tax. }}{\text { In- }}$ & $\begin{array}{c}\text { Ex- } \\
\text { cluding } \\
\text { tax. }\end{array}$ & & \\
\hline 1901 (first half)... & $\$ 1.50$ & $\$ 2.65$ & $\$ 1.15$ & $\$ 0.88$ & $\$ 0.27$ & & & & & \\
\hline 1901 (second half). & .55 & 1.60 & 1.05 & .79 & .26 & 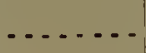 & & & & \\
\hline $1902 \ldots \ldots$ & .54 & 1.67 & 1.13 & .88 & .25 & $\$ 1.08$ & $\$ 2.92$ & $\$ 1.84$ & $\$ 2.93$ & $* \$ 1.09$ \\
\hline $1903 .$. & .54 & 1.68 & 1.14 & .79 & .35 & 1.08 & 2.91 & 1.83 & 2.22 & *.39 \\
\hline 1904 & .54 & 1.68 & 1.14 & .81 & .33 & 1.08 & 3.11 & 2.03 & 1.98 & .05 \\
\hline 1905. & .54 & 1.67 & 1.13 & .85 & .28 & 1.08 & 3.03 & 1.95 & 1.69 & .26 \\
\hline 1906. & .54 & 1.77 & 1.23 & .85 & .38 & 1.08 & 3.00 & 1.92 & 1.68 & .24 \\
\hline 1907. & .54 & 1.78 & 1.24 & .90 & .34 & 1.08 & 3.13 & 2.05 & 1.86 & .19 \\
\hline \multirow{3}{*}{ Period. } & \multicolumn{5}{|c|}{ Brand No. 3 (per thousand). } & \multicolumn{5}{|c|}{ Brand No. 4 (per thousand). } \\
\hline & \multirow[b]{2}{*}{$\begin{array}{c}\text { Rate } \\
\text { of tax. }\end{array}$} & \multicolumn{2}{|c|}{ Price. } & \multirow[b]{2}{*}{ Cost. } & \multirow[b]{2}{*}{ Profit. } & \multirow[b]{2}{*}{$\begin{array}{c}\text { Rate } \\
\text { of tax. }\end{array}$} & \multicolumn{2}{|c|}{ Price. } & \multirow[b]{2}{*}{ Cost. } & \multirow[b]{2}{*}{ Profit. } \\
\hline & & $\underset{\substack{\text { In- } \\
\text { cluding }}}{\text { tax. }}$ & $\begin{array}{c}\text { Ex- } \\
\text { cluding } \\
\text { tax. }\end{array}$ & & & & 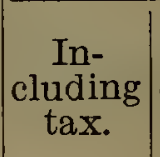 & $\begin{array}{l}\text { Fx- } \\
\text { cluding } \\
\text { tax. }\end{array}$ & & \\
\hline 1901 (first half)... & $\$ 1.50$ & $\$ 3.63$ & $\$ 2.13$ & $\$ 1.05$ & $\$ 1.08$ & $\$ 1.50$ & $\$ 5.71$ & $\$ 4.21$ & $\$ 2.06$ & $\$ 2.15$ \\
\hline 1901 (second half) & 1.08 & 3.54 & 2.46 & 1.21 & 1.25 & 1.08 & 5.61 & 4.53 & 2.09 & 2.44 \\
\hline $1902 \ldots \ldots \ldots \ldots$ & 1.08 & 3. 64 & 2.56 & 1.68 & .88 & 1.08 & 5.64 & 4.56 & 2.56 & 2.00 \\
\hline 1903. & 1.08 & 3.65 & 2.57 & 1.39 & 1.18 & 1.08 & 5.66 & 4. 58 & 2.47 & 2.11 \\
\hline 1904. & 1.08 & 3.64 & 2.56 & 1.47 & 1.09 & 1.08 & 5.83 & 4.75 & 3.26 & 1. 49 \\
\hline 1905. & 1.08 & 3.59 & 2.51 & 1.13 & 1.38 & 1.08 & 5.86 & 4.78 & 3.28 & 1.50 \\
\hline 1906. & 1.08 & 3.64 & 2.56 & 1.15 & 1.41 & 1.08 & 5.90 & 4.82 & 2.33 & 2.49 \\
\hline $1907 \ldots$ & 1.08 & 3.64 & 2.56 & 1.27 & 1.29 & 1.08 & 5.89 & 4.81 & 2.29 & 2.52 \\
\hline
\end{tabular}

* Loss, less than 1 cent. 



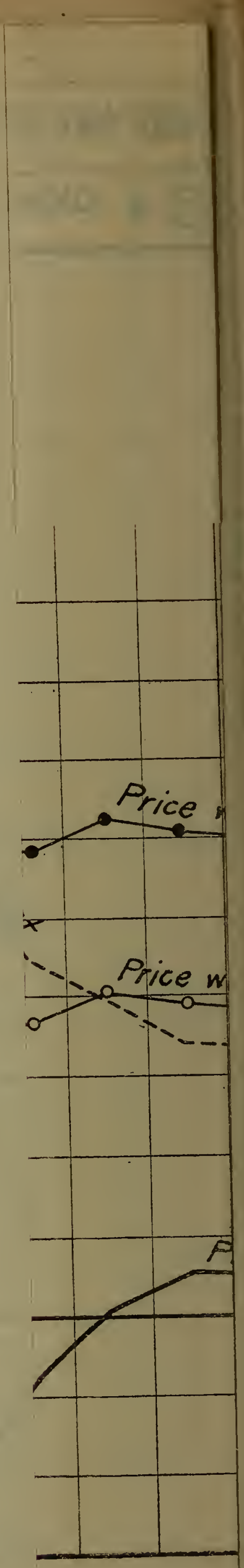


TABLE 84.-Cigarettes-American Tobacco Company: Prices, costs, and profits for leuding individual brands-Continued.

\begin{tabular}{|c|c|c|c|c|c|}
\hline \multirow{3}{*}{ Period. } & \multicolumn{5}{|c|}{ Brand No. $\tilde{s}$ (per thousand). } \\
\hline & \multirow{2}{*}{$\begin{array}{l}\text { Rate of } \\
\text { tax. }\end{array}$} & \multicolumn{2}{|c|}{ Price. } & \multirow{2}{*}{ Cost. } & \multirow{2}{*}{ Profit. } \\
\hline & & $\begin{array}{l}\text { Includ- } \\
\text { ing tax. }\end{array}$ & $\begin{array}{l}\text { Exclud- } \\
\text { ing tax. }\end{array}$ & & \\
\hline 1901 (first half) .... & $\$ 1.50$ & $\$ 1.48$ & $* \$ 0.02$ & \$0. 89 & $* \$ 0.91$ \\
\hline 1901 (second half). & .54 & 1.44 & .90 & .81 & .09 \\
\hline $1902 \ldots \ldots \ldots \ldots$ & .54 & 1.49 & .95 & .95 & *.00 \\
\hline $1903 .$. & .54 & 1.61 & 1.07 & .85 & .22 \\
\hline $1904 .$. & .54 & 1.67 & 1.13 & .80 & .33 \\
\hline $1905 .$. & .54 & 1.77 & 1.23 & .87 & .36 \\
\hline $1906 .$. & .54 & 1.82 & 1.28 & .86 & .42 \\
\hline $1907 \ldots$ & .54 & 1.82 & 1.28 & .90 & .38 \\
\hline
\end{tabular}

* Ioss, less than 1 cent.

Brands 1 and 5 in this table and diagram are cigarettes selling to the consumer at 20 for 5 cents, equal to $\$ 2.50$ per thousand (classified by the internal-revenue law as cigarettes selling at wholesale for $\$ 2$ and less per thousand) and taxed at 54 cents per thousand since July 1, 1901 , prior to which time the rate was $\$ 1.50$ per thousand, being uniform at that time on all classes of cigarettes excepting those weighing over 3 pounds per thousand. Brands 2 and 3 are cigarettes selling at 10 for 5 cents, the tax on which prior to July 1,1901 , was $\$ 1.50$ and since then $\$ 1.08$ per thousand. Brand 4 is a cigarette selling at 10 for 10 cents, which is taxed at the same rate as Nos. 2 and 3.

It will be seen that the policy of the American Tobacco Company was entirely different with respect to brand 1 from what it was with brand 5 . Brand 1 had been sold prior to the Spanish war, when the rate of tax was 50 cents per thousand. At the time of the war, when the tax was increased to $\$ 1.50$ per thousand, the American Tobacco Company raised the price to the jobbers to about $\$ 2.80$ per thousand, which was more than the price to the consumer $(\$ 2.50)$ on the basis of the customary price of 20 for 5 cents. The jobber and retailer were left to determine whether they would cut out the sales of such cigarettes or raise the price. There were, however, comparatively small sales of these cigarettes by the American Tobacco Company on the basis of this higher price to jobbers. When the tax was reduced from $\$ 1.50$ to $\$ 0.54$ per thousand in 1901 , the American Tobacco Company promptly reduced the price to jobbers on this brand by practically the same amount, so that it could thereafter be sold again to the consumer at 20 for 5 cents with a profit to the jobber and retailer. Since July 1, 1901, there has been some increase in the price of this brand to the jobber, and of course the same increase in the price less tax. The American Tobacco Company could not, of course, have secured the benefit of the 54-cent tax had it charged more than $\$ 2$ per thousand for these cigarettes.

The American Tobacco Company had practically ceased to manufacture brand 5--a 20-for-5 cents brand-during the period of the prohibitive tax rates of the Spanish war. Just before the tax was re- 


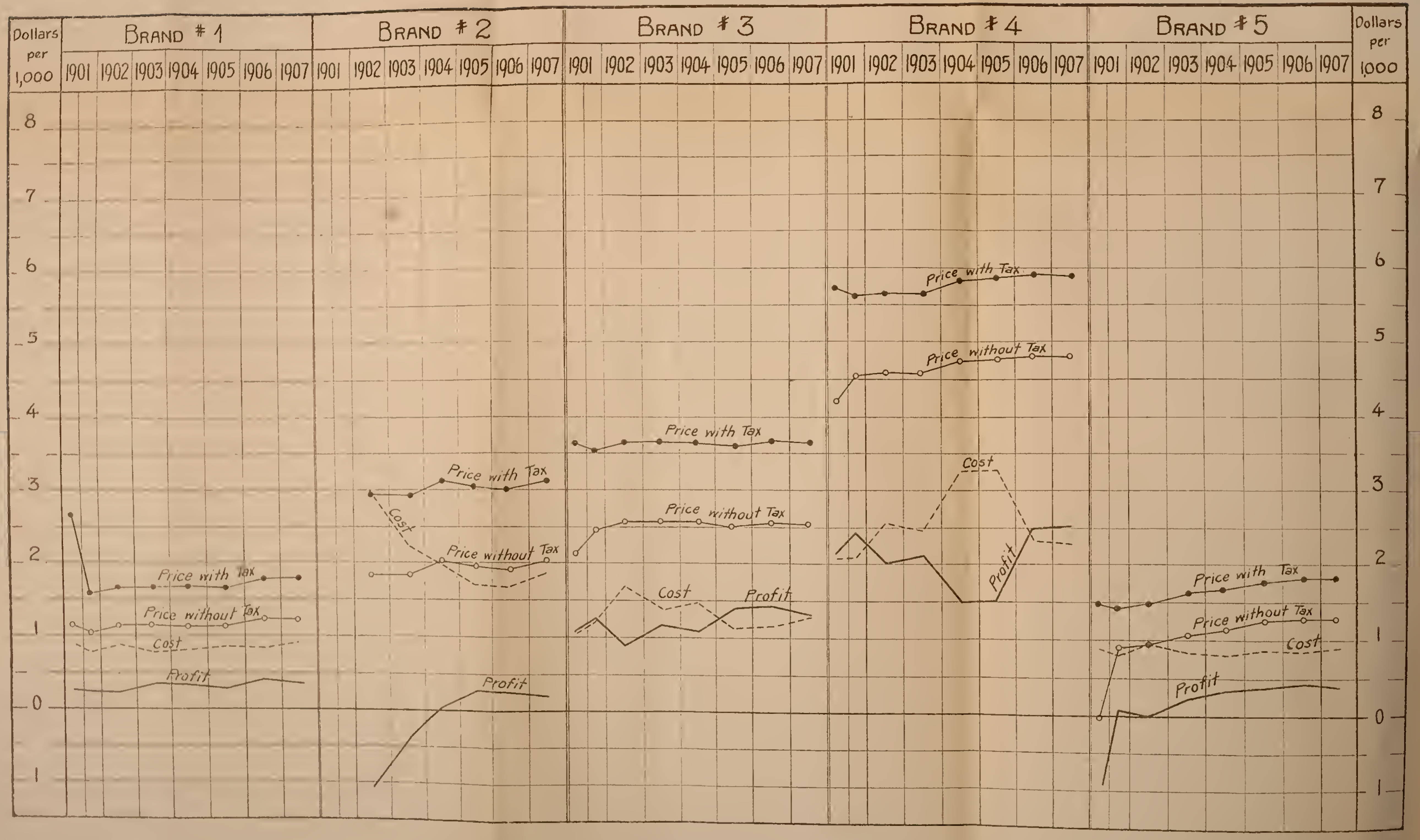


o 
duced from $\$ 1.50$ to $\$ 0.54$, however, the company began to sell considerable quantities of the cigarettes at a little less than the amount of the tax, $\$ 1.48$ per thousand, so that its actual net price was 2 cents less than zero. The purpose was evidently to build up the demand for these cigarettes in order to take advantage of it when the tax went down and thereby to forestall competition. When the tax was reduced, there was practically no change in the price charged to jobbers, so that the net price, less tax, to the company increased from 2 cents less than zero to $\$ 0.90$ in the second half of 1901 . Since that time the price has been further raised until in 1907 it was $\$ 1.28$ per thousand. The costs on brands Nos. 1 and 5 have not varied greatly during the entire period, so that the profits have changed substantially parallel to the changes in price. This means that there has been little change in the profit on brand 1 as compared with brand 5, although the actual increase has been about 40 per cent. On brand 5 , however, there is now a considerable profit as against the loss of nearly $\$ 1$ per thousand during the first half of 1901, on account of the policy above mentioned. This brand has markedly increased in profit even since 1903.

Brands 2 and 3 represent the 10 -for-5-cent class. Brand 2 was first started in 1902, and the price during the more recent years has been somewhat higher than during 1902 and 1903. The high costs of 1902 were chiefly in advertising and were the natural result of the introduction of a new brand, and the decline in cost is the natural result of the increase in the output and the reduced necessity of advertising. The leaf costs for this brand have gone up somewhat, so that the reduction in the total cost is entirely attributable to the reduction in advertising and selling expenses. The brand now commands a moderate profit, as compared with a loss during the earlier years, when it was being introduced.

Brand 3 has been on the market for many years. It will be seen that there was very little reduction in the price. at the time the tax was reduced from $\$ 1.50$ to $\$ 1.08$ per thousand, in 1901 , and that the price was restored again in 1902 and has since remained practically unchanged, so that the net price, less tax, which is the real price received by the company, has increased by practically the full amount of the reduction in tax. The cost shows very considerable variations, but these are almost wholly due to changes in the expenditure for advertising. Large amounts were spent for this purpose immediately after the war taxes were reduced, apparently for the purpose of enabling the company to keep up the sales of the brand in the face of the increase in the net price, less tax. At present the advertising expenses are insignificant, and the fact that the total cost is higher than in 1901 is due to the higher price of leaf tobacco entering into the cigarettes. The variations in the profit on this brand correspond chiefly to the variations in advertising expenses. The profit has at all times been large and is materially higher for the last three years covered by the table than for the first four.

Brand 4 is one sold to the consumer at 10 for 10 cents. The price to the jobber has at all times been high and the profit high, but the profit has varied on account of changes in advertising expenses. There was a slight reduction in the price of this brand at the time 
when the tax was reduced, but it was again raised by a still greater amount in 1904 and has since remained practically unchanged, so that the net price, less tax, during the more recent years exceeds that during the first half of 1901 by more than the change of 42 cents in the tax. The fact that the costs at the present time are somewhat higher than in 1901 is wholly due to the increase in leaf prices. The cost, however, has not increased as much as the price, so that the profit during 1906 and 1907 was more than 30 cents per thousand higher than during the first half of 1901 . The decline in profits during 1904 and 1905 was due to unusual expenses incurred in advertising this brand at that time, which have since been wholly cut out.

PRICES OF CIGARETTES BEFORE AND AFTER THE SPANISH WAR PEDIOD.

Although it has been possible to present the true arerage price, cost, and profit for the entire cigarette output of the American Tobacco Company since 1895, the averages are, of course, as already explained, much affected by the variations of the different classes of cigarettes entering into the total. Precise bookkeeping figures showing the prices, costs, and profits of individual brands made by the American Tobacco Company have been presented, covering the period back to 1901, but such data are not arailable for the earlier years. In order to show, therefore, the effect of the increase of taxes during the Spanish war period upon the prices of individual brands of cigarettes it is necessary. to rely upon the less accurate evidence obtained from price lists, invoices, discount sheets, and the like. From such sources, however, approximately correct average prices can be obtained for the leading brands of cigarettes made by the American Tobacco Company since 1890 . The prices to jobbers are compiled and averaged in the same manner as those for plug and smoking tobacco, already described (see page 83 , above).

The following table shows the price to the consumer, the jobbers' net price, and the price, less tax, for 7 important brands of cigarettes. These brands have throughout the period covered by the table all been manufactured by the American Tobacco Company. Brand Nos. 1 to 5 sell to the consumer at 5 cents for 10 , and brands 6 and 7 at 5 cents for 20. These brands are all made from domesticleaf tobacco and do not include any of the Turkish brands. The American Tobacco Company itself does not now manufacture Turkish cigarettes, and it was not interested in that business through subsidiary companies until 1900 . Moreover, there were very few Turkish cigarettes sold prior to the Spanish war, and the great derelopment of the business. has been within the past few years.

87442-S. Doc. $78,61-1--11$ 
TABLE 85.-Cigarettes-Average net prices to consumers and jobbers on brands of cigarettes made by the American Tobacco Company.

[Compiled from price list, invoices, discount sheets, etc.]

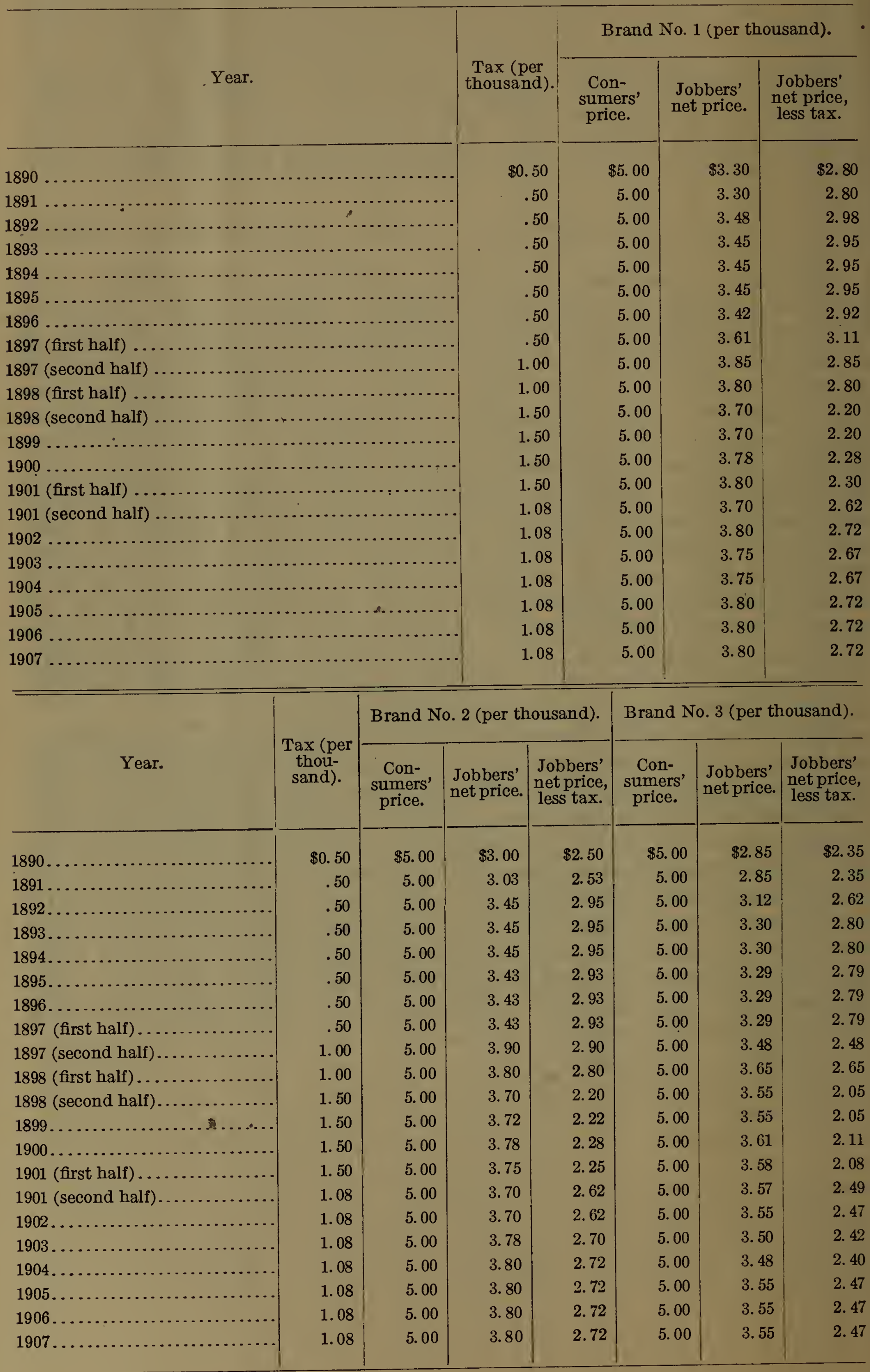


TABLE 85.-Cigarettes-Average net prices to consumers and jobbers on brands of cigarettes made by the American Tobacco Company-Continued.

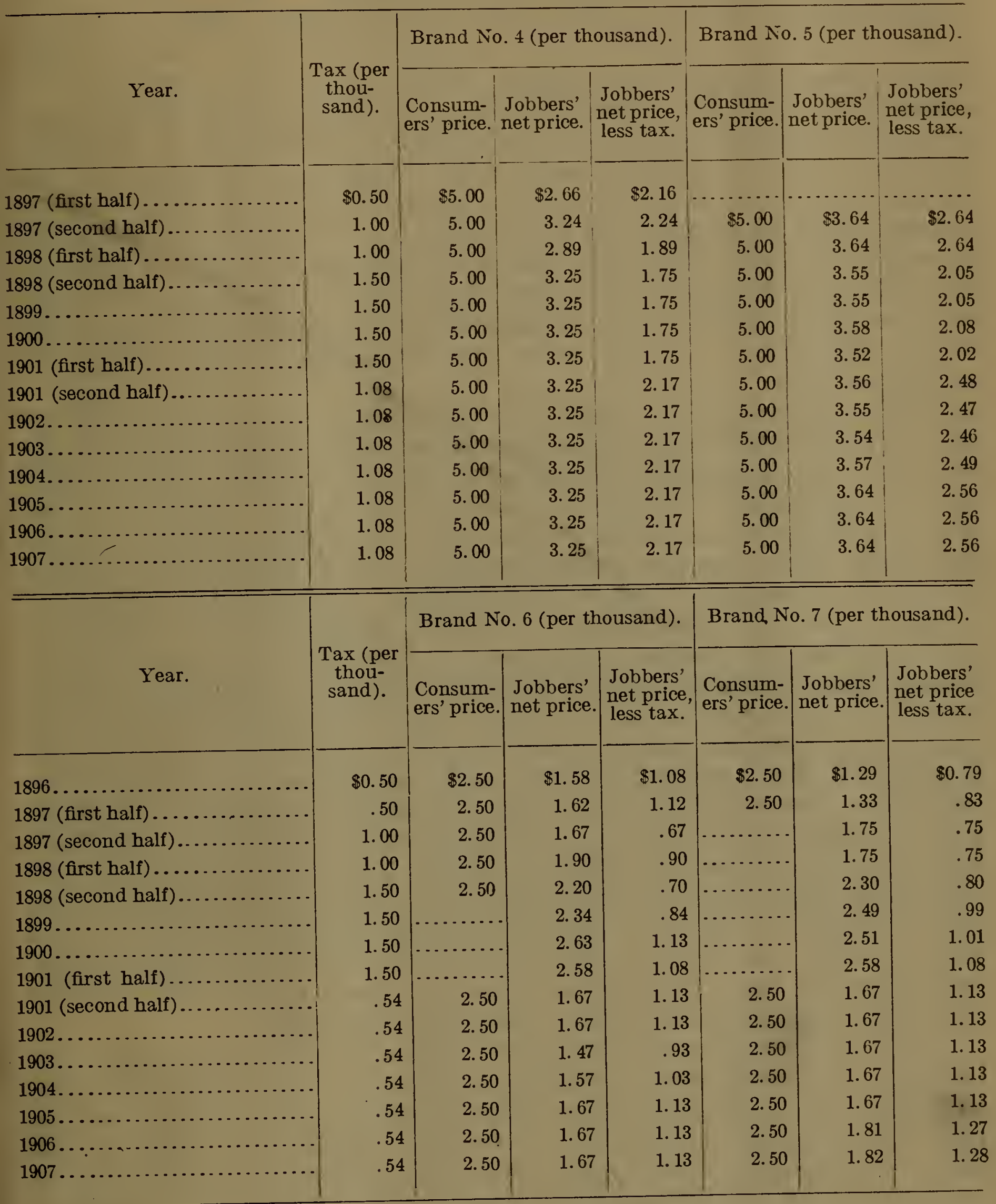

It will be seen from the above table that the price charged to the consumer for those brands of cigarettes which sell at the rate of 10 for 5 cents remained unchanged despite the changes in the taxes. Although the tax rose from $\$ 0.50$ in the earlier years to $\$ 1.50$ during the Spanish war, the consumer paid the same price as before. On the other hand, the cheap cigarettes retailing at the present time at 20 for 5 cents, or $\$ 2.50$ per thousand, either were not sold in appreciable numbers during the high-tax period or the prices were advanced. The prices to the consumer on brands 6 and 7 , which represent this class of cigarettes, are not shown during the war period, since it is uncertain to what extent retailers continued to sell in limited numbers at the low prices, incurring a loss in doing so, and to what extent they raised 
the price. With the tax at $\$ 1.50$ per thousand, manufacturers had necessarily advanced their prices, so that there could be no profit to the retailer in selling at $\$ 2.50$ per thousand.

Although the prices of those grades of cigarettes selling at retail at 10 for 5 cents have thus not been changed at any time, the consumer has at times been given premiums which practically amounted to a reduction in the price. Coupons have at different times been packed with the cigarettes, which were redeemable occasionally in cash, but more often in a premium of some sort. This was especially the case during the years 1901 to 1904 , immediately after the tax had been reduced from $\$ 1.50$ to $\$ 1.08$ per thousand. The expenditures of the American Tobacco Company for such premium systems or schemes are not treated by it as a reduction in price, but as an advertising expense, and, in fact, such arrangements are fundamentally advertising, although in a certain sense they do change the price which the consumer pays.

To some extent the American Tobacco Company made the jobbers and retail dealers who handled cigarettes share in the burden of the increased tax during the Spanish-war period, but the price charged by the company to jobbers was not increased by it as much as the tax was advanced, so that the company bore part of the increased tax itself. This was the natural result of the peculiarly fixed character of the consumers' prices of cigarettes, owing to the custom of selling a package containing a definite number for a convenient coin- 5 cents or 10 cents, respectively. It is much less practicable to change the consumers' price of cigarettes than the consumers' price of plug and smoking tobacco. The price to jobbers for most of the brands selling at 5 cents for 10 was increased somewhat by the cutting out of discounts. $^{a}$ On brands Nos. 1,2 , and 3 the increase in the net price to jobbers was from 25 to 35 cents per thousand, as against an increase of $\$ 1$ per'thousand in the tax. On brand No. 4 the price was increased from $\$ 2.66$ per thousand in the first half of 1897 to $\$ 3.25$ per thousand during the war period, or by about 60 cents per thousand. It may be noted that brand No. 5 , for which prices are not available back of July 1, 1897, was sold at a somewhat lower price during 1898 to 1901 , under the tax rate of $\$ 1.50$ per thousand, than during 1897 and the first half of 1898 , when the tax was $\$ 1$ per thousand.

As to the cheap brands selling at retail at 5 cents for 20, the Combination was forced by the marked increase in taxes to raise the price to jobbers to a point nearly if not quite equal to the former consumers' price of $\$ 2.50$ per thousand. As already stated, the sales of this class of cigarettes were largely cut out, as there was no profit to anybody at the established price, though some of them were doubtless sold to consumers at an advanced price.

It has already been pointed out in presenting the actual bookkeeping figures of the average prices of leading brands since 1901 that there was in general no reduction in the price of cigarettes other than those of the 20 -for-5-cents class at the time the internal-revenue tax was reduced from $\$ 1.50$ to $\$ 1.08$ per thousand, on July 1, 1901 . Such a reduction was, of coursè, scarcely to be expected, in view of the fact

$a$ It may be noted that the invoice price of those brands of cigarettes selling at retail at 5 cents for 10 has been unchanged throughout the entire period, usually $\$ 3.80$ or $\$ 3.60$ per thousand, and the variations in the net price to the jobber have been made by variations in the discounts. 
that the price had been increased comparatively so little when the tax was advanced. Although the prices of most of the brands during the recent years have been somewhat higher than during the years before the war, the difference is not as great as the difference in the tax, the present rate being $\$ 1.08$, as compared with $\$ 0.50$ before the war.

In considering this evidence regarding the effect of the changes in taxation upon the price of cigarettes sold by the American Tobacco Company, it should be remembered that during the years preceding the Spanish war the American Tobacco Company had quite as great a control of the cigarette business as it has at the present time; in fact, although the company has as large a proportion of the output of cigarettes made from domestic leaf at the present time as before the war, if not, indeed, a larger proportion, its proportion of the total business, including Turkish cigarettes, is considerably smaller than it was before the Spanish war.

With reference to the prices of Turkish cigarettes, which are made in large numbers by subsidiary companies of the American Tobacco Company, it may be said that there has been little change in the price to consumers or to jobbers on these brands since they were introduced. These brands are, of course, nearly all high-priced brands, which, although introduced before the Spanish war, were then of small output, and moreover were not affected to the same relative extent as the lower priced domestic product by any changes in the rate of taxation. It is presumable that not only the Tobacco Combination, but other manufacturers, have been more anxious to push the sale of Turkish cigarettes, which command relatively high prices, because the tax on cigarettes at present is so much higher than before the Spanish war, and because the same rate of taxation is applied on all cigarettes (except the very cheap cigarettes selling at retail at 20 for 5 cents), regardless of their value. It has already been made clear that more than half in value of the cigarette business controlled by the Tobacco Combination now consists of Turkish cigarettes, and that the aggregate profits of the cigarette business of the Combination are now rapidly increasing by reason of the development of this branch of the business. 


\section{LITTLE-CIGAR BUSINESS OF THE COMBINATION.}

The term "little cigars" was first officially adopted by the Bureau of Internal Revenue about 1898. Most little cigars are similar to cigarettes in shape, being wrapped, however, with tobacco instead of paper. Little cigars, moreover, also include some which have a shape similar to that of a cigar, although they are very much smaller than the ordinary cigar. Little cigars were taxed at the same rate as cigarettes until 1898, when the tax on little cigars was left unchanged at \$1 per thousand, and that on cigarettes raised to $\$ 1.50$ per thousand. At the present time the tax on little cigars is $\$ 0.54$ per thousand, the same rate which is applied to the cheap grade of cigarettes selling for $\$ 2$ and less per thousand at wholesale, while the rate on the cigarettes selling at more than $\$ 2$ per thousand is $\$ 1.08$ per thousand.

The little-cigar business of the country ranks next to the cigarette business in importance, and exceeds in importance the fine-cut tobacco business. There are no data available by which the value of the little cigars produced in the country as a whole could be compared with the value of other tobacco products. But an approximate idea of the relative importance of the little-cigar business may be gained from the value of those sold by the Tobacco Combination itself. In 1907 the value of the little cigars sold by the American Tobacco Companywhich manufactures nearly the entire output of this product controlled by the Combination-was $\$ 3,365,097.81$ (exclusive of tax), equal to about one-tenth of the value of the plug tobacco manufactured by the American Tobacco Company (including the Lorillard company), about one-sixth of the value of the smoking tobacco, and a little over half the value of the cigarettes, and about double the value of the fine-cut tobacco made by that company.

On account of lack of information regarding the total number of little cigars manufactured in the United States prior to 1898-this product not being then distinguished from cigarettes-it is impossible to state the proportion then controlled by the American Tobacco Company. In 1898 that company produced 48.7 per cent of the national output of little cigars. ${ }^{a}$ The total output of little cigars has very rapidly increased since 1898 , being $456,826,384$ in that year and 1,074,083,976 in 1907. The Combination's output, however, has increased much more rapidly, less as the result of the buying up of independent concerns than by the growth of its earlier acquired brands, so that it produced in 1907, 975,692,600 little cigars, or 90.8 per cent of the total output.

$a$ There is no doubt that prior to that time its proportion was less, and before 1895 the company produced practically no little cigars. 
Practically the entire output of little cigars which the Combination controls is manufactured in the plants directly owned by the American Tobacco Company, and since, as already stated, the Combination has controlled more than four-fifths of the business for several years the results of the little-cigar business of the American Tobacco Company in recent years represents not only practically the results of the entire business of the Combination in that product, but also represents the results of the greater part of the industry as a whole.

GENERAL RESULTS OF THE LITTLE-CIGAR BUSINESS OF THE AMERICAN TOBACCO COMPANY.

Table 86 shows the number of little cigars sold by the American Tobacco Company in each year since 1895, the net value less tax, and the profit.

TABLE 86.-Little cigars-American Tobacco Company: Quantity of sales, net ralue of sales, and profits (domestic business).

\begin{tabular}{|c|c|c|c|c|}
\hline & Year. & $\begin{array}{l}\text { Sales } \\
\text { (thou- } \\
\text { sands). }\end{array}$ & $\begin{array}{l}\text { Net value (less } \\
\operatorname{tax}) .\end{array}$ & Profits. \\
\hline 1895. & & 121,105 & $\$ 557,300.99$ & $\$ 52,620.31$ \\
\hline 1896. & & 148,409 & $658,045.51$ & $60,646.77$ \\
\hline 1897 & & 186,575 & $738,314.59$ & $125,140.44$ \\
\hline 1898. & & 224,641 & $825,600.60$ & $96,503.90$ \\
\hline 1899 & & 341,115 & $1,115,889.50$ & $22,508.74$ \\
\hline 1900 & & 410,490 & $1,309,955.69$ & $132,373.51$ \\
\hline 1901. & & 545,233 & $1,818,733.72$ & $340,769.20$ \\
\hline 1902 & & 533,463 & $2,332,513.62$ & $105,639.59$ \\
\hline 1903 & & 490,372 & $2,120,956.97$ & $190,056.58$ \\
\hline 1904 & & 586,137 & $2,290,623.40$ & $424,204.27$ \\
\hline 1905 & & 655,305 & $2,353,331.32$ & $600,044.86$ \\
\hline 1906 & & 788,424 & $2,835,015.02$ & $541,198.44$ \\
\hline 1907. & & 935,217 & $3,365,097.81$ & $52 \bar{\tau}, 869.53$ \\
\hline
\end{tabular}

It will be seen from this table that the little-cigar business of the Combination is rapidly increasing. This increase represents in part the general growth of the consumption of little cigars and in part the increased proportion of the output controlled by the American Tobacco Company. In 1895 the company sold 121,105,000 little cigars, while by 1907 the sales had increased to $935,217,000$, nearly eight times as many as in 1895 . It should be noted that there is no such break in the continuity of the figures for little cigars as in the case of plug and smoking tobacco. Whereas in these two latter branches of the business the year 1899 marks the formation of a new combination, the Continental Tobacco Company, the Continental did not add to the little-cigar business of the Combination. The increase in the little-cigar business of the American Tobacco Company, however, during the period from 1897 to 1901 , while to a limited extent due to the acquisition of formerly independent concerns, was primarily due to the rapid growth of its own brands.

Owing to the fact that there have been very considerable changes in the average net value per thousand of the little cigars manufactured by the American Tobacco Company, the changes in the total 
net value of the output do not correspond altogether to the changes in the quantity of sales. The total value less tax increased from $\$ 557,300.99$ in 1895 to $\$ 3,365,097.81$ in 1907 .

The profits of the company on little cigars have been decidedly variable. On the whole there has naturally been a very marked increase in the aggregate profit on account of the great increase in the output, but the fluctuations from year to year have been marked. Starting at $\$ 52,620.31$ in 1895 , the profit increased to $\$ 125,140.44$ in 1897. Despite the approximate doubling of the output in 1899 as compared with 1897 the profits fell to $\$ 22,508.74$. By 1901, however, the profits had increased many fold, amounting to $\$ 340,769.20$. They again fell off very greatly in 1902, after which they increased remarkably until 1905 , when the maximum of $\$ 600,044.86$ was reached. Despite the increase in the output since 1905 the profits have declined somewhat.

Table 87 and the accompanying diagram show the average net price, including tax and excluding tax, the costs of manufacture, and the profits per thousand for the little-cigar business of the American Tobacco Company.

TaBLE 87.-Little cigars-American Tobacco Company: Prices, costs, and profits (domestic business).

\begin{tabular}{|c|c|c|c|c|c|c|c|}
\hline \multirow[b]{2}{*}{ Year. } & \multicolumn{3}{|c|}{ Net price (per thousand). } & \multicolumn{3}{|c|}{ Cost (per thousand). } & \multirow{2}{*}{$\begin{array}{c}\text { Profit } \\
\text { (per thou } \\
\text { sand). }\end{array}$} \\
\hline & $\begin{array}{l}\text { Includ- } \\
\text { ing tax. }\end{array}$ & Tax. & $\begin{array}{l}\text { Exclud- } \\
\text { ing tax. }\end{array}$ & $\begin{array}{l}\text { Manufac- } \\
\text { ture and } \\
\text { freight. }\end{array}$ & $\begin{array}{c}\text { Selling } \\
\text { and ad- } \\
\text { vertising. }\end{array}$ & Total. & \\
\hline 1895. & $\$ 5.10$ & $\$ 0.50$ & $\$ 4.60$ & $\$ 3.31$ & $\$ 0.86$ & $\$ 4.17$ & $\$ 0.43$ \\
\hline 1896. & 4.93 & .50 & 4. 43 & 2.97 & 1.05 & 4.02 & .41 \\
\hline $1897 \ldots \ldots$ & 4. 68 & .72 & 3.96 & 2.42 & .87 & 3.29 & .68 \\
\hline $1898 \ldots$ & 4. 68 . & 1.00 & 3. 68 & 2.60 & .65 & 3.25 & .43 \\
\hline $1899 \ldots$ & 4.27 & 1.00 & 3.27 & 2.56 & .64 & 3.20 & .08 \\
\hline $1900 \ldots$. & 4. 19 & 1.00 & 3.19 & 2.42 & .45 & 2.87 & .32 \\
\hline $1901 \ldots$. & 4.10 & .76 & 3.34 & 2.31 & .40 & 2.71 & .63 \\
\hline $1902 \ldots$ & 4.91 & .54 & 4.37 & 3.16 & 1.01 & 4.17 & .20 \\
\hline $1903 \ldots . . .$. & 4.87 & .54 & 4.33 & 3.29 & .65 & 3.94 & .39 \\
\hline $1904 \ldots \ldots \ldots$ & 4. 45 & .54 & 3.91 & 2.74 & .45 & 3.19 & .72 \\
\hline $1905 \ldots$ & 4.13 & .54 & 3.59 & 2.39 & .28 & 2.67 & .92 \\
\hline 1906. & 4.14 & .54 & 3. 60 & 2.65 & .26 & 2.91 & .69 \\
\hline $1907 \ldots \ldots \ldots$ & 4.14 & .54 & 3. 60 & 2.71 & .33 & 3.04 & .56 \\
\hline
\end{tabular}

The change in the average prices of little cigars are largely due to changes in the proportions of the several grades and brands, and do not at all accurately reflect the changes in the actual prices for specific brands. Part of the changes in average prices are, of course, due to the changes in the prices of individual brands.

It will be seen that, notwithstanding the advance in the internalrevenue tax from $\$ 0.50$ per thousand in 1895 to $\$ 1$ per thousand in 1898 , the average price of little cigars, including tax, fell $\$ 0.42$ per thousand, from $\$ 5.10$ to $\$ 4.68$, and there was a still further decrease in the price during 1899 and 1900 . Consequently there was a very great decrease during these years in the net price, less tax, which averaged $\$ 3.19$ in 1900 , as compared with $\$ 4.60$ in 1895 . On the other hand, when the tax was reduced again in 1901 the average price, including tax, at first rose very materially, being $\$ 4.91$ in 1902 , the first full year of the reduced rate, as compared with $\$ 4.19$ in 1900 . This 


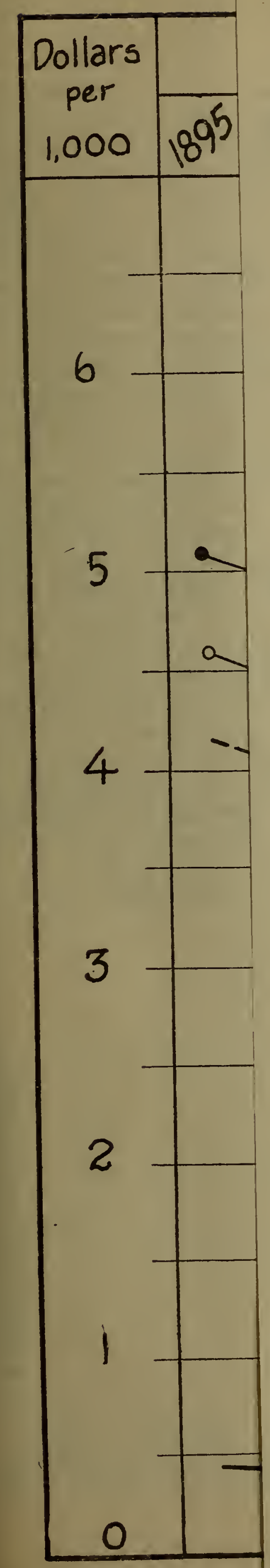



TITPLE CICARS.

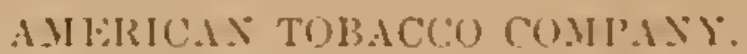

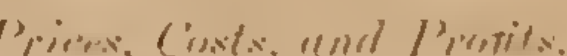

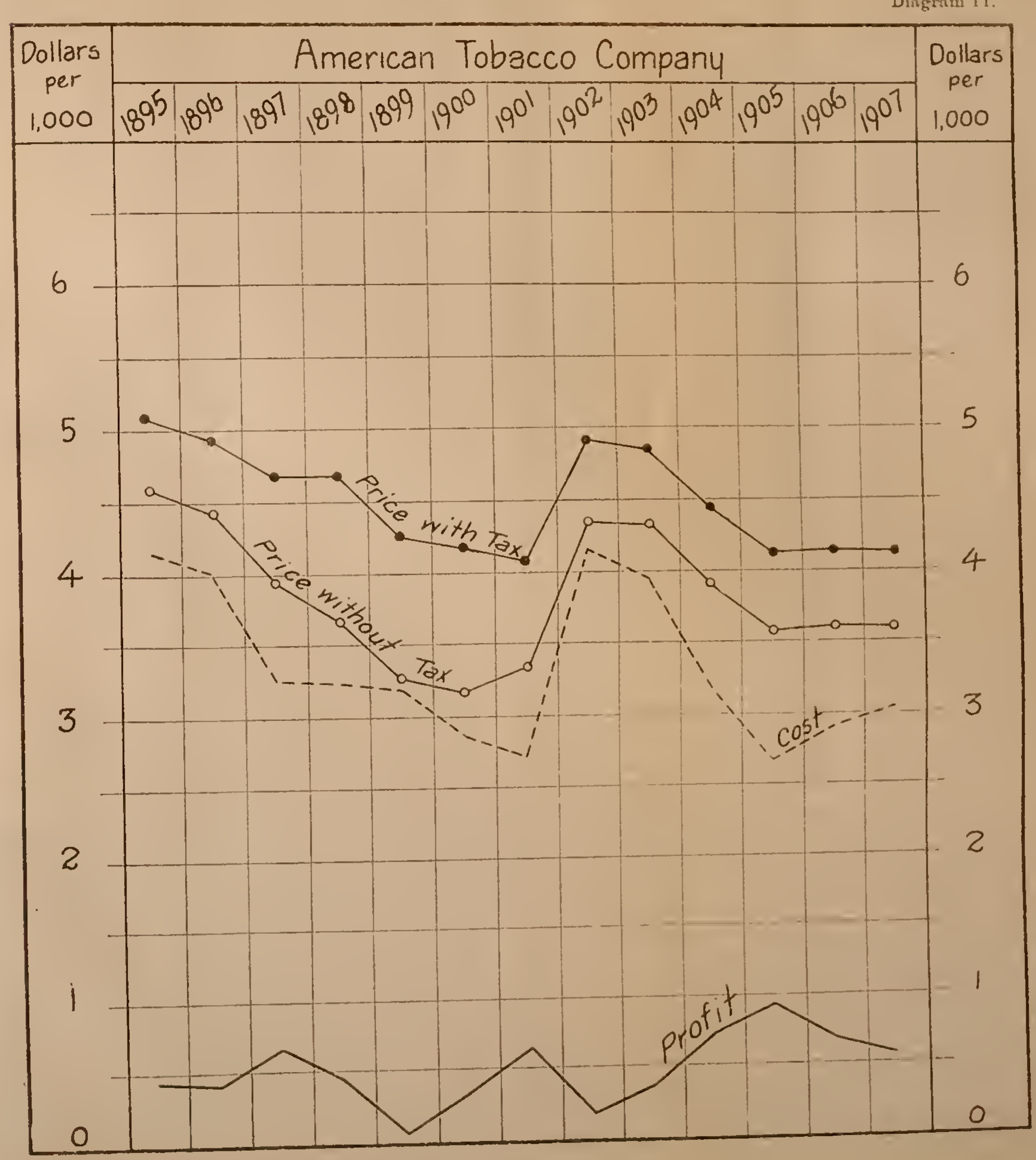



increase was not, however, due to an advance in the price of individual brands. The net price, less tax, therefore, rose from $\$ 3.19$ to $\$ 4.37$. From 1902 to 1905 there was a very marked reduction in the average price. The figures for individual brands show again that this was not due to a reduction in the price of any given brand, but rather to a larger proportion of lower-grade sales. The net price, less tax, fell from \$4.37 in 1902 to $\$ 3.59$ in 1905 and remained substantially unchanged in 1906 and 1907.

The costs of manufacture and sale show also marked variations, being again in part due to changes in the proportions of the different grades covered. Especially variable, however, have been the selling and advertising expenses, and these variations to a considerable extent represent changes in the activity of the Combination in pushing the little-cigar business.

The profit of the little-cigar business has been even more variable than the prices and costs. It has ranged from a minimum of 7 cents per thousand in 1899 to a maximum of 92 cents per thousand in 1905 . On the whole, the profits were higher during the period before the increase in taxation and during the period after the reduction in taxation than they were during the years 1899 to 1901 , when the taxes were on the war basis. Moreover, the profits for the years 1904 to 1907 háve averaged somewhat more per thousand than during the years 1895 to 1898 . The exceptionally low profit of 1899 was due to the reduction in the average price, while the exceptionally low profit of 1902 was due to unusually high selling expenses.

Table 88 shows the amount of tax, cost, and profit, respectively, entering into the net price of little cigars. For reasons already stated, it is scarcely practicable to compare these figures from one period to another, but the data for any given year are significant. It will be seen that for 1907 , of the net average price of $\$ 4.14$ per thousand, the tax represented $\$ 0.54$, cost $\$ 3.04$, and pronit $\$ 0.56$, the profit being, therefore, substantially equal to the tax.

TABLE 88.-Little cigars-American Tobacco Company: Amount of tax, cost, and profit entering into net selling price.

\begin{tabular}{|c|c|c|c|c|}
\hline \multirow{2}{*}{ Year. } & \multicolumn{3}{|c|}{$\begin{array}{l}\text { Elements entering into } \\
\text { price (per thousand). }\end{array}$} & \multirow{2}{*}{$\begin{array}{c}\text { Net } \\
\text { price } \\
\text { (per } \\
\text { thou- } \\
\text { sand). }\end{array}$} \\
\hline & Tax. & Cost. & Profit. & \\
\hline 1895 & $\$ 0.50$ & 34.17 & $\$ 0.43$ & $\$ 5.10$ \\
\hline 1896 & .50 & 4. 02 & .41 & 4.93 \\
\hline 1897 & .72 & 3. 29 & .67 & 4.68 \\
\hline 1898. & 1.00 & 3.25 & .43 & 4. 68 \\
\hline 1899. & 1.00 & 3.20 & .07 & 4.27 \\
\hline 1900. & 1.00 & 2.87 & .32 & 4. 19 \\
\hline 1901. & .76 & 2.71 & .63 & 4. 10 \\
\hline 1902 & .54 & 4. 17 & .20 & 4.91 \\
\hline 1903. & .54 & 3. 94 & .39 & 4.87 \\
\hline $\begin{array}{l}1904 \\
1905 .\end{array}$ & .54 & 3. 19 & .72 & 4. 45 \\
\hline $\begin{array}{l}1905 . . \\
1906 .\end{array}$ & .54 & $\begin{array}{l}2.67 \\
291\end{array}$ & $\begin{array}{r}.92 \\
.69\end{array}$ & $\begin{array}{l}4.13 \\
4.14\end{array}$ \\
\hline & $\begin{array}{l}.54 \\
.54\end{array}$ & $\begin{array}{l}2.91 \\
3.04\end{array}$ & .56 & $\begin{array}{l}\text { 7. } 14 \\
4.14\end{array}$ \\
\hline
\end{tabular}

Table 89 shows the average cost of little cigars, exclusive of tax, the average profit, and the per cent of profit on cost. As with the other tables, the data are scarcely comparable from one period to 
another, on account of the changes in the proportions of the different classes of little cigars included. It will be seen that for 1907 the profit represented 18.6 per cent on cost.

TABLE 89.-Little cigars-American Tobacco Company: Relation of profit to cost.

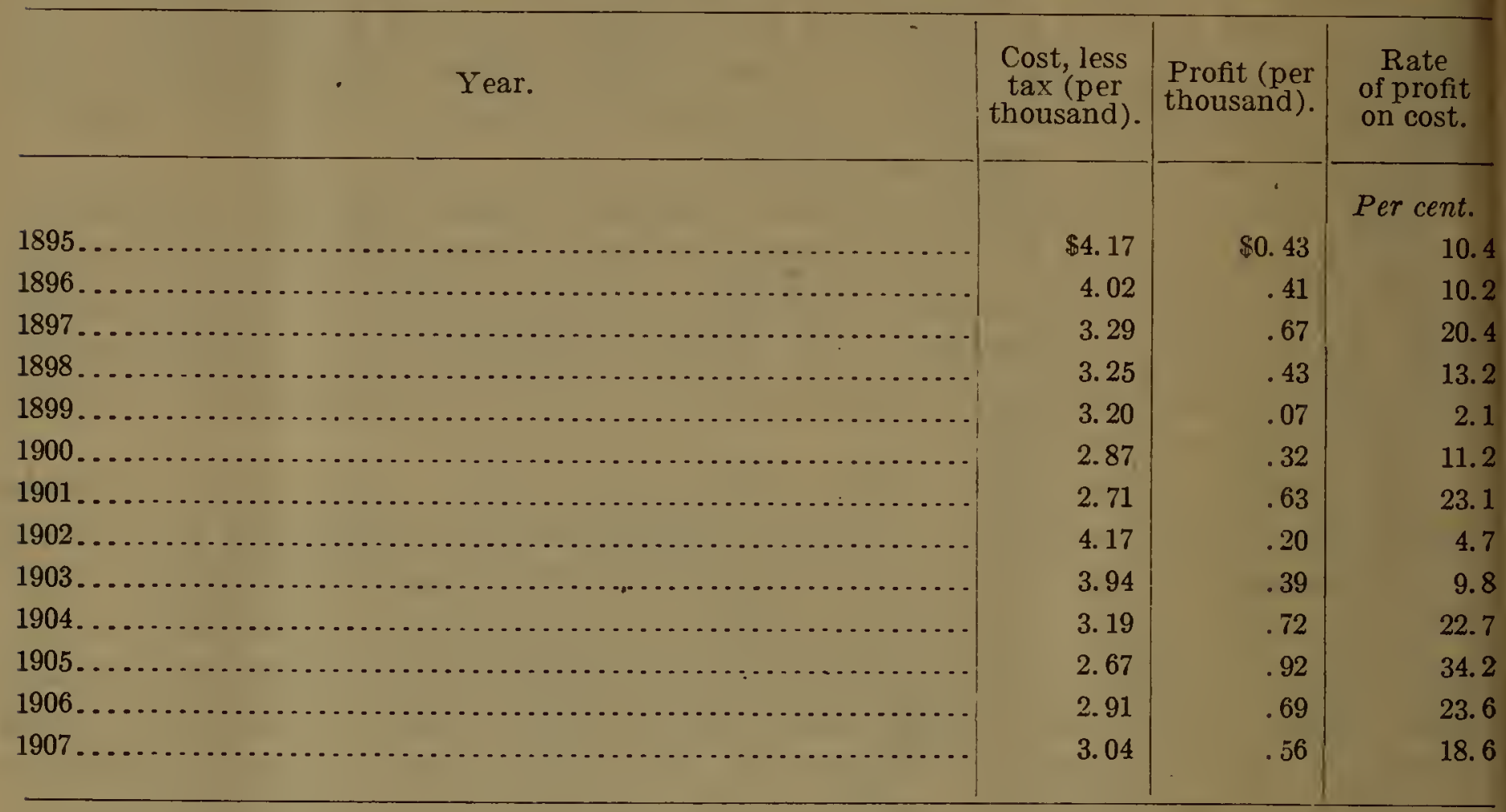

Table 90 shows the net selling price, less tax, of little cigars, and the percentage thereof represented by cost and profit, respectively. This table shows that in 1907, 84.3 per cent of the net selling price, less tax, was represented by cost and 15.7 per cent by profit.

TABLE 90.-Little cigars-American Tobacco Company: Division of net selling price (less tax) between cost and profit.

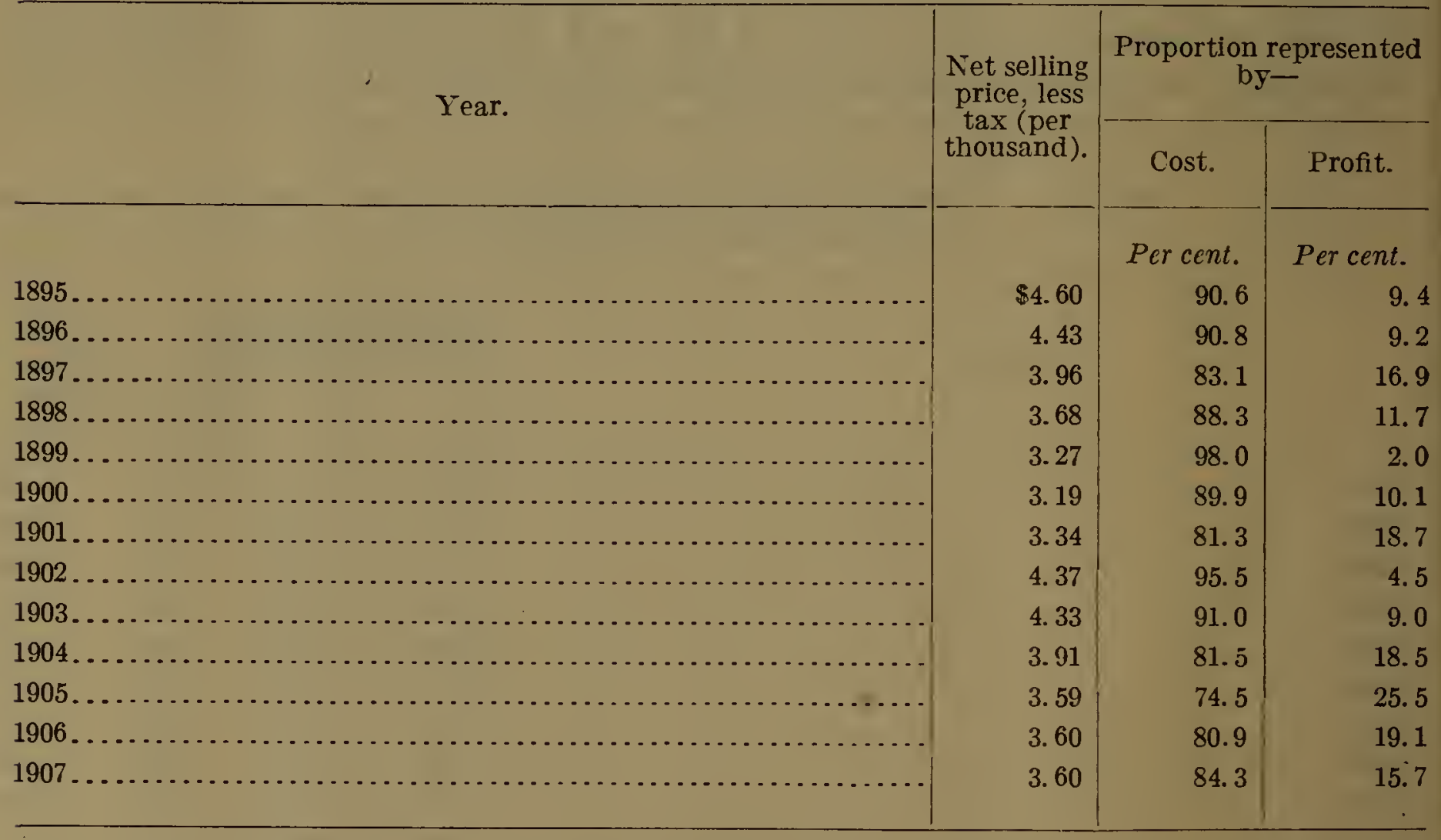

PRICES, COSTS, AND PROFITS OF INDIVIDUAL BRANDS OF LITTLE CIGARS MADE BY THE AMERICAN TOBACCO COMPANY.

For reasons already explained, the figures on the average prices, costs, and profits of the entire output of little cigars made by the American Tobacco Company do not furnish a satisfactory basis of comparison from year to year. A much clearer view of the price 
policy of the company is obtained by considering the figures for individual brands. Table 91 and the accompanying diagram show the prices, costs, and profits for five of the principal brands of little cigars made by the American Tobacco Company. These five, together, cover much the greater part of its output.

TABLE 91.-Little cigars-American Tobacco Company: Prices, costs, and profits for leading individual brands.

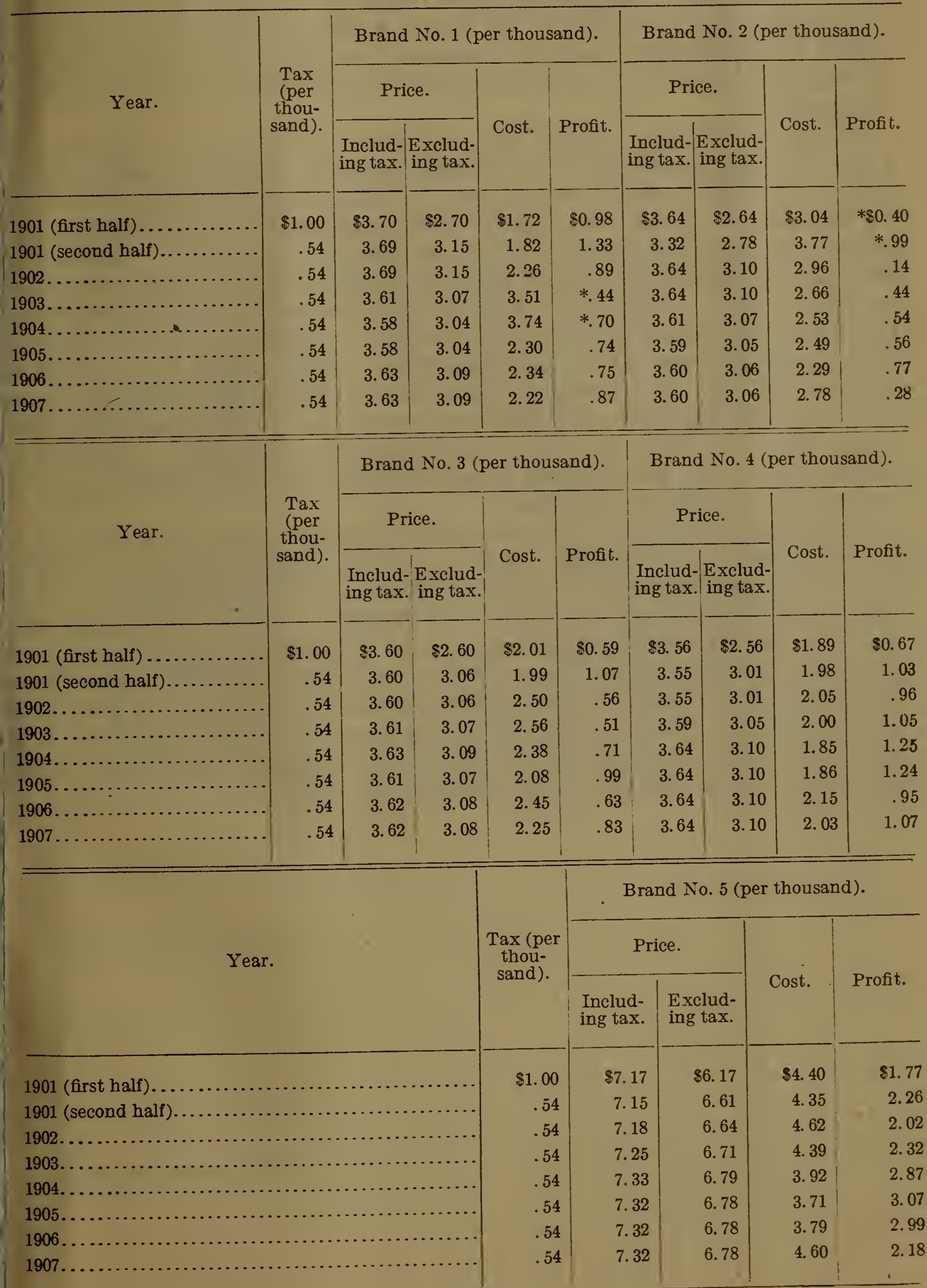

* Loss. 
Brands 1 to 4 in this table sell to the consumer at 10 for 5 cents, while brand 5 sells at 10 for 10 cents. It will be recalled that the tax on little cigars was reduced on July 1, 1901, from $\$ 1$ per thousand to $\$ 0.54$ per thousand, or by $\$ 0.46$ per thousand. For only one of the five brands (No. 2) was there any appreciable reduction in the price charged to jobbers at that time, and in the case of brand No. 2 the price was restored in 1902. The prices of all of the brands have been substantially unchanged since that time except that brand No. 5 has advanced somewhat. In other words, the net price, less tax, which is practically what the company receives for its product, has increased by at least the full amount of the reduction in the internalrevenue tax.

All of the brands except No. 4 show very marked variations in costs; but these variations are chiefly due to changes in advertising expenses. The costs of leaf tobacco entering into little cigars (except for brands No. 2 and No. 5) have been considerably higher during the later years covered by the table than during the earlier. Brand 1 is an extreme illustration of the marked changes in advertising expenses on little cigars. In the first half of 1901 the advertising expenses on this brand averaged $\$ 0.039$ per thousand, whereas in 1903 the advertising expense was $\$ 1.28$ per thousand. This brand had shown a tendency to fall off in output from 1901 to 1903 , but doubtless as a result of this unusual advertising expense the output had increased more than fourfold by 1907 as compared with 1903 . Again, for brand No. 2 the advertising expense fell from $\$ 0.78$ in the second half of 1901 to $\$ 0.001$ in 1906 .

These marked changes in advertising expenses largely account for the changes in the profits of the various brands. For all of the brands except brand No. 1 the profit was decidedly higher in 1907 than in the first half of 1901 . On brand 1, which is an important brand, notwithstanding the increase in the net price, less tax, the profit is somewhat lower from 1905 to 1907 than in 1901, the difference being due chiefly to the decided increase in the cost of leaf used in this brand. The sales of this brand have, however, increased very greatly, so that the aggregate profit derived from it in the more recent years is much in excess of that obtained in 1901. 


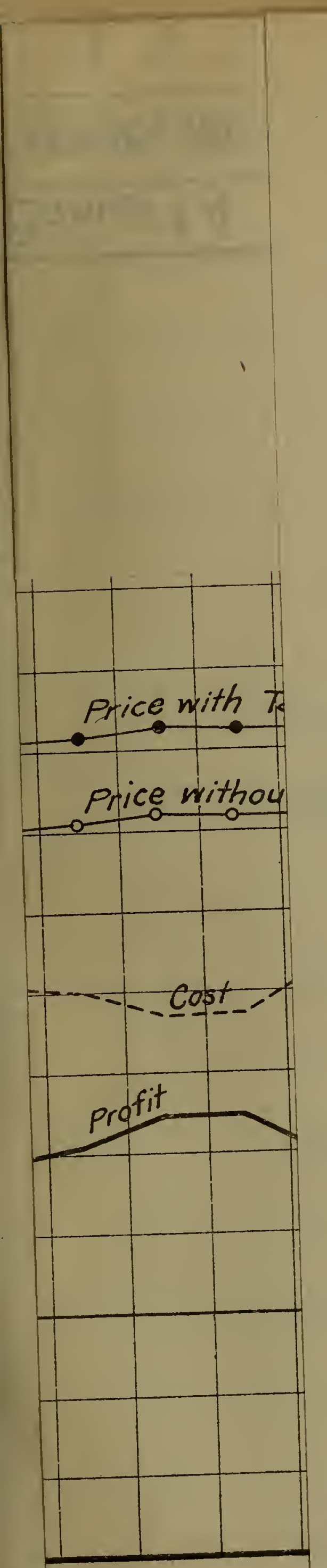





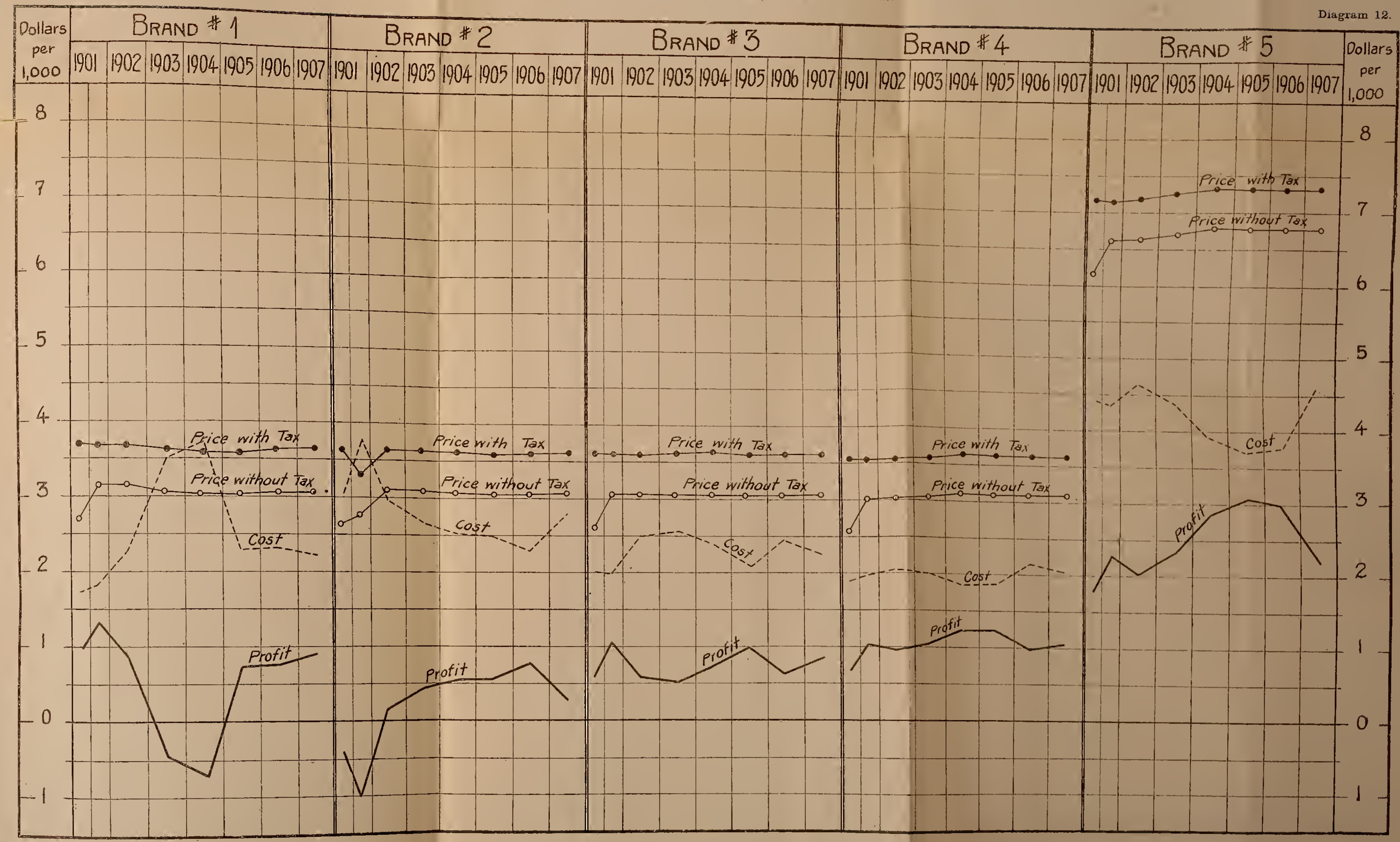





\section{SNUFF BUSINESS OF THE COMBINATION.}

Although the snuff business is not one of the most important branches of tobacco manufacture, the output of snuff has increased in recent years more rapidly than that of any other product of tobacco, and the relatively high profit per pound in the snuff business makes the profit on snuff a considerable and increasing fraction of the total profits of the Tobacco Combination-amounting to one-tenth of the total in 1907.

The increase in the output of snuff for the country as a whole ard the increasing proportion of that output controlled by the Combination are fully set forth in Part I of the Report of the Commissioner of Corporations on the Tobacco Industry, Chapter XXI. The facts may be briefly summarized as follows:

\begin{tabular}{|c|c|c|c|}
\hline \multirow[b]{2}{*}{ Year. } & \multirow{2}{*}{$\begin{array}{l}\text { Output of } \\
\text { United } \\
\text { States. }\end{array}$} & \multicolumn{2}{|c|}{ The Combination. } \\
\hline & & Output. & $\begin{array}{l}\text { Per cent } \\
\text { of total. }\end{array}$ \\
\hline 1891. & $\begin{array}{l}\text { Pounds. } \\
\text { - } 10,674,241\end{array}$ & $\begin{array}{l}\text { Pounds. } \\
\quad 383,162\end{array}$ & 3.6 \\
\hline 1898. & $13,607,631$ & 829,844 & 6.1 \\
\hline 1899. & $14,723,392$ & $4,770,472$ & 32.4 \\
\hline $1901 \ldots \ldots$ & $17,513,317$ & $14,037,863$ & 80.2 \\
\hline $1907 \ldots \ldots \ldots \ldots$ & $23,305,340$ & $22,307,105$ & 95.7 \\
\hline
\end{tabular}

The American Tobacco Company had a comparatively small snuff business during the period from 1891 to 1898 . In 1899 it increased its snuff business, and the affiliated Continental Tobacco Company and Lorillard Company also had a very considerable snuff business.

The American Snuff Company in 1900 took over this business of the American, Continental, and Lorillard companies, and also took in the G. W. Helme Company and the Atlantic Snuff Company; the output of the latter was nearly equal to that of the other four companies together. The year 1901 was the first full year of operation of the American Snuff Company, and already at that time it controlled 80.2 per cent of the total output of snuff in the United States. In part as the result of the acquisition of additional concerns which were formerly independent, the output of the American Snuff Company increased to no less than 95.7 per cent of the total in 1907.

It will be seen, therefore, that, particularly during the more recent years, a consideration of the prices of snuff must be principally a consideration of the business of the American Snuff Company. 
GENERAL RESULTS OF THE BUSINESS OF THE AMERICAN SNUFF COMPANY.

The following table shows the income of the American Snuff Company, including the Garrett and Weyman companies, for the years 1901 to $1907:^{a}$

\begin{tabular}{|c|c|c|c|}
\hline Year. & Profits. & Year. & Profits. \\
\hline 1900 (10 months). & $\$ 531,667.92$ & 1904. & $\$ 2,458,419.37$ \\
\hline $1901 \ldots \ldots \ldots$ & $1,066,605.31$ & $1905 .$. & $3,269,469.70$ \\
\hline $1902 \ldots$ & $1,739,616.84$ & $1906 .$. & $3,846,240.85$ \\
\hline $1903 \ldots \ldots \ldots$ & $2,177,827.75$ & $1907 .$. & $3,623,611.36$ \\
\hline
\end{tabular}

This table shows that during the year 1907 the true profits of the American Snuff Company were about three and one-half times as great as in 1901, the first full year of its operation.

Much the greater part of the income of the American Snuff Company is derived from its direct manufacturing profits. A small part of the profits, however, consist of dividends on stocks in other companies. The American Snuff Company holds stock in two or three small snuff companies which it operates independently and only the dividends of which appear in its income account. The only dividends received from these companies were $\$ 50,000$ in the year 1902 and the same amount in 1903 . During the years 1904 to 1907 some dividends were received from stock in the American Tobacco Company and the American Cigar Company. A small amount of profit was also obtained by the American Snuff Company from handling leaf tobacco for other concerns in the Tobacco Combination.

The following table separates the profits of the American Snuff Company (including Garrett \& Sons and Weyman \& Bro.) into those derived from the manufacturing business and those derived from other sources:

TABLE 92.-Profits of American Snuff Company, 1900-190\%.

\begin{tabular}{|c|c|c|c|}
\hline Year. & Total profits. & $\begin{array}{l}\text { Profits from } \\
\text { miscellaneous } \\
\text { sources. }\end{array}$ & $\begin{array}{l}\text { Profits from } \\
\text { own snuff } \\
\text { business. }\end{array}$ \\
\hline 1900 (10 months)........ & $\$ 531,667.92$ & & $\$ 531,667.92$ \\
\hline $1901 \ldots \ldots \ldots \ldots \ldots \ldots \ldots$ & $1,066,605.31$ & ….......... & $1,066,605.31$ \\
\hline $1902 \ldots$ & $1,739,616.84$ & $\$ 50,000.00$ & $1,689,616.84$ \\
\hline $1903 \ldots$ & $2,177,827.75$ & $50,000.00$ & $2,127,827.75$ \\
\hline $1904 \ldots$ & $2,458,419.37$ & $* 118,008.63$ & $2,576,428.00$ \\
\hline $1905 \ldots$ & $3,269,469.70$ & $150,219.40$ & $3,119,250.30$ \\
\hline $1906 \ldots$ & $3,846,240.85$ & $51,461.77$ & $3,794,779.08$ \\
\hline $1907 \ldots \ldots \ldots \ldots \ldots$ & $3,623,611.36$ & $79,602.20$ & $3,544,009.16$ \\
\hline
\end{tabular}

$a$ With the exception of dividends amounting to $\$ 50,000$ in 1902 and also in 1903 , the above table does not cover the earnings of several small subsidiary corporations of the American Snuff Company, which are now making about 5 per cent of the total output of the snuff combination.

* Loss. 
This table shows that the profits of the American Snuff Company from its manufacturing business increased from $\$ 1,066,605.31$ in 1901 , its first full year of operation, to $\$ 3,544,009.16$ in 1907 .

As in the case of the American Tobacco Company and some of the other companies in the Combination, a comparison between the profits and the capitalization of the American Snuff Company, or the assets carried on its books, could be of little value except after a thorough examination of the basis of capitalization and of the item of good will in the assets. In the balance sheets of the American Snuff Company the item "patents, trade-marks, and good will" has at all times far exceeded the net tangible assets. Of the total net assets in the manufacturing business in 1900, as carried on the books, 81 per cent consisted of good will. In 1907, principally owing to the increase in the net tangible assets, the proportion represented by good will was reduced to 71 per cent. There is in the snuff busines, as in other branches of tobacco manufacture, a large legitimate value of good will, due to the demand of consumers for established brands. There can be no question, however, that a part of the good-will item as carried on the books of the American Snuff Company represents merely the balancing of overcapitalization. The assets side of the balance sheet must, of course, be made equal to the liability side, including the full amount of capitalization, however much that amount may be "watered."

While it would not be just to judge the profits of the American Snuff Company by the relation which they bear to the tangible assets alone, nevertheless the change in the rate of profit on tangible assets from year to year is significant. Although the tangible assets have very considerably increased since the organization of the American Snuff Company, the profits have increased so much more that the rate of profit on tangible assets in the years 1905 to 1907 averaged about four times as high as in 1900, and considerably more than twice as high as in 1901, the first full year of operation.

Table 93 shows the quantity of snuff sold by the American Snuff Company from year to year, the net value thereof, exclusive of internal-revenue tax, and the profit thereon.

TABLE 93.-American Snuff Company-Quantity of sales, net value of sales, and net profits.

\begin{tabular}{|c|c|c|c|}
\hline Year. & Sales. & $\begin{array}{l}\text { Net value of } \\
\text { sales, less tax. }\end{array}$ & Profits. \\
\hline 1900 (10 months). & $\begin{array}{l}\text { Pounds. } \\
8,558,762\end{array}$ & $\$ 2,501,726.13$ & $\$ 531,667.92$ \\
\hline $1901 \ldots \ldots \ldots \ldots$ & $13,343,506$ & $3,961,686.93$ & $1,066,605.31$ \\
\hline 1902 & $15,465,353$ & $4,933,447.61$ & $1,689,616.84$ \\
\hline 1903. & $17,230,982$ & $5,705,178.14$ & $2,127,827.75$ \\
\hline 1904 & $16,762,422$ & $5,860,142.73$ & $2,576,428.00$ \\
\hline $1905 .$. & $19,246,717$ & $7,005,804.99$ & $3,119,250.30$ \\
\hline 1906. & $21,539,275$ & $7,954,454.26$ & $3,794,779.08$ \\
\hline 1907 & $21,345,113$ & $7,925,440.46$ & $3,544,009.16$ \\
\hline
\end{tabular}

It will be seen that the sales of the American Snuff Company have increased very greatly. From $13,343,506$ pounds, worth $\$ 3,961,686.93$ in 1901 , the first full year of operation, they increased to $21,539,275$ 
pounds, worth $\$ 7,954,454.26$ in 1906 , the maximum year. The sales in 1907 were slightly less. From 1901 to 1906 the quantity of sales increased by about two-thirds, while the net value, less tax, doubled.

The increase in the aggregate profits of the American Snuff Company and in the rate of profit on its investment has been partly due to a great increase in its output, but still more to an increase in the average price obtained, this increase in the average price in turn being in part due to a relative increase in the sales of the higherpriced brands, but more largely to an advance in the price, less tax, of individual brands.

The following table and accompanying diagram show, for the years 1900 to 1907, the average price received by the American Snuff Company for its entire product (rebates and discounts deducted), the amount of fax paid, the net price, less tax, the various elements of cost, and the profit per pound.

Table 94.-American Snuff Company-Prices, costs, and profits on entire business.

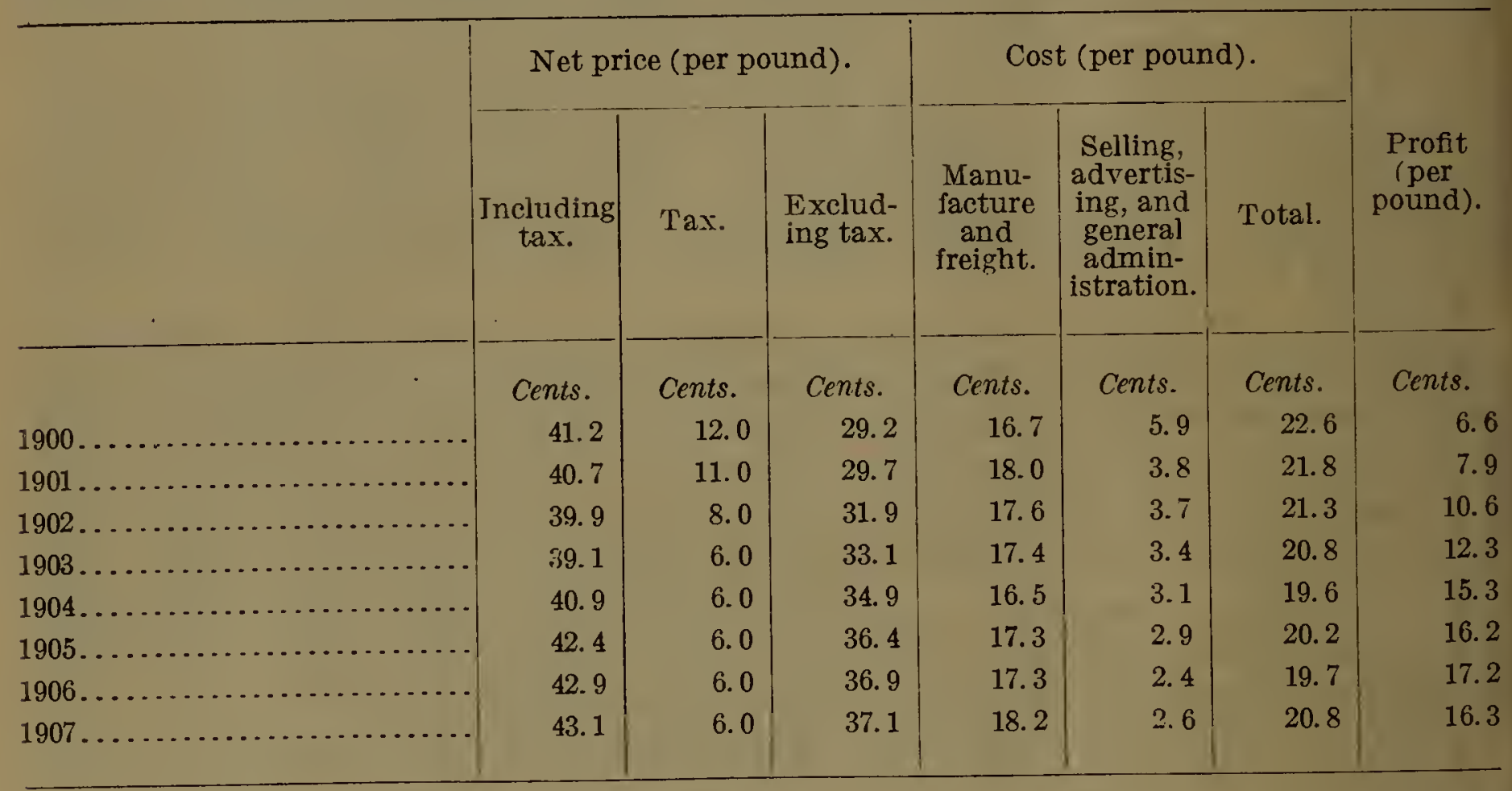

The average price received by the American Snuff Company, without deducting the tax, fell slightly from 1900 to 1903 , but, as will be seen, fell much less than the decrease in the tax. The average net price (with tax) in 1900 was 41.2 cents, and in $1903,39.1$ cents, the tax having in the mean time been reduced 6 cents. Since 1903 the average net price, including tax, has gradually increased, until in 1907 it was 43.1 cents, or nearly 2 cents higher than in 1900 , notwithstanding a decrease of 6 cents per pound in the tax paid out of the price to the Government. The net price less tax has shown a steady and marked increase in every year, being 29.2 cents in 1900 and 37.1 cents in 1907 , an advance of about 8 cents per pound, or 27 per cent.

On the other hand, the total cost of manufacture and distribution has not increased. It fell gradually from 22.6 cents in 1900 to 19.6 cents in 1904. Thereafter it fluctuated somewhat, and in 1907 was 20.8 cents, or about $1 \frac{1}{2}$ cents less than in 1900 . The costs in 1900 were doubtless exceptionally high, because the Combination was new and not yet in full working order. The large expense assigned to general administration, however, represented, in part, expenses now charged directly as a cost of manufacture. 
AMERICAN SNUFF COMPANY.

Prices, Costs, and Profits.

Diagram 13.

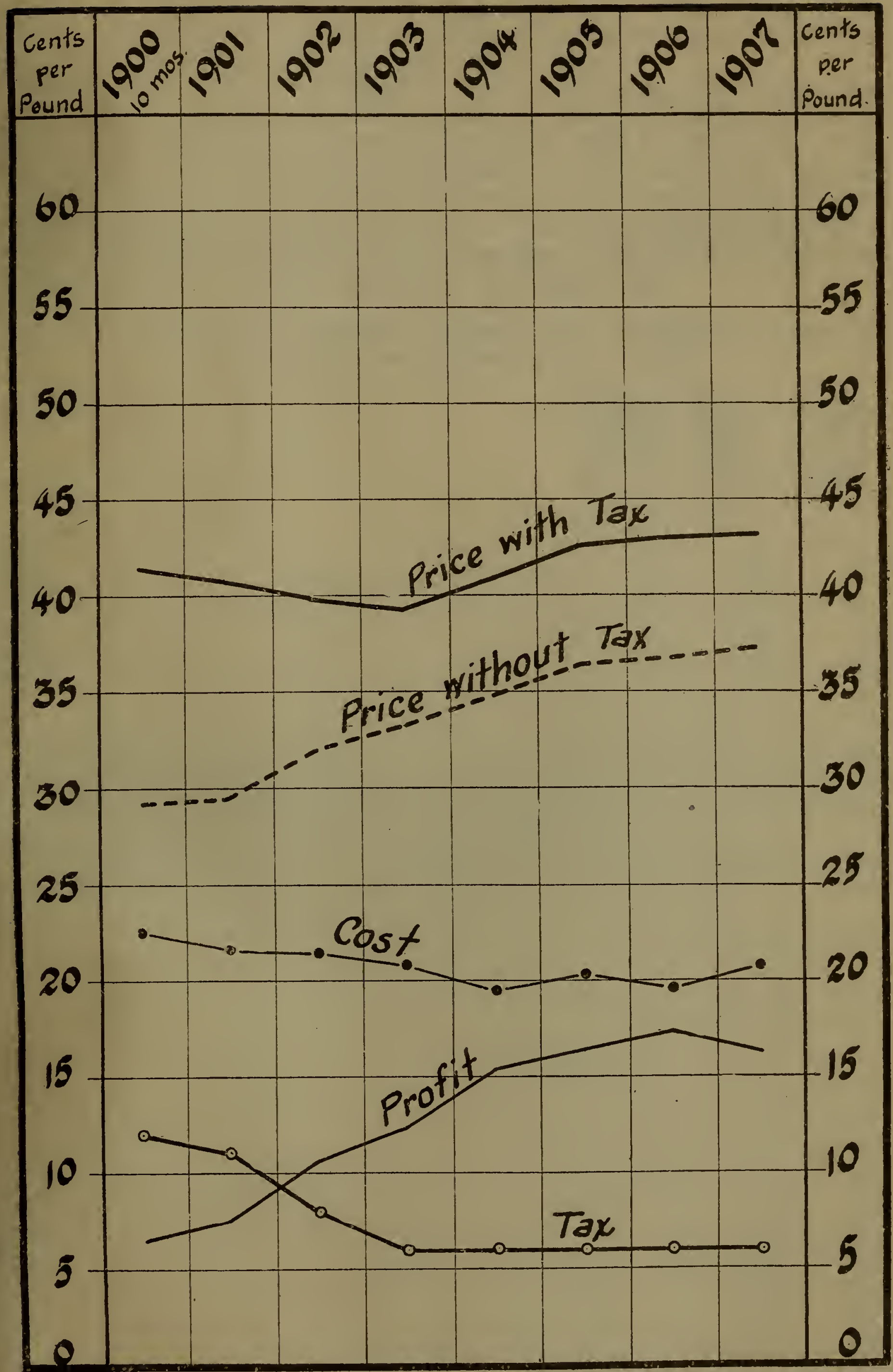



The great increase in profit per pound shown by the table has been primarily due to an increase in the average net price less tax, and to a less extent to a decrease in cost. The profit rose from 6.6 cents in 1900 to 17.2 cents in 1906 , an increase of 160 per cent. From 1901, the first full year of operation, to 1906, the increase was 117 per cent. The profit in 1907 was slightly less than in 1906.

The relative effect of changes in price and changes in cost on the profits of the American Snuff Company is indicated by the following statement, which shows for each year from 1902 to 1907 how much the net price, less tax, exceeded the price of 1901, how much the cost fell below the cost of 1901, and the sum of these two figures, which shows the increase in profit over 1901 . The year 1901 is taken as a basis rather than the year 1900, because the conditions of the business were doubtless somewhat unusual in the former year.

TABLE 95.-American Snuff Company-Increase in price (excluding tax), decrease in cost (excluding tax), and increase in profit, 1901-190\%.

Year.
$\ldots$

The increase in the net price, less tax, and in the profit per pound of the American Snuff Company during the period 1900 to 1903 was due in part, as already noted, to the reduction in the internal-revenue tax, of which the company was able to take advantage.

Table 96 shows the amount of the three elements entering into the price of snuff, namely, tax, cost, and profit, for each year.

TABLE 96.-American Snuff Company-Division of net selling price into tax, costs, and profit.

\begin{tabular}{|c|c|c|c|c|}
\hline \multirow{2}{*}{ Year. } & \multirow{2}{*}{$\begin{array}{l}\text { Net price } \\
\text { (per } \\
\text { pound). }\end{array}$} & \multicolumn{3}{|c|}{$\begin{array}{l}\text { Elements entering into price } \\
\text { (per pound). }\end{array}$} \\
\hline & & Tax. & Cost. & Profit. \\
\hline 1900 (10 months). & $\begin{array}{l}\text { Cents. } \\
\quad 41.2\end{array}$ & $\begin{array}{l}\text { Cents. } \\
12.0\end{array}$ & $\begin{array}{r}\text { Cents. } \\
22.6\end{array}$ & $\begin{array}{r}\text { Cents. } \\
6.6\end{array}$ \\
\hline $1901 \ldots \ldots \ldots \ldots$ & 40.7 & 11.0 & 21.8 & 7.9 \\
\hline $1902 \ldots \ldots \ldots$ & 39.9 & 8.0 & 21.3 & 10.6 \\
\hline $1903 \ldots \ldots \ldots \ldots \ldots . . . . . .$. & 39.1 & 6.0 & 20.8 & 12.3 \\
\hline $1904 \ldots \ldots$. & 40.9 & 6.0 & 19.6 & 15.3 \\
\hline $1905 \ldots \ldots \ldots$ & 42.4 & 6.0 & 20.2 & 16.2 \\
\hline $1906 \ldots \ldots$. & 42.9 & 6.0 & 19.7 & 17.2 \\
\hline $1907 \ldots \ldots \ldots \ldots \ldots$ & 43.1 & 6.0 & 20.8 & 16.3 \\
\hline
\end{tabular}

87442—S. Doc. $78,61-1-12$ 
This table shows that in 1900 and 1901 nearly 30 per cent of the net selling price of snuff was represented by the federal tax, a little over one-half by the cost, and about one-sixth by the profit. On the other hand, in the years from 1904 to 1907 the federal tax represented about one-seventh of the price, the cost a little less than one-half, and the profit considerably more than one-third. Comparing 1901, the first full year of operation of the American Snuff Company, with 1907, it will be seen that in the former year the price of 40.7 cents per pound was made up of 11.0 cents tax, 21.8 cents cost, and 7.9 cents profit; whereas in 1907 the increased price of 43.1 cents was made up of 6 cents tax, 20.8 cents cost, and 16.3 cents profit.

Table 97 shows the net price of snuff sold by the American Snuff Company, exclusive of tax, and the proportion thereof represented, respectively, by cost and profit. This table shows that in 1900 the profit represented 21.3 per cent of the price and in 190126.9 per cent, while from 1904 to 1907 the proportion represented by profit has ranged from 44.0 per cent to 47.7 per cent.

TABLE 97.-American Snuff Company-Division of net price (less tax) between cost and profit.

\begin{tabular}{|c|c|c|c|}
\hline \multirow{2}{*}{ Year. } & \multirow{2}{*}{$\begin{array}{l}\text { Average } \\
\text { net selling } \\
\text { price, less } \\
\text { tax (per } \\
\text { pound). }\end{array}$} & \multicolumn{2}{|c|}{$\begin{array}{l}\text { Proportion represented } \\
\text { by- }\end{array}$} \\
\hline & & Cost. & Profit. \\
\hline 1000 (10 monthe) & Cents. & Per cent. & Per cent. \\
\hline $1901 \ldots \ldots \ldots$ & 29.7 & 73.1 & 26.9 \\
\hline $1902 .$. & 31.9 & 65.8 & 34.2 \\
\hline $1903 \ldots$ & 33.1 & 62.7 & 37.3 \\
\hline $1904 .$. & 34.9 & 56.0 & 44.0 \\
\hline $1905 .$. & 36.4 & 55.5 & 44.5 \\
\hline $1906 \ldots$ & 36.9 & 52.3 & 47.7 \\
\hline $1907 \ldots \ldots \ldots$ & 37.1 & 55.3 & 44.7 \\
\hline
\end{tabular}

The statement below showing the relation of the profit to the cost per pound on snuff sold by the American Snuff Company shows that in 1900 the cost, excluding tax, was 22.6 cents per pound, and had fallen to 20.8 cents in 1907 , and that in the earlier year the profit was 27.0 per cent on cost, and in 1907 had increased to 80.9 per cent.

TABLE 98.-American Snuff Company-Relation of profits to costs.

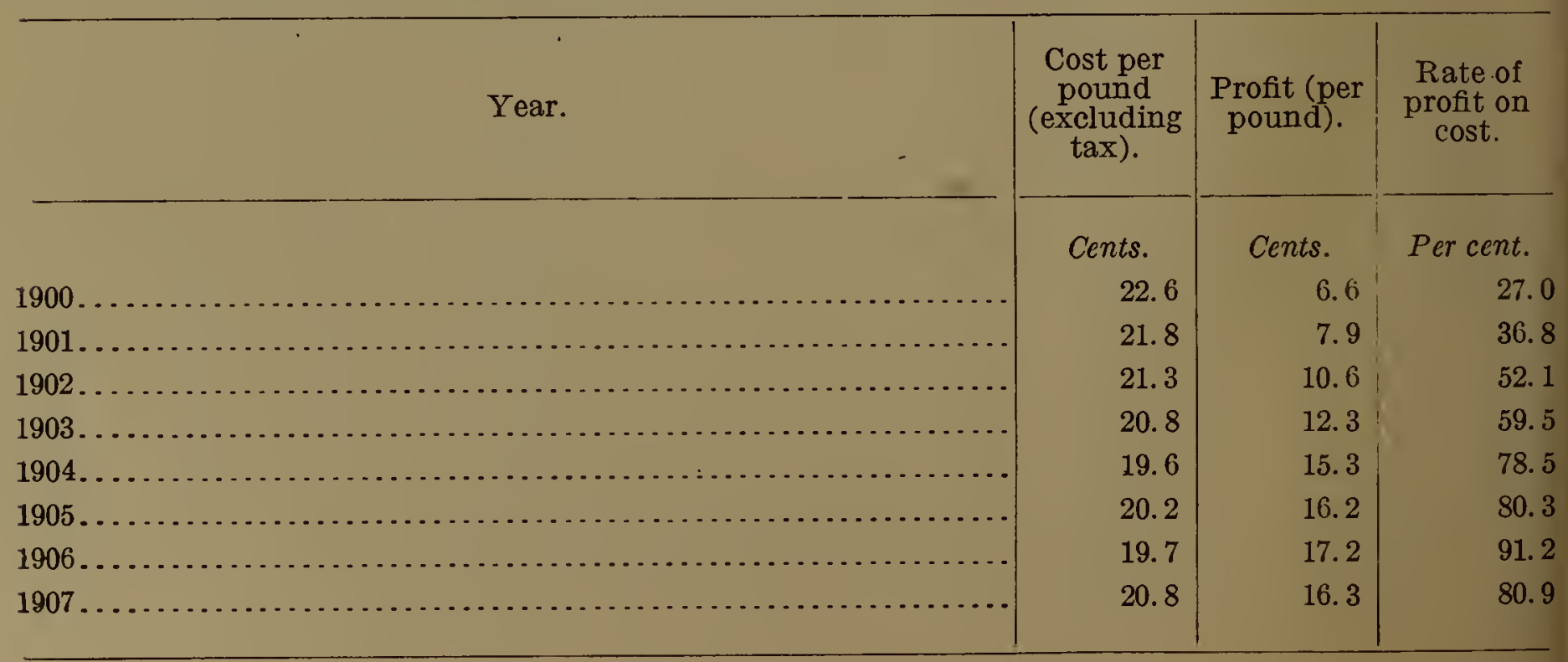


TABLE 100.-American Snuff Company-Prices, costs, and profits of representative brands of strong Scotch snuff.

\begin{tabular}{|c|c|c|c|c|c|c|c|c|c|}
\hline \multirow{3}{*}{ Year. } & \multirow{3}{*}{$\begin{array}{l}\text { Tax (per } \\
\text { pound). }\end{array}$} & \multicolumn{4}{|c|}{ Brand No. 1 (per pound). } & \multicolumn{4}{|c|}{ Brand No. 2 (per pound). } \\
\hline & & \multicolumn{2}{|c|}{ Price. } & \multirow{2}{*}{ Cost. } & \multirow{2}{*}{ Profit. } & \multicolumn{2}{|c|}{ Price. } & \multirow{2}{*}{ Cost. } & \multirow{2}{*}{ Profit. } \\
\hline & & $\begin{array}{l}\text { Includ- } \\
\text { ing tax. }\end{array}$ & $\begin{array}{l}\text { Exclud- } \\
\text { ing tax. }\end{array}$ & & & $\begin{array}{l}\text { Includ- } \\
\text { ing tax. }\end{array}$ & $\begin{array}{l}\text { Exclud- } \\
\text { ing tax. }\end{array}$ & & \\
\hline & Cents. & Cents. & Cents. & Cents. & Cents. & Cents. & Cents. & Cents. & Cents. \\
\hline 1901 . & $\left\{\begin{array}{r}12.0 \\
9.6\end{array}\right.$ & 49.9 & 38.8 & 23.2 & 15.6 & 52.6 & 41.4 & 21.7 & 19.7 \\
\hline 1902. & $\begin{array}{l}9.6 \\
6.0\end{array}$ & 48.3 & 39.7 & 23.4 & 16.3 & 52.0 & 43.8 & 21.8 & 22.0 \\
\hline 1903. & 6.0 & 48.1 & 42.1 & 23.3 & 18.8 & 50.4 & 44.4 & 21.6 & 22.8 \\
\hline $1904 \ldots$ & 6.0 & 48.8 & 42.8 & 21.5 & 21.3 & 50.2 & 44.2 & 20.5 & 23.7 \\
\hline $1905 \ldots$ & 6.0 & 48.7 & 42.7 & 22.1 & 20.6 & 51.7 & 45.7 & 20.3 & 25.4 \\
\hline $1906 \ldots$. & 6.0 & 48.4 & 42.4 & 22.3 & 20.1 & 52.7 & 46.7 & 20.5 & 26.2 \\
\hline $1907 \ldots$ & 6.0 & 48.9 & 42.9 & 23.8 & 19.1 & 53.1 & 47.1 & 21.8 & 25.3 \\
\hline
\end{tabular}

\begin{tabular}{|c|c|c|c|c|c|c|c|c|c|}
\hline \multirow{3}{*}{ Year. } & \multirow{3}{*}{$\begin{array}{l}\text { Tax (per } \\
\text { pound). }\end{array}$} & \multicolumn{4}{|c|}{ Brand No. 3 (per pound). } & \multicolumn{4}{|c|}{ Brand No. 4 (per pound). } \\
\hline & & \multicolumn{2}{|c|}{ Price. } & \multirow{2}{*}{ Cost. } & \multirow{2}{*}{ Profit. } & \multicolumn{2}{|c|}{ Price. } & \multirow{2}{*}{ Cost. } & \multirow[b]{2}{*}{ Profit. } \\
\hline & & $\begin{array}{l}\text { Includ- } \\
\text { ing tax. }\end{array}$ & $\begin{array}{l}\text { Exclud- } \\
\text { ing tax. }\end{array}$ & & & $\begin{array}{l}\text { Includ- } \\
\text { ing tax. }\end{array}$ & $\begin{array}{l}\text { Exclud- } \\
\text { ing tax. }\end{array}$ & & \\
\hline & Cents. & Cents. & Cents. & Cents. & Cents. & Cents. & Cents. & Cents. & Cents. \\
\hline 1901 . & $\left\{\begin{array}{r}12.0 \\
9.6\end{array}\right.$ & 39.8 & 28.5 & 24.5 & 4.0 & 38.7 & 27.8 & 19. 6 & 8.2 \\
\hline 1902. & $\begin{array}{l}9.6 \\
6.0\end{array}$ & 42.8 & 34.9 & 23.6 & 11.3 & 36.2 & 28.2 & 20.2 & 8.0 \\
\hline $1903 \ldots .$. & 6.0 & 40.8 & 34.8 & 23.3 & 11.5 & 33.3 & 27.3 & 18. 7 & 8.6 \\
\hline $1904 \ldots$. & 6.0 & 43.9 & 37.9 & 22.7 & 15.2 & 362 & 30.2 & 18.1 & 12.1 \\
\hline $1905 \ldots$ & 6.0 & 44.2 & 38.2 & 21.7 & 16.5 & 37.0 & 31.0 & 17.9 & 13.1 \\
\hline $1906 \ldots$ & 6.0 & 44.1 & 38.1 & 20.2 & 17.9 & 37.1 & 31.1 & 17.1 & 14.0 \\
\hline $1907 \ldots$ & 6.0 & 43.6 & 37.6 & 21.0 & 16.6 & 366 & 30.6 & 18.2 & 12.4 \\
\hline \multirow{3}{*}{ Year. } & \multirow{3}{*}{$\begin{array}{l}\text { Tax (per } \\
\text { pound). }\end{array}$} & \multicolumn{4}{|c|}{ Brand No. 5 (per pound). } & \multicolumn{4}{|c|}{ Brand No. 6 (per pound). } \\
\hline & & Pri & & & & Pric & & & \\
\hline & & $\begin{array}{l}\text { Includ- } \\
\text { ing tax. }\end{array}$ & $\begin{array}{l}\text { Exclud- } \\
\text { ing tax. }\end{array}$ & Cost. & Profit. & $\begin{array}{l}\text { Includ- } \\
\text { ing tax. }\end{array}$ & $\begin{array}{l}\text { Exclud- } \\
\text { ing tax. }\end{array}$ & Cost. & Pront. \\
\hline & Cents. & Cents. & Cents. & Cents. & Cents. & Cents. & Cents. & Cents. & Cents. \\
\hline $1901 \ldots$ & $\left\{\begin{array}{r}12.0 \\
9.6\end{array}\right.$ & 33.2 & 22.1 & 20.2 & 1.9 & 36.4 & 25.4 & 24.1 & 1.3 \\
\hline 1902. & $\begin{array}{l}9.6 \\
6.0\end{array}$ & 33.6 & 25.4 & 17.1 & 8.3 & 36.0 & 28.4 & 22.4 & 6.0 \\
\hline 1903. & 6.0 & 33.8 & 27.8 & 15.3 & 12.5 & 36.1 & 30.1 & 20.6 & 9.5 \\
\hline 1904. & 6.0 & 34.7 & 28.7 & 14.3 & 14.4 & 38.7 & 32.7 & 19.4 & 13.3 \\
\hline $1905 \ldots$ & 6.0 & 34.8 & 28.8 & 15.2 & 13.6 & 40.7 & 34.7 & 19.7 & 15.0 \\
\hline $1906 \ldots$ & 6.0 & 34.9 & 28.9 & 16.1 & 12.8 & 40.9 & 34.9 & 19.9 & 15.0 \\
\hline $1907 \ldots$ & 6.0 & 34.9 & 28.9 & 17.8 & 11.1 & 40.3 & 34.3 & 21.2 & 13.1 \\
\hline
\end{tabular}




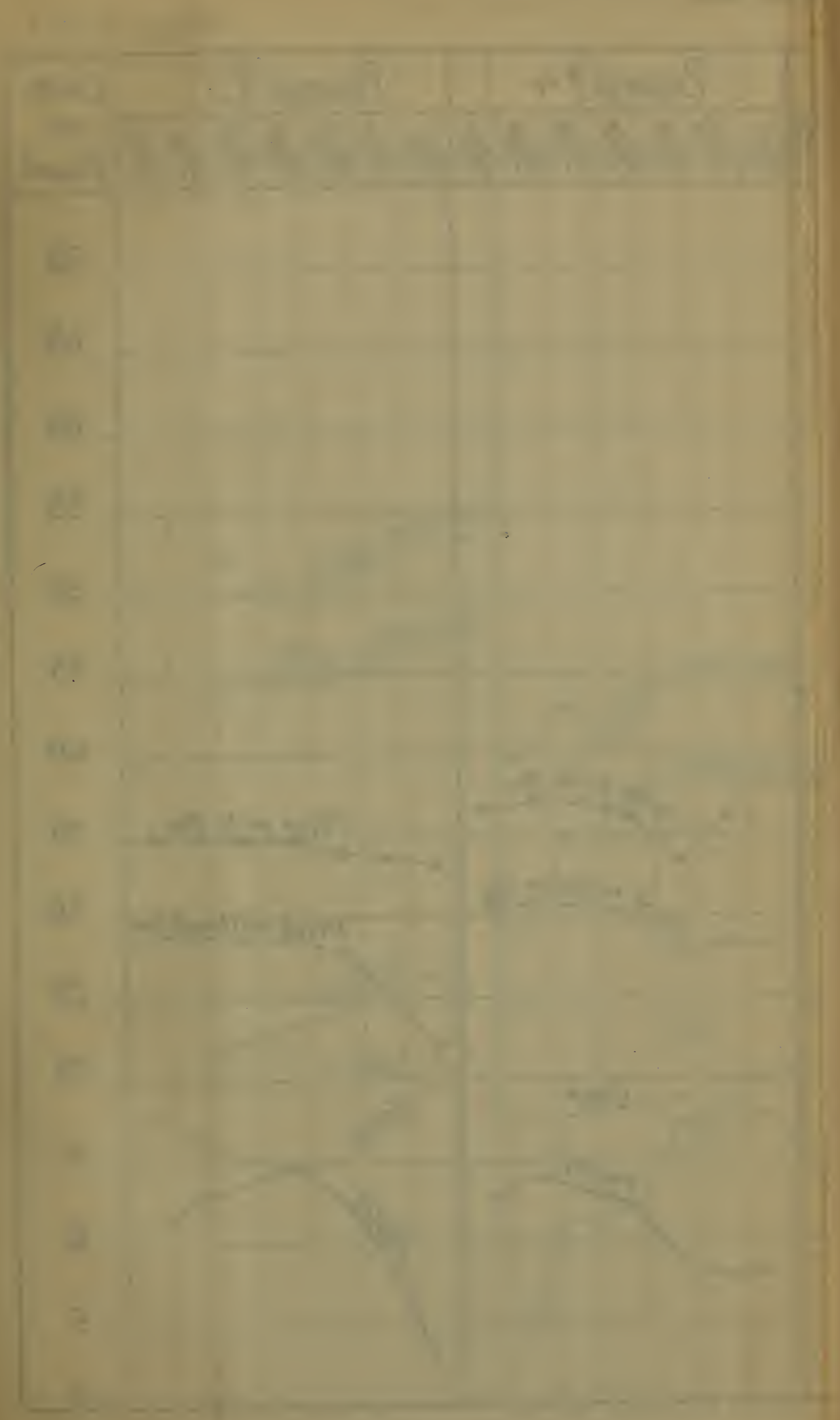


gram 14-No. 1.

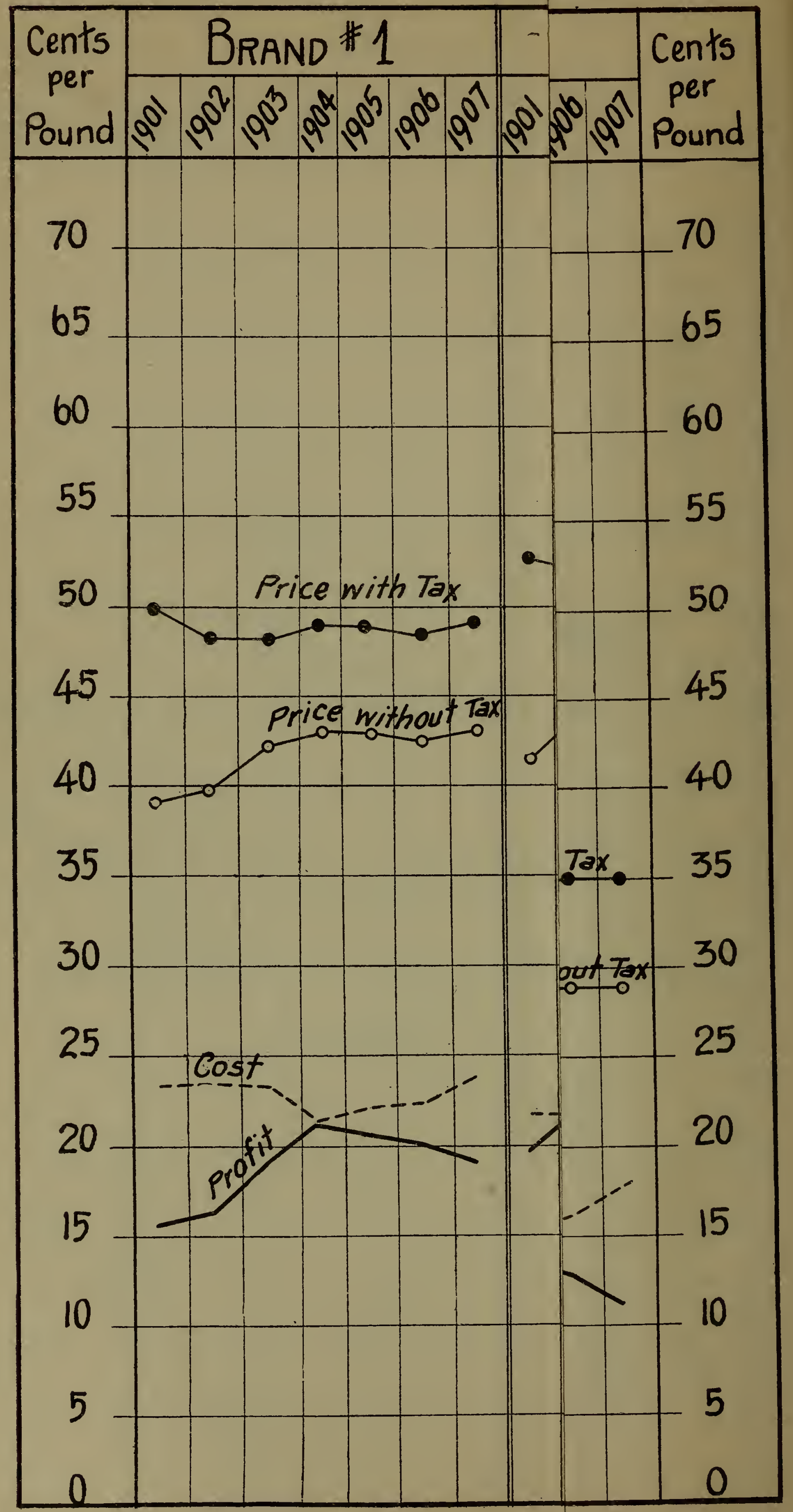




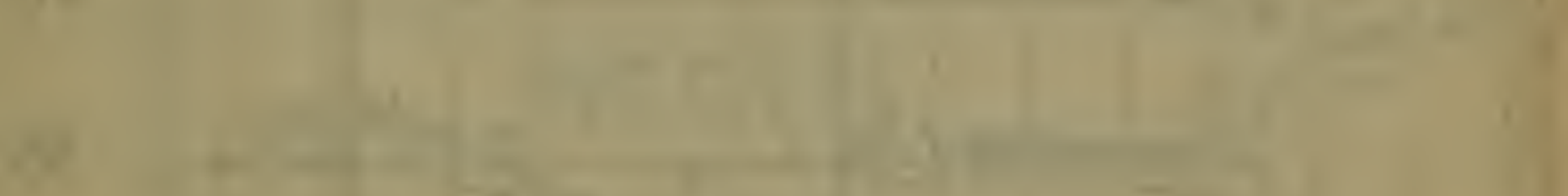

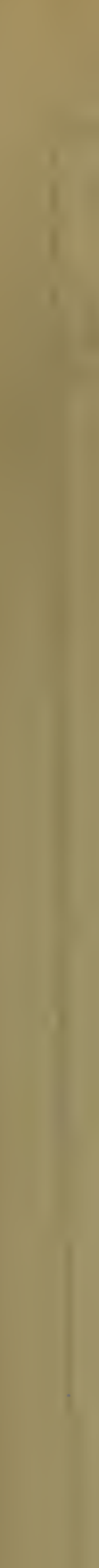


SNUFF.

AMERICAN SNUFF COMPANY

Prices: Costs, and Profits of Representative Brands.

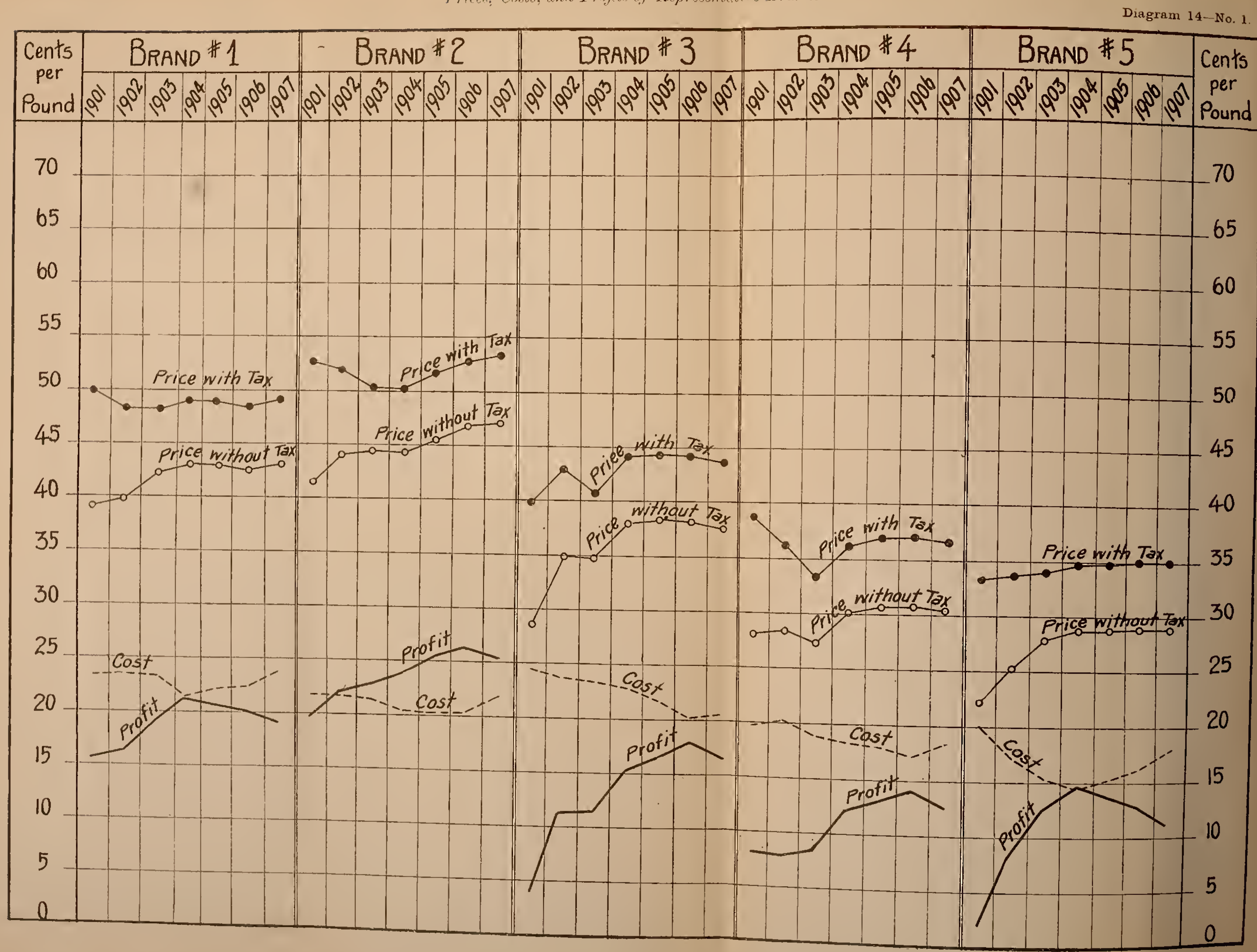




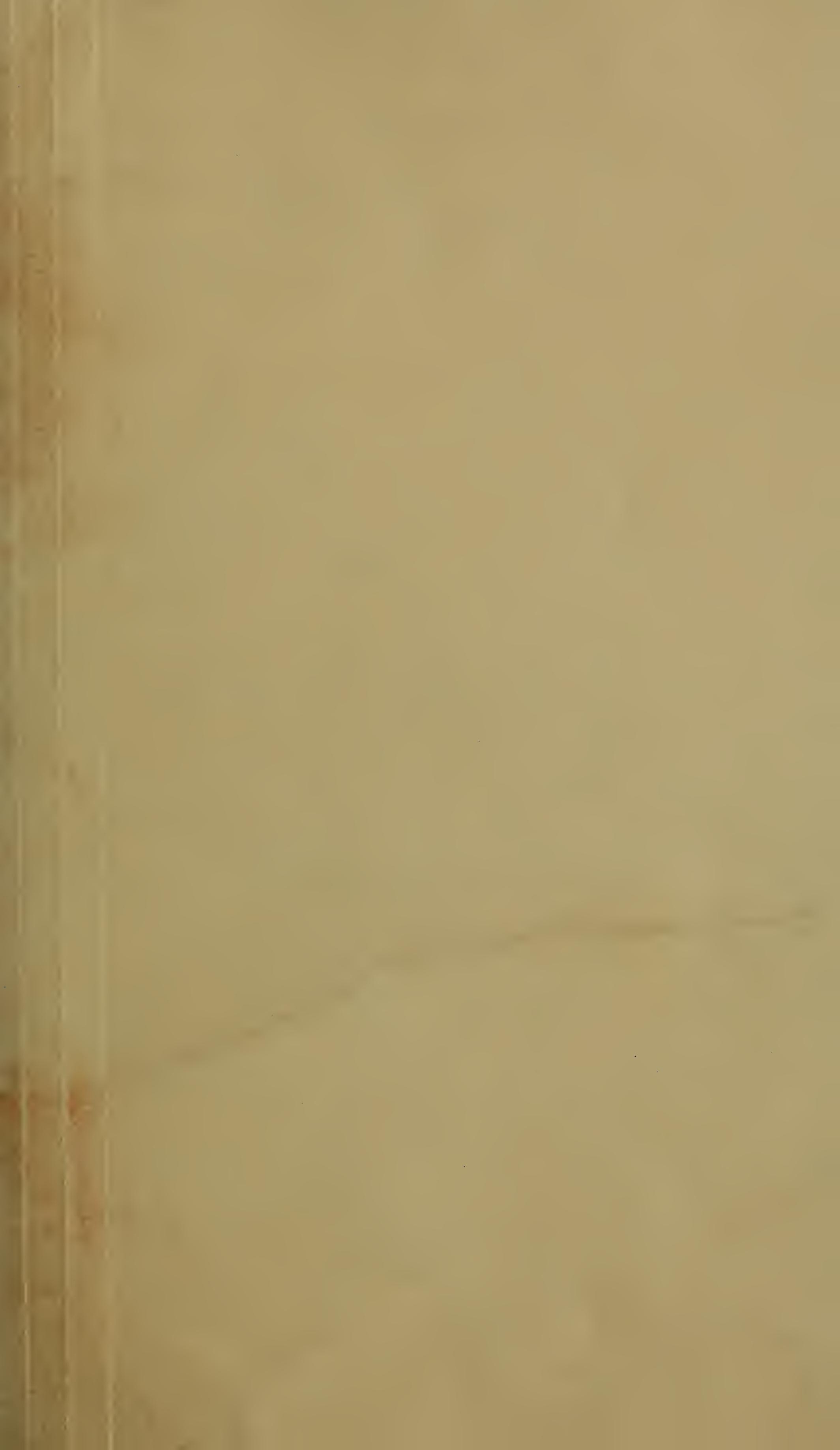


iagram 14-No. 2.

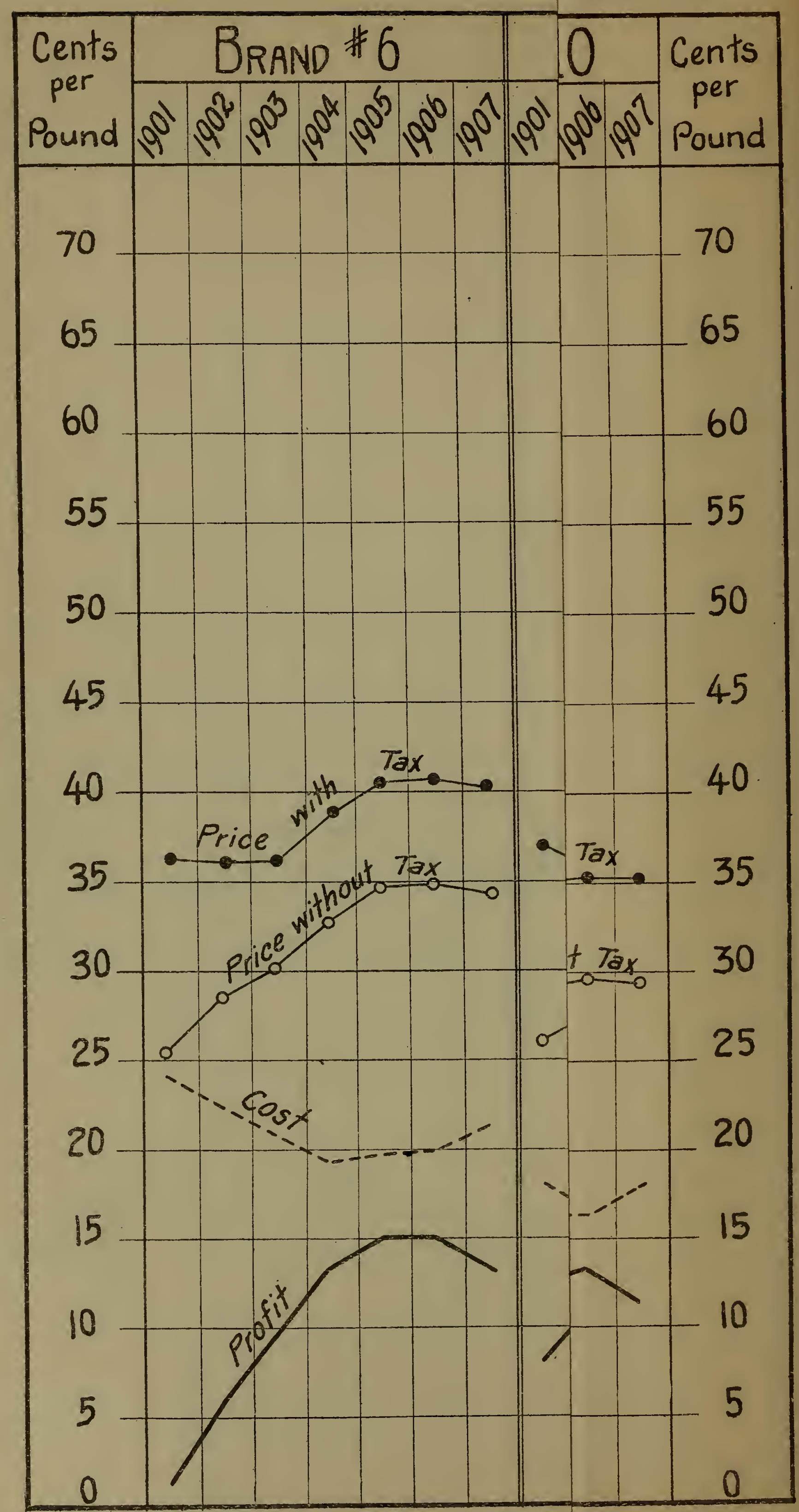



Diagram 14-No. 2

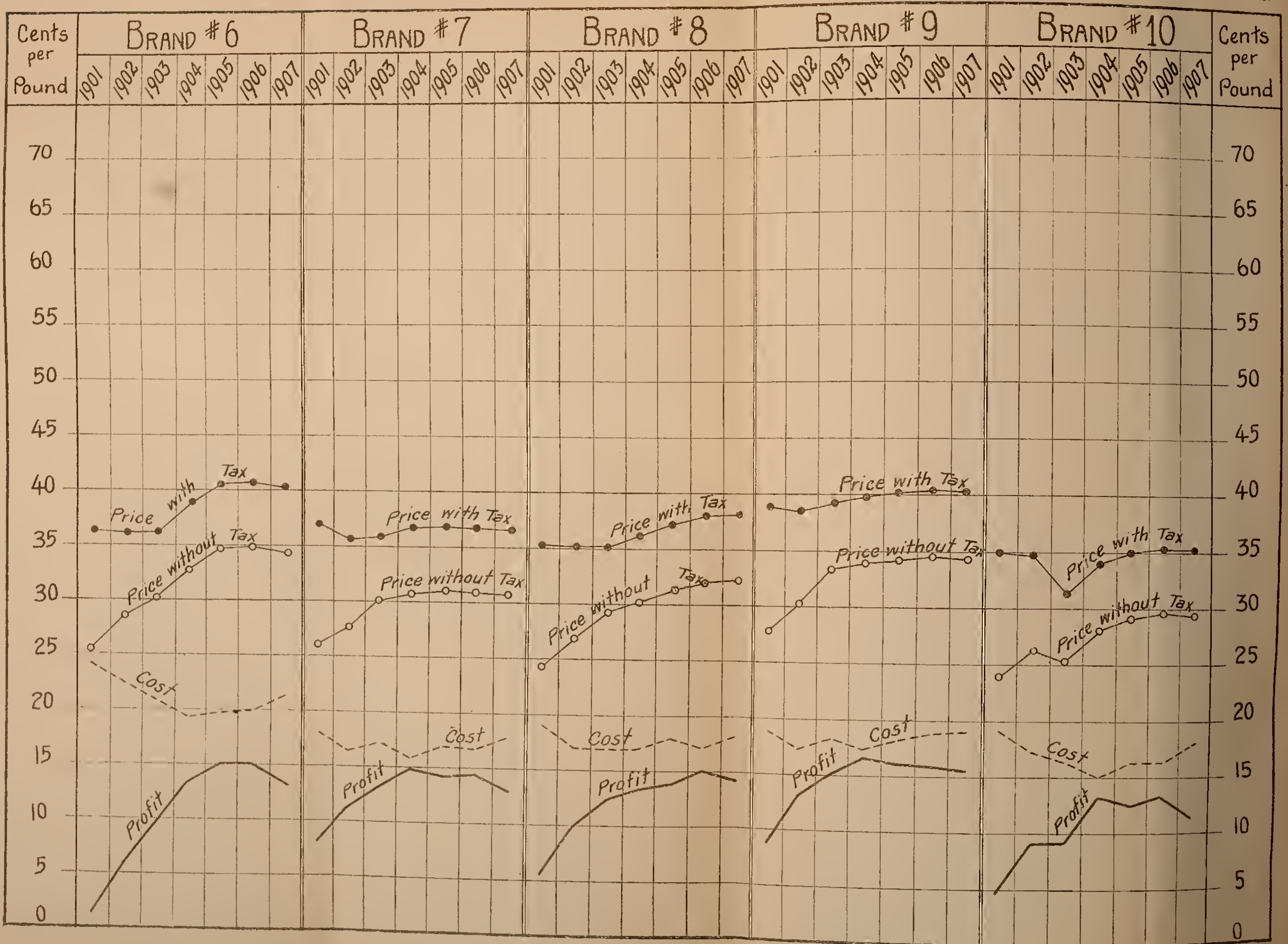




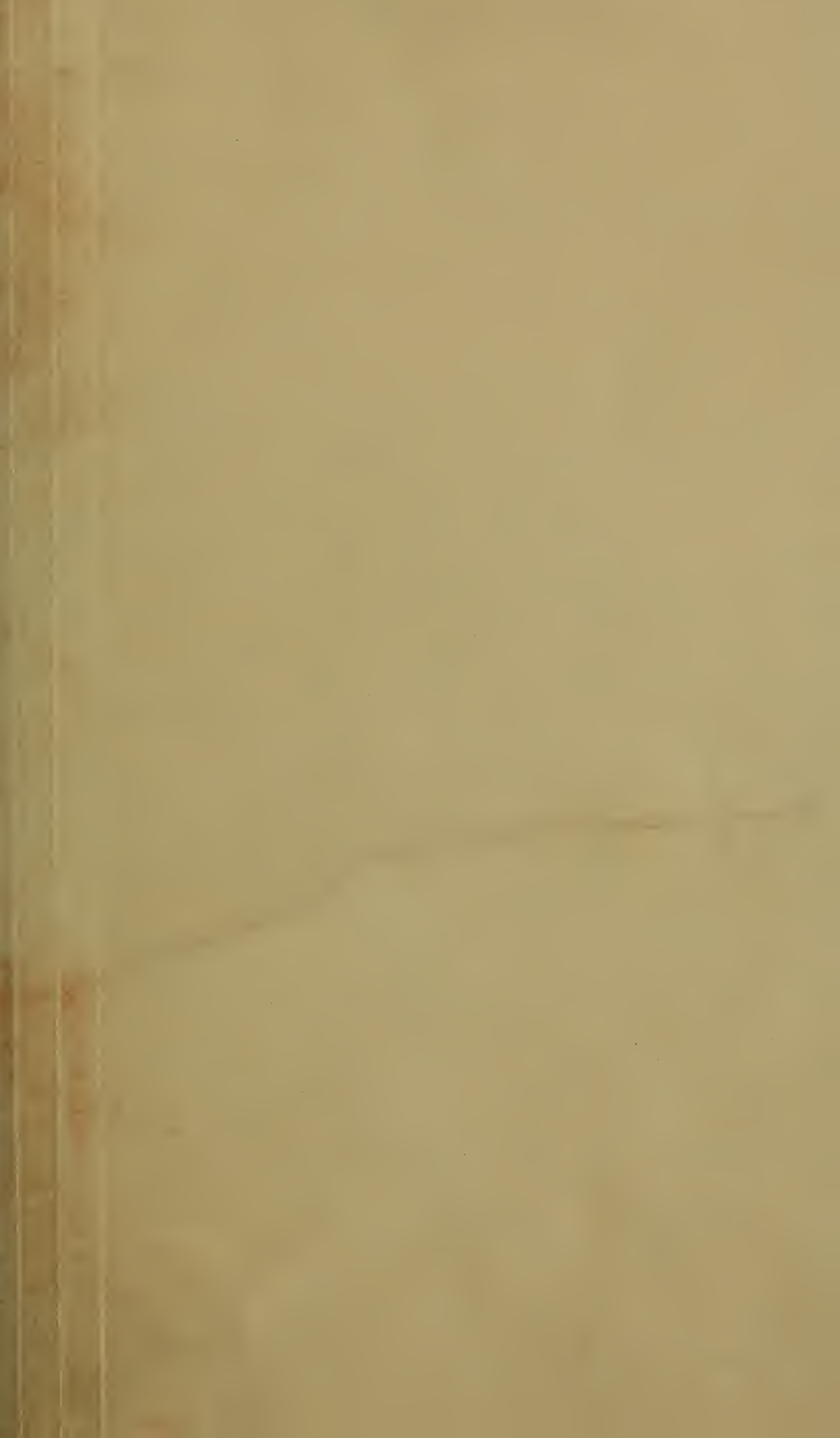


No. 3.

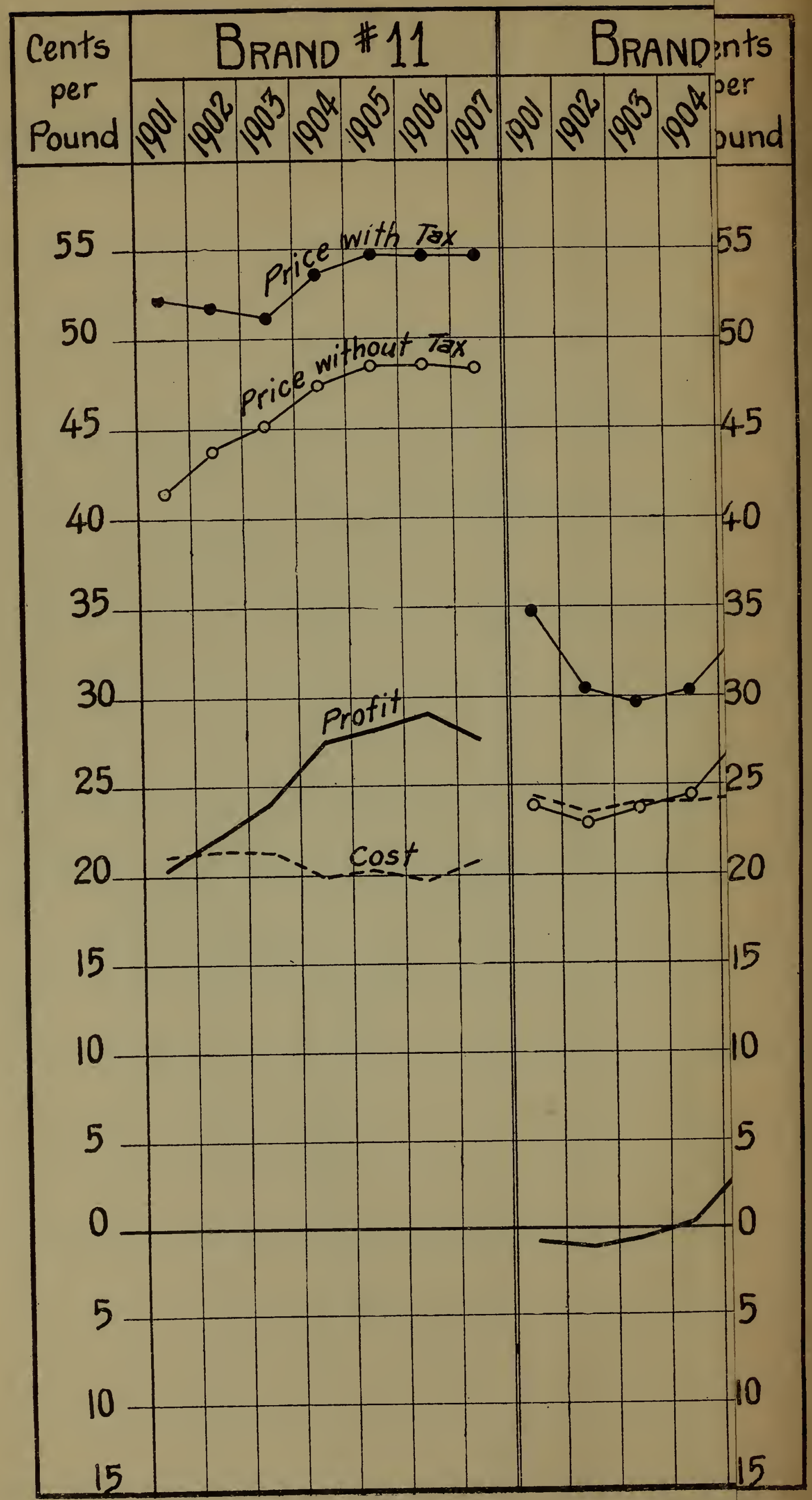


This table shows an increase in the net price per pound, less tax, on every one of the brands during the period since 1901, while in every case except two the cost of manufacture and distribution was lower in 1907 than in 1901. Consequently there was an increase in the net profit on every one of the brands. It is noteworthy that the increase in price and profit has been much greater on those brands which at the outset commanded relatively low prices and low profits than on the brands which at the outset had high prices and high profits. In other words, there has been a tendency toward an approximate uniformity in the prices and profits on all the brands. Instead of discontinuing the sale of the brands which were less profitable, their price has been advanced so as to make them more profitable. In some cases this advance in price has been accompanied by a decline in output, while in other cases there has been an increase not only in the absolute amount of output, but in the proportion which that amount bears to the total product of the company.

The following table shows similar information regarding the prices, costs, and profits of five of the principal brands (numbered from 7 to 11 in the table and in diagram 14) of Sweet Scotch and Salt snuff manufactured by the American Snuff Company:

TABLE 101.-American Snuff Company-Prices, costs, and profits of representative brands of sweet Scotch and salt snuff.

\begin{tabular}{|c|c|c|c|c|c|c|c|c|c|}
\hline \multirow{3}{*}{ Year. } & \multirow{3}{*}{$\begin{array}{l}\text { Tax (per } \\
\text { pound). }\end{array}$} & \multicolumn{4}{|c|}{ Brand No. 7 (per pound). } & \multicolumn{4}{|c|}{ Brand No. 8 (per pound). } \\
\hline & & \multicolumn{2}{|c|}{ Price. } & \multirow[b]{2}{*}{ Cost. } & \multirow[b]{2}{*}{ Profit. } & \multicolumn{2}{|c|}{ Price. } & \multirow[b]{2}{*}{ Cost. } & \multirow[b]{2}{*}{ Profit. } \\
\hline & & $\begin{array}{l}\text { Includ- } \\
\text { ing tax. }\end{array}$ & $\begin{array}{l}\text { Exclud- } \\
\text { ing tax. }\end{array}$ & & & $\begin{array}{l}\text { Includ- } \\
\text { ing tax. }\end{array}$ & $\begin{array}{l}\text { Exclud- } \\
\text { ing tax. }\end{array}$ & & \\
\hline & Cents. & Cents. & Cents. & Cents. & Cents. & Cents. & Cents. & Cents. & Cents. \\
\hline 1901 & $\left\{\begin{array}{r}12.0 \\
9.6\end{array}\right.$ & 37.0 & 26.0 & 18.0 & 8.0 & 35.5 & 24.3 & 19.0 & 5.3 \\
\hline 1902 & $\left\{\begin{array}{l}9.6 \\
6.0\end{array}\right.$ & 35.7 & 27.5 & 16.4 & 11.1 & 35.2 & 26.9 & 17.0 & 9.9 \\
\hline 1903. & 6.0 & 36.0 & 30.0 & 17.0 & 13.0 & 35.1 & 29.1 & 16.8 & 12.3 \\
\hline 1904. & 6.0 & 36.7 & 30.7 & 15.8 & 14.9 & 36.2 & 30.2 & 16.8 & 13.4 \\
\hline $1905 \ldots$ & 6.0 & 36.9 & 30.9 & 16.8 & 14.1 & 37.4 & 31.4 & 17.8 & 13.6 \\
\hline 1906. & 6.0 & 36.9 & 30.9 & 16.6 & 14.3 & 38.0 & 32.0 & 17.0 & 15.0 \\
\hline 1907. & 6.0 & 36.7 & 30.7 & 17.8 & 12.9 & 38.2 & 32.2 & 18.1 & 14. 1 \\
\hline \multirow{3}{*}{ Year. } & \multirow{3}{*}{$\begin{array}{l}\text { Tax (per } \\
\text { pound). }\end{array}$} & \multicolumn{4}{|c|}{ Brand 9 (No. per pound). } & \multicolumn{4}{|c|}{ Brand No. 10 (per pound). } \\
\hline & & \multicolumn{2}{|c|}{ Price. } & & & \multicolumn{2}{|c|}{ Price. } & \multirow[b]{2}{*}{ Cost. } & \multirow[b]{2}{*}{ Profit. } \\
\hline & & $\begin{array}{l}\text { Includ- } \\
\text { ing tax. }\end{array}$ & $\begin{array}{l}\text { Exclud- } \\
\text { ing tax. }\end{array}$ & Cost. & Profit. & $\begin{array}{l}\text { Includ- } \\
\text { ing tax. }\end{array}$ & $\begin{array}{l}\text { Exclud- } \\
\text { ing tax. }\end{array}$ & & \\
\hline & Cents. & Cents. & Cents. & Cents. & Cents. & Cents. & Cents. & Cents. & Cents. \\
\hline 1901 & $\begin{array}{r}12.0 \\
9.6\end{array}$ & 38.7 & 27.7 & 18.9 & 8.8 & 35.0 & 23.9 & 19.2 & 4. 7 \\
\hline 1902 & $\begin{array}{l}9.6 \\
6.0\end{array}$ & 38.6 & 30.3 & 17.2 & 13.1 & 34.7 & 26.3 & 17.3 & 9.0 \\
\hline 1903. & 6.0 & 39.3 & 33. 3. & 18.1 & 15.2 & 31.3 & 25.3 & 16.2 & 9. 1 \\
\hline $1904 \ldots$ & 6.0 & 39.7 & 33.7 & 17.2 & 16.5 & 33.9 & 27.9 & 15.0 & 12.9 \\
\hline $1905 \ldots$ & 6.0 & 40.2 & 34.2 & 18.0 & 16.2 & 35.0 & 29.0 & 16.4 & 12.6 \\
\hline $1906 .$. & 6.0 & 40.5 & 34.5 & 18.7 & 15.8 & 35.5 & 29.5 & 16.3 & 13.2 \\
\hline $1907 .$. & 6.0 & 40.3 & 34.3 & 18.8 & 15.5 & 35.3 & 29.3 & 17.9 & 11. 4 \\
\hline
\end{tabular}




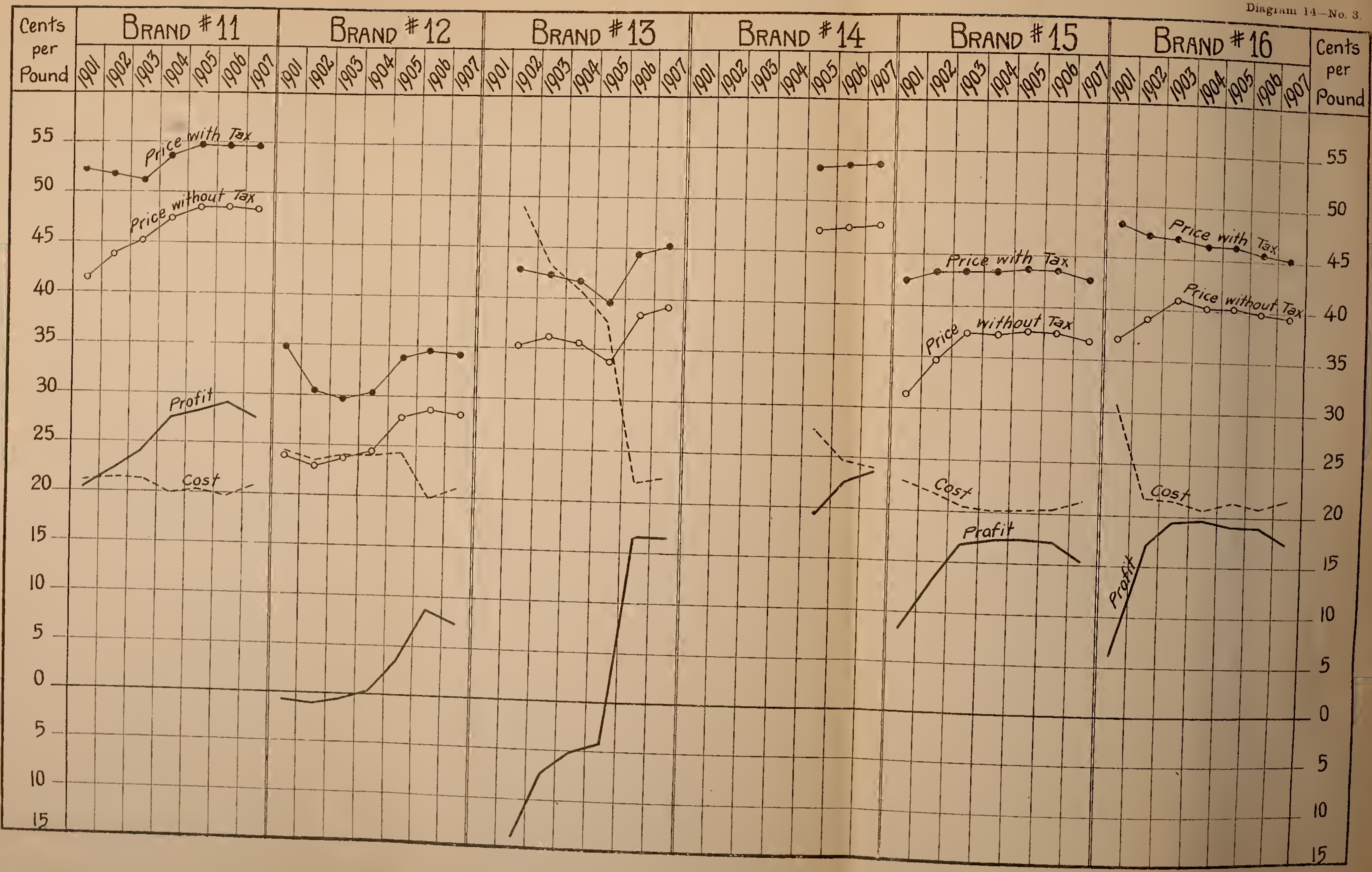




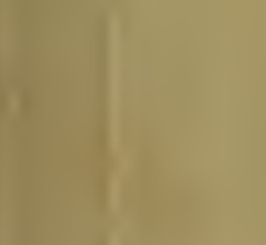

11

1.1

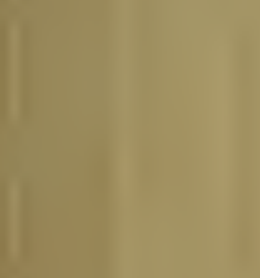

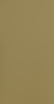
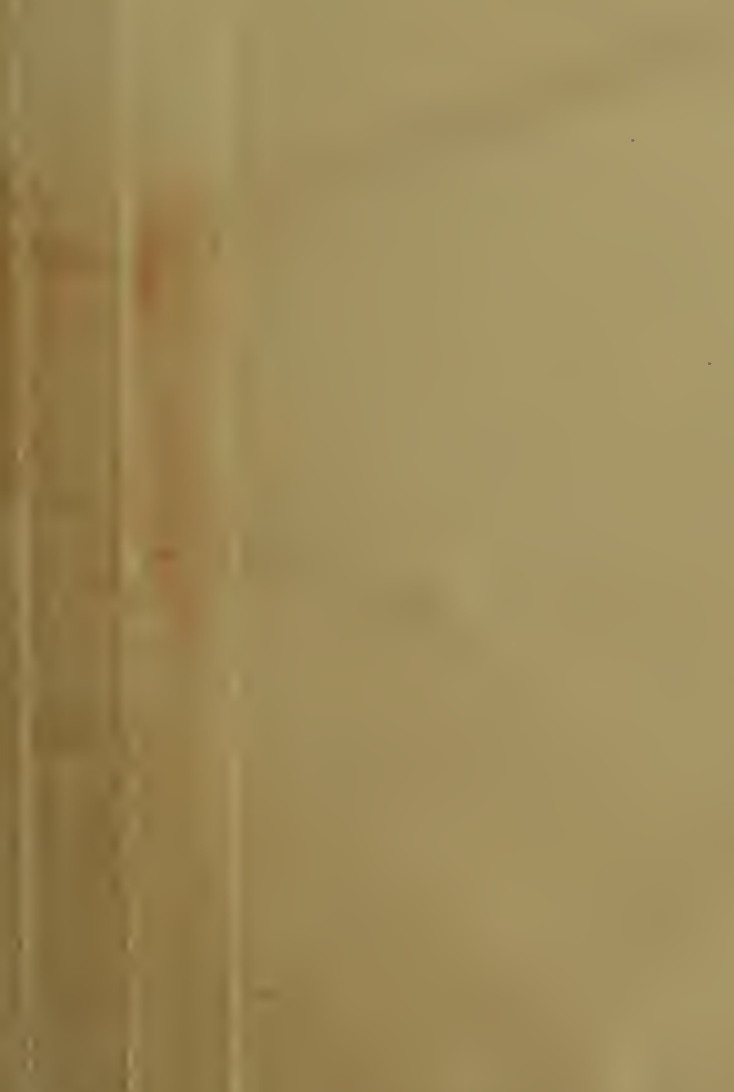
TABLE 101.-American Snuff Company-Prices, costs, and profits of representative brands of sweet Scotch and salt snuff-Continued.

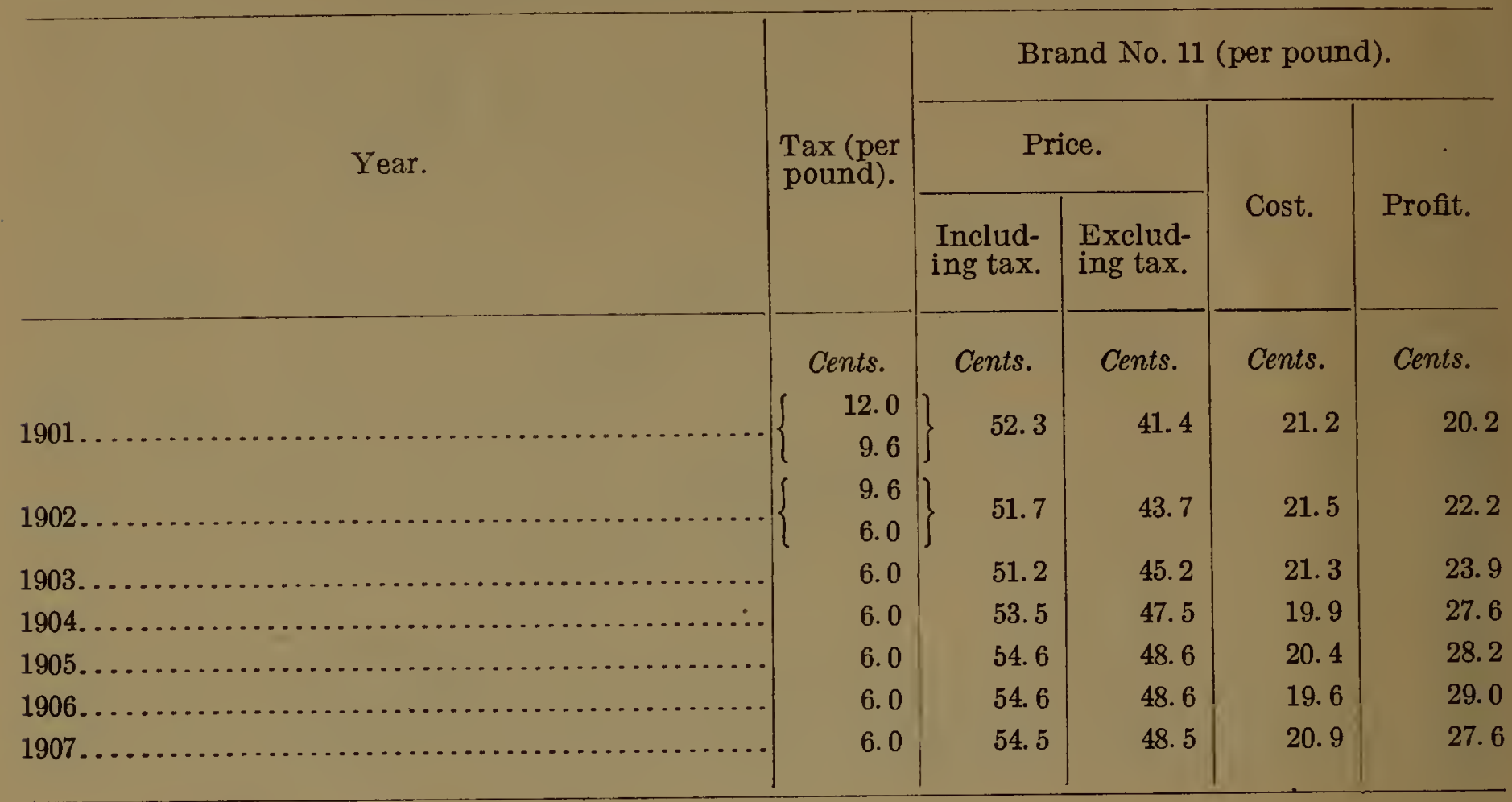

The figures for these brands show substantially the same situation as with the Strong Scotch brands. In all cases the net price, less tax, has increased materially, while the cost has declined or remained approximately unchanged, so that the profit has decidedly increased. The profits per pound are also more nearly uniform in the later years than in the earlier ones.

Table 102 shows similar information for two of the principal brands (numbered 12 and 13 in the table and in diagram 14) of Swedish snuff made by the American Snuff Company.

TABLE 102.-American Snuff Company-Prices, costs, and profits of representative brands of Swedish snuff.

\begin{tabular}{|c|c|c|c|c|c|c|c|c|c|}
\hline \multirow{3}{*}{ Year. } & \multirow{3}{*}{$\begin{array}{l}\text { Tax (per } \\
\text { pound). }\end{array}$} & \multicolumn{4}{|c|}{ Brand No. 12 (per pound). } & \multicolumn{4}{|c|}{ Brand No. 13 (per pound). } \\
\hline & & \multicolumn{2}{|c|}{ Price. } & \multirow{2}{*}{ Cost. } & \multirow{2}{*}{ Profit. } & \multicolumn{2}{|c|}{ Price. } & \multirow{2}{*}{ Cost. } & \multirow{2}{*}{ Profit. } \\
\hline & & $\begin{array}{l}\text { Includ- } \\
\text { ing tax. }\end{array}$ & $\begin{array}{l}\text { Exclud- } \\
\text { ing tax. }\end{array}$ & & & $\begin{array}{l}\text { Includ- } \\
\text { ing tax. }\end{array}$ & $\begin{array}{l}\text { Exclud- } \\
\text { ing tax. }\end{array}$ & & \\
\hline & Cents. & Cents. & Cents. & Cents. & Cents. & Cents. & Cents. & Cents. & Cents. \\
\hline 1901. & $\begin{array}{r}12.0 \\
9.6\end{array}$ & 34.7 & 23.8 & 24.4 & $* 0.6$ & & & & \\
\hline 1902. & $\begin{array}{l}9.6 \\
6.0\end{array}$ & 30.7 & 22.8 & 23.5 & $* .7$ & 42.6 & 35.3 & 49.0 & $* 13.7$ \\
\hline 1903. & 6.0 & 29.6 & 23.6 & 24.1 & $* .5$ & 42.2 & 36.2 & 43.4 & $* 7.2$ \\
\hline 1904. & 6.0 & 30.5 & 24.5 & 24.2 & .3 & 41.6 & 35.6 & 40.8 & $* 5.2$ \\
\hline $1905 \ldots$ & 6.0 & 33.8 & 27.8 & 24.3 & 3.5 & 39.7 & 33.7 & 37.8 & $* 4.1$ \\
\hline $1906 \ldots$ & 6.0 & 24.5 & 28.5 & 19.9 & 8.6 & 44.4 & 38.4 & 21.9 & 16.5 \\
\hline $1907 \ldots$ & 6.0 & 34.2 & 28.2 & 20.9 & 7.3 & 45.2 & 39.2 & 22.6 & 16.6 \\
\hline
\end{tabular}

* Loss. 
This table shows very different conditions from those indicated by the preceding tables. There was very active competition between the American Snuff Company and the firm of Weyman \& Bro. in the manufacture of Swedish snuff down to about July 1, 1905, when Weyman \& Bro. were bought out. Consequently there was practically no increase in the price of brands Nos. 12 and 13 when the tax was reduced, and both of these brands were sold at an actual loss down to 1903, while the loss continued on brand No. 13 until 1905. With the acquisition of Weyman \& Bro., the prices, less tax, of both these brands rapidly increased and the cost decreased, chiefly on account of the reduction in selling and advertising expenses incident to active competition. After the acquisition of Weyman \& Bro. the American Snuff Company greatly reduced its sales of brand No. 13 and laid special stress upon pushing the brands acquired from Weyman \& Bro. This brand, it may be noted, sells at a very high price, since the American Snuff Company acquired it.

Table 103 shows the prices, costs, and profits of two of the principal brands (numbered 14 and 15 in the table and in diagram 14) of maccaboy snuff manufactured by the American Snuff Company.

TABLE 103.-American Snuff Company-Prices, costs, and profits of representutive brands of Maccaboy snuff.

\begin{tabular}{|c|c|c|c|c|c|c|c|c|c|}
\hline \multirow{3}{*}{ Year. } & \multirow{3}{*}{$\begin{array}{l}\text { Tax (per } \\
\text { pound). }\end{array}$} & \multicolumn{4}{|c|}{ Brand No. 14 (per pound). } & \multicolumn{4}{|c|}{ Brand No. 15 (per pound). } \\
\hline & & \multicolumn{2}{|c|}{ Price. } & \multirow{2}{*}{ Cost. } & \multirow{2}{*}{ Profit. } & \multicolumn{2}{|c|}{ Price. } & \multirow{2}{*}{ Cost. } & \multirow{2}{*}{ Profit. } \\
\hline & & $\begin{array}{l}\text { Includ- } \\
\text { ing tax. }\end{array}$ & $\begin{array}{l}\text { Exclud- } \\
\text { ing tax. }\end{array}$ & & & $\begin{array}{l}\text { Includ- } \\
\text { ing tax. }\end{array}$ & $\begin{array}{l}\text { Exclud- } \\
\text { ing tax. }\end{array}$ & & \\
\hline & Cents. & Cents. & Cents. & Cents. & Cents. & Cents. & Cents. & Cents. & Cents. \\
\hline 1901. & $\begin{array}{r}12.0 \\
9.6\end{array}$ & 42.5 & 31.3 & 22.9 & 8.4 & 48.2 & 37.1 & 30.8 & 6.3 \\
\hline 1902 & $\begin{array}{l}9.6 \\
6.0\end{array}$ & 43.2 & 34.6 & 21.7 & 12.9 & 47.1 & 39.0 & 21.8 & 17.2 \\
\hline 1905 & 6.0 & 43.3 & 37.3 & 20.5 & 16.8 & 47.0 & 41.0 & 21.6 & 19.4 \\
\hline 1904 & 6.0 & 43.3 & 37.3 & 20.1 & 17.2 & 46.3 & 40.3 & 20.7 & 19.6 \\
\hline 1905. & 6.0 & 43.6 & 37.6 & 20.2 & 17.4 & 46.3 & 40.3 & .21 .5 & 18.9 \\
\hline $1906 .$. & 6.0 & 43.5 & 37.5 & 20.4 & 17.1 & 45.8 & 39.8 & 21.0 & 18.8 \\
\hline 1907 & 6.0 & 42.8 & 36.8 & 21.4 & 15.4 & 45.3 & 39.3 & 21.8 & 17.5 \\
\hline
\end{tabular}

The price, less tax, of brand No. 14 showed a very marked increase from 1901 to 1903 , and that of brand No. 15 a less increase, the prices of both brands thereafter remaining almost unchanged. On account of the great decline in the cost of brand No. 15, due substantially to a decrease in advertising expenses, that brand shows a much greater increase in profit than brand No. 14 .

It may be added that the available information regarding the prices of these same brands of snuff, prior to their acquisition by the American Snuff Company, shows that the prices generally were advanced after the tax was increased in 1898 , by an amount sufficient to cover the additional tax. 

